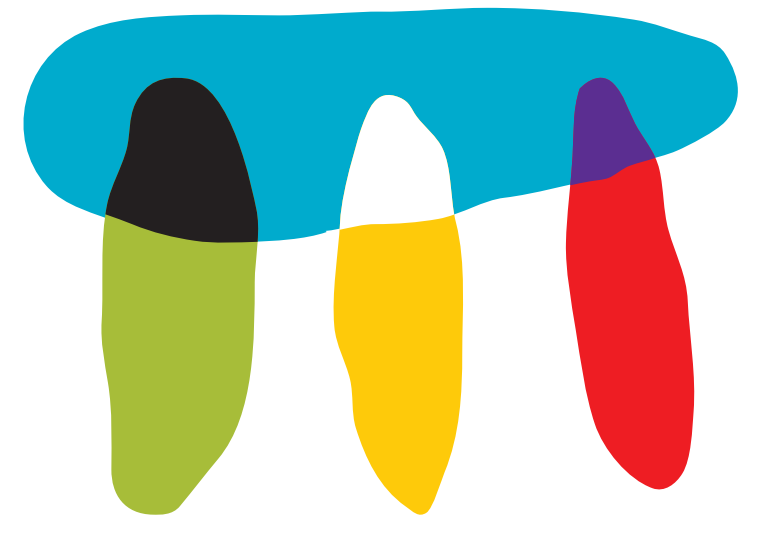

iV EnCONTRO PAulista QUESTÕES INDÍGENAS e Museus

V Seminário Museus, IDENTIDADES E PATRIMÔNIO CULTURAL

Governo do Estado de São Paulo Secretaria da Cultura

\section{ACAM Portinari}

Universidade de São Paulo

Museu de Arqueologia e Etnologia

COLEÇÃO MUSEU ABERTO

\section{DIREITOS INDÍGENAS} NO MUSEU

Novos procedimentos para uma nova política: a gestão de acervos em discussão 


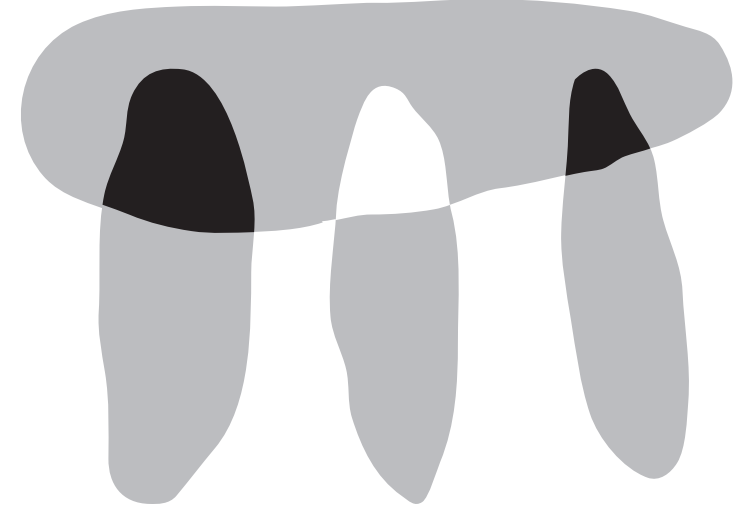

IV ENCONTRO PAULISTA QUESTÕES INDÍGENAS

e Museus

V Seminário Museus, IDENTIDADES E PATRIMÔNIO CULTURAL

Marília Xavier Cury

\section{Organizadora}

Governo do Estado de São Paulo Secretaria da Cultura

ACAM Portinari

Universidade de São Paulo

Museu de Arqueologia e Etnologia

São Paulo e Brodowski

2016

COLEÇÃO MUSEU ABERTO

DOI : $10.11606 / 9788563566201$

\section{DIREITOS INDÍGENAS \\ NO MUSEU}

Novos procedimentos

para uma nova

política: a gestão

de acervos em

discussão 
Ficha catalográfica

Direitos indígenas no Museu : novos procedimentos para uma nova política : a gestão de acervos em discussão /

Marília Xavier Cury, organizadora. -- São Paulo: Secretaria da Cultura : ACAM Portinari : Museu de Arqueologia e Etnologia da Universidade de São Paulo, 2016.

248 p. ; il. color. -- (Coleção Museu Aberto).

ISBN: $978-85-63566-20-1$

DOI : $10.11606 / 9788563566201$

1. Etnologia indígena - Museus. 2. Museus etnológicos. I. Cury, Marília Xavier. II. São Paulo (Estado). Secretaria da Cultura. III. ACAM Portinari. IV. Universidade de São Paulo. Museu de Arqueologia e Etnologia. 
DIREITOS INDÍGENAS NO MUSEU

Novos procedimentos para uma nova política:

a gestão de acervos em discussão 


\section{Sumário}

\author{
Apresentação \\ Secretaria da Cultura do Estado \\ de São Paulo
}

ACAM Portinari

Museu de Arqueologia e Etnologia da Universidade de São Paulo

Introdução

Direitos indígenas no museu - Novos procedimentos para uma nova política: a gestão de acervos em discussão

$$
\text { Marilia Xavier Cury }
$$

Memória indígena: um desafio para os museus paulistas

$$
\text { Davidson Panis Kaseker }
$$

Representação fonográfica e curadoria sonora: notas sobre dialogia e desentendimento Edmundo Pereira

Desafios da plena efetividade dos direitos culturais e os instrumentos de proteção dos saberes e práticas tradicionais dos povos indígenas brasileiros Robson Rodrigues

e Grasiela Lima

Desenvolvimento e gestão das coleções etnográficas do Museu do Índio: 1942 aos dias de hoje

Ione Helena Pereira Couto 
A coleção etnográfica do Museu Goeldi e os povos indígenas: desafios contemporâneos

$$
\begin{aligned}
& \text { Suzana Primo dos Santos } \\
& \text { e Claudia Leonor López Garcés }
\end{aligned}
$$

A participação indígena no Museu de Arqueologia e Etnologia da Universidade Federal de Santa Catarina Viviane Wermelinger Guimarães

Museu Professor Roberto Baruzzi - Escola Paulista de Medicina, Projeto Xingu da Universidade Federal de São Paulo Leandro da Cruz Silva

0 Museu Regional de Arqueologia de Rondônia e os desafios da diversidade cultural no presente Maurício André da Silva

104

A arqueologia e o patrimônio arqueológico indígena em exposições museais no Centro-0este de São Paulo e Norte do Paraná

Leilane Patrícia de Lima

A curadoria da coleção Asurini do Xingu no Wel tMuseum Wien

Fabíola Andréa Silva

A fotorreportagem como projeto etnocida: 0 caso da índia Diacuí na revista o Cruzeiro Helouise Costa

Leituras visuais da criança indígena: uma abordagem para além da estética e do racismo Josué Carvalho

Museus e indígenas - novos procedimentos para uma nova política: a gestão de acervos em discussão Juliana Dal Ponte Tiveron e José F. M. Henriques Bairrão
Xamanismo indígena e cultura brasileira Laércio Fidelis Dias

Museu Kaingang, Krenak e Terena: o problema da temática do concreto na exposição indígena museográfica

Niminon Suzel Pinheiro

Meruri 2015: do território cultural ao território dos entraves morais Aramis Luis Silva

"0 passado vai tá sempre na frente do presente": museus indígenas em rede, etnografia em processo

Alexandre Oliveira Gomes

Politique, représentation et dialogue aux Musées de la Civilisation: Premiers Peuples et muséologie autochtone au Québec Jean Tanguay

Tradução

Política, representação e diálogo: nos Museus da Civilização: Primeiros Povos e museologia indígena no Québec Jean Tanguay

ANEXO

Memória do IV Encontro Paulista Questões Indígenas e Museus e V Seminário Museus, Identidades e Patrimônios Culturais

Créditos 


8 


\section{Apresentação}

Secretaria da Cultura do Estado de São Paulo
0 artigo 216 da Constituição Federal defende a memória dos diferentes grupos formadores da sociedade brasileira como um patrimônio cultural nacional. Com a mesma legitimidade, o Programa Nacional de Direitos Humanos (PNDH-3) reconhece expressamente o direito à memória histórica como pilar fundamental para "afirmar a importância da memória e da verdade como princípios históricos dos Direitos Humanos", responsáveis tanto pela "construção da identidade social e cultural de um povo" como pela "formulação de pactos que assegurem a não repetição de violações de Direitos Humanos, rotineiras em todas as ditaduras".

Em consonância com a defesa da dignidade humana, portanto, não se trata somente de pugnar pela garantia e promoção dos direitos dos povos indígenas enquanto cidadãos, ou mesmo pela reparação das violências já apuradas, há também que propugnar igualmente pelo direito à memória indígena. 0 primeiro passo é admitir que o direito à memória não constitui um discurso homogêneo, não é sinônimo de consenso, não se reduz a si mesmo, nem se refere a direitos aprisionados num tempo e num espaço geográfico.

No âmbito das políticas públicas da Secretaria da Cultura do Estado de São Paulo, o direito à memória indígena e à preservação e difusão do patrimônio cultural das etnias Kaingang e Krenak tem sido sistemática e exemplarmente garantido pelo Museu Índia Vanuíre, localizado em Tupã (SP) e gerido em parceria com a ACAM Portinari. Entre as ações realizadas destacam-se o IV Encontro Paulista Questões Indígenas e Museus (EPQIM) e - V Seminário Museus, Identidades e Patrimônio Cultural, realizado em 2015, em parceria com
- Museu de Arqueologia e Etnologia (MAE-USP) e com o apoio da Fapesp e da Capes, que viabilizou a participação de pesquisadores de diversas universidades brasileiras. A temática "Direitos Indígenas no Museu - Novos Procedimentos para uma Nova Política: a gestão de acervos em discussão" denota o enfrentamento da discriminação e da desigualdade com que esses povos foram historicamente tratados.

Cabe ressaltar, ainda, que além da exposição temporária "Fortalecimento da Memória Tradicional Kaingang - De Geração em Geração", composta por uma autonarrativa, e uma apresentação cultural do grupo Kaingang da T.I. Vanuíre, localizada em Arco-Íris (SP), a programação dos eventos contou com um encontro de professores-pesquisadores indígenas do Oeste de São Paulo.

A publicação dos anais deste EPQIM e do Seminário, por consequência, mais uma vez se reveste de grande significado, ampliando o alcance das reflexões desenvolvidas por palestrantes nacionais e internacionais que contribuíram para a discussão dos direitos indígenas relacionados ao papel das instituições de memória, mas, sobretudo porque dá voz à causa indígena também por meio de seus próprios representantes. 


\section{Apresentação}

Associação Cultural de Apoio ao Museu Casa de Portinari

É uma alegria e uma honra para a ACAM Portinari - Associação Cultural de Apoio ao Museu Casa de Portinari, na qualidade de Organização Social de Cultura parceira da Secretaria da Cultura do Estado de São Paulo na gestão do Museu Histórico e Pedagógico Índia Vanuíre, ver assegurada a realização do IV Encontro Paulista Questões Indígenas e Museus e do V Seminário Museus, Identidade e Patrimônio Cultural, em parceria com o MAE-USP - Museu de Arqueologia e Etnologia da Universidade de São Paulo e apoio Capes e Fapesp.

A cada edição, se fortalece e consolida o compromisso e o propósito central do Encontro e do Seminário em torno do debate e reflexão das questões inerentes às culturas indígenas em suas relações com os museus na atualidade e, o que é mais importante, se mantém uma perspectiva plural e ética que reúne profissionais, pesquisadores das várias áreas de museus, indígenas, professores e estudantes.

Saudamos de forma especial a participação nesta edição dos “Musées de la civilisation" de Québec, cuja parceria enriquecerá o intercâmbio de informações e experiências, possibilitando conhecer outras realidades e os pontos em comum nas agendas das relações e políticas para povos indígenas.

Momentos como este, de compartilhamento e troca de conhecimentos e experiências sob diferentes olhares e dinâmicas, paradoxalmente, servem tanto para acalmar como para suscitar as inquietações que necessária e inevitavelmente permeiam o desafio e o encantamento de pensar e fazer museu num cenário de múltiplas relações e contínuas mudanças. Daí serem extremamente enriquecedores, mobilizadores e bem-vindos!
Bem-vindos em especial nesta edição, que trata de temas fundamentais na pauta dos museus que se relacionam com grupos indígenas presentes no seu entorno e possuem coleções que os representam e a outras etnias. Relações permeadas sobretudo por questões éticas, nas quais o diálogo tem se configurado como essencial, dados os múltiplos atores e as diferentes dinâmicas presentes nos processos de trabalho e as novas questões que vão resultando dessas novas vivências e experiências pessoais, coletivas e institucionais.

A ACAM Portinari considera muito oportuno que este museu seja o cenário dessas reflexões, tendo em vista o trabalho que vem sendo realizado na instituição a partir de uma reestruturação e implementação de políticas institucionais que contribuem para a preservação, pesquisa, valorização e difusão das culturas e saberes indígenas, bem como para a proteção de autorias e imagens, tanto pessoais quanto coletivas, que na prática se configura como um grande desafio e oportunidade de aprofundamento do diálogo, respeitando direitos e limites acordados entre as partes.

Assim, a cooperação, a parceria, o diálogo entre os diferentes, as reflexões e as trocas de experiências sob a ótica de múltiplos e enriquecedores olhares são o melhor caminho para a construção contínua das relações que se desdobram atualmente no trabalho realizado no Museu Índia Vanuíre, com ênfase no seu papel e relevância social. Apoio ao Museu Casa de Portinari (ACAM Portinari) 


\section{Apresentação}

Museu de Arqueologia e Etnologia da Universidade de São Paulo

A gestão museológica, em sua estreita e necessária interlocução entre premissas conceituais e experiências técnicas, transita em direção ao amadurecimento dos processos museológicos. Esse trânsito é permeado por tradições e inovações, mas também por dilemas éticos e contextos socioeconômicos que ora privilegiam os museus, ora os abandonam à própria sorte.

Entretanto, é possível identificar que o enfrentamento desses dilemas tem permitido a aproximação entre diversos campos de conhecimento e o entrelaçamento de práticas originárias dos diferentes segmentos profissionais. É o que aproxima as instituições museológicas das sociedades com base nos resultados dos procedimentos de salvaguarda e comunicação dedicados aos acervos e aos conteúdos que estão sob o controle dos museus. Mas esses mesmos dilemas também podem ser permeados por intransigências e ausência de percepção sobre a diversidade cultural.

De toda forma, no cotidiano dos museus - as minúcias técnicas que envolvem os trabalhos com os acervos em toda a cadeia operatória curatorial e o acolhimento do público no amplo e multifacetado cenário de desafios socioculturais -, a perspectiva da gestão se coloca como premissa essencial para a consolidação das instituições.

No âmbito das rotas que sustentam a gestão museológica, no que tange às expressões culturais e aos indicadores da memória indígena, podemos identificar na contemporaneidade dilemas cruciais para a melhor interpretação e preservação desses acervos e dessas manifestações culturais. Esse é o enredo e o comprometimento desta publicação, que reúne um conjunto expressivo e diversificado de trabalhos que problematizam aspectos pontuais das ações museográficas, para além de abordagens conceituais, éticas e políticas.

Para o Museu de Arqueologia e Etnologia da Universidade de São Paulo (MAE-USP) esses dilemas são cotidianos, e paulatinamente a instituição tem procurado aplicar novas condutas em seus procedimentos de gestão museológica mas, em especial, tem buscado também discutir e problematizar as práticas correntes com o propósito de dar protagonismo a esses problemas no cenário das interrogações que têm povoado os embates museológicos. Em especial, procuramos que esse protagonismo conte com a participação direta das sociedades indígenas.

0 compartilhamento institucional que experimentamos para a produção desta publicação, precedido por outras ações acadêmicas congêneres, só vem enriquecer nossas estratégias de gestão para o MAE. Temos a certeza de que esta obra terá repercussões importantes para os enfrentamentos museológicos que entrelaçam os museus com as sociedades indígenas.

Maria Cristina Oliveira Bruno

Diretora do Museu de Arqueologia e Etnologia da Universidade de São Paulo (MAE-USP) 


\title{
Direitos indígenas no museu - Novos procedimentos para uma nova política: a gestão de acervos em discussão - Introdução
}

\author{
Marília Xavier Cury \\ Museu de Arqueologia e Etnologia, Universidade de São Paulo (MAE-USP)
}

Há um descompasso entre a museologia e a museografia que precisamos corrigir. Os museus que lidam com objetos indígenas, como o Museu de Arqueologia e Etnologia da Universidade de São Paulo (MAE-USP) e o Museu Histórico e Pedagógico Índia Vanuíre, podem, em grande medida, fazer essa correção, sobretudo se a parceria universidade e poder público se estabelecer. A museologia preconiza, sobretudo após o Maio de 1968 e o movimento da nova museologia, uma relação com a sociedade diferente da anterior, passando a incorporar o público no museu como elemento constitutivo da instituição, abrindose para participações na elaboração de políticas institucionais e de acervo e nas formas de aquisição, de elaboração de discursos e narrativas e de abordagens que vão além da visão dos especialistas de campos disciplinares. Na atualidade podemos, sem correr riscos, a depender do caráter e do modelo de instituição, ter segmentos da sociedade atuando nas instituições museais de modo a transformá-las. Nesse sentido, muitos museus têm sua conceituação fundamentada na atuação direta de frações culturais e/ou segmentações sociais. Os indígenas, nesse sentido, vêm cada vez mais participando de processos museais, ora requalificando coleções outrora formadas por antropólogos, ora elaborando autonarrativas a serem comunicadas por meio de exposições ou outras estratégias. Ainda na linha de intervenção direta, os indígenas formam coleções, informam sobre elas para pesquisadores e documentalistas e, não raro, restauram artefatos, dentre outras intervenções. De outra parte, cada vez mais as equipes de museus (é o caso do Museu Índia Vanuíre e do MAE-USP) vêm interagindo com os indígenas em suas aldeias e/ ou terras homologadas, participando do cotidiano e/ou de momentos festivos, realizando ações e gerando registros a serem integrados nos museus como elementos de acervo.

Há um nível de entendimento mútuo que permite que essa atuação participativa ou conjunta aconteça com o consentimento dos indígenas, considerando as mais diversas formas de registros (sonoros, visuais, escritos, artefatuais) que, levados ao museu, devem passar por um controle documental, aqui considerado como um "termo contratual", um acordo escrito enfim, a ser firmado pelas partes envolvidas, a saber: museu, lideranças e/ou representações indígenas, indígenas e seus pais, quando menores são envolvidos, iletrados ou analfabetos funcionais. A museografia não está preparada para acompanhar esse processo de formação, aquisição e entrada de acervo, dada a situação dos envolvidos - indígenas que vêm sofrendo expropriações de seus lugares sagrados, de seu modo de vida, de sua cultura e saberes por mais de cinco séculos. Isso acontece até hoje em diferentes níveis e planos na sociedade brasileira.

Temos exemplos do que queremos alterar. Os manuais de documentação museológica orientam que:

1. No que se refere à musealização:

a) Na visão sobre a biografia do objeto - "Assim, o objeto passa a ser descrito sob duas circunstâncias: sua vida útil antes de fazer parte do museu e depois, quando ganha novos usos e sentidos dentro do espaço de salvaguarda" (Padilha, 2014, p. 20)

b) $\mathrm{Na}$ visão sobre procedimentos de gestão - "Assim, ao ingressar no museu, um objeto 
passará por um processo de musealização, ou seja, ele deixará de ter uma função cotidiana e passará a ter uma função simbólica. Na prática, isso significa que, inicialmente, ele será avaliado por uma comissão que deverá decidir se deve - ou não - fazer parte da coleção. (Bottallo, 2010, p. 53)

2. No que se refere ao status de objeto museológico:

Uma vez selecionado, interpretado, registrado, organizado e armazenado, o objeto museológico torna-se patrimônio cultural. Essas ações são as que dão intencionalmente valor documental, patrimonial e informacional a ele, tornando-o um documento. (Padilha, 2014, p. 20)

3. No que se refere ao uso do objeto no museu:

Para tais definições [sobre aquisição e descarte de objetos museológicos], é necessário o reconhecimento do objeto ou da coleção com a finalidade e a missão do museu que pretende incorporá-lo. Cabe ressaltar que o objeto ou a coleção não devem ter condições e nem restrições para sua utilização, pois, uma vez acervo museológico, seu acesso deve ser permitido ao público em geral. (Padilha, 2014, p.26)

Não visamos fazer a crítica aos manuais. Eles têm uma importante função a cumprir, baseiamse na legislação e éticas vigentes ${ }^{1}$ e buscam a normalização de ações de salvaguarda dentro dos museus. 0 que se coloca em evidência é que a presença indígena no Brasil e no estado de São Paulo ainda não chegou aos museus da forma como propomos atualizar e, por isso, não impactou a museografia. ${ }^{2}$ Esses manuais, corretamente, embora parcialmente, fazem uma abordagem considerando experiências com determinada

1. Código de Ética para Museus do Conselho Internacional de Museus (Icom), legislação profissional do Conselho Federal de Museologia (Cofem), Estatuto Brasileiro de Museus.

2. Sobre questionamentos acerca do "lugar do índio no museu", ver Cury e Vasconcellos 2012. natureza de objetos e coleções e com as mais diversas formas de aquisição, considerando os usos futuros dos objetos e informações sobre eles pela instituição. Nesse sentido, baseiam-se em normas estabelecidas e seguidas por profissionais de museus brasileiros e do mundo em elaboração há anos, mas a atualização depende, a meu ver, não de uma evolução, mas de uma transformação, acompanhando a Museologia. A questão em pauta é que a normativa atual, no plano museográfico, não se amolda aos processos de musealização relacionados às culturas indígenas (como também em outros não tratados neste texto) e aqui a Museologia se faz necessária, nas suas diversas vertentes, tais como a Museologia Social, a Museologia Crítica e a Museologia Indígena. Não queremos que as culturas indígenas sejam tratadas pelos museus tradicionais como exceções, mas como especificidades e diferenças baseadas na ideia de contrapúblico: não somos iguais, logo, devemos ter direitos distintos. 0 museu pode fazer isso.

Vamos retornar aos itens citados, problematizando-os em face do processo participativo que engendramos. 0 marco entre a vida do objeto e os novos sentidos adquiridos no museu, dentre eles e especialmente o simbólico, o antes e o depois do ingresso no museu para as culturas indígenas deve ser relativizado. Por exemplo, o objeto doado ao museu por indígenas - ou seja, escolhido por ele para ser preservado pelo seu caráter patrimonial - já tem um valor simbólico atribuído que não se perde, como se na passagem ao museu o objeto fosse destituído de seus valores essenciais definidos anteriormente por uma coletividade e, ainda, esvaziado politicamente em termos da sua escolha para a musealização. Não raramente, certos simbolismos relacionados ao sagrado somente são percebidos e vividos por alguns indígenas, o que impõe um reconhecimento e respeito pelo museu. E porque há uma seleção prévia feita pelos indígenas a respeito do que é importante estar no museu, qualquer comissão de avaliação, que deve existir, deverá considerar as escolhas indígenas, mesmo que haja controvérsias geradas por outros pontos de vistas, inclusive os acadêmicos. 0 caráter de patrimônio cultural é também deveras problemático, posto que todo objeto indígena é, antes de tudo, um patrimônio 
indígena. O quanto abrangências e generalizações (patrimônio nacional e da humanidade, por exemplo) podem sobrepor o direito indígena a ter os seus patrimônios demarcados como tal? Os museus tradicionais estão atuando nos devidos esclarecimentos aos indígenas sobre essa questão? Estão propondo outras e diferenciadas formas de participação indígena nos processos curatoriais? Quanto ao uso e acesso do objeto pelo museu, no caso das culturas indígenas, devem-se prever condições e restrições a serem discutidas e estabelecidas com os indígenas para cada caso ou situação, o que pode comprometer o acesso ao público em geral, entendendo acessos a públicos especificados.

0 que afirmamos e o que queremos debater é como os museus estão preparados e o que devem considerar para uma política institucional e de gestão de acervo contemporâneas, que respeitem os direitos indígenas de musealizar aspectos da sua cultura para as futuras gerações indígenas, inclusive de pajés, e não indígenas, e que também aceitem a maneira como querem dialogar com os profissionais de museus e com a sociedade da qual fazem parte. Como pano de fundo temos o papel contemporâneo dos museus e a definição de procedimentos que garantam no presente e no futuro os direitos indígenas.

\section{Abordagem}

Devemos fazer a consulta aos povos indígenas; não há outro caminho para a construção de políticas de gestão de acervo que se propõe. Os museus isoladamente não encontrarão o caminho e a metodologia para um novo modelo de gestão de acervo que respeite os direitos indígenas sem esse diálogo estabelecido. Somente com a ação recíproca entre o museu e os grupos indígenas a museografia acompanhará os passos da museologia, na circunstância colocada. Neste ponto chegamos a outra questão essencial - a ética. Se os direitos estão garantidos pela Constituição Brasileira, a aplicação da legislação não garante a correção nesse sentido. Igualmente comprometidos com o diálogo com os índios, precisamos construir uma "nova ética", uma vez que a vigente não dá conta de novos paradigmas museológicos e museais. Este é o maior desafio que encontramos no momento.

A relação mantida pelo Museu Índia Vanuíre em cooperação com o Museu de Arqueologia e Etnologia da USP com os indígenas no Oeste de São Paulo é a base para um debate a ser aprofundado, transcendendo as boas relações estabelecidas, entendendo um acordo tácito de ação mútua, dirigindo-se para a construção de mecanismos que intervenham na política institucional e de gestão de acervo, alcançando todos os níveis da ação do Museu Índia Vanuíre, contribuindo com o debate ético a ser levado a cabo por um coletivo formado por profissionais de museus e indígenas.

A abordagem proposta, então, abrange:

- pesquisa em aldeias e/ou terras indígenas e os retornos aos indígenas dos resultados, considerando diversas estratégias;

- coleta de material para o museu (formação de acervo contemporâneo), a normalização e procedimentos de documentação museológica, respeitando-se os anseios dos indígenas no que se refere ao fortalecimento de suas culturas e as formas de apoio que o museu pode oferecer;

- direitos da personalidade;

- direito à imagem;

- direito autoral individual e coletivo;

- uso e acesso de materiais indígenas no museu e pelo museu, o que deve ser definido caso a caso e com os indígenas; e

- anseios e estratégias dos indígenas para a musealização de seus patrimônios, considerando aquilo que querem que integre o museu e as razões que os levaram a essa forma de musealizar (pelos museus tradicionais) e não a outras (museus indígenas).

Há duas questões que devemos explicitar. A primeira envolve a relação dos indígenas com pesquisadores (da antropologia, arqueologia, museologia, psicologia, educação, saúde e outras 
áreas): como são procurados e abordados, como entendem a sua colaboração na pesquisa e a pesquisa em si e como recebem, quando acontece, o retorno dos resultados das pesquisas realizadas. As áreas têm, certamente, seus códigos de ética e protocolos de pesquisa, mas a visão dos indígenas sobre os processos de pesquisa vai além. Por outro lado, os indígenas hoje têm anseios quanto às diversas formas de construção de autonarrativas - em outros termos, querem falar por si. Outra questão refere-se à legislação, que reconhecemos como apoio aos objetivos propostos. O novo Código Civil Brasileiro, de 2002, trata dos direitos da personalidade em capítulo próprio, do artigo 11 ao 21. Dentre os direitos da personalidade está o direito à imagem, no capítulo II (Dos direitos da personalidade), artigo 20 :

Salvo se autorizadas, ou se necessárias à administração da justiça ou à manutenção da ordem pública, a divulgação de escritos, a transmissão da palavra, ou a publicação, a exposição ou a utilização da imagem de uma pessoa poderão ser proibidas, a seu requerimento e sem prejuízo da indenização que couber, se lhe atingirem a honra, a boa fama ou a respeitabilidade, ou se se destinarem a fins comerciais.

Outro aspecto relevante: direito autoral. 0 direito autoral é relativo à criação, tendo o autor direito de decidir como a criação ou obra será usada. A proteção ao direito autoral se dá pela Lei 9.610 de 1998. Essa legislação, pelo art. 5², inciso VIII, alínea b, não se ajusta, no entanto, ao direito autoral coletivo, como é o caso dos povos indígenas. Não podendo identificar os autores, a lei tratará de autoria anônima, deixando a criação desprotegida. Outra visão enquadra o patrimônio coletivo indígena como obra de folclore, ou seja, “de domínio público, podendo ser livremente utilizado por qualquer pessoa sem necessidade de autorização de ninguém, sem qualquer tipo de remuneração" (Baptista; Valle, 2004, p.19). Contrariando essas posições sobrepõese a Constituição Federal, que reconhece aos índios o direito ao seu patrimônio material e imaterial e a suas formas de organização, tradições e crenças e outros interesses coletivos, cabendo ao Estado o dever de zelar por esse direito. E por existir a possibilidade de identificação de autoria, mesmo que coletiva e relativa a um povo, ao contrário do folclore, a lei de direitos autorais distancia os conhecimentos étnicos e tradicionais do folclore e do domínio público (art. 45, inciso II), protegendo-os, embora na prática a autoria coletiva encontra-se num entrave de entendimento e de aplicação legal e jurídica.

Assim, os indígenas têm seus direitos de personalidade e de imagem resguardados (apesar das limitações na interpretação do direito coletivo) e o controle do uso da sua imagem, compreendendo a representação fiel ou da sua aparência por meio de fotografias, retratos, pinturas, desenhos, gravuras e outras formas plásticas, caricaturas e elementos de decoração, ainda compreendendo manequins, máscaras, imagem sonora e gestual e outras formas de expressão da personalidade. Têm, também, seus direitos autorais individuais ou coletivos garantidos pela Constituição e pela lei de direitos autorais, embora os casos específicos mereçam atenção.

Esse debate com aspiração a alterar o "estado da arte" da gestão museal no que concerne à política de gestão de acervo tem antecedentes. O Museu do Índio, em 2013, elaborou um documento sobre essa questão, resultado de uma discussão. Dentre vários pontos, tal documento salienta:

- 0 interesse dos índios por seus acervos documentais e culturais impõe uma nova agenda para as instituições públicas de repensar sua relação com os povos indígenas, a partir de demandas para a identificação, reunião e recuperação e acesso a acervos constituídos no passado, depositados em inúmeras instituições, constituindo fundos de referência para a preservação cultural indígena.

- 0 registro e a documentação cultural, com o uso de diferentes tecnologias, colocam a questão da necessidade de estabelecer critérios sobre o que guardar e para que guardar, bem como levantam a questão do direito de uso das informações e imagens coletadas no passado e no presente. (Museu do Índio, 2013, p.3)

Entre os direitos que reconhecemos e os entendimentos dos indígenas, há a formalidade 
dos museus que deve ser estruturada, visto que se trata também de formas de proteção, seja dos indígenas, dos profissionais envolvidos, das relações entre eles e da instituição que se coloca comprometida com uma função social. Embora a práxis nos apresente muitas dificuldades para que essa concepção política reverta em mudanças de gestões, tecnológicas, procedimentais e técnicas, uma mudança de cultura institucional deve chegar aos museus, isso está assinalado. Mas a questão de fundo é outra: a ética. Para essa "nova ética" há muita discussão a ser travada a partir de ações realizadas.

\section{A práxis e as discussões}

0 IV Encontro Paulista Questões Indígenas e Museus realizado em 2015 com o V Seminário Museus, Identidades e Patrimônios Culturais propôs o enfrentamento da relação entre os museus e os indígenas, destacando a centralidade das instituições museais no processo de incorporação de novas práticas, para a consideração das contribuições das culturas indígenas na formação da cultura brasileira, como também para tratar as culturas indígenas como produções de saberes a serem respeitados nas suas especificidades, complexidades e peculiaridades.

A edição anterior dos eventos debateu o início da construção de uma ética a partir das relações e do trabalho conjunto entre os grupos indígenas presentes na região Oeste do estado de São Paulo - Kaingang, Krenak, Terena e Guarani, das T.I. Icatu (Braúna) e Vanuíre (Arco-Íris) e, recentemente, da T.I. Araribá (Avaí) -, o Museu Índia Vanuíre e o Museu de Arqueologia e Etnologia da USP (MAE-USP). Temos como marco o ano de 2010 e a participação dos Kaingang e Krenak da T.I. Vanuíre no processo expográfico cooperativo (ou colaborativo) para o módulo Aldeia Indígena Vanuíre da exposição de longa duração Tupã Plural, inaugurada nesse ano no Museu Índia Vanuíre. O referido módulo expositivo possibilitou que as necessidades desses grupos fossem atendidas pela participação antes não contemplada pelo Museu. A cooperação permitiu a construção da narrativa baseada no processo de expropriação, sofrimento, "resgate" das culturas e, como consequência, com o fortalecimento cultural e identitário. Desde então, diversas ações vêm sendo realizadas pelo Museu Índia Vanuíre, muitas vezes em conjunto com o MAE-USP por meio de convênio firmado entre as partes, cada uma com suas problematizações, desafios e conquistas. Os eventos em pauta funcionam como fechamento de trabalhos com reflexões. Os temas tratados pelos eventos até a presente data foram:

- 2012 - Questões indígenas e museus Debates e possibilidades: ${ }^{3}$

- 2013 - Questões indígenas e museus Enfoque regional para debate museológico; ${ }^{4}$

- 2014 - Museus e indígenas - Saberes e ética, novos paradigmas em debate; ${ }^{5}$

- 2015 - Direitos indígenas no museu - Novos procedimentos para uma nova política: a gestão de acervos em discussão; e

- 2016 - Museus etnográficos e Museu indígenas - Diálogo e diferenciação.

O panorama atual dessa relação densa e intensa - na qual o Museu Índia Vanuíre e o MAE-USP se colocam como provocadores e articuladores, papel que assumem como atores comprometidos - nos leva a avanços que, no momento, referem-se a formalidades quanto à gestão de acervo. Em outros termos, os dois museus vêm atuando diretamente com os grupos indígenas presentes no Oeste de São Paulo e essas vivências geram a coleta de materiais, informações e conhecimentos, muitas vezes registrados em áudio, vídeo e fotografias. Esses registros integram, a priori, o acervo do Museu Índia Vanuíre. Aqui se coloca a questão da política de gestão de acervo da instituição e do que entendemos como tecnologias e procedimentos

3. Foi organizada uma coletânea a partir desse tema organizada por Marília Xavier Cury, Camilo de Mello Vasconcellos e Joana Montero Ortiz, Questões Indígenas e Museus - Debates e Possibilidades. Brodowski: ACAM Portinari; MAE-USP; SEC, 2012.

4. Ver coletânea organizada por M. X. Cury, Questões indígenas e museus - Enfoque regional para debate museológico, Brodowski: ACAM Portinari; MAE-USP; SEC, 2015.

5. Ver coletânea organizada por M. X. Cury, Museus e indígenas - Saberes e ética, novos paradigmas em debate, Brodowski: ACAM Portinari; MAE-USP; SEC, 2016. 
para coleta, entrada, inserção institucional, uso e acesso. No momento, não temos orientações a seguir oriundas de políticas culturais ou códigos de ética que apoiem as necessidades de um museu e os anseios dos indígenas. Dessa forma, temos o desafio de conceituar e encontrar caminhos metodológicos e procedimentais para que as culturas e os saberes indígenas, assim como o indígena individual, em grupo e/ou coletivamente, tenham suas autorias, imagens e personalidades preservadas pelo museu e nos espaços do museu, resguardando seus desejos atuais e motivações para as futuras gerações de indígenas e de profissionais que atuem nas instituições envolvidas, considerando o caráter de permanência dos museus. É nesse sentido que as instituições envolvidas organizam anualmente eventos, para problematizar as ações e processos engendrados com os indígenas da localidade. Para o ano de 2015 estabelecemos, então, os seguintes objetivos, que retomamos pois relacionam-se com este livro:

1) Discutir aspectos relativos à aquisição de coleções indígenas que venham a colaborar com a formulação de políticas públicas e institucionais:

2) Apontar procedimentos para a gestão documental de coleções oriundas de grupos indígenas contemporâneos;

3) Ver formas de correção e atualização de documentação de outros momentos passados; e

4) Rediscutir a representação dos indígenas em exposições.

Os objetivos aqui expostos tiveram o propósito de fomentar um debate entre profissionais de museus, antropólogos e indígenas no 0este de São Paulo e outros interessados. Tais objetivos foram alcançados a partir dessas participações, levando-se em consideração que há antigos procedimentos a serem superados, assim como aspectos que comprometem as relações entre indígenas e não indígenas quanto ao uso de conhecimento em pesquisas, exposições e tantas outras formas de comunicação, como materiais de educação, veiculação por site institucional e redes sociais e outras estratégias de divulgação que exploram logotipos e elementos gráficos tão utilizados pela comunicação social por causa de sua visualidade.

A legislação e os códigos de ética atuais relativos à museologia e aos museus não respondem a todas as nossas dúvidas e inquietações sobre direitos da personalidade, de imagem e autorais para os indígenas no intuito de sustentar as ações museais, mas há proteção ao patrimônio material e imaterial no ordenamento jurídico brasileiro. No entanto, há lacunas a serem preenchidas pelos intérpretes do Direito, posto, sobretudo, que o que se aplica à sociedade nacional não se enquadra às questões indígenas (Baptista; Valle, 2004, p.55), o que está avançando, reconhecemos.

Nos museus, a ausência de legislação específica e normativa se torna preocupante para aqueles que se dedicam cotidianamente à musealização das culturas indígenas, os próprios índios e profissionais de museus. Apesar de lacunas ou ausência de suporte legal ou ético atualizado, - museu deve buscar a regularização da tomada de registros e da entrada desses nos museus, assim como construir uma normalização para o sistema documental da instituição, para avançar na relação entre museologia e museografia, museu e culturas indígenas.

É exatamente no ponto de cruzamento entre "o que" e "como" deve ser feito, as interpretações possíveis (nem sempre cabíveis ao museu) e as impossibilidades de fundamentos que os eventos IV Encontro Paulista Questões Indígenas e Museus e V Seminário Museus, Identidades e Patrimônios Culturais se colocaram. Foram discutidos direitos da personalidade, autoral e de imagem para os povos indígenas na relação com os museus.

Entendemos que, com isso, avançaremos não somente no debate, mas na prática museal, intervindo possivelmente em outras esferas de atuação da preservação e comunicação patrimonial nas quais os índios participam e são respeitados.

Com essas questões em pauta é que organizamos o livro que ora apresentamos, a partir de convites a autores que pudessem contribuir com suas práxis e reflexões. 


\section{Apresentação dos autores - a obra}

Recebidos os artigos dos convidados a compor este livro e considerando a diversidade de contribuições, a sequência dos textos seguiu o critério "da perspectiva maior à mais específica". Assim, e sem organizar a obra em partes, iniciamos com questões das políticas públicas, seguimos pela abordagem das práticas em museus e por estudos voltados à instituição museal como realidade empírica; detivemo-nos nas pesquisas de coleções e/ou que envolvem a cultura material ou a imaterialidade, incluindo métodos colaborativos e crítica ao discurso sobre os indígenas;

finalizamos com atenção aos museus indígenas pela visão de não indígenas.

No plano das políticas públicas, Davidson Kaseker traz para o livro a sua contribuição como agente do Sistema Estadual de Museus de São Paulo (Sisem-SP). 0 autor parte das transformações sofridas pelos museus no decorrer dos séculos e de uma visão histórica sobre a formação de museus etnográficos no Brasil, para tratar do patrimônio arqueológico e etnográfico em museus e, assim, chegar ao estado de São Paulo utilizando como entrada no tema a rede de museus históricos e pedagógicos (décadas de 1950 e 1970) e na discussão de como o indígena se fez presente (ou não) nessas instituições pelo acervo. Cabe salientar as diversas indagações colocadas pelo autor no fim de seu artigo, promovendo um debate maior e em rede.

A obra segue com o instigante artigo

"Representação fonográfica e curadoria sonora: notas sobre dialogia e desentendimento", autoria do antropólogo Edmundo Pereira, docente do renomado Museu Nacional da Universidade Federal do Rio de Janeiro, destacando, sobretudo, a liderança que os pesquisadores de museus universitários podem exercer em debates como este que o livro se propõe a promover. Os exemplos e as questões trazidos pelo professor são essenciais para a construção de novas visões e novas práticas.

A contribuição de Robson Rodrigues e Grasiela Lima retoma a importância do protagonismo dos indígenas no alcance de seus direitos, recolocando as questões centrais e reafirmando o papel das universidades e seus pesquisadores no debate.

No aspecto da prática em museus, a museografia que se coloca para viabilizar a musealização das coleções indígenas, Ione Pereira Couto nos apresenta no artigo "Desenvolvimento e gestão das coleções etnográficas do Museu do Índio: 1942 aos dias de hoje" a trajetória e soluções alcançadas pela instituição criada por Darcy Ribeiro para promover as culturas indígenas no Brasil. Organiza seu artigo desde as primeiras coleções formadas na década de 1940, o impacto da criação da Funai na década de 1970 , os novos rumos que a Constituição Federal de 1988 permitiu para que, então, levasse o leitor às questões de gestão de acervo e de comunicação pelas exposições que passam a revelar ainda mais a participação indígena nos processos museais, uma das marcas dessa instituição.

As práticas relacionadas às coleções do Museu Paraense Emílio Goeldi foram trazidas para este livro por Suzana Primo dos Santos e Claudia Leonor López Garcés em "A coleção etnográfica do Museu Goeldi e os povos indígenas: desafios contemporâneos". 0 título sugere que há um trabalho novo a fazer no que se refere à novas perspectivas, inserindo os indígenas nos processos museais. Suzana é uma Karipuna que trabalha em museu com objetos de seu povo e de outros, e o texto coloca reflexões baseadas nos "diálogos e interações" entre esse museu centenário e os povos indígenas, apontando para as transformações que a instituição museu deve promover em convergência com as demandas sociais no século XXI.

Se as transformações são necessárias para os museus etnográficos se atualizarem, Viviane Guimarães apresenta uma síntese da pesquisa que desenvolveu no artigo "A participação indígena no Museu de Arqueologia e Etnologia da Universidade Federal de Santa Catarina". Viviane aponta claramente um caminho pela participação indígena nos processos de curadoria de exposições. Relata a trajetória do referido museu universitário, particularizando as exposições realizadas, com destaque a duas delas desenvolvidas 
sob a metodologia cooperativa, envolvendo representantes dos povos Guarani, Kaingang, Xoklenk/Laklanõ e Ticuna.

Outras experiências museais são apresentadas. Leandro da Cruz Silva nos informa sobre um museu ainda pouco conhecido entre profissionais da museologia, o "Museu Professor Roberto Baruzzi - Escola Paulista de Medicina, Projeto Xingu da Universidade Federal de São Paulo". Pelo título do artigo já temos dados importantes para situar a instituição e inferir sobre o seu acervo e papel preservacionista. Com o olhar atento ao museu, Maurício André da Silva analisa as formas de enfrentamento de uma instituição de arqueologia em face da diversidade cultural da área onde se situa e como deve interagir com distintos atores sociais, um desafio dos museus de arqueologia no Brasil. No artigo “0 Museu Regional de Arqueologia de Rondônia e os desafios da diversidade cultural no presente" o autor traz à discussão alguns pontos de uma complexa realidade empírica: diversidade das populações pré-coloniais no confronto com a diversidade atual na região Amazônica - indígenas e migrantes -, visando à construção de memórias e interpretações sobre o patrimônio arqueológico. 0 museu referido foi fruto de necessidades locais, mas com formação de acervo peculiar, posto que os objetos arqueológicos foram coletados pelos cidadãos. A passagem desses objetos de espaços privados (casas etc.) para um espaço público (museu) foi o processo desencadeador de ação de comunicação entre os agentes envolvidos, trazendo novas questões e desafios à instituição criada, em especial a participação que o autor promoveu recorrendo à história oral.

Outra forma de destacar o papel do museu e suas formas de atuação refere-se aos estudos sobre instituições, para entendimento sobre suas formas de operar, estatuto conceitual e os discursos que sustenta. Leilane de Lima realiza pesquisa de pós-doutoramento em que se ocupa de investigar exposições museais, o que nos apresenta pelo artigo "A arqueologia e o patrimônio arqueológico indígena em exposições museais no CentroOeste de São Paulo e Norte do Paraná”. Não por acaso a pesquisadora escolheu o locus do estudo considerando os territórios Kaingang disputados durante o processo de colonização no início do século $X X$, o que resultou no aldeamento dos remanescentes e na exclusão cultural até a atualidade. 0 que a autora faz é nos apresentar dados que, apesar de preliminares, já revelam a pouca ocorrência do tema indígena nas instituições tratadas, assim como a baixa presença indígena nos museus dessas regiões paulista e paranaense.

No artigo "A curadoria da coleção Asurini do Xingu no WeltMuseum Wien", Fabíola Andréa Silva ressalta a importância de os indígenas saberem e conhecerem as coleções indígenas formadas no passado e guardadas em museus no mundo todo. No artigo relata experiência com a coleção Asurini formada em 1971 como ação do WeltMuseum Wien. Inicialmente lamenta o fato de os Asurini desconhecerem o destino das peças coletadas por Anton Lukesh e enfatiza a relevância delas como registro do modo de vida e da transformação sofrida por esse povo desde o contato na década de 1970. Ao contrário do colonialismo, a autora entende o papel do museu etnográfico como "locais de produção de conhecimento e um possível espaço de diálogo intercultural”. Nesse sentido, como escreve, há um processo colaborativo colocado em questão para que a participação dos Asurini se faça no processo de concepção de uma exposição. É surpreendente como os museus vêm trocando suas antigas práticas por novas, como o esforço com a “repatriação virtual dos objetos", para colocálos acessíveis aos Asurini. A autora discutirá com os Asurini constatações a que chegou ao estudar os 86 objetos no museu em Viena, seguindo a linha que adota há anos de curadoria compartilhada.

A mídia impressa e televisiva, para nos remetermos às mais "tradicionais", sempre atuou intensamente na construção da imagem do indígena no Brasil. A construção da imagem do Outro e das representações sociais acontece por um discurso de manutenção de uma hegemonia que se acentuou nas décadas de 1940 e 1950, quando emergem os meios de comunicação de massa. Pela visão de Helouise Costa temos instigante artigo que analisa a construção do discurso jornalístico da fotorreportagem que em muito se assemelha ao modelo da novela, pela imagem, seriação, e por 
atingir o gosto do público. Para tanto a autora recorre às fotorreportagens da revista O Cruzeiro entre 1952 e 1953, quando publicou a relação do sertanista Ayres Câmara Cunha com a índia Diacuí - romance impossível entre "branco e índia", "civilizados e selvagens", que superou obstáculos para concretizar noivado, casamento e o processo de aculturação da indígena. A história gerou um folhetim seguindo a fórmula de mobilização da temática indígena, dilemas, romance, dramaticidade e sensacionalismo, ao passo que condizia com o modelo desenvolvimentista que a revista ajudava a promover e explorava a imagem de uma indígena para favorecer aos interesses de Assis Chateaubriand e sua rede de comunicação. A análise sobre a narrativa jornalística com ênfase nas fotos é o que a autora nos apresenta criticamente em seu artigo "A fotorreportagem como projeto etnocida: 0 caso da índia Diacuí na revista O Cruzeiro".

Josué Carvalho, Kaingang nascido na Terra Indígena (T.I.) Nonoai, em Nonoai, Rio Grande do Sul, também se debruça sobre os usos da fotografia para nos trazer a sua reflexão por meio do artigo "Leituras visuais da criança indígena: uma abordagem para além da estética e do racismo". Inicia a discussão referindo-se à antropologia visual e a disseminação de imagens pela internet, para levar a discussão ao contexto museológico. Sua atenção recai sobre as crianças Kaingang e como vêm sendo fotografadas, e ele indaga: "Como na contemporaneidade os flashes fotográficos se inserem no universo da criança indígena e tecem leituras visuais sobre ela?". 0 que o autor coloca em discussão são as formas de representação da criança indígena e como impactam negativamente ao reforçar ainda mais estereótipos e preconceitos, levando sofrimento à criança na aldeia e fora dela.

Pelo viés da psicologia, os pesquisadores Juliana Tiveron e José Francisco Bairrão elaboraram o artigo “Museus e indígenas - Novos procedimentos para uma nova política: a gestão de acervos em discussão". O propósito dos autores, em especial a doutoranda Tiveron, é "comunicar uma reconciliação com a ideia de morte, por via da etnopsicologia”. 0 museu, assim, é “um espaço que apresenta mais expressamente os vestígios do morto, ou melhor, o próprio morto", indo além, sendo "um grande cemitério", e a "ousadia" dos autores está em "permitir que o morto seja escutado”, o que para a comunicação museológica é um viés instigante. Longe do preconceito sobre o museu, a aproximação com a ideia de morte impulsiona a política de gestão de acervo a voltar-se para o morto e o que ele diz. Os autores sugerem que o museu não deixe esquecer os guerreiros que morreram para defender os Kaingang, "trabalhar com a restituição dos nomes dos grandes líderes Kaingang, para homenageá-los, e reconhecermos os nomes Kaingang e os guerreiros que ainda estão do nosso lado". De fato, o artigo nos faz pensar, mas ilustra de maneira eficaz que os museus atingem o que outras instituições são incapazes de alcançar.

Ainda contribuindo com a visão interdisciplinar própria dos estudos museológicos, Laércio Fidelis Dias na visão da antropologia aborda "Xamanismo indígena e cultura brasileira". Para tanto, nos ajuda com conceituações sobre xamã, pajé, encantado e outras denominações, e apresenta o que considera o legado indígena à cultura brasileira, em se tratando da espiritualidade e chegando à religiosidade.

A pesquisadora e educadora Niminon Suzel Pinheiro relata a dinâmica realizada com indígenas, recorrendo a metodologias que desenvolveu com base em autores citados. O propósito da autora com a dinâmica é mostrar a organicidade dos processos que envolvem as culturas indígenas, a comunicação pela unificação do pensamento, escrita e fala.

Aramis Luis Silva nos traz importante reflexão sobre uma situação particular, a Missão Salesiana do Sagrado Coração de Meruri, onde se debruçou a estudar as "relações sociais cujos sentidos locais só podem ser compreendidos quando se consegue situar todos os agentes ali entrelaçados frente a quadros de referência que escapam aos limites da aldeia”. Os casos tratados pelo autor são o Museu Comunitário de Meruri e as relações constitutivas, e o projeto da aldeia Meri Ore Eda, as ideias, iniciativas e desilusões. Aproxima os dois eventos por meio de depoimentos de agentes envolvidos no projeto do Museu de Meruri, explorando a movimentação 
deles de lugares, posições e ideias. 0 artigo é provocador, e os depoimentos anotados no caderno de campo do pesquisador e registrados no artigo revelam os dilemas dos indígenas, as questões econômicas, religiosas, políticas, culturais e espirituais, entre outras, que os envolvem, e como isso, em interação com outros protagonistas - a universidade, a igreja - afeta o museu do Meruri e suas ações.

0 movimento dos “museus indígenas", relativamente recente no Brasil se comparado com o que ocorreu no México, por exemplo, vem se tornando ligeiro e consistente, como Alexandre Oliveira Gomes nos demonstra claramente em seu artigo "0 passado vai tá sempre na frente do presente': museus indígenas em rede, etnografia em processo". A rede, como defende o autor, é uma estratégia de integrar iniciativas e agentes que se envolvem no processo: indígenas e as comunidades nas quais estão inseridos, e parceiros, na grande maioria das vezes acadêmicos de universidade públicas, docentes e discentes. 0 autor, ele mesmo pesquisador do tema sobre o qual escreve, faz sua interpretação do museu indígena como objeto de estudo com viés histórico-antropológico, etnografando a rede indígena que se forma na direção desses museus. No artigo há cronologia de ações que relacionam os indígenas à construção de memórias, autonarrativas e museus nos estados do Ceará e Pernambuco, importante registro socializado, com destaque também às ações colaborativas. Apresenta, também, um mapeamento de iniciativas brasileiras nessa mesma direção, assim como documentos elaborados em eventos. 0 artigo contribui em muitos aspectos, mas destaco a aproximação entre antropologia e museologia e como ambas as áreas nos fazem refletir sobre os museus criados pelos indígenas.

0 livro se fecha com uma experiência internacional já consolidada. No Canadá, segundo Jean Tanguay em seu artigo "Politique, représentation et dialogue aux Musées de la civilisation: Premiers Peuples et muséologie autochtone au Québec" (com tradução para o português), há uma museologia indígena referendada após a Conferência Nacional de Ottawa. Tanguay nos informa que após a Conferência articulou-se um projeto importante impulsionado pelo grupo de trabalho sobre os museus e as Primeiras Nações que propôs uma agenda de ação e estratégia ética "que permitam aos indígenas e às instituições culturais trabalhar em conjunto para melhor representar a história e as culturas dos Primeiros Povos". Bem, é essa missão que o Encontro Paulista Questões Indígenas e Museus abraçou para si, com o apoio do Seminário Museus, Identidades e Patrimônio Cultural. Jean Tanguay, nesse sentido, nos ajuda a ver que temos muito o que articular e propor para o Estado, para que os povos indígenas no estado de São Paulo e no Brasil tenham uma participação efetiva nos processos museais. Comparando o Canadá com o Brasil verificamos uma desproporção quantitativa imensa, pois no contexto canadense há 11 povos indígenas e, no brasileiro, 246 povos, mais de 150 línguas diferentes e 896.917 indígenas nos meios urbano e rural. Se os números no Brasil impressionam e nos desafiam, no estado de São Paulo podemos vislumbrar uma possibilidade real. Será que conseguimos? O que precisamos? O que nos falta?

Este livro se sobressai pela diversidade de contribuições e pensamentos, destacando que os campos de conhecimento aqui presentes - museologia, sociologia, antropologia, arqueologia, educação, comunicação, artes, psicologia - denotam a complexidade do tema e enfoque que queremos aprofundar: gestão de acervo e novas práticas museais. Nesse sentido, esperamos que os leitores nos ajudem nessa empreitada.

\section{Referências}

BAPTISTA, Fernando Mathias; VALLE, Raul Silva Telles do. Os povos indígenas frente ao Direito autoral e de imagem. São Paulo: Instituto Socioambiental, 2004.

BOTTALLO, Marilúcia. Diretrizes em documentação museológica. In: SÃO PAULO (Estado). Secretaria da Cultura; ACAM Portinari. Documentação e conservação de acervos museológicos. Brodowski; São Paulo, 2010. p.48-79.

BRASIL. Código Civil Brasileiro. Lei n 10.406, 
de 10 de janeiro de 2002 .

CURY, Marília Xavier; VASCONCELLOS, Camilo de Mello. Questões indígenas e Museus. Introdução. In: CURY, Marília Xavier; VASCONCELLOS, Camilo de Mello; ORTIZ, Joana Montero (Org.) Questões Indígenas e Museus: debates e possibilidades. Brodowski: ACAM Portinari; São Paulo: MAE-USP; SEC, 2012. p.17-19.

ENCONTRO DE MUSEUS INDÍGENAS DE PERNAMBUCO, 1. Documento final. Recife: Universidade Federal de Pernambuco, 2012.

MUSÉES DE LA CIVILISATION. Indigenous peoples policy. Québec, Jan. 2015.

MUSEU DO ÍNDIO. Gestão de acervos culturais em centros de formação, de documentação, de cultura e museus indígenas no Brasil. Documento final do seminário. Rio de Janeiro, 2013.

PADILHA, Renata Cardozo. Documentação museológica e gestão de acervo. Florianópolis: FCC, 2014. (Coleção Estudos Museológicos, v.2).

SÃo PAULO (Estado). Secretaria da Cultura; ACAM Portinari. Documentação e conservação de acervos museológicos. Brodowski: ACAM Portinari; São Paulo: Governo do Estado de São Paulo, 2010.

SEMINÁRIO POLÍTICAS PÚBLICAS PARA O PATRIMÔNIO, A MEMÓRIA E OS MUSEUS DOS GRUPOS ÉTNICOS E TRADICIONAIS DO CEARÁ. Documento final do seminário Emergência étnica. Fortaleza: Rede Cearense de Museus Comunitários, 2009.

\footnotetext{
* Marília Xavier Cury é museóloga e educadora de museus, mestre e doutora em Ciências da Comunicação pela Universidade de São Paulo (USP). Coordenou o Programa de Pós-Graduação Interunidades em Museologia da USP (2014-2016) e foi vicecoordenadora o Programa de Pós-Graduação em Arqueologia do MAE-USP (2015-2016). Como docente do Museu de Arqueologia e Etnologia da USP (MAE-USP) desenvolve pesquisas nos temas: gestão e planejamento institucional, comunicação museológica, expografia, estudos receptivos e avaliação museal, educação patrimonial e em museus, público de museus e musealização do patrimônio industrial. Desde 2010 vem se dedicando aos temas museus e indígenas e museus indígenas, reconhecendo a contribuições desses povos na constituição da ideia de museu e no desenvolvimento da Museologia.
} 


\title{
Memória indígena: um desafio para os museus paulistas
}

\author{
Davidson Kaseker* \\ Sistema Estadual de Museus de São Paulo (Sisem-SP)
}

Parte integrante do IV Encontro Paulista Questões Indígenas e Museus e do V Seminário Museus, Identidades e Patrimônios Culturais, promovido pelo Museu Índia Vanuíre, a mesa intitulada "Os indígenas e o museu, os indígenas no museu, museus indígenas" traz uma temática a um só tempo instigante e desafiadora.

Instigante porque suscita reflexões que envolvem diversificados campos de conhecimento e desafiadora justamente pela complexidade dos temas abordados. Tanto assim que inicio observando que o título da mesa introduz por si mesmo uma dupla abordagem sobre a relação entre indígenas e museus ao subdividi-la em duas perspectivas distintas: o indígena no museu e os museus indígenas.

Antes de confrontar as duas perspectivas, é preciso indagar de que museu estamos falando. Se o museu surge, no passado, como um equipamento urbano, encerrado entre quatro paredes, voltado preponderantemente para a conservação, pesquisa e exposição de coleções constituídas por objetos materiais, no mundo contemporâneo surge o museu compreendido como espaço de interação social com o patrimônio cultural como um todo em suas múltiplas dimensões e, portanto, nessa nova gramática museal estende-se por todo o território como campo de intervenção.

Há que se ressaltar, a bem da verdade, que a memória e a cultura indígenas entendidas como patrimônio cultural são objeto de estudo em diversos campos de conhecimento como a Arqueologia, a Etnologia e a Antropologia, que no museu atuam de forma interdisciplinar e multidisciplinar, colocando o campo da Museologia igualmente em destaque. No entanto, a relação dos museus com essas disciplinas tem sido marcada por movimentos de aproximação, distanciamento, reaproximação e, mais recentemente, de novas perspectivas de diálogos (Vasconcellos, 2011).

Evidentemente a presença indígena no museu tradicional não raras vezes terá um enfoque restrito ao da cultura material no seu sentido mais limitado, que a circunscreve à seara do exótico ou quando muito da estética, ao passo que em situações notoriamente adversas o patrimônio cultural indígena, extrapolando as fronteiras entre patrimônio tangível e intangível, é tratado como recurso para promover o debate sobre questões identitárias que dizem respeito a sua própria inserção social.

Para além de uma abordagem dicotômica, as instituições museológicas por si mesmas são antropofágicas, ressignificam fragmentos do patrimônio cultural para parcelas da sociedade. No caso dos museus arqueológicos, analisar a inserção do patrimônio indígena é um exercício complexo, dada a peculiaridade característica da interface entre Museologia e Arqueologia, marcada pelo que Cristina Bruno denomina de "estratigrafia do abandono". ${ }^{1}$

1. A autora denominou como "estratigrafia do abandono" omissão dos estudos interpretativos do Brasil diante das fontes arqueológicas, baseando essa afirmação em vasto exame bibliográfico, cuja produção, via de regra, recorre às fontes escritas, em detrimento das orais e da cultura material. No âmbito das reflexões propostas na tese de Bruno, não só a postura dos intérpretes da cultura brasileira resulta em prejuízo da Arqueologia como também é motivadora do distanciamento entre ela e o processo cultural contemporâneo, fenômeno que, a seu ver, se origina no desinteresse dos arqueólogos pela comunicação museológica das pesquisas de sua área (Bruno, 1995) 
Na tese "Musealização da Arqueologia: um estudo de modelos para o Projeto Paranapanema" (Bruno, 1995), a autora estabelece um marco teórico no que tange à musealização da arqueologia ao defender que o patrimônio arqueológico está ausente na construção da memória nacional, imperceptível aos olhos daqueles que interpretam - Brasil. Para a museóloga paulista, barreiras de ordem museológica configuraram esse estado de coisas de tal forma que, embora os objetos arqueológicos estejam presentes em instituições museológicas de diversas tipologias e portes, como testemunhos materiais da cultura indígena, eles compõem "memórias exiladas", a despeito da potencialidade de cultivarem noções de identidade e pertencimento e de provocarem reflexões e debates, especialmente em relação à presença indígena em território brasileiro e sua contribuição cultural não apenas num passado remoto, mas também no tempo presente.

As ponderações aqui explicitadas à guisa de advertência fazem sentido principalmente quando analisamos a historicidade da trajetória de inserção das questões indígenas nos museus brasileiros e, em especial, nos museus paulistas, recorte contemplado neste artigo.

Feitas essas primeiras considerações, há que se destacar que, embora tratada com relevância secundária, bem ou mal a presença indígena é desde sempre assinalada nos museus brasileiros.

Um recuo panorâmico no cenário museológico brasileiro aponta que na mais antiga experiência museológica de que se tem registro, contamos com uma menção, ainda que vaga, da existência de objetos indígenas nas coleções da Casa dos Pássaros, que deram origem ao Museu Real em 1818, renomeado posteriormente para Museu Nacional. Nesse protomuseu brasileiro não faltam evidências de que o acervo reservava aos testemunhos arqueológicos e etnográficos um lugar secundário. Dentre outros objetos e animais taxidermizados, havia algumas curiosidades e "muito poucas amostras relativas aos usos e costumes dos diferentes povos" (Lopes apud Wichers, 2010).

Vale lembrar que a partir da Revolução Francesa as nações modernas passaram a ter estruturas de legitimação do discurso do Estado-nação. Foi o início da estruturação do conceito de patrimônio que toma como base o "monumento histórico". Além dos monumentos, temos as belas artes (representando o belo), a arqueologia (representando a longevidade) e a etnologia (representando o "outro" colonizado). Os museus públicos, filhos do pragmatismo do século XVIII, foram então concebidos para salvar, coletar, pesquisar e preservar um patrimônio nacional.

Ao longo do século XIX, quando foram criados os primeiros museus brasileiros, com o intuito de colocar a nação brasileira no concerto das grandes nações, a abordagem da presença indígena substituiu a curiosidade pela investigação científica, embora mantivesse a perspectiva colonial, marcada pelo interesse em um passado exótico e distante. O evolucionismo, o positivismo e o naturalismo começaram a penetrar no Brasil a partir da segunda metade do século $\mathrm{XIX} .^{2}$

Nesse período que se estende até meados do século $X X$, o ordenamento taxonômico e classificações rígidas dos vestígios arqueológicos em culturas indígenas, fases e tradições marcaram as exposições concernentes à pesquisa arqueológica brasileira, distanciando as narrativas arqueológicas da sociedade. 0 discurso narrativo dos museus apontava na direção do evolucionismo social, sustentado pelas publicações do antropólogo inglês Edward Tylor e do americano Lewis H. Morgan, os quais defendiam que as sociedades teriam evoluído de um "estado selvagem", passando por um "estado bárbaro" chegando a um "estado civilizado" (Wichers, 2010).

Se pesquisadores respeitados como Von Martius reconheciam a presença indígena na formação do povo brasileiro, atribuindo-lhe por esse motivo um cunho muito particular, ante as conclusões do evolucionismo a mestiçagem era tida como prejudicial, mesmo com a contribuição de "uma raça superior".

2. Três temáticas predominaram no período: o debate acerca da origem natural ou cultural dos sambaquis, a antiguidade da raça de Lagoa Santa e a discussão acerca da origem local ou externa das culturas do baixo Amazonas. 
No Museu Paulista, inaugurado em 7 de setembro de 1895, a ótica se reproduz liminarmente. Dedicado originalmente à História Natural, o ideário evolucionista fica patente no discurso de Hermann Von Ihering, diretor do museu desde sua fundação, em 1894, até 1916, quando atribui à instituição a função de local de pesquisa, instrução e serviço público, atrelado a uma visão expansionista de um modelo ainda colonialista.

Nesse contexto, a presença indígena no museu é associada a um pretenso estado selvagem de uma civilização sedenta de modernização. Com efeito, a despeito da imagem dócil e inocente dos indígenas em representações pictóricas como a Primeira missa no Brasil (1861), de Victor Meirelles, pertencente ao acervo do Museu Nacional de Belas Artes, ou mesmo a Fundação de São Vicente (1900), de Benedito Calixto, pertencente ao Museu Paulista, Ihering chegou a denunciar o extermínio dos Kaingang que resistiam ao avanço da colonização do Oeste paulista:

Os atuais indígenas do Estado de São Paulo não representam um elemento de trabalho e progresso. Como também nos outros Estados do Brasil, não se pode esperar trabalho sério e continuado dos índios civilizados e como os Kaingangs selvagens são um empecilho para a colonização das regiões do sertão que habitam, parece que não há outro meio, de que se possa lançar mão, senão o seu extermínio. (Ihering apud Wichers, 2010, p.92)

Não obstante o viés ideológico que cerceou Ihering pelo fato em processo que evidenciou,

uma marca comum a esses museus foi a inclusão dos estudos antropológicos, arqueológicos e etnográficos que se firmavam no país em seus programas de investigação. Estudos esses que ainda não se haviam desvinculado completamente do âmbito das Ciências Naturais, o que por vezes a visão compartimentalizada de hoje não permite alcançar em toda a sua dimensão. (Lopes apud Wichers, 2010, p.98)

Assim, o Museu Paulista e os museus brasileiros em geral entraram neste século com coleções arqueológicas provenientes de coletas "assistemáticas" e de pesquisas "sistemáticas", como locais de produção científica e de ensino, atuando a partir de uma perspectiva enciclopédica, evolucionista e classificatória (Bruno, 1995).

0 desprestígio dos acervos arqueológicos e etnográficos, no entanto, acentuou-se na medida em que entre os intelectuais brasileiros, formados sob a ótica colonial europeizante, se frustravam especulações predominantes sobre um pretérito grandioso, condenando-os a se resignar com um passado indígena "pobre", ao contrário de vizinhos latino-americanos que, em seus movimentos nativistas e anticoloniais, podiam evocar a tradição de altos impérios e civilizações, como as dos astecas e incas. À medida que os ideais de identificação com altas civilizações são desautorizados por pesquisas mais sistemáticas, o inconformismo tende a se converter em desinteresse e desprezo das elites intelectuais pela arqueologia brasileira (Barreto, 1999-2000).

A partir da década de 1920 novas teses nacionalistas ganharam força com o movimento modernista. Como ponto de convergência tem-se a busca incessante de uma identidade brasileira, capaz de individualizar o país no concerto internacional das nações modernas, desta feita a partir da construção de uma brasilidade original.

Nesse movimento, os museus ganharam contornos nacionalistas, agora em louvores republicanos, envolvidos em uma política cultural, que embora se apresentasse como renovadora, mantinhase engajada com a ideia de Estado-nação: "As instituições museológicas passaram a ser encaradas sob outra ótica, a saber, como instrumentos de status, poder e ufanismo de um novo Estado que se 'inventava' e que se 'forjava', tendo a Revolução de 1930 e a ascensão de Getúlio Vargas como marcos fundamentais" (Sá apud Wichers, 2010, p.101).

Essa concepção está associada ao que Canclini (1994) denominou de imaginário conservacionista monumentalista, onde as ações no campo patrimonial independem da relevância social 
dos usos atuais do patrimônio. No imaginário conservacionista, predominam os bens capazes de exaltar a nacionalidade, de serem símbolos de coesão e grandeza, ações frequentes em museus históricos públicos.

0 patrimônio arqueológico não se coadunava com - racionalismo universalista das práticas de preservação que marcaram a atuação do Serviço do Patrimônio Histórico e Artístico Nacional (Sphan), criado em 1937 e sucedido posteriormente pelo Instituto do Patrimônio Histórico e Artístico Nacional (Iphan). O Decreto-Lei $\mathrm{n}^{\circ}$ 25/1937 estava marcado por categorias relacionadas às noções de monumentalidade e excepcionalidade, atribuídas, via de regra, às manifestações culturais das elites e à história oficial. ${ }^{3}$

Com esse viés tradicionalista, o Museu Paulista continuou sua trajetória no cenário da musealização da Arqueologia e da Etnografia na primeira metade do século XX. Em 1917, Taunay ${ }^{4}$ assume a direção da instituição, que da proeminência das coleções de história natural passa à ênfase na história de São Paulo e do Brasil. Nesse período, as diretrizes do Museu Paulista foram reorientadas para

contar a história da constituição da nação brasileira do ponto de vista de São Paulo, isto é, como esforço paulista, desdobrado desde os primórdios da colonização. Por isso, era também fundamental contar a história da cidade e do Estado de São Paulo para mostrar como já no início do Brasil colônia seus habitantes estiveram envolvidos em um projeto de construção de uma identidade nacional. (Brefe apud Wichers, 2010, p.109)

Nota-se, ainda, o ranço do colonialismo.

3. No Decreto Lei 25/1937: "Constitui o patrimônio histórico e artístico nacional o conjunto de bens móveis existentes no país e cuja conservação seja de interesse público, quer por sua vinculação a fatos memoráveis da história do Brasil, quer por seu excepcional valor arqueológico e etnográfico. bibliográfico ou artístico..." (Sphan, 1980, grifo nosso).

4. Afonso d'Escragnolle Taunay foi diretor do Museu Paulista (conhecido como Museu do Ipiranga), entre 1917 e 1945.
Caminho oposto foi assumido pelo Museu do Índio, concebido no Rio de Janeiro pelo antropólogo Darcy Ribeiro. Criado em 1953 já sob uma nova ótica em relação ao patrimônio indígena, desprovido de preconceito e focado na preservação de acervos das muitas etnias indígenas, o Museu do Índio logo se torna uma referência ao valorizar o patrimônio imaterial. Combativo e crítico, o Museu do Índio iria enfrentar grandes dificuldades durante a ditadura militar.

Em São Paulo, entre 1930 e 1970, quando as atividades de investigação e pesquisa migraram dos museus paulistas para a academia, as instituições museológicas caíram em certo ostracismo, conforme relata Vasconcellos (2011). Verificou-se por aqui, então, um maior distanciamento entre os museus e o patrimônio indígena, justamente na década de 1970, quando ganhava força a Nova Museologia, configurando mudanças profundas no mundo dos museus e do patrimônio.

Enquanto os novos museus se transformavam em organismos vitais para a comunidade como instrumentos eficazes para seu desenvolvimento integral, promovendo a consciência pública sobre a defesa da diversidade e do patrimônio cultural e natural dos povos, ao longo de mais de duas décadas em que o país esteve submetido a um regime autoritário, personagens como Waldisa Rússio Camargo Guarnieri e Paulo Freire, tão caros para os museus e para o movimento da Nova Museologia, foram cerceados, impedindo que as transformações sociais viessem a ser alavancadas por suas ideias inovadoras, o que só viria a ocorrer com a redemocratização do país.

No período entre os anos de 1950 e 1970, foram criados no âmbito estadual cerca de oitenta museus, denominados Museus Históricos Pedagógicos (MHP), localizados em diversas regiões do estado, dos quais efetivamente 57 museus foram instalados, coletaram e mantiveram acervos, quase sempre por meio de gestão compartilhada informalmente com os municípios, formando uma rede de museus que passou a intermediar a relação das cidades com o patrimônio local. Em geral, seus acervos foram coletados junto às comunidades, reunindo fundos ecléticos, compostos 
por objetos do cotidiano doméstico e do trabalho, incluindo artefatos arqueológicos e etnográficos que almejavam valorizar a história local.

Tinham eles a missão de servir como instrumento de educação não-formal e de difusão cultural. Imbuídos do propósito de construir uma memória que criasse a identidade histórica e política delineada pela elite republicana do período, a existência de um grande número de coleções de zoologia, botânica, taxidermia, geologia, arqueologia e antropologia presentes em grande parte dos acervos dos MHP, em certa medida, revela também o intuito "de preservar as características naturais e culturais das diferentes localizações geográficas das respectivas cidades que integraram a rede de museus" (Misan, 2008, p.186).

Engajados, porém, em certa medida no esforço de construção de uma identidade paulista, do qual seu principal articulador Vinicio Stein Campos (1907-1990) era tributário, esses museus foram impregnados por sentimentos ufanistas que visavam à inclusão das sociedades locais no concerto das grandes cidades. Note-se, ainda, que Stein Campos atribuiu aos MHP uma subdivisão em três períodos históricos - colonial, monárquico e republicano - preterindo o período pré-histórico na constituição da paisagem cultural paulista.

"Possivelmente, Stein traçou não só uma estratégia de disseminação do ideário republicano, mas de desbravamento e ocupação do Estado por esta ideologia”, adverte Anna Carolina Xavier Ávila (2014, p.37).

Para Simona Misan, Stein Campos fez dos MHP novos agentes que pudessem promover antigos propósitos. Ambas as pesquisadoras consideram que, possivelmente, por seu profundo envolvimento com os meandros da Educação e princípios historiográficos adotados pelo Instituto Histórico e Geográfico de São Paulo (IHGSP), ele converteu esses museus em novos meios de difundir "antiga mentalidade" de abordagem histórica. Já na década de 1960, aponta Ávila,

os procedimentos de produção do conhecimento e interpretação historiográfica utilizados nos MHPs, advindos da visão do Instituto Histórico e Geográfico de São Paulo (IHGSP), mostravam-se ultrapassados, mas a resistência de Stein a este fato fez desses museus ferramentas de perpetuação e cristalização de conceitos históricos que atingem essas instituições museológicas até os dias de hoje. (Ávila, 2014, p.46)

De modo geral, os MHP foram constituídos com exíguos recursos, sem equipes profissionalizadas, e dependiam em grande parte do protagonismo de personalidades locais de tal maneira que evoluíram heterogeneamente e alcançaram distintos graus de desenvolvimento institucional na proporção em que foram mais ou menos apropriados pelas comunidades locais.

A presença indígena na rede de MHP, via de regra, dava-se pela inclusão de alguns poucos objetos de plumária, cestaria, cerâmica, tecelagem, armas, instrumentos de trabalho, objetos cerimoniais, flautas, colares e outros adereços, além de cerâmicas e urnas funerárias, coletadas fortuitamente nas localidades. Em muitos casos, tais objetos se misturavam com objetos decorativos de natureza artesanal, produzidos para o consumo de turistas, sem que houvesse a devida distinção de uns e de outros. Dadas as fragilidades institucionais, muitas vezes os testemunhos da cultura indígena não eram expostos com a identificação adequada nem quanto a sua origem e etnia, nem quanto a sua funcionalidade.

Uma das características dos MHP é que em geral suas exposições se tornaram "permanentes", sem renovação. Nesses museus, mesmo que fizessem sentido quando foram incorporadas, com o tempo, sem as devidas contextualizações, as coleções emudeceram.

Se comumente o índio era tratado como se tivesse sido extinto e raramente houvesse alguma menção a comunidades indígenas existentes no território paulista, há que se mencionar algumas exceções. Uma delas é o Museu Histórico e Pedagógico Dr. Carlos de Campos, criado em 1968 e depois incorporado ao Museu Municipal Elizabeth Aytai, em Monte Mor, onde o antropólogo e arqueólogo húngaro Desidério Aytai (1905-1998) reuniu um 
acervo indígena de excepcional valor, colecionado ao longo de expedições de cunho científico realizadas em território paulista e no Planalto Central junto aos índios Xavante, Bororo, Pareci, Guarani e Karajá, dentre outros.

Destaque ímpar nesse contexto merece o Museu Histórico e Pedagógico Índia Vanuíre, criado em 1966, cujo acervo é composto aproximadamente por $38 \mathrm{mil}$ peças que representam a história da cidade e de diferentes povos indígenas do Brasil, formando um dos mais importantes acervos etnográficos do estado de São Paulo.

Seguindo a tradição dos MHP, o Museu Índia Vanuíre sempre manteve ao longo de sua história vínculos acentuados com a educação e a história do município de Tupã, localizado na região do Oeste paulista que foi alvo da expansão cafeeira no início do século XX e palco da chamada "ação pacificadora", que dizimou aldeias indígenas e praticou o etnocídio (Pinheiro, 2005).

Trata-se de um percurso marcado por singularidades - a partir de personagens emblemáticos como a Índia Vanuíre, única patronesse de MHP de origem indígena, cuja presença é envolta em uma aura mítica, como também o de Luiz de Souza Leão, fundador do município e doador de grande parte da coleção etnográfica e da própria sede do museu, que em 1980 mandou construir para essa finalidade. Nessa ocasião, o Estado implantou ali o Projeto de Revitalização do Museu Histórico e Pedagógico Índia Vanuíre (1981).

Além de estar plenamente integrado à vida do município de Tupã e de ter impulsionado a frequência da população local, o que the assegurou grande vitalidade, outro diferencial do Museu Índia Vanuíre é a crescente participação ativa e a integração em suas atividades de membros da Terra Indígena (T.I.) Vanuíre, onde vivem diferentes comunidades indígenas, em especial os Kaingang, povo que ainda hoje habita a região Centro Oeste do Estado, e Krenak vindos da Terra Indígena de mesmo nome, em Resplendor, Minas Gerais.

De início essa participação se limitava à presença em efemérides como o Dia do Índio, contudo, paulatinamente a cooperação se ampliou para muito além do 19 de abril por meio de uma programação cultural acentuada com o objetivo de promover a valorização das culturas indígenas e o respeito às suas memórias. Em atividades variadas realizadas durante todo o ano - como oficinas temáticas, cursos, debates, exposições, visitas orientadas, feiras e festivais culturais -, o museu passou a oferecer uma programação gratuita e diversificada, dinamizando e ampliando o atendimento a diferentes públicos, com a presença constante de representantes da comunidade indígena.

0 marco dessa virada se deu em 2008, quando sua gestão passou a ser compartilhada com a Associação Cultural de Apoio ao Museu Casa de Portinari (ACAM Portinari), organização social parceira do governo do estado na gestão de dois outros equipamentos museológicos localizados no interior paulista: o Museu Felícia Leirner, em Campos de Jordão, e o próprio Museu Casa de Portinari, em Brodowski.

Após reforma predial e requalificação museológica, - Museu Índia Vanuíre reabre em 2010 com uma exposição de longa duração que destaca a sua vocação intercultural e, por meio de suas exposições temporárias e de sua programação cultural, problematiza o território onde a instituição se insere, explorando as construções de memórias de seus habitantes, indígenas e não indígenas. Assinala-se aí a participação dos Kaingang e Krenak da T.I. Vanuíre, localizada no município de Arco Íris, no processo expográfico colaborativo que concebeu o módulo Aldeia Indígena Vanuíre da exposição de longa duração Tupã Plural, inaugurada naquele ano.

Para a requalificação do museu, a ACAM Portinari estabeleceu convênio com a Universidade de São Paulo, por meio do Museu de Arqueologia e Etnologia (MAE-USP), com o objetivo de intercâmbio e pesquisa, o que dentre outras realizações resultou na criação do Centro de Referência Kaingang e dos Povos Indígenas no Oeste Paulista como estratégia para reunir e disseminar informações sobre as culturas e os povos indígenas. Desde 2012, o Centro de Referência disponibiliza materiais distintos para consulta de pesquisadores de universidades 
e outros interessados nas culturas Kaingang, Krenak, Terena e Guarani.

Outras iniciativas de relevante destaque do Museu Índia Vanuíre são o Encontro Paulista de Questões Indígenas e Museus e o Seminário Museus, Identidades e Patrimônios Culturais, sediados desde 2012 pela entidade, eventos que, segundo seus organizadores, “debatem a construção de procedimentos a partir das relações e do trabalho conjunto entre os grupos indígenas presentes na região Centro Oeste do estado de São Paulo - Kaingang, Krenak, Terena e Guarani, das T.I. Icatu (Braúna) e Vanuíre (Arco Íris) e, recentemente, da T.I. Araribá (Avaí)". As programações contam com palestras e conferências sobre a ética e os novos paradigmas na prática museal relacionada à cultura indígena. Dos debates participam instituições e grupos heterogêneos de profissionais e interessados, entre eles os próprios indígenas, que hoje ocupam posição central nas discussões.

Para levar ao extremo o exercício de suas funções social e educacional fundamentado nos princípios democráticos e nos diálogos interculturais, o museu deu um passo adiante, não só inserindo a presença indígena em suas atividades museológicas, incluindo aqui a curadoria autoral de exposições, como também apoiando as próprias iniciativas de preservação e valorização da memória e da cultura indígena empreendidas pela comunidade da T.I. Vanuíre.

Nesse sentido, a inédita e inovadora parceria com a T.I. Vanuíre transcende os limites da Antropologia e da Arqueologia na medida em que, no campo museológico, os indígenas deixaram de ocupar o lugar do Outro para se tornarem sujeitos de sua própria narrativa.

\section{0 estado da arte}

Não cabe aqui, nestes breves apontamentos, esmiuçar o mapeamento realizado pela Secretaria da Cultura do Estado de São Paulo em 2010, quando foram identificadas no âmbito do Sistema Estadual de Museus 415 instituições museológicas públicas e privadas, localizadas em 190 municípios paulistas. Entretanto vale destacar que, dentre elas, há 53 instituições com perfil de acervo arqueológico e etnográfico que compõem um conjunto diverso e bastante significativo. Menos da metade dessas instituições, é bem verdade, postulam atuar propriamente por meio da cadeia operatória da Museologia, que compreende preservação, pesquisa, documentação e comunicação. Muitas delas podem ser consideradas coleções visitáveis, outras se caracterizam como laboratórios, núcleos de pesquisas ou centros de memória.

Chama a atenção, sobretudo, que a maior parte dos museus paulistas com acervos arqueológicos e etnográficos está vinculada institucionalmente à esfera municipal e, via de regra, tais instituições não possuem dotações orçamentárias condizentes com as finalidades a que se propõem, situação que se agrava a cada crise econômica que o país atravessa.

Há que se reconhecer nesse contexto, entretanto, iniciativas que sobressaem - seja pelo grau de maturidade institucional, seja pela expressividade de seus acervos ou mesmo pela abordagem da questão indígena no mundo contemporâneo - recorrendo a um discurso expositivo que se abstém de reproduzir a imagem do índio como vencido e extinto. Notese, todavia, que em geral a qualificação dessas instituições está associada a parcerias institucionais com universidades.

É o caso do Museu Água Vermelha, criado em 2001 em Ouroeste. 0 acervo, composto por documentos e materiais arqueológicos do período pré-colonial, está sob a guarda do município. Suas coleções totalizam aproximadamente 12.500 peças. Conta ainda com exposição de longa duração "Ouroeste: 9 Mil Anos de História”, sala multiuso para exibição de vídeos, reserva técnica, espaço para ações educativas e de atendimento a pesquisadores. Concebido pela Profa. Marília Xavier Cury (MAE-USP), o projeto de comunicação do Museu Água Vermelha - que engloba a exposição e a ação educativa vinculada a ela - é um exemplo de como se pode estruturar a musealização da arqueologia a partir de uma pesquisa de recepção, com resultados relevantes sobretudo 
para a qualificação da experiência de visitação do público.

Em situação similar, o Museu da Cultura, criado em 1999 na Faculdade de Ciências Sociais da Pontifícia Universidade Católica de São Paulo (PUC-SP) a partir de iniciativas do Departamento de Antropologia, destaca-se por abordar a cultura indígena em seus múltiplos aspectos, desenvolvendo fortes laços com a etnologia que não se reduzem à centralidade das coleções.

Em parceria com o Núcleo de Etnologia Indígena, Meio Ambiente e Populações Tradicionais (Nema) do Programa de Estudos Pós-Graduados em Ciências Sociais, o Museu da Cultura promove exposições, mesas-redondas e eventos diversos sobre a questão indígena, que incluem o Programa Pindorama, desenvolvido em parceria com a Pastoral Indigenista da Arquidiocese de São Paulo, por meio do qual são acolhidos estudantes indígenas que ingressam pelo vestibular na universidade. Procuram eles os mais diversos cursos, visando, em grande parte, após obterem a formação escolhida, atuar profissionalmente para suas etnias ou até nas aldeias de origem. São índios urbanizados que, apesar de viverem na megalópole, continuam identificando-se como índios Atikum, Fulni-ô, Guarani Mbyá, Guarani Nhandeva, Kaingang, Krenak, Pankararu, Pankararé, Pataxó, Potiguara, Terena e Xucuru, entre outros (Passetti, 2009).

Por meio da Pastoral, as ações se estendem à criação de núcleos de cooperativas de economia solidária que atuam na produção de artesanato e de arte indígena objetivando a sustentabilidade das comunidades e aldeamentos indígenas da capital e do litoral paulista.

Haveria certamente outros museus a serem citados com o intuito de assinalar iniciativas bem-sucedidas na musealização do patrimônio arqueológico e etnográfico. Invariavelmente, como já mencionado, os êxitos são alcançados quando emanam da contribuição de profissionais da área compromissados em potencializar, no cenário contemporâneo, o diálogo entre os campos de conhecimento da musealização da Arqueologia e da Etnologia e a própria Educação Patrimonial.
Nesse contexto, constitui um capítulo à parte o Museu de Arqueologia e Etnologia da Universidade de São Paulo (MAE-USP). É inegável, sem dúvida, a contribuição do MAE-USP para os avanços da ação museológica não somente do Museu Índia Vanuíre, mas também do campo como um todo, seja por meio da atuação direta do seu corpo docente e do seu corpo técnico, seja por meio das pesquisas acadêmicas desenvolvidas sob a égide da instituição.

Criado em 1989, com a fusão dos acervos do antigo Instituto de Pré-História estabelecido em 1952 por Paulo Duarte, do antigo Museu de Arte e Arqueologia (1964), assim como dos setores de Arqueologia e Etnologia do Museu Paulista e do Acervo Plínio Ayrosa, do Departamento de Antropologia da Faculdade de Filosofia, Letras e Ciências Humanas (FFLCH-USP), o MAE-USP tornouse a principal referência paulista para a musealização da arqueologia e da etnologia.

Não resta dúvida, portanto, quanto à importância de que se reveste a atuação do MAE-USP nesse panorama, especialmente a partir da criação do Programa de Pós-Graduação Interunidades em Museologia, responsável pela formação de profissionais em nível de mestrado com potencial de suprir as carências específicas do setor e de ampliar a possibilidade de estudos na área da museologia.

Estamos nos referindo, todavia, a um conjunto de museus e de instituições de pesquisa e memória que se caracteriza, singularmente, pela heterogeneidade institucional. Um conjunto de museus que, a despeito da similitude tipológica de seus acervos, não atua em rede, inexistindo mecanismos específicos de apoio mútuo e intercâmbio técnico e cultural entre eles.

Nesse cenário, têm sido criadas e desenvolvidas ações pontuais tanto de musealização do patrimônio cultural arqueológico como de Educação Patrimonial, em detrimento do desenvolvimento de ações continuadas com educadores, agentes de memória e sujeitos das comunidades locais.

A reversão dessa conjuntura depende obviamente da construção de políticas públicas de caráter 
permanente, do reconhecimento público da importância desses equipamentos culturais como vetores de transformação social e, também, da formação e qualificação de profissionais que atuem na construção de processos de comunicação museológica onde as relações entre patrimônio cultural e processos de representações identitárias sejam abordadas de forma crítica, estimulando o respeito à diversidade cultural.

Além do estímulo à aproximação e ao diálogo interinstitucional, apresenta-se como prioridade a discussão e formulação de uma metodologia de trabalho interdisciplinar que contemple ações continuadas e a fidelização/comprometimento das equipes museológicas.

Diante da necessidade de requalificação desses museus e da perspectiva de atuação em rede temática, como forma de articulação, qualificação dos debates e promoção do reconhecimento do patrimônio cultural indígena, permanecem alguns desafios:

- Como superar o conhecido isolamento da musealização do patrimônio arqueológico e etnográfico, integrando-o a outros patrimônios culturais e ambientais?

- Como potencializar a participação dos museus públicos e privados no fortalecimento das redes de integração dos museus paulistas?

- Que alternativas podemos construir para alcançarmos a gestão eficaz destes recursos e que, ao mesmo tempo, permitam, dinamizem e impulsionem a apropriação deste patrimônio como herança cultural e recurso de desenvolvimento social?

- Mais ainda: fazendo coro às provocações lançadas no âmbito dos eventos promovidos pelo Museu Índia Vanuíre, devemos indagar qual é o papel dos museus etnográficos na atualidade. Qual compromisso têm os museus e os profissionais da Museologia com os indígenas? Qual participação os museus etnográficos reservam aos indígenas hoje? Qual a relação entre os museus etnográficos e os museus indígenas?
São muitos os desafios que os museus e a Museologia têm a enfrentar para superar os impasses no que diz respeito à mediação entre as características dos museus tradicionais e a demanda relacionada aos novos processos museais.

No que concerne ao patrimônio cultural indígena, há que se almejar uma gestão cultural participativa capaz de assegurar a devida proteção, valorização e difusão da capacidade criadora e memória cultural de nossos povos ancestrais.

Temos muito a avançar, especialmente no que tange à criação e instituição de processos de educação patrimonial e museal que assumam seu caráter político, explorem a problematização da realidade indígena no presente e exercitem a crítica e a autocrítica permanentes.

Tanto quanto promover a construção dialógica e democrática de alternativas de gestão do patrimônio cultural, importa, sobretudo, reconhecer o direito à vida e o direito à memória dos povos indígenas.

\section{Referências}

ÁVILA, Anna Carolina Xavier. Museus Históricos e Pedagógicos no Século XXI: processo de municipalização e novas perspectivas. Dissertação (Mestrado em Museologia) Universidade de São Paulo. São Paulo, 2014.

BARRETO, Cristiana. A construção de um passado pré-colonial: uma breve história da Arqueologia no Brasil. Revista da USP, São Paulo, n.43/44, p. 32-51, 1999/2000.

BRUNO, Maria Cristina Oliveira. Musealização da Arqueologia: um estudo de modelos para o Projeto Paranapanema. Tese (Doutorado em Arqueologia) Museu de Arqueologia e Etnologia, Universidade de São Paulo. São Paulo, 1995.

CHAGAS, Mário. Veredas e construções de uma política nacional de museus. In: CHAGAS, Mário; NASCIMENTO JUNIOR, José do (Org.) Política nacional de museus. Brasília: MinC, 2007. p.12-41. 
CANCLINI, Néstor Garcia. Diferentes, desiguais e desconectados. Rio de Janeiro: Ed. UFRJ, 2007. - 0 patrimônio cultural e a construção imaginária do nacional. Revista do Patrimônio Histórico Artístico Nacional, n.23, p.95-115, 1994.

CURY, Marília Xavier. Comunicação Museológica: uma perspectiva teórica e metodológica de recepção. Tese (Doutorado em Ciências da Comunicação) - Escola de Comunicações e Artes, Universidade de São Paulo. São Paulo, 2005.

LOPES, Maria Margareth. O Brasil descobre a pesquisa científica: os museus e as ciências naturais do século XIX. São Paulo: Hucitec, 1997.

MISAN, Simona. Os Museus Históricos e Pedagógicos do Estado de São Paulo. Anais do Museu Paulista, São Paulo, v.16, p.175-204, 2008.

PASSETTI, Dorothea Voegeli. O Museu da Cultura e os indígenas de São Paulo. São Paulo: Departamento de Antropologia/Museu da Cultura, PUC-SP. (Texto apresentado na VII Semana de Museus, USP, 2009). Disponível em: http://WWW. pucsp.br/museudacultura/downloads/artigo_1.pdf; Acesso em: 27 mar. 2016.

PINHEIRO, Niminon Suzel. Terra não é troféu de guerra. In: SIMPÓSIO NACIONAL DE HISTÓRIA: História: guerra e paz, 23, 2005, Londrina. Anais... Londrina: ANPUH, 2005. CD ROM. Disponível em: http://anais.anpuh.org/?p=17953; Acesso em: 29 mar. 2016.

SANJAD, Nelson. A Coruja de Minerva: o Museu Paraense entre o Império e a República (18861907). Brasília: Instituto Brasileiro de Museus; Belém: Museu Paraense Emilio Goeldi; Rio de Janeiro: Fundação Oswaldo Cruz, 2010.

VASCONCELLOS, Camilo de Melo. Museus antropológicos na contemporaneidade: perfil, perspectivas e novos desafios. In: SEMINARIO DE INVESTIGACIÓN EN MUSEOLOGÍA DE LOS PAÍSES DE LENGUA PORTUGUESA Y ESPAÑOLA, 2., Buenos Aires. Anales... Buenos Aires: Comité Internacional del ICOM para la Museología - ICOFOM, 2011. p. 707-715.

VON MARTIUS, Karl Friedrich Philip. Como se deve escrever a História do Brasil. Revista IHGGB, Rio de Janeiro, n.6, p.381-384, 392-397, 1845.
WICHERS, Camila Azevedo de M. Museus e Antropofagia do Patrimônio Arqueológico: caminhos da prática brasileira. Lisboa: Universidade Lusófona de Humanidades e Tecnologias, 2010 .

\footnotetext{
* Davidson Panis Kaseker, mestre em Museologia pelo Programa de Pós-Graduação Interunidades em Museologia da Universidade de São Paulo (PPGMus-USP), desde 2013 é diretor do Grupo Técnico de Coordenação do Sistema Estadual de Museus de São Paulo (Sisem-SP).
} 


\title{
Representação fonográfica e curadoria sonora: notas sobre dialogia e desentendimento
}

\author{
Edmundo Pereira* \\ Museu Nacional, Universidade Federal do Rio de Janeiro (MN-UFRJ)
}

Nas últimas décadas, dentre os artefatos culturais de perfil étnico encontrados em edições públicas (de museus, galerias e lojas especializadas a sítios digitais), intensificouse a geração de representações sonoro-musicais em formato fonográfico (CDs, vídeos, arquivos digitais). Tais processos de gravação-edição tanto evidenciam uma maior e crescente agência dos grupos representados no controle da produção sonoro-musical em todas as suas etapas, quanto alimentam discussões teóricas no campo da pragmática e das políticas de representação de alteridades. Da mesma forma que outros regimes de representação, o fonográfico é perpassado por cisões, articulações e negociações entre valores, saberes e práticas musicais. A crítica a regimes coloniais de classificação e representação sonoromusicais, assim como as revisões históricosociológicas das práticas colecionistas e de comparação-definição ocidentais, têm levado à proposição de práticas etnográficas e curatoriais 'colaborativas' (participativas, recíprocas, compartilhadas) que a estes se contrapõe, propondo modos alternativos de entendimento, organização e experiência da música.

Neste exercício, a partir da recuperação sóciohistórica (bastante operacional) da formação de certas práticas de colecionamento, arquivo e edição (de instrumentos e transcrições a registros fonográficos), apresento breves cenas de dois processos fonográficos (edição de CDS com repertórios afro-brasileiro e indígena) para refletir sobre as resultantes musicais que atingimos e quais condições de possibilidade sonora e de registro geramos.

\section{Estudos sobre música 'exótica': organização de protocolos de registro e imaginações musicais}

Um primeiro exercício que me parece rentável para pensar o quadro recente de certa produção fonográfica e o modo como alternativas e questionamentos musicais têm sido gerados, é o de recuperação de certas práticas de colecionamento poético-musical das quais herdamos concepções sobre repertórios culturais diversos (inventando até mesmo a ideia de 'repertório cultural'); bem como organizamos situações de registro, edição e divulgação de material fonográfico (por razões que vão da salvaguarda e pesquisa científica até a comodificação em mercados de world music). Ao final, no horizonte do aumento de produção de representações fonográficas étnicas das últimas décadas, ${ }^{1}$ e do modo como estas adentram e reorganizam os debates sobre a geração de coleções e arquivos sonoros, gostaria de voltar nossa atenção para as condições de geração de 'situação de gravação', processo já bastante ritualizado de geração de transcrições e fonogramas para arquivo e edição do qual nos ocupamos sobretudo nos últimos três séculos. Estas se dão no contexto mais amplo das práticas de colecionamento e organização de coleções no nosso caso 'etnográficas' - no quadro geral

1. Consulte-se, por exemplo, qualquer catálogo de grande sítio de venda da internet, bem como sítios mais especializados, de associações de investigação e difusão, ou de instituições de memória dos próprios grupos étnicos, populares ou religiosos. Para o caso de 'edições' em que os múltiplos usos das tecnologias de gravação ultrapassam o científico, chegando até expressões da música clássica contemporânea, veja-se por exemplo Brown, 2000; Ghuman, 2014. 
de formação das ciências e das artes. Na maior parte das vezes, conformam eventos de interação (bastante) padronizados, relacionando tecnologias diversas (de audição, gravação e escrita, por exemplo) em projetos investigativos e de administração audiovisual de populações. ${ }^{2}$ Nas últimas décadas, esse percurso tem sido refeito criticamente, e questionamentos de políticas de representação e contrassonoridades têm sido gerados.

De maneira bastante resumida: por que 'gravamos' como gravamos certos 'repertórios' poéticomusicais? Quais as implicações dos modos como organizamos a situação de gravação para as resultantes fonográficas alcançadas? Qual as implicações das práticas musicais locais para as práticas de gravação?

Essas questões, de um ponto de vista que se desenvolve entre o folclore, a musicologia e a antropologia, parecem ficar mais claras na virada do século XIX para o XX. ${ }^{3}$ 'Gravar' é referente que antecede - para o caso de materiais sonoros - o advento da invenção do registro fonográfico, no final do século XIX. É usado por musicólogosfilólogos para registros poético-musicais escritos de 'canções populares'; da mesma forma que para registros de música 'exótica'. ${ }^{4}$ Expressa-se, em forma impressa, na edição de partituras e em debates sobre os níveis de detalhamento que estas podem ter entre edições 'populares' e edições 'eruditas' (Gelbart, 2007).

Sabemos que na Idade Moderna, no pós-Renascimento, houve investimentos colecionistas de canções na Europa desde as primeiras décadas do século XVIII, e as terras altas da Escócia se constituem como 'região' imaginada (de costumes e moralidades), estudada e compendiada, no nosso caso, materializada em objetos musicais em museus e reservas técnicas, e coletâneas de cantos

e poemas. Estas seriam citadas por Herder na

Alemanha em formação como exemplo de investimento

2. Ver, por exemplo: Bleichmar, 2012; Findlen, 1994; Thomas, 1991; Henare, 2005.

3. Travassos, 1987; Bartók, 1976; Gelbart, 2007.

4. Classificação que aparece impressa no século XVI, no início da formalização dos estudos organológicos (Inving, 2009). para a geração de coleções e coletâneas com fins de estudo e difusão do 'espírito' de certo 'povo' (ou nação, ou raça). Alguns autores pensam esse período como o da invenção da ideia de 'canção popular' - em especial no campo intelectual germânico do século XVIII (Wiora, 1971). Esse processo se estende para outros repertórios e classificação de populações, razão pela qual o etnólogo italiano Cocchiara (em sua compilação da formação dos estudos de 'folclore' na Europa), enfatiza que este se dá no quadro mais geral do aparecimento dos 'estudos dos povos' entre 'europeus', 'orientais' e 'selvagens' (Cocchiara, 1985). Na década de 1720, publicamse as primeiras coletâneas de poemas registrados a partir de trabalho de investigação in loco, na região 'afastada' do norte escocês, material girando em torno das peripécias de Ossiam, personagem que representaria sobrevivências da antiguidade (no caso de narrativas 'fenícias') no seio da cultura anglo-saxã. Além disso, os textos editados seriam registros de poetas populares (bardos), representantes de tradições poéticas antigas (Gelbart, 2007).

Para o nosso exercício, o interessante é que ao longo do século XVIII, adentrando o XIX, se constitui um "campo de debate" ${ }^{5}$ no entorno de algumas questões e colecionamentos de narrativas, cantos e instrumentos de música: (1) a mais polêmica, a de não se saber, ao final, das referências pessoais e do paradeiro físico dos tais 'bardos', 'poetas tradicionais das terras altas' registrados por filólogos-poetas; (2) e a mais técnica, a de que, em sendo os materiais reunidos em edições finais do coletor-editor, como garantir que referências como 'temas', 'expressões', ou características dialetais sejam 'tradicionais', sejam ao final chanceladas como 'autênticas'? As discussões de cunho inicialmente poético-filológico vão se tornando, para o final do século XVIII, também 'musicológicas', com a produção de transcrições musicais e coletâneas de partituras dessas canções. 0 problema da 'autenticidade' dos fragmentos e peças coletadas e editadas desdobra-se para as características sonoro-musicais, com medições-comparações de 'escalas', 'rítmicas', caracterização de modos

5. Gelbart, 2007; Agawu, 2003; Kartomi, 1990. 
de cantar e tocar, e arquivo e classificação de instrumentos de música. ${ }^{6}$

Se seguimos um pouco mais nessa linha, algumas dessas questões aparecem então na Alemanha de romantismo em formação do final do século XVIII, desdobradas de ideias de Herder, no entre filosofia-filologia-política, sobre o 'espírito germânico' depositado e revelado em sua poética camponesa; e a consequente produção de arquivos e coleções de poemas e canções a partir de registros textualizados de oratória 'vernacular' nas regiões "afastadas ao máximo das cidades" (Kamenetsky, 1992). Algumas das questões da filologia colecionista escocesa aparecem dando referência aos trabalhos de registro-edição de contos (Bauman; Briggs, 2003). 0 debate (entre filólogos, investigadores e editores) sobre a definição e colecionamento de canções populares já está em curso, e os trabalhos dos irmãos filólogos Grimm é exemplar para pensarmos, especialmente, 'protocolos' de constituição de situações de registro que vão se formalizando e vulgarizando; e certas "imaginações musicais" (Agawu, 2003)7 associando certos repertórios com certos lugares e populações.

No quadro das vulgarizações de versões, os irmãos teriam viajado para o 'interior' e registrado contos de 'camponeses'. Hoje, a partir de cartas e diários (Kamenetsky, 1992), sabemos que a rede de colaboradores dos irmãos não foi extensa, se deu em Kessel, sua cidade natal, e poucos foram de fato 'camponeses' seus interlocutores, mas 'informantes' residentes nos arredores da cidade, ou famílias conhecedoras de tradições narrativomusicais (dentre estas a própria família

6. Gelbart, 2007; Irving, 2009.

7. A ideia de "imaginação musical" não aparece especialmente definida ao longo das publicações operacionalizadas para este exercício, ainda que instrumentalize o exame de contextos coloniais, e o lugar da música em movimentos de dominação e de resistência e indigenização cultural (como em: Agawu, 2003; Ghuman, 2014). É associada especialmente, para além da música, ao trabalho de Said (1996), mas também aos de Anderson, 2008; Appadurai, 1996; Appiah, 1997; Woodfield, 2000 , e Richards, 2001. Em coletânea dedicada a casos latinoamericanos (Cepeda, 2010), a ideia é especialmente vinculada ao trabalho de Appadurai (1996, p.10), em especial ao modo como este associa a produção de imaginações sociais no cotidiano por meio de múltiplas tecnologias de comunicação.
Grimm). A maior parte dos registros foi feita no apartamento dos irmãos. Ainda que apareçam - sem detalhamento - em suas cartas e diários referências aos 'narradores', estes não aparecem nas coletâneas de contos que se seguiriam às primeiras edições; ainda que se definam as características ideais de tal 'narrador': ser não letrado, 'espontâneo', conhecer os repertórios vernaculares (ibidem). Essa será uma característica das práticas de colecionamento musical e narrativo até meados do século XX, quando passam a ser criticadas pelo emudecimento das vozes que performaram tradições músicoverbais. Duplamente: pela não citação das fontes; e pela edição final das narrativas associando ou editando versões. Este é, portanto, um dos pontos centrais das discussões dialógicas e críticas das últimas décadas por meio de ideias como as de 'coautoria'; e 'participação', 'colaboração' nas etapas de produção das situações de registro e edição sonoros. É ponto em torno do qual discutem-se desde políticas de representação sonora até ideologias de performance e recepção e direitos jurídico-patrimoniais.

Se tomarmos movimentos tecnológicos mais recentes, do ponto de vista do registro fonográfico, de seu uso como instrumento musicológico, podemos tomar o trabalho de Béla Bartók como ponto de inflexão, de formalização de questões e procedimento para o uso do fonógrafo e da transcrição-audição continuada que adentram o século XX atribuindo e classificando musicalidades. Por um lado, estamos no contexto de ênfase - do final do século XIX, nas ciências alemãs - em métodos indutivos de geração de hipóteses e encaminhamento de reflexões. Bartók é exaustivo: usar ao máximo o fonógrafo, ouvir ao máximo as gravações, transcrever, comparar... Em texto de 1936 (Bartók, 1976), já passado longo período de colecionamento fonográfico e transcrição-audição, momento de resumo, no quadro de certa disciplina entre as ciências e as artes, a 'musicologia comparada', Bartók trata da "caçada a canções folclóricas" (1976, p.9). 0 advento do fonógrafo permitiria "mensuração e fixidez" das formas musicais. Era o ponto de chegada do trabalho que advinha da organologia e da transcrição de cantos. Tratando do que chama de "colecionamento de música do povo” (ibidem, p.12), propõe certo encaminhamento 
investigativo, tanto pelo arquivo já considerável da diversidade musical humana quanto pelo avanço das tecnologias de representação. A escolha de um lugar ou população, por exemplo, poderia decorrer dos resultados dos levantamentos bibliográficos e de arquivos sonoros. Quando no lugar (que por princípio deve ser o mais distante possível das 'cidades'): evitar "pessoas educadas" (recomendação que já faziam os Grimm); gravar pessoas das 'vilas', de preferência pessoas que seus moradores apontem como uma "coleção viva de canções" (ibidem, 18); evitar moradores que saíram e voltaram da cidade (ibidem, p.13); e, central: "como conseguir a confiança dos cantores, especialmente os mais velhos?" (ibidem, p.17). "Os velhos", adverte, "por vezes requerem tratamento especial". Por fim, não menos importante, e central para entender certas sinédoques de itens em emblemas culturais: se possível, fazer várias versões para escolher a melhor performance. "Por vezes", salienta o autor (ibidem, p.18), "a melodia é boa, mas a performance é afetada". Por fim: no quadro nas propostas de métodos indutivos nas ciências da natureza e do homem, seu trabalho, como dito, é 'exaustivo' e 'meticuloso', comparando centenas de gravações e partituras de coletâneas de outros estudiosos, para ao final propor certas características musicais, no caso sobretudo expresso em 'ornamentos' ao final de frases melódicas, que seriam, mais do que sequências melódicas ou rítmicas, os pontos de distinção entre 'musicalidades' na região estudada pelo húngaro.

Um segundo ponto geral a ressaltar é dos resultantes sonoro-musicais de situações musicais não ordinárias como 'situações de gravação'. Neste ponto, podemos recuperar o referente edição para dar conta das essencializações fonográficas a que se chega e procura difundir, dentro de qual quadro de "imaginações" e "contraimaginações" musicais (Agawu, 2003; Said, 1990, Ghuman, 2014).

Para o caso africano, por exemplo, o lugar que o continente vai ocupando nas grandes classificações da música pela ciência europeia, ou talvez o uso da música para gerar classificações, evidencia o que o musicólogo ganês Agawu (2003), dentre outros, tem chamado de "imaginação musical" (inspiração nas 'imaginações' europeias a que se dedica Said para o caso do 'Oriente'): certo modo de conceber e representar as músicas não europeias em quadros evolucionistas e contextos coloniais; certo modo de produzir estereótipos, de selecionar e sobre-enfatizar aspectos em quadros hierárquicos de comparação de musicalidades. As representações em torno ao referente "música africana" são bons exemplos. Por um lado, porque se alinham no quadro mais geral da imaginação de músicas "tradicionais": comunal e convidativa, espontânea, autêntica, emotiva, intimamente integrada na vida social, profunda (Agawu, 2003, p.xi). Por outro lado, quando ganham localidade, as representações sobre a música africana, de longa data, enfatizam seu caráter sobretudo rítmico (associado à sua especificidade coreográfica, à dança como forma indissociável da música) (Agawu, 2003, p.4$5)$. Do ponto de vista das imaginações musicais europeias, difundidas desde o início dos estudos e coleções organológicos, os "africanos" são "incorrigíveis dançarinos e ritmistas instintivos" (ibidem, p.5). Em especial, a África subsaariana. Não é sem razão, portanto, a ênfase colecionista e classificatória nos 'membranofones' (vários tipos de tambores); bem como sua contrapartida musical, sua pobreza harmônica, se é que é possível classificar sua teoria musical como 'harmônica'. Nesse cenário, o ganês tanto recupera criticamente a produção do campo de estudos da "música africana" e o modo como certas imagens e ênfases vão se consagrando, quanto, a partir apenas do caso de Gana, apresenta a diversidade musical presente na região, muito além da dança e do ritmo (também presentes, evidentemente), para poder ao fim constatar: "o 'ritmo africano', em resumo, é uma invenção, uma construção, uma ficção, um mito, ao final, uma mentira" (Agawu, 2003, p.61).

Sem que possamos avançar muito nas consequências contemporâneas do exposto, gostaria apenas de marcar que temos estabelecido relações fonográficas (de gravação-edição) com diversos grupos e populações faz algum tempo, desde períodos de regimes de assimetria colonial ${ }^{8}$ (imperial e nacional), ao complexo e intrincado mundo dos processos 'colaborativos' e das

8. Said, 1990; Agawu, 2003; Woodfield, 2000. 
organizações étnicas e populares de produção de discos, CDs, DVDs, sites. Atualmente, 'gravar', 'editar' e 'divulgar' podem conformar modos de organizar as ações em arenas de alta negociação, intragrupos e destes com agentes e grupos exógenos. Do ponto de vista sônico, vivemos período de economias sonoras complexas. Ao contrário dos silenciamento de vozes, do controle da participação, da monotonia das versões eurocêntricas sobre as identidades musicais, processos contemporâneos de representação e criação sonoro-musical do mundo têm procurado contemplar a heteroglossia de éticas e estéticas envolvidas na produção de situações de gravaçãoedição e difusão de fonogramas.

No campo das 'contestações', não são poucos os exemplos de contrarrepresentações musicais, processo recente, que supõe um empoderamento das múltiplas posições em que se compõe o processo fonográfico, entre músicos, produtores, pesquisadores, técnicos de gravação e editores. ${ }^{9}$ Se é certo que protocolos de gravação e edição gerados em regimes coloniais se difundiram e consagraram, esses mesmos processos foram incorporados aos instrumentos de performance e política dos grupos e populações antes representados. Em muitos casos, em diálogo com contextos mais amplos de reivindicação ampla de cidadania. Neste ponto, voltamos ao exemplo da invenção musical da africanidade, mas desta vez em contradição, a partir de "projetos de gravação" zulus em estúdios sulafricanos (Meintjes, 2003). Ao longo da década de 1990, entre o fim do regime do apartheid e o aparecimento, no contexto da indústria fonográfica internacional, do subitem world music (música do mundo), uma geração de músicos, técnicos e produtores reorganiza 'estilos' locais (rítmicos, vocais e poéticos) em diálogo com gêneros populares pan-africanos e afro-americanos em bases de guitarras, baixos, teclados e naipes de metal. Ao final de um processo em que o estúdio de gravações é tomado por certos projetos político-estéticos e por certa maneira 'mágica' de conceber os processos sociais, gera-se uma estética musical 'zulu', eletronicamente mediada,

9. Scales, 2012; Troutman, 2009; Meintjes, 2003; Woodfield, 2000 . mixada a partir de musicalidades variadas, locais e extralocais. Desse processo destacamos:

\section{A rentabilidade etnográfica de processos} fonográficos para o mapeamento de imaginações coloniais e práticas artístico-científicas e de administração audiovisual de populações;

2. Da mesma forma, mais recentemente, para acompanhar a geração de contrarrepresentações musicais das 'realidades' sonoras em que se organiza o mundo, suas bases locais e quais regimes de mixagem de referências multiculturais;

3. Neste sentido, índices de africanidade podem ser expressos em múltiplos materiais rítmico-melódicos e arranjos harmônicos (para além dos limites da noção geral de 'África') ;

4. Por fim, situações de gravação e edição de 'identidades musicais' compõem 'campos de debate', no caso zulu (e outros) das últimas décadas, de contradição de imaginações musicais hegemônicas.

\section{Dois pequenos dramas sobre gravação e edição, música e cultura}

\author{
Estes riscos são inerentes ao fazer \\ etnografia colaborativa e se exacerbam quando \\ projetos colaborativos se engajam em visões, \\ agendas e expectativas que levam para muito \\ além do acadêmico. Em certo sentido, nos \\ levam para territórios desconhecidos. Quando \\ nos aventuramos por esses territórios, \\ devemos entender que o valor e a relevância \\ desse tipo de colaboração como uma proposta \\ de pesquisa não são entendidos da mesma \\ maneira. (Lassiter, 2005, p.148)
}

Um dos pontos de chegada dos 'campos de debate' e 'resultados fonográficos' resumidos acima é o do desenvolvimento de estudos voltados, etnograficamente, para os "processos de gravação"10

10. Goody, 2012; Meintjes, 2003; Makanon; Neuman, 2009 ; Neuenfeldt, 2005. 
no entre pesquisa-produção-mercado. Nestes, políticas de representação sonora se revelam, são questionadas, se adequam à diversidade de realidades sônicas em interação. Situações de 'gravação' e 'edição', do ponto de vista técnico (Leach, 1966), dos ofícios, podem ser bastante ritualizadas, estando as performances condicionadas pelo aspecto tecnológico do evento (como o posicionamento de microfones e seu espectro de captação e os suportes do registro) e as operações e tempos de gravação e edição. São repetitivas (entre gravação-escuta-regravação; mixagem-escuta-mixagem) e (algo) ensaiadas. De certa forma, do mesmo modo que as práticas rituais musicais que tentam registrar, não são práticas ordinárias, mas reorganizadas para gerar certa performance acústico-musical capaz de representar, presentificar grupos sociais em sua diferença cultural. Além disso, de acordo com as condições socioculturais, podem ser ritualizadas na forma de estabelecer e administrar relações e conceber as práticas musicais e seus efeitos sonoros, práticas por vezes marcadamente hierárquicas, outras dialógicas, agonísticas. Nesse sentido, situações de gravação e edição podem ser pensadas como pequenos "dramas sociais" (Turner, 2008, p.33-37), ${ }^{11}$ ações sequenciadas na seleção de repertórios e executantes, organização de situações de gravação, edição de representações fonográficas. Nestas, políticas de representação musical entram em argumentação, desentendimentos acontecem, dialogias se ensaiam, produtos culturais constituem biografias e se comodificam. ${ }^{12}$

11. Vinculado a certa subtradição britânica de antropologia, em sua operação com a noção de 'drama', para além de suas características sequenciais e extraordinárias de ação. Turner enfatiza sua característica de "processo anarmônico ou desarmônico" (p.33). Para os casos em etnografia e análise, ainda que seja evidente que resultantes estéticas se conformem em debates político-artísticos (em que a organização das sequências de repertórios e performances se define), ainda que o 'conflito' seja o outro lado da 'coesão' (p.40), não chegaríamos a tanto em nossas tipificações. De todo modo, ao final, estaremos diante de representações musicais em contradição com modos de entendimento e percepção de fundação eurocêntrica. O que interessa ao exercício é recuperar algumas das "condições de produção para metáforasradicais, arquétipos conceituais, paradigmas, modelos" (p.45), no caso sonoro-musicais, e o modo como estes "condensam várias referências" (p.49)

12. Leach, 1966; Labov, 2010a, 2010b; Clifford, 2003;
Diante desse quadro, quais lições podemos tirar para etnografias e curadorias sonoras que se propõem 'críticas' e 'colaborativas', que tanto participam nas recuperações sócio-históricas das condições de produção do conhecimento sobre as músicas "exóticas" em regimes coloniais de objetificação quanto propõem alternativas conceituais e práticas para a geração e administração de coletâneas e arquivos sonoros?

Lassiter (2005), organizando os debates sobre 'etnografias colaborativas' (ou participativas, ou recíprocas) para a etnomusicologia e a antropologia norte-americanas, reúne situações limite de negociação de processos de representação sonora (musical e narrativa) ao redor da ideia de 'risco'. Riscos são inerentes ao trabalho 'colaborativo', uma vez que podem levar a atividade etnográfica para além das ações e concepções acadêmicouniversitárias (ibidem, p.115). Momentos em que campos de experiência e coentendimentos se desencontram, se sobrepõem (ibidem, p.109). Em que a etnografia apresenta suas "inadequações" (ibidem, p.111). Nessa situação, zonas de comunicação (como interpreta Labov, 2010a, $2010 b)$ se "inflacionam" de entendimentos, alguns destes geradores de conflitos, de não conciliação de representações fonográficas. Um dos eixos comparativos que gostaria de retomar é o da "dialogia", em especial em contexto de "gravação da cultura" (Makanon; Neuman, 2009). Não é a ocasião para explicitar melhor o que a ideia traduz, mas aparece a partir dos anos 1980 como regime possível de crítica e revisão de padrões coloniais (imperiais ou nacionais) de interação e representação com as populações estudadas, bem como de reorganização das formas de relacionamento entre pesquisadores e representantes de grupos e comunidades e de cooperação em todas as etapas de produção de representações culturais. ${ }^{13}$ No caso dos processo de "gravação" em sentido sonoro-musical, como desdobramentos dos debates sobre 'dialogia' e os limites da 'autoridade etnográfica' na

Oliveira, 2004; Oliveira, 2006; Thomas, 1991; Gell, 1998 ; Appadurai, 2012.

13. Clifford; Marcus, 1986; Clifford, 1998; Oliveira, 2004; Oliveira, 2006 
antropologia praticados nos Estados Unidos, na ampliação dos investimentos e legitimidades de distintas mídias para registro e exibição de material etnográfico, aparece nas últimas duas décadas a preocupação com a "gravação da cultura" (recording culture), propondo a ampliação da noção-operação de dialogia para além do texto, ou, no caso, além da edição sonora, para todas as etapas da produção do registro e representação (ibidem). Por um lado, aproxima-se dos problemas do trabalho de campo por seu aspecto narrativo, no caso em particular nos debates sobre a "criação de realidades sônicas". Tanto do ponto de vista da organização das situações de gravação quanto das situações de escuta (Sterne, 2003), de produção do juízo e explicitação de parâmetros estéticos.

As cenas que trago fazem parte de repertório etnográfico-analítico resultante do trabalho de coeditoria da Coleção Documentos Sonoros do Museu Nacional. ${ }^{14}$ Diante dos cinco "projetos de gravação" já realizados, da promoção de registros e edição de material musical, proponho breve exercício reflexivo, e algo comparativo, a partir de dois casos, no eixo geral: situar processos de gravação como eventos comunicacionais em suas feições de "desentendimento" (Labov, 2010a, 2010b; Gumperz, 1982) e "coentendimento" (Lassiter, 2005) na passagem de regimes de variação e multivocalidade de certas tradições musicais (no nosso caso, indígena e afrobrasileira) para definições como "estilo",

14. O projeto Coleção Documentos Sonoros é idealizado e implementado em coeditoria com Gustavo Pacheco, a partir de 2000 , estendendo-se até 2012. 0 projeto, com patrocínio inicial por edital de fomento da Petrobras, a partir das coleções do Setor de Etnologia e Etnografia com o do Museu Nacional, previa três volumes iniciais: a restauração das gravações históricas de Roquette-Pinto, e o registroedição de repertório afro-brasileiro (Ile Omolu oxum) e indígena (Tikuna, alto Solimões) contemporâneo. Para estes últimos casos, uma vez que o material produzido superou o editado no formato CD, coleções completas de todos os materiais registrados foram depositadas nos arquivos das instituições de memória locais. Posteriormente, outros dois volumes foram idealizados e produzidos com Renata Menezes (NuAP, PPGAS-MN-UFRJ) e Maria José Freire (Laced-MN-UFRJ), mediante outros editais de fomento. Faz parte das atividades do Laced (Laboratório de Estudos em Etnicidade, Cultura e Desenvolvimento) e pode ter alguns de seus resultados acessados gratuitamente em: http://laced.etc.br/site/ projetos/projetos-executados/colecao-documentos-sonoros/. "timbre" e "composição" para fins de registro e edição de fonogramas.

Os dois trabalhos em questão são os CDs Ile Omolu Oxum, cantigas e toques para os Orixás, e Magüta arü wiyaegü, cantos Tikuna, realizados em acordo com duas instituições patrimoniais locais, o Memorial Ya Davina, situado na Comunidade de Terreiro localizada em São João de Meriti (RJ); e o Museu Magüta, museu de administração indígena localizado em Benjamin Constant (AM). Um primeiro ponto a destacar é o das condições de possibilidade para o encontro de representantes das instituições e pesquisadores universitários. Em ambos os casos, as redes de articulação partem de capitais de relação de colegas pesquisadores com longa relação com os grupos, bem como do próprio interesse patrimonial de ambas as instituições em registrar parte de seus repertórios "tradicionais", exemplares de seus conjuntos de saberes e expressões culturais. Nesse sentido, no quadro da dialogia, do que o trabalho de pesquisa tem de dádiva e dívida, parte-se já de circuitos de reciprocidade anteriores, de capitais de relação já constituídos. Além disso, sabemos de toda a mobilização patrimonial e museológica em que hoje os grupos étnicos e populares estão envolvidos, questionando representações consagradas, propondo outros processos de representação (que questionam até mesmo o estatuto heurístico da ideia de 'representação' ). ${ }^{15}$

Nesse sentido, ressaltem-se de saída as diferenças de organização do encontro fonográfico, com posições menos hierárquicas, capitais técnicos e culturais mais distribuídos e, talvez (para acionar uma das deficiências apontadas pelas críticas aos processos etnográficos em períodos coloniais), com menos 'distância' entre os atores e suas possibilidades, com menos "controle da participação” (Cooke; Kothari, 2001). Mas retomando as instituições museais locais, em quadro geral, ambas instituições têm histórico de mobilização comunitária e mais ampla em sentido político por reconhecimento identitário e territorial e de cidadania. Ao contrário (ou ao menos em notável diferença) dos silenciamentos

15. Clifford, 2003; Stanley, 2007; Oliveira, 2012. 
de vozes e políticas de representação hierárquica que marcam a fundação e o desenvolvimento das coleções de cantos, temas e narrativas, estamos em quadros de reconhecimento de 'autoria' e demanda por direitos autorais, em heterodoxas mixagens de materiais musicais inquirindo e contra-argumentando com representações eurocêntricas do que seja "música africana”, "música indígena", "música brasileira”.

Ile Omolu Oxum. Tomemos o primeiro caso, o processo de gravação-edição realizado junto à comunidade de terreiro Ile Omolu Oxum, tradicional casa de candomblé (religião afrobrasileira) do estado do Rio de Janeiro. ${ }^{16}$ Neste caso, fomos procurados por alguns de seus representantes que indagavam sobre a possibilidade de realização de registro sonoro de parte do repertório de cantigas e toques dedicados aos orixás, considerados como "patrimônio da casa". Esses repertórios estavam salvaguardados na memória oral pelos membros da comunidade, em especial por Mãe Meninazinha de Oxum, conhecida Mãe de Santo, localmente e em nível nacional. Interessante notar que dentro do Ile Omolu Oxum já havia experiência em curso de salvaguarda patrimonial da memória da casa com a constituição de um pequeno museu batizado como Memorial Ya Davina, Mãe de Santo fundadora da linhagem a que se filia Mãe Meninazinha.

Se tomarmos a organização político-religiosa da Casa, estaremos diante de certo regime hierárquico de organização da vida e das relações entre homens, deuses e coisas. Hierárquico e de distributividade de conhecimento ritualmente controlada ${ }^{17}$ ao longo de etapas, posições

rituais. ${ }^{18}$ Esse regime incide sobre os regimes do colecionamento, modelando-lhe a discussão e

16. Trabalho realizado entre os anos de 2000 e 2004 . Estúdio móvel montado no espaço do Ile Omolu Oxum. Para algum detalhamento, ver Pereira (2014b).

17. Barth, 1987; Carvalho, 1984.

18. Sobre as práticas musicais e musicalidades encontradas em algumas das religiões afro-brasileiras, consulte-se, por exemplo: Carvalho, 2000; Carvalho; Segato, 1992; Béhague, 1976; Cambria, 2006; Amaral; Silva, 1992; Barros, 2000; Prandi, 2005 organização de cada etapa de trabalho, da seleção de repertórios até a organização de situações de gravação. Uma breve etnografia das 'reuniões' em que se acordou a realização do trabalho de gravação e edição de cantigas e toques dos-para os Orixás evidencia essa configuração. Parte da literatura sobre 'participação' para outros campos (Cooke \& Kothari, 2001) tem mostrado como no entorno à noção são negociados desde a própria organização que antecede o evento, até os modos de organizar a comunicação e sua posterior representação. No caso das relações estabelecidas no Ile Omolu Oxum, e o modo como a organização política se dá na Casa, ressaltamos certa organização hierárquica das falas (com centralidade para a Ialorixá), bem como dos modos de gesticular e organizar os corpos por parte nos envolvidos no trabalho de gravação (entre altos e baixos, de acordo com suas respectivas posições).

Além disso, a reunião se dava em local da Casa onde havia uma mesa comprida de múltiplo uso, tanto para preparação quanto para consumo de comida. Não raro, nessas reuniões, se comia e bebia. Ao longo delas, se acordou, sempre com palavra fina da Mãe de Santo, que as gravações seriam realizadas no próprio terreiro, em tal data e lugar. Se é certo que os regimes locais englobaram os de colecionamento, as condições técnicas (acústicas e de captação) incidiram decisivamente sobre a organização espacial do processo de gravação: as gravações se dariam na Alameda Tia Fióti (personagem histórico da (asa), única área aberta que poderia comportar o conjunto de pedestais, microfones, cabos, fones e mesa de som. Esse fato também gerou uma mudança no posicionamento de ritmistas, do coro e da voz principal, mudando as condições de execução musical (tema a desenvolver em outra oportunidade).

Do ponto de vista dos repertórios selecionados, do encadeamento de cantigas e toques e seus significados, os pesquisadores-produtores pouco participaram de sua seleção. Sabemos que se trata de um xirê, ritual público, no qual se canta para todos os Santos cultuados na Casa. Que a ordem das faixas é a em que cada Santo é chamado e cuidado ao longo do ritual. Por uma questão técnica (de tempo máximo de registro do suporte 
CD), cada cantiga tem três ciclos de repetição, e as cantigas são encadeadas uma após as outras. Ao final, apresentam-se ainda alguns dos principais gêneros rítmicos tocados na Casa.

Por fim: a qual representação sonora chegamos? Em que medida questões culturais, estéticas e políticas incidiram sobre o resultado final do CD? Feita a gravação, entramos em etapa de ediçãoescuta dos materiais gerados. Os trabalhos de escuta conjunta (sempre no Ile) levaram a opções de edição. Alguns pontos foram especialmente discutidos. Dois conjuntos de materiais foram editados, canal por canal: os 'coros' (com 6 canais de captação) e os 'tambores' (com 4 canais de captação). Não temos espaço aqui para desenvolver essas ideias, mas salientamos o cuidado na mixagem dos três tambores em que se compõe a orquestra rítmica captada (rum, rumpi, le). O lugar sonoro (expressão de outros domínios do simbólico e do emotivo) do 'tambor' se expressa tanto no volume e presença que estes ganham na edição final, quanto na hierarquia de planos dos tambores base (rumpi e le) em relação ao tambor solista (rum). Todos esses efeitos e formas finais são mediados tecnicamente pelos tipos de captação por microfone e pelo trabalho de edição final, de possibilidades das mais diversas do ponto de vista da reformulação da forma, do tempo e do timbre. Para o caso da produção de uma musicalidade 'zulu' (África do Sul), Meintjes (2003), de sua etnografia dos trabalhos de estúdio, de produção seletiva de certa musicalidade, enfatiza algumas das características mediadas pela tecnologia de captação, dentre outros instrumentos de música, para as 'orquestras rítmicas', também associando índices de identidade musical com certos aspectos como 'timbre' e 'forma'. Se recuperamos em histórico as gravações do gênero no Brasil (Pereira; Pacheco, 2004), é notável que, apesar da centralidade do tambor na música e no dia a dia da religião, do ponto de vista da organização de planos sonoros, tambores têm estado em planos secundários, privilegiando as harmonizações e as vozes solistas.

\section{$*$}

Museu Magüta. O segundo trabalho começa em sentido inverso ao anterior: em 2002, também a partir de capitais de relações de pesquisadores do Museu Nacional, fizemos viagem explanatória ao Alto Solimões (AM) para propor a realização do trabalho de gravação-edição. ${ }^{19}$ Nessa ocasião, estabelecemos contato com outro Museu local, desta vez dos índios Tikuna, em Benjamin Constant, estado do Amazonas, o Museu Magüta. ${ }^{20}$ Inicialmente, propunha-se a gravação de material 'tradicional' (localmente classificado como 'cultural' por nossos interlocutores), em especial dos repertórios encontrados na "Festa de Moça Nova”. ${ }^{21}$ Do ponto de vista demográfico, estamos numa realidade social de proporções bem diferentes da Comunidade de Terreiro, aqui da ordem de 30 a $40 \mathrm{mil}$ pessoas. A tomar os aldeamentos onde ao final se realizou o trabalho (Benjamin Constant, Filadélfia, Lauro Sodré, Otawari, Nova Jerusalém e Feijoal), temos situações Tikuna que vão de aldeamentos de poucas dezenas de pessoas, com pouco uso do português, até aldeamentos de milhares de pessoas, com português como língua dominante. Pois bem, assim o quadro de musicalidades Tikuna se ampliou. E mais complexo: gerava um campo de debate que tomava como variável de valor a 'autenticidade' musical (sendo que a falta de 'autenticidade' podia também ser associada com seu caráter 'colonizador').

Esse fato se evidenciou nas primeiras reuniões que fizemos. Desta vez, estávamos na sala da direção do Museu, entre mobiliário de escritório e sua pequena biblioteca. Representando a direção do Museus estavam Diretor, Vice-diretor e um especialista em rituais que cuidava das coleções. Sentados em cadeiras, em círculos, a situação conversacional é (digamos) pouco hierárquica: após saudações e cumprimentos, enquadramos a

19. Trabalho realizado entre os anos de 2002 e 2009. Gravador DAT, microfone cardioide. Para algum detalhamento, Pereira $(2014 a)$.

20. A literatura antropológica dedicada ao povo é extensa, desde os trabalhos de Curt Nimuendaju nas décadas de 19301940, passando pelos de Cardoso de Oliveira, chegando, por exemplo, aos de João Pacheco de Oliveira, no Brasil; Hugo Camacho e Maria Emília Montes, na Colômbia, e Jean Pierre Goulard na França.

21. Em todos os aldeamentos em que trabalhamos, esse era o nome dado para a moça em torno de cuja narrativa se organiza a Festa, nome que também se refere à festa em si. 
conversa com nossa proposta. E uma contraproposta começou a ser esboçada. Etnografias de situações conversacionais podem ser bastante minuciosas na explicitação de enquadramentos e contraargumentos que organizam e definem a comunicação (Goffman, 2002; Gumperz, 1982). Para o caso em questão, enunciar consensos ao final do encontro (que se traduziu já em primeira organização de cronograma e pessoas e aldeias a visitar) não significa necessariamente 'entendimento'. Como já colocou Gumperz (1982, p.4): “Há uma tendência a tomar como garantido que o envolvimento conversacional existe, que os interlocutores estão cooperando e que convenções interpretativas estão sendo compartilhadas". Essas reflexões, hoje, decorrem de todo o processo que se seguiria e da produção ao final de múltiplos desentendimentos entre os envolvidos na produção de registros e edição de fonogramas. O que evidencia limites de dialogia e, em particular, do modelo 'reunião' como organizador de situações de comunicação. Do ponto de vista musical, essa multivocalidade se expressa em uma dupla classificação (não muito rígida) de repertórios a se dar conta: 'cultural' e 'moderno', o que podia abranger uma série de situações musicais. Isto porque dentre os conhecidos e parentes, havia grupos de música de jovens que cantavam em tikuna e português, que tanto arranjavam (harmonizando com violões e teclados) repertório 'cultural'

(tradicional), quanto compunham em ambas línguas. Na prática, isso significou a ampliação dos repertórios a serem registrados. Além disso, iniciado o processo, as redes que se entreteciam ao redor da direção e funcionários do Museu Magüta foram se ampliando, até mesmo para além do alcance das redes primárias, levando-nos a certo conjunto de aldeamentos, redes e repertórios.

Se no caso do Ile Omolu Oxum tivemos adensamento em um ritual específico (o xirê), no caso Tikuna, o repertório abrangeu: gêneros da Festa da Moça Nova, um amplo repertório de cantos (de míticocosmológicos a improvisos e acalantos), temas instrumentais com trompa (aricano) e rabeca, composições atuais, cantos protestantes, grupos musicais do entorno da cidade de Benjamin Constant. Ao final, chegamos a pouco mais de 11 horas de material. Apesar dos desentendimentos que se seguiriam, o rico material propunha espectro amplo de possibilidades performáticas e de significação, ampliando a noção de 'música Tikuna' e colocando-a em debate no processo de composição da coletânea de fonogramas que comporia Magüta arü wiyaegü (traduzível por (cantos Tikuna').

Apesar de ao final de cada pequena situação de gravação que realizávamos nos reunirmos com a Direção do Museu para escutar e avaliar o trabalho, e de termos deixado duas cópias de todo o material, por aldeamento (em um total de 11 discos), quanto mais o material se ampliava, tanto mais negociadas 22 eram as novas situações de seleção de repertório e gravação, tanto mais a noção de 'música Tikuna' se ampliava, tanto mais concepções locais entravam em regimes de relativização e debate. 0 caso é que a ampliação da rede de interlocutores e situações de gravação, se por um lado significou um rico painel das musicalidades Tikuna hoje, significou também, ao final, certa segmentação entre os participantes. Diante das condições de etnografia de que dispúnhamos, e da complexa organização social Tikuna, diversa e com marcada autonomia entre aldeamentos e organizações associativas, o trabalho de registro levou para além das redes do Museu, em alguns casos em rede de contradição com marcada diferenciação musical. Além disso, os gêneros cobertos pelos referentes 'cultural' e 'moderno' podiam variar e transitar entre as classificações. Esse fato se acentuava do ponto de vista da religião, nos 'cantos de igreja', como os classificaram alguns Tikuna em tom crítico por sua inclusão na coletânea final. Note-se que o debate religioso e musical se dava entre religiosidades cristãs praticadas pelo grupo, não tanto em uma oposição 'cultural' (referido ao redor da 'Festa da Moça Nova') e 'moderno' (os demais repertórios).

Do ponto de vista da representação fonográfica a que chegamos: por conta da variedade e extensão do material, optamos pela edição de um CD

22. Por 'negociado' entendemos a produção dos interesses para novas gravações, em especial quando não faziam parte das redes em que o Museu Magüta se relacionava. Esse fato passava especialmente, na performance discursiva, em questões religiosas ou de pertencimento associativo (dentre os Tikuna há mais de uma associação de representação). 
duplo, operando com a classificação 'cultural' - 'moderno'. Um ponto central a ressaltar é o de que ao contrário do trabalho anterior, no período de campo realizado (cerca de 3 meses) não tivemos situações de escuta coletiva para seleção de repertório. Fizemos pontualmente, em alguns casos, escutas no ato mesmo das gravações; numa escuta seguida ao registro, já reunindo as que os músicos e participantes considerassem as mais bem executadas. Do ponto de vista de nossas discussões 'éticas', ressaltese que a ampliação do repertório significa também múltiplo comprometimento pesquisadores-músicos com as redes de cada aldeia visitada. ${ }^{23}$ Para concluir essa etapa do processo, uma versão final foi enviada para o Museu e foi acordada sua prensagem.

Para pontuarmos essas cenas etnográficas, fechamos o processo fonográfico com um 'lançamento' do material com momentos de tensão. Ao longo do dia de organização do Museu para receber o evento e seus convidados (políticos locais, professores da universidade, os participantes das gravações, representantes de algumas associações de representação indígena, e algum público mais amplo), o disco foi ouvido e debates intensos se travaram. 0 valor em disputa era o da 'autenticidade' e dos efeitos 'maléficos' - em termos de efeito sobre a cultura Tikuna - de certos repertórios. Houve acusações e ameaças por parte de algumas posições. Esse enquadramento geral só foi quebrado durante o evento propriamente, quando então o trabalho foi apresentado como "importante", "ainda não foi feito pela gente mesmo, mas é importante”. Além disso, posições historicamente antagônicas cumprimentaram umas às outras e ressaltaram a importância de estarem juntas.

23. Essas visitas sempre foram feitas acompanhadas de membros do Museu Magüta, bem como as articulações de visitas realizadas a partir de encontros na sede do Museu. Nesse sentido, ainda que falemos de segmentação, podemos pensar em graus de relação entre a Direção do Museu e aldeias, mais do que se não houvesse nenhum tipo de relação.

\section{Colaboração fonográfica e objetificação musical}

Um primeiro ponto que gostaria de ressaltar, tomando os casos pontualmente traçados, é o dos limites de entendimento - por parte do pesquisador-produtor - do conjunto de ações e supostos que antecedem e organizam situações de gravação-edição como as relatadas. Esse ponto fica evidente, nos parece, com a densidade etnográfica e de questões que os casos anteriores deixam em aberto. Situações fonográficas como as apresentadas rendem bases iniciais de dados, primeiras hipóteses etnográfico-analíticas, e primeiras redes e processos de articulação. São rentáveis não só para acompanhar a 'música' em prática e discussão, mas a partir dos repertórios registrados, acessar sua relação com a organização ritual-religiosa, com o gênero, com a juventude, com a família, com as relações entre identidade e alteridade. Seja em regime hierárquico, seja em regime de segmentação, os casos fonográficos evidenciam a complexidade dos jogos relacionais e configurações culturais postos em debate pela definição do que seja 'música', de como esta se relaciona com e configura mundos socioculturais. Do ponto de vista do método e da narrativa, condições de produção do conhecimento etnográfico entram também no esquadro das atenções etnográficas dos antropólogos. Na arena das

'dialogias' (sobretudo a norte-americana), essa é uma faceta contemporânea bastante salientada por pesquisadores e músicos; somando-se aos problemas da subjetividade do pesquisador, do caráter não positivo, interpretativo do conhecimento; e da crítica das relações entre ciência-arteadministração na produção de 'representações' audiovisuais coloniais.

Nesse cenário, para os casos resumidos, problemas de objetificação ${ }^{24}$ sonora se colocam. Objetificação sonora da cultura, em contexto colecionista, materializada em 'produtos' como CDs e DVDs; e na organização e disponibilização de arquivos. Etnografias do processo fonográfico dentro de suas etapas e tecnologias de interação e representação, são também rentáveis tanto

24. Bourdieu, 1998; Agawu, 2003; Porto, 2009 
para rever as condições de geração de arquivos sonoros-musicais já constituídos, como para pensar sua administração hoje, do acesso à produção de novos fonogramas. Para os dois casos relatados, ainda que esquematicamente, gostaria de ressaltar o modo como organizações políticas locais (dentro de seus respectivos quadros sociodemográficos) contribuíram para geração de certo 'consenso' na hierarquia, com a repetição exaustiva de repertório específico, de um único evento sonoro musical; e certo 'dissenso' na segmentação, com a ampliação de repertórios e entendimentos sobre o que seja 'música', e de situações e projetos musicais.

Voltando aos cadernos de campo desses períodos de produção de situações musicais e edição de fonogramas e coleções, não conseguimos seguir as trajetórias dos discos após seus lançamentos, para poder ampliar o entendimento das situações fonográficas vividas, e dos usos e significados que os produtos CDs e arquivos podem ter. Notícias esparsas do alto Solimões chegam de seus usos em salas de aula, e segue sendo vendido na sede do Museu. Em 2015, durante um encontro de etnomusicologia, uma jovem estudante Tikuna, lecionando em Manaus, apresentou um trabalho sobre a Festa da Moça Nova em sua aldeia (nenhuma das que havíamos registrado) com um conjunto de imagens acompanhado de um dos fonogramas elaborados com o Museu Magüta. No caso do Ile Omolu Oxum, o material teve ampla difusão digital, do site do Laced ao Youtube. Encontramos cópias 'piratas' tanto nos mercados populares do Rio de Janeiro quanto de Recife (PE). Nesse ponto, tomado o pano de fundo do desenvolvimento de práticas de colecionamento sonoro-musical e edição de fonogramas e as cenas dramáticas da produção de dois CDs de perfil 'étnico', alguns alcances, limites e agendas de práticas 'colaborativas' podem ser comentados.

De nossa parte, recuperando os ideais iniciais que nortearam os trabalhos da coleção 'documentos sonoros', 'dialogia' apontava tanto para rever certas condições de produção do conhecimento, quanto certas práticas narrativas do colecionamento sonoro (dentro do hoje grande campo dos registros fonográficos etnomusicológicos). Na concretude dos processos já realizados, significou trabalhar conjuntamente desde a organização das situações conversacionais de definição de processos e fins, até as situações de gravação propriamente, e as posteriores de escuta e edição. Significou adaptar-se às vicissitudes locais e refazer pressupostos diante dos limites das redes de mediação articuladas, do tempo disponível para realização do trabalho, ao domínio linguístico e os recursos materiais e simbólicos das redes iniciais dentro das quais a prática colecionista aporta (Clifford, 1994; 0'Hanlon, 2002; Cohn, 1996). Em cada caso, ao final, buscávamos na polifonia a consonância, algum acordo entre os projetos pessoais e de grupo envolvidos. Diante desses multiescalonados contextos, o colecionismo idealmente proposto vai se tornando prática, adaptando-se às vicissitudes locais e refazendo seus pressupostos.

Diante dos desafios organizacionais e de representação colocados, etnografias e curadorias 'colaborativas' podem ser mais do que "metáforas do diálogo" (Lassiter, 2005, p.3), um dos estados atuais da crítica?

Seja como dialogia hierárquica, seja como desentendimento estratégico, apostaria que sim. Ambos processos exigiram de todos os envolvidos interesse nos debates sobre 'música', na definição de significados e formas, no ensaio e na repetição, na edição de fonogramas. Políticas de representação foram questionadas, representações fonográficas foram produzidas. Para encerrar este exercício, partindo de algumas das ideias de Seeger $(1986,1996)$ sobre o duplo investimento de geração de fonogramas (processo de gravação) e posterior salvaguarda e disponibilização (arquivos sonoros), gostaria de enfatizar, para os casos apresentados:

1. Os investimentos etnográficos no campo da etnomusicologia (patrimônio do campo dos colecionamentos de múltiplos períodos) devem, faz não muito tempo, incluir etnografias das condições de possibilidade do 'campo', problematizando as posições e poderes em que este se organiza. Neste quadro, etnografias históricas e contemporâneas de 'situações de gravação' dão continuidade tanto ao 
desenvolvimento e qualificação de práticas de colecionamento, quanto ao trabalho de organização e disponibilização de 'arquivos'. Como vimos na literatura mais recente, o mesmo se aplica para 'situações de edição' (mixagem) e o modo como valores de 'autenticidade' e 'tradicionalidade' passam, agora, por mediações tecnológicodigitais em economias sonoras complexas e negociadas.

2. As revisões de ideias e práticas relacionadas aos referentes 'colaborativo' 'participativo' - 'compartilhado' passam tanto pela realização do processo fonográfico, quanto pelo trabalho de organização e disponibilização de 'arquivos'. Sabemos que representantes de grupos étnicos, populares e religiosos frequentam cada vez mais as 'reservas técnicas' e os corredores expográficos de instituições museais. Essa presença pode incidir sobre requalificações de acervos graças à interlocução com especialistas indígenas, bem como sobre a geração de novos objetos culturais.

3. Seguindo os ideais e jurisprudências patrimoniais mais recentes, colocam-se também os problemas e questões envolvendo a disponibilização digital de materiais editados audiovisualmente, arenas também de geração de regimes colaborativos de reflexão e prática e de adequação jurídica a noções coletivas de patrimônio, bem como concepções distintas do que seja 'música'. Editar fonogramas e disponibilizálos incide sobre alguns direitos patrimoniais. Até onde nos é possível acompanhar (Seeger, 1996; Mills, 1996; Baptista, 2004), pouco mudou no cenário que gira em torno da impossibilidade do direito 'autoral' em reconhecer direitos 'coletivos'. Como editar fonogramas sem autoria individual reconhecida, mas com reconhecido patrimônio de um determinado povo ou irmandade? Mas além disso, o curador norte-americano lembra que do ponto de vista do 'arquivo', além dos direitos do povo ou grupo registrados, estão ainda outros direitos: além do autoral, estaria o direito 'intelectual', o do pesquisador como autor; e o de 'depósito', do arquivo que salvaguarda e disponibiliza. Este último deve ainda regular o acesso e veiculação de itens e coleções e os limites de seu uso público. Desafios em aberto, mas já com alguns instrumentos que possibilitam, em caso de discussões jurídicas, algum reconhecimento de 'autoria' e 'propriedade' (Baptista, 2004 ; Mills, 1996). ${ }^{25}$

Por fim, uma última lição que tiraria dos processos fonográficos aqui resumidos é a de que medidores de 'sucesso' e 'risco' (se são pertinentes) não se dão separando situações de dissenso de situações de consenso, nem classificando rigidamente 'estilos' e 'gêneros' musicais. Como enfatizamos, processos fonográficos se complexificaram, regimes de representação sonora se contradizem. Ao longo do processo de seleção-gravação-edição, dilemas administrativos, estéticos e éticos têm acompanhando a "produção da diversidade musical" intra e extragrupos humanos (Neuenfeldt, 2005, p.84). Do ponto de vista das resultantes sonoras, nem sempre são previsíveis os materiais e arranjos acionados para gerar musicalidades referidas a gentes e lugares. Além disso, museologias e ações patrimoniais 'indígenas' não deixam de viver dilemas de representação, autoridade e autoria, ainda que trabalhando em regimes de contrarrepresentação (Clifford, 2003; Stanley, 2007). Os trabalhos de que já dispomos (Lassiter, 2003; Araujo; Cambria, 2013) demonstram que processos 'colaborativos' são processos marcados por heteroglossia, de narrativas e modos de fazer; mas que se organizam na busca de arranjos que possibilitem articulação de ações e interesses. Nesse plano, nem sempre

25. Para o caso do CD Ile Omolu Oxum, conseguimos registrar as cantigas como de 'domínio público'; e a Yalorixá respondeu como intérprete. Em uma segunda edição, nenhuma editora quis reconhecer as cantigas para os Orixás como de 'domínio público'. No caso do CD Magüta arü wiyaegü, tanto editoras não reconheceram as cantigas como de domínio público, como não era possível, em especial pelo material gravado da Festa da Moça Nova, recuperar dados de intérprete. Nesse caso, o material foi editado após a assinatura de um termo de responsabilidade pelos pesquisadores-produtores com a fábrica de prensagem. 
representações fonográficas dão conta da pluralidade musical em seleção, nem sempre a diversidade é gerada pelo consenso.

Rancière (2005, p.17), pensando as demandas recentes de práticas políticas forjadas esteticamente, enfatiza o modo como estas conformam "maneiras de fazer que intervêm na distribuição geral das maneiras de fazer". Não sem razão, esse é um dos pontos centrais de discussão e reivindicação atuais sobre os processos de colecionamento musical (e da etnografia em sentido mais amplo): o da organização, das condições em que 'diálogos', 'acordos' e 'desacordos' se dão. Não apenas uma maior abertura aos saberes indígenas, mas também a seus modos de transmissão de conhecimento, de organização conversacional da vida. Nesta seara, campos de debate sobre 'música' e políticas de representação sonora têm proposto, ao longo de toda a cadeia de produção e significado de objetos de 'cultura', formas alternativas de diálogo e política, de entendimento, organização e experiência do que seja 'música', seu lugar na formação de mundos sociais, naturais e espirituais; sua capacidade de agregar materiais multirreferenciais; seu valor e domínio patrimonial.

\section{Agradecimentos}

A Marília Cury e Tamimi Borsatto pelo convite para participação no IV Encontro Paulista Questões Indígenas e Museus/ V Seminário Museus, Identidades e Patrimônios Culturais, e pelo estímulo à escrita destas reflexões; aos colegas indígenas e não indígenas pelo profícuo debate nessa ocasião; a Mãe Meninazinha de 0xum e à comunidade do 'Ile Omolu Oxum'; à Direção do Museu Magüta e a todos os músicos registrados.

\section{Referências}

AGAWU, Kofi. Representing African Music: Postcolonial notes, queries, positions. New York: Routledge, 2003.
AMARAL, Rita; SILVA, Vagner Gonçalves da. Cantar para subir - um estudo antropológico da música ritual no candomblé paulista. Religião e Sociedade, v.16, n.1/2, 1992.

ANDERSON, Benedict. Comunidades imaginadas: reflexões sobre a origem e a difusão do nacionalismo. São Paulo: Companhia das Letras, 2008.

APPADURAI, Arjun. Modernity at Large: Cultural dimensions of globalization. Minneapolis: University of Minnesota Press, 1996.

(Org.) A vida social das coisas. Rio de Janeiro: Ed. UFF, 2015.

APPIAH, Kwame Anthony. Na casa de meu pai: África na filosofia da cultura. Rio de Janeiro: Contraponto, 1997.

ARAUJ0, Samuel; CAMBRIA, Vincenzo. Sound Praxis, Poverty, and Social Participation: Perspectives from a Collaborative Study in Rio de Janeiro. Yearbook for Traditional Music, v.45, 2013.

BAPTISTA, Fernando Mathias. Os Povos Indígenas frente ao Direito Autoral e de Imagem. São Paulo: Instituto Socioambiental, 2004.

BARRos, José Flávio Pessoa de. Mito, Memória e História: a música sacra. Espaço e Cultura, v.9-10, 2000

BARTH, Fredrik. Cosmologies in the making: A generative approach to cultural variation in inner New Guinea. London: Cambridge University Press, 1987.

BARTÓK, Béla. [1936]. Why and How do We Collect Folk Music? In: . Essays. (ed. Benjamin Suchoff). Lincoln: University of Nebraska Press, 1976.

BAUMAN, Richard; BRIGGS, Charles. Voices of Modernity: Language Ideologies and the Politics of Inequality. Cambridge: Cambridge University Press, 2003

BÉHAGUE, Gerard. Correntes regionais e nacionais na música do Candomblé baiano. Revista AfroÁsia, Salvador: Centro de Estudos AfroOrientais da Universidade Federal da Bahia, n. 12, 1976.

BLEICHMAR, Daniela. Visible Empire: Botanical Expeditions \& Visual Culture in the Hispanic Enlightment. Chicago: The Univesity of Chicago Press, 2012 
BOURDIEU, Pierre. Economia das Trocas Lingüísticas. São Paulo: Edusp, 1998.

BRADY, Erika. A Spiral way: How the phonograph changed ethnography. Jackson: University of Mississippi Press, 1999.

BROWN, Katherine. Reading Indian Music: the interpretation of seventeenth-century European travel-writing in the (re)construction of Indian music history. British Journal of Ethnomusicology, v.9, p.1-34, 2000.

CAMBRIA, Vincenzo. A fala que faz: Música e identidade negra no bloco afro Dilazenze (Ilhéus, Bahia). Anthropológicas, v.10, n.17(1), p.81-102, 2006.

CARVALHO, José Jorge de. Um Panorama da Música Afro-Brasileira. Parte 1. Dos Gêneros Tradicionais aos Primórdios do Samba. Série Antropologia, n.275, 2000.

A racionalidade antropológica em face do segredo. Anuário Antropológico, Rio de Janeiro: Tempo Brasileiro, p.214-222, 1985.

; SEGATO, Rita. Shango Cult in Recife,

Brazil. Caracas: Fundef; Conac; 0as, 1992.

CEPEDA, Maria Elena. Musical Imagination: U.S. Colombian Identity and the Latin Music Boom. New York: New York University Press, 2010.

CLIFFORD, James. Museologia e contra-história: viagens pela Costa Noroeste dos Estados Unidos. In: ABREU, R.; CHAGAS, M. (Org.) Memória e patrimônio: ensaios contemporâneos. Rio de Janeiro: DP\&A, 2003.

Sobre a autoridade etnográfica. In: - A experiência etnográfica: antropologia e literatura no século XX. Rio de Janeiro: Ed. UFRJ, 1998. .; MARCUS, George. Writing Culture: The Poetics and Politics of Ethnography. Los Angeles: University of California Press, 1986.

COCCHIARA, Giuseppe. The History of Folklore in Europe. USA: Institute of Human Issues, 1985.

COHN, Bernard. Colonialism and Its Forms of Knowledge. Princeton: Princeton University Press, 1996.

COOKE, Bill; KOTHARI, Uma (Ed.) Participation: The new tyranny? New York: Zed Books, 2001.

FINDLEN, Paula. Possessing Nature: Museums,
Collecting and Scientific Culture in Early Modern Italy. Los Angeles: University of California Press, 1994.

GELBART, Matthew. The invention of "Folk music" and "Art music". Cambridge: Cambridge University Press, 2007

GELL, Alfred. Art and Agency: An Anthropological Theory. Cambridge: Cambridge University Press, 1998.

GHUMAN, Nalini. Resonances of the Raj: India in the English Musical Imagination, 1897-1947. London: University of 0xford Press, 2014.

GOFFMAN, Erving. “FOOTING”. Em: RIBEIRO, B. T.; GARCEZ, P. M. (Org.) Sociolinguística Interacional. São Paulo: Loyola, 2002.

GOODY, Jack. 0 antropólogo e o gravador de sons. In: o Mito, o Ritual e o Oral. Petrópolis: Vozes, 2014

GUMPERZ, John. Discourse Strategies. Cambridge: Cambridge University Press, 1982.

HENARE, Amiria. Museums, Anthropology and Imperial Exchange. Cambridge: Cambridge University Press, 2005

IRVING, David. Comparative organography in early modern empires. Music \& Letters, v.90, n.3, p. 372-398, 2009.

KAMENETSKY, Christa. The Brothers Grimm and their Critics: Folktales and the Quest for Meaning. Columbus: Ohio University Press, 1992.

KARTOMI, Margaret. On Concepts and Classifications of Musical Instruments. Chicago: The University of Chicago Press, 1990.

LABOV, William. Principles of Linguistic Change: Social Factors. v.2. New York: Wiley-Blackwell, 2010 a.

Principles of Linguistic Change: Cognitive and Cultural Factors. v.3. New York: Wiley-Blackwell, 2010b.

LASSITER, Luke. The Chicago Guide to Collaborative Ethnography. Chicago: University of Chicago Press, 2005

LEACH, Edmond. Ritualization in Man. Philosophical Transactions of the Royal Society of London, Series B, Biological Sciences, v.251, n.772, p.403-408, 1966.

MAKANON, Daniel; NEUMANN, Mark. Recording 
Culture: Audio Documentary and The Ethnographic Experience. Thousand Oaks: Sage, 2009.

(Introduction; Writing Culture and Recording Culture).

MEINTJES, Louise. Sound of Africa! Making Music Zulu in a South Africa Studio. Durham, NC: Duke University Press, 2003.

MILLS, Sherylle. Indigenous Music and the Law: An Analysis of National and International Legislation. Yearbook for Traditional Music, v.28, p.57-86, 1996.

NEUENFELDT, Karl. Nigel Pegrum, “DidjeriduFriendly Sections" and What Constitutes an "Indigenous" CD: an australian case study of producing World Music recordings. In: GREENE, Paul; PORCELLO, Thomas (Ed.) Wired for Sound: Engineering and Technologies in sonic cultures. Middleton, CT: Wesleyan University Press, 2005.

0'HANLON, Michael. Introduction. In: 0'HANLON, M.; WELSCH, R. (Ed.) Hunting the gatherers: Ethnographic Collectors, agents and agency in Melanesia, 1870-1930s. New York: Berghahn Books, 2002.

OLIVEIRA, João Pacheco de. A refundação do Museu Magüta: etnografia de um protagonismo indígena. In: MAGALHÃES, Aline Montenegro; BEZERRA, Rafael Zamorano (Org.) Coleções e colecionadores: A polissemia das práticas. Rio de Janeiro: Museu Histórico Nacional, 2012.

Pluralizando tradições etnográfica:

sobre um certo mal-estar na antropologia. Em: LANGDON, Esther Jean; GARNELO, Luiza (Org.) Saúde dos Povos Indígenas: reflexões sobre antropologia participativa. Rio de Janeiro: ContraCapa; ABA, 2004.

OLIVEIRA, Roberto Cardoso de. O trabalho do antropólogo. São Paulo: Ed. Unesp, 2006.

PEREIRA, Edmundo. Notas sobre representação fonográfica, rituais de gravação e tradição musical. In: LIMA FILHO, Manuel; ABREU, Regina; ATHIAS, Renato (Org.) Museus e atores sociais: perspectivas antropológicas. Recife: Editora da UFPE, 2016. p. 215-243.

Política, desentendimento e representação fonográfica entre os Tikuna. In: Ciclo de Debates "Território, Museus e Sociedade: práticas, poéticas e políticas na contemporaneidade". Rio de Janeiro: UniRio, 2014a. (mimeo).

PORTO, Nuno. Modos da objetificação da dominação colonial: o caso do Museu do Dundo, 1940-1970. Portugal: Fundação Calouste Gulbenkian, 2009.

PRANDI, Reginaldo. Música sacra e música popular. In: Segredos guardados: orixás na alma brasileira. São Paulo: Companhia das Letras, 2005.

RANCIÈRE, Jacques. A partilha do sensível: estética e política. São Paulo: Ed. 34, 2009.

RICHARDS, Jeffrey. Imperialism and Music: Britain, 1876-1953. Manchester: Manchester University Press, 2001.

SAID, Edward. Orientalismo: o Oriente como invenção do Ocidente. São Paulo: Companhia das Letras, 1990.

SCALES, Christopher. Recording Culture: Powwow music and the aboriginal recording industry on the northern plains. Durham, NC: Duke University Press, 2012.

SEEGER, Anthony. Ethnomsciology, archives, professional organizations and the shifting ethics of intellectual property. Yearbook for Traditional Music, v.28, p.87-105, 1996.

The Role of Sound Archives in Ethnomusicology today. Ethnomusicology, v.30, n.2, p.261-276, 1986.

STANLEY, Nick (Ed.) The Future of Indigenous Museums: Perspectives from the Southwest Pacific. New York: Berghahn Books, 2007.

STERNE, Jonathan. Techniques of Listening. In: The Audible Past: Cultural Origins of Sound Reproduction. Durham, NC: Duke University Press, 2003.

THOMAS. Nicholas. Entangled Objects: Exchange, Material Culture and Colonialism in the Pacific. Cambridge, MA: Harvard University Press, 1991.

TRAVASSOS, Elizabeth. Os Mandarins Milagrosos: arte e etnografia em Mário de Andrade e Béla Bartók. Rio de Janeiro: Funarte; Jorge Zahar, 1987.

TROUTMAN, John W. Indian Blues: American Indians and the Politics of Music, 1879-1934. Norman: University of Oklahoma Press, 2009.

TURNER, Victor. Dramas sociais e metáforas 
rituais. In: Dramas, campos e

metáforas. Niterói: Ed. UFF, 2008.

Os símbolos no ritual ndembu. In: - Floresta de símbolos: aspectos do

ritual ndembu. Niterói: Ed. UFF, 2005.

WIORA, Walter. Reflection on the problem: how old is the concept folksong? Yearbook of the International Folk Music Council, v.3, p.23-33, 1971.

WOODFIELD, Ian. Music of the Raj: A social and economic history of music in late Eighteenth Century Anglo-Indian society. Oxford: University of 0xford Press, 2000.

* Edmundo Marcelo Mendes Pereira é antropólogo e etnomusicólogo. Tem mestrado (1999) e doutorado (2005) em Antropologia Social pelo Programa de Pós-Graduação em Antropologia Social (PPGAS), Museu Nacional, Universidade Federal do Rio de janeiro (MN-UFRJ). Entre 2006 e 2014, fo professor adjunto do DAN-PPGAS da Universidade Federal do Rio Grande do Norte (UFRN). Atualmente, é professor adjunto do PPGAS-MN-UFRJ. Pesquisador vinculado ao Setor de Etnologia e Etnografia (MN-UFRJ), ao Laboratório de Pesquisas em Etnicidade, Cultura e Desenvolvimento (Laced-MN-UFRJ) e ao Grupo de Estudos Sobre Cultura Popular (GECP-UFRN). Co-editor da Coleção Documentos Sonoros do Museu Nacional. Vencedor do II Prêmio ABA/GIZ (2012). Atua principalmente nos seguintes campos de investigação: etnologia indígena, etnicidade, etnomusicologia, cultura popular e patrimonialização. 


\title{
Desafios da plena efetividade dos direitos culturais e os instrumentos de proteção dos saberes e práticas tradicionais dos povos indígenas brasileiros
}

\author{
Robson Rodrigues* \\ Grasiela Lima** \\ Fundação Araporã
}

É comum aparecerem pessoas nas aldeias que gravam as músicas, copiam as histórias e depois lançam isso no mercado, ficando com todo o crédito. Indústrias também copiam a extração de uma planta e não dizem que veio de um saber tradicional. A ideia não é impedir a divulgação, mas dar aos índios um controle sobre o uso que é feito dela.

Marcos Terena ${ }^{1}$

Quando pensamos na realidade dos povos indígenas no Brasil hoje, duas questões fundamentais emergem nesse campo que contempla um amplo debate, contradições e polêmicas: a violação de direitos humanos e as desigualdades sociais. As recentes notícias publicadas pelos meios de comunicação, fatos reiteradamente denunciados pelos movimentos indígenas e indigenistas, apresentam temas que são recorrentes e se interrelacionam: pobreza, miséria, fome, desnutrição, suicídio de jovens, alcoolismo, drogas,

invasões e processos emperrados de demarcação e homologação de terras, assassinato de lideranças, perda de territórios e de recursos naturais, políticas públicas inconsistentes nas áreas de educação e saúde.

\footnotetext{
1. Presidente do Comitê Intertribal e coordenador do programa Viatan - Central de Informações Indígenas. Coordenador do Fórum Indígena Internacional sobre Biodiversidade e do tema Conhecimento Tradicional e Espiritualidade na Cátedra Indígena Internacional. Trecho de entrevista concedida à Agência Estado, 4 jun. 2004.
}

Trata-se de uma questão de grande complexidade e que se coloca com extrema urgência nos dias atuais, levando-se em conta, como assinala Baggio (2009), o intensivo processo de globalização e o acirramento da competitividade internacional no campo da economia, da deterioração das condições ambientais e da escassez de recursos naturais.

No Brasil, a configuração dessa realidade tem levado a crescentes e intensos conflitos nas demarcações de terras indígenas, que passam a ser cada vez mais cobiçadas em razão do potencial de seus recursos naturais.

Para enfrentar essa situação de profunda desigualdade e violência existem várias manifestações, movimentos e organizações políticas dos povos indígenas, apoiados por outros sujeitos, que buscam a efetividade das prerrogativas constitucionais relacionadas aos seus direitos e o respeito à sua identidade cultural.

Essas organizações têm denunciado cotidianamente a violação de seus direitos e colocado em pauta reivindicações ${ }^{2}$ como a aprovação do Novo Estatuto

2. Destacamos especialmente alguns dos pontos fundamentais da Carta Pública endereçada à Presidência da República pela Articulação dos Povos Indígenas do Brasil (Apib) em abril de 2011, cujo teor foi reproduzido em 2012 na realização do Acampamento Terra Livre (ATL 2012), na "Conferência das Nações Unidas sobre Desenvolvimento Sustentável” (Rio+20). São reivindicações que não saem da pauta de lutas indígenas nos últimos anos, tendo em vista o não atendimento pelos órgãos competentes. 
dos Povos Indígenas; aprovação e implementação da Secretaria Especial da Saúde Indígena; demarcação, proteção e desintrusão das terras indígenas; não construção de empreendimentos que impactam direta ou indiretamente as terras indígenas; fim da criminalização e prisão arbitrária das lideranças indígenas; publicação de Decreto que institui a Política Nacional de Gestão Ambiental e Territorial das Terras Indígenas; e a reestruturação da Fundação Nacional do Índio (Funai), instituindo um novo patamar de política indigenista que não seja paternalista, assistencialista, tutelar e autoritária.

Temos, portanto, elementos que configuram uma realidade cuja abordagem implica um diálogo na perspectiva inter e multidisciplinar, mas, para efeito da presente reflexão, privilegiaremos apenas alguns conceitos e categorias analíticas do Direito e da Antropologia, levando em conta a compreensão de uma problemática que envolve discussões e questionamentos sobre democracia, cidadania, direitos humanos, direitos culturais, direito à diferença, alteridade, identidade, cultura, etnia, pluralidade, diversidade, multiculturalismo e pluralismo jurídico. São aspectos que nos levam a trazer para o campo de debates as abordagens realizadas pelas ciências humanas, mas principalmente a própria visão dos indígenas sobre problemas que os envolvem diretamente.

Buscamos, assim, realizar uma reflexão sobre a luta pela efetivação dos direitos dos povos originários no Brasil e o enfrentamento das desigualdades sociais que vivenciam, a partir de três aspectos fundamentais que denotam a complexidade da questão. Em primeiro lugar, os indígenas apresentam uma diversidade étnicocultural, pois constituem diferentes povos que se encontram espalhados em diferentes regiões do país, em espaços rurais e urbanos, o que caracteriza situações e modos de vida bastante diferenciados, elementos que os tornam sujeitos com demandas e necessidades também diferenciadas e diversas. Tal fato nos remete à importância de se entender a construção da identidade na perspectiva das "diferenças nas diferenças" (Pierucci, 2008).
Em segundo lugar, destaca-se a configuração histórica da tradição de um Direito, de leis e da Justiça realizadas a partir de concepções sociopolíticas e culturais concebidas e executadas por não-indígenas. Portanto, buscase aqui discutir essas questões segundo as abordagens críticas da visão etnocêntrica do Direito e também do reconhecimento apenas formal do direito à autodeterminação dos povos indígenas, previsto na Constituição Brasileira.

A partir daí, e em terceiro lugar, torna-se fundamental apreender a dinâmica desse processo na perspectiva do protagonismo indígena, ou seja, da fala, do lugar e da percepção desse sujeito que tem participado ativamente em vários momentos da sua construção, como nos debates da Constituinte de 1987.

Portanto, existem nessa realidade dois aspectos contraditórios: a concepção desses direitos vem de uma matriz não-indígena e o que existe de direito não existe de fato, ou seja, boa parte dos direitos positivados não são efetivados.

Levando em conta essas considerações iniciais, nós, intelectuais e pesquisadores não-indígenas, priorizamos no presente artigo uma abordagem teórico-metodológica que leva em conta um compromisso acadêmico e político com as causas indígenas no que se refere à promoção de seus direitos e das suas culturas e o respeito ao seu protagonismo na perspectiva crítica dos direitos humanos, mais precisamente no enfoque da efetivação dos direitos culturais.

Sabemos o quanto etnocêntrica é a expressão "direitos humanos" com suas pretensões hegemônicas inerentes a formações culturais específicas, ancoradas em instituições, estados e demais aparatos de poder. Por outro lado, embora inscrita nesta mesma história que se vê como universal, a tradição disciplinar antropológica nos legou como herança a possibilidade de questionar preconceitos e ver os "direitos" dos outros. É por este ângulo que podemos reconhecer hoje no interior do campo dos "Direitos Humanos" instrumentos valiosos para a reafirmação do valor da diversidade cultural, 
para o questionamento das desigualdades sociais, para a defesa dos valores democráticos. (Novaes; Lima, 2001, p.9)

Ainda na visão crítica dos direitos humanos e defesa dos valores democráticos, a presente reflexão também se alinha a algumas contribuições dos estudos sobre multiculturalismo, entendido como pensamento teórico e político que promove um discurso emancipatório, a valorização da diversidade, a afirmação das identidades plurais e o questionamento das desigualdades. Destacamos, em especial, o enfoque dado por Santos (2010) que coloca a necessidade de (re)pensarmos no atual contexto o sentido das diferentes concepções de justiça e de direitos e novas formas de cidadania.

É relevante, também, salientar que a conquista dos direitos constitucionais dos povos indígenas também foi possível mediante diferentes pessoas e instituições não-indígenas que se alinharam à luta desses povos, promovendo estudos, pesquisas, apoio político e outras formas de parceria, ajudando a divulgar e publicizar a diversidade de culturas, procurando desconstruir visões preconceituosas ou ideias enraizadas e contraditórias de que os indígenas são selvagens ou que não existem mais (a ideia de que não são mais índios) porque foram assimilados pela cultura nacional.

Tentando mudar essa visão, essas pessoas revelaram ao país traços culturais característicos desses povos, como pinturas corporais e artesanatos, botaram no papel línguas que não tinham forma escrita, mostraram o valor e a importância das tecnologias indígenas e dos conhecimentos tradicionais sobre plantas e outros recursos naturais, fotografaram e filmaram aldeias, enfim, procuraram expor de várias maneiras as culturas e imagens desses povos, bem como as ameaças que pairavam - e ainda pairam sobre eles. (Baptista, 2004, p.7)

Entende-se, a partir daí, e nas próprias palavras do autor citado, que "mostrar a cara dos povos indígenas ao Brasil" foi fundamental para que o
Estado finalmente assumisse que este é um país pluriétnico e multicultural, e também que é necessário garantir o direito a um território e à proteção de suas culturas.

Baptista (2004) também destaca que, a partir desses fatos, as imagens e culturas indígenas passaram a ser divulgadas das mais diferentes formas, por diferentes sujeitos e com diferentes interesses ou objetivos.

Este amplo universo de atores não-indígenas interessados na cultura e na imagem indígena e os diferentes meios de utilização desse 'patrimônio' pela sociedade envolvente (em benefício ou detrimento dos povos indígenas) têm implicações distintas no campo do direito autoral e do direito de imagem dos povos indígenas. (Baptista, 2004, p.8)

Assim, a presente reflexão apresenta como objetivo específico problematizar algumas questões relacionadas à defesa do patrimônio cultural dos povos indígenas, os instrumentos de proteção aos saberes e práticas tradicionais, à luz da legislação pertinente aos direitos culturais.

\section{Quem são os indígenas: identidade, diversidade e alteridade}

No âmbito das discussões sobre os povos originários no Brasil, à luz das abordagens sobre diversidade cultural, direito à diferença e pluralismo jurídico, uma primeira questão se apresenta como fundamental: quem são os indígenas sujeitos de direitos no nosso país?

Como na história brasileira as populações indígenas sempre foram tratadas de forma homogênea, pois o objetivo era um só - o domínio político, econômico e religioso -, ao longo dos tempos, definir quem era indígena ou não passou a ser uma questão legal. Vários países americanos, após suas independências, estabeleceram diferentes legislações em relação aos indígenas e foram criadas instituições oficiais para cuidar dos assuntos a eles relacionados. No caso do 
Brasil, nas últimas décadas, o critério da autoidentificação étnica vem sendo amplamente aceito pelos estudiosos da temática indígena. Nesta perspectiva, a identidade étnica depende sempre do próprio indivíduo e povo, ou seja, todos aqueles que se identificam com um povo indígena e quem é reconhecido como tal pelo respectivo povo.

Já na década de 1950 o antropólogo Darcy Ribeiro baseou-se na definição elaborada pelos participantes do II Congresso Indigenista Interamericano, no Peru, em 1949, para assim definir, no texto "Culturas e línguas indígenas no Brasil”, o indígena como:

Aquela parcela da população brasileira que apresenta problemas de inadaptação à sociedade brasileira, motivados pela conservação de costumes, hábitos ou meras lealdades que a vinculam a uma tradição précolombiana. Ou, ainda mais amplamente: índio é todo o indivíduo reconhecido como membro por uma comunidade pré-colombiana que se identifica etnicamente diversa da nacional e é considerada indígena pela população brasileira com quem está em contato.

(Ribeiro, 1957, p.254)

A partir dos anos 1980, uma nova concepção passa a ser aceita, tendo em vista que os próprios povos indígenas deveriam definir quem seriam os indivíduos participantes de seu meio. Por sua vez, Melatti (1980) destaca que:

0 que decide se um grupo de indivíduos pode ser considerado indígena ou não, seja qual for sua composição racial, estejam em que estado estiverem suas tradições précolombianas, é o fato de eles próprios se considerarem índios ou não e de serem considerados índios ou não pela população que os cerca. (Melatti, 1980, p.26)

A preocupação com conceituações - que se estende desde a época colonial até a atualidade - sempre esteve vinculada a problemas e propósitos práticos: identificação, reconhecimento jurídico, direitos, assistência especial, entre outros, e de modo geral, questões recorrentes do chamado “problema indígena”. Em suma, as questões pertinentes ao relacionamento das sociedades indígenas com o Estado e com a sociedade como um todo. Atualizando a definição do conceito de identidade indígena, Oliveira (1995) ao destacar o projeto de Lei relativo à revisão do Estatuto das Sociedades Indígenas que se encontra no Congresso Nacional desde 1991, observa que:

Estas são conceituadas como "as coletividades que se distinguem entre si e no conjunto da sociedade em virtude de seus vínculos históricos com populações de origem pré-colombiana". Para a maioria das pessoas, saber se um grupo indígena realmente tem direitos a terra e proteção especial implica verificar se nele cabem as características de permitividade contidas na imagem genérica existente sobre os "índios". (Oliveira, 1995, p.78)

É certo, porém, que existe, atualmente, um consenso entre os pesquisadores associados à temática indígena: efetivamente, o que conta, é que uma dada coletividade se autoidentifique como indígena, sendo índios todos os indivíduos que são por ela reconhecidos enquanto membros desse grupo étnico. Para essa conceituação, que se reflete no plano jurídico-administrativo, não tem importância alguma saber se tal população apresenta características 'primitivas', se mantém os traços físicos ou a carga genética de populações pré-colombianas, ou ainda se preserva os elementos de sua cultura original.

Não se trata, portanto, de resgatar um uso "adequado" (no sentido do dicionário) da palavra índio, mas exclusivamente de verificar a aplicação de um status jurídico, o qual, por sua vez, não se articula com critérios biológicos nem com a persistência de padrões culturais, mas tão somente com a continuidade de uma autodefinição coletiva. (Oliveira, 1995, p.78-79)

Nesse aspecto, devem ser considerados indígenas indivíduos ou grupos de pessoas que se considerarem indígenas, ou se assim forem considerados pela população que os cerca. 
No que diz respeito à identidade étnica, as mudanças ocorridas em várias sociedades indígenas, como o fato de falarem português, vestirem roupas iguais às dos outros membros da sociedade nacional com que estão em contato, utilizarem modernas tecnologias (como câmeras de vídeo, notebooks, máquinas fotográficas e celulares), não os fazem perder sua identidade étnica e deixar de ser indígenas.

Percebemos que as populações indígenas são vistas pela sociedade brasileira ora de forma preconceituosa, ora de forma idealizada. 0 preconceito parte, muito mais, daqueles que convivem diretamente com os indígenas, principalmente, as populações rurais. Dominadas política, ideológica e economicamente por elites municipais com fortes interesses nas terras dos índios e em seus recursos ambientais, tais como madeira e minérios, muitas vezes as populações rurais necessitam disputar as escassas oportunidades de sobrevivência em sua região com membros de sociedades indígenas que aí vivem. Por isso, utilizam estereótipos, chamando-os de "ladrões", "traiçoeiros", "preguiçosos" e "beberrões", enfim, de tudo que possa desqualificálos. Procuram justificar, dessa forma, todo tipo de ação contra os índios e a invasão de seus territórios (0liveira, 1995).

Já a população urbana, que vive distanciada das áreas indígenas, tende a ter deles uma imagem favorável, embora os veja como algo muito remoto. Os índios são considerados a partir de um conjunto de imagens e crenças amplamente disseminadas pelo senso comum: eles são os donos da terra e seus primeiros habitantes, aqueles que sabem conviver com a natureza sem depredá-la (Oliveira, 1995). São também vistos como parte do passado e, portanto, como estando em processo de desaparecimento ou de aculturação, isto é, deixando de ser indígenas e ter sua própria cultura.

A partir do avanço das organizações dos povos indígenas e de seus apoiadores que atuam na desconstrução de preconceitos e estereótipos presentes em grupos sociais não-indígenas, só recentemente diferentes segmentos da sociedade brasileira estão se conscientizando de que os índios são seus contemporâneos. Eles vivem no mesmo país, participam da elaboração de leis, elegem candidatos e compartilham problemas semelhantes, como a consequências da poluição ambiental e das diretrizes e ações do governo nas áreas da política, economia, saúde, educação e administração pública em geral.

Entendendo a cultura como o conjunto de respostas que uma determinada sociedade humana dá às experiências por ela vividas e aos desafios que encontra ao longo do tempo, percebe-se o quanto as diferentes culturas são dinâmicas e estão em contínuo processo de transformação. o Brasil possui uma imensa diversidade étnica e linguística, estando entre as maiores do mundo. A multiplicidade das línguas representa um grande valor. Ao mesmo tempo é um indicador da diversidade cultural dos povos indígenas (Monserrat, 1992).

Constituída por 305 etnias indígenas, a população indígena brasileira é detentora de uma grande diversidade cultural. As línguas indígenas estão divididas em troncos ou famílias linguísticas. Atualmente são, pelo menos, 274 línguas faladas pelos membros dessas sociedades (IBGE, 2010).

Se compararmos os dados do IBGE desde o início da inclusão do tema indígena, veremos que em 1991 o censo indicava $294 \mathrm{mil}$ índios; em 2000 esse número cresceu para $734 \mathrm{mil}$, ou seja, um salto de $150 \%$. Atualmente a população indígena cresce quatro vezes mais do que a não-índia. Este aumento no número tem relação com o processo de retomada e construção da identidade desses grupos sociais que reclamam a condição de indígenas. De acordo com dados atualizados do IBGE, hoje, no Brasil, vivem $817 \mathrm{mil}$ índios, cerca de $0,4 \%$ da população brasileira, segundo dados do Censo 2010. Eles estão distribuídos entre 688 Terras Indígenas (T.I.) e algumas áreas urbanas.

$\mathrm{Na}$ atualidade, esses grupos são denominados resistentes, emergentes, ressurgidos,

remanescentes ou ressurgentes, dentro de um processo antropológico conhecido como etnogênese, termo usado para descrever a constituição de novos grupos étnicos. Esse processo é fruto do modo como os grupos humanos estão se organizando 
nos dias atuais enquanto grupo étnico, e o reconhecimento da identidade étnica é realizado a partir de informações básicas a respeito da autodeterminação, localização, população e, principalmente, manifestação de vontade do próprio povo (0liveira, 1998).

0 que importa é compreender as razões, os meios e os processos que permitem um determinado indivíduo qualquer se instituir como grupo étnico, ao reivindicar para si o reconhecimento de uma diferença em meio à indiferença, instituindo uma fronteira onde antes só se postulava a homogeneidade.

Se o etnocídio é o extermínio sistemático de um estilo de vida, a etnogênese, em oposição a ele, é a construção de uma autoconsciência e de uma identidade coletiva contra uma ação de desrespeito (em geral produzida pelo Estado nacional), com vistas ao reconhecimento e conquista de objetivos coletivos (0liveira, 1998).

Em 2003, o Brasil ratificou a Convenção 169 da Organização Internacional do Trabalho (OIT) sobre os "Povos Indígenas e Tribais em Países Independentes". O texto é de 1989 e traz referências aos direitos ambientais, humanos e étnicos. Assim, determinados acordos internacionais passaram a valer como leis nacionais. Um dos artigos da Convenção determina que os países abandonem a política da assimilação para adotar uma política de reconhecimento pleno das diferenças culturais e étnicas, e que aceitem a autonomia de organização desses grupos.

O Estado brasileiro passa, então, a adotar uma postura de respeito pela diferença e deixa de ser soberano classificador de quem é o quê. Com a ratificação da Convenção 169 pelo Brasil, são os povos étnicos que definem sua identidade.

A partir dessa nova situação, alguns grupos conseguiram recuperar ou afirmar essa identificação por meio da ritualidade ou da religiosidade ligadas a uma ancestralidade indígena. Outros afirmam essa identidade pela presença em determinado território, ou a partir de reações discriminatórias de outros grupos, o que fortalece a identidade desse povo. Tudo isso tem ajudado no aumento do número dos povos indígenas no país.

Esse fenômeno tem se evidenciado de forma mais clara nas últimas décadas, quando as histórias regionais passam a ser reestudadas; os direitos indígenas, mais reconhecidos e respeitados; e as organizações de apoio aos povos indígenas se consolidam de forma mais efetiva e passam a ser agentes importantes da causa indígena.

0 que todos os povos indígenas têm em comum? Antes de tudo, o fato de cada qual se identificar como uma coletividade específica, distinta de outras com as quais convive e, principalmente, do conjunto da sociedade nacional na qual está inserida. Portanto, quando pensarmos a temática indígena teremos de entender que o povo Guarani não quer ser confundido com o povo Yanomami ou com o Kaingang, ou com Tukano, ou Pataxó ou Krenak, ou com o Maxakali etc. Cada povo tem seu nome próprio, seus valores, saberes, virtudes e defeitos, frutos de sua construção cultural e de seu modo de ser.

Gersem Baniwa, pesquisador e expressiva liderança indígena no nosso país, desenvolveu importantes estudos sobre essa questão das diferenças e traz para o debate valiosas contribuições, além de apresentar questionamentos extremamente pertinentes no que se refere à condução das políticas públicas voltadas para a promoção da igualdade com respeito às diferenças, em especial no âmbito da diversidade cultural apresentada pelos povos indígenas.

Por que é diferente? Porque cada povo tem sua linguagem própria, sua cosmologia própria, que se distinguem das demais. Mas isso é muito pouco considerado na forma, por exemplo, de as instituições lidarem com essas populações, particularmente no que se refere às políticas públicas. (Luciano, $2008, p .67$ ) 


\section{A construção e efetivação dos direitos humanos: da diferença à igualdade}

Como vimos, a história dos povos indígenas brasileiros é marcada pela violência, nas suas mais diferentes formas de expressão, incluindo o desrespeito à sua cultura, o preconceito, a discriminação e o etnocídio, mas também pela resistência e desconstrução de estereótipos. Além disso, destacamos nesse processo a postura do Estado frente aos indígenas que passou da ignorância dos seus direitos à tutela, na medida em que foram vistos como relativamente incapazes para os atos da vida civil.

Os elementos fundamentais que demonstram a construção histórica da atual situação dos indígenas em relação à conquista, respeito e efetivação dos seus direitos, sob a perspectiva de avanços dos direitos humanos relacionados à defesa do direito à identidade cultural, podem ser entendidos na perspectiva da superação da questão do relativismo cultural versus universalismo e a elevação da temática da diversidade cultural (Barroso, 2008).

Assim, nesse contexto de debates e visões críticas sobre as ideias positivistas e o eurocentrismo, um primeiro aspecto a ser ressaltado é a própria concepção de Estado de Direito no Brasil, construída a partir do ideário liberal de cunho jusracionalista, tendo como fundamento as noções correlatas de legalidade e realização da justiça. Destacam-se, também, dois outros aspectos: a criação do Estado intimamente relacionado à ideia de Nação, fato que reconhece apenas uma cultura nacional; e a questão da soberania nacional, que não permite a existência, no mesmo território, de sistemas jurídicos diferentes (Barbieri, 2007)

Temos, assim, a compreensão de um Estadonação balizado na visão de um povo homogêneo e na lógica da centralidade da produção do Direito, a partir do órgão estatal. Dessa forma, toda a legislação indigenista brasileira, até a Constituição de 1988 , esteve pautada por uma mentalidade integracionista, fato que desconsidera qualquer possibilidade de respeito à diferença cultural.

Porém, como já mencionado, a Carta de 1988 e a ratificação no Brasil da Convenção 169 da OIT trouxeram novas determinações para as relações entre o Estado, a sociedade brasileira e os povos indígenas, reconhecendo o direito à diferença e à autodeterminação desses povos. Além disso, é importante destacar que "uma adequada leitura, interpretação e aplicação de tais direitos transcende a questão de sua mera positivação no ordenamento jurídico nacional" (Baggio, 2009, p.27), ou seja, existe a necessidade de se fazer avançar as ideias e políticas voltadas para um Estado Pluralista de Direito, tendo em vista o efetivo respeito à diversidade dos povos indígenas e suas especificidades.

Apresentam-se, a partir daí, duas ordens de questões, pois, em primeiro lugar, existe a configuração de um debate relacionado à afirmação de identidades plurais em sociedades multiculturais e desiguais (Canen, 2001) e os respectivos questionamentos relacionados às visões sobre a Declaração Universal dos Direitos Humanos, princípios que fundamentam a Constituição Brasileira, mas que se traduzem numa construção da cultura ocidental eurocêntrica, que se pretende universal e não considera a diversidade cultural dos povos.

Para contraporem a esse discurso universalista ocidental, estudiosos, ativistas e representantes de diferentes minorias sociais iniciaram uma luta pelo reconhecimento de identidades particulares, sem que isso resultasse na legitimação da desigualdade social, como bem observou Sousa (2001). 0 autor ainda destaca:

Outra fonte de contestação da homogeneização cultural pretendida pelos que confundiam igualdade e identidade foi a própria emergência da alteridade cultural ou de gênero, na cena pública. A crítica a uma razão abstrata unívoca operada por novos sujeitos sociais tornou necessária a reformulação dos próprios fins do Direito, o qual teve de atentar para a evidência 
de outras "sensibilidades jurídicas", para usar uma expressão de Geertz (1997), enraizados em outros costumes, oriundos de particularidades histórico-culturais e não de ideias abstratas de justiça elaboradas por uma suposta "razão universal”. (Sousa, 2001, p. 56)

Assim, e em segundo lugar, os próprios movimentos indígenas a partir de suas organizações políticas colocaram o desafio de pensar sobre o processo de radicalização da democracia quando se apropriam dos princípios fundamentais dos direitos humanos e reivindicam os direitos culturais. Nesse sentido, uma das primeiras conquistas se deu formalmente na Declaração Universal da Unesco sobre Identidade Cultural (2001), que definiu o direito à identidade cultural e trouxe como aspecto fundamental o "reconhecimento da diferença como constituinte de uma subjetividade inalienável dos sujeitos sociais” (Sousa, 2001, p. 55 ).

Temos, portanto, que a questão dos direitos culturais emerge no contexto da globalização, a partir de reivindicações relacionadas às identidades culturais em várias partes do mundo. No caso dos povos indígenas no Brasil, ao lado da luta pelo direito à terra somou-se a questão do reconhecimento de sua alteridade no plano nacional e a formação multiétnica e pluricultural do Estado-nação, trazendo uma nova concepção de direitos indígenas relacionados aos direitos coletivos e ao reconhecimento das diferenças (Aparicio, 2015).

\section{Direitos Culturais: respeito aos saberes, imagem e criações artísticas dos povos indígenas}

Como vimos, os direitos constitucionais perfilham os "múltiplos modos de ser, fazer e viver que configuram os direitos culturais coletivos indígenas" (Dantas, 2014, p.343), constituindose em direitos coletivos diferenciados que têm na territorialidade uma dimensão fundamental.
Contudo, os direitos culturais ainda não se concretizaram na realidade brasileira e, entre os aspectos relevantes desta questão, destaca-se em especial o limite jurídico imposto aos povos indígenas nos governos de seus territórios a partir da ideia da integralidade e unidade do Estado, assim como a doutrina da segurança nacional.

Assim, neste ponto específico da discussão a reforma do Estado se apresenta como um dos itens de pauta dos movimentos sociais indígenas, tendo em vista a reformulação no conceito clássico de povo e de Estado e o pleno reconhecimento e efetividade de direitos diferenciados:

0 reconhecimento constitucional das diferenças socioculturais indígenas representa um marco descolonial na histórica trajetória de negação e invisibilidade dos povos indígenas brasileiros. Entretanto, reconhecer, somente no plano formal, a natureza plural e multicultural que conforma a sociedade brasileira não é tudo.

É necessária a efetivação dos direitos diferenciados e a construção de espaços de lutas pelos direitos mediados pelo diálogo intercultural. 0 diálogo intercultural, portanto, se configura como um espaço e um instrumento da nova cidadania indígena, diferenciada, multicultural, dinâmica, criativa e participativa, no sentido de construir e reconstruir os direitos diferenciados indígenas e, como consequência, criar, também, contextos jurídicos, sociais e políticos descolonizados, plurais e heterogêneos onde a convivência democrática possibilite o desenvolver das ações da vida sem opressão, sem exclusão. (Dantas, 2014, p.362-363, grifo do autor)

A partir da proposta de constituição de espaços de diálogos interculturais e efetiva participação dos povos indígenas nos assuntos que lhes são afeitos, destacamos como exemplo o Plano Setorial para as Culturas Indígenas (PSCI), uma política pública construída a partir da participação e negociação estabelecida entre os indígenas e o Ministério da Cultura (MinC) que 
prevê o desenvolvimento de ações voltadas para a proteção, a promoção, o fortalecimento e a valorização das culturas indígenas com objetivos de atender às emanadas e necessidades dos povos indígenas (Brasil, 2012).

Destacam-se os seguintes objetivos:

a) contribuir para a manutenção, atualização e reprodução sociocultural dos saberes, práticas, formas narrativas, instituições e rituais indígenas;

b) incentivar os processos comunitários de transmissão de saberes e práticas, valorizando os sábios e os anciãos indígenas:

c) colaborar para a atualização das línguas indígenas:

d) possibilitar a criação de espaços comunitários para o diálogo e a reflexão sobre temas culturais de interesse dos povos indígenas;

e) incentivar a troca de experiências e o intercâmbio entre comunidades e povos indígenas ;

f) propiciar a inclusão digital dos povos indígenas, garantindo-lhes o acesso às tecnologias de informação e da comunicação;

g) incentivar e fomentar a realização de mapeamentos comunitários sobre as culturas indígenas, visando produzir conhecimentos sobre a diversidade sociocultural dos povos indígenas no Brasil;

h) promover o registro dos conhecimentos e práticas das culturas indígenas contribuindo para a elaboração de materiais didático-pedagógicos.

A construção desse processo participativo de uma política de valorização e fortalecimento das culturas indígenas fundamenta-se na necessidade de se criar condições para a cidadania cultural desses povos, fato que coloca alguns desafios como a questão da sociodiversidade indígena no Brasil e a necessidade de diálogo intercultural tendo em vista a efetividade da Portaria 177-2006 da Funai que visa o respeito aos povos indígenas, a proteção do seu patrimônio material e imaterial relacionados a imagem, criações artísticas e culturais.

Contudo, é relevante retomar aqui a atuação de não-indígenas interessados nas culturas e imagem indígenas e os diferentes meios de utilização desse patrimônio pela sociedade envolvente, fato que pode levar a ações em beneficio ou em detrimento dos povos originários. Nesse sentido, devem-se dimensionar as diferentes implicações desses atos no campo do direito autoral e do direito de imagem dos povos indígenas.

Estudiosos do patrimônio imaterial indígena que defendem a necessidade, e mesmo a urgência de sua documentação, têm deparado com um debate que coloca questões desafiadoras: o conhecimento tradicional é mais bem preservado quando mantido em segredo e/ou reservado para uso exclusivamente local? Ou ele se fortalece quando é mostrado, explicado, traduzido ou defendido com a ativa participação de seus detentores nas ações de difusão? (Gallois, 2008).

Grande parte dos problemas enfrentados para a legitimação dos direitos sobre o conhecimento tradicional encontra-se na demora da efetivação de políticas públicas, ações afirmativas e sistemas que ponham em prática essas políticas, assegurando a titularidade desses povos.

A sobrevivência deles depende de ações que defendem os direitos do índio e, também, a conservação do meio ambiente em que tradicionalmente vivem, pois seus conhecimentos estão estreitamente relacionados ao cenário que habitam. (Gitahy; Fukushima, 2009, p.21)

Assim, além dos princípios democráticos relacionados à efetiva participação dos povos indígenas nos assuntos de seus interesses e a concretização de políticas públicas que assegurem seus direitos culturais, temos também a questão específica da proteção do patrimônio material e imaterial, na medida em que esta apresenta 
problemas de ordem jurídica, de desconhecimento ou incorreta interpretação da legislação pertinente. Dessa forma, "o desrespeito ao consentimento livre, prévio e informado e à justa e equitativa repartição dos benefícios caracteriza violação e utilização ou apropriação indevida do patrimônio cultural do(s) Povo(s) Indígena(s)” (Kaingang, 2006, p.135).

As organizações dos povos indígenas e várias de suas lideranças têm plena consciência de que o patrimônio cultural de um povo integra sua identidade e diversidade cultural. Assumem, portanto, a defesa de sua garantia e efetividade legal.

São nossos cantos e danças, as formas próprias de educação, as pinturas corporais de cada Povo, as técnicas artesanais herdadas dos ancestrais, inclusive a arte plumária, que traz significado e beleza aos nossos rituais. São ainda as rezas e os conhecimentos tradicionais dos pajés, a relação de espiritualidade que nos une aos nossos territórios tradicionais e tudo o que neles preservamos, porque são parte integrante do nosso universo cultural, a sabedoria dos anciãos, as histórias contadas ao redor da fogueira, as brincadeiras das crianças, as festas e os rituais e todos os aspectos que integram as nossas formas culturais de viver e de ver o mundo.

(Kaingang, 2006, p.132)

Levando em consideração essa diversidade cultural, outro aspecto que deve ser mencionado relaciona-se ao fato de que "não há como estabelecer um procedimento único para a obtenção da imagem ou criação artística de determinado povo" (Baptista, 2004, p.11), o que demanda determinados procedimentos cautelosos de se verificar caso a caso.

Cada povo tem entendimento, regras de convivência, de repartição de benefícios, de organização social, de representação e legitimidade diferentes. Isso posto, podemos afirmar que a solução adotada para um determinado caso pode não se aplicar em um caso idêntico, mas referente a outro povo, pois as regras de tomada de decisão podem ser totalmente diferentes. (Baptista, 2004, p.11)

Assim, a questão da proteção dos conhecimentos tradicionais, do patrimônio material e imaterial e uso da imagem dos povos indígenas insere-se num universo de muitas contradições e interpretações equivocadas no campo jurídico, carecendo de políticas públicas efetivas que correspondam ao nível de complexidade que essa realidade impõe especialmente no que se refere à relação de seus diferentes sujeitos e interlocutores.

Contudo, a prioridade na resolução desses problemas relacionados à preservação do patrimônio cultural dos povos indígenas é o respeito ao protagonismo desses povos, portanto sua participação efetiva como sujeitos nesses processos, como garante a Convenção 169 da OIT.

\section{Considerações finais}

Ao lançarmos um olhar mais atento para a realidade dos povos indígenas no Brasil percebemos que a violação de direitos humanos e as desigualdades sociais vêm apresentando um constante crescimento. Atualmente o agravamento dessas ocorrências tem levado a crescentes e intensos conflitos, principalmente por conta das demarcações de terras indígenas, direito constitucional, porém, por conta da cobiça pelo potencial de seus recursos naturais, passam a ser alvo de intensas invasões e ataques aos seus legítimos detentores.

No enfrentamento dessa situação, percebe-se o crescimento de movimentos e organizações sociais e políticas dos povos indígenas, apoiados por diferentes atores sociais não indígenas, fortalecendo, portanto, as várias manifestações que buscam, de modo efetivo, prerrogativas constitucionais relacionadas aos seus direitos e o respeito à sua identidade cultural .

Nesse aspecto, é importante frisar que as variadas culturas das sociedades indígenas modificam-se constantemente e reelaboram-se com o 
passar do tempo, como a cultura de qualquer outra sociedade humana. É preciso considerar que essa sistemática aconteceria mesmo que não tivesse ocorrido o contato com as sociedades de origem europeia e africana, no período colonial.

A proteção das terras indígenas é, portanto, uma medida estratégica para o país, seja porque se assegura um direito dos indígenas, seja porque se garantem os meios de sua sobrevivência física e cultural, e ainda porque se garante a proteção da biodiversidade brasileira e do conhecimento que permite o seu uso racional.

Vive-se no Brasil, atualmente, uma onda vergonhosa de preconceito e discriminação contra os povos indígenas, provocada pelo modo como a sociedade observa a luta por seus direitos, prova inconteste de que a sociedade moderna está longe de deixar de ser uma sociedade racista.

A questão dos direitos indígenas é a principal fonte de discriminação e preconceito contra os povos indígenas. A garantia de um futuro digno e desejável para os indígenas depende fundamentalmente do respeito às suas culturas próprias e aos seus direitos de cidadania universal e específica, não somente como pertencentes a culturas e identidades particulares.

Assim, proteger o patrimônio material e imaterial dos povos originários, seus conhecimentos tradicionais, se impõe a partir da necessidade de consolidação de políticas que assegurem a diversidade cultural, contrapondo-se às tentativas de uniformização e homogeneização da sociedade brasileira, pois o respeito à diferença e à diversidade constitui-se na base da democracia.

Por fim o indígena precisa ser visto como um cidadão, esteja ele vivendo na cidade ou na aldeia, pois nunca deixará de ser indígena. As políticas de inclusão devem garantir os direitos desses povos e a preservação de sua relação com os recursos naturais e de sustentabilidade de seus territórios e de suas unidades socioculturais. Sendo assim, colocase a necessidade urgente de se conhecer melhor os povos indígenas e a sua realidade, fato que convoca toda a sociedade a se mobilizar para buscar os caminhos desse entendimento.

\section{Referências}

APARICI0, Adriana Biller. Novos Direitos Indígenas e a Desconstrução do Conceito Hegemônico de Identidade Nacional. Revista Anicus Curiae - Direito, Universidade do Extremo Sul Catarinense, v.12, n.1, p.31-40, jan./jun. 2015.

BAGGI0, Moacir Camargo. Alteridade e Diferença na 'Conquista da América': alguns pressupostos para uma compreensão inicial dos direitos constitucionais indígenas. Revista Direitos Culturais, n.7, p.27-53, dez. 2009.

BAPTISTA, Fernando Mathias. Os Povos Indígenas frente ao Direito Autoral e de Imagem. São Paulo: Instituto Socioambiental, 2004.

BARBIERI, Samia Roges Jordy. 0 princípio da Dignidade da Pessoa Humana e os Povos Indígenas. 2007. Disponível em: http://WWW. direitonet.com.br/artigos/exibir/3799/0principio-da-Dignidade-da-Pessoa-Humana-e-osPovos-Indigenas; Acesso em: 15 mar. 2016.

BARROSO, Marcela Giorgi. Multiculturalismo e Direito Internacional. Revista âmbito Jurídico, Rio Grande, v.58, 31 out. 2008. Disponível em: http://WWw. ambito-juridico.com.br/site/index. php?n link=revista artigos leitura\&artigo $i d=5230$; Acesso em: 15 mar. 2016.

BRASIL. Ministério da Cultura. Secretaria da Identidade e da Diversidade Cultural. Plano Setorial para as Culturas Indígenas. Brasília, 2012.

CANEN, Ana. Universos Culturais e Representações Docentes: subsídios para a formação de professores para a diversidade cultural. Educação e Sociedade, Campinas, SP, v.22, n.77, p. 207-227, 2001.

DANTAS, Fernando Antonio de Carvalho. Descolonialidade e Direitos Humanos dos Povos Indígenas. Revista de Educação Pública, Cuiabá, v.23, n.53/1, p.343-367, maio/ago. 2014.

GALLOIS, Dominique Tilkin. Por Que Valorizar Patrimônios Culturais Indígenas? Ciência e 
Cultura, São Paulo, v.60, n.4, out. 2008.

GEERTZ, C. A Interpretação das Culturas. Rio de Janeiro: LTC, 1997.

GITAHY, Raquel Rosan Christino; FUKUSHIMA, Joyce Camargo. Direitos Autorais como Instituto de Proteção aos Conhecimentos Indígenas.

Colloquium Humanarum, Presidente Prudente, v.6, n.2, p.18-27, jul./dez. 2001.

IBGE. Censo Indígena. Disponível em: http:// indigenas.ibge.gov.br; Acesso em: 15 mar. 2016.

KAINGANG. Lúcia Fernanda Jófej. A Proteção Legal do Patrimônio Cultural dos Povos Indígenas no Brasil. In: ARAUJ0, Ana Valéria et al. Povos Indígenas e a Lei dos Brancos: o direito à diferença. Brasília: Ministério da Educação. Secretaria de Educação continuada, Alfabetização e diversidade; Laced-Museu Nacional, 2006.

LUCIANO, Gersem José dos Santos. Diversidade Cultural, Educação e a questão indígena. In: BARROS, José Márcio (Org.) Diversidade Cultural: da proteção à promoção. Belo Horizonte: Autêntica, 2008. v.1, p.65-75.

MELATTI, Júlio C. Índios do Brasil. São Paulo: Hucitec, 1980.

MONSERRAT, Ruth M. F. Línguas Indígenas no Brasil Contemporâneo. In: GRUPIONI, Luís D. B. (Org.) Índios no Brasil. São Paulo: Secretaria Municipal de Cultura, 1992.

NOGUEIRA, J. K.; FELIPE, D. A.; TERUYA, T. K. Conceitos de gênero, etnia e raça: reflexões sobre a diversidade cultural na educação escolar. Fazendo Gênero, v.8. Corpo, violência e poder, Florianópolis, 2008.

NOVAES, Regina Reyes; LIMA, Roberto Kant de (Org.) Antropologia e Direitos Humanos. Niterói: EdUFF, 2001.

OLIVEIRA, João Pacheco. Uma Etnologia dos "índios misturados"? Situação colonial. territorialização e fluxos culturais. Mana, Programa de Pós-Graduação em Antropologia Social - PPGAS - Museu Nacional da Universidade Federal do Rio de Janeiro (UFRJ), Rio de Janeiro, v.4, n.1, 1998.

Mensurando Alteridades, Estabelecendo Direitos: Práticas e Saberes Governamentais na Criação de Fronteiras Étnicas. Dados - Revista de Ciências Sociais, Rio de Janeiro, v.55, n.4, 2012 .

Muita terra para pouco índio? Uma

introdução (crítica) ao indigenismo e à atualização do preconceito. In: SILVA, A. L.; GRUPIONI, L. D. B. A temática indígena na escola: novos subsídios para professores de $1^{\circ}$ e $2^{\circ}$ graus. Brasília: MEC:Mari:Unesco, 1995.

PIERUCCI, Antônio Flavio. Ciladas da Diferença. 3.ed. São Paulo: Ed. 34, 2008.

RAMOS, Alcida R. Sociedades Indígenas. São Paulo: Ática, 1986. (Série Princípios).

RIBEIRO, Darcy. Culturas e línguas indígenas do Brasil. Educação e Ciências Sociais, Rio de Janeiro, v.2, n.6, 1957.

SANTOS, Boaventura de Sousa (Org.) Reconhecer para Libertar: os caminhos do cosmopolitismo multicultural. Rio de Janeiro: Civilização Brasileira, 2010.

SENADO FEDERAL. Constituição da República Federativa do Brasil. Texto promulgado em 5 de outubro de 1988. Secretaria Especial de Informática. Brasília, 2013

SILVA, Aracy L. (Org.) A questão indígena na sala de aula: subsídios para professores de $1^{\circ}$ e $2^{\circ}$ graus. São Paulo: Brasiliense, 1987.

SOUSA, Rosinaldo Silva. Direitos Humanos através da História Recente em uma Perspectiva Antropológica. In: NOVAES, Regina R.; LIMA, Roberto Kant (Org.) Antropologia e Direitos Humanos. Niterói: EdUFF, 2001.

\footnotetext{
Robson Antônio Rodrigues é etnoarqueólogo e doutor em Arqueologia pelo Museu de Arqueologia e Etnologia da Universidade de São Paulo (MAE-USP). Atualmente é pesquisador de pós-doutorado no Instituto de Ciências Sociais da Universidade Federal de Uberlândia (Incis-UFU) com bolsa PNPD/Capes, e presidente da Fundação Araporã.

** Grasiela Lima é mestre e doutora em Sociologia pela Faculdade de Ciências e Letras da Universidade Estadual Paulista Júlio de Mesquita Filho (FCLAr-Unesp). Atualmente é professora das Faculdades Integradas de Jaú, pesquisadora do Grupo de Estudos e Pesquisas Violência, Instituições, Direitos Humanos e Etnias (VIDHE) na FCLAr-Unesp, membro do Grupo de Estudos Direito e Educação na Sociedade Contemporânea na Universidade Federal de São Carlos (UFSCar) e coordenadora do Grupo de Estudos Educação e Relações Etnicorraciais na Temática Indígena (Geereri) na Fundação Araporã.
} 


\title{
Desenvolvimento e gestão das coleções etnográficas do Museu do Índio: 1942 aos dias de hoje
}

\author{
Ione Helena Pereira Couto *
}

Museu do Índio, Fundação Nacional do Índio (Funai)

\author{
Década de 1940 - 0 início das \\ coleções
}

Gosto muito das palavras de Ulpiano Bezerra de Meneses que informam sobre o enfrentamento do objeto (Meneses, 1994). Suas palavras estão calcadas na necessidade de as instituições museológicas assumirem que sua comunicação se dá por meio dos objetos, elemento estruturador tanto para quem concebe quanto para quem visita a instituição. Mas para que o enfrentamento se dê é necessário um movimento anterior, aquele que envolve a captação e gestão do objeto museológico.

É sobre a formação e gestão do acervo museológico do Museu do Índio que este texto trata, mas para entendermos como foi tal processo é necessário, inicialmente, dividir a trajetória da Instituição em dois momentos. 0 primeiro, relativo a sua criação e funcionamento dentro do Serviço de Proteção aos Índios - SPI (1910-1967). 0 segundo, quando passou a fazer parte da estrutura administrativa da Fundação Nacional do Índio Funai (1967), após a extinção do Serviço.

o Museu do Índio foi criado em 1953, dentro da estrutura administrativa do extinto Serviço de Proteção aos Índios (SPI), mas a formação e gestão de suas primeiras coleções etnográficas tiveram início 11 anos antes de sua abertura, em 1942, quando o SPI passou por uma reforma administrativa marcada por um novo Regimento Interno, em que constava, entre outras coisas, a criação da Seção de Estudos, ou SE, como ficou conhecida, entre cujas atribuições estava a de promover "estudos" e "pesquisas" para "registros" e "inventários" das manifestações culturais das populações indígenas e criação de um museu na sede do Serviço.

Para efetivação daquelas atribuições, o SPI contratou um grupo de fotógrafos e cinegrafistas designados a promover os "estudos" e as "pesquisas" conforme determinava o novo Regimento. Esse período se estendeu até 1947, quando o grupo, denominado Equipe Etnográfica, realizou uma série de viagens a postos e aldeias indígenas dos povos Umutina, Pareci, Terena, Kamayurá, Waurá, Mehinanco e Kuikuro, recolhendo para a SE conjuntos, não sistematizados, de objetos dos povos visitados. O registro e gestão desse conjunto documental, fotos, filmes e objetos, eram parte integrante do trabalho da Equipe, que, além de promover a documentação dos itens, os exibia nas salas contíguas à dos laboratórios fotográficos e fílmicos então utilizados, situados no Instituto Benjamim Constant. Extramuros, eram exibidos em salões de prédios públicos durante as comemorações do Dia do Índio.

Em 1947, a SE contrata o etnólogo Darcy Ribeiro e - Linguista Max Boudin. A partir dessa data, são realizadas, dentro de uma metodologia etnológica, as primeiras pesquisas etnográficas do SPI. Darcy Ribeiro, já no ano de sua contratação, promove pesquisa junto ao povo Kadiwéu (MT). Aproveita seu deslocamento para realizar uma visita aos índios Terena e Kaiwá, ambos localizados no estado de Mato Grosso. Max Boudin, na mesma ocasião, realiza pesquisa junto aos índios Funi-ô e Kariri, situados no Nordeste brasileiro. Em 1948, Darcy Ribeiro retorna aos núcleos indígenas por ele já visitados para complementar seus 
primeiros registros, mas inclui uma visita aos índios Ofayé. Já Max Boudin desloca-se para as aldeias do povo Maxakali, situadas no estado de Minas Gerais. Entre 1949 a 1951, ambos promovem pesquisas junto aos índios Ka'apor, habitantes do estado do Maranhão.

Das pesquisas realizadas resultam coleções orgânicas, concebidas dentro da metodologia etnológica, mas o modelo de gestão pouco foi alterado, ou seja, continuava sob responsabilidade dos servidores que atuavam na SE, que além de promoverem sua organização e guarda, organizavam pequenas exposições em galerias de arte e prédios públicos, principalmente no período de comemoração do Dia do Índio.

A mudança na gestão da documentação só veio a ocorrer em 1949, quando a SE incluiu em seus quadros dois museólogos, Dulce Rebello e Geraldo Pitaguary, contratados para desenvolverem atividades de conservação que incluíam a identificação, separação, higienização e guarda das peças, bem como sua documentação, e para isso adotaram um Livro de Tombo. Nesse período, a documentação primária referente à SE informa que o acervo etnográfico contava com mais de 2 mil itens.

Paralelamente às pesquisas promovidas pela SE, financiamentos eram concedidos pelo SPI, principalmente a integrantes de instituições de pesquisa. Nessa situação encontra-se o etnólogo Egon Schaden, então assistente de pesquisa de Emilio Willens na Faculdade de Filosofia da Universidade de São Paulo que, em 1949, recebe financiamento para realizar pesquisas entre os Guarani Kaiwá e Nhandéva. Das pesquisas que realizou, que se estenderam até 1955, resultou a coleção de 135 peças daqueles povos, que integraram o acervo da SE.

Seguindo a sequência de pesquisa que resultaram na captação de acervo, em 1950, o então museólogo da Seção, Geraldo Pitaguary, viaja a Goiás e realiza um recolhimento de mais de seiscentos itens do povo Karajá (TO), aumentando consideravelmente as coleções já existentes.
Em 1952, a SE contrata novos etnólogos, Eduardo Galvão. Oriundo do Museu Nacional, com título de PhD pela Universidade de Columbia, Estado Unidos, ingressa no SPI em 1952, e no ano seguinte viaja ao Amazonas para promover uma pesquisa entre os índios Baniwá (AM). O resultado mais imediato foi o recolhimento para a SE de objetos de cerâmicas onde a morfologia tradicional de cada item estava representada.

Em relação às pesquisas que vinham sendo realizadas no SPI, por meio da diretoria encaminhavam-se pedidos de envio de material etnográfico às suas sucursais e inspetorias situadas em várias regiões do país, destinadas a gerenciar os postos indígenas. Essas unidades remetiam, sem ordenamento, objetos etnográficos, muitos sem qualquer informação quanto ao povo de origem, mas que avolumavam, de modo significativo, o acervo da Seção.

Após um ano de obras e adaptações no prédio onde a SE funcionava, na Rua Mata Machado, Maracanã, Darcy Ribeiro, então chefe da Seção, inaugura o Museu do Índio (MI) em 19 de abril de 1953, Dia do Índio, durante uma cerimônia que contou com a presença de funcionários do Serviço e de autoridades locais. 0 acervo exposto era aquele coletado e organizado durante os 11 anos de funcionamento da Seção de Estudos.

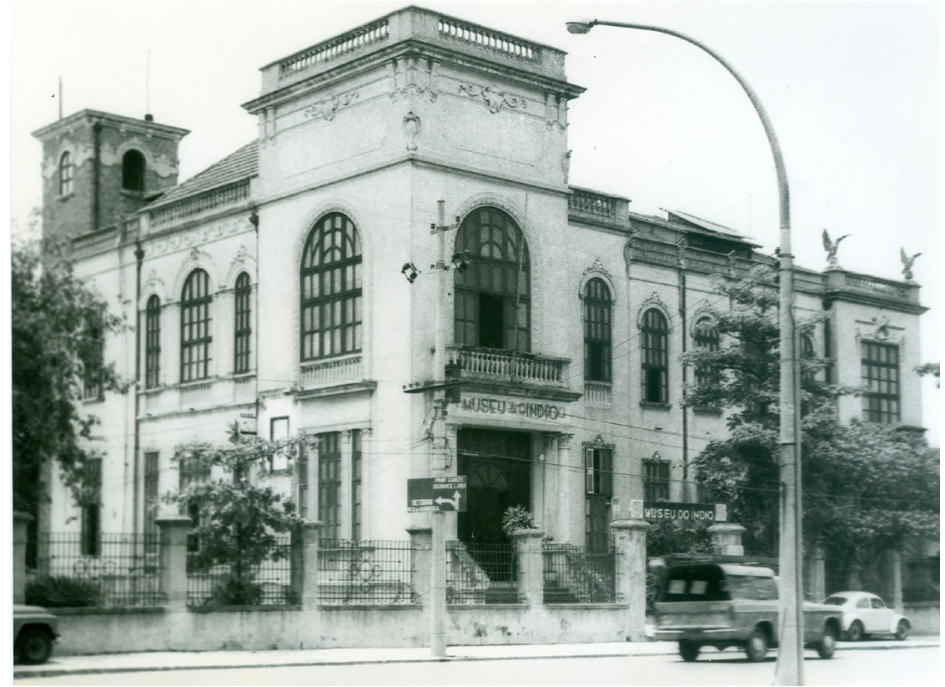

Foto 1 - Fachada do Museu do Índio na rua Mata Machado, 1953. Foto: Acervo Museu do Índio. 
transformadas, após a criação da Funai, em Delegacias Regionais. Criou-se, assim, um arquivo de segunda geração. Mas a iniciativa não impediu que parte da história de formação e gestão do acervo do Museu do Índio apresentasse lacunas, principalmente entre meados das décadas de 1950 e de 1960, visto que os documentos relativos ao seu funcionamento - ou seja, as pesquisas realizadas, os itens etnográficos coletados, os custos destas operações, os gestores do acervo, as exposições e mostras organizadas - faziam parte dos arquivos administrativos da SE, alocados na diretoria do SPI, cuja documentação foi quase que integralmente consumida pelo incêndio, e o Livro de Tombo, um dos poucos instrumentos disponíveis, traz informações precárias que não permitem promover o mapeamento dos objetos coletados, tampouco de seus agentes coletores ou do modelo de sua gestão.

Importa ressaltar que a recuperação parcial da documentação administrativa associada à bibliografia deixada por etnólogos como Darcy Ribeiro, Eduardo Galvão e Roberto Cardoso de Oliveira, que na qualidade de antigos servidores do SPI que participaram tanto das pesquisas organizadas pelo Serviço quanto da gestão das coleções, permitiu apurar que a política de captação de acervo e sua gestão tinham como base a pesquisa etnográfica. Esta foi inicialmente promovida por agentes contratados a partir de 1942 para registrar, imageticamente, tanto o cotidiano dos postos indígenas quanto a administração do SPI. A partir de 1947 , etnólogos, linguistas e museólogos ingressaram no quadro de funcionários do Serviço e, em parceria com os primeiros, promoveram pesquisas de campo, assim como organizaram e difundiram o acervo.

As coleções captadas naquele momento refletiam os temas que preocupavam as Ciências Sociais: as mudanças sociais e culturais. Nesse aspecto, dentro dos conjuntos recolhidos, os objetos refletiam, em pequenos detalhes, as mudanças pelas quais os índios vinham passando, principalmente observadas na morfologia tradicional de elaboração, no emprego da matéria-prima e na inclusão de novos elementos decorativos.

A gestão dessas coleções, entendida aqui como um processo que envolvia os índios, os objetos, as exposições e os clientes (público e pesquisadores), estava a cargo de agentes especializados com formação em museologia, contratados pelo SPI em 1949 para sistematizar - documentar e organizar os objetos coletados. Esses se avolumavam na SE, onde a gestão e divulgação de suas informações estavam restritas à sua documentação, acondicionamento e difusão por meio de publicações, tendo como público-alvo a comunidade científica. Com a criação do Museu do Índio, o SPI foi forçado a ampliar o recolhimento de objetos e melhorar sua gestão, visto que a abertura do Museu resultou na necessidade de um número maior de coleções, na melhoria das informações sobre os objetos coletados, aumento de exibições e de público.

\section{Década de 1970}

A criação da Funai ocorre em plena reorganização do Estado brasileiro pelo Regime Militar (1964-1985), característica que influenciará suas ações, voltadas para o apoio às medidas desenvolvimentistas promovidas por esse Regime. Nesse contexto, a Funai inicia suas atividades elaborando um novo Regimento Interno (1970), onde departamentos são criados providos de unidades executivas para aplicar a política indigenista. Também elabora o Estatuto do Índio que, em 1973, foi transformado na Lei $n^{\circ} 6.001$, vigente até os dias de hoje. Este último reafirma as premissas de assimilação e integração dos índios à sociedade nacional, a demarcação de terras indígenas, principalmente dos povos considerados não integrados, e reforça o regime tutelar. Com a publicação do Estatuto, a Funai passa a promover ações de atração e pacificação de povos indígenas localizados em regiões destinadas à construção de rodovias e hidrelétricas, a fazendas agrícolas e à extração mineral. Sua atuação consistia em atrair os povos indígenas e pacificá-los. Após tais medidas, promovia as transferências de suas aldeias para regiões de menor valor econômico, visando "limpar" as rotas de crescimento. Simultaneamente, intensificava-se a política de assimilação dos índios, principalmente dos classificados como de alto contato com a sociedade 
nacional, e aumentava o monopólio tutelar por meio da centralização de projetos de saúde, educação, alimentação e habitação, além de se limitar o acesso de pesquisadores às terras indígenas.

As explicações são úteis porque as ações da Funai, no início de sua gestão, vão refletir nas coleções do Museu do Índio, então ligado ao Departamento Geral de Estudos e Pesquisas (DGEP), na condição de unidade descentralizada, ambiente institucional responsável pelos levantamentos socioculturais em terras indígenas e pelo recolhimento de objetos durante suas atividades.

Em seus primeiros anos de funcionamento a Funai restringiu o acesso às áreas indígenas, controlando e limitando o acesso aos pesquisadores, e, como não dispunha ainda de quadros técnicos, as ações que resultaram em recolhimento de objetos, posteriormente encaminhados ao MI, eram executadas por agentes da Fundação, na grande maioria sertanistas, que promoviam o recolhimento de itens etnográficos durante suas atividades de atração e pacificação. Esses itens eram posteriormente encaminhados para o Museu do Índio pelo DGEP. Participaram desse processo os sertanistas Antonio Cotrim Soares, irmãos Vilas Boas, Gilberto Pinto de Figueiredo Costa, João de Carvalho e Israel Praxedes, entre outros, responsáveis pelos primeiros contatos com índios ainda isolados. Produto dessas ações são as coleções Parakanã (Antonio Cotrim Soares). Waimiri-Atroari (Gilberto Pinto de Figueiredo Costa), Asurini do Xingu (Antonio Cotrim Soares), Kren-Akarore (irmãos Vilas Boas), Avá Canoeiro (Israel Praxedes), Cinta-Larga (Francisco Meirelles), Arara (Camiranga e Afonso Alves) e Guajá (antropóloga Valéria Parisi).

As coleções, formadas por um número reduzido de itens, eram compostas de objetos deixados pelos índios nos acampamentos de atração ou largados nas fugas dos índios de suas aldeias, diante da proximidade das frentes de contato organizadas pela Funai. Incluídos na primeira situação estão as armas e, na segunda, os utensílios de cerâmica e os implementos de trabalho. São coleções incompletas, mas que ilustram parte da cultura material utilizada por povos nos momentos iniciais de seus contatos com a sociedade nacional.

A gestão cabia ao Museu do Índio, responsável pela documentação e difusão por meio de exposições temporárias em sua sede. Ocorre que as informações relativas ao coletor e à situação em que os objetos foram coletados não acompanhavam os itens recolhidos, resultando em registros precários no Livro de Tombo, então utilizado para o registro do acervo. Nesse documento consta como coletor o Departamento Geral de Estudos e Pesquisas, mas os dados relativos ao nome do agente responsável pela coleta e à situação do recolhimento foram suprimidos. 0 levantamento sobre tais informações só é possível com a associação da data de recolhimento do objeto a uma bibliografia específica, produzida ou pela Funai $^{1}$ ou por cientistas sociais que trataram, anos mais tarde, da situação vivenciada pelos povos indígenas com o Estado brasileiro.

No final da década de 1970 observa-se um novo modelo de captação de peças para o Museu do Índio. Os motivos estão relacionados ao panorama político-social do país e envolvem três aspectos distintos. Surgem organizações não governamentais de apoio aos índios, ${ }^{2}$ que passam a financiar pesquisas. Agregado a este aspecto, o aumento do número de cursos de Pós-Graduação em Ciências Sociais, implantados em várias regiões, cujos integrantes começaram a ser treinados para desenvolverem pesquisas que refletissem a situação social do país, em que a produção etnológica esteve voltada, principalmente, para uma ação social em prol dos direitos humanos, ambientais e territoriais das populações tradicionais (Lima; Cortes, 2013). 0 segundo aspecto está relacionado à organização administrativa da Funai, visto que após a publicação de seu Regimento Interno (1970) e do Estatuto do Índio (1973) passou a ter amparo jurídico e legislativo para organizar seus

1. Boletins informativos da Funai, publicação trimestral, de 1972 a 1976

2. Comissões pró-índio (CPIs), 1978; Associações Nacionais de Apoio aos Índios (ANAIs), 1979; Conselho Indigenista Missionário (Cimi), 1972; Centro de Trabalho Indigenista (CTI), 1979; Operação Amazônia Nativa (Opan), 1969; Centro Ecumênico de Documentação e Informação (Cedi), 1974; Núcleo de Direitos Indígenas (NDI), 1979. 
quadros técnicos, que será composto de cientistas sociais com conhecimento em antropologia social e que passam a promover pesquisa voltada para instrução de processos fundiários. ações de competência da Fundação. 0 terceiro, intrinsecamente relacionado ao segundo, foi a iniciativa da Funai de buscar, para reforçar as pesquisas que pretendia desenvolver, o apoio dos centros de pesquisas das universidades, principalmente das Universidades de Brasília (UnB) e da Bahia (UFBA), criando o programa "Frente de Estudos", organizado pelo Departamento Geral do Planejamento Comunitário (DGPC). ${ }^{3}$

As pesquisas realizadas, no final da década de 1970 e na década seguinte, tanto pelas organizações não governamentais e pelas Escolas de Ciências Sociais, nacionais e estrangeiras, quanto pelos cientistas sociais integrantes do quadro da Fundação ou inseridas no Programa resultaram em produtos materiais que, em muitos casos, foram encaminhados para o Museu do Índio. Os objetos, como parte integrante das pesquisas realizadas, tinham em sua base dados relevantes e indispensáveis para sua qualificação, o que resultou em coleções orgânicas e bem documentadas. Desse período temos coleções formadas pelos antropólogos Júlio Cezar e Delvair Montagner (1975), referentes aos índios Marubo; Gustaaf Hubert Verswijver (1976), dos índios Menkrangnotí; Denny Moore (1977), dos índios Gavião e Suruí; Claudia Menezes (1977), dos índios Xavante, Tukano e Pankararu; Regina Polo Müller (1978), dos índios Asurini; Darrell A. Posey (1978), dos povos Kayapó e Gorotire; Nássaro Nasser (1978), dos índios Tuxá; Silvia Regina Brogiolo Tafuri (1978), dos índios Miranha; Célio Horst (1979), dos índios Wai-Wai; Berta G. Ribeiro (1981), dos índios Arawéte, e Marco Antonio Gonçalves (1984), dos índios Pareci, entre outras. ${ }^{4}$

É também no final da década de 1970, precisamente em 1977, que ocorre a transferência da sede

3. Boletim Informativo da Funai, Ano III, número $11 / 12$, $\mathrm{s} / \mathrm{n}^{\circ}$ de página.

4. Fundo Museu do Índio. Série Documentação e Informação. Subsérie Acervo Museológico. Código de referência: MI-DI 22.10 . original do Museu do Índio, situada na Rua Mata Machado, Maracanã, para um casarão localizado na Rua das Palmeiras, 55, Botafogo, tombado em 1967 pelo Instituto de Patrimônio Histórico e Artístico Nacional (Iphan, 2009). A transferência resultou em uma série de problemas para o Museu do Índio em virtude da redução do espaço físico para instalação e acomodação de todos os seus serviços e atividades, visto que para o Museu foi cedido apenas o casarão - as demais construções situadas no terreno estavam ocupadas por outras instituições, também integrantes da estrutura administrativa do Ministério do Interior, no qual a Funai estava inserida. Assim, restou espaço exíguo para a guarda e acondicionamento das coleções do Museu do Índio.

\section{A Constituição Federal de 1988 - novos rumos}

A Constituição de 1988, especificamente no título VIII, “Da Ordem Social”, capítulo VIII, “Dos Índios”, que trata dos direitos dos indígenas, afeta sobremaneira os trabalhos desenvolvidos pela Funai, visto que a Constituição traz duas grandes inovações quando comparada às Constituições anteriores e ao Estatuto do Índio.

A primeira refere-se ao abandono da tradição legislativa e jurídica de promover a integração e a assimilação dos índios, então entendida como uma categoria transitória. A segunda informa que são direito dos índios suas terras originais, isto é, a posse à terra é anterior à criação do próprio Estado.

Dessa forma a Constituição estabelece novos marcos para a relação entre o Estado e as sociedades indígenas. Diante da nova legislação a Funai perde o papel de tutora, responsável pela educação e pela saúde, restando como sua missão a promoção e acompanhamento dos processos fundiários, ou seja, vê-se esvaziada de um grande número de atribuições.

Nesse contexto, o Museu do Índio ficou seriamente ameaçado, tanto no que se refere aos meios que o 
auxiliavam na captação de novos acervos, quanto no que toca a recursos para promover ações culturais, visto encontrar-se inserido em uma estrutura administrativa cuja missão era promover a demarcação de terras indígenas e promover sua assistência social.

De 1988 a 1993, o Museu do Índio mergulha em uma crise, aprofundada em 1990, quando da eleição de Fernando Collor de Mello, que inicia seu mandato promovendo uma reforma administrativa que vai resultar na demissão ou redistribuição de um expressivo contingente de servidores, tanto da Funai quanto de outras agências públicas. Nesse cenário, o Museu do Índio sofre com baixas em seu quadro técnico que o obrigam a desativar alguns de seus serviços. Os que restaram foram praticamente paralisados.

Em 1992, no auge da crise, a direção do Museu informou que o prédio central, local onde a exposição de longa duração se encontrava instalada, entraria em restauração, exigindo sua desmontagem, interrompendo, assim, aquela prestação de serviço. Os demais Setores, que já vinham prestando serviços em condições precárias em razão da falta de equipamento e material, agora sem uma exposição para oferecer suporte à Instituição, injungem ao Museu do Índio o fechamento de suas portas para atendimento ao público, de abril de 1992 a janeiro de 1994.

Os fatos refletiram

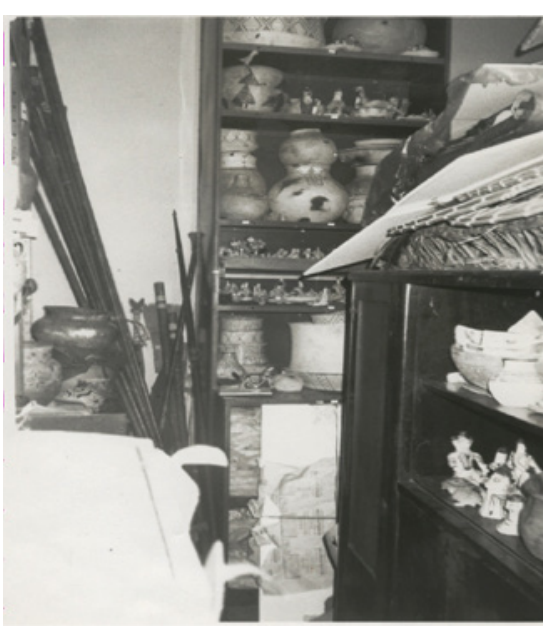

Foto 3 - Reserva técnica do Museu do Índio, 1987. Foto: Acervo Museu do Índio. na integridade dos acervos, cujas instalações, já deficientes, se agravaram. Sem condições de gerir seu acervo e difundi-lo, o Museu inicia uma nova política institucional, cujo eixo central ficou voltado para captação e preservação dos acervos, envolvendo a reforma do prédio, o desenvolvimento de coleções, eventos, mostras e publicações que partiriam daquele eixo organizador e estariam a ele vinculado.

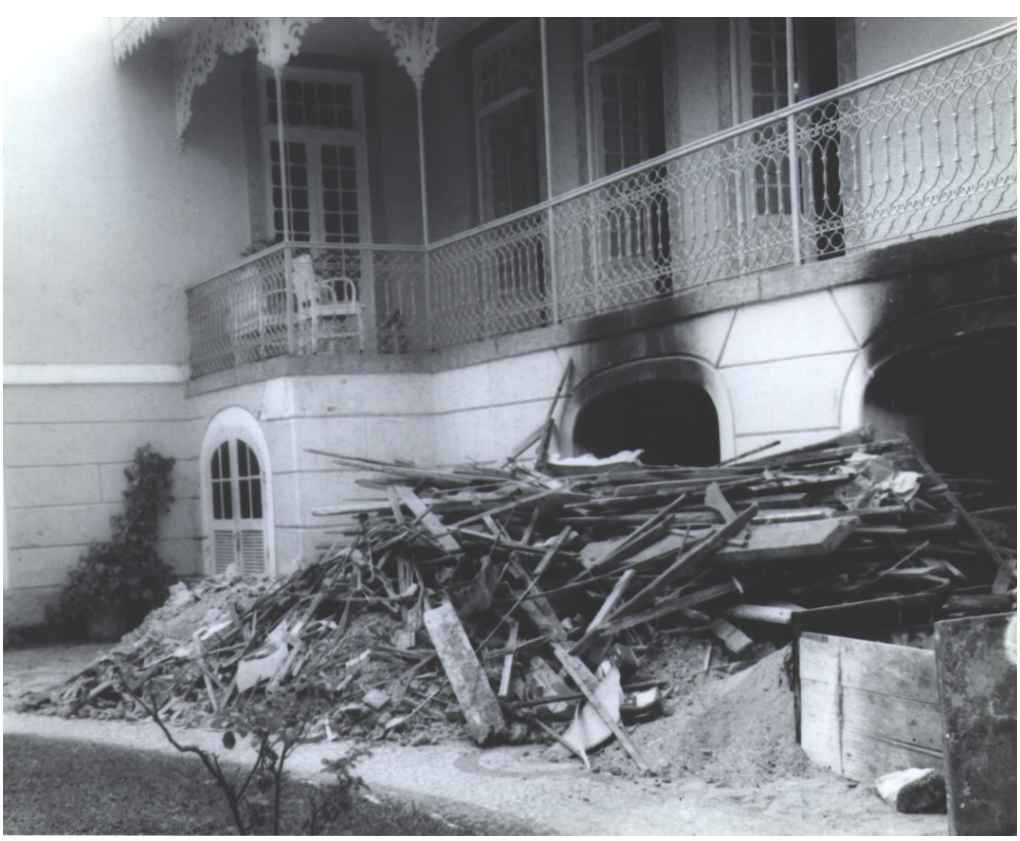

Foto 4 - Imagem da fachada lateral do prédio central do Museu do Índio, 1998. Foto: Acervo Museu do Índio.

Mesmo com baixa infraestrutura para promover a guarda de seus acervos, o Museu não interrompeu o fluxo de captação de coleções, que continuou por meio de um conjunto de medidas que envolviam seu corpo funcional, encaminhamento de peças etnográficas pelo então Departamento Geral de Patrimônio Indígena (DGPI), responsável pela aquisição e comercialização de objetos indígenas por meio das lojas Artíndia, ${ }^{5}$ doações de coleções

5. 0 programa de captação e coleção de objetos indígenas foi criado pela Funai em 1971, dentro da Divisão de Renda Indígena do Departamento Geral de Patrimônio Indígena (DGPI) recebendo o nome de Artíndia. O objetivo do Programa era estimular a produção de artefatos indígenas por meio da comercialização propiciando, desse modo, renda e autonomia para os povos que dele participavam. Um dos eventos criados e mantidos pela Artíndia, era o Moitará, atividade que ocorria anualmente cujo nome fazia alusão a uma prática de troca intertribal, que ocorre entre os povos que habitam próximo ao rio Xingu, MT. Para a promoção desta atividade, a Artíndia selecionava um determinado povo indígena, onde uma pesquisa era desenvolvida, promovida por antropólogos que tanto pertenciam ao quadro da Fundação quanto podiam ser convidados a executarem tal atividade que, encaminhados às terras indígenas, promoviam a compra de itens etnográficos e 
A fim de aumentar seus recursos financeiros, o Museu, por meio do então Serviço de Museologia, encaminha à Vitae - Apoio à Cultura, Educação e Promoção Social projeto voltado para o reacondicionamento de todo o seu acervo etnográfico. Em julho de 1999 o projeto foi aprovado e o Museu promoveu o acondicionamento de seu acervo dentro das normas então estabelecidas pelo campo museológico.

Em 1998, vem em auxílio ao Museu do Índio um fato novo relacionado à elaboração do $\mathrm{Plano}$ Plurianual (PPA), exigência do Estado para alocação de recursos nas agências públicas. Naquele ano, a presidência da Fundação tomou a decisão de apresentar uma proposta orçamentária organizada pelos seus departamentos, em que o Museu do Índio teve a oportunidade de apresentar quatro propostas de planos de ação - a primeira, específica para o Museu do Índio, voltada para conservação dos seus acervos, e as demais para revitalizar, registrar e difundir o patrimônio cultural indígena. 0 valor aprovado era

inexpressivo, mas o efeito era enorme porque significava que a União passaria a alocar, por um período de 4 anos, recursos para a proteção do patrimônio indígena. A aprovação das ações propostas pelo Museu do Índio para o PPA da Funai, além de ter possibilitado à direção do MI ampliar sua área de atuação e manter seus projetos, acabou auxiliando a Fundação na redefinição de seu papel já que introduzia no seu eixo de atuação, em conjunto com a questão fundiária, a questão cultural.

Com os valores recebidos por meio do PPA, o Museu empreendeu, em 2000, a climatização de suas Reservas Técnicas com a implantação de um sistema de monitoramento eletrônico de umidade e temperatura, o que permitiu o controle sistemático desses ambientes. Em 2001, um laboratório de restauração para úmidos foi inaugurado, com o objetivo de recuperar o acervo de papel e promover a higienização do acervo etnográfico com mais eficácia. Para tanto, novos equipamentos foram adquiridos e, em 2002, uma nova reforma foi iniciada nas Reservas Técnicas com a finalidade de melhorar as suas condições físicas.

Paralelamente às medidas de conservação preventivas, o Museu do Índio inicia um projeto de exposição de longa duração, visto que, em 1994, ano marcado pela sua reabertura, as exposições etnográficas, de pequeno porte, haviam sido organizadas e montadas em salas então disponibilizadas para aqueles fins, uma vez que o prédio central se encontrava em restauração.

Em 2000 o Museu abre ao público, já em seu prédio central, a exposição Corpo e Alma Indígena, tema que tinha como objetivo apresentar o corpo como uma construção cultural e enfatizar o aspecto da diversidade e da contemporaneidade das sociedades indígenas. Mas esse movimento ainda estava longe de expressar o que o Museu do Índio buscava apresentar.
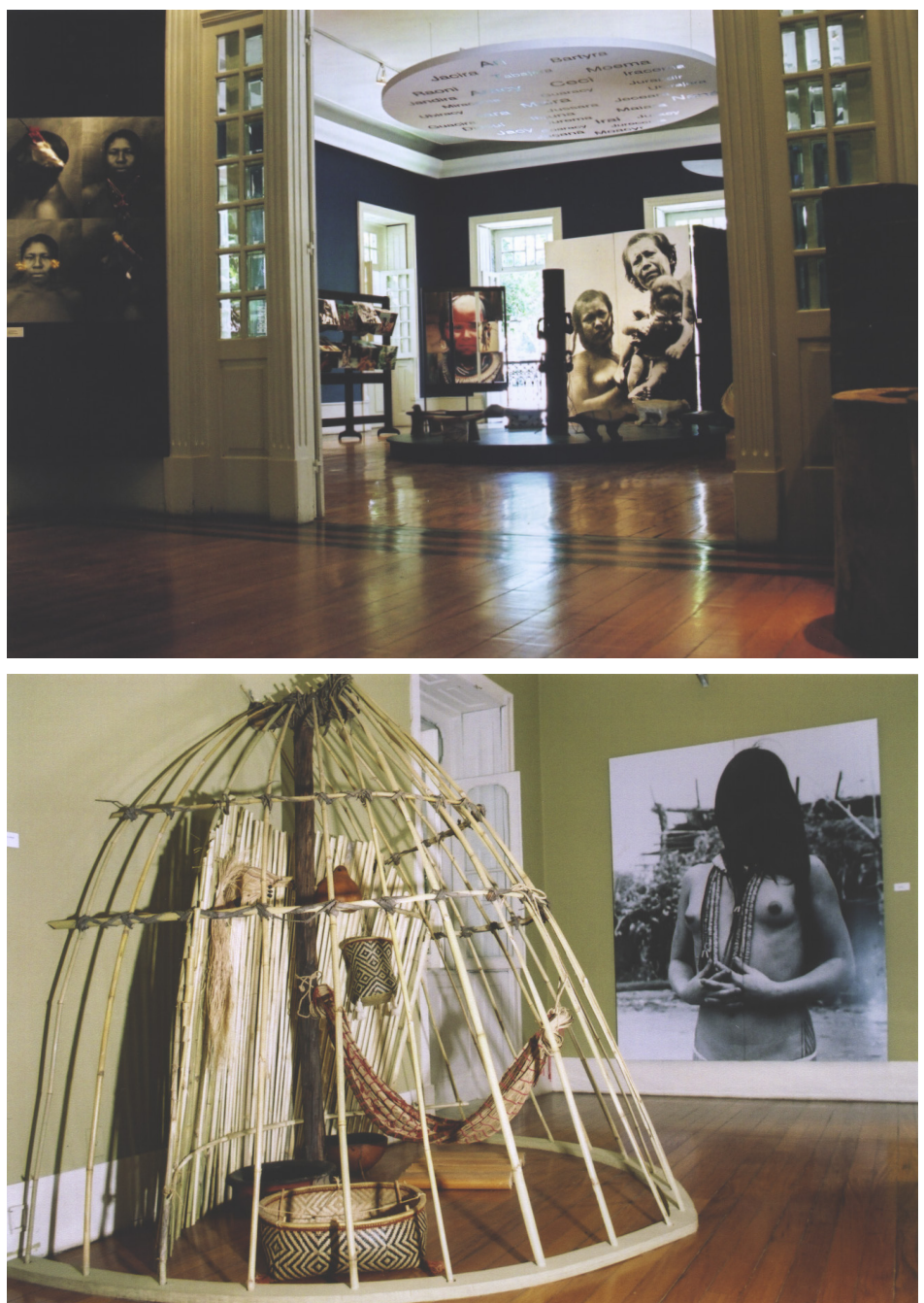

Fotos 7 (no alto) e 8 - Exposição Corpo e Alma Indígena, 2000 Foto: Acervo Museu do Índio. 
Com uma exposição de grande porte dando suporte à difusão de informações sobre as sociedades indígenas, o Museu do Índio passa a se dedicar a um projeto de exposição mais audacioso. Para tanto busca parcerias entendendo que o índio é seu sujeito museológico, mas não seu sujeito de pesquisa, ou seja, o Museu do Índio era o responsável pela difusão e proteção do patrimônio cultural dos povos indígenas, e nessa posição deveria atuar promovendo projetos que atinjam esse objetivo, mas seu desenvolvimento cabia aos profissionais que apresentavam largo convívio com as populações indígenas. Assim, o projeto de exposição a ser desenvolvido necessitaria da participação de especialistas com longa experiência tanto na questão indígena quanto no convívio diário com os índios, característica indispensável para que pudesse interpretar como incluir, em todas as etapas, a participação indígena.

Uma segunda marca do projeto de exposição a ser elaborado era ser parte integrante da política institucional, ou seja, nessa condição o Projeto deveria apresentar características como participação dos índios na definição do tema e aprovação e desenvolvimento pelo corpo técnico e administrativo do Museu. Complementando, a proposta deveria contemplar a promoção de oficinas para registro e produção de itens culturais necessários à exibição e a promoção de treinamento do povo indígena envolvido no gerenciamento e registro de seu patrimônio cultural. Um conjunto de ações que culminariam na aquisição de novos acervos, não só etnográficos como também imagéticos.

Estabelecidos os critérios que norteariam o futuro projeto de exposição, a direção do Museu do Índio buscou estabelecer diálogos com agentes e agências que manifestassem interesse em congregar seus objetivos com os do Museu. Dos diálogos travados com o Centro de Trabalho Indigenista (CTI), surgiu a parceria com a antropóloga Dominique Gallois, professora do Departamento de Antropologia da USP e integrante da equipe do Centro. Dessa parceria resultou a primeira exposição de longa duração Tempo e Espaço na Amazônia: Os Wajãpi (2001/2006). Em 2002, agregou aos resultados obtidos com a parceria criada o primeiro registro de um patrimônio cultural indígena - a Arte Kusiwá: pintura corporal e arte gráfica Wajãpi - no Livro dos Saberes do Patrimônio Imaterial (MinC) e, posteriormente, como Obra-Prima do Patrimônio Oral e Imaterial da Humanidade (Unesco).
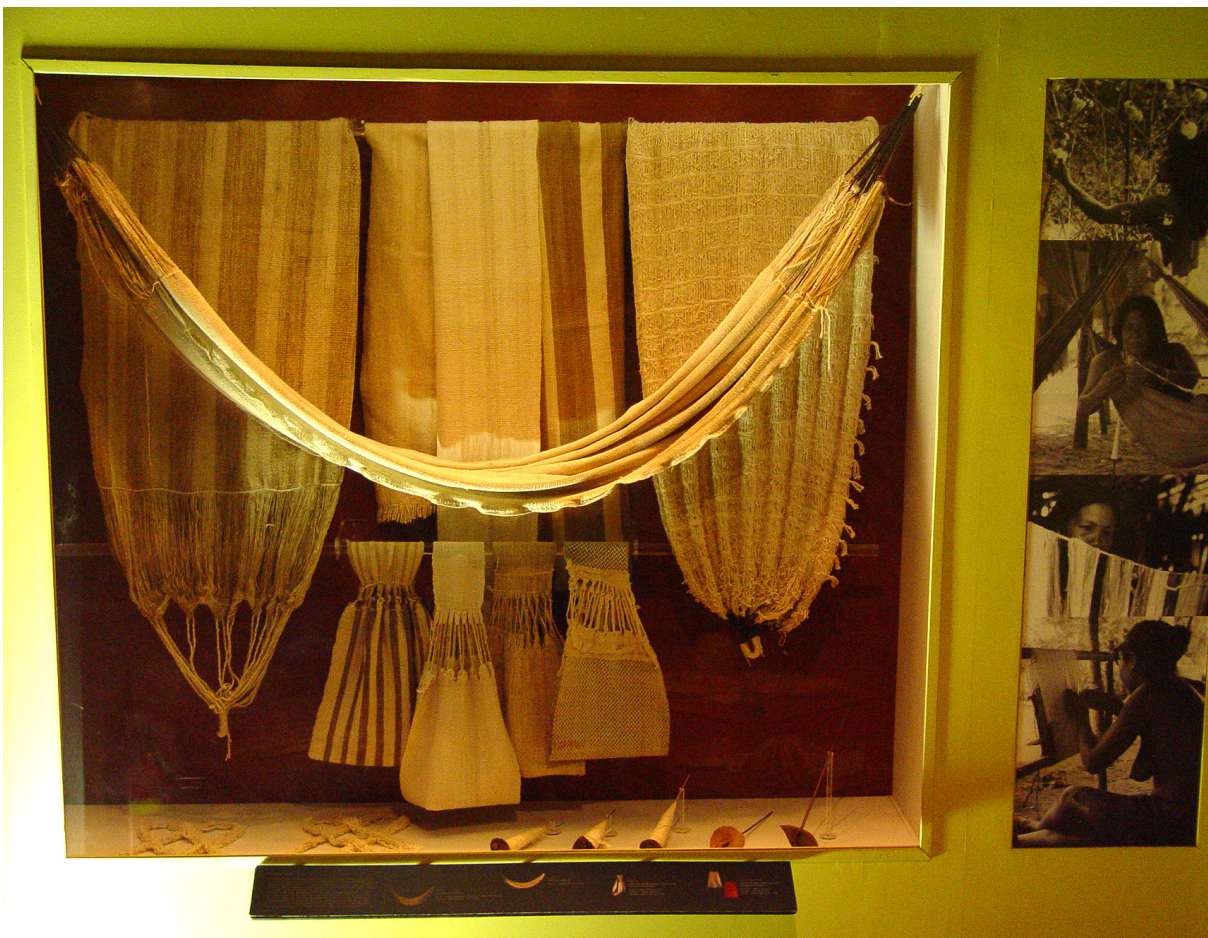

Foto 9 - Interior da exposição Tempo e Espaço na Amazônia: os Wajãpi, 2001. Foto: Acervo Museu do Índio.

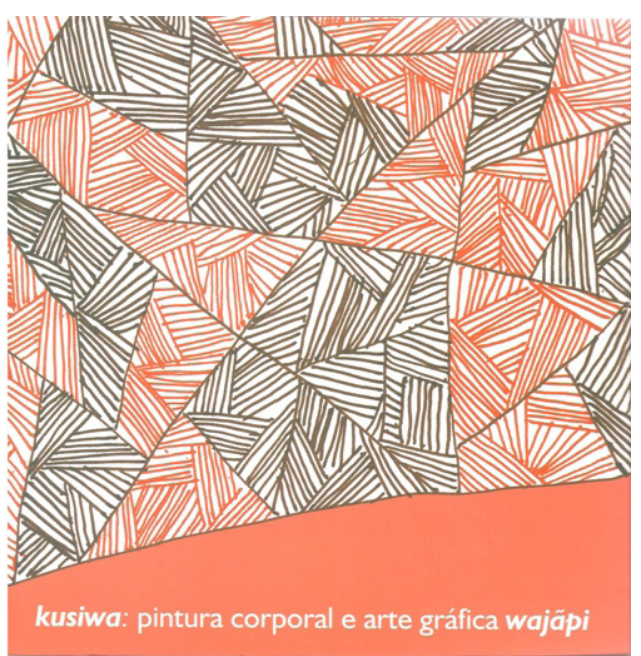

Foto 10 - Catálogo Kusiwa: pintura corporal e arte Wajãpi, 2002. Foto: Acervo Museu do Índio. 
Como o traço fundamental da exibição era a vida atual dos Wajãpi, não era possível a utilização do acervo etnográfico institucional, não só porque o Museu não possuía objetos em número suficiente que viesse a sustentar a exibição, mas também pela necessidade de aquisição de novos acervos, incluída na proposta da política institucional. Dentre os vários resultados da parceria estabelecida está a coleção de 307 itens etnográficos adquirido do povo Wajãpi. Trata-se da produção de todos os indivíduos que formam a comunidade Wajãpi, que chegou ao Museu do Índio devidamente qualificada, ou seja, acompanhada de todas as informações necessárias à sua documentação .

A experiência positiva do primeiro projeto incentivou o desenvolvimento de um novo projeto de exposição. Em 2007, ainda em parceria com o CTI, mas sob a orientação da antropóloga Lux Vidal, o Museu do Índio inaugura a exposição $A$ presença do Invisível: na vida cotidiana e ritual dos povos indígenas do Oiapoque, que permitiu oferecer ao visitante um panorama da vida ritual, pública e privada dos povos Galibi Kali'na, Karipuna, Palikur e Galibi-Marworno, habitantes do Amapá, na fronteira com a Guiana Francesa.

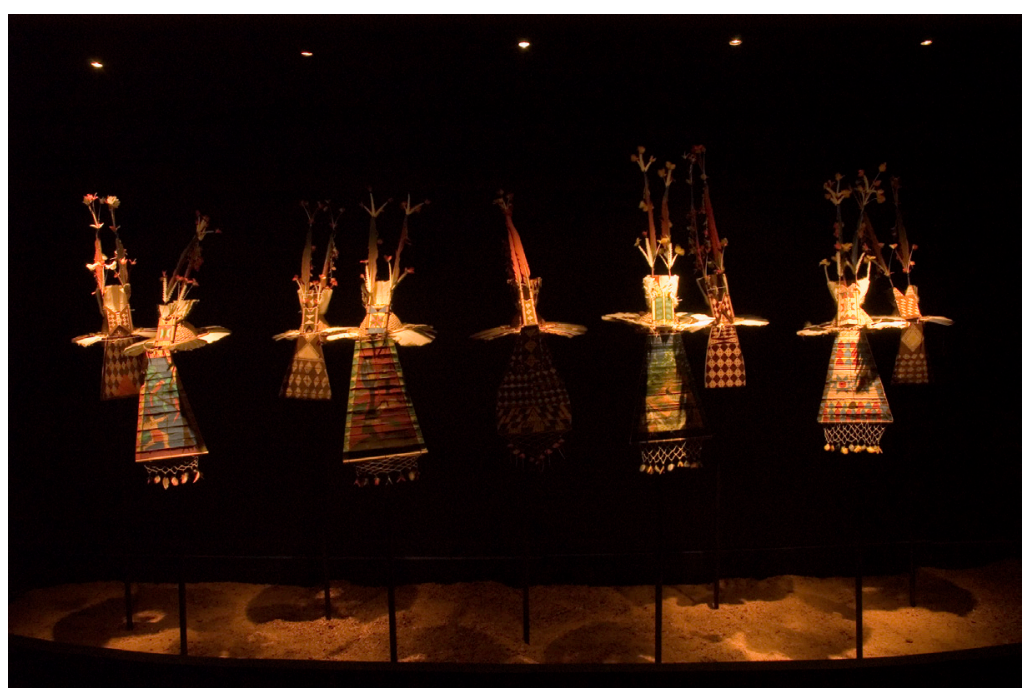

Foto 11 - Interior da exposição A presença do Invisível: na vida cotidiana e ritual dos povos indígenas do 0iapoque, 2007 Foto: Acervo Museu do Índio.

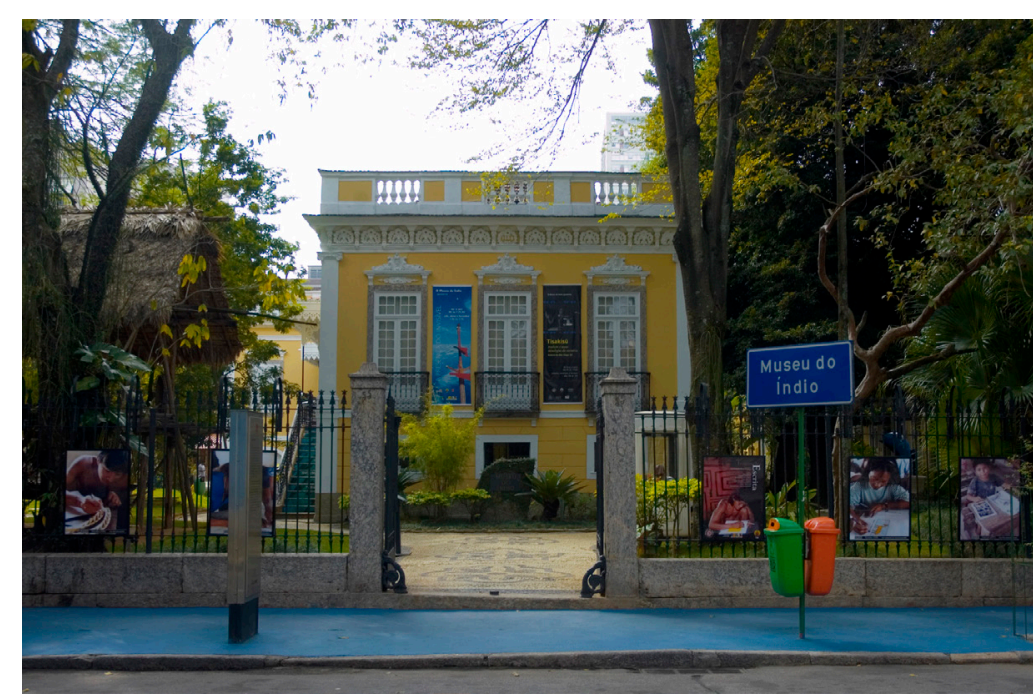

Foto 12 - Fachada do prédio central do MI com banner sobre a exposição A presença do Invisível: na vida cotidiana e ritual dos povos indígenas do Oiapoque, 2007. Foto: Acervo Museu do Índio.

Dessa ação resultou uma coleção de 297 objetos, dos quais 250 foram selecionados para exibição, somados a outros 19 oriundos da coleção histórica do Museu do Índio. Objetos novos e antigos que reunidos deram vida à narrativa dos povos do 0 iapoque.

Os resultados dos projetos de exposição e principalmente a parceria com os índios. agregados a outras experiências vivenciadas no Museu do Índio, ${ }^{7}$ resultaram na revisão da Política Institucional, pois o projeto de exposição passou a ser um produto de um Programa de Documentação

7. Lançamento do Catálogo Povos Indígenas no Sul da Bahia, resultado da organização de mais de 20 mil documentos que foram colocados à disposição dos índios na forma de catálogo. 2002; Primeira experiência de cooperação da Unesco com o Museu do Índio, por meio de seu Programa Regular, resultou na publicação, em CD, do Vocabulário Básico de Línguas Indígenas, incluindo 10 povos indígenas, (contendo, além dos registros sonoros e visuais da fala, dados sobre aspectos demográficos, sociais e culturais desses povos), 2004; Preservação do Patrimônio Cultural dos Parintintim, envolveu a devolução aos Parintintin do material de pesquisa do Prof. Waud Kracker, durante a inauguração do Centro Cultural Boreí dos Povos Indígenas do Alto Madeira, na aldeia Traíra (AM), com a presença do pesquisador, (2007); Publicação do Tesauro de Cultura Material dos Índios no Brasil (2006); Assinado documento de cooperação entre a Fundação Nacional do Índio/ Funai e o Instituto Max Planck para Psicolinguística (MPI) sediado em Nijmegen, Holanda, em abril de 2008. 
do Patrimônio Cultural dos Povos Indígenas, que englobava a promoção e documentação de línguas e culturas indígenas visando sua salvaguarda. Funcionando de modo articulado, o Programa auxiliaria na consolidação da documentação linguística e cultural das populações indígenas por meio da formação de pesquisadores indígenas e não indígenas, pela promoção de oficinas de capacitação que ocorreriam em terra indígena gerando acervos, e, no Museu do Índio, promovendo a qualificação das coleções existentes. O Programa também se destinava ao desenvolvimento de arquivos digitais, filmes, fotos e iconografia que enriqueceriam os acervos do Museu, material que, organizado, seria disponibilizado para os centros de documentação existentes em terras indígenas. A difusão das pesquisas realizadas e dos produtos obtidos pelo Programa era de competência do Museu do Índio e aconteceria, principalmente, por meio de exposições, publicações e site. As exposições, intramuros, de longa e curta duração, e extramuros, de curta duração, ocorreriam, preferencialmente, em museus geridos pelos índios. A ele foi dado o nome de Programa de Documentação de Línguas e Culturas Indígenas Brasileiras (ProgDoc).

o Museu do Índio efetivou o ProgDoc e o estruturou em quatro projetos distintos, buscando com isso uma melhor orientação para sua execução. Ao ProDoclin ${ }^{8}$ coube a documentação de línguas indígenas. Ao ProDocult, 9 a documentação de culturas indígenas. Ao Prodocson, ${ }^{10}$ a documentação sonora, e ao

8. Projeto de documentação de línguas indígenas (ProDoclin) executou a construção de gramáticas pedagógicas para línguas indígenas, material elaborado com novas metodologia que permite o ensino-aprendizagem de línguas indígenas sobretudo nas escolas das aldeias. 0 projeto piloto ocorreu entre os Ikeng, Pareci, Kawaiwete, Karajá e Wapichana.

9. Projeto de documentação de culturas Indígenas (ProDcult), registrou os saberes tradicionais, mitos, rituais, dimensões simbólicas e estéticas, modos de fazer associados a aspectos específicos de cada cultura. Foi desenvolvido em parceria com 31 povos indígenas, a saber: Asurini do Xingu (PA), Baniwá(AM), Kalapalo (MT), Karajá (TO), Kaxinawá (AC), Krahô (TO), Marubo (AM), Suruí (RO), Wajãpi (AP), Ye’kana (RR), Pataxó (BA), Galibi, Palikur, Karipuna (AP),

10. Projeto de documentação sonora (ProDocson), constituído do registro e documentação dos corpora acústico-musicais dos povos indígenas. Os projetos pilotos ocorreram entre os Maxakali MG, Enawene-Nawe (MT), Baniwá (AM), Krahô (T0) e Guarani-Mbyá (RS)
ProDocerv, ${ }^{11}$ o incentivo à captação de acervos textuais, sonoros, iconográficos e fotográficos organizados por pesquisadores da temática indígena, oferecendo, para sua preservação, as instalações e os equipamentos do Museu.

Para um Programa dessa envergadura, o Museu do Índio buscou parcerias com as sociedades indígenas e a colaboração de pesquisadores oriundos de instituições científicas e culturais, para em conjunto viabilizarem a execução do Programa. Por fim, em 2009 estabeleceu-se cooperação técnica com a Organização das Nações Unidas para a Educação, Ciência e Cultura (Unesco) e a Funai, ficando como executor do Programa.

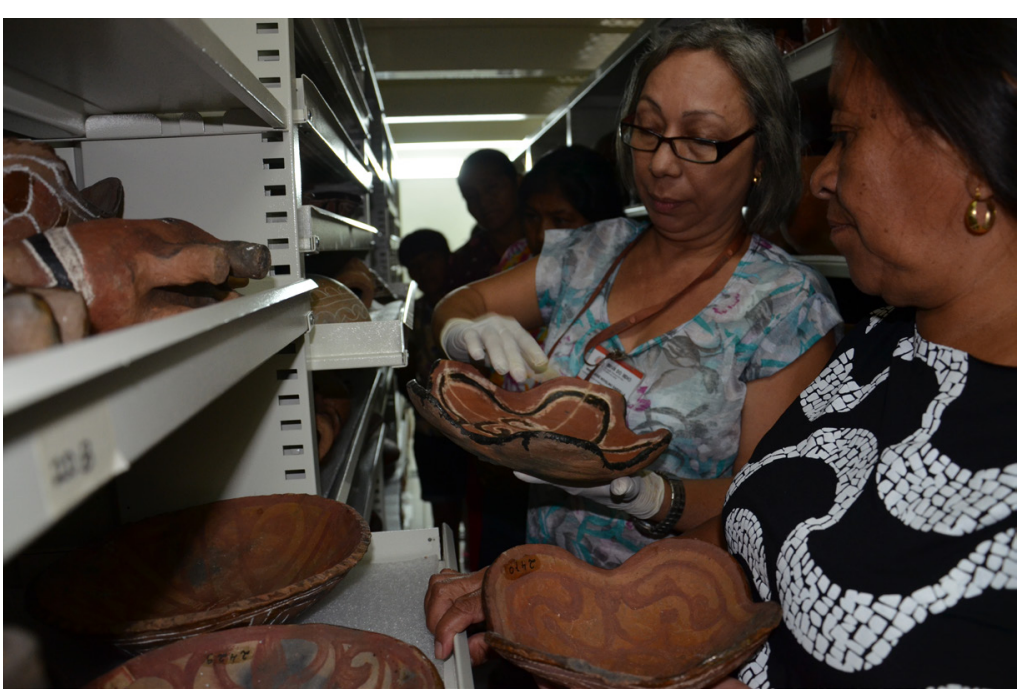

Foto 13 - Qualificação do acervo de cerâmica do povo Kadiwéu, MT, 2014. Foto: Acervo Museu do Índio.

Os resultados foram imediatos. Seis anos depois de sua implantação, o ProgDoc resultou em um volume expressivo de acervo. ${ }^{12} 0$ ProDocult,

11. Projeto de documentação de acervos (ProDocerv), constituído pelo recebimento, pelo Museu do Índio, a partir de 2009, de coleções formadas por pesquisadores, onde o material é tratado e disponibilizado para os povos indígenas. 12. 0 ProgDoc atuou em 14 estados, distribuídos em todas as regiões do País. Foram 135 aldeias abrangidas, 328 oficinas e atividades de documentação realizadas tanto em terra indígena quanto no Museu do Índio, que envolveu 200 pesquisadores, indígenas, sendo 60 bolsistas. Registros produzidos, 1.626 horas de filmagens de vídeo, 425 horas de gravações sonoras, 70.070 fotografias digitais, 28 
voltado para a captação e qualificação do acervo etnográfico, resultou em 3.674 itens etnográficos incorporados ao acervo institucional, devidamente qualificados.

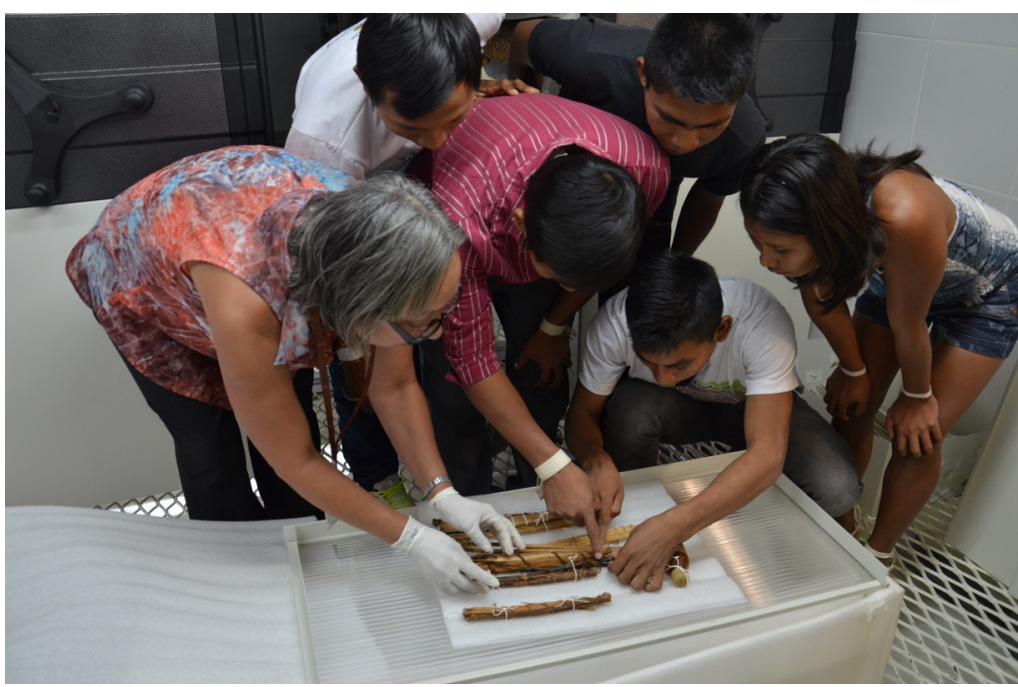

Foto 14 - Qualificação do acervo de armas do povo Matís, AM, 2014. Foto: Acervo Museu do Índio.

Produto também do Programa são as exposições, hoje organizadas como meio de divulgar os resultados alcançados pelo ProgDoc. São mostras curatoriais, de curto e longo prazo, organizadas intra e extramuros. Servem de exemplo as atuais exposições, Ashaninka: o poder da beleza (2014) e No Caminho das miçangas: um mundo que se faz de contas (2015), a primeira assinada pelo antropólogo Peter Beysen e a fotógrafa Sonja Fersona, a segunda pela antropóloga Els Lagrau, produtos da nova orientação adotada pelo Museu do Índio.

É importante informar que os projetos relativos à aquisição e gestão de novos acervos pelo Museu do Índio tiveram, em sua base, três matrizes. A primeira refere-se à história da instituição,

mil imagens geradas e $7 \mathrm{mil}$ imagens do acervo etnográfico capturados digitalmente para inserção no banco de dados, que constituíram coleções fotográficas, iconográficas e textuais. Formou coleccões contemporâneas de 3.674 itens de cultur material. Executou exposições etnográficas e fotográficas publicou pesquisas, gramáticas, dicionários, materiais didáticos e paradidáticos bilíngues, traduções de obras em línguas estrangeiras, catálogos, boletins informativos. Criou sites e blogs dos projetos e dossiês dos registros e acervos que foram entregues às comunidades indígenas, produziu filmes documentários, de curta metragem e clipes.

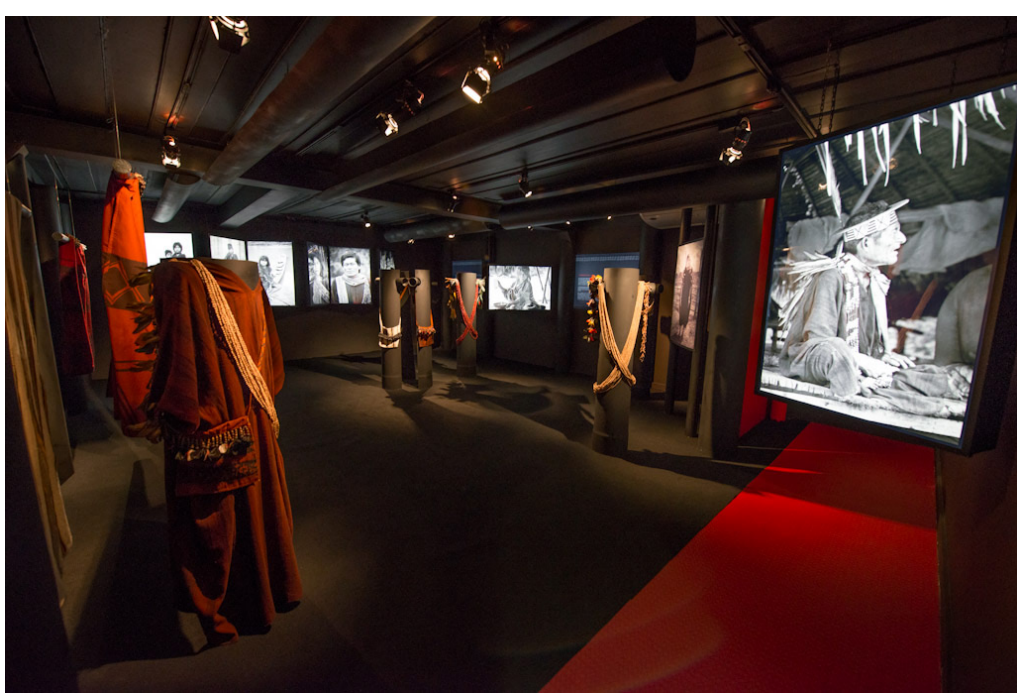

Foto 15 - Interior da exposição Ashaninka: o poder da beleza, 2014. Foto: Acervo Museu do Índio.

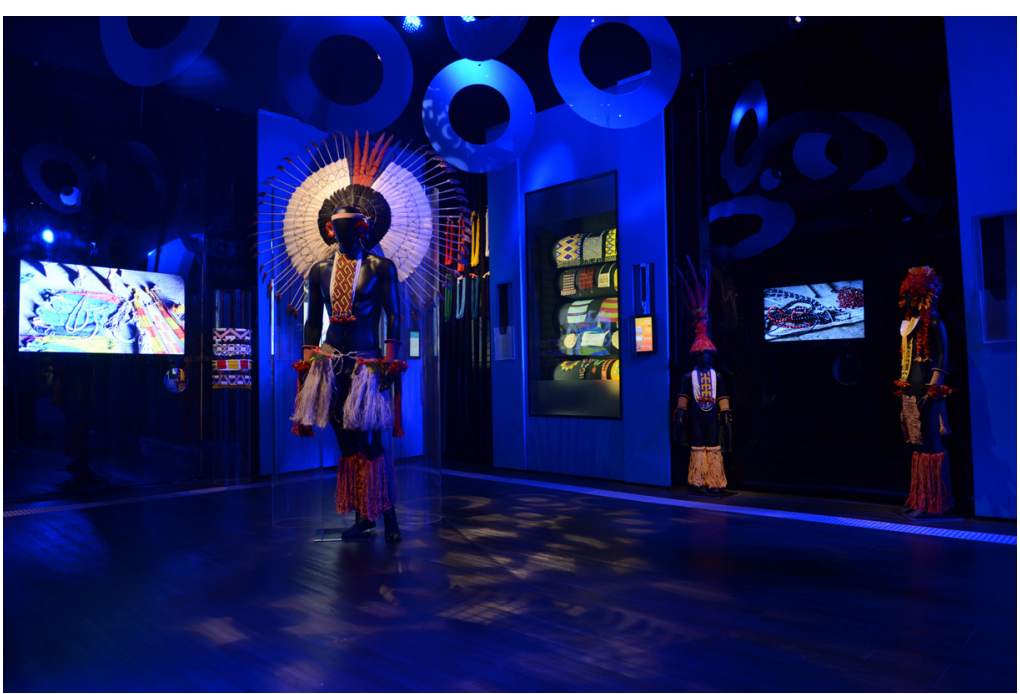

Foto 16 - Interior da exposição No caminho das miçangas: um mundo que ser faz de contas, 2015. Foto: Acervo Museu do Índio.

elemento que orientou as novas aquisições; a segunda, a um conhecimento bem embasado da formação do acervo preservado, buscando entender e localizar as lacunas das coleções existentes; e a terceira, à existência de um projeto institucional de longo prazo, que considere as demandas potenciais feitas pela sociedade e todas as possibilidades e limitações do museu.

Atualmente, o acervo se encontra totalmente identificado, acondicionado e disponibilizado 
virtualmente, por meio de base de dados onde os itens etnográficos, em sua grande maioria, vêm acompanhados de suas respectivas imagens. Nesse processo, a participação dos índios foi constante e indispensável, uma vez que eles contribuíram na identificação e documentação das peças, bem como em sua restauração e exibição.

Hoje, o Museu do Índio vem preservando tanto a memória dos povos indígenas quanto a sua própria história, constituindo desse modo um patrimônio cultural que envolve o resgate de seu passado, visando, com isso, compreender as diferenças e reconhecer os limites de cada período. Pois acredita que, refletindo sobre a sua história, não apenas como quem recorda, mas exercitando uma verdadeira práxis, em que a reflexão e a prática andam lado a lado, terá referências consistentes para construir o presente e planejar o seu futuro.

\section{Referências}

BOLETIM INFORMATIVO/FUNAI. Brasília, DF: Fundação Nacional do Índio, v.1, n.1, out. 1971. 60p.

BOLETIM INFORMATIVO/FUNAI. Brasília, DF: Fundação Nacional do Índio, v.1, n.2, 1972. 84p.

BOLETIM INFORMATIVO/FUNAI. Brasília, DF: Fundação Nacional do Índio, v.1, n.3, 1972. 60p.

BOLETIM INFORMATIVO/FUNAI. Brasília, DF: Fundação Nacional do Índio, v.1, n.4, 1972. 64p.

BOLETIM INFORMATIVO/FUNAI. Brasília, DF: Fundação Nacional do Índio, v.2, n.5, 1972. 72p.

BOLETIM INFORMATIVO/FUNAI. Brasília, DF: Fundação Nacional do Índio, v.2, n.6, 1973. 64p.

BOLETIM INFORMATIVO/FUNAI. Brasília, DF: Fundação Nacional do Índio, v.2, n.7, 1973. 72p.

BOLETIM INFORMATIVO/FUNAI. Brasília, DF: Fundação Nacional do Índio, v.2, n.8, 1973. 70p.

BOLETIM INFORMATIVO/FUNAI. Brasília, DF: Fundação Nacional do Índio, v.3, n.9/10, 1973. 80p.

BOLETIM INFORMATIVO/FUNAI. Brasília, DF: Fundação Nacional do Índio, v.3, n.11/12, out. 1974. 160p.

BOLETIM INFORMATIVO/FUNAI. Brasília, DF: Fundação Nacional do Índio, v.4, n.13, mar. 1975. 78p.
BOLETIM INFORMATIVO/FUNAI. Brasília, DF: Fundação Nacional do Índio, v.5, n.15/16, 1975. 86p.

BOLETIM INFORMATIVO/FUNAI. Brasília, DF: Fundação Nacional do Índio, v.5, n.17, jun. 1976. 63p.

COUT0, Ione Helena Pereira. Armazém da Memória da Seção de Estudos do Serviço de Proteção aos Índios - SPI. Tese (Doutorado em Memória Social) - Universidade Federal do Estado do Rio de Janeiro. Rio de Janeiro, 2009.

IPHAN. Instituto do Patrimônio Histórico e Artístico Nacional. Lista dos Bens culturais inscritos no livro de Tombo (1938-2012), Rio de Janeiro, fev. 2013. p.108. Disponível em: http: //portal . iphan.gov.br/uploads/ckfinder / arquivos/guia\%20de\%20bens\%20tombados\% 20 aatualizad\%20em\%202012.pdf; Acesso em: $20 \mathrm{abr}$. 2015.

LIMA, Jacob Carlos; CORTES, Soraya Maria Vargas. A sociologia no Brasil e a interdisciplinaridade nas ciências sociais. Dossiê: Disciplinas e profissões em debate. Civitas, v.13, n.3, p.416-435, 2013.

MENESES, Ulpiano T. Bezerra de. Do teatro da memória ao laboratório da história: a exposição museológica e o conhecimento histórico. Anais do Museu Paulista, História e Cultura Material, São Paulo, Nova Série, v.2, p.9-42, jan./dez. 1994.

RONDINELLI, Rosely Curi. Inventário analítico do arquivo permanente do Museu do Índio: documentos textuais: 1950-1994. Rio de Janeiro: Museu do Índio, 1997. 147p. il.; $29 \mathrm{~cm}$.

* Ione Helena Pereira Couto é Doutora em Memória Social pelo Programa de Pós-Graduação em Memória Social da Universidade Federal do Estado do Rio de Janeiro (UniRio) e Coordenadora de Patrimônio Cultural do Museu do Índio, Funai. 


\title{
A coleção etnográfica do Museu Goeldi e os povos indígenas: desafios contemporâneos
}

\author{
Suzana Primo dos Santos* \\ Claudia Leonor López Garcés** \\ Museu Paraense Emílio Goeldi (MPEG)
}

A coleção de objetos etnográficos que o Museu Paraense Emílio Goeldi (MPEG) guarda tem uma trajetória que se funde com a própria criação do museu. No transcurso de 150 anos de história, o Museu Goeldi foi acumulando amadurecimento com relação a suas pesquisas, nos vários ramos do conhecimento que competem às suas coordenações de Ciências Humanas e Biológicas.

Os mais de 14 mil objetos etnográficos hoje guardados na Reserva Técnica Curt Nimuendaju, na área de antropologia, são documentos que contam a história de diversos povos indígenas e populações tradicionais da Amazônia, por meio dos materiais usados na sua confecção, das amarrações, dos tipos e formas e dos usos do objeto, além das relações sociais implícitas e demais informações possíveis que os objetos etnográficos oferecem aos nossos olhares e à pesquisa sobre eles. Uma flecha, por exemplo, é cultura, visto que representa uma sociedade indígena em determinada época. No âmbito do museu, ela se torna uma fonte de informação, desde sua saída do local de origem, onde tem outras conotações e significados, até o espaço das reservas técnicas, onde interagem, principalmente, os olhares museológico e antropológico sobre o objeto. Apesar de muitas coleções no acervo etnográfico apresentarem informação precária, o que permite obter maior informação sobre os objetos, além das leituras especializadas e da pesquisa de campo, é o contato com os povos indígenas e as populações locais que os criaram.

Uma vez incorporados ao acervo, esses objetos adquirem um valor científico e museológico próprio, mas, ao mesmo tempo, contribuem para reconhecer, valorizar e visibilizar o povo que os confeccionou. Nas últimas décadas, o Museu Goeldi tem propiciado espaços de diálogo com os povos indígenas por meio de visitas e oficinas e pela incorporação de uma funcionária do povo Karipuna (uma das autoras deste artigo) no quadro que atua na coleção etnográfica. Essas ações têm facilitado o contato dos povos indígenas com o acervo, viabilizando as próprias pesquisas indígenas, por meio do mergulho no seu passado, em busca de algo já esquecido, ao mesmo tempo que enriquecem as informações sobre os objetos etnográficos e a atuação institucional no seu fazer museológico, pelo diálogo e interação com os conhecimentos indígenas.

0 objetivo deste artigo é refletir sobre esses diálogos e interações Museu Goeldi-povos indígenas, mostrando os avanços e os desafios em termos das transformações necessárias que o Museu Goeldi, como instituição científica, deve assumir em prol da adequação às demandas sociais no século XXI.

\section{0 acervo etnográfico do Museu} Goeldi: história e contexto atual

0 interesse em preservar objetos indígenas começou século XIX, com a criação da Sociedade Filomática, em 1866, cujo objetivo principal era "manter um museu de história natural e de artefatos indígenas" (Sanjad, 2010). Os objetos adquiridos pelos naturalistas da época, entre eles Domingo Soares Ferreira Pena, médico fundador do Museu, e o geógrafo francês Henri Coudreau (1896), contribuíram para formar 
as incipientes coleções (Van Velthem et al., 2004; Crispino et al., 2006). Assim formou-se uma coleção conjunta de objetos arqueológicos e etnográficos para ser mostrada ao público visitante, pois nessa época a instituição não contava com pesquisadores especialistas nas áreas das ciências humanas.

No início do século XX, com o incentivo do zoólogo suíço Emílio Goeldi na direção, foram adquiridas outras importantes coleções, tais como uma coleção de objetos Ka'apor adquirida em 1900 - isto é, 27 anos antes do contato oficial desse povo efetuado pelo Serviço de Proteção aos Índios (SPI), sendo a mais antiga entre todas as coleções de objetos desse povo que hoje se encontram nos museus do mundo, e também a coleção de objetos dos Irã Amrã, comprada por Emílio Goeldi a um grupo de indígenas desse povo de língua Jê, hoje considerado extinto, que visitou o Museu em 1902, acompanhado por Frei Gil de Villanova, quem intermediou a compra para apoiar a missão de Conceição de Araguaia (Chaves, 2012). Importantes coleções de objetos de povos indígenas da região do Rio Negro e, em menor proporção, de regiões que hoje pertencem à Amazônia colombiana, coletadas pelo etnólogo alemão Theodor Koch-Grünberg (1995) nas suas viagens (1903-1905), também fazem parte do acervo etnográfico do Museu Goeldi e até hoje estão intactas.

Foi Curt Nimuendaju quem catalogou os objetos em 1921, e depois Eduardo Galvão, na década de 1950, classificou o acervo por "áreas culturais indígenas" (Van Velthem et al., 2004). No início do século XXI, com a construção do novo espaço da Reserva Técnica e mudança para o campus de pesquisa, em 2003, o acervo etnográfico do Museu Goeldi foi organizado por "categorias artesanais", seguindo as orientações do Dicionário do Artesanato Indígena, de Berta Ribeiro (1988).

A atual organização e distribuição do acervo por "categorias artesanais" busca priorizar o objetivo museológico da conservação dos objetos, em termos de acondicionamento e organização temática (cerâmica, plumária, trançados, armas, instrumentos musicais, objetos lúdicos etc.), mas, ao mesmo tempo, busca traduzir a complexidade do acervo numa linguagem simples ao olhar do observador. Os armários, gaveteiros e prateleiras comportam os objetos das diversas categorias por tamanho e forma, priorizando também o aproveitamento do espaço.

Seguindo os princípios da conservação preventiva, a reserva técnica que guarda o acervo etnográfico está acondicionada com um sistema de climatização implantado no início do século XXI, tendo como foco o controle da biodeterioração por meio da atividade de fungos e insetos, considerada uma das principais ameaças da coleção etnográfica na época, pois a degradação química e a mecânica não foram consideradas como ameaça naquele momento (Maekawa, 2007).

O sistema de climatização se constitui de ventiladores insufladores e exaustores, e desumidificadores. Projetado para manter a umidade relativa (UR) abaixo de 70\%, a temperatura varia conforme o aquecimento e as variações externas. Os ventiladores internos entram em funcionamento quando a UR está inferior na área externa da reserva em relação à parte interna, visando a diminuição de umidade. Quando a UR ultrapassa a faixa de $70 \%$, os desumidificadores são acionados. Atualmente, o valor máximo para o sistema é de $60 \%$ de umidade (Vicente, 2014). Dessa maneira, o acervo etnográfico do Museu Goeldi tem conseguido se manter em condições favoráveis perante o controle de pragas e insetos. No momento atual, estão em andamento diversas pesquisas visando dimensionar os impactos do atual sistema de climatização nos diversos tipos de matériasprimas das quais se constituem os objetos (metais, cerâmicas, fibras e penas).

Nos últimos anos, o trabalho da equipe de curadoria do acervo etnográfico tem se desdobrado sobre o processo de inventário e informatização das coleções, por meio do Sistema de Informação das Coleções Etnográficas (Since), ferramenta criada no âmbito do Museu Goeldi (Benchimol et al., 2012) com objetivo de organizar, documentar e facilitar a gestão das importantes coleções de objetos etnográficos guardados no acervo, em sua maior parte elaborados por povos indígenas e populações tradicionais da Amazônia, bem como 
disponibilizar ao público informações básicas para consulta on-line. Ainda em processo de implementação, as informações sobre as coleções são disponibilizadas na medida em que vão sendo catalogadas e registradas no sistema, processo mediado em algumas ocasiões por diálogos em oficinas com os povos indígenas e no contexto de diversos projetos de pesquisa. Com o Since, o Museu Goeldi dá mais um passo na sua importante missão de guardar, conservar, documentar e difundir seus acervos, ao mesmo tempo que adquire novos desafios, pois entendemos que a divulgação ampla do registro fotográfico e documental do acervo, ainda que as informações sejam mínimas, gera situações em que é necessário lidar com os direitos de propriedade intelectual coletiva, direitos de personalidade e de proteção dos conhecimentos tradicionais dos povos indígenas, fatores que só podem ser conduzidos por meio do diálogo e acordos estabelecidos com os povos artífices dos acervos de cultura material que guardamos.

\section{Diálogos com os povos indígenas}

No transcurso do século XXI, a Coleção Etnográfica do Museu Goeldi vem sendo cenário de importantes diálogos com diversos povos indígenas da Amazônia brasileira, por vezes indo além das fronteiras, como tem acontecido no caso do povo Tikuna. Esses encontros, no espaço da reserva técnica, são resultado do trabalho em parceria entre povos indígenas e antropólogos pesquisadores, buscando interagir com as coleções de objetos a fim de elucidar as suas próprias perguntas e inquietações, mas também os interrogantes que surgem no caminho da pesquisa. Prolíferos na geração de novos conhecimentos e na intensificação de emoções, os diálogos contribuem para a documentação das coleções etnográficas, ao mesmo tempo que trazem novos desafios na pesquisa e nas ações museológicas.

Em 2002, a antropóloga Priscila Faulhaber desenvolveu um projeto de pesquisa que colocou em contato os Tikuna da fronteira Brasil-Colômbia com o acervo etnográfico coletado por Curt Nimuendaju, guardado no Museu Goeldi. Os Tikuna discorreram sobre matérias-primas e técnicas de elaboração, lembraram e narraram histórias tradicionais, interpretaram os grafismos das suas máscaras mostrando detalhes importantes da sua cosmologia (Faulhaber, 2003), mas também preservando os conhecimentos que "não podem ser mostrados aos kori" (palavra em Tikuna para os "brancos"). Isso nos fez entender que, de acordo com a visão Tikuna, os diálogos interculturais também têm seus limites, porém, são extremamente profícuos para estudos comparativos, no nível do intercâmbio de conhecimentos entre povos indígenas que habitam em regiões de fronteiras geopolíticas entre Estados nacionais.

Ao longo da sua história sesquicentenária, o Museu Goeldi tem mantido uma relação privilegiada com o povo Mebêngôkre, principalmente com os Kayapó do sul do Pará, pois já no início do século XX recebeu um grupo de indígenas Irã Amrãnh, acompanhado por Frei Gil de Villanova, missionário francês da ordem capuchinha, ocasião em que Emílio Goeldi comprou uma coleção de mais de 600 objetos da cultura material desse povo hoje considerado extinto (Chaves, 2012). Com os Mebêngôkre-Kayapó foram realizadas duas oficinas de reconhecimento do acervo, no contexto de dois projetos de pesquisa. A primeira oficina, denominada "Mebêngôkre-Kayapó: um encontro com os objetos do passado", efetuada em julho de 2009, contou com a participação de indígenas da aldeia Moikarakô (Terra Indígena Kayapó - TIK).

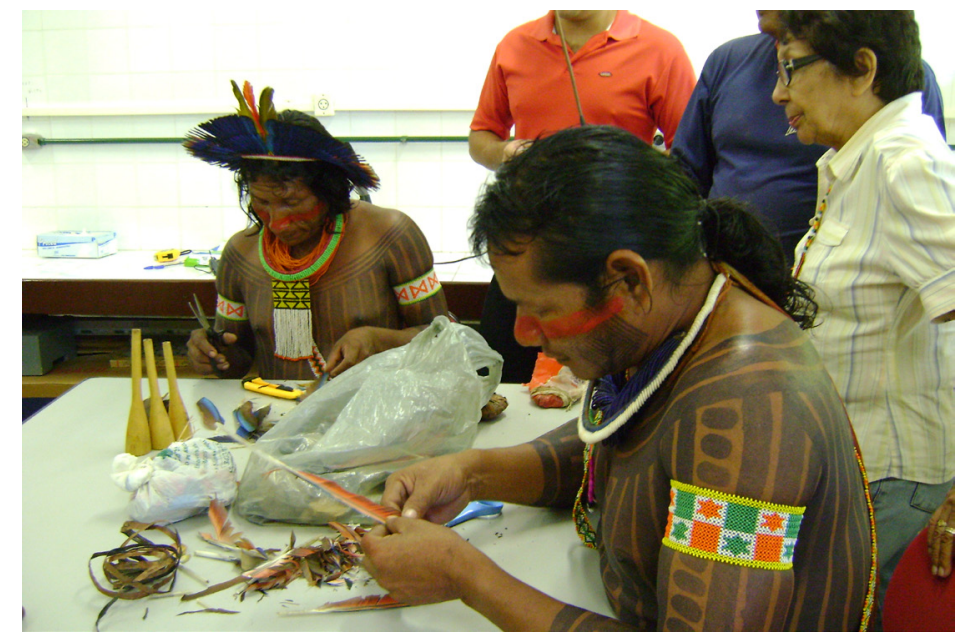

Foto 1 - Oficina realizada com os Kayapó em 2009. Foto: Claudia López. 
A segunda oficina contou com a participação de seis líderes Mebêngôkre-Kayapó das aldeias Moikarakô e Kikretum (TIK). Essas duas experiências proporcionaram informações detalhadas sobre matérias-primas, técnicas de elaboração, grafismos e motivos decorativos das coleções de objetos Mebêngôkre-Kayapó e Irã Amrãhn, permitindo identificar continuidades e descontinuidades estilísticas ao longo do tempo; também foram registradas narrativas e cantos associados aos objetos, documentando assim importantes aspectos cosmológicos sobre eles. Por iniciativa dos indígenas, foram reparados alguns objetos, principalmente flechas, e foram elaboradas três máscaras usadas em rituais e festas Mebêngôkre, posteriormente doadas à Coleção Etnográfica do Museu Goeldi. Oficinas semelhantes temos realizado mais

recentemente com o povo Ka'apor, a partir das pesquisas colaborativas no contexto do projeto "Compartilhando coleções e conectando histórias: um projeto colaborativo do Museu Nacional de Etnologia, Holanda, e Museu Paraense Emílio Goeldi, Brasil”.

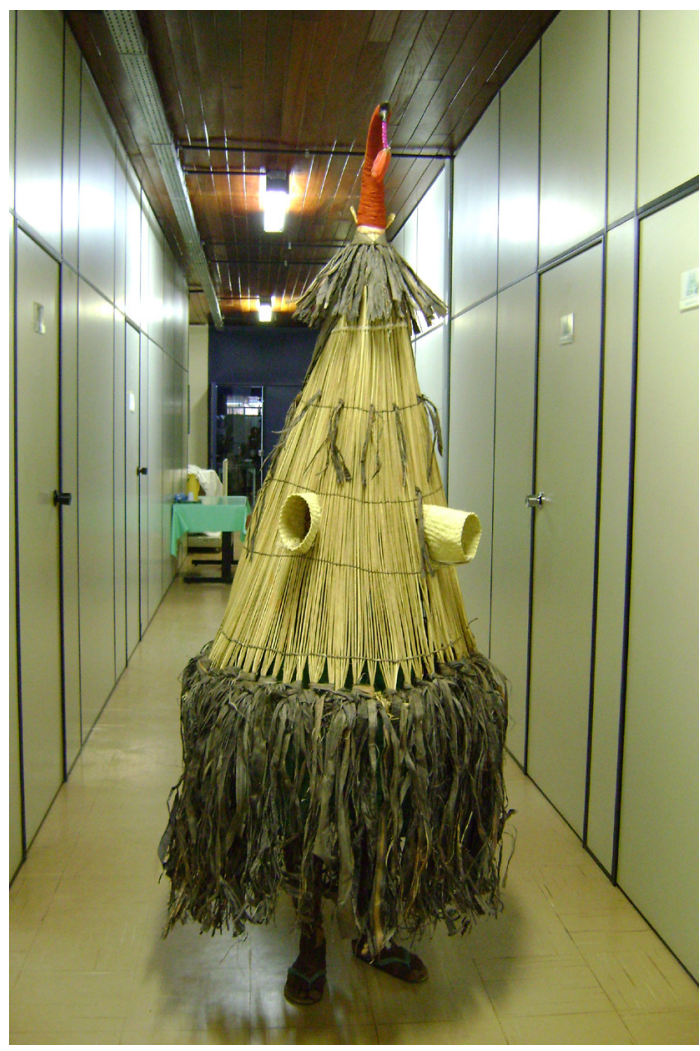

Foto 2 -

Máscara Kayapó confeccionada em oficina na Reserva Técnica Curt Nimuendaju, 2009. Foto: Claudia López.

As oficinas, além de possibilitar uma primeira aproximação ao mundo das representações indígenas sobre objetos e coleções etnográficas, constituem espaços para identificar procedimentos que precisam ser aprimorados nas ações de curadoria. Por exemplo, identificar objetos que, do ponto de vista indígena, faltam para completar as coleções do Museu Goeldi, assim como os objetos que precisam ser reparados ou substituídos por estarem danificados. Também são espaços para escutar as vozes indígenas sobre as coleções - por exemplo, os Ka'apor sugeriram que nas próximas coleções seja identificado o nome da pessoa que confeccionou o objeto. Dessa maneira abrem-se novos caminhos para efetuar atividades que possam conduzir a uma cogestão das coleções etnográficas com os povos indígenas.

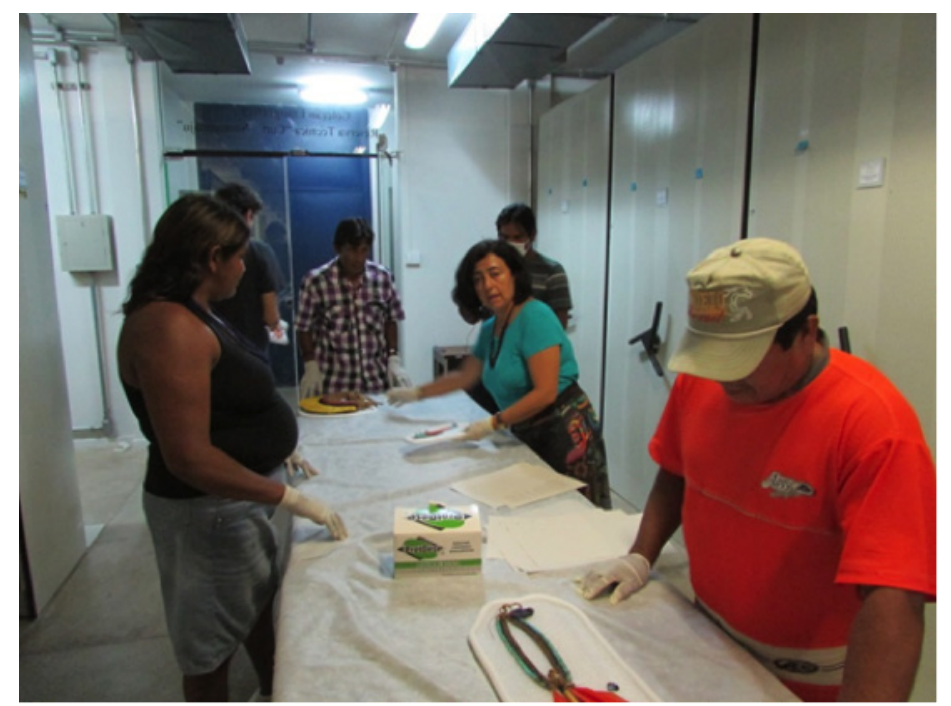

Foto 3 - Oficina com os Ka'apor na Reserva Técnica Curt Nimuendaju, 2013. Foto: Hugo Camarinha.

\section{Os desafios contemporâneos: à maneira de conclusão}

Um olhar crítico da história do Museu Goeldi com relação aos objetos das culturas indígenas que estão sob sua guarda permite observar que nestes 150 anos de formação do acervo etnográfico, até o fim do século XX, predominou uma visão/ atuação centrada nos objetos e distante dos 
povos indígenas, artífices desses objetos. Isso ainda se pode perceber pelo fato de a coleção etnográfica estar hoje organizada e classificada por "categorias artesanais", seguindo as orientações de Berta Ribeiro (1988). Aqui vale a pena mencionar que antes da atual classificação, a coleção etnográfica esteve organizada por "áreas culturais indígenas", com base nos ensinamentos de Eduardo Galvão, curador do Museu na década de 1950. Essa organização tornava as coleções mais visíveis em termos etnológicos, mostrando o conjunto da cultura material dos povos indígenas das respectivas "áreas culturais" (Norte-Amazônica, Juruá-Purus, Guaporé, TapajósMadeira, Alto-Xingu, Tocantins-Xingu, PindaréGurupi). A atual organização por "categorias artesanais" (Cerâmicas, Trançados, Cordões e Tecidos, Plumárias, Armas, Utensílio de Madeira e Outros Materiais) mostra-se adequada em termos de facilitar ações museológicas de conservação preventiva do acervo, mas invisibiliza a riqueza do conjunto da cultura material de cada povo indígena. Isso traz consequências no encontro das visões disciplinares (antropologia, museologia) e indígenas, olhares que se entrecruzam nas coleções etnográficas, constituindo desafios que devem ser observados.

Nota-se também que se deu maior importância aos colecionistas de objetos que aos povos artífices dos objetos. Isso se percebe na cultura institucional de identificar as coleções pelo nome do coletor: coleção Coudreau (composta de objetos do povo Yudjá ou Juruna); coleção Frey Gil de Villa Nova (composta por objetos do povo Irã Amrã, considerado extinto); coleção KochGrünberg (composta por objetos de diversos povos indígenas da região do Rio Negro, fronteira Brasil/Colômbia).

Hoje, o acervo etnográfico do Museu Goeldi também é composto por coleções organizadas pelos próprios indígenas, destacando as coleções de Jaké Apalai, Suzana Primo dos Santos (autora deste artigo), ambas do ano de 1987.

Lideranças Mebêngôkre-Kayapó têm mostrado interesse de que seus objetos façam parte do acervo etnográfico do Museu Goeldi. Em 2014, uma coleção de objetos contemporâneos do povo Xipaia foi doada por Luis Xipaia ao acervo etnográfico, após a exposição que mostrou a relação da zoóloga Emília Snethlage, diretora do Museu Goeldi em 1912, com esse povo indígena. Esta é uma nova tendência que se está despertando entre os vários povos indígenas - quem faz sentido e de quem se considera importante ter objetos representativos de sua cultura no Museu Goeldi.

A nova política museal, incentivada nas últimas duas décadas do século XX, trouxe mais abertura para o diálogo com os povos indígenas em torno dos objetos etnográficos. Sabe-se que o acervo indígena é composto de objetos de aproximadamente 122 povos indígenas do Brasil, Peru e Colômbia, além de outras sociedades amazônicas como ribeirinhos, pescadores, artesãos urbanos de Belém e sociedades marroom do Suriname, o que torna o acervo etnográfico do Museu Goeldi o mais representativo em termos quantitativos e de diversidade de povos em toda a grande Amazônia.

Além das oficinas, exposições e semanas dos povos indígenas, existem também as visitas por demanda dos povos indígenas, quando desejam conhecer os objetos da sua cultura guardados no acervo. Nessas visitas, ao entrar em contato com os objetos, os povos indígenas lembram detalhes na estrutura e forma de elaboração dos objetos que já foram esquecidos nas comunidades, trazendo o conhecimento e o reconhecimento de como se fazia antigamente.

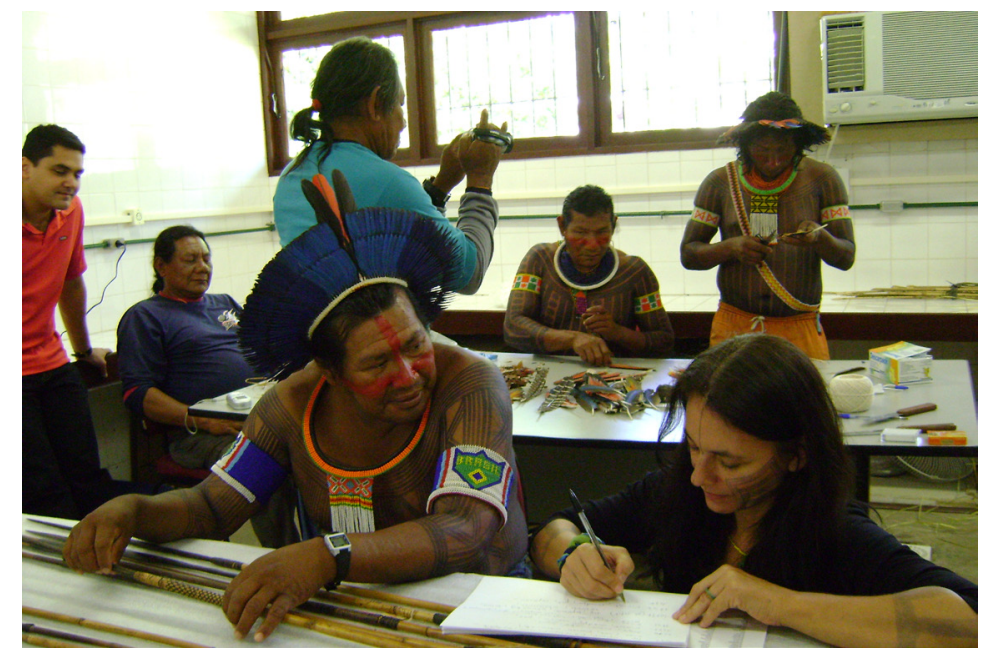

Foto 4 - Elaboração de novos objetos para exposição e guarda no acervo, 2009. Foto: Claudia López. 


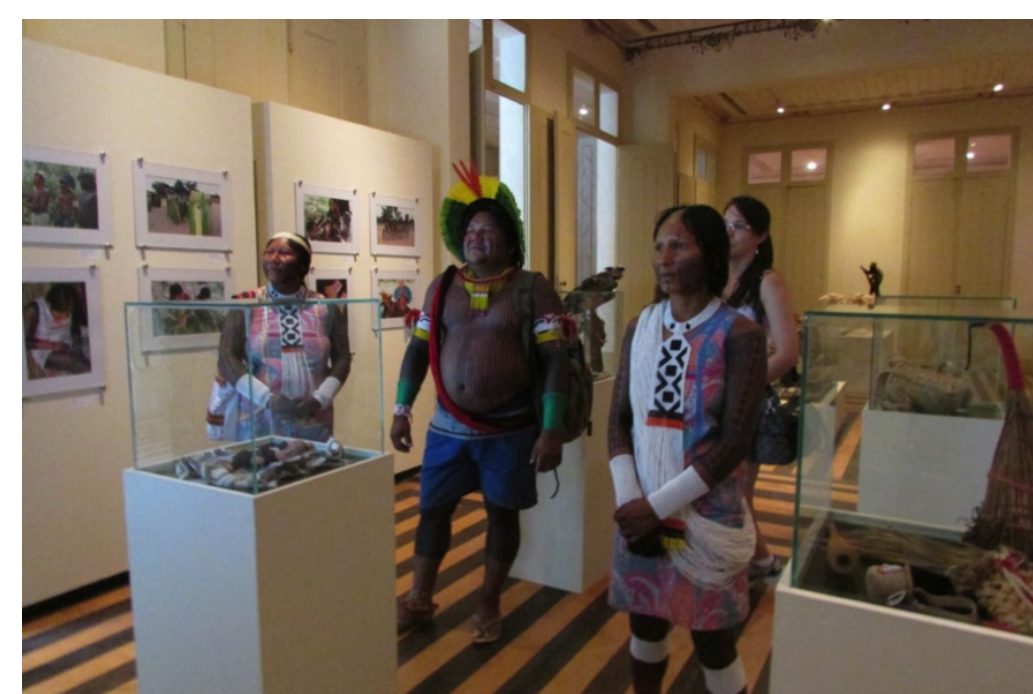

Foto 5 - Exposição com objetos do povo Kayapó, 2012. Foto: Claudia López.

Esses encontros com os objetos etnográficos são espaços de intensificação de emoções onde se expressam sentimentos de alegria, tristeza, saudade, orgulho, medo e raiva, por meio de choros, cantos, risos, orações, transes xamânicos etc. Isso nos faz entender que a coleção etnográfica não é só uma coleção de objetos inertes, como se poderia pensar desde uma perspectiva não indígena - longe disso, as coleções etnográficas constituem espaço de relações sociais e centros de preservação de conhecimentos dos povos que têm sua cultura material ali guardada.

Para que esse conjunto de conhecimentos, emoções e percepções sobre os objetos etnográficos possa ser acionado é necessário que os museus que trabalham com povos indígenas e comunidades tradicionais incentivem programas de valorização cultural que contribuam para a transmissão e reprodução de conhecimentos ancestrais associados à cultura material dos povos representados nas suas coleções.

Cabe mencionar que os conhecimentos associados aos objetos da cultura material estão ao alcance de todos os membros dos povos indígenas e sociedades tradicionais, pois eles confeccionam objetos para o dia a dia da vida em comunidade, tais como cuias, bancos, flechas, flautas e cestos, mas também para os momentos especiais relacionados com rituais e festas, quando são usados objetos como máscaras rituais, adereços plumários etc. Todos esses objetos, quando saem do meio em que foram elaborados e são colocados em museus, adquirem novos significados relacionados com os processos de musealização, mas continuam falando pelo povo que os confeccionou, contribuindo para desvendar formas de expressão do mundo material e imaterial dos povos indígenas e da sua história.

Como curadoras do acervo etnográfico do Museu Goeldi, consideramos que muitos são os desafios enfrentados por nós. Além dos já mencionados, gostaríamos de assinalar as implicações dos processos de tombamento dos objetos etnográficos, questionando o fato de que esse processo garante o reconhecimento dos objetos etnográficos como patrimônio da nação brasileira, mas ainda invisibiliza o reconhecimento dos objetos como patrimônios indígenas. Isso abre espaço para compreender o fato de que as instituições museais que lidam com cultura material indígena têm ainda um grande caminho por percorrer, em prol de uma melhor compreensão e atuação, em constante aprendizado e diálogo com os povos indígenas.

\section{Agradecimentos}

As autoras agradecem muito especialmente à Dra. Marília Xavier Cury o convite para participar do IV Encontro Paulista Questões Indígenas e Museus. Este artigo baseia-se nas ideias expostas pelas autoras nesse evento.

\section{Referências}

BENCHIMOL, Alegria; VIEGAS, Victor; KADOSAKI, Elcio; SOUSA, Marcos Paulo A. Da necessidade de diálogo interdisciplinar na criação de um sistema de informação para a Coleção Etnográfica do Museu Goeldi. In: ENCONTRO NACIONAL DE PESQUISA EM CIÊNCIA DA INFORMAÇÃO, 13. GT Museus, Patrimônio e Informação. Comunicação oral, 2012. 
CHAVES, Carlos Eduardo. Nas trilhas Irã Ãmrãnh: sobre história e cultura material Mebêngôkre. Dissertação (Mestrado em Ciências Sociais) - Instituto de Filosofia e Ciências Humanas, Universidade Federal do Pará. Belém, 2012.

CRISPINO, Luis Carlos Bassalo; BASTOS, Vera; TOLEDO, Peter Mann de (Ed.) As origens do Museu Paraense Emílio Goeldi. Aspectos históricos e iconográficos (1860-1921). Belém: Paka-Tatu, 2006.

FAULHABER, Priscila (Org.) Magüta arü inü. Jogo de memória - Pensamento Magüta. Belém: Museu Paraense Emílio Goeldi. CD-ROM, 2003.

GOELDI, Emilio Augusto. Relatório apresentado ao Exmo. Sr. Dr. Secretário de Estado da Justiça, Interior e Instrucção Pública referente ao anno de 1902 pelo Diretor do Museu. Boletim do Museu Goeldi (Museu Paraense) de História Natural e Ethnographia, Tomo 4, n.4, p.467-509 (Parte Administrativa), 1906.

KOCH-GRÜNBERG, Theodor. Dos años entre los indios; viajes por el noroeste brasileño, 19031905. Santafé de Bogotá: Editorial Universidad Nacional, 1995.

MAEKAWA, Shin. Estratégias alternativas de controle climático para instituições culturais em regiões quente úmidas. In: BITTENCOURT, José; BENCHETRIT, Sarah; GRANATO, Marcus (Org.) Seminário Internacional Museus, Ciência e Tecnologia. Rio de Janeiro: Museu Histórico Nacional, 2007.

RIBEIRO, Berta G. Dicionário do artesanato indígena. São Paulo: Edusp, 1988.

SANJAD, Nelson. A coruja de Minerva: o Museu Paraense entre o Império e a República (18661907). Belém: Museu Paraense Emílio Goeldi; Rio de Janeiro: Fundação Oswaldo Cruz, 2010.

VAN VELTHEM, Lúcia Hussak; TOLEDO, Franciza Lima; BENCHIMOL, Alegria; ARRAES, Rosa; SOUZA, Ruth Cortez de. A coleção Etnográfica do Museu Goeldi: memória e conservação. Musas: Revista Brasileira de Museus e Museologia, v.1, n.1, p. 121-134, 2004 .

VICENTE, Bianca. Conservação preventiva na Reserva Técnica da Coleção Etnográfica do Museu Goeldi: monitoramento e análise de condições climáticas. Relatório final Programa
Institucional de Iniciação Científica (Pibic/ MPEG), 2014

* Suzana Primo dos Santos é Indígena Karipuna, socióloga, técnica da Coleção Etnográfica Curt Nimuendaju do Museu Paraense Emílio Goeldi (MPEG).

** Claudia Leonor L6́pez Garcés é Antropóloga, doutora em Antropologia da América Latina e Caribe pelo Centro de Pesquisa e Pós-Graduação Sobre América Latina e o Caribe (Ceppac) da Universidade de Brasília (UnB), pesquisadora do Museu Paraense Emílio Goeldi (MPEG) e curadora da Coleção Etnográfica Curt Nimuendaju. 


\title{
A participação indígena no Museu de Arqueologia e Etnologia da Universidade Federal de Santa Catarina ${ }^{1}$
}

\author{
Viviane Wermelinger Guimarães * \\ Museu de Arqueologia e Etnologia, Universidade de São Paulo (MAE-USP)
}

O Museu de Arqueologia e Etnologia Professor Oswaldo Rodrigues Cabral (MArquE) teve sua formação a partir de objetos coletados por pesquisadores da universidade, objetos que são frutos de pesquisas de campo e que posteriormente são utilizados para o ensino, a pesquisa e a extensão. Originou-se do Instituto de Antropologia, criado por meio da Resolução $n^{\circ} 017 / 68$ do Conselho Universitário, do dia 2 de maio de 1968, 6 anos depois da criação da Universidade Federal de Santa Catarina (UFSC), utilizando como cenário de fundo o Curso de História da então Faculdade de Filosofia, Ciências e Letras da UFSC.

0 principal articulador do instituto foi o Professor Oswaldo Rodrigues Cabral, titular da cadeira de Antropologia, com os professores Walter Fernando Piazza e Silvio Coelho dos Santos, ${ }^{2}$ este último assistente do Professor Oswaldo no início da década de 1960.

O Professor Silvio Coelho dos Santos foi um dos primeiros pesquisadores na área de etnologia indígena. Em 1962, fez seu primeiro trabalho de campo quando era aluno do Curso de Especialização em Antropologia no Museu Nacional. Nesse trabalho realizado junto à População Indígena Ticuna, Silvio Coelho coletou artefatos e fez imagens que foram depositadas no Instituto para serem utilizadas como material didático e de pesquisa.

1. Este artigo baseia-se na dissertação de Mestrado da mesma autora, intitulada Exposições museológicas do Museu de Arqueologia e Etnologia da Universidade Federal de Santa Catarina: espaço para construções de parcerias (Guimarães, 2014)

2. Diretor do museu no período de 1970 a 1975.
A reforma universitária implantada na UFSC em 1970 culminou na transformação do Instituto de Antropologia em Museu de Antropologia, pois na época acreditava-se que a palavra Instituto era incompatível com a estrutura da Universidade que contava com departamentos, centros e subreitorias.

No começo, a mudança de nomenclatura não transformou o caráter científico da Instituição, que ainda priorizava as atividades de pesquisa, mas com o tempo passou a assumir, paralelamente, atividades próprias de museu, principalmente nas áreas de Arqueologia e Etnologia Indígena. Assim, foi o primeiro museu universitário de Santa Catarina.

0 visitante sentiu-se mais próximo da Instituição quando ela se transformou em Museu, pois estes são abertos ao público e oferecem atividades relacionadas às suas pesquisas e acervos, diferentemente de um instituto de pesquisa, que tem o seu foco internalizado, pois seus trabalhos são realizados com os seus pesquisadores, professores e alunos.

Nesse momento, o público interno e externo da UFSC passou a procurar o Museu para conhecer o acervo originário das pesquisas arqueológicas, etnológicas e de antropologia física. Mas os pesquisadores não estavam preparados para o atendimento ao público, principalmente escolar, e as instalações não contemplavam espaço para exposições do acervo. Foram construídos três anexos para abrigarem as exposições, mas essas construções eram de caráter temporário, inseguras para os acervos e os visitantes. 
$\mathrm{Na}$ época a equipe começou a entender seu papel para o estado de Santa Catarina, pois o Museu Universitário possuía potencial para ser uma liderança museológica no Estado. Diante desse quadro, foi desenvolvido o setor de Museologia.

Além da preocupação com a criação do setor de museologia, no início da década de 1980 a Instituição iniciou o processo de dinamização e visibilidade, buscando atrair um grande número de visitantes, vindo ao encontro de uma ideia antiga do primeiro reitor da UFSC, Professor João David Ferreira Lima, para quem o Museu deveria ser o "cartão-postal" da Universidade. No seu entender, - Museu realizava pesquisas científicas e coletas de materiais e deveria estar aberto ao público para apresentar os resultados desses estudos.

As pesquisas continuaram no Museu, principalmente em arqueologia e etnologia indígena,

solidificando-o como espaço político em relação aos grupos indígenas que viviam na região Sul do país. A Instituição participou da elaboração de laudos antropológicos para a demarcação de terras indígenas, sendo reconhecida pelos grupos indígenas como local de apoio para a reivindicação de seus direitos.

Desde o seu início no Instituto de Antropologia, e posteriormente como parte integrante do Departamento de Sociologia, os estudos e pesquisas no campo da Antropologia representaram significativa importância no diálogo com as comunidades indígenas de todo o estado. Os professores ligados à Antropologia da UFSC proporcionaram visibilidade às comunidades indígenas, atuando na defesa de seus interesses perante o poder estadual. (Neckel; Küchler, 2010, p. 267)

Há quase 50 anos, questões relacionadas aos processos culturais vinculados às populações indígenas no território catarinense já eram temas de pesquisa. Tendo em vista a diversidade étnica das populações indígenas e pré-coloniais no sul do Brasil, a equipe do MArquE-UFSC impulsionou os primeiros projetos de pesquisa desenvolvidos na área da antropologia no estado de Santa Catarina.
0 MArquE-UFSC tem na sua trajetória trabalho com os indígenas que estão no estado de Santa Catarina, principalmente os Guarani e o Xokleng/ Laklanõ. Sua equipe está envolvida em projetos em parceria com os grupos indígenas, em relação à demarcação de territórios, à preservação cultural, à educação e à comunicação, entre outros. Grande parte das exposições dessa temática realizada pelo Museu, conforme relata Dorothea Darella (2014), "foi concebida por via de trabalhos de campo e atuações que vinham sendo efetivadas no Museu com comunidades localizadas, a princípio, na Grande Florianópolis".

Ao levantarmos as exposições concebidas pelo MArquE-UFSC, encontramos no universo de 372 exposições, ${ }^{3} 68$ (18\%) que tinham como temática a etnologia indígena, das quais, algumas fizeram parte de eventos acadêmicos e políticos relacionados aos grupos indígenas. Em 1996 foi realizado o projeto "Diversidade Cultural Desvelando Povos e Movimentos Indígenas no Brasil e em Santa Catarina". No âmbito desse projeto, foram realizadas oito ${ }^{4}$ exposições abordando diversas culturas indígenas e duas ${ }^{5}$ delas utilizaram o acervo do Museu.

Outras exposições também foram concebidas em eventos, como: "Realidade das aldeias dos Guarani-Mbyá de Massiambu e Morro dos Cavalos - Palhoça - SC", como parte do $7^{\circ}$ Encontro das Comunidades Eclesiais de Base (1996); "Os Guarani no litoral de Santa Catarina" no evento Nossas Florestas, nossa herança (1997); no $3^{\circ}$ Encontro Ibero-Americano de Unidades Ambientais do Setor de Transporte fez parte a exposição "Sítios Arqueológicos e Comunidades Guarani na Área de Influência das Obras de Duplicação da BR 101 em Santa Catarina" (1998); "Como seguir [sendo] Guarani agora?" (2001), exposição que contou com depoimentos dos índios Guarani e fez parte do IV

3. Levantamos exposições temporárias, itinerantes, visitantes, de longa duração e exposições que utilizaram o acervo do MArquE-UFSC (Guimarães, 2014, p.149-209).

4. "Os Kayapó do Brasil"; "Os Guarani" (montada em dois momentos); "Os Kaingang e os Xokleng/Botocudo"; "A arte e a cultura material Tikuna"; "Diversidade Cultural na América Latina"; "A Diversidade Cultural inscrita em peças artesanais e na organização política"; "Grupos indígenas na Amazônia". 5. "Os Guarani"; "Os Kaingang e os Xokleng/Botocudo". 
Encontro Nacional sobre a Atuação do Ministério Público Federal na Defesa das Comunidades Indígenas e Minorias, na Assembleia Legislativa de Santa Catarina e no Centro de Filosofia e Ciências Humanas da UFSC, entre outras.

Diante desse cenário, podemos destacar três exposições organizadas pelo Museu que tiveram participação ativa de grupos indígenas: na década de 1990, relata Cristina Castellano (2014), houve uma experiência junto a uma população indígena; em 2011, com os alunos Guarani, Kaingang e Xokleng/Laklanõ do Curso de Licenciatura Intercultural Indígena do Sul da Mata Atlântica da UFSC; ${ }^{7}$ e em 2012 a exposição "Ticuna em Dois Tempos".

As duas últimas exposições citadas vão ao encontro da atuação contemporânea dos museus, onde há uma busca constante de aproximação com distintos grupos por meio de processos museológicos em cumprimento de um dos seus papéis na sociedade, que é a transformação do patrimônio em herança cultural. No caso do MArquEUFSC o caminho escolhido foi o dos processos expográficos.

A primeira dessas duas exposições utilizou o método cooperativo na construção da narrativa expositiva, e a outra contou com a participação ativa da Comunidade Tikuna Wotchimaücü na

6. Não encontramos na documentação mais informações sobre essa exposição.

7. 0 curso de Licenciatura tem como enfoque “Territórios indígenas: questões fundiária e ambiental no Bioma Mata Atlântica", e habilita os seus alunos em "Licenciatura da Infância: Formação inicial comum para a docência na Educação Infantil e nos anos iniciais do Ensino Fundamental das escolas indígenas"; "Licenciatura das Linguagens: Ênfase Línguas Indígenas"; "Licenciatura em Humanidades: Ênfase em Direitos Indígenas" e "Licenciatura do Conhecimento Ambiental: Ênfase em Gestão Ambiental". Tem a carga horária de 3.348 horas, com duração de 4 anos ( 8 semestres). Podem candidatar-se ao curso os povos indígenas que vivem na parte meridional do Bioma Mata Atlântica: Guarani (ES, RJ, SP, PR, SC, RS), Kaingang (SP, PR, SC, RS) e Xokleng/Laklanõ (SC), com Ensino Médio completo. O curso é realizado em regime presencial especial com etapas concentradas e é desenvolvido na "Pedagogia da Alternância: Tempo Universidade e Tempo Comunidade". A parceria entre o MArquE-UFSC e a Licenciatura já existia desde a construção do curso na Universidade, pois os antropólogos do Museu fizeram parte da Comissão Interinstitucional para Educação Superior Indígena (Ciesi). elaboração de recurso audiovisual. A primeira foi realizada no começo de 2011, quando se iniciou na UFSC o curso de Licenciatura Intercultural do Sul da Mata Atlântica. Alguns meses antes do início do Curso, os profissionais do Museu fizeram uma proposta de concepção de uma exposição com os objetos museológicos da cultura dos três grupos indígenas - Guarani, Kaingang e Xokleng/Laklanõ para fazer uma recepção aos alunos e apresentar o acervo institucional.

0 projeto foi amadurecendo, e a equipe decidiu convidar os alunos para participarem ativamente de todo o processo expográfico. Assim, a parceria entre o Museu e o Curso foi ampliada com a intenção de criar vínculos entre os alunos, a Instituição e o patrimônio cultural preservado.

Não basta expor contextualizando a partir da origem e trajetória do artefato, e sim expor fazendo com que se estabeleçam vínculos entre culturas, entre grupos e entre pessoas de culturas diferentes, e isto só se dá na comunicação de sentidos. Acredito que somente estabelecendo vínculos é que conseguiremos estabelecer uma relação dialógica entre exposição - e grupos culturais - e o receptor. (Cury, 2005a, p. 23)

A concepção do processo iniciou-se por meio de visitas à Reserva Técnica do MArquE-UFSC, em que se possibilitou a aproximação com a produção artefatual dos distintos grupos indígenas.

A Coleção de Etnologia Indígena do MArquE-UFSC tem na sua formação procedências diferentes. Cronologicamente, as primeiras coleções a darem entrada foram as referentes aos Ticuna e Xokleng. Posteriormente, a coleção cresceu com artefatos oriundos de outros grupos indígenas, como os Guarani-Mbya, Kaingang, Bororo, Galibi, Kadiwéu, Kamayurá, Kanamari, Karajá, Kaxinawá, Marubo, Palikur e Terena, dentre outros.

A mais expressiva numericamente é a coleção relacionada ao grupo indígena Xokleng, coletada durante as pesquisas do antropólogo Silvio Coelho dos Santos, que atuou no MArquE-UFSC junto a esse grupo na década de 1960. 
Essas visitas proporcionaram aos alunos indígenas conhecer o espaço de guarda do acervo do Museu e as atividades de conservação, restauração, documentação e pesquisa, que a Instituição realiza com o seu acervo museológico (Foto 1 ).

A atividade na Reserva Técnica foi o primeiro passo para que a parceria do Museu com os alunos indígenas rendesse bons frutos. Os alunos, na visita, perceberam como os museus são instituições a serviço da sociedade. Como parte integrante dela, podem participar na formação da consciência no espaço onde se inserem, contribuindo para o desenvolvimento local.

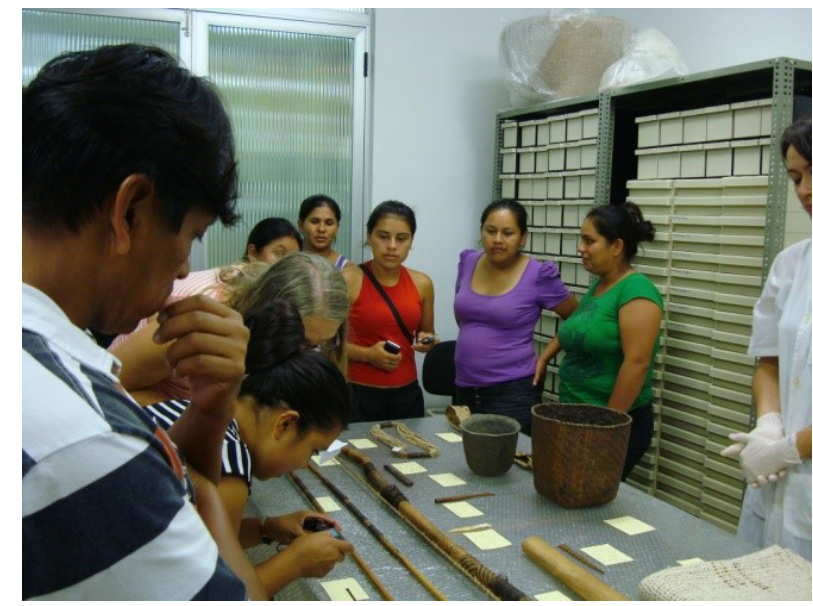

Foto 1 - Visita à Reserva Técnica, Turma Xokleng/Laklanõ, fev. 2011. Foto: Viviane Wermelinger. Fonte: MArquE-UFSC.

Podemos constatar a emoção dos alunos durante essa visita pelo relato da aluna Walderes

Coctá Pripra de Almeida (Xokleng/Laklanõ), no documentário ${ }^{8}$ realizado no período da concepção da exposição:

Conhecia mais por desenho, por foto, nunca tinha visto assim. Então teve sim coisas né? A lança com formato diferente, o que

8. Guarani, kaingang, xokleng... UFSC. Documentário produzido no contexto do curso de Licenciatura Intercultural Indígena do Sul da Mata Atlântica (UFSC). Acompanha a montagem da exposição "Memórias e Atualidades ao Sul da Mata Atlântica" realizada pelo Museu Universitário Oswaldo Rodrigues Cabral (UFSC) em parceria com os alunos do curso. ACERVO VIRTUAL SILVIO COELHO DOS SANTOS. VÍDEOS. 2011. Disponível em: http://avisc.wordpress.com/videos/; Acesso em: 30 mar. 2016. a gente produz lá é muito diferente das de antigamente. Quando eu cheguei aqui, quando eu entrei a primeira vez no museu, eu me senti uma pessoa que praticamente não conhecia nada, entendeu? Me senti pequenininha ali dentro, sabe? Aí quando eu cheguei em casa, fui comentando com as crianças, com meu pai, com minha mãe, da importância da nossa cultura, como ela é importante. (Guarani..., 2011)

Após esse encontro, a equipe do Museu e os alunos conversaram sobre a possibilidade da construção em parceria de uma exposição no começo de 2011. Realizamos uma reunião com todos os alunos, professores do Curso, profissionais do Museu e grupo de pesquisa Sigmo-UFSC. ${ }^{9}$ Nessa reunião, os alunos aceitaram participar da proposta e decidiram conceber uma exposição com o objetivo de apresentar à comunidade universitária da UFSC e à comunidade em geral o modo de vida dos três povos indígenas com as suas especificidades. Essa exposição foi elaborada utilizando o método cooperativo, ${ }^{10}$ em que todas as etapas para a sua concepção e montagem foram discutidas pelo MArquEUFSC, pelos alunos indígenas, pelos professores do Curso de Licenciatura e pelo Sigmo-UFSC.

Foram realizadas diversas reuniões para a realização da exposição, nas quais decidimos como seria sua concepção. Nas reuniões decidimos em conjunto o nome da exposição, “Guarani, Kaingáng e Xokleng: memórias e atualidades ao sul da mata atlântica", e também as cores e os desenhos gráficos que iam representar cada grupo. Foram eleitos dois representantes por turma para fazer a conexão entre os responsáveis pela exposição no Museu e os alunos, enquanto estivessem no "tempo comunidade" (março e abril de 2011). ${ }^{11}$

9. Significação da Marca, Informação e Comunicação Organizacional, grupo coordenado pelos professores Richard Perassi de Sousa e Luciano Castro do Curso de Design Gráfico da UFSC.

10. 0 método cooperativo incorpora, ao método em equipe representantes das culturas tratadas na formulação da enunciação expositiva. A incorporação coloca a narrativa expositiva na primeira pessoa, EU/Nós, ao passo que no processo em equipe a narrativa é colocada na terceira pessoa, ELE/ELES (Cury, 2012)

11. O Curso utiliza a Pedagogia da Alternância, em que o "tempo comunidade" é quando os alunos estão em suas 
Na Universidade naquele momento só havia o hall do prédio da Reitoria disponível para abrigar a exposição, pois os prédios do MArquE e da Galeria de Arte da UFSC encontravam-se em obras. Diante desse cenário, tivemos de nos adaptar à ideia inicial. Os alunos achavam importante que o acervo do MArquE-UFSC relativo às suas comunidades fizesse parte da exposição, mas naquele momento não poderia sair da Reserva Técnica, que possui controle de temperatura e umidade, diferentemente do hall da Reitoria, onde não havia espaço para expor acervos museológicos. Como na visita à Reserva Técnica, os indígenas apontaram a necessidade de complementar os objetos da Coleção de Etnologia Indígena do Museu. Eles resolveram coletar e produzir artefatos em suas aldeias para que fizessem parte da exposição e posteriormente fossem doados ao Museu.

\section{Ao retornaram à UFSC para a etapa "tempo} universidade" as três turmas trouxeram objetos para serem expostos. Marcamos um dia para a seleção de quais iriam para a exposição, pois trouxeram cerca de 250 objetos e não usaríamos todos no discurso expositivo. Decidimos fazer primeiro uma pré-seleção de trinta objetos por grupo, e eles escolheram dois a três alunos de cada turma para fazer a seleção. Separamos três salas no Museu, e cada dupla ou trio de alunos foi auxiliado pelos profissionais e bolsistas, sendo selecionados trinta objetos, e suas legendas foram elaboradas naquele momento com informações em português e nas respectivas línguas.

Sobre a coleta e a seleção dos objetos, apresentamos olhares de pessoas que estavam em posições diferentes no processo. 0 aluno Kaingang Claudemir Pinheiro, que fez parte da seleção dos objetos para a exposição, explica como foi a coleta na sua aldeia e a importância de todo o processo para ele:

Na verdade a gente passou pra comunidade que a gente iria expor esse material, onde a gente ia estar também identificando a cultura Kaingang, porque ninguém sabia que tinha lá na universidade federal de Florianópolis,

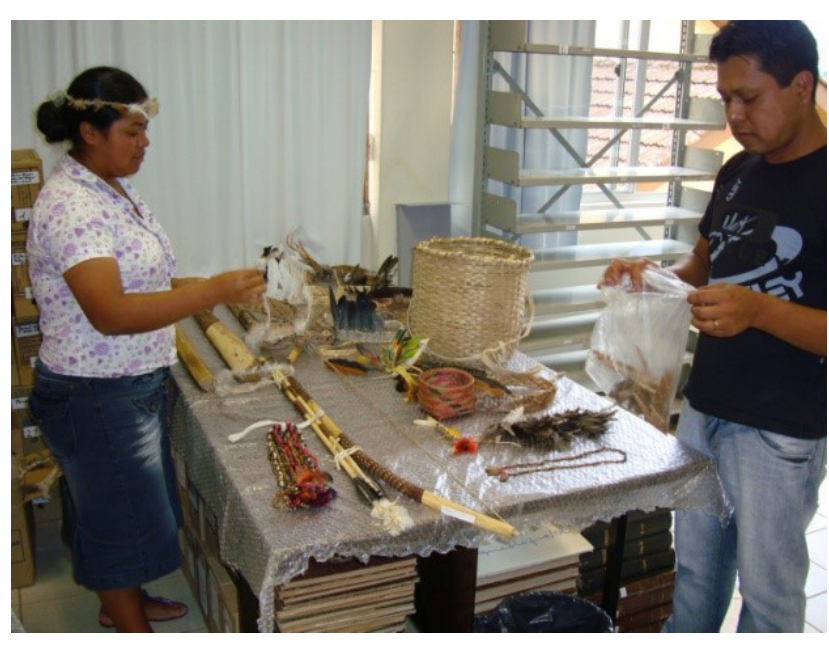

Foto 2 - Seleção de objetos para a exposição, Turma Xokleng/ Laklanõ, maio 2011. Fonte: MArquE-UFSC.

não sabia que tinha um museu Kaingang, então a gente viu um monte de coisa lá e agora a gente quer estar colaborando com eles, e está levando isso pra exposição... (Guarani..., 2011)

A bolsista Nádia Philippsen Fürbringer, que acompanhou o processo nas terras Guarani e no Museu, declara:

Pesquisar no museu implica ser engolida por suas políticas culturais também, nesse caso enquanto observadora participei ativamente de todas as etapas da montagem da exposição. E todo o processo foi contagiante, porque é um processo criativo em todos os momentos. A explicação de cada um dos objetos, de quem era, quando foi feito, como se usa, é um processo extremamente interessante. E é interessante porque cada um lembra de algo novo e diferente em relação a um objeto, renovando sempre a própria ideia desta pesquisa, de que um objeto não se encerra somente nesta ou naquela informação, sempre há mais para se acrescentar, há mais para lembrar. (Fürbringer, 2013, p.54)

Em relação aos objetos coletados pelos alunos dos três grupos indígenas, temos algumas impressões 
a relatar. Na visita à Reserva Técnica, todas as turmas ficaram emocionadas ao conhecer o acervo do Museu relativo às suas culturas. Organizamos a visita para cada grupo em dias diferentes, separamos o acervo representativo de cada cultura no dia da visita, e colocamos o acervo com legendas em uma mesa dentro da Reserva Técnica para que conseguissem observar com mais atenção.

Na visita conversamos sobre o papel dos museus e os procedimentos de conservação, documentação, pesquisa e comunicação em relação ao acervo museológico. Fizeram várias observações, falaram sobre os objetos, seus nomes e funções, ajudando a equipe a atualizar as informações do acervo na documentação museológica, e depois iam conhecer o restante dos objetos acondicionados na Reserva.

Essas visitas tiveram repercussão positiva entre os alunos, principalmente a turma Xokleng/ Laklanõ. Os artefatos desse grupo indígena são dos mais representativos do Museu graças ao trabalho realizado por Silvio Coelho dos Santos. A maioria dos alunos conheceu Silvio e lembrava-se dos objetos coletados por ele. Essa foi a mais emocionante de todas, principalmente quando depararam com a "manta de urtiga".12 Houve comoção, principalmente das mulheres, pois relataram que a maioria delas não sabe mais confeccionar; muitas se lembraram das utilizadas pelos seus antepassados e se comprometeram a aprender a fazer nas suas aldeias.

No dia em que chegaram os objetos para a exposição percebemos a particularidade de cada

12. Saia-cobertor feita por mulheres, conhecida como "Kulo to mazê". Antigamente a manta era usada pelas mulheres ao redor da cintura ou abaixo dos seios, atingindo a altura dos joelhos. A menina recebia sua manta entre os 7 e 8 anos. Além de peça de vestir, poderia ser utilizada como cobertor da família nos dias frios. Utilização de tear primitivo ou entretrançadas à mão, sem auxílio de tear. Na época da pesquisa - fim da década de [19]60 - algumas índias ainda faziam a manta, mas somente por encomenda, como no caso desta peça. Segundo dados etnográficos, a urtiga é apanhada e dela são feitos cordões. Depois fervem-se as cordas a fim de branqueá-las e, a seguir, inicia-se a textura. Após a confecção, a saia-cobertor é lavada e batida para "encorpar" o tecido. Coletada pelo pesquisador Silvio Coelho dos Santos, durante pesquisa de campo no ano de 1967. Banco de Dados online do MArquE-UFSC. Disponível em: http://notes.ufsc.br/ aplic/MUSEU.NSF?OpenDatabase; Acesso em: $30 \mathrm{mar} .2016$. grupo, quando combinamos com os alunos que eles fariam as coletas nas suas terras; deixamos livres para que escolhessem quais artefatos trariam.

As turmas Guarani ${ }^{13}$ e Kaingang ${ }^{14}$ contam com alunos de procedência de diversos estados da parte meridional do Bioma Mata Atlântica; já na turma Xokleng/Laklanõ, todos habitam a mesma terra indígena em Santa Catarina.

Quando os três alunos Guarani foram fazer a seleção dos objetos, houve dificuldades, pois tinham objetos que buscamos anteriormente em Morro dos Cavalos e M'biguaçu, e no dia vieram mais objetos de Amaral. Os alunos não tinham conhecimento dos objetos que já estavam no Museu, por isso não se sentiram à vontade para fazer a escolha, afinal, apesar de os objetos pertencerem à cultura Guarani, eram de outros Guarani. Nesse sentido, podemos refletir sobre a forma mais satisfatória, neste caso, de escolha de representação por meio de objetos e etnia.

A turma Kaingang trouxe diversos objetos, mas grande parte deles eram cestas, balaios e colares, produtos feitos para venda, com legendas indicando os nomes das pessoas que os fizeram e os detalhes de fabricação e utilidades das peças. Alguns objetos vieram com preço, mas a venda não havia sido discutida quando pensamos a exposição, motivo pelo qual descartou-se essa possibilidade.

Cabe ressaltar que não trouxeram somente objetos feitos para venda. A turma Kaingang trouxe também alguns objetos que são utilizados no dia a dia: chocalho especial para uso do Pajé; chapéu de criciúma; peneira sem aro e flauta. Ao catalogar - chocalho, os alunos Kaingang destacaram essa peça, dizendo que era especial, pois só o Pajé poderia usar nos rituais e cerimônias; falaram sobre o grafismo do chocalho. Ao colocar os objetos nas vitrinas, demos destaque a esse chocalho e não o colocamos junto aos outros trazidos por eles.

13. Espírito Santo, Rio de Janeiro, São Paulo, Paraná, Santa Catarina e Rio Grande do Sul.

14. São Paulo, Paraná, Santa Catarina e Rio Grande do Sul. 
Na última semana da exposição, fizemos reuniões com os alunos das três turmas, cada uma em um momento diferente. As reuniões tinham como intuito avaliar o processo e a exposição e falar sobre a possibilidade de itinerância. A turma Kaingang perguntou se nas próximas montagens poderiam trazer outros objetos, pois muitos eram semelhantes. Não tinham previsto uma repercussão tão positiva e gostariam de apresentar outros artefatos feitos e utilizados por eles. Concordamos que seria importante a mudança, proporcionando assim dinamismo à exposição, mas por fim não trouxeram novos objetos nas outras etapas.

Os objetos da turma Xokleng/Laklanõ diferenciaram-se dos outros, pois em grande parte eram antigos, utilizados pelos avós e bisavós dos alunos, heranças familiares e de diversas tipologias. Trouxeram a primeira carteira de identidade de um Xokleng/Laklanõ; fotografias antigas; arco e flecha, machadinha e a manta de urtiga. A aluna Walderes conseguiu a manta com sua mãe, feita por sua bisavó como presente para sua avó, mas a manta estava inacabada, pois a bisavó morreu antes do término.

Na sua fala, percebemos o valor desse objeto para a sua família: "Isso aqui é uma relíquia. Que ela já disse que isso vai passar para mim, que é para eu cuidar porque isso é meu" (Guarani..., 2011).

Quando a mãe emprestou a manta, recomendou que fosse levada de volta ao término da exposição, mas nos últimos dias já tínhamos dois destinos para a itinerância - $10^{a} \operatorname{Sepex}^{15}$ e o Museu Júlio

15. A Semana de Ensino, Pesquisa e Extensão da UFSC é um dos maiores eventos de divulgação científica de Santa Catarina. Desde 2000, o encontro reúne trabalhos desenvolvidos na Universidade em uma mostra científica aberta ao público, montada em frente à Reitoria, no campus da Trindade, em Florianópolis (SC). São aproximadamente 200 estandes com projetos nas áreas de comunicação, cultura, educação, tecnologia, ambiente, trabalho, direitos humanos e saúde. Visitam o pavilhão da Sepex mais de $50 \mathrm{mil}$ pessoas. São também realizados durante a Sepex minicursos abertos à comunidade, palestras e eventos paralelos, como o Seminário de Iniciação Científica. A $10^{a}$ Sepex aconteceu no período de 19 a 22 de outubro de 2011. A exposição foi montada na Sepex de forma reduzida, pois não havia espaço suficiente para comportar a mostra completa. de Castilhos. ${ }^{16}$ Pedimos, então, que a manta continuasse emprestada para as outras montagens, e ela concordou, mas ficou apreensiva sobre a reação da mãe quando voltasse para casa sem o objeto.

Depois da seleção dos objetos por grupo indígena, passamos para outra etapa do processo, desta vez sem a participação dos alunos, pois estavam em aulas e não podiam se ausentar. Nesse momento somente a equipe do Museu participou, definindo os lugares onde os objetos ficariam expostos. Esse ponto foi muito interessante, pois cada pessoa da equipe ficou responsável pela seleção de uma turma, e no momento da disposição dos objetos nas vitrinas houve apropriação dos objetos pelo grupo responsável.

Não eram mais os objetos distantes com que estávamos acostumados a trabalhar na Instituição, durante a aplicação dos procedimentos de conservação/restauração, de documentação e de exposição. Naquele momento eram objetos de pessoas que conhecíamos, que nos disseram o que significavam para eles, para seus familiares e para as pessoas de suas culturas. Houve uma ressignificação dos objetos para a equipe e, com isso, uma mudança de construção da relação entre a equipe e os artefatos. Não era mais uma relação somente museológica, havia também a apropriação desses objetos por todos, e isso ficou bem claro durante a disposição dos objetos nas vitrinas. Elaboravam justificativas para alguns objetos mereceram destaque; uns precisavam estar junto a outros, e alguns tinham de estar na exposição.

Fez parte da exposição também o acervo do MArquE-UFSC representado por imagens, já que não podíamos expor as peças no hall da Reitoria. Os alunos entenderam a ausência do acervo, mas gostariam que as peças estivessem representadas na exposição, e essa foi a solução encontrada.

A abertura da exposição aconteceu no dia 11 de maio de 2011 no prédio da Reitoria da UFSC, logo após a Aula Magna do Curso. Estiveram presentes

16. A exposição ficou aberta no período de 5 de novembro de 2011 a 31 de março de 2012 no Museu Júlio de Castilhos, em Porto Alegre, RS. 
as autoridades da Universidade, os professores do Curso de Licenciatura e dos demais cursos da UFSC, alunos de outros cursos, o presidente da Fundação Nacional do Índio (Funai), os alunos do Curso de Licenciatura Indígena Kaingang da Universidade Unochapecó e os alunos e familiares do Curso de Licenciatura Intercultural do Sul da Mata Atlântica. A exposição ficou aberta até o dia 27 de maio, recebendo cerca de 800 pessoas - entre as quais alunos de escolas da cidade -, com avaliação positiva, principalmente pelos alunos indígenas.

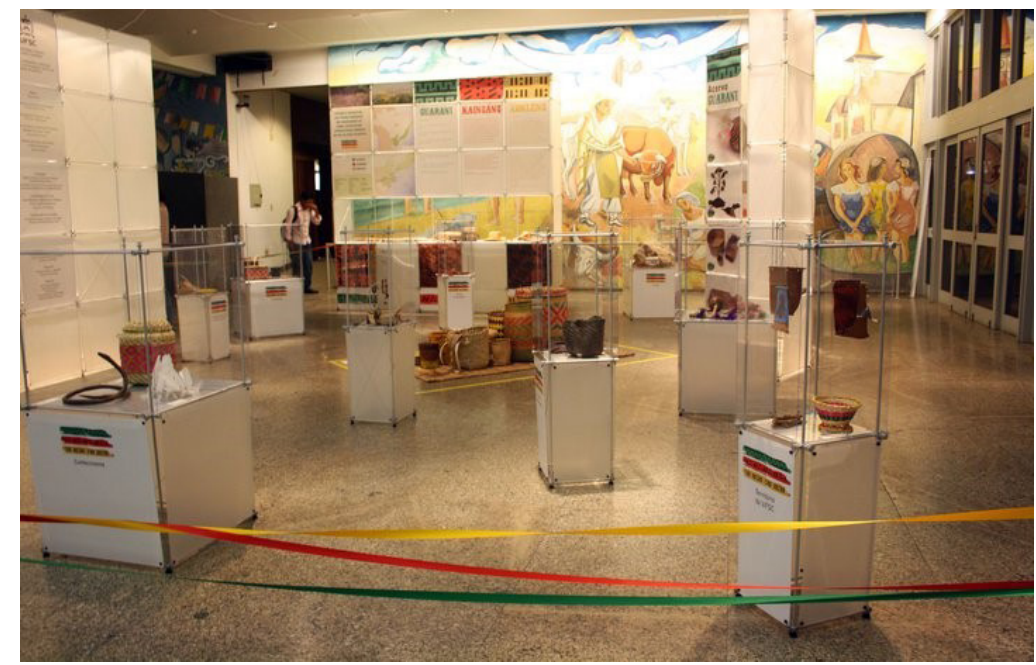

Foto 3 - Exposição: Guarani, Kaingang e Xokleng: Memórias e Atualidades ao Sul da Mata Atlântica no dia da inauguração, 11 maio 2011. Fonte: MArquE-UFSC.

Após a montagem da exposição na Reitoria, grande parte dos objetos trazidos pelos alunos foi doada ao MArquE-UFSC, principalmente objetos da turma Guarani e Kaingang, e outros ficaram em comodato para itinerarem com a exposição. A turma Xokleng/ Laklanõ decidiu doar poucos objetos, pois tem a intenção de criar um museu na sua terra indígena.

Esse movimento da doação dos objetos pelos alunos inverte o papel do público e do museu, principalmente quando nos referimos a um museu universitário. Em muitos museus etnográficos, os indígenas compõem o público com outros segmentos sociais, mesmo que a exposição presente seja de sua cultura. o público nesse caso foi ativo não somente no processo expográfico, mas também no processo de pesquisa e coleta de acervo, decidindo que artefatos iriam para a exposição e também quais fariam parte da coleção museológica. Grande parte do acervo da Coleção de Etnologia Indígena do Museu foi coletada por meio de pesquisas de campo da equipe. O olhar da seleção sobre os artefatos era, então, de um antropólogo ou técnico. Apesar de serem pesquisadores da cultura, o olhar tinha uma intenção diferente das do grupo que fabrica, utiliza e agrega valor e significado.

Houve então uma mudança do sentido na entrada dos objetos no Museu, e com isso, na cadeia operatória usual dos processos curatoriais, em que temos como ponto de partida a coleta, depois a pesquisa, conservação e documentação para chegar à comunicação. Nesse caso, foi por meio da comunicação que os objetos entraram no Museu, e durante o processo realizou-se a pesquisa e a documentação. Esse dado nos mostra que o movimento é cíclico, e essas oportunidades proporcionam um dinamismo à instituição, ao patrimônio preservado e ao papel do público.

Acreditamos que essa experiência de parceria com os grupos indígenas foi enriquecedora não só para o MArquE-UFSC mas também para os alunos indígenas e para toda a comunidade universitária. A exposição permitiu apresentar os novos alunos da UFSC, mostrando a toda comunidade acadêmica que agora eles são parte da Universidade, e que existem atualmente indígenas no sul do país.

No discurso de abertura da exposição o aluno Kaingang afirmou:

Nesse momento eu quero agradecer à professora Ana Lucia, à professora Maria Dorothea, ao pessoal do Museu por nos dar essa oportunidade de poder mostrar para Santa Catarina, aos universitários que estão aí, que nós também existimos em Santa Catarina. (Guarani..., 2011)

Além disso, a parceria foi enriquecedora por proporcionar a reflexão sobre a diversidade cultural. Esse processo efetivamente abriu a possibilidade de outras parcerias, destacando nas 
suas aldeias a confecção e a coleta de objetos que compuseram a coleção e posteriormente foram doados ao MArquE-UFSC, como ainda a disponibilidade de trabalharem na pesquisa e documentação museológica do acervo etnográfico relativo às suas culturas.

A segunda experiência que tratamos nesta pesquisa refere-se à exposição "Ticuna em Dois Tempos", ${ }^{17}$ aberta em maio de 2012. Essa exposição foi realizada em parceria com o Instituto Nacional de Pesquisa Brasil Plural/CNPq (IBP), com o Museu Amazônico da Universidade Federal do Amazonas (MA-Ufam), com a Comunidade Tikuna Wotchimaücü, do bairro Cidade de Deus em Manaus, AM, com o Sigmo, com o Acervo Virtual Sílvio Coelho dos Santos (Avisc) ${ }^{18}$ e com a colaboração dos professores e pesquisadores João Pacheco de Oliveira, do Museu Nacional da Universidade Federal do Rio de Janeiro (UFRJ), e Priscila Faulhaber Barbosa, do Museu de Astronomia e Ciências Afins, Ministério da Ciência e Tecnologia e Informação (MCTI), os quais escreveram textos para a exposição e para o catálogo, lançado em abril de 2014.

A exposição é resultado do projeto de pesquisa "Olhares plurais sobre a arte e cultura material Ticuna: concepções de colecionamento em dois museus universitários”, da Rede Museus, Coleções e Patrimônios Plurais do Instituto Nacional de Pesquisa Brasil Plural (IBP).

Na concepção dessa exposição não utilizamos o método cooperativo com os Ticuna, pois tínhamos como objetivo apresentar as duas coleções museológicas da cultura material dos indígenas Ticuna dos dois museus: MArquE-UFSC e MA-Ufam.

As duas coleções possuem recortes diferentes, pois foram coletadas segundo critérios de seus

17. A exposição ficou no MArquE-UFSC no período de maio a novembro de 2012 e foi montada novamente de abril a novembro de 2013 no Museu Amazônico - Universidade Federal do Amazonas. Em Manaus, a comunidade Tikuna Wotchimaücü participou da abertura da exposição apresentando elementos de sua cultura.

18. O Avisc é um acervo virtual em hipermídia construído a partir do material acadêmico e de pesquisa etnográfica, inicialmente divulgando o acervo do professor Sílvio Coelho dos Santos, depositado no Núcleo de Estudos de Povos Indígenas/UFSC (Nepi), e no MArquE-UFSC. ACERVO VIRTUAL SILVIO COELHO DOS SANTOS. SOBRE O AVISC. Disponível em: http://avisc.wordpress.com/; Acesso em: 30 mar. 2016. colecionadores. A que pertence ao MArquE-UFSC foi coletada pelo antropólogo Silvio Coelho dos Santos em seu primeiro trabalho de campo, na década de 1960, com os Ticuna que viviam no Alto Solimões. A coleção é composta por objetos e diapositivos. A coleção do MA-Ufam pertencia ao artista plástico Jair Jacqmont, que a adquiriu junto aos Ticuna que viviam na cidade de Manaus em 1989.

O trabalho de campo de Silvio Coelho dos Santos aconteceu em julho e agosto de 1962, no Alto Solimões, AM, quando atuava como auxiliar de pesquisa de Roberto Cardoso de Oliveira. Essa viagem ${ }^{19}$ marca o início da trajetória de Santos na Antropologia. Ele fazia parte da terceira turma de Especialização em Antropologia com ênfase em Antropologia Cultural e Sociologia Comparada, criado por Darcy Ribeiro no Museu Nacional da Universidade Federal do Rio de Janeiro, na época denominada Universidade do Brasil.

A viagem estava relacionada com o projeto de pesquisa de Roberto Cardoso de Oliveira, "Estudos de áreas de fricção interétnica do Brasil”, iniciado em 1959. Silvio Coelho dos Santos participou fazendo o censo demográfico e o esquema de parentesco, conforme afirma Fürbringer (2013, p.75):

A construção do projeto de pesquisa ocorreu já em 1959, a partir de uma viagem de Roberto Cardoso de Oliveira entre os Ticuna, enquanto pesquisava a produção de curare na região amazônica. Nesta etapa alguns rascunhos sobre este projeto de pesquisa começam a se desenhar e algumas atividades foram feitas, como o censo demográfico da região, refeito por seus estagiários em 1962. De tal forma que os estagiários participavam desta pesquisa revendo dados e acrescentando outros tantos. Silvio Coelho dos Santos ficou dois meses em campo, sendo que apenas no primeiro mês teve a companhia do orientador e da colega. No segundo mês, em julho, percorreu os igarapés que fizeram parte do itinerário da pesquisa feita em 1959, além de outros.

19. "Esta pesquisa de campo dava continuidade ao trabalho feito em 1959 e resultou no livro O Índio e o Mundo dos Brancos (1972), de Roberto Cardoso de Oliveira" (Fürbringer, 2013, p. 73) 
Além do censo demográfico e do esquema de parentesco, Silvio Coelho dos Santos também apontava para questões que iriam nortear seus estudos pessoais, no futuro.

Na viagem ele produz caderno de campo em dois volumes, coleta $48^{20}$ objetos entre os Ticuna ${ }^{21}$ e faz 135 diapositivos com imagens da pesquisa de campo. Esse material é doado no retorno ao Instituto de Antropologia, atualmente MArquEUFSC, exceto o diário de campo que ele doa numa versão datilografada e copiada. 0 diário de campo encontra-se atualmente com sua família. Essa coleção é um marco, não só na trajetória do Silvio Coelho dos Santos, mas também do Museu, pois inaugura a Coleção de Etnologia Indígena da Instituição.

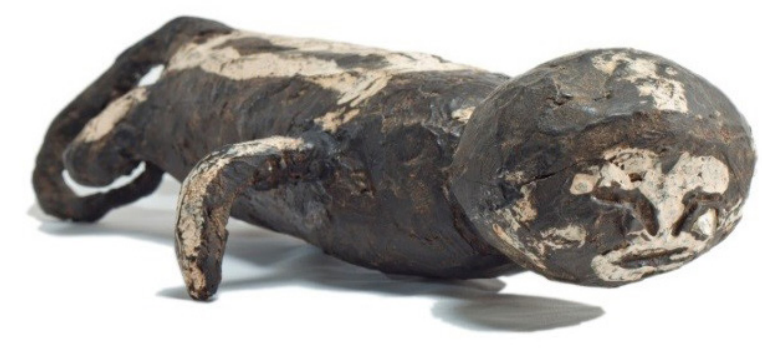

Foto 4 - Escultura de madeira, fibra vegetal e resina coletada por Silvio Coelho dos Santos em 1962. Foto: Hans Denis Schneider, 2012. Acervo: MArquE-UFSC. Fonte: MArquE-UFSC.

20. Cinco objetos não fazem mais parte da coleção, um foi furtado na exposição na década de 1980 e outro doado ao Museu da Universidade Federal de Santa Maria em 15 jul. 1967. Três não foram localizados no Museu desde 1972 (Castellano, 2011, p.39, 41-43 e 47).

21. Silvio Coelho dos Santos nomeava como Tukuna na época, mas vou utilizar a grafia Ticuna, pois é a que consta na bibliografia especializada. Os Ticuna atualmente se autodenominam Magüta, em relação ao mito sobre sua origem: segundo os registros da tradição oral, foi $Y_{0}{ }^{i}$ [um dos principais heróis culturais] que pescou os primeiros Ticuna das águas vermelhas do igarapé Eware (próximo às nascentes do igarapé São Jerônimo). Estes eram os Magüta (literalmente, "conjunto de pessoas pescadas com vara"; do verbo magü, "pescar com vara", e do indicativo de coletivo -ta), que passaram a habitar nas cercanias da casa de $Y^{\prime}{ }^{\prime} i$, na montanha chamada Taiwegine. Mesmo hoje em dia, esse é para os Ticuna um local sagrado, onde residem alguns dos imortais e onde estão os vestígios materiais de suas crenças (como os restos da casa ou a vara de pescar usada por $Y_{O^{\prime}} i$ ). INSTITUTO SOCIOAMBIENTAL. Ticuna. 2008. Disponível em: http://pib.socioambiental.org/pt/ povo/ticuna/1342; Acesso em: $30 \mathrm{mar} .2016$.
Além dos objetos, Santos produziu 135

diapositivos em preto e branco; podemos destacar algumas categorias das imagens feitas por ele: as casas Ticuna, sua arquitetura e modo de vida no interior da casa; famílias e suas formações em diversas localidades; ritual da "moça nova";22 tipos físicos - homens jovens e velhos

\section{A FESTA DA MOÇA NOVA}

Um mito Tikuna conta que, muito antigamente, uma jovem estava reclusa aguardando o ritual de iniciação, quando escutou muito próximo o som triste do uaricana (uma longa flauta que as mulheres são proibidas de ver) e em seguida ouviu o som de vozes que cantavam e batiam tambor. Curiosa, ela abandonou o seu retiro e resolveu ir olhar os dançarinos. Estes, no entanto, eram seres malévolos que a violentaram e mataram. Desde esse dia, como castigo, o céu separou-se da terra e os homens deixaram de ser imortais. Eles hoje adoecem, envelhecem e morrem.

Os Tikunas realizam o ritual do worecu justamente para lembrar aquela infeliz moça. Ao fazê-lo cada família cuida para que as suas adolescentes possam receber todos os conhecimentos de que necessitam, transformando-se com o tempo em mães e esposas, sem passar por um destino tão trágico. Ao sinal da primeira menstruação, a menina é separada de todos, passando a permanecer sempre dentro de um cercado, em um canto da casa ou em jirau. Somente à noite é que, escondida, ela sai para banhar-se e para a sua higiene, e só a sua mãe a visita.

Para alimentar os convidados, a família faz grandes roçados, caçadas e pescarias. Constrói uma casa de festa e nela levanta um bonito cercado, feito com líber (entrecasca de certas árvores) e adornado com pinturas coloridas associadas ao clã paterno da jovem. Quando a data de fazer a festa se aproxima, o pai, o tio paterno ou os irmãos mais velhos percorrem os igarapés tocando uma buzina especial, convidando os parentes e amigos. Hoje muitas vezes isso é realizado através de "bilhetes" (de que os parentes mais próximos continuam a ser portadores) ou mesmo de mensagens por radiofonia.

0 ritual dura três dias. No primeiro recebem-se os convidados e se inicia a música, surgindo os primeiros mascarados. No segundo as danças são mais animadas e contínuas, os mascarados são as figuras destacadas. À noite são preparados os enfeites que a moça nova irá utilizar. Ao amanhecer do último dia os mascarados, alimentados e pacificados, entregam ao dono da festa os seus fardamentos e, agora como pessoas comuns, juntam-se na dança aos demais convidados.

0 "curral" é então aberto, surgindo a menina ricamente paramentada. Após terem sido arrancados ou cortados os seus cabelos, seus parentes mais próximos ficam à sua volta, dançando, tocando e cantando. Forma-se então um cortejo, ao qual todos os convidados se agregam, que circula por toda a aldeia reapresentando essa nova pessoa. Ao final dirigese para o rio e aí, entre risos e brincadeiras, todos os participantes se banham e se livram de adereços e pinturas, a seguir retornando à sua rotina normal.

Conta-se que quando a festa está bem animada e quando os imortais sentem-se adequadamente lembrados e celebrados, a casa da festa, com todos os convidados e participantes, 
e mulheres; atividades na roça; fabricação e utilização dos artefatos; paisagens; crianças nas escolas e em atividades lúdicas; aspectos das vilas em diversas cidades.

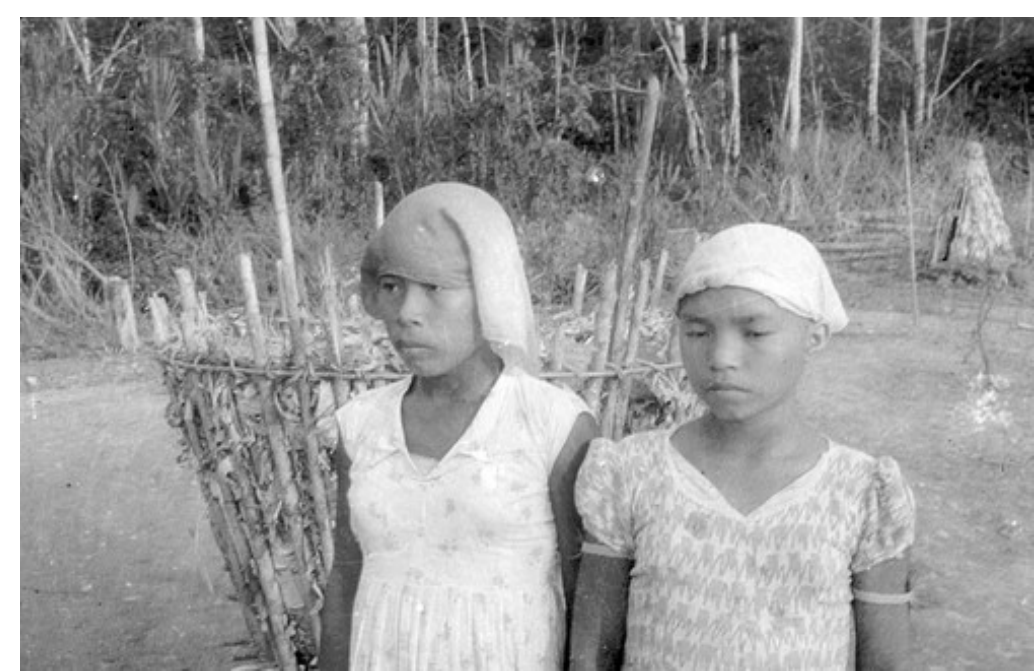

Foto 5 - "Duas jovens Tukuna depiladas no ritual Moça Nova". Benjamin Constant, Amazonas, junho de 1962. Foto: Silvio Coelho dos Santos. Acervo: MArquE-UFSC. Fonte: MArquE-UFSC.

o Museu Amazônico-Ufam possui quatro coleções relacionadas aos Ticuna, a saber:

1) decorrente de missões científicas em área Ticuna desenvolvidas pelo Museu Amazônico nos anos de 1992 e 1993; 2) coleção Magüta, resultante de oficinas e exposição desenvolvidas por artistas Ticuna em Manaus em 1994, cujos artefatos foram incorporados ao acervo do museu; 3) coleção Jair Jacqmont, adquirida pelo Museu Amazônico em 1994, cujo material foi comprado pelo próprio artista plástico, que dá nome à coleção, de comerciantes na área portuária de Manaus; 4) coleção Ibama, doada em 2002 pelo órgão federal após apreensão de 2.400

se eleva do chão, como que se distanciando da terra e das pessoas mortais. Fazer a festa é, portanto, restabelecer a comunicação com os imortais. Por isso dizem os mais velhos, "se o povo Maguta morrer acaba o mundo" (Oliveira Filho, 2012). Sobre a Festa da Moça Nova, ver também Harald Schultz, Hombu: Indian Life in the Brazilian Jungle (Rio de Janeiro: Colibris, 1962). artefatos de várias etnias, inclusive Ticuna, destinados ao comércio ilegal internacional (2002). (IBP, 2014)

Foi escolhida para fazer parte do discurso expográfico a coleção constituída pelo artista plástico Jair Jacqmont, pois a intenção era apresentar e refletir sobre os olhares distintos de colecionadores.

Ao ser indagado, em entrevista para a exposição, sobre o processo da constituição da coleção de artefatos Ticuna, Jacqmont explica como ponto de partida "Sou do Amazonas"; essa afirmação introdutória nos mostra o seu olhar voltado para o estado onde nasceu e vive e a inserção dos indígenas no local, conforme texto da exposição:

como artista plástico amazonense, Jair reconhece a inserção dos indígenas na composição cultural local que lhe dá inspiração criativa. Mas não para por aí em sua resposta. Continua sua explicação contextualizando o lugar do indígena na sociedade urbana de Manaus: "A História Indígena não era valorizada e as classes sociais mais altas não valorizavam as peças indígenas, diziam que era 'panema' (azar) dentro das casas. Não queriam saber delas. Faziam o jogo do colonizador em oposição aos índios, considerado-os bárbaros, escravizados. Mas os indígenas traziam sua cultura e a História que tentavam construir antes de chegar os colonizadores." (Ticuna..., 2012)

0 artista afirma que adquiriu os artefatos no Mercado Municipal Adolpho Lisboa, em Manaus, onde eram considerados artesanato, mas ele os via como obras de arte. Além de se inspirar no imaginário Ticuna para produzir algumas de suas obras, Jacqmont diz ter como motivação maior preservar obras artísticas no seu lugar de origem:

A motivação definitiva para se tornar um colecionador de peças indígenas veio com a Exposição "Memórias da Amazônia - Expressões de Identidade e Afirmação Étnica”, organizada em 1997, por iniciativa do Museu Amazônico 
da Universidade Federal do Amazonas, em parceria com a Universidade de Coimbra e a Universidade do Porto. A Exposição reuniu no deslumbrante Palácio Rio Negro, em Manaus, trezentas peças de diversos povos indígenas na Amazônia do século XVIII que foram coletadas diretamente pelo naturalista Alexandre Rodrigues Ferreira, entre 1783 e 1792, na sua "Viagem Filosófica pelas Capitanias do Grão Pará, Rio Negro, Mato Grosso e Cuiabá”. O fato de a Coleção exposta ter sido trazida de Portugal fez Jair Jacqmont assumir para si a necessidade de os amazonenses terem cultura de colecionador, evitando, desta forma, que riquezas como aquelas deixassem seu local de origem para serem mantidas em terras tão distantes. (Ticuna..., 2012)

A coleção de Jair Jacqmont é composta de artefatos confeccionados pelos Ticuna para a venda em Manaus, que eles intitulam de artesanato. Mas alguns desses objetos também poderiam ser utilizados diariamente por eles, pois em grande parte são objetos inspirados no ritual da "moça nova" - máscaras, bastões de comando - e utilitários: bolsa, cuia, rede e painéis de tururi.

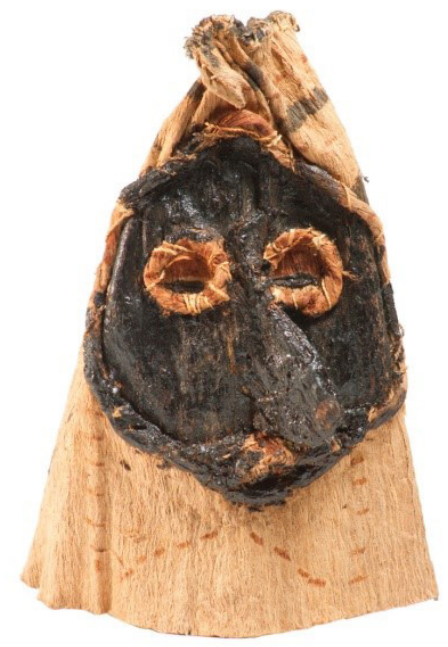

Foto 6 - Máscara Ritual de dança em líber e resina negra, coletada por Jair Jacqmont em 1989. Foto: Hans Denis Schneider, 2012. Acervo: MA-Ufam. Fonte: MArquE-UFSC.

A construção da narrativa da exposição "Ticuna em Dois Tempos” teve como objetivo principal apresentar as duas coleções museológicas e seus colecionadores, focando nos olhares distintos e no espaço temporal de 27 anos.

Além da construção da narrativa da exposição com essas coleções, decidimos utilizar quatro vídeos, ${ }^{23}$ intitulados: Cantando desenhos; Retratos Ticuna; Viagem ao Alto Solimões e Casas Ticuna, com o intuito de aproximar a Comunidade Tikuna Wotchimaücü da exposição e da sua cultura material, que estão no MArquE-UFSC desde 1963. Cabe ressaltar que o MArquE-UFSC está situado na cidade de Florianópolis, em Santa Catarina, a aproximadamente 4.300 quilômetros da cidade de Manaus, onde esses indígenas habitam.

As distâncias geográfica e temporal entre os indígenas e seus bens culturais preservados no MArquE-UFSC despertaram o desejo de aproximação. Durante o processo da exposição, em abril de 2012, a equipe do MA-Ufam foi ao Centro Cultural da Associação Comunidade Wotchimaücü e levou as imagens das peças e as fotos da Coleção de Silvio Coelho dos Santos para os Ticuna Bernardino Alexandre Pereira, Rosa Dica Manuel, Domingos Ricardo Florentino (segundo Cacique), Marta Nicanos Alfredo, Cleonice Cândido da Silva e Evandro Guilherme Pinto, que vivem no bairro Cidade de Deus, Zona Norte de Manaus, a fim de que pudessem conhecer e apresentar suas narrativas sobre as imagens.

Após 50 anos, os Ticuna puderam rever ou conhecer esses objetos e fotografias depositados no MArquEUFSC. A equipe do MA-Ufam filmou todo o processo de aproximação das peças, por meio de imagens, com a comunidade contemporânea Ticuna que habita Manaus.

As imagens na íntegra foram trabalhadas por uma equipe da UFSC e tiveram como resultado final os quatro vídeos utilizados na exposição, conforme relata Fürbringer (2013, p.82):

Em Florianópolis, eu, o Professor Rafael Victorino Devos, bolsistas do Marque,

23. Os vídeos podem ser acessados em: ACERVO VIRTUAL SILVIO COELHO DOS SANTOS. FOTOS COMENTADAS. 2012. Disponível em: http://avisc.wordpress.com/videos-da-exposicao/; Acesso em: 30 mar. 2016. 
bolsistas do Nepi, trabalhamos em cima da análise de cada diapositivo registrado pelo antropólogo, identificando, comparando, analisando e cruzando com informações dos diários de campo e também das produções bibliográficas que perpassam essa pesquisa.

Dessa experiência algumas animações foram produzidas para a exposição através do cruzamento das imagens com extratos de diários de campo do antropólogo. Tal oficina foi registrada em vídeo e foi a este material que tivemos acesso, na íntegra, numa relação de compartilhamento de pesquisa, que possibilitou o início da conexão entre a pesquisa que é feita no acervo das imagens em Florianópolis e as dinâmicas da memória na Amazônia contemporânea .

0 vídeo Cantando desenhos mostra as narrativas em relação aos artefatos coletados por Santos e também as imagens em que os Ticuna fabricam e utilizam os artefatos.

Bernardino fala sobre alguns artefatos: a rede coletada por Silvio e a transformação dos grafismos utilizados pelos Ticuna com o passar do tempo; a matéria-prima com que são feitos os colares e as formas zoomórficas que eles têm:

“Esse aí é feito de tucumã. Lá em cima é uma arte do porco do mato. Aqui é tracajá. Macaco esse aqui... Esse é sapo. Esse parece que é peixe..."

o vídeo mescla as narrativas dos Ticuna e passagens do diário de campo de Silvio sobre o processo de coleta dos objetos. Rosa Manuel, ao ver a imagem de uma mulher Ticuna tecendo um cesto, fala sobre as músicas de todos os animais e afirma que agora as pessoas que moram na sua comunidade não lembram mais das músicas. Ela aprendeu um pouco com uma pessoa que ainda sabe todas as histórias.

No segundo vídeo, Retratos Ticuna, eles apresentam-se e falam sobre as imagens dos Ticuna retratadas por Santos. Ao se apresentarem, informam a quais nações pertencem, há quanto tempo moram no bairro Cidade de Deus, dizem seus nomes em português e de quais aldeias vieram. Ao verem as imagens, reconhecem algumas pessoas; outras não são reconhecidas, mas pelas características identificam de que aldeias são. Bernardino reconhece seu tio João Forte; Rosa, Bernardino e Domingos identificam uma pessoa chamada Cupetchu, que em português significa Tartaruga. Na foto do capitão de Umariaçu (Ponciano), Rosa o reconhece; Embora não lembre o nome dele, sabe que sua nação é Puma. Domingos explica que ele era capitão, pois naquele tempo não existia cacique entre os Ticuna, mas atualmente, após o contato com outras aldeias, possuem caciques.

A maioria das imagens de pessoas feitas por Santos é identificada genericamente como: "Homem Tukuna de Mariuaçu, tipo físico"; "Jovem Tukuna de Mariuaçu, tipo físico"; "Jovens Tukuna de S. Rita"; somente cinco fotos têm o nome das pessoas. Por esse motivo, não é possível fazer a conexão entre as informações fornecidas pelos Ticuna e as de Santos.

Em uma das imagens de um casal Ticuna de São Jerônimo, eles conseguem identificar, por meio do dente do rapaz, a qual comunidade eles pertencem. É a aldeia Vendaval, onde fazem dentes de piranha para não estragar.

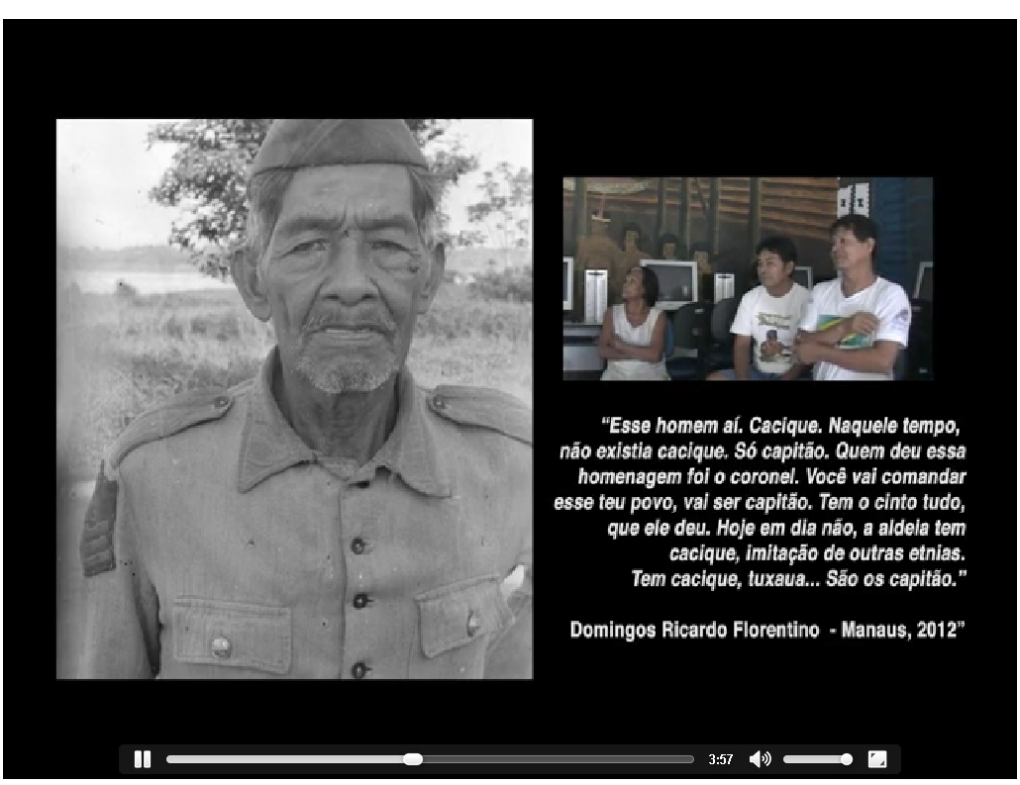

Foto 7 - Imagem do vídeo "Retratos Ticuna", 2012. Fonte: Avisc-UFSC. 
0 vídeo Viagem ao Alto Solimões traz imagens de paisagens e locais da região do Alto Solimões em composição com trechos do diário que fazem a descrição dos locais. No fim do vídeo, alguns Ticuna comentam sobre a região e suas transformações na paisagem.

Silvio Coelho dos Santos fez 18 imagens das casas dos Ticuna, imagens do exterior e interior das casas e dos Ticuna em suas casas. No vídeo Casas Ticuna as imagens compõem com as descrições de Santos sobre os detalhes das casas:

Uma descrição da habitação Tukuna, podemos fazer baseado na casa no 26. Ali em um amplo terreiro ergue-se uma casa de quatro águas, na forma dos esquemas que se seguem: em todo correr há um estrado, a um metro do solo, onde ficam as redes em que descansam os membros da família. Ao chegar o adventício, convidam-no a subir no estrado, onde oferecem-lhe uma rede para sentar, e é dessa maneira que, geralmente, temos tomado notas durantes as entrevistas. (1962, p.14)

0 vídeo traz, também, a fala dos Ticuna de Manaus e suas memórias sobre as construções e a relação com a preservação de suas culturas.

A fala de Domingos Ricardo Florentino no vídeo sobre a imagem "A vida no interior de uma casa Tukuna” (Foto 8), mostra que a aproximação com as imagens trouxe o sentimento de valorização e preservação da sua cultura, mesmo distante do seu lugar de origem:

Nossa casa é assim... É tipo assim ó. É por isso que nós fizemos assim como vai ficar. A moça nova está aí. Do mesmo jeito assim, lembrando agora esse jirau que está lá em cima. É uma maloca grande. É a mesma coisa dessa pintura. Por isso que nós chamamos centro cultural do Ticuna. Para não esquecer a nossa cultura. 0 tradicional. Nós vivemos aqui na cidade, mas a gente tem que lembrar.

Encontramos no recurso audiovisual a possibilidade de aproximação da Comunidade Ticuna com a instituição e com a coleção, e dos visitantes com a comunidade. A elaboração dos vídeos da exposição "Ticuna em Dois Tempos" proporcionou ao público uma aproximação ao grupo indígena Ticuna com o objetivo de repensar o seu olhar sobre os grupos indígenas que vivem no Brasil, buscando uma mudança de perspectiva da cultura indígena, que muitas vezes é apresentada no pretérito, num tempo passado e longínquo nos museus.

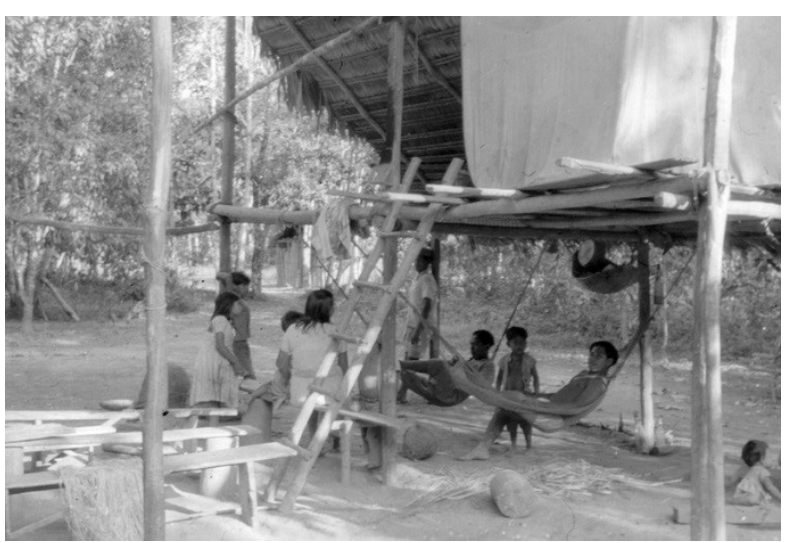

Foto 8 - "A vida no interior de uma casa Tukuna", Benjamin Constant, AM. Foto: Silvio Coelho dos Santos, 1962. Acervo: MArquE-UFSC. Fonte: MArquE-UFSC.

Acreditamos que em relação ao grupo Ticuna, a aproximação com os seus bens culturais, mesmo que por meio de imagens, possibilitou o contato com os objetos que já foram produzidos por seus antepassados e também das imagens feitas na década de 1960 . Podemos constatar, por meio das suas narrativas, que esse contato possibilitou aos Ticuna a construção da noção de pertencimento sobre essa coleção, pois a maioria não sabia da sua existência, trazendo questões sobre a preservação e difusão de seus patrimônios e das suas memórias.

Assim, essa exposição foi um espaço propício para construção da relação do Museu com esse grupo cultural indígena. Essa coleção é representativa para a trajetória do Museu e da antropologia catarinense, pois foi a primeira coleção a fazer parte da Instituição, quando ainda era o Instituto de Antropologia da UFSC.

Acreditamos que essas parcerias realizadas com os indígenas vieram confirmar os princípios 
fundamentais dos museus e ressaltar a função social das instituições museológicas, demonstrando as possibilidades de integração de museus tradicionais com distintas segmentações sociais, principalmente as que possuem sua cultura material representada nos acervos museológicos.

Ao fazermos o recorte desses dois processos museológicos em relação à dinâmica de atuação do MArquE-UFSC, vimos que essas exposições contribuíram para a construção de outros trabalhos que têm como objetivo a proposição de parcerias com diversos atores sociais. Esse cenário atual, em conjunto com a trajetória institucional, vem ao encontro das políticas museológicas da contemporaneidade e reafirma o papel do MArquE-UFSC como espaço de transformação do patrimônio em herança cultural pela sociedade e desenvolvimento social.

\section{Referências}

ACERVO VIRTUAL SILVIO COELHO DOS SANTOS (AVISC). Disponível em: <http://avisc.wordpress.com/ about/>. Acesso em: 30 mar. 2016.

ACERVO VIRTUAL SILVIO COELHO DOS SANTOS. FOTOS COMENTADAS. 2012. Disponível em: <http://avisc. wordpress.com/videos-da-exposicao/>. Acesso em: 30 mar. 2016

ACERVO VIRTUAL SILVIO COELHO DOS SANTOS. Sobre O AVISC. Disponível em: <http://avisc.wordpress. com/>. Acesso em: 30 mar. 2016.

ACERVO VIRTUAL SILVIO COELHO DOS SANTOS. Vídeos. 2011. Disponível em: <http://avisc. wordpress.com/videos/>. Acesso em: $30 \mathrm{mar}$. 2016.

CASTELLANO, Cristina. As exposições museológicas do MArquE-UFSC, Florianópolis. 13 maio 2014. Entrevista concedida à pesquisadora Viviane $W$. Guimarães.

- Museu, linguagem e a coleção etnográfica Ticuna: a trajetória e 0s Contextos. Palhoça - SC, 2011. 118p. Dissertação (Mestrado em Ciências da Linguagem) - Universidade do Sul de Santa Catarina, Palhoça, 2011.
CURY, Marília X. Museologia, comunicação museológica e narrativa indígena: a experiência do Museu Histórico e Pedagógico Índia Vanuíre. Museologia \& interdisciplinaridade, Revista do Programa de Pós-Graduação em Ciência da Informação da Universidade de Brasília, Brasília, v.1, n.1, p.49-76, jan./jul. 2012.

Comunicação museológica: uma perspectiva teórica e metodológica de recepção. 2005. 366 $f$. Tese (Doutorado em Ciências da Comunicação) - Escola de Comunicações e Artes, Universidade de São Paulo, São Paulo, 2005.

DARELLA, Maria Dorothea Post. As exposições museológicas do MArquE-UFSC, Florianópolis. 25 abr. 2014. Entrevista concedida à pesquisadora Viviane W. Guimarães.

ENTREVISTA com Sílvio Coelho dos Santos. Entrevista concedida a Matias Godio; Edição: Izomar Lacerda e Fábio Lessa Peres; Coordenação: Carmen Rial. Série: Antropólogos da Ilha. Realização: NAVI-UFSC; Ano: 2005. 1 vídeo. Disponível em: <http://avisc.wordpress. $\mathrm{com} / \mathrm{videos} />$. Acesso: $30 \mathrm{mar} .2016$.

EXPOSIÇÃO Ticuna em dois tempos. Museu de Arqueologia e Etnologia da Universidade Federal de Santa Catarina. Florianópolis, maio a novembro de 2012. Texto da exposição. Acervo do Museu de Arqueologia e Etnologia da Universidade Federal de Santa Catarina. Não publicado.

FÜRBRINGER, Nádia P. Coleções Etnográficas: objetos, fotografias e registros de campo. Novas articulações e ressignificações. Florianópolis, SC, 2013. 131 p. Dissertação (Mestrado em Antropologia Social) - Universidade Federal de Santa Catarina, Florianópolis, 2013.

GUARANI, Kaingang, Xokleng... UFSC. Direção de Rafael Devos e Marcos Alexandre Albuquerque. Edição: Rafael Devos e Marcos Alexandre Albuquerque. Realização: Navi - UFSC; Nepi UFSC; Curso de Museologia-UFSC. Disciplina de Exposição Museográfica I. 2011. Disponível em: <http://avisc.wordpress.com/videos/>. Acesso: 30 mar. 2016.

GUIMARÃES, Viviane W. Exposições museológicas do Museu de Arqueologia e Etnologia da Universidade Federal de Santa Catarina: espaços para construções de parcerias. Dissertação 
(Mestrado em Museologia) - Universidade de São Paulo, São Paulo, 2014.

INSTITUTO NACIONAL DE PESQUISA BRASIL PLURAL (IBP). Olhares plurais sobre a arte e cultura material Ticuna: concepções de colecionamento em dois museus universitários. 2014.

Disponível em: <http://WWw.brasilplural. ufsc.br/index.php?option=com content\&view=a rticle\&id=246: olhares-plurais-sobre-a-artee-cultura-material-ticuna-concepcoes-decolecionamento-em-dois-museus-universitarios\&catid=66:atividades\&Itemid=218>. Acesso em: 2 jun. 2014 .

JACQMONT. In: ENCICLOPÉDIA Itaú Cultural Artes Visuais. 2005. Disponível em: <http://WWw. itaucultural.org.br/aplicExternas/enciclopedia_ ic/index.cfm? fuseaction=artistas_biografia\&cd verbete $=2149 \& c d$ item $=3 \& c d$ idioma $=28555>$. Acesso em: 30 mar. 2016

NECKEL, R; KÜCHLER, A. D. C. (Org.) UFSC 50 anos: trajetórias e desafios. Florianópolis: UFSC, 2010 .

OLIVEIRA FILHO, J. P. Festa da Moça Nova. Exposição Ticuna em dois tempos. Museu de Arqueologia e Etnologia da Universidade Federal de Santa Catarina. Florianópolis, maio a novembro de 2012. Texto da exposição. Acervo do Museu de Arqueologia e Etnologia da Universidade Federal de Santa Catarina. Não publicado.

SANTOS, S. C. Diários de campo. Universidade Federal de Santa Catarina. Museu de Arqueologia e Etnologia Professor Oswaldo Rodrigues Cabral, 1962 .

\footnotetext{
* Viviane Wermelinger Guimarães é museóloga graduada (2006) pela Universidade Federal do Estado do Rio de Janeiro (UniRio) e mestre (2014) em Museologia pelo Programa de PósGraduação Interunidades em Museologia da Universidade de São Paulo (PPGMus-USP). Atualmente é Chefe da Seção Técnica de Expografia do Museu de Arqueologia e Etnologia da Universidade São de São Paulo (MAE-USP). Tem experiência na área de Museologia, com ênfase em expografia, atuando principalmente nos seguintes temas: exposição e curadoria compartilhada.
} 


\title{
Museu Professor Roberto Baruzzi - Escola Paulista de Medicina, Projeto Xingu da Universidade Federal de São Paulo (EPM-Xingu/Unifesp)
}

\author{
Leandro da Cruz Silva* \\ Escola Paulista de Medicina, Universidade Federal de São Paulo (EPM-Unifesp)
}

Em 1961 foi criado o Parque Nacional do Xingu, atual Parque Indígena do Xingu (PIX). A preocupação com a sobrevivência de povos indígenas levou Orlando Villas Bôas, diretor do PIX, a buscar apoio para salvaguarda da saúde desses povos, agravada por doenças infectocontagiosas decorrentes do contato que se iniciava com a sociedade nacional.

Em julho de 1965, um grupo de médicos da Escola Paulista de Medicina (EPM), atual Universidade Federal de São Paulo (Unifesp), coordenado pelo Dr. Roberto Baruzzi, a convite do Orlando Villas Bôas, descia do avião DC-3 da Força Aérea Brasileira (FAB) no campo de pouso do Posto Indígena Leonardo Villas Bôas, no Alto Xingu, que atendia a dez etnias no PIX: Yawalapiti, Kamayurá, Kuikuro, Kalapalo, Matipu, Nafuquá, Mehinaco, Trumai, Aweti e Waurá, que constituíam o mosaico cultural alto-xinguano. Nos meses seguintes, as ações de saúde se estenderam à área centro-norte do PIX, atendendo os Suyá (Kisêdje), Juruna (Yudjã), Kayabi (Kawaiweté) e Metuktire. Posteriormente, três outros povos, ameaçados pela invasão de suas terras, foram acolhidos no PIX: Ikpeng, em 1968; Tapayuna, em 1970; e os KrenAkarore (Panará), em 1975.

Em 1966, foi assinado um termo de cooperação na assistência à saúde entre o PIX e a EPM e, por meio do Departamento de Medicina Preventiva (Unifesp), iniciou-se o maior e mais bemsucedido programa de atenção à saúde indígena da América Latina desenvolvido por uma escola médica: O Projeto Xingu, coordenado e idealizado pelo Dr. Roberto Baruzzi. ${ }^{1}$ Hoje com mais de

1. Roberto Geraldo Baruzzi formou-se médico pela Unifesp
50 anos de atuação no PIX e em outras áreas indígenas o Projeto Xingu se mantém na atuação, seja na formação de profissionais indígenas e não indígenas, temos como exemplo a formação dos Agentes Indígenas de Saúde (AIS) no PIX e o primeiro Curso de Especialização em Saúde pela Universidade Aberta do Brasil (UAB) em conjunto com o Projeto Xingu-Unifesp (em vias de iniciar seu $3^{\circ}$ curso), consultorias, apoio à nova Secretaria Especial de Saúde Indígena (Sesai) do Ministério da Saúde (MS) com 14 convênios nos distritos sanitários de saúde em 2012 e atualmente com nove convênios. No acordo a EPM se comprometia a enviar equipes de saúde periódicas e em situações epidêmicas, iniciar um plano de vacinação e abrir o Hospital São Paulo como hospital de retaguarda para os índios do PIX. Este último item assumia grande importância em face do isolamento geográfico do PIX, e tornavase viável com o apoio da FAB que mantinha um voo semanal ligando São Paulo ao Xingu. O PIX, por sua vez, comprometia-se a acolher as equipes de saúde e possibilitar o acesso às aldeias.

em 1957. Em 1960 inicia-se na linha de pesquisa Saúde dos Povos Indígenas, com ampliação em 1965 para as linhas Saúde e Doença em Povos Indígenas do Brasil Central, Transição epidemiológica no padrão de saúde-doença em Povos Indígenas, Qualidade de vida e condições de saúde de idosos do Parque Indígena do Xingu e Condições de Saúde-doença de Índios Panará. Em 1965 atua na capacitação e formação de agentes indígenas de saúde do Parque Indígena do Xingu e em 1966 realiza treinamento e supervisão de campo de agentes indígenas de saúde e de pessoal não-índio atuando em áreas indígenas, e começa a implantação do Projeto Xingu. Em 1996, como professor titular aposentado, passa a atuar como colaborador, com atividades docentes e participação no programa de saúde da Unifesp em áreas indígenas, até falecer no início de 2016. 


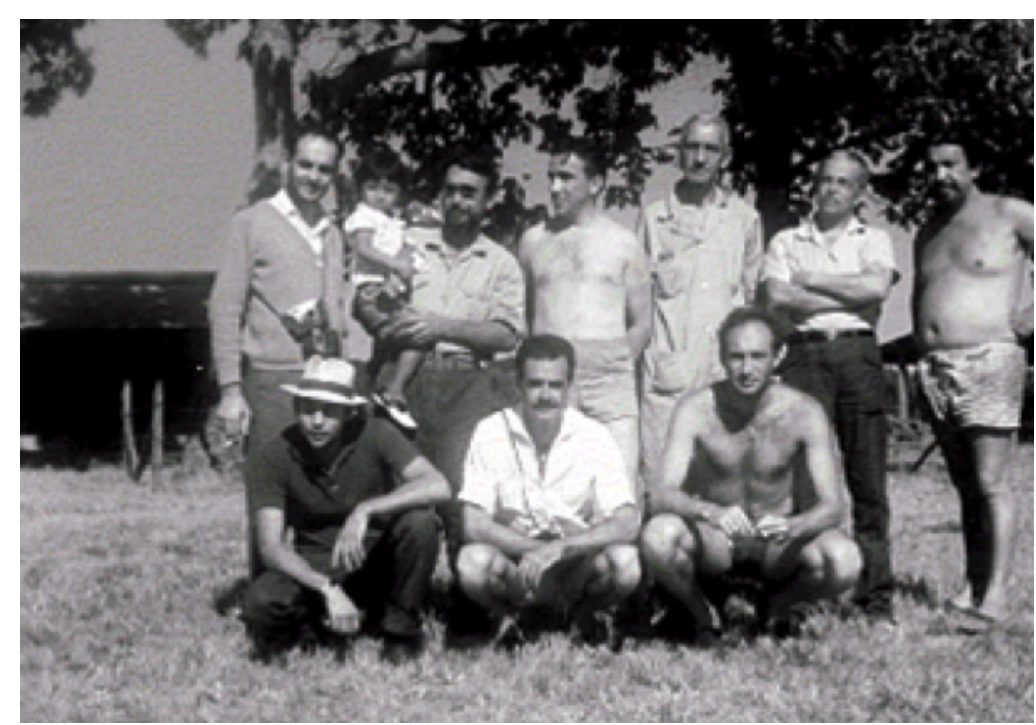

Foto 1 - Primeira Equipe Médica da EPM no PIX e os irmãos Villas Bôas, jul. 1965. Foto: Acervo Projeto Xingu.

Ao longo de mais de quatro décadas do Programa de Saúde da EPM no PIX - ou Projeto Xingu, como é conhecido - formou considerável acervo relacionado às áreas da saúde, antropologia, história e demografia e da cultura material dos povos do PIX. O PIX é habitado por 16 povos indígenas pertencentes aos troncos ou famílias linguísticas Aruak, Caribe, Jê e Tupi, incluindo os índios Trumai de língua isolada. Cabe mencionar, ainda, o ingresso de outros povos no PIX para fugir de riscos decorrentes da invasão de suas terras: Ikpeng (Txicão), 1967; Tapayuna (Beiço de Pau), 1970; Panará (Kren-Akarore), em 1975. Estes últimos haviam perdido mais de $80 \%$ de sua população no processo de contato e nos 2 anos que se seguiram à abertura da estrada CuiabáSantarém (BR-165), cortando o seu território indígena.

Em 8 de dezembro de 1992, por iniciativa do Dr. Roberto Baruzzi, criou-se o Museu EPM-Xingu. Estiveram presentes na inauguração o sertanista Orlando Villas Bôas, lideranças indígenas do PIX e participantes do Projeto Xingu. Em 2009, foi reinaugurado, após uma reforma sob curadoria de Maureen Bisilliat, com o nome de Museu EPM-Xingu - Sala Prof. Roberto Baruzzi.
0 acervo do Projeto Xingu tem contribuído para a divulgação e valorização da cultura indígena ao manter aberta à visitação pública a Sala EPM-Xingu Professor Roberto Baruzzi, no prédio histórico da EPM, localizado na rua Botucatu, no 715, Vila Mariana, em São Paulo. 0 museu conta com uma reserva técnica, onde está preservada parte do seu acervo.
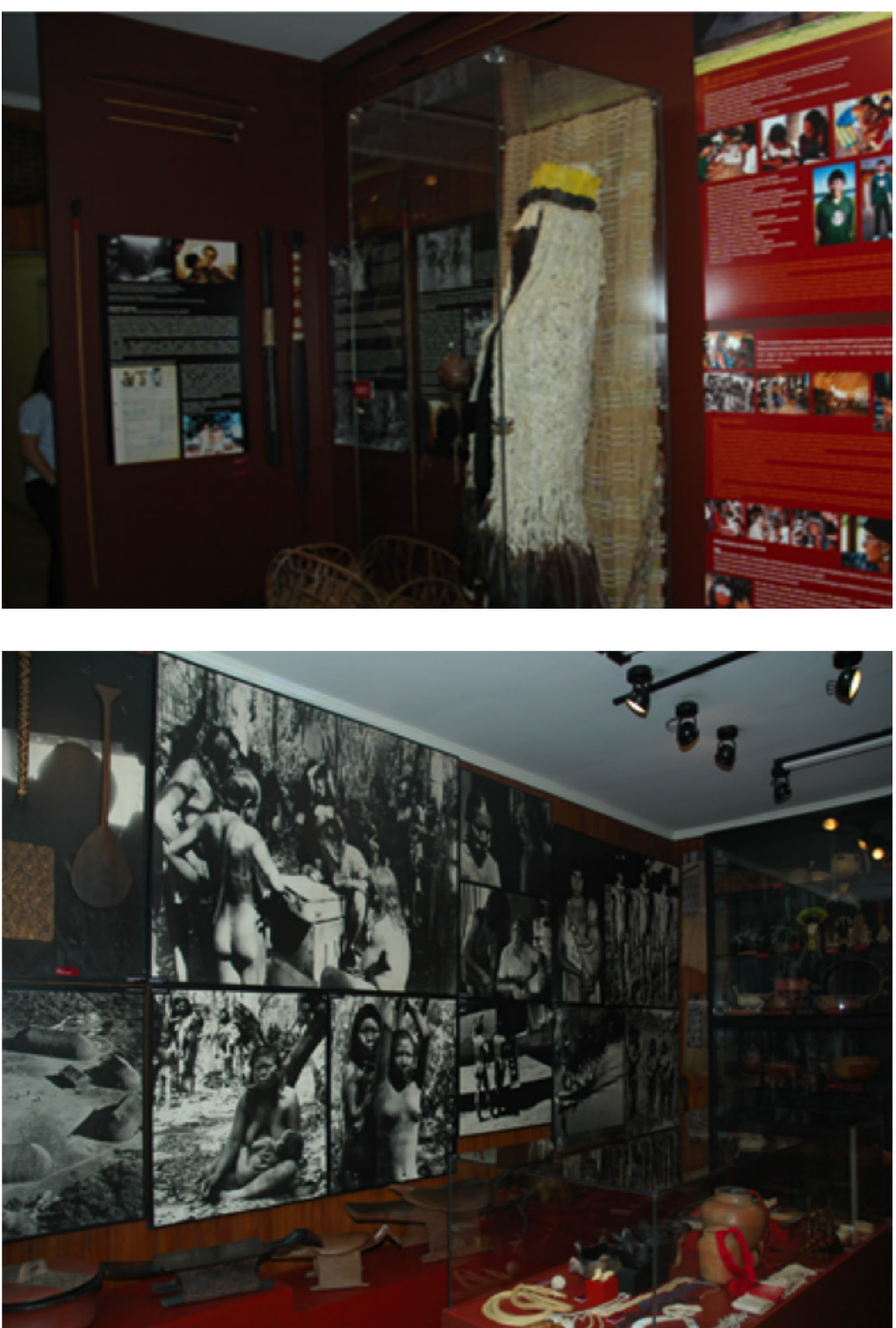

Fotos 2 e 3 - Museu EPM-Xingu - Prof. Roberto Baruzzi Unifesp em 2012. Foto: Acervo Projeto Xingu. 
0 acervo do Museu está exposto com painéis fotográficos que permitem acompanhar o transcorrer do Projeto desde 1965 aos dias atuais. Várias etapas do programa de saúde são apresentadas, bem como a participação de médicos, dentistas, enfermeiras, técnicos e alunos. Outras fotos focalizam a vida nas aldeias e seus habitantes, a partir de uma época em que viviam em estado de relativo isolamento. Até os dias atuais a diversidade cultural entre os 16 povos do PIX pode ser reconhecida em sua manifestação material pelo artesanato exposto, usado em cerimônias e no cotidiano das aldeias. Alguns povos possuem os melhores arcos e flechas, outros se dedicam mais à cerâmica, cestaria e confecção de cocares e colares, machados e utilitários de pedra ou ao preparo de um sal vegetal, de amplo uso. Nessa diversidade se baseava o moitará, troca tradicional de objetos entre as diferentes etnias e aldeias no PIX. 0 acervo do Museu aqui apresentado em sua grande maioria foi fruto do moitará, ou de presentes dos indígenas do PIX para o Dr. Roberto Baruzzi durante seu trabalho de atendimento médico no PIX.

0 acervo do Projeto Xingu tem cerca de 900 peças (objetos) etnográficas de diversas tipologias: armas, bancos, cestaria, cerâmicas, máscaras, adornos - colares, brincos, botoques, plumas -, cocares, braçadeiras e coifas emplumadas, objetos lúdicos e instrumentos musicais, entre outras.

Desde seu início, o Projeto Xingu instituiu uma ficha médica individual, cujo número já se aproxima de $10 \mathrm{mil}$, incluindo os óbitos ocorridos desde sua implantação. Contém número e data de registro, local do exame, etnia, nome, data do nascimento, sexo, números de registro e nomes dos pais, cônjuges e filhos, dados do exame físico, vacinas aplicadas e intercorrências clínicas registradas ao longo dos anos. Uma foto tamanho $3 \times 4 \mathrm{~cm}$, atualizada periodicamente, facilita a identificação, dado o costume indígena de mudar o nome em diferentes fases da vida.

Foto 10 - Abertura da ficha médica do povo Metuktire do rio Jarina e José Roberto Jardim, médico-residente da EPM. PIX, 1971 Foto: Acervo Projeto Xingu.
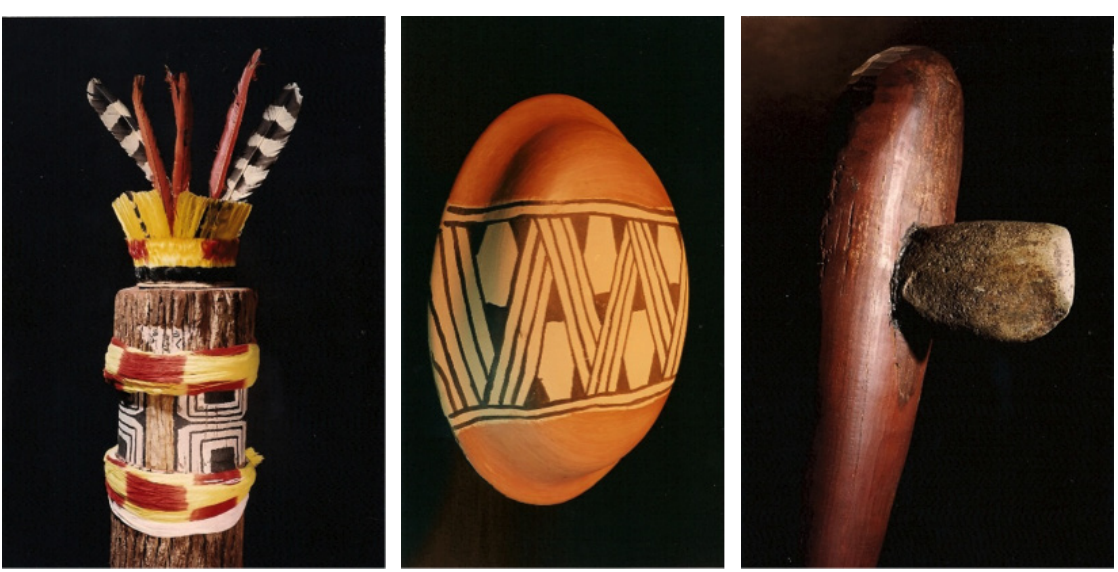

Fotos 4, 5 e 6 - Da esquerda para a direita: tronco do Kuarup, Alto Xingu; cerâmica Waurá; machado de pedra Metuktire (Kayapó). Fotos: Renato Soares.
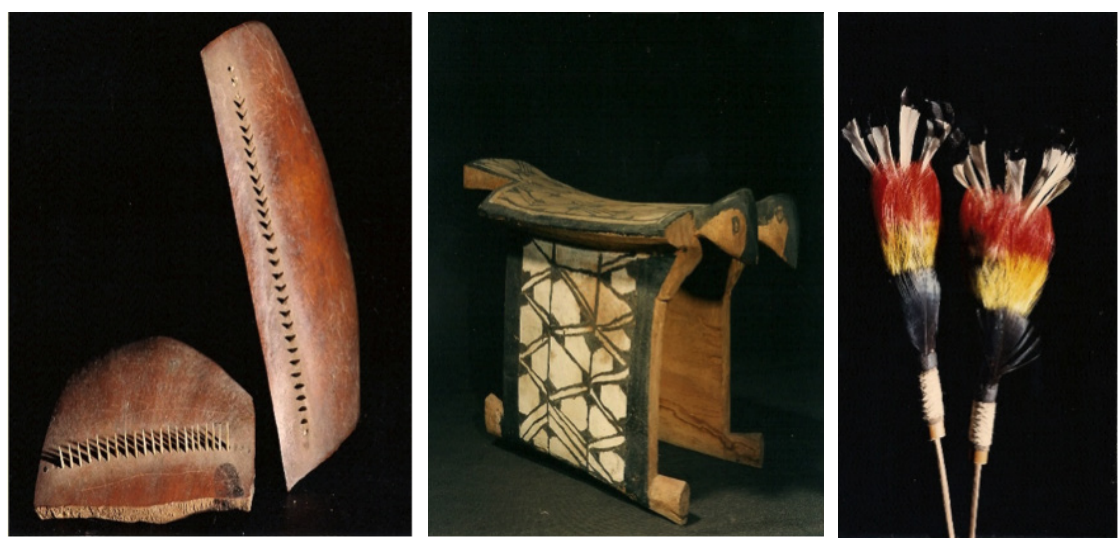

Fotos 7, 8 e 9 - Arranhadeiras-escarificadores; banco-gavião de chefe; par de brincos emplumados Kalapalo. Fotos: Renato Soares.

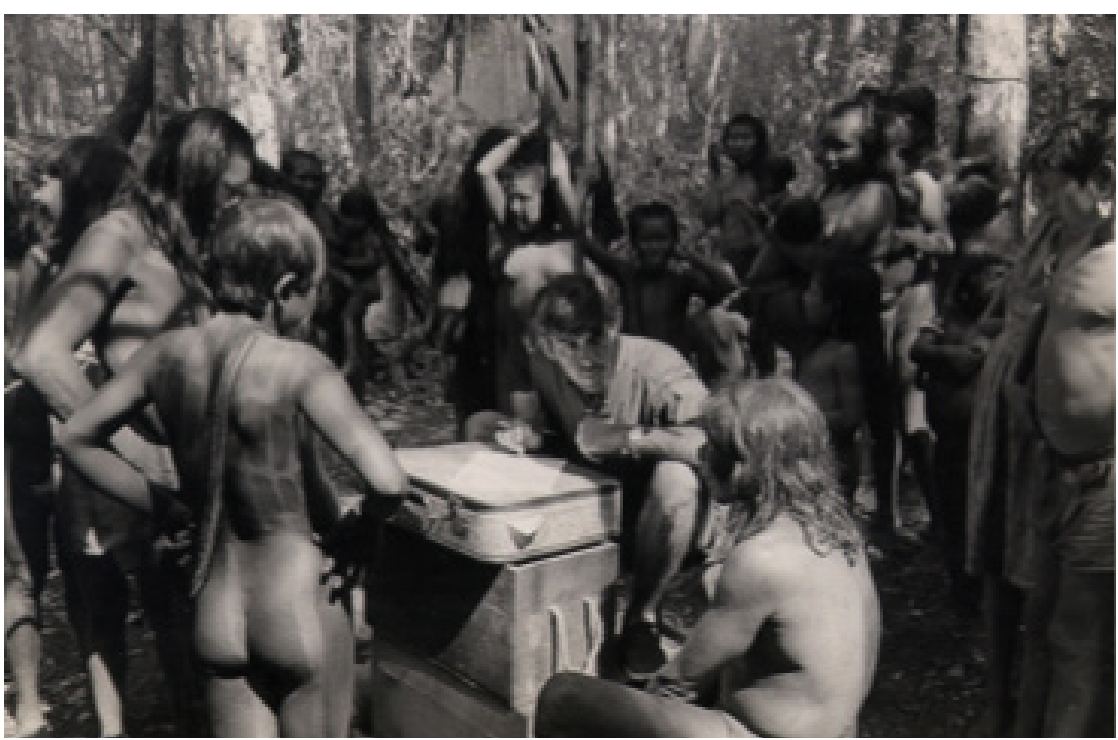




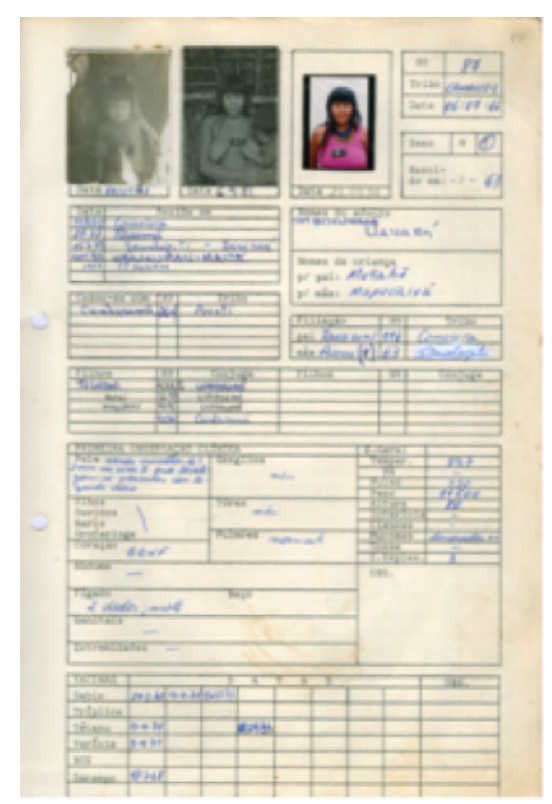

Figura 1 - Modelo da ficha médica. Acervo Projeto Xingu.
0 material

audiovisual é

composto por cerca

de $30 \mathrm{mil}$ fotografias

e 5 mil slides que

mostram o dia a

dia nas aldeias,

festivais e rituais, hábitos alimentares,

bem como a atuação

das equipes de saúde; o acervo inclui, também, grande número de gravações em VHS, DVD e fitas cassetes com depoimentos e entrevistas.

A Biblioteca reúne cerca de 600 livros e publicações em antropologia,

sociologia, história, epidemiologia, saúde de povos nativos e medicina tropical, ao lado de numerosos documentos, teses, correspondências, artigos de jornais e revistas relacionados à política indigenistas, a trajetória do Projeto Xingu e a atuação da EPM-Unifesp em outras áreas indígenas do país.

Em resumo, o acervo do Projeto Xingu, com a sua cobertura do universo dos povos do PIX por quase cinco décadas, conta com um sistema de informações inéditas em nosso país no que se refere a povos indígenas, abrindo um amplo campo de estudos para os interessados.

Em 2013 o museu perdeu seu espaço expositivo, e o acervo foi guardado em uma sala. No final de 2015 o Projeto Xingu realizou suas primeiras reuniões para tratar de um projeto junto à PróReitoria de Planejamento da Unifesp, objetivando a criação de um espaço para o Museu Professor Roberto Baruzzi - EPM-Xingu. A proposta inicial era um espaço expositivo. Após algumas reuniões por meio de um diálogo, considerando a necessidade de salvaguardar o acervo histórico do Projeto Xingu, o projeto começou a considerar a importância de um Museu, contanto também com um espaço para a reserva técnica e uma sala para as ações educativas do Museu. O projeto, inovador pelo seu estatuto conceitual, será instalado no mesmo prédio da Biblioteca do Campus São Paulo da Unifesp, contando ainda com espaço literário e expositivo sobre a história da Escola Paulista de Medicina e auditório.

A inauguração do Museu Professor Roberto Baruzzi - EPM-Xingu, prevista para o ano de 2017, será uma homenagem ao incansável idealizador e fundador do Projeto Xingu que, por mais de 50 anos, trabalhou com os povos indígenas no PIX, entre outras populações.

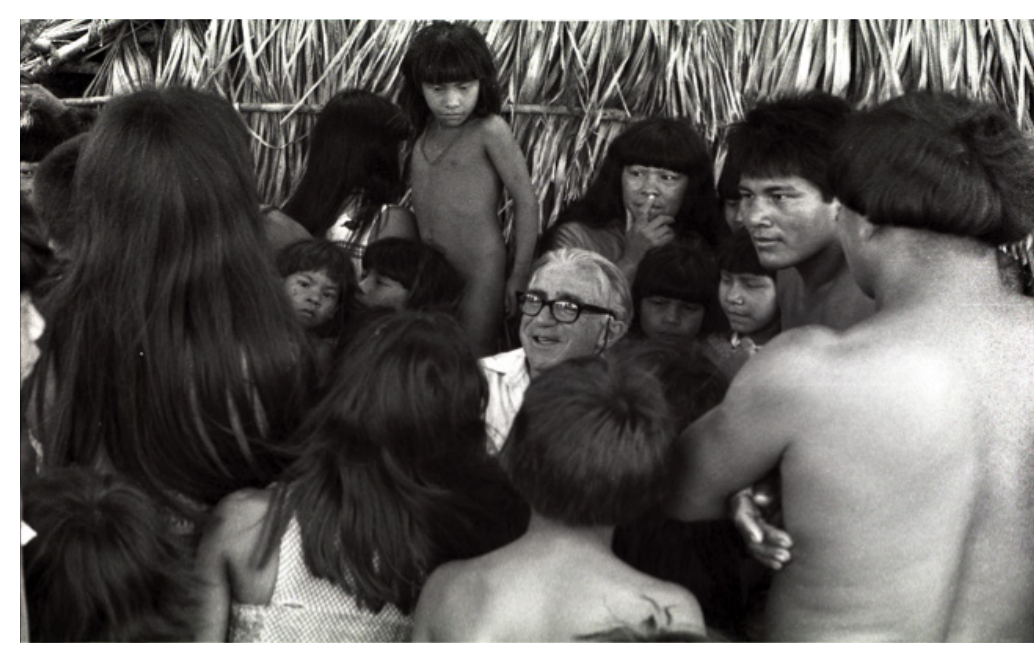

Foto 11 - Dr. Baruzzi entre os xinguanos, Alto Xingu, PIX, set. 1991. Foto: Acervo Projeto Xingu.

Nos últimos anos de vida o Professor Baruzzi atuou na preservação e organização do acervo histórico do Projeto Xingu. Seu trabalho é um marco na história do Brasil em termos de práticas médicas junto às populações indígenas, um exemplo de respeito às tradições indígenas no campo da saúde.

\section{Referências}

ALMANAQUE Socioambiental Parque Indígena do Xingu: 50 anos. São Paulo: Instituto Socioambiental (ISA), 2011.

AUGUSTINHO, Pedro. Kwar'ip: mito e ritual no Alto Xingu. São Paulo: Edusp, 1974. 
BARUZZI, Roberto; JUNQUEIRA, Carmen (Org.) Parque Indígena do Xingu: saúde, cultura e história. São Paulo: Unifesp; Terra Virgem, 2005.

BRUNO, Maria Cristina 0. (Coord.) O ICOM-Brasil e o pensamento museológico brasileiro: documentos selecionados. São Paulo: Pinacoteca do Estado., 2010. 2v .

- (Coord.) Waldisa Rússio Camargo Guarnieri: textos e contextos de uma trajetória profissional São Paulo: Pinacoteca do Estado, 2010. 2v.

CURY, Marília X. Exposição: concepção, montagem e avaliação. São Paulo: Annablume, 2005.

Museologia, novas tendências. In: MAST.

Museu e museologia: interfaces e perspectivas. Rio de Janeiro, 2009. p.25-41. (MAST Colloquia, 11).

GOMES, Alexandre 0. Por uma antropologia dos museus indígenas: práticas de colecionamento, categorias nativas e regimes de memória. In: REUNIÃO BRASILEIRA DE ANTROPOLOGIA, 29. 3-6 ago. 2014, Natal, RN. (Mimeo).

HEMMING, John. Die if you must: Brazilian Indians in the Twentieth Century. London: Macmillan, 2003 .

SCHWARCZ, Lilia K. Moritz. A Era dos Museus de Etnografia no Brasil: o Museu Paulista, o Museu Nacional e o Museu Paraense em finais do século XIX. In: FIGUEIRED0, Betânia; VIDAL, Diana G. Museus: dos gabinetes de curiosidades ao museu moderno. Belo Horizonte: Argumentum, 2005. p. 113-136.

VILLAS BÔAS, Orlando; VILLAS BÔAS, Cláudio. A marcha para o Oeste. São Paulo: Globo, 1994.

\footnotetext{
* Leandro da Cruz Silva é graduado em História. Atua no Projeto Xingu no Departamento de Medicina Preventiva da Escola Paulista de Medicina, Universidade Federal de São Paulo (EPM-Unifesp).
} 


\title{
0 Museu Regional de Arqueologia de Rondônia e os desafios da diversidade cultural no presente
}

\author{
Maurício André da Silva* \\ Museu de Arqueologia e Etnologia, Universidade de São Paulo (MAE-USP)
}

Nos últimos anos, cresceu o número de museus de arqueologia pelo país, assim como o de coleções arqueológicas espalhadas em diferentes tipologias de instituições. O encontro entre populações indígenas e museus antropológicos é recorrente e também um caminho possível para as instituições com acervos arqueológicos, sobretudo na região Amazônica, que possui uma rica história de longa duração, traduzida no presente de muitas formas.

Este artigo ${ }^{1}$ propõe algumas reflexões baseadas no estudo de caso do Centro de Pesquisas e Museu Regional de Arqueologia de Rondônia (CPMRARO), criado em 2008 no interior do estado de Rondônia, na cidade de Presidente Médici. Esse Museu possui um acervo regional com predomínio de material arqueológico cerâmico e lítico. ${ }^{2}$ Desde 2011 duas novas exposições foram abertas ao público: a temporária e itinerante Homens e objetos na préhistória: aprendendo sobre Arqueologia, e a de longa duração Arte e Tecnologia: diversidade do patrimônio arqueológico do Centro-Leste de Rondônia, esta baseada no acervo da instituição. Ambas discutem o papel da arqueologia e o processo de ocupação local por populações no passado.

1. Esses dados estão baseados na dissertação de mestrado do mesmo autor intitulada Memórias e histórias no sudoeste amazônico: o Museu Regional de Arqueologia de Rondônia defendida no Programa de Pós-Graduação em Arqueologia do MAE-USP (Silva, 2015), sob orientação do Prof. Dr. Camilo de Mello Vasconcellos. Bolsa CNPq (processo 135479/2011-8).

2. 0 acervo do Museu foi formado com materiais arqueológicos oriundos dos municípios vizinhos: Alta Floresta, Alto Alegre dos Parecis, Alvorada D'Oeste, Castanheiras, Cacoal, Ji-

Paraná, Ministro Andreazza, Presidente Médici, Seringueiras, São Miguel do Guaporé, São Francisco do Guaporé, Rolim de Moura, Novo Horizonte D’Oeste, Urupá, Nova Brasilândia D’0este e Santa Luzia D’0este.
0 Museu surgiu pela iniciativa dos moradores locais (migrantes), com destaque para a atuação dos professores de história da rede pública Maria Coimbra de Oliveira e José da Silva Garcia, além de outros habitantes que passaram a colecionar objetos arqueológicos encontrados em suas atividades cotidianas e a se interessar pela arqueologia. Cabe destacar que durante as aulas, muitos alunos traziam para os professores objetos encontrados em suas residências, com uma série de inquietações a respeito. Nesse sentido, a partir de uma imaginação museal (Chagas, 2008, p.47) e com apoio e orientação do Instituto do Patrimônio Histórico Artístico e Nacional (Iphan), deram início à implementação da instituição e de ações de proteção, preservação e comunicação. A prefeitura municipal de Presidente Médici e o Instituto Brasileiro de Museus (Ibram) também colaboraram com a consolidação do espaço. ${ }^{3}$

A criação de um museu de arqueologia na região Amazônica pode apontar caminhos para o tratamento e preservação do patrimônio arqueológico, assim como para a produção de memórias a respeito da localidade. Cria-se um potencial espaço fórum (Gonçalves, 2007; Bruno, 2000) que contribui para estimular na população o exercício da reflexão e do debate sobre seu passado e seu presente. 0 acervo do CPMRARO oriundo de coleções formadas por distintas curadorias dos migrantes, hoje musealizadas, possuem em sua história olhares que indicam caminhos identitários. Cada lâmina

3. Cabe destacar o papel do licenciamento ambiental no estado por meio dos endossos institucionais que viabilizaram uma série de reformas estruturais e a implementação de ações no Museu. Atualmente vários desafios são postos, relacionando a gestão e a contratação de profissionais para o desempenho pleno de suas funções. 
de machado polido, cada fragmento de cerâmica presente na reserva e na exposição, tem o potencial de comunicar não somente sobre o passado pré-colonial, mas também sobre a vida das pessoas que os encontraram, assim como sobre as relações entre populações indígenas e não indígenas, dentre outras temáticas.
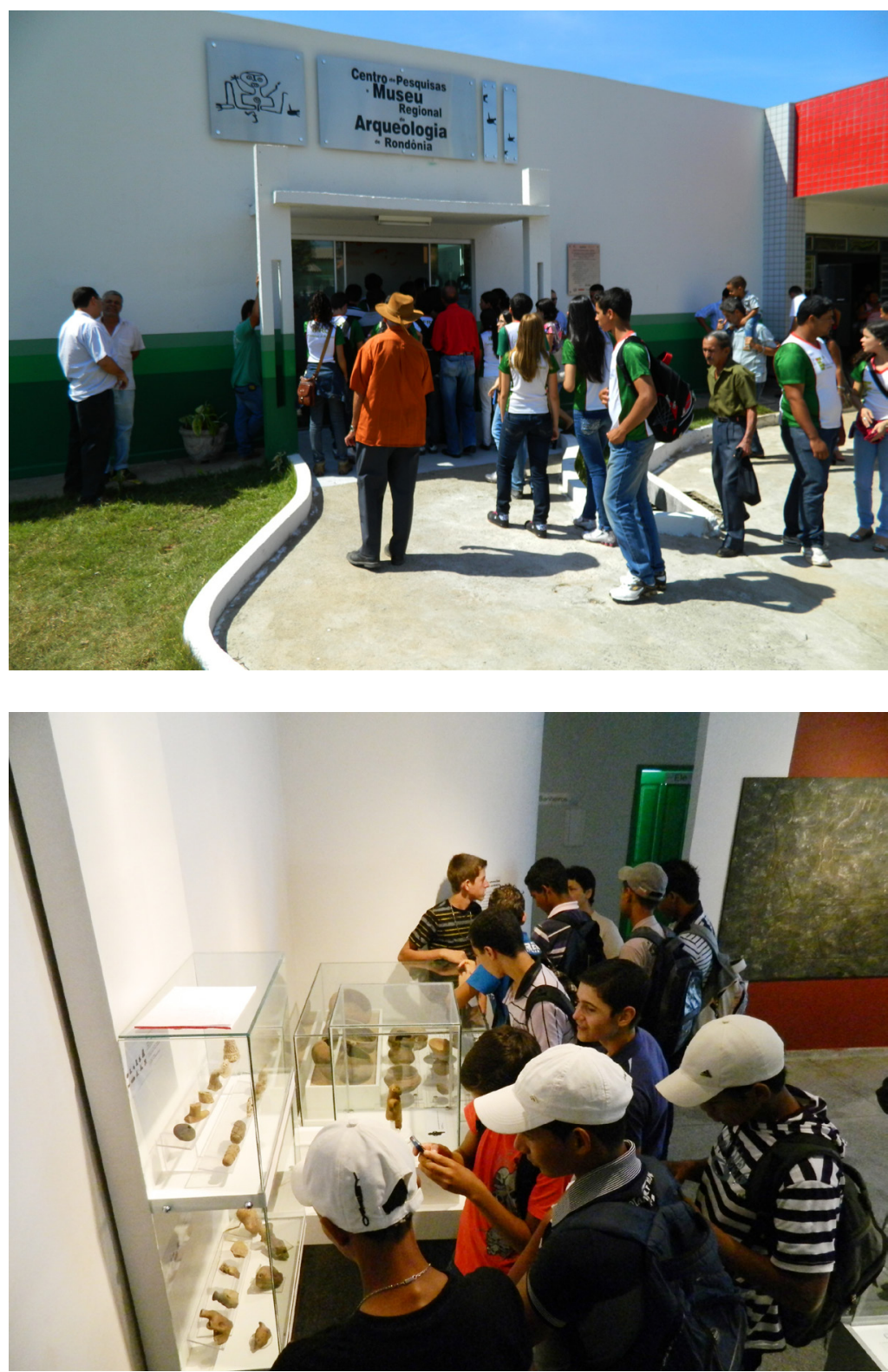

Fotos 1 e 2 - Reinauguração do Centro de Pesquisas e Museu Regional de Arqueologia de Rondônia, 2011. Fotos: Acervo pessoal Maurício André da Silva.
A passagem dos objetos arqueológicos de um espaço privado (casas, terreiros e áreas de roçado, entre outros) para um espaço público (museu) em que se atendem os requisitos da legislação patrimonial foi realizada, sobretudo, pela sensibilização da comunidade, pelos professores e pela atuação do Iphan. Esse encaminhamento tende a agradar mais alguns pesquisadores e gestores, entretanto a transformação das coisas (Ferreira, 2013) em patrimônio pode implicar a dificuldade da compreensão de outras semânticas relacionadas à dinâmica da vida. Na floresta amazônica, o colecionismo de objetos arqueológicos e a interação diversa com os sítios é bem recorrente, e, pela proximidade desses espaços com as moradias, as evidências arqueológicas são interpretadas de muitas formas. Pesquisas atuais sobre essas relações complexificam o debate patrimonial e ajudam a mapear outros modos de se relacionar com os objetos, em que se colocam desafios para o campo da arqueologia e da preservação (Bezerra, 2011, 2013, 2014; Carneiro, 2014a, 2014b).

Com o surgimento de um museu de arqueologia que tem como objetivo a valorização e promoção do patrimônio arqueológico, cabe refletir em que medida também contribui para a valorização da diversidade cultural do presente, sobretudo das populações indígenas e de parcelas dos migrantes que passaram a valorizar esse passado. As pesquisas indicam para a localidade uma história indígena com cerca de $9 \mathrm{mil}$ anos (Almeida, 2013; Cruz, 2008; Miller, 2009; Mongelo, 2015; Oliveira, 2013; Suñer, 2015; Trindade, 2015; Zimpel Neto, 2008; Zuze, 2014, entre muitas outras), e se evidencia uma grande variabilidade cultural no passado, com continuidades e mudanças ao longo do tempo.

A interdisciplinaridade com a história oral praticada pelo Núcleo de Estudos em História Oral da Universidade de São Paulo (Neho-USP) (Meihy, 1996, 2009, 2010a, 2010b; Meihy; Holanda, 2007; Meihy; Ribeiro, 2011) permitiu a evidenciação de olhares alternativos para a interpretação da história e do patrimônio. Mediante o destaque do colaborador (entrevistado) na pesquisa,

supera-se a busca de informantes ou de vazios documentais, pois é relevante a maneira como 
os sujeitos significam o mundo por meio de suas experiências de vida. O corpo documental gerado fornece ferramentas para a atuação da arqueologia e da museologia de maneira mais engajada com os contextos nos quais se insere. Não se pode desconsiderar que a prática etnográfica também indica caminhos para intepretação do presente.

Doze narrativas de migrantes oriundos de distintas partes do país foram ouvidas ${ }^{4}$ em um primeiro momento. São pequena parte de um grande conjunto que pode vir a ser conhecido, e a produção desse material, com a negociação entre pesquisador e colaborador, caracterizou uma determinada memória daquele que narra. Ao trabalhar com as memórias de colaboradores, entende-se que elas estão impregnadas de aspectos relacionados aos grupos dos quais fazem parte afetivamente, pois nunca se está só, posto que se é um ser social (Halbwachs, 2003). Dada a envergadura do projeto de mestrado desenvolvido entre 2011 e 2014, não foi possível ouvir as populações indígenas do entorno. Ressaltase, entretanto, o fôlego que essas pesquisas podem trazer para a instituição, sobretudo na aproximação com tais populações.

No processo de consideração da experiência das pessoas que vivem uma determinada realidade não se fornece voz a elas, mas sim ouvidos, reflexão trilhada nos últimos anos pelo Neho-USP. Uma das contribuições dos pesquisadores ao praticarem esse exercício é o processo de transformação e reflexão sobre a própria produção do conhecimento e a sua comunicação à sociedade. A equidade entre a disseminação desses saberes em diferentes meios, sobretudo no acadêmico, vem sendo um caminho percorrido por diferentes áreas, assim como na arqueologia e na museologia.

4. A partir da história oral praticada pelo Neho-USP, as experiências de vida foram transcritas, textualizadas. transcriadas e validadas com seus autores. Esse processo busca uma relação dialógica entre pesquisador e colaborador Foi construída uma rede de colaboradores na pesquisa (Silva, 2015), formada por Arentino Monteiro da Costa, Charles Seizi Modro, Devanir Domingues Fernandes, José da Silva Garcia, José Ferreira Isidoro, José Garcia Sorrilo, José Ribeiro da Silva Filho, Maria Coimbra de Oliveira, Maurício Martins Alves, Moisés Gomes dos Santos, Neuza Jordão dos Santos. Onofre Bernadino, Raimundo Corrêa de Souza, Vileuda Rodrigues da Silva e Wilson Modro.
Esses documentos registram por um lado a memória da população naquele momento, e por outro criam uma série de possibilidades de utilizações para o Museu - seja nas pesquisas arqueológicas, na concepção de novas exposições, seja no trabalho educativo. Uma contação de histórias por meio das experiências de vida da população; uma exposição em primeira pessoa em que a arqueologia se entrelaça com questões subjetivas e do cotidiano; algumas ações educativas que para além de trabalhar a importância do passado pré-colonial possam discutir o papel político desses estudos no presente, representatividade da comunidade nas ações do Museu, interpretações indígenas dos acervos arqueológicos, entre inúmeras outras ações, são alguns exemplos desses desdobramentos. Pode-se criar um espaço real de empatia pela história do outro e, consequentemente, diminuir a distância entre as populações indígenas e não indígenas.

Atualmente em Rondônia existem vinte instituições com acervos, algumas das quais se configuram como museus, segundo o Cadastro Nacional de Museus do Ibram. A população de Presidente Médici conseguiu implantar e manter aberto um espaço para o tratamento da temática arqueológica, entretanto, abrir museus no cenário brasileiro tem sido algo recorrente e mais fácil se comparado com sua manutenção e a viabilização efetiva de todas as suas ações. Dessa forma, o CPMRARO tem papel importante na região, dada a ausência de outras instituições que possam abordar tais temas.

\section{Encontros e desencontros entre migrantes e populações indígenas}

Durante o século XX, a Amazônia recebeu diferentes projetos e ações desenvolvimentistas, como a introdução de multinacionais, da indústria extrativista, da mineração e da pecuária e a fixação desordenada de colonos e pequenos agricultores (D’Araújo, 1991, p.2; Silva, 2010). Durante a ditadura militar, esse processo se intensificou e acarretou problemas como o desmatamento, conflitos entre diferentes populações indígenas e não indígenas, e 
extermínio da bio e sociodiversidade (Brum, 2014; ISA, 2013). Sob o famoso slogan "Terra sem gente para gente sem terra" procurou-se garantir o controle da região e torná-la produtiva economicamente.

A cidade de Presidente Médici, ${ }^{5}$ onde o CPMRARO está localizado, surge nesse contexto econômico e político no estado de Rondônia, às margens da BR-364 (rodovia que interligou São Paulo, Mato Grosso e Acre). Essa rodovia foi construída a partir da década de 1960 e mudou a dinâmica sociocultural do estado. Em pouco tempo transformou a floresta em uma área de pastagens para criação de gado e de cultivo monocultor, como no caso da soja (Silva, 2010). Por meio da nova via de acesso à região, chegaram migrantes de diferentes partes do país com diferentes sonhos, sobretudo de melhoria de vida e conquista de um pedaço de terra para morar e plantar. Segundo a política vigente, eram "terras virgens”, que precisavam ser ocupadas, entretanto eram habitadas há milênios por populações indígenas e, mais recentemente, por seringueiros e quilombolas, entre outros. Ocorreram e ainda ocorrem muitos conflitos entre as diferentes populações, marcas latentes na atualidade.

Diante desse contexto, o CPMRARO enfrenta um grande desafio em sua atuação, pois, para além de salvaguardar e comunicar o passado pré-colonial, pode correlacionar imaginários e identidades da população de migrantes, populações indígenas e outros grupos no presente. Diferentes visões e pontos de vista estão em jogo nesse processo. Ouvir uma parcela do grupo de migrantes foi relevante, pois se identificou no discurso a construção de uma identidade de "pioneiros", que superaram juntos as adversidades locais (Silva, 2015, pg.69), mas esse grupo aparentemente homogêneo é bem diverso, com seus conflitos e distanciamentos internos, da mesma forma que a diversidade indígena é a tônica do país e da localidade.

Rondônia possui atualmente uma grande diversidade cultural indígena, resultante do movimento de

5. O município recebeu o nome de um dos ditadores do país, que hoje é motivo de vergonha para boa parcela da população.

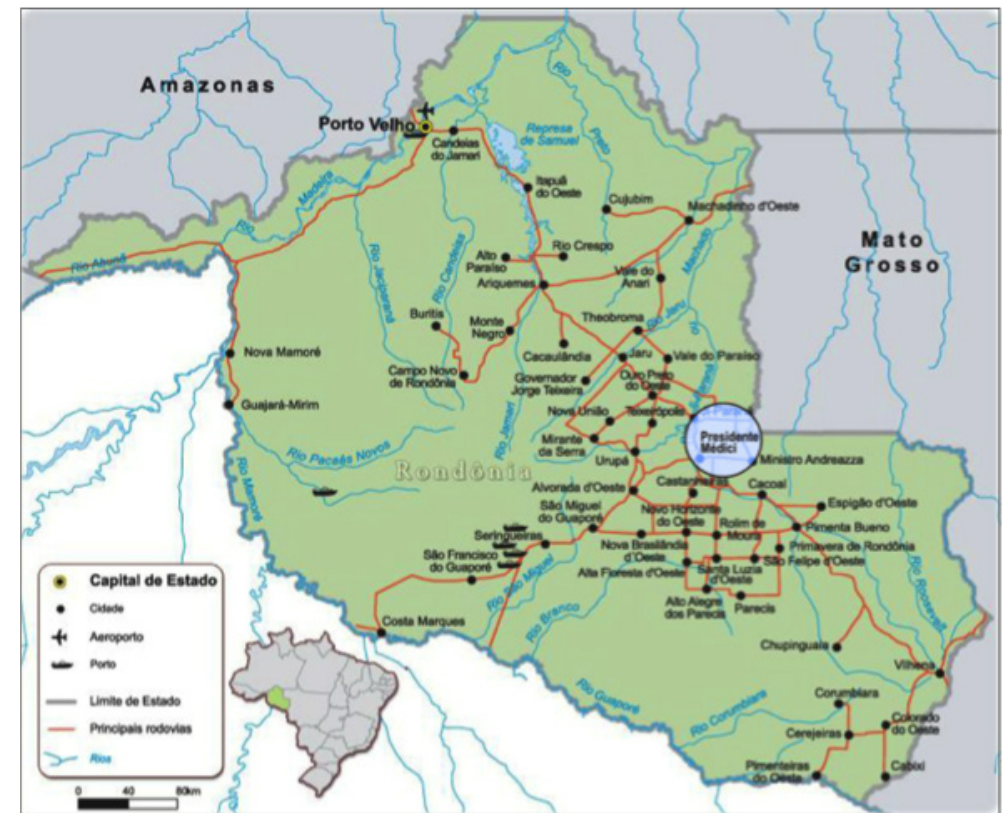

Mapa 1 - Estado de Rondônia com destaque para a localização de Presidente Médici. Adaptado do Guia Geográfico de Estados Brasileiros.

resistência frente aos projetos de colonização. No entorno do município encontram-se as terras indígenas (T.I.): T.I. Sete de Setembro dos Suruí Paiter, T.I. Roosevelt dos Cinta Larga e dos Apurinã, T.I. Igarapé Lourdes dos Gavião e dos Arara Karo, T.I. dos Uru Eu Wau Wau e T.I. Rio Branco, esta habitada por vários grupos (Aikaná, Arikapu, Aruá, Djeoromitxí, Kanoê, Makurap, Tupari) (ISA, 2013), fora os demais grupos no estado, totalizando 28.

Em virtude da maneira como as populações indígenas foram e ainda são consideradas, existe uma série de barreiras visíveis e invisíveis para a aproximação com os não indígenas, que estão presentes nas memórias individuais e coletivas de ambas,

fortalecendo o afastamento. Para exemplificar, podese destacar no estado o silencioso massacre de povos indígenas isolados na região de Corumbiara (sul de Rondônia) pela frente de migração (Carelli, 2012); diversos problemas enfrentados pelos UruEu-Wau-Wau que resistem à frente expansionista desde o início do século XX (ISA, 2013; Leonel, 1995); violação dos direitos humanos dos CintaLarga, Kanoê, Akuntsu, Karipuna de Rondônia e Karo, entre outros grupos, durante a ditadura 
militar (Comissão..., 2014, p.233); e as obras de infraestrutura implementadas pelo Programa de Aceleração do Crescimento (PAC) do Governo Federal no estado, como as hidrelétricas de Santo Antônio e Jirau, que vêm acarretando impactos sociais, econômicos, ambientais e simbólicos para populações ribeirinhas e indígenas, entre outras (Ferreira; Maciel, 2012, p.173).

Não se pode desconsiderar toda a campanha ideológica promovida contra essas populações, potencializada durante o governo militar e nos últimos anos pela bancada ruralista (incentivados por um modelo de desenvolvimento). o protagonismo e a resistência desses grupos nas últimas décadas têm sido fundamentais para reverter situações difíceis. É possível elencar inúmeras iniciativas de grupos indígenas que vêm se mobilizando na luta por suas terras, assim como pelo direito ao seu modo de vida e à sua diversidade cultural. Esses grupos se organizam em ONGs, criam sites e blogs, utilizam diferentes tecnologias a favor da luta pelos seus territórios, como o Google Earth e a internet, realizam eventos, participam de movimentos políticos, produzem filmes e documentários, buscam formação em universidades e criam museus, entre muitas outras ações.

Essas problemáticas indicam diferentes passados em jogo, vinculados aos migrantes, às populações indígenas, aos seringueiros e aos ribeirinhos, entre outros. Esses passados são agentes de negociação, e a museologia pode considerar essas semânticas com o objetivo de realizar uma reflexão conjunta, contribuindo para a produção de novas memórias. Como discute Marília Xavier Cury em seu trabalho com as populações indígenas Kaingang, Krenak, Guarani e Terena no entorno do Museu Histórico e Pedagógico Índia Vanuíre em Tupã, São Paulo, os museus antropológicos têm papel social fundamental, sobretudo em relação à "pacificação" dos não indígenas (Cury, 2012, p.178), ou seja, a criação de espaços de reflexão sobre a relação entre essas diferentes populações potencializando a atuação dos museus. Diante da diversidade de relações entre populações indígenas e não indígenas, ouvir a percepção de diferentes grupos sobre essas questões é fundamental para calibrar e potencializar a história de longa duração contada pelo CPMRARO.

\section{Ouvir, interpretar e propor}

Os colaboradores ouvidos trouxeram diferentes perspectivas em torno das impressões sobre as populações indígenas e também desafios ao tratamento dessas questões no Museu. ${ }^{6}$ Mais do que informar sobre os grupos, falam, todavia, a respeito do imaginário dos migrantes (não indígenas). Essas percepções são portas de entrada para a abordagem da temática na localidade. Destacam-se as narrativas de Devanir Domingues Fernandes, professor de história da rede pública; de José Ribeiro da Silva Filho, ex-prefeito do município; de Maria Coimbra de Oliveira, professora de história da rede pública e ex-diretora do CPMRARO; de Maurício Martins Alves e Raimundo Correa de Souza, ambos ex-seringueiros e ex-soldados da borracha; de Vileuda Rodriguez da Silva, professora de Geografia na rede pública, e de Wilson Modro, professor aposentado.

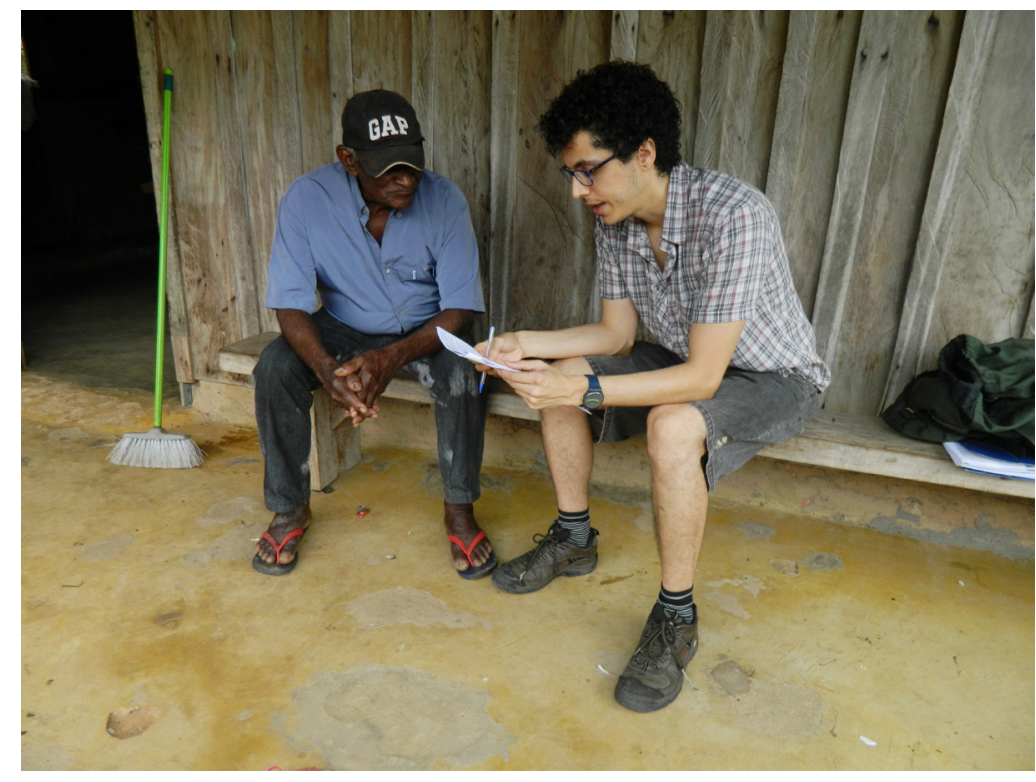

Foto 3 - Validação da história de vida do ex-seringueiro Maurício Martins Alves, 2013. Foto: Acervo pessoal Maurício André da Silva.

Em relação ao grupo de professores que atuam ou atuaram em sua maioria na rede pública de

6. Para acesso aos documentos produzidos pelos colaboradores, consultar Silva, 2015 
ensino, nas áreas de história e geografia, notase flexibilidade na aproximação da temática indígena e um exercício da alteridade diante do outro. Esses professores migrantes de distintas partes do país, que em sua maioria foram imersos em uma campanha ideológica de Estado contra os indígenas, reverteram essa percepção e passaram olhar as populações sob outros parâmetros.

Em alguns casos foram testemunhas, ou ouviram histórias de processos de desterritorialização e perseguição. Essas semânticas marcam o imaginário e se difundem na localidade de distintas formas, entretanto, o que poderia ser uma realidade ainda presente - os vestígios arqueológicos - os inquietou e possibilitou novos questionamentos a respeito da história local.

A professora Vileuda Rodriguez da Silva, nascida na cidade de Orós, Ceará, migrou em 1975, trabalhou com sua família nos seringais e em outras atividades e obteve várias experiências na floresta que contribuíram para ampliação de sua visão sobre as populações locais. O professor José da Silva Garcia, nascido em Martinópolis, São Paulo, migrou com 5 anos de idade para Mato Grosso, e com 27 para Rondônia; a partir da sua formação em História, desde 2002 passou a mapear e identificar coleções arqueológicas entre os proprietários rurais. Nos últimos anos ressalta a importância de ter começado a dar aula na T.I. Igarapé de Lourdes para os indígenas Araras, o que lhe trouxe diferentes noções sobre a história de longa duração, assim como o respeito por eles.

A professora Maria Coimbra de Oliveira, nascida em Lagoa Formosa, Minas Gerais, foi com a família ainda criança para Goiás e com 17 anos mudouse para Rondônia; atuante no ensino local, demonstra como a imagem das populações indígenas se alterou com o tempo, sobretudo pelas práticas relacionadas à educação patrimonial iniciadas com a criação do Museu:

Em relação à questão indígena você tem uma valorização maior atualmente. Porque começa a perceber junto com esse trabalho de educação patrimonial para preservação do material arqueológico, você também faz a ponte entre as comunidades locais, atuais. Porque ainda temos muitos grupos indígenas no estado de Rondônia e muito próximos daqui, que de uma forma direta ou indireta a população tem muito contato. Médici nem tanto, mas se você pegar a população de JiParaná, de Cacoal, Alvorada, de Espigão. Pimenta Bueno. Assim, de uma certa maneira há uma valorização maior e ao mesmo tempo um interesse maior de conhecer as comunidades atuais. Começamos a perceber que os professores que trabalham com essas... com esses grupos, eles também estão começando a se preocupar com o próprio sistema de educação que está sendo oferecido a eles. (Maria Coimbra de Oliveira)

o campo da educação é um dos espaços adequados para se evidenciar e discutir o que significa a diversidade do ponto de vista cultural, político e social. O Museu, ao abordar a arqueologia, pode discutir a diversidade no passado e no presente, que não é algo a ser temido, pois a história da humanidade é marcada por diferentes escolhas e caminhos ao longo do tempo. 0 modo de vida atual não foi e não é o único, nem será o último. A mudança e a escolha de novos rumos sobre a história são a única constante da humanidade.

É significativo refletir o quanto a população de migrantes e indígenas sofreu com o processo de colonização, ${ }^{7}$ obviamente com suas particularidades. A primeira, estimulada a deixar sua localidade de origem em busca de um sonho de melhoria de vida, deparou com uma realidade bem distinta e com o abandono do Estado; a segunda, milenarmente presente na região, enfrentou o processo de perseguição, desmatamento e roubos de suas terras pelo processo de colonização.

Maurício Martins Alves, nascido no Ceará, veio ainda pequeno para Rondônia com a família e passou a trabalhar nos seringais. Raimundo Correa de Souza nasceu em 1941 no seringal que se chamava Santa Rosa, Casa Cotim Anibal e Cia., em

7. Os assentamentos dos colonos em Rondônia foram complicados e desorganizados (Matias, 2001; Silva, 2010). O Incra não foi capaz de assentar a demanda de migrantes que chegava, - Ibama não conseguiu fiscalizar o desmatamento, assim como a Funai foi ineficaz na assessoria e proteção das populações indígenas que lá habitavam. 
Rondônia. Ambos construíram suas vidas a partir do trabalho da coleta da borracha, desde pequenos aprenderam a viver do que a floresta oferecia. Em muitos momentos presenciaram os conflitos entre seringalistas e populações indígenas pela ocupação dos territórios. Nessa lógica, os indígenas "mansos", que não se colocaram contra o processo de tomada de suas terras, não sofriam represálias. Cabe destacar os movimentos de resistência dessas populações diante das frentes expansionistas:

Então ali era seringal, muito grande, muito bom de leite que pegava seringa da serra, seringa dos baixões e também das várzeas. Então por exemplo ali tinha uma linha que se chamava linha do ouro negro, era uma serra que tinha muita seringa, mas os índios não deixavam os seringueiros trabalhar. Fazia a colocação, a casinha, o defumador, que tudo era borracha defumada, não era borracha escorrida apodrecida, era do leite se formava a pelota de borracha. Então ali os índios suportavam até quando tinha bastante gente. Na hora que os seringueiros ficavam sós, eles vinham e matavam. Aí botava outro e haja coragem para ir lá. (Raimundo Correia de Souza)

A falta de contato entre migrantes e populações indígenas reforça esses imaginários socialmente construídos e impede que se olhem mutuamente e percebam suas semelhanças e diferenças. No caso desse município, que possui diferentes aldeias em seu entorno, há muito a se ganhar com essa aproximação:

0 preconceito com população indígena ainda é grande. Porque a maioria da nossa população branca do estado de Rondônia eles nunca sequer foram numa área indígena. Eles nunca visitaram uma aldeia. Eu mesmo, eu só fui visitar uma aldeia, inclusive dos Araras, eu já estava completando 30 anos de Presidente Médici. 0 anseio das populações que não conhecem é negativo. A partir do momento que vai lá, visita e conversa com eles, convive com eles, isso muda totalmente. Então, o Museu vai ser importante para poder fazer com que estas populações brancas possam ter um melhor conhecimento dessas áreas indígenas, dessas comunidades e que aproxime as populações brancas dos indígenas. (José Ribeiro)

No caso do ex-prefeito da cidade de Presidente Médici, José Ribeiro da Silva Filho, nascido em Ituiutaba, Minas Girais, a partir do momento em que tomou contato com algumas aldeias indígenas da região, sua visão se ampliou e ele passou a compreendê-los de outra maneira. Essas populações precisam deixar de ser consideradas invisíveis, têm de ser reconhecidamente entendidas como habitantes do estado de Rondônia, sobretudo porque estavam nessa região há muito tempo. Do ponto de vista museológico, o país tem uma riqueza imensa que é a possibilidade de envolver as populações indígenas em curadorias compartilhadas para se revisitar seus acervos, assim como para mantê-los vivos diante da ampliação da noção de patrimonialização (Bruno, 2012 , p.41).

A região centro-leste do estado de Rondônia aponta para um caminho rico de contato com a diferença, uma vez que distintos grupos estão no seu entorno, e os vestígios arqueológicos também indicam uma diversidade no passado. O Museu pode evidenciar cada vez mais essas diferentes histórias e se constitui em um espaço potencial de discussão e transformação desses conflitos, em conjunto com outras instituições, como a escola, as associações de moradores, as organizações não governamentais etc. Seria ingenuidade depositar somente no Museu o papel de transformador da visão em relação às populações indígenas. Sua prática precisa ser crítica e atenta, pois ao invés de refletir sobre essas dinâmicas, pode apenas construir um fetiche dessas histórias e cair na imagem do indígena bom selvagem, um dos pilares da fundação da nacionalidade.

\section{Considerações finais}

Diferentes problemáticas emergem sobre as populações indígenas nesse pequeno recorte das narrativas dos colaboradores. Essas visões podem 
ser pontos de partida para calibrar a atuação do CPMRARO, sobretudo na sua prática educativa e na aproximação com elas. A diversidade é a tônica da localidade e pode ajudar a implementar ações locais engajadas com seu contexto. Diversidade essa que precisa sair do abstrato e passar a ser entendida de maneira relacionada com a vida, pois não existe 'o migrante', assim como 'o índio', mas migrantes de distintas localidades e diversas populações indígenas, plenos em suas diferenças.

A utilização da história oral pelos museus de arqueologia contribui para ampliar sua função social e as potencialidades interpretativas de seus acervos. As histórias de vida materializadas em documentos podem alimentar a cadeia operatória museológica (Bruno, 2013) em todas as suas etapas, da salvaguarda à comunicação. Nesse sentido a sugestão da criação de um Programa de História Oral e um Banco de Histórias (Silva, 2015, p.196), que busca com ações em curto e longo prazos ouvir e materializar em documentos diferentes histórias, pode ser valorizada. A região possui muitas pessoas idosas que viveram todo o processo de migração e de dificuldades na chegada e que poderiam ampliar o exercício da diversidade. Da mesma forma, muitos grupos indígenas do entorno do Museu podem ajudar a entender as distâncias simbólicas a serem superadas.

A prática da história oral, que contempla desenvolvimento de um projeto, realização de entrevistas, posterior passagem do texto oral para o escrito e análise deste, assim como a posterior devolução dos resultados à comunidade e a consequente construção de políticas públicas voltadas ao grupo ao qual pertencem os colaboradores, tem partes fundamentais e indissociáveis (Meihy, 2010b). Um dos resultados do emprego da metodologia da história oral é a identificação de questões e problemáticas relacionadas ao grupo colaborador da pesquisa, que, muitas vezes, são grupos minoritários que buscam reconhecimento e espaço na sociedade. Dessa forma, evidenciam-se questões latentes a serem abordadas no contexto:

Apropriadas para i/emigrantes, comunidades submetidas a situações incomuns, entidades em busca de redefinição social, os bancos funcionam como coleções ou séries de histórias de vidas produzidas para: 1. promover a coleta planejada de experiências; 2. favorecer o autoconhecimento grupal; 3 . instruir políticas públicas direcionadas à integração social; 4. reunir documentos capazes de permitir estudos futuros sobre adequação social. (Meihy; Ribeiro, 2011 , p. 96)

As temáticas abordadas pela arqueologia nos últimos anos deixaram de se referir apenas a um passado distante, essas pesquisas vêm demonstrando cada vez mais uma preocupação com o engajamento no presente. Na floresta amazônica, em que o processo de longa duração de ocupação humana se traduz no cotidiano atual das suas populações de muitas formas, reforçase a necessidade do calibramento entre passado e presente. Os museus de arqueologia podem se renovar na aproximação com as populações indígenas e com outras distintas parcelas da sociedade, no envolvimento pleno delas em suas atividades. Trabalhar com e para as comunidades em geral, sobretudo as indígenas, pode ser um caminho fundamental de aprendizado para os museus de arqueologia no século XXI.

As ações do CPMRARO podem relacionar as experiências de vida da população e potencializar o compromisso ético da promoção e preservação do patrimônio arqueológico. Dessa forma,

consideram-se outras polissemias que os vestígios arqueológicos desempenham nas populações locais, contribuindo para o desafio de uma discussão complexa sobre o patrimônio arqueológico. Esse exercício é mais trabalhoso, pois, muitas vezes, as narrativas apontam para entendimentos de rupturas, de não identificação, de elaboração de outras histórias; necessitam, portanto, da construção de um espaço democrático para tais discussões. Dessa forma, a relação entre tradição (noção de patrimônio) e inovação (apropriações outras do patrimônio arqueológico) pode abrir fissuras para o novo, para novas formas de significar passado e presente. 


\section{Referências}

ALMEIDA, Fernando 0zório. A tradição policroma no Alto rio Madeira. Tese (Doutorado em Arqueologia) - Museu de Arqueologia e Etnologia, Universidade de São Paulo. São Paulo, 2013.

BEZERRA, Márcia. Arqueologia e [des]envolvimento: patrimônio, contrato e comunidades locais na Amazônia. Simpósio Patrimônio. In: ROSTAIN, Stéphen (Ed.) Antes de Orellana. Actas del 3er Encuentro Internacional de Arqueologia Amazônica. Instituto Francês de Estudios Andinos, Facultad Latinoamericana de Ciencias Sociales, Embajada de EEUU, Quito, Ecuador, 2014.

"As Moedas dos índios": um estudo de caso sobre os significados do patrimônio arqueológico para os moradores da Vila de Joanes, ilha de Marajó, Brasil. Boletim do Museu Emílio Goeldi. Ciências Humanas, Belém, v.6, n.1, p.57-70, jan./abr. 2011.

os sentidos contemporâneos das coisas do passado: Reflexões a partir da Amazônia. Revista de Arqueologia Pública, Campinas: LAP-NepamUnicamp, n.7, jul. p. 107-122. 2013.

BRUM, Eliane. A ditadura que não diz seu nome. $E l$ País, Coluna Opinião, 31 mar. 2014. Disponível em: http://brasil.elpais.com/brasil/2014/03/31/ opinion/1396269693_200037.html; Acesso em: 1 abr. 2014.

BRUNO, Maria Cristina 0 . As futuras gerações têm direito a herança arqueológica? Premissas e desafios dos processos de musealização. In: MACHADO, Gerson; SOUZA, Flávia Cristina A.; STEINBACH, Judith (Org.) Educação Patrimonial e Arqueologia Pública: experiências e desafios. Prefeitura Municipal, Fundação Cultural, Museu Arqueológico de Sambaqui. Itajaí: Casa Aberta, 2013. p. 21-39.

- Museologia: a luta pela perseguição ao abandono. Tese (Livre-Docência) - Museu de Arqueologia e Etnologia, Universidade de São Paulo. São Paulo, 2000.

Principais pontos a serem debatidos sobre a ampliação do conceito e dos processos de patrimonialização. In: CURY, Marília X.; VASCONCELLOS, Camilo de M.; ORTIZ, Joana M.
(Coord.) Questões Indígenas e museus: debates e possibilidades. Brodowski: ACAM Portinari; São Paulo: Museu de Arqueologia e Etnologia da Universidade de São Paulo; Secretaria de Estado da Cultura, 2012. p. 40-42.

CARELLI, Vincent. Corumbiara. Documentário (Online). Disponível em: http://Www.youtube.com/ watch?v=2sKHJ6GdUf4; Acesso em: 10 out. 2012 .

CARNEIRO, Carla G. Educação Patrimonial e Arqueologia: alguns aspectos dessa interface. Amazônia. Revista de Antropologia (Online), v.6, n.2, p.442-458, 2014a.

Educação Patrimonial, Educação

Patrimonial em Museus e Participação. In: CURY, Marília X. (Coord.) Questões indígenas e museus: enfoque regional para um debate museológico.

Brodowski: ACAM Portinari; São Paulo: Secretaria de Cultura do Estado de São Paulo (SEC); Museu de Arqueologia e Etnologia da Universidade de São Paulo (MAE-USP), 2014b. p. 88-95.

CHAGAS, Mário de S. A Radiosa Aventura dos Museus. In: BRUNO, Maria Cristina 0.; NEVES, Kátia Regina F. (Coord.) Museus como Agentes de Mudança Social e Desenvolvimento: propostas e reflexões museológicas. São Cristovão: Museu de Arqueologia de Xingó, 2008. p. 41-52.

COMISSÃO NACIONAL DA VERDADE. Relatório: textos temáticos. v.2. Brasília, 2014.

CRUZ, Daniel G. Lar Doce Lar? Arqueologia Tupi na Bacia do Ji-Paraná (R0). Dissertação (Mestrado em Antropologia) - Museu de Arqueologia e Etnologia, Universidade de São Paulo. São Paulo, 2008.

CURY, Marília X. Referências Kaingang: Discussão para um Centro. In: CURY, Marília X.; VASCONCELLOS, Camilo de M.; ORTIZ, Joana M. (Coord.) Questões Indígenas e museus: debates e possibilidades. Brodowski: ACAM Portinari. São Paulo: Museu de Arqueologia e Etnologia da Universidade de São Paulo; Secretaria de Estado da Cultura, 2012. p. 173-179.

D’ARAÚJ0, Maria Celina. Amazônia e desenvolvimento à luz das políticas governamentais: as experiências dos anos 1950. In: ENCONTRO ANUAL DA ANPOCS, 15., Caxambu, MG, 1991. GTs/GT34 - Ecologia, Política e Sociedade. Disponível em: http://WWW.anpocs. org/portal/index.php?option=com_content\& 
view=article\&id=473\%3Aanais-do-encontrogt\&catid=1056\%3A15o-encontro\&I temid=366.

FERREIRA, Iremar A.; MACIEL, Márcia N. Um olhar sobre a Amazônia: história oral e debate de políticas desenvolvimentistas. Oralidades Revista de História Oral, São Paulo: Núcleo de Estudos em História Oral do Departamento de História da Faculdade de Filosofia, Letras e Ciências Humanas da Universidade de São Paulo, ano 6, n.11, p. 155-179, 2012.

FERREIRA, Lúcio M. Essas coisas não lhe pertencem: relações entre legislação arqueológica, cultura material e comunidade. Revista de Arqueologia Pública, Campinas: LAPNepam-Unicamp, n.7, p. 87-106, jul. 2013.

GONÇALVES, José R. Antropologia dos objetos: coleções, museus e patrimônio. Rio de Janeiro: [s.n.], 2007.

HALBWACHS, Maurice. A memória coletiva. Trad. Beatriz Sidou. 2.ed. São Paulo: Centauro, 2003.

ISA. Instituto Sócio Ambiental. Uru-Eu-Wau-Wau. 2013. Histórico do Contato. Disponível em: http://pib.socioambiental.org; Acesso em: 18 jul. 2013.

LEONEL, Mauro. Etnodicéia Uruéu-au-au: 0 Endocolonialismo e os índios no Centro de Rondônia. O direito à diferença e à preservação ambiental. São Paulo: Edusp, 1995.

MATIAS, Francisco 0. Ocupação, políticas públicas e gestão ambiental de unidade de conservação no estado de Rondônia. 0 estudo de caso do parque estadual de Guarajá Mirim. Dissertação (Mestrado) - Universidade Estadual Paulista Júlio de Mesquita Filho. Rio Claro, $20 \odot 1$.

MEIHY, José Carlos Sebe Bom. História Oral: desafios conceituais. Oralidades, Revista de História Oral, Núcleo de Estudos em História Oral (Neho) do Departamento de História da Faculdade de Filosofia, Letras e Ciências Humanas da Universidade de São Paulo, São Paulo, n.5, p. 136-146, jan./jun. 2009

História Oral: memória, história oral e memória. Oralidades, Revista de História Oral, Núcleo de Estudos em História Oral (Neho) do Departamento de História da Faculdade de Filosofia, Letras e Ciências Humanas da Universidade de São Paulo, São Paulo, n.8, p.
179-194, jan./jun 2010a.

História oral testemunhal, memória oral

e memória escrita e outros assuntos [entrevista

a Marta Gouveia de Oliveira Rovai e Eduardo Meinberg de Albuquerque Maranhão Filho].

História Agora, Revista do Tempo Presente, São

Paulo, 2010b. p. 259-274.

Manual de História Oral. São Paulo:

Loyola, 1996.

- HOLANDA, Fabíola. História oral, como

fazer, como pensar. São Paulo: Contexto, 2007.

- RIBEIRO, Suzana Lopes S. Guia prático

de história oral para empresas, universidades, comunidades e família. São Paulo: Contexto, 2011.

MILLER, Eurico T. A cultura cerâmica do Tronco Tupi no alto Ji-Paraná, Rondônia, Brasil: algumas reflexões teóricas, hipotéticas e conclusivas. Revista Brasileira de Linguística Antropológica, v.1, p.35-136, 2009.

MONGELO, Guilherme Z. O Formativo e os Modos de Produção: ocupações pré-ceramistas no Alto Rio Madeira - Ro. Dissertação (Mestrado em Arqueologia) - Museu de Arqueologia e Etnologia, Universidade de São Paulo. São Paulo, 2015

OLIVEIRA. Maria C. Arte Rupestre em Rondônia. Presidente Médici: [s.n.], 2013.

SILVA, Maurício André. Memórias e Histórias no sudoeste amazônico: o Museu Regional de Arqueologia de Rondônia. Dissertação (Mestrado em Arqueologia) - Museu de Arqueologia e Etnologia, Universidade de São Paulo. São Paulo, 2015

SILVA, Ricardo Gilson da C. Dinâmicas Territoriais em Rondônia: conflitos na produção e uso do território no período de 1970 a 2010. Dissertação (Mestrado) - Faculdade de Filosofia, Letras e Ciências Humanas, Universidade de São Paulo. São Paulo, 2010.

SUÑER, Rodrigo. Arqueologia Tupi no Médio JiParaná: teoria do não-equilíbrio dinâmico e abordagem multifocal dos processos de mobilidade populacional no Sudoeste Amazônico. Tese (Doutorado em Arqueologia) - Museu de Arqueologia e Etnografia, Universidade de São Paulo. São Paulo, 2015. 
TRINDADE, Thiago B. Geoglifos, zanjas ou earthworks? Levantamento geral dos sítios arqueológicos com estruturas de terra em vala no médio rio Guaporé (RO) e análise comparada com os demais sítios no Sudoeste da Bacia Amazônica. Dissertação (Mestrado em Arqueologia) - Museu de Arqueologia e Etnologia, Universidade de São Paulo. São Paulo, 2015.

ZIMPEL NETO, Carlos A. Na direção das periferias extremas da Amazônia: estudo da Bacia do Rio Ji-Paraná, Rondônia. Dissertação (Mestrado em Arqueologia) - Museu de Arqueologia e Etnologia, Universidade de São Paulo. São Paulo, 2008.

ZUSE, Silvana. Variabilidade cerâmica e diversidade cultural no alto rio Madeira, Rondônia. Tese (Doutorado em Arqueologia) Museu de Arqueologia e Etnologia, Universidade de São Paulo. São Paulo, 2014.

* Maurício André da Silva é bacharel em história pela Faculdade de Filosofia, Letras e Ciências Humanas (FFLCH). licenciado pela Faculdade de Educação (FE) pela Universidade de São Paulo (USP), mestre em Arqueologia pelo Museu de Arqueologia e Etnologia da USP (MAE-USP), instituição onde atua como Educador de Museu. 


\title{
A Arqueologia e o patrimônio arqueológico indígena em exposições museais no centro-oeste de São Paulo e norte do Paraná: questões preliminares
}

\author{
Leilane Patricia de Lima* \\ Museu de Arqueologia e Etnologia, Universidade de São Paulo (MAE-USP)
}

\begin{abstract}
A recente pesquisa de doutorado de minha autoria discutiu o patrimônio arqueológico na esfera da educação formal e apresentou como proposta metodológica os estudos de público na perspectiva comunicacional, buscando compreender as relações dos sujeitos com a Arqueologia e com o passado arqueológico indígena, a partir de um recorte amostral (público escolar) e em um contexto particular - Londrina (PR), cidade que rejeita o passado indígena e reforça uma memória em detrimento de outras (Lima, 2014).
\end{abstract}

As características próprias da pesquisa e a trajetória que percorri durante o doutoramento (disciplinas de pós-graduação, estágios etc.) levaram-me à aproximação dos debates com a Comunicação Museológica e com os estudos de recepção e, por sua vez, à reorientação do meu interesse, voltado agora ao estudo das articulações entre a Arqueologia, o patrimônio arqueológico indígena e os museus, por meio de suas exposições.

Nesse sentido, apresentarei aqui alguns dados preliminares do meu estudo de pós-doutoramento ${ }^{1}$ vinculado ao MAE-USP, sob supervisão da professora Dra Marília Xavier Cury. Nesta investigação proponho uma análise sobre como a Arqueologia e o patrimônio arqueológico indígena são evidenciados em exposições museais localizadas em municípios do centro-oeste de São Paulo e do norte do Paraná.

1. A pesquisa é intitulada "Os Museu de Arqueologia e a Arqueologia nos Museus: análise de exposições museais no oeste de São Paulo e norte do Paraná", jul. 2015 a jul. 2017, com apoio da Fapesp. (processo 2015/07756-9)
Tal proposta está amparada, sobretudo, nos campos da Arqueologia Pública e da Comunicação Museológica. Da parte da Arqueologia Pública, os debates apontam que os profissionais envolvidos com esse campo disciplinar têm interesse em compreender como as pessoas se relacionam com o passado e com o patrimônio arqueológico, como usam, ativam e negociam esse patrimônio. Investigações dessa natureza podem ajudar a trazer à tona perspectivas sobre a Arqueologia, os vestígios arqueológicos e o passado. De outra parte, as trajetórias e discussões da Museologia e da Comunicação Museológica apontam para a interdisciplinaridade, para o diálogo e para a emergência nos estudos dos produtos comunicacionais dos museus.

Nesse contexto amplo de possibilidades, os museus se caracterizam como importantes objetos de estudo e reflexão para os profissionais envolvidos com a Arqueologia Pública, uma vez que nesses espaços, além dos processos de pesquisa e salvaguarda do patrimônio arqueológico (documentação e conservação), são promovidas propostas comunicacionais, especialmente por meio de exposições e ações de educação, que apresentam ou não o conhecimento arqueológico.

Acrescentam-se a isso outras particularidades dessas instituições: são locais potenciais de aprendizagens, espaços de experiências individuais e coletivas, e, assim como as escolas, são arenas complexas onde circulam diferentes saberes e podem ser ambientes onde noções de Arqueologia e do passado são 
produzidas, reproduzidas, negadas, excluídas etc. (Lima, 2014, p.22).

De maneira específica, as exposições são produtos comunicacionais potenciais de análises porque elas constituem o principal instrumento de comunicação do museu com seus públicos. Elas exercem uma das funções fundamentais nessas instituições, uma vez que um museu sem exposição não é um museu no sentido pleno (Granato, 2006, p.4). Dito de outra forma, as exposições legitimam e caracterizam as instituições museais como tal, pois na ausência delas os museus seriam importantes reservas técnicas, expressivas coleções, centros de documentação ou arquivos (Scheiner, 2003).

Segundo Davallon (2010, p.17-21), as exposições são dispositivos complexos que destacam a comunicação cultural. Elas compreendem uma distribuição de "coisas" que podem ser de natureza muito heterogênea, colocadas em um espaço com o objetivo de torná-las acessíveis às pessoas. E, ao mesmo tempo em que podem constituir formas simples, são também muito elaboradas porque atendem a ideias e intenções.

Conduru também notou a capacidade de significado das exposições e as pensou como discursos. Sendo assim, entendeu que todos os elementos que constituem esses produtos comunicacionais são componentes desse discurso. Entre eles, os objetos em exibição, os textos de apresentação e os explicativos, as imagens complementares, as legendas das peças, a ficha técnica, o aparato de segurança das peças e do público (tanto os equipamentos quanto o pessoal), o mobiliário, o edifício, os agentes envolvidos e as instituições parceiras, entre outros (2006, p.63).

Ainda a esse respeito, Roque (2010, p.50-51) sinalizou que os museus - a partir de exposições - apresentam uma sequência lógica, entre tantas possíveis. Nesse caso, a elaboração do discurso expositivo não é isenta e muito menos neutra. Em verdade, as exposições resultam de sucessivos exercícios de seleção e síntese, aplicados sobre os objetos ou sobre as informações que lhes são associadas e podem revelar a faceta parcelar e fragmentada do grupo que a organizou. 0 reconhecimento disso, no entanto, não invalida o discurso museológico.

Lima e Francisco (2013, p.93) também refletiram sobre o papel das exposições em relação aos museus. Inspirados nas discussões de Cury (2008) e Moraes (2008), esses autores indicaram que, de fato, as exposições podem revelar o lugar social do museu, seus propósitos, a ciência exercida e aplicada, a interdisciplinaridade, a integração de sua equipe, os conflitos e, em certa medida, a sua postura político-ideológica. Tudo isso porque a exposição é a parte mais visível dos museus, aquela que se coloca mais à frente no processo museológico e na relação que se constrói entre sujeito e patrimônio cultural musealizado.

Diante desse cenário, as exposições se caracterizam também como "lugares" metodológicos, espaços importantes de estudos não somente de profissionais da Comunicação Museológica e de outras áreas da Museologia, mas também de uma rede diversificada de disciplinas que estão vinculadas ao museu e que irão se apropriar desse universo de maneiras muito particulares (Moraes, 2008 , p.52), como é o caso do estudo aqui proposto.

\section{Metodologia da pesquisa}

No que se refere à metodologia da pesquisa, baseou-se nas discussões promovidas no âmbito da Avaliação em Museus. Segundo Cury, a avaliação é, antes de tudo, uma postura profissional, considerada essencial à vida dos museus, mas ainda pouco praticada. É também uma ferramenta capaz de aprofundar a compreensão do trabalho desenvolvido no museu. É um meio de refinamento do trabalho que dá condições de (re)orientar os procedimentos do processo comunicacional - elaboração, execução e recepção pelo público - permanentemente (Cury, 2006, p.123-125). Compreende uma linha de pesquisa em Museografia cuja aplicabilidade é ampla e pode colaborar com recursos estruturantes e técnicos em projetos de pesquisa (Cury, 2012, p.9).

Com o objetivo de compatibilizar a avaliação museológica ao sistema de comunicação museal, 
essa autora propôs os seguintes tipos de avaliação (Cury, 2006, p.132-134):

1. Avaliação Preliminar ou Conceitual: ocorre na fase de planejamento e colabora para a definição do conteúdo e conceitos da exposição;

2. Avaliação Formativa: ocorre na fase inicial de desenvolvimento do design e colabora para o refinamento da exposição durante o seu processo executivo;

3. Avaliação Corretiva: colabora com a correção de aspectos não satisfatórios da exposição a partir da comparação entre o proposto e o executado. Pode contar. ainda, com a participação do público;

4. Avaliação Somativa: ocorre depois da montagem da exposição e avalia a interação entre exposição e público, a partir do modelo de comunicação proposto;

5. Avaliação Técnica ou Apreciação Crítica: levanta questões técnicas não satisfatórias e o mérito da exposição. São avaliados o projeto e o desenho no espaço expositivo; pode ser realizada por integrantes da equipe ou por profissionais externos:

6. Avaliação do processo: é promovida pela equipe responsável pelo desenvolvimento do processo de concepção/execução de uma determinada exposição, com o intuito de colaborar para a aprendizagem da equipe e no monitoramento das ações planejadas.

Seguindo as orientações metodológicas do projeto "Análise de Exposições Antropológicas",2 foi

2. A pesquisa de pós-doutorado está vinculada ao projeto "Análise de Exposições Antropológicas", coordenado pela professora Dra. Marília Xavier Cury, do MAE-USP, e financiado pelo CNPq. Segundo Cury, a proposta é "levantar dados para subsidiar a proposição de categorias que possam sustentar modelos expográficos, parte substantiva da discussão para uma crítica de exposições museológicas" (Cury, 2012, p.2). Ainda, como objetivos específicos o referido projeto procura entender processos expográficos - condições de produção, resultado formal e recepção - para compreensão de metodologias, construção de retóricas, análise da forma/design e apreensão adotada como aporte metodológico para a pesquisa em andamento a Avaliação Técnica, que, de acordo com Cury (2012, p.12), consiste em observar tecnicamente a exposição posta no espaço, como ela se apresenta para o público, valendo-se de observação, amplo registro fotográfico e registro criterioso em caderno de campo.

Para a coleta de informações durante as visitas técnicas foi elaborado um roteiro, ${ }^{3}$ instrumento preenchido em todas as instituições e exposições visitadas. Nele foram anotados os dados institucionais e operacionais, as características geográficas, físicas e arquitetônicas da instituição-sede, os elementos referentes à infraestrutura e dados relacionados às exposições estudadas: acervo exposto, recursos expográficos, mobiliário, temas propostos etc. Em específico, foi indicada a presença ou não de vestígios arqueológicos indígenas e de referências à Arqueologia nos espaços expositivos.

Até o momento, foram realizadas visitas técnicas em 22 instituições no centro-oeste do estado de São Paulo e em 21 instituições no norte do estado do Paraná (Quadro 1), a saber:

dos usos públicos e colaborar para uma crítica de exposição, levantando pontos de (des)construção da linguagem expositiva (Cury, 2012, p.4)

3. Esse roteiro é uma adaptação do "Roteiro de Observação para Visita a Museus", elaborado pela professora Dra. Marília Xavier Cury. 


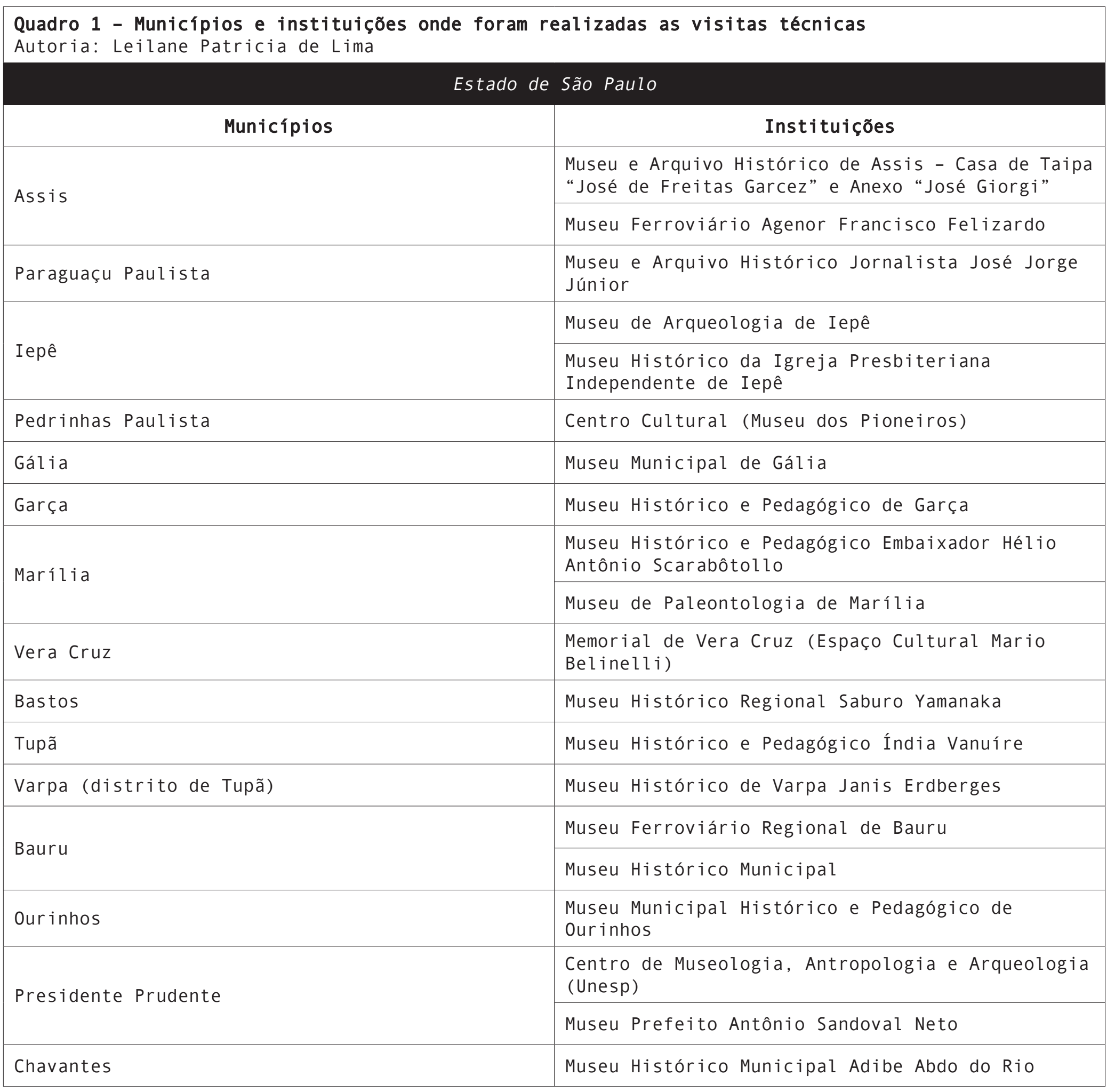




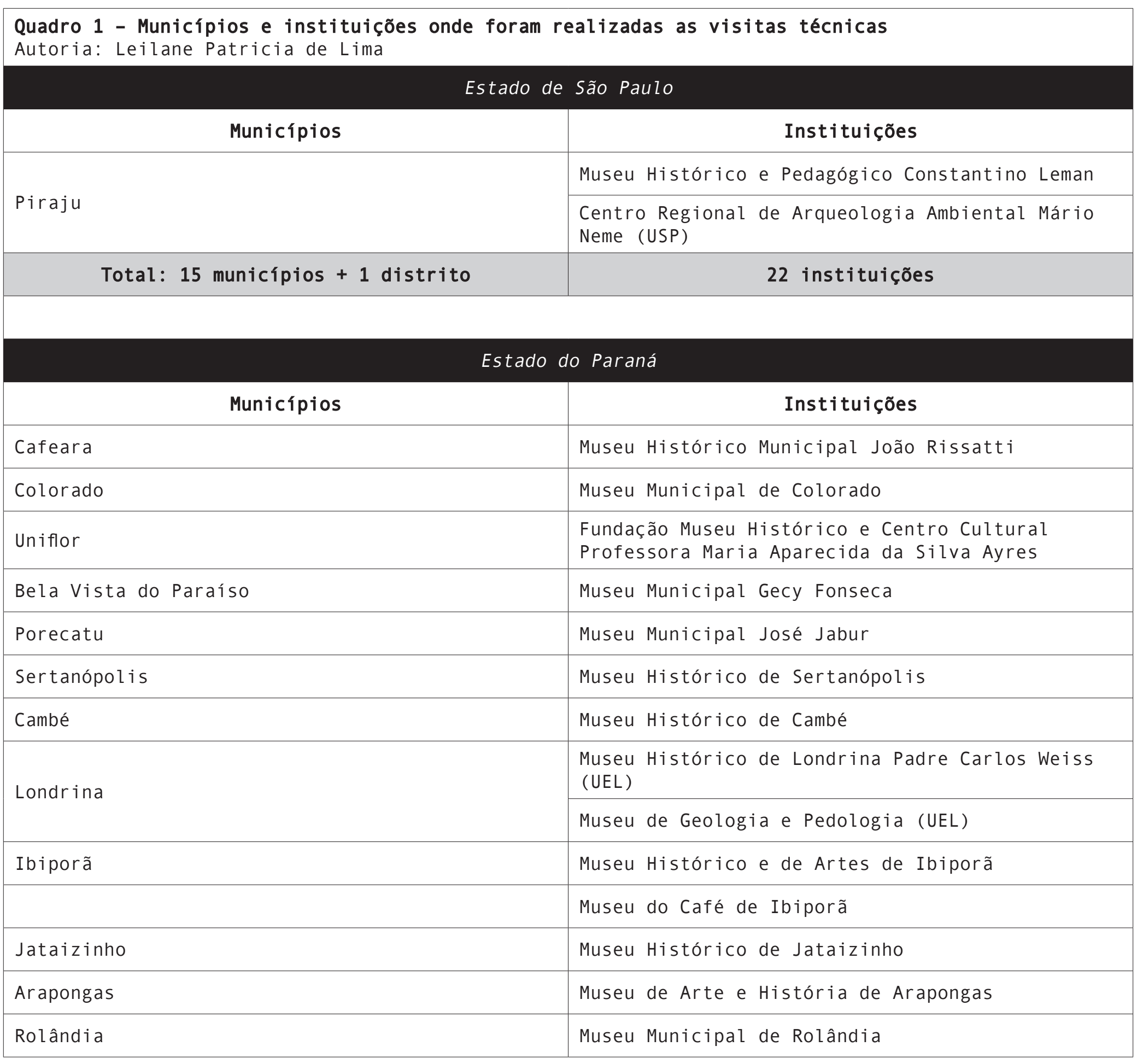




\begin{tabular}{|c|c|}
\hline \multicolumn{2}{|c|}{ Estado do Paraná } \\
\hline Municípios & Inst ituições \\
\hline \multirow{4}{*}{ Maringá } & Museu Dinâmico Interdisciplinar (UEM) \\
\hline & Museu de Geologia (UEM) \\
\hline & Museu de História e Artes Hélenton Borba Côrtes \\
\hline & $\begin{array}{l}\text { Laboratório de Arqueologia, Etnologia e Etno- } \\
\text { história (UEM) }{ }^{4}\end{array}$ \\
\hline Total: 13 municípios +1 distrito & 21 instituições \\
\hline
\end{tabular}

De modo geral, tais cidades compartilharam processos de ocupação humana e colonização bem semelhantes. Primeiramente, grupos indígenas habitaram as regiões e, em seguida, a colonização esteve relacionada à expansão da cafeicultura, ou seja, às formas capitalistas de ocupação e uso da terra - entre o final do século XIX e o início do século XX - com a presença de frentes pioneiras, ferrovias, terras boas para o cultivo do café e outros produtos, investimentos da iniciativa privada, imigração etc.

Uma hipótese é que, apesar de investigar exposições apresentadas por instituições e municípios diversos, em dois estados, os elementos históricos comuns podem sugerir pontos recorrentes nas propostas comunicacionais, bem como evidenciar não apenas disputas territoriais, mas também a seleção e a valorização de algumas memórias em detrimento de outras, algo

4. O Laboratório de Arqueologia, Etnologia e Etno-história compreende um espaço de ensino, pesquisa e extensão na Universidade Estadual de Maringá (UEM). Foi considerado porque apresenta em seu interior um espaço expositivo que recebe visitas eventuais. que o estudo do meio permitirá corroborar ou refutar. E, como resultado das visitas técnicas realizadas, está sendo elaborado um banco de dados atualizado sobre os museus visitados, conforme descrito a seguir.

\section{0 banco de dados}

Em posse do material levantado durante as visitas técnicas e considerando a complexidade das exposições como produtos comunicacionais de uma instituição museal, comecei a elaborar um banco de dados para registro de informações observadas em campo. Essa plataforma digital, em fase de elaboração, apresentará os elementos que considero importantes para a análise.

Até o momento, sua proposta contempla cinco perspectivas diferentes: o museu, a exposição, a arqueologia, o patrimônio arqueológico indígena e a experiência da visita.

Cabe dizer que cada um desses cinco temas (A-E) apresentará suas unidades de análise e suas 
unidades de contexto, respectivamente. As primeiras compreendem 14 tópicos gerais distribuídos entre os temas analisados (I-XIV). As segundas são compostas por alguns itens potenciais de análise que foram observados a partir do estudo do meio (1-68), ${ }^{5}$ conforme Quadro 2.

\section{Quadro 2 - Protótipo do banco de dados - Temas, Unidades de Análise e Unidades de Contexto \\ Autoria: Leilane Patricia de Lima}

\section{A - MUSEU}

I - Sobre a identidade do museu pesquisado

1. Categoria Institucional

2. Natureza Administrativa

3. Tipologia de Acervo

$$
\begin{gathered}
\text { II - Sobre os "pontos" de encontro com o } \\
\text { público }
\end{gathered}
$$

4. Atendimento Telefônico

5. Atendimento Eletrônico

\section{Atendimento Presencial}

\section{III - Sobre o espaço geográfico e físico}

7. Localização

8. Equipamentos culturais próximos

9. Circulação no entorno

10. Entorno imediato da instituição museal

11. Uso do espaço externo (arredores do edifício)

5. Vale destacar que as unidades de contexto serão desdobradas em categorias e subcategorias. Por exemplo, a unidade de contexto "Categoria Institucional" desdobra-se nas seguintes opções: "Fundação, Espaço ou Centro Cultural", "Memorial", "Museu" e "Outra". Em "Museu" há as seguintes subcategorias: "Museu Arqueológico", "Museu Histórico", "Museu de Ciências", "Museu de Geologia” e "Museu de Paleontologia".
Quadro 2 - Protótipo do banco de dados - Temas, Unidades de Análise e Unidades de Contexto Autoria: Leilane Patricia de Lima

\section{A - MUSEU}

IV - Sobre a comunicação visual

12. Comunicação Externa

13. Comunicação Interna

V - Sobre o acesso à instituição

14. Meios

15. Formas

16. Pisos

17. Entrada

18. Potenciais barreiras de acesso

\section{VI - Sobre o espaço arquitetônico}

19. Tipo de imóvel

20. Funções do imóvel

21. Formas de institucionalização

22. Infraestrutura de uso interno

23. Infraestrutura e equipamentos de uso externo (público)

24. Segurança

25. Segurança contra incêndio

VII - Sobre a organização espacial

26. Setor Expositivo

27. Setor Técnico

28. Setor Administrativo

VIII - Sobre o relacionamento com o público

29. Controle de visitas (quantitativo) 
Quadro 2 - Protótipo do banco de dados - Temas, Unidades de Análise e Unidades de Contexto

Autoria: Leilane Patricia de Lima

\section{A - MUSEU}

VIII - Sobre o relacionamento com o público

30. Controle de visitas (qualitativo)

31. Ações de marketing

32. Ações de atendimento e eventos

\section{$B$ - EXPOSIÇÃOO}

\section{IX - Concepção política}

33. Ficha técnica

34. Tomada de decisão

\section{X - Concepção museológica}

35. Título

36. Tipo de exposição

37. Narrativa

38. Temas

39. Recorte conceitual

40. Desenvolvimento conceitual

41. Acervo exposto

42. Orientações para o público

43. Elementos de atração

44. Trajeto

45. Circulação interna

46. Pontos do percurso

47. Acessibilidade na exposição
Quadro 2 - Protótipo do banco de dados - Temas, Unidades de Análise e Unidades de Contexto

Autoria: Leilane Patricia de Lima

\section{$B$ - EXPOSIÇÃO}

\section{XI - Concepção expográfica}

48. Recursos expográficos

49. Mobiliário que dá suporte ao acervo exposto

50. Vitrines

51. Cores

52. Iluminação

53. Textos verbais

54. Expografia

55. Controle ambiental do acervo exposto

56. Segurança da exposição

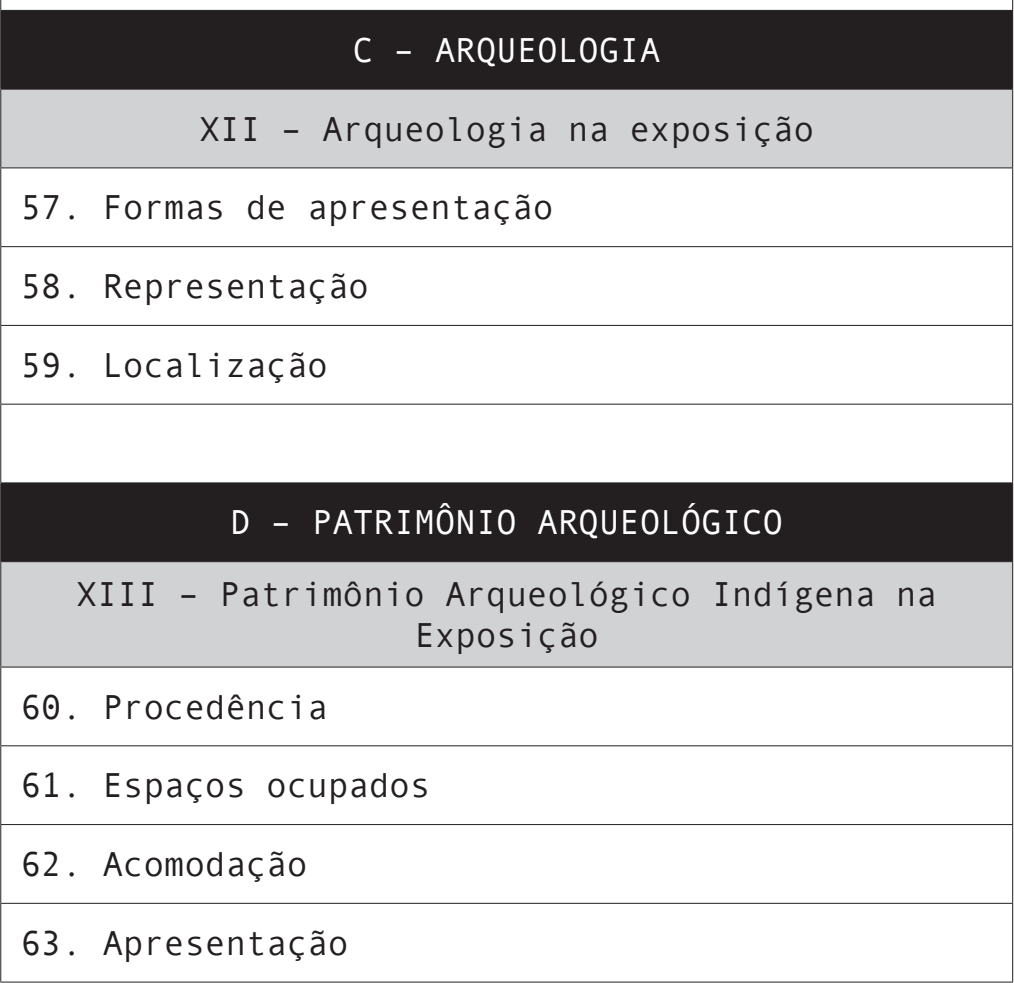




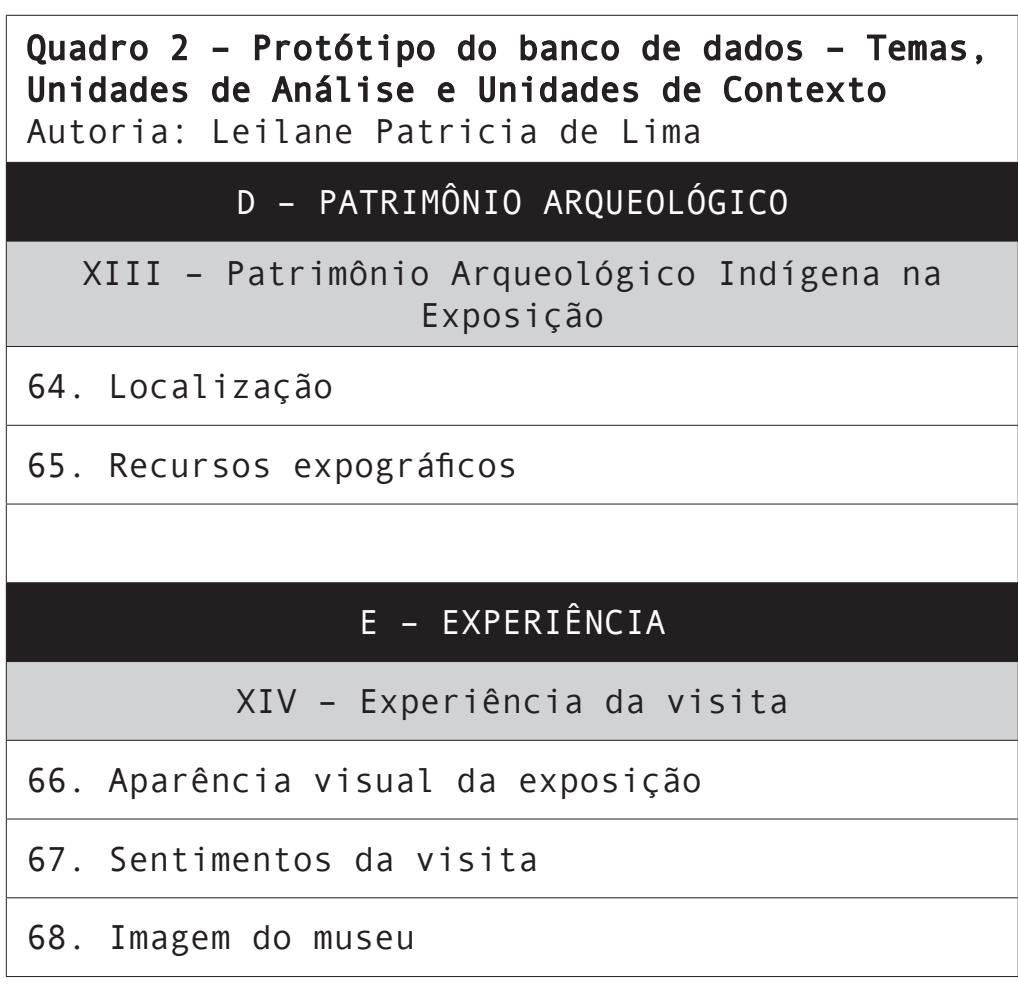

A partir desta base de dados digital serão produzidos relatórios específicos e comparativos que permitirão uma visão mais ampla das propostas comunicacionais que foram estudadas. Com isso, pretendo pensar em um panorama geral de modelos expográficos que utilizam (ou não) vestígios arqueológicos musealizados em suas propostas comunicacionais, colaborando assim para uma crítica de exposições.

\section{Apontamentos gerais sobre as visitas técnicas}

Apesar de a pesquisa ainda estar em andamento, farei algumas considerações a respeito do que pude constatar durante as visitas técnicas realizadas. Antes, no entanto, vale dizer que essas visitas contemplaram locais de diferentes categorias institucionais. Sendo assim, foram visitados espaços denominados "Centro Cultural", "Memorial", "Laboratório" e "Museu". Busquei também considerar não apenas Museus
Arqueológicos, mas outras instituições com potencial para a apresentação desses vestígios, como os Museus Históricos, de Ciências, de Geologia e de Paleontologia.

A natureza administrativa também foi diversa. Nesse sentido, foram considerados museus cuja administração é privada, mista e pública. Entre os museus públicos estão os municipais e estaduais. No que se refere à localização geográfica, foram visitados espaços na zona urbana, tanto em áreas centrais, quanto periféricas, e na zona rural. Cabe dizer que essas instituições abrigam uma variedade de acervos: Antropologia e Etnografia, Arqueologia, Artes Visuais, Ciências Naturais e História Natural, Ciência e Tecnologia, História, Imagem e Som, Biblioteconômico, Documental etc.

Retomando a questão das considerações, chamoume muito a atenção o número de museus que não estavam funcionando. Muito embora algumas instituições sejam indicadas como ativas no Cadastro Brasileiro de Museus (2011), no Sistema Estadual de Museus de seus respectivos estados e/ou em mídias sociais, no momento das visitas técnicas as encontrei com as portas fechadas ou completamente desativadas.

Os Museus de Geologia e da Bacia do Paraná, ambos nas dependências da Universidade Estadual de Maringá (UEM), e os Museus Municipais de Rolândia e de Arapongas estavam fechados para reformas e/ou reorganização de exposições. A respeito do primeiro, sua reforma está bastante adiantada, algo que pude constatar em campo. No segundo caso, foi publicada a notícia na página do Facebook - Museu da Bacia do Paraná (MBP) de que a instituição está passando por uma fase de restauração da edificação e do acervo, além dos trabalhos de reformulação da área técnica, com apoio da Caixa e da UEM. ${ }^{6}$ Em Rolândia, o prédio que abriga o Museu Municipal também estava passando por reformas em razão do excesso de chuvas no município e, em Arapongas, a exposição de longa duração estava sendo reformulada no momento da visita técnica e, por esse motivo, a

6. Mais informações disponíveis em: https://WWw. facebook.com/ MuseuDaBaciaDoParanaMBP; Acesso em: jan. 2016. 
instituição não estava aberta à visitação pública, mas, mesmo assim fui recebida e atendida.

Em Colorado, a instituição museal também estava com as portas fechadas. Nesse caso, informações de moradores locais apontaram que o museu foi fechado, com todo o acervo dentro, durante a gestão municipal vigente. 0 espaço está tomado por mato, insetos e sujeira. Tentei por diversas vezes contato, mas não encontrei nenhum funcionário municipal que pudesse esclarecer a si tuação .

Outros museus foram desativados porque os prédios que os abrigavam tiveram problemas estruturais.

Foram os casos encontrados nos municípios paranaenses de Uniflor e Bela Vista do Paraíso. No primeiro, o museu foi desativado porque o prédio que o abrigava foi condenado pela defesa civil.

Ali também funcionava a Biblioteca Municipal, que foi reativada em outro espaço, mas o museu não. Em Bela Vista do Paraíso, o telhado do prédio que abrigava o Museu, a Biblioteca e o Teatro Municipal desabou há 4 anos aproximadamente. Todas as instituições foram desativadas por tempo indeterminado.

No estado de São Paulo, apesar de a Secretaria de Cultura e Turismo de Chavantes informar que - Museu Histórico estava fechado para reformas, não constatei nenhum indicativo de obras no local. 0 espaço parece completamente abandonado. Por fim, o Memorial de Vera Cruz também estava desativado. A instituição havia sido substituída por um Telecentro, um espaço de informática para acesso à internet e uso da população. Segundo informações de funcionários municipais, seu acervo era composto por fotografias que ilustram a história da cidade. Esse acervo foi arquivado na Escola Municipal Monsenhor Florentino Santamaria.

A respeito desse último caso, quero destacar o número de instituições que cederam seus espaços expositivos ou de uso interno para a instalação de centros de informática. Além de Vera Cruz, cuja instituição foi desativada completamente, no município paulista de Gália, mais da metade do espaço expositivo do Museu foi tomada por computadores. Ali, em meio à exposição de objetos históricos, são ofertados cursos de informática para idosos. No período em que ocorrem esses cursos (4 dias da semana, à tarde), o acesso ao Museu fica restrito. No imóvel ainda funcionam a Biblioteca e o Acessa São Paulo. Caso semelhante também foi encontrado no distrito de Varpa, em Tupã. 0 anexo dessa instituição, que antes funcionava como copa para utilização da equipe interna, foi desativado e reformado para abrigar computadores do Programa Acessa São Paulo.

No Paraná, o espaço expositivo do Museu de História e Artes de Ibiporã foi também ocupado, em grande parte, por uma central de informática para uso da população. Nesse caso, o setor expositivo foi desativado e as peças foram encaminhadas para a reserva técnica. Curiosamente, uma das poucas peças que permaneceram no que havia sido o espaço expositivo é uma urna funerária Guarani, que fica exposta ao lado de computadores.

No que se refere aos museus com vestígios arqueológicos indígenas apresentados em exposições de longa duração, os encontrei nos dois estados. Em São Paulo, identifiquei esses vestígios nas seguintes instituições: Museu Ferroviário Regional de Bauru, Centro de Museologia, Antropologia e Arqueologia (CemaArq-Unesp), em Presidente Prudente, Museu Municipal Histórico e Pedagógico de Ourinhos, Museu Histórico Regional de Bastos, Museu e Arquivo Histórico Jornalista José Jorge Júnior, em Paraguaçu Paulista, Centro Regional de Arqueologia Ambiental Mário Neme (Casa da USP), em Piraju, e Museu de Arqueologia de Iepê. Vale dizer que na Casa de Taipa de Assis os vestígios arqueológicos foram retirados de uma das salas expositivas (Anexo "José Giorgi") porque sofreram depredações. No Museu Índia Vanuíre, em Tupã, e no Museu Histórico e Pedagógico de Garça as peças arqueológicas encontravam-se em suas reservas técnicas.

No Paraná, foram identificados vestígios arqueológicos indígenas nas exposições de longa duração do Museu Histórico de Jataizinho, Museu Municipal de Porecatu, Museu Histórico de Sertanópolis, Museu Histórico de Cambé, Museu Histórico de Londrina (UEL), Museu de Geologia e Pedologia (UEL), Laboratório de Arqueologia, 
Etnologia e Etno-história (UEM) e Memorial Kimura, no distrito de Floriano, Maringá. Em Bela Vista do Paraíso também encontrei peças arqueológicas no local onde hoje se encontra o acervo da instituição museal que foi desativada (não estão expostas), e no Museu Histórico e de Artes de Ibiporã há uma urna funerária Guarani no antigo espaço expositivo, como apontado anteriormente.

Gostaria de acrescentar que durante as visitas técnicas também notei as instituições que apresentam objetos etnográficos em suas exposições museais, relacionados às populações indígenas locais, de outras regiões e, até mesmo, de outros países. Os museus visitados que têm essa tipologia de acervo no estado de São Paulo são: Museu e Arquivo Histórico Jornalista José Jorge Júnior, em Paraguaçu Paulista, Museu Municipal de Gália, Museu Histórico e Pedagógico Embaixador Hélio Antônio Scarabôtollo, em Marília, Museu Histórico Regional de Bastos, Museu Histórico de Varpa Janis Erdberges, Museu Histórico e Pedagógico Índia Vanuíre, em Tupã, Museu Municipal Histórico e Pedagógico de Ourinhos e Centro de Museologia, Antropologia e Arqueologia, em Presidente Prudente. Outros museus mantêm os acervos etnográficos em suas reservas técnicas: Museu Ferroviário Regional e Museu Histórico Municipal, ${ }^{7}$ ambos em Bauru, e Museu Histórico e Pedagógico de Garça. Por fim, Motta (2012, p.20) indicou a existência de vestígios arqueológicos e/ou etnográficos no Museu Histórico Adibe Abdo do Rio, em Chavantes, mas não pude ter acesso a essa instituição porque se encontrava fechada.

No Paraná, objetos etnográficos foram identificados nos espaços expositivos das seguintes instituições: Museu Municipal de Porecatu, Museu Histórico de Jataizinho, Museu Dinâmico Interdisciplinar, Laboratório de Arqueologia, Etnologia e Etno-história da UEM, Museu Histórico Unicesumar e Memorial Kimura, sendo estes quatro últimos na região de Maringá. O Museu Histórico de Londrina mantém o acervo etnográfico em sua reserva técnica.

7. O Museu Histórico Municipal de Bauru não tem área expositiva, somente reserva técnica.
É imprescindível ressaltar, no entanto, que a quantidade e a variedade de vestígios arqueológicos e etnográficos associados aos indígenas são bastante diversas entre as instituições museais. Nesse sentido, considerei museus que têm desde uma peça até parte de uma coleção ou coleções expostas.

A respeito da Arqueologia em exposições museais, foram poucas as instituições que fizeram referência ao assunto. Entre São Paulo e Paraná são: Museu de Arqueologia de Iepê, Centro de Museologia, Antropologia e Arqueologia, em Presidente Prudente, Centro Regional de Arqueologia Ambiental Mário Neme, em Piraju, Museu Histórico de Cambé e Museu Histórico de Londrina. A maneira de apresentar ou fazer referências à Arqueologia variou. Ora a Arqueologia foi destacada como ciência interdisciplinar, ora como método de campo, ora como nome de seção expositiva etc.

\section{Considerações finais}

Neste capítulo apresentei alguns dados preliminares de minha pesquisa de pósdoutoramento, cuja proposta é estudar a Arqueologia e o patrimônio arqueológico indígena em exposições museais no centro-oeste de São Paulo e no norte do Paraná. Como resultado, está sendo elaborado um banco de dados digital e, com essa plataforma finalizada, será possível compreender melhor os tipos de vestígios arqueológicos que cada instituição apresenta, a procedência, os espaços ocupados dentro das exposições e sua localização, a forma em que estão acomodados, como são apresentados, quais os recursos expográficos usados junto aos objetos, como colaboram com o recorte temático proposto etc. Toda essa análise ajudará a pensar certos padrões em exposições e museus. E, mais do que isso, se os objetos arqueológicos indígenas são elementos comuns nessas propostas comunicacionais que têm função essencial na memória coletiva.

Como a grande maioria das instituições pesquisadas são de natureza administrava municipal, quero encerrar este texto com algumas 
reflexões sobre esses museus. ${ }^{8}$ De modo geral, pude notar com o estudo do meio que os museus municipais são, em sua maioria, instituições cuidadas por uma pessoa só ou por um pequeno grupo de pessoas. Essas instituições sofrem com a ausência de recursos humanos e financeiros, de colaboradores especializados, de planejamento institucional, de gestão continuada, de políticas públicas e de legislação eficazes.

Por essas ausências, caracterizam-se como espaços contraditórios. De um lado são ricas no acervo que abrigam e, de outro, pobres no orçamento e nas condições com as quais trabalham (Bloise, 2011, p.47), o que pode incorrer em conservação precária do acervo, em propostas comunicacionais inadequadas (Fabbri, 2011, p.54) e na consolidação de uma imagem de fragilidade ou passividade no município onde se localizam. Talvez por isso, um número considerável de museus municipais foi desativado ou teve seus espaços cedidos para outras funções, algo que afeta não somente a pesquisa, a salvaguarda e a comunicação do patrimônio arqueológico, mas também todas as áreas científicas que estão relacionadas ao universo museal.

\section{Referências}

BLOISE, Ana Silvia. O desafio da gestão dos pequenos museus. In: SISTEMA Estadual de Museus de São Paulo. Museus: o que são, para que servem? Brodowski, 2011. p.43-49. Disponível em: http://WWw.sisemsp.org.br/images/ Publicacoes/Museus_o_que_sao_para_que_servem. pdf; Acesso em: jan. 2016.

CONDURU, Roberto. Exposições como discurso. In: GRANATO, Marcus; SANTOS, Cláudia Penha dos. Discutindo exposições: conceito, construção e avaliação. Rio de Janeiro: Mast, 2006. p.61-68.

CURY, Marília X. Análise de Exposições Antropológicas - Subsídio para uma Crítica. In: ENCONTRO NACIONAL DE PESQUISA EM CIÊNCIA DA INFORMAÇÃO (ENANCIB), 13., Rio de Janeiro, 2012. p.1-20. Exposição: concepção, montagem e avaliação. São Paulo: Annablume, 2006.

- Reflexões sobre a importância pública das exposições antropológicas. Revista do Museu de Arqueologia e Etnologia, São Paulo, Suplemento 7, p. 77-87, 2008 .

DAVALLON, Jean. Comunicação e sociedade: pensar a concepção da exposição. In: BENCHETRIT, Sarah F.; BEZERRA, Rafael Z.; MAGALAHÃES, Aline M. (Org.) Museu e comunicação: exposição como objeto de estudo. Rio de Janeiro: Museu Histórico Nacional, 2010. p.17-34.

FABBRI, Angelica. Museus: 0 que são? Para que servem? In: SISTEMA Estadual de Museus de São Paulo. Museus: o que são, para que servem? Brodowski, 2011. p.50-61. Disponível em: http://www.sisemsp.org.br/images/Publicacoes/ Museus_o_que_sao_para_que_servem.pdf; Acesso em: jan. $201 \overline{6}$.

GRANATO, Marcus. Apresentação. In: GRANATO, Marcus; SANTOS, Cláudia P. dos. Discutindo exposições: conceito, construção e avaliação. Rio de Janeiro: Mast, 2006. p.4-6.

LIMA, Leilane P. de. A Arqueologia e os indígenas na escola: um estudo de caso em Londrina-PR. Tese (Doutorado em Arqueologia) - Museu de Arqueologia e Etnologia, Universidade de São Paulo. São Paulo, 2014.

. ; FRANCISCO, Gilberto da S. Exposição, comunicação e alteridade. In: LIMA, Ângela Maria de S. et al. (Org.) Diálogos entre as licenciaturas e a educação básica: aproximações e desafios. Londrina: Ed. UEL, 2013. p.91-104. .; PIRES, João Davi A. Os restos de um museu que não "morreu": o caso do Museu Municipal Gecy Fonseca, Bela Vista do Paraíso-PR. In: SEMINÁRIO INTERNACIONAL EM MEMÓRIA SOCIAL, 2., Rio de Janeiro: UniRio, 2016. Anais... Disponível em: http:// seminariosmemoriasocial.pro.br/anais/; Acesso em: mar. 2016.

MORAES, Julia. L. N. Faces e interfaces da Museologia: um olhar interdisciplinar sobre exposições museológicas. Dissertação (Mestrado em Ciência da Informação) - Instituto Brasileiro de Informação em Ciência e Tecnologia, Universidade Federal Fluminense. Niterói, 2008. 
MOTTA, Renata Vieira da. Acervos etnológicos em museus paulistas. In: CURY, Marília X.; VASCONCELLOS, Camilo de M.; ORTIZ, Joana M. (Org.) Questões indígenas e museus: debates e possibilidades. Brodowski: ACAM Portinari; São Paulo: Museu de Arqueologia e Etnologia da Universidade de São Paulo; Secretaria de Estado da Cultura, 2012. p.20-27. (Coleção Museu Aberto).

ROQUE, Maria Isabel R. Comunicação no museu. In: BENCHETRIT, Sarah F.; BEZERRA, Rafael Z.; MAGALAHÃES, Aline M. (Org.) Museu e comunicação: exposição como objeto de estudo. Rio de Janeiro: Museu Histórico Nacional, 2010. p. 47-68.

SCHEINER, Tereza C. M. Comunicação - educação - exposição: novos saberes, novos sentidos. Semiosfera (UFRJ), Rio de Janeiro, v.4-5, 2003.

* Leilane Patricia de Lima é mestre e doutora em Arqueologia pelo Museu de Arqueologia e Etnologia da Universidade de São Paulo (MAE-USP). Atualmente é pesquisadora de pós-doutorado no Programa de Pós-Graduação Interunidades em Museologia da Universidade de São Paulo (PPGMus-USP) com sede no MAE-USP. 


\title{
A Curadoria da Coleção Asurini do Xingu no Wel tmuseum Wien
}

\author{
Fabíola Andréa Silva* \\ Museu de Arqueologia e Etnologia, Universidade de São Paulo (MAE-USP)
}

Os Asurini do Xingu são falantes de uma língua da família Tupi-Guarani. Eles se autodenominam awa ete, "gente (humanos) de verdade", mas ao mesmo tempo, adotaram o nome Asurini que lhes foi atribuído desde, pelo menos, o final do século XIX, devido à pintura vermelha dos seus cabelos e corpos produzida com urucum. A definição específica de Asurini do Xingu surgiu após o primeiro contato oficial, no início dos anos 1970, para distingui-los dos Asurini do Trocará ou Asurini do Tocantins, também conhecidos como AkuáwaAsurini ou, simplesmente, Akuáwa, que estiveram em evidência desde a década de 1960. Atualmente, os Asurini do Xingu vivem na T.I. Koatinemo, na Amazônia Oriental, nas aldeias Kwatinemu e Itaaka, às margens do rio Xingu, no Pará. Essa terra foi declarada de posse indígena, na década de 1990, e tem 387.834 hectares distribuídos pelos municípios de Altamira e Senador José Porfírio (Mapa 1).

\section{A ocupação territorial dos Asurini} na região do baixo-médio rio Xingu

A história sobre a ocupação territorial desse povo na região do baixo-médio Xingu foi narrada por Anton Lukesch (1976), Berta Ribeiro (1982) e Regina Polo Müller (1990) pela pesquisa de fontes históricas e orais, desde os anos 1970. Nos últimos anos, ela vem sendo retomada por mim mediante pesquisa arqueológica colaborativa, que tem o objetivo de compreender a história de ocupação da T.I. Koatinemo a partir da memória dos Asurini e da localização dos seus antigos assentamentos às margens dos igarapés Piranhaquara e Ipiaçava (Silva et al., 2011; Silva, 2013).

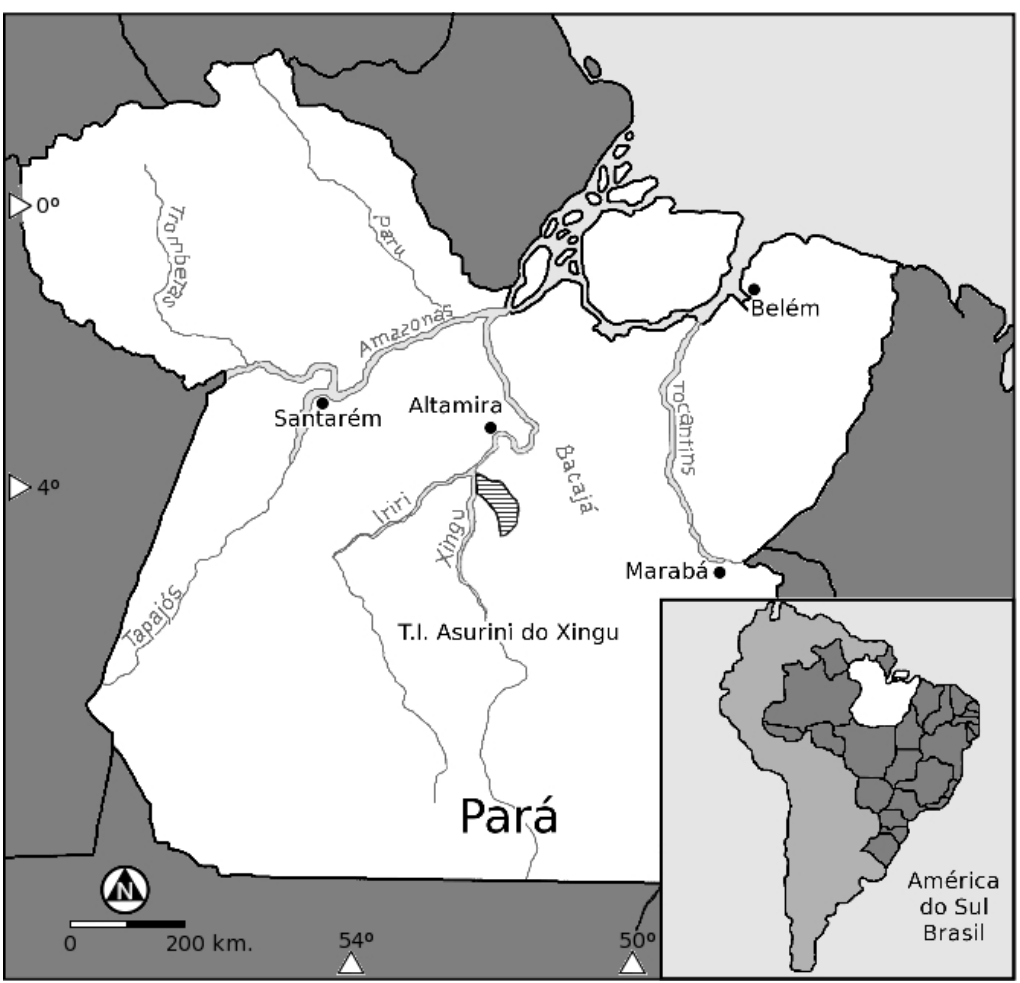

Mapa 1 - Mapa de localização da Terra Indígena Koatinemo.

A memória e o conhecimento dos mais velhos sobre a sua trajetória nessas terras do médiobaixo curso do rio Xingu abrangem em torno de cinco décadas antes do seu encontro com a expedição liderada por Anton Lukesch, em maio de 1971. Segundo eles, sua ocupação definitiva, na década de 1970, da área que abrange a T.I Koatinemo, especialmente nas proximidades do igarapé Ipiaçava, ocorreu após um longo ciclo de mobilidade que, em grande parte, foi motivada pelos ataques de populações indígenas inimigas. 
A lembrança mais antiga dos Asurini os leva ao rio Bacajá, que parece ter sido uma área por eles ocupada desde a segunda metade do século XIX. Segundo as informações históricas e orais eles teriam se deslocado dessa região para as proximidades do rio Xingu em razão das pressões dos extrativistas regionais e dos ataques dos Gorotire-Kayapó. 0 seu assentamento na região dos igarapés Piranhaquara e Ipiaçava, afluentes do rio Xingu, provavelmente aconteceu entre o final da década de 1920 e o início da seguinte, com o estabelecimento de várias aldeias, e perdurou até eles serem atacados pelos XikrinKayapó, por volta dos anos 1950, e forçados a se deslocar para a região do igarapé Ipixuna, na atual T.I. Araweté. Permaneceram nessa região até serem expulsos pelos Araweté que para lá se deslocaram, no final da década de 1950, empurrados pelos Xikrin-Kayapó e Parakanã. Os Asurini então retornaram ao igarapé Piranhaquara, onde permaneceram até serem novamente atacados pelos Xikrin-Kayapó e Araweté, na década de 1960, quando então se assentaram na região do igarapé Ipiaçava (Mapa 2). Diante da situação de perigo iminente e já debilitados pelas perdas populacionais que vinham sofrendo ao longo dos anos, os Asurini finalmente buscaram o contato com os brancos, no início da década de 1970, acreditando ser essa a única solução para evitar o seu extermínio. Portanto, as narrativas dos Asurini descrevem a região entre os rios Bacajá e Xingu e, mais especificamente, do alto curso dos igarapés Ipiaçava, Piranhaquara e Ipixuna como o território por eles ocupado no período pré e pós-contato, corroborando as informações históricas. Trata-se de um período que na sua memória se caracteriza, em grande parte, por fugas, belicosidade com outros povos e morte de seus entes queridos (Silva; Noelli, 2015).

No ano de 1971, quando os Asurini do Xingu foram contatados oficialmente, a maioria deles estava dispersa em pequenos grupos, ocupando acampamentos espalhados pela região do alto curso do igarapé Ipiaçava e a aldeia denominada Taiuviaka, que ficava a 4 quilômetros da margem direita do igarapé. Logo após o contato, a população Asurini fixou-se em uma única aldeia denominada Akapepugĩ , às margens do igarapé Ipiaçava. Esse assentamento perdurou apenas até 1972, quando passaram a ocupar a antiga aldeia Kwatinemu, nesse mesmo igarapé, onde permaneceram até 1985, quando se transferiram para as margens do rio Xingu, primeiramente para a aldeia Awatikirera, que foi abandonada em pouco tempo, e em seguida para a atual aldeia Kwatinemu (Müller, 1990, p.35-40). Em 2011, depois de 40 anos de contato, eles novamente se dispersaram, e parte da atual população Asurini estabeleceu uma nova aldeia no rio Xingu, denominada Itaaka, no extremo norte da T.I. Koatinemo (Silva, 2013).

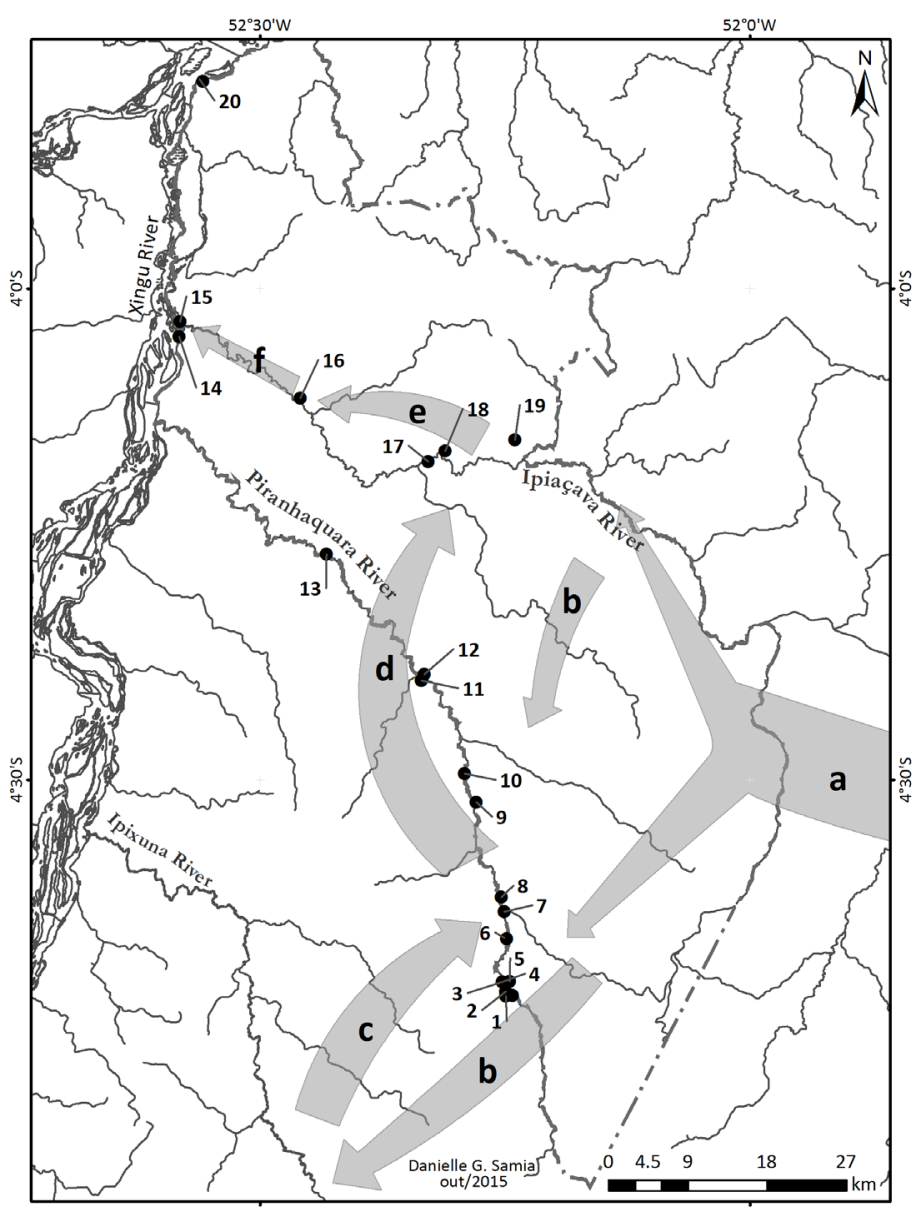

Mapa 2 - Deslocamentos dos Asurini do Xingu e sítios arqueológicos (século XX): (1) final da década de 1920; (2) década de 1950; (3) década de 1960; (4) década de 1960; (5) 1972; (6) 1982. Sítios arqueológicos: (1) Myiryna; (2) Itapytiuu; (3) Myiryna II; (4) Cachoeira Uiasimbé; (5) Uirasimbé; (6) Jaumapina; (7) Tapipiri; (8) Ipukui; (9) Itatatu; (10) Araí'pijá; (11) Kwatinemu; (12) Mariata'Juapijá; (13) Itajuara; (14) Kwatinemu; (15) Avatikirera; (16) Kwatinemu Velho; (17) Itapemuu; (18) Akapepugi; (19) Taiuviaka; (20) Itaaka. 
Desde 2008, a pedido dos Asurini, tenho desenvolvido uma pesquisa etnoarqueológica que visa compreender o modo e as vicissitudes da ocupação Asurini na T.I. Koatinemo ao longo do tempo. Os objetivos específicos desta pesquisa são: 1) localizar e georreferenciar os antigos e atuais locais de ocupação dos Asurini na T.I. Koatinemo; 2) vistoriar algumas partes da T.I. que há muitos anos não eram visitadas e que podem estar sendo invadidas por grileiros, madeireiros, posseiros etc.; 3) documentar os relatos autobiográficos dos anciãos sobre a sua experiência com o evento do contato e sobre as suas vivências nos diferentes lugares por eles ocupados na T.I. Koatinemo; 4) fazer um levantamento do potencial arqueológico dessa área do baixo-médio rio Xingu. Com a participação dos Asurini já foram realizadas duas expedições às áreas de localização dos seus antigos assentamentos (2010 e 2013), tendo sido localizadas nove antigas aldeias Asurini e outros dez sítios arqueológicos (Mapa 2). Esses dias passados no interior da floresta desencadearam um profundo diálogo entre as novas e velhas gerações, entre o passado e o presente, e, ao mesmo tempo, possibilitou a eles (re)viver e (re) elaborar suas memórias sobre a sua trajetória nessas terras do Xingu.

\section{A coleção Asurini do Xingu no Wel tmuseum}

Em novembro de 2013, participando do Workshop Tropical Lowlands Indigenous in European Collections patrocinado pelo Wolkenkunde Museum de Leiden, na Holanda, fui informada de que o Weltmuseum de Viena guardava em seu acervo uma coleção formada por Anton Lukesh de objetos dos Asurini do Xingu. Tratava-se de objetos que foram por ele coletados, no ano de 1971, durante os dias em que permaneceu junto aos Asurini no igarapé Ipiaçava. Essa coleção nunca foi estudada e os Asurini não sabiam da sua existência, pois jamais foram informados sobre o paradeiro dos objetos que haviam sido levados por Lukesh naquela ocasião. Diante disso, resolvi realizar um estágio de pesquisa no Weltmuseum, em Viena, a fim de documentar e analisar essa coleção, pois ela é o registro material daquele encontro, e a importância desses objetos reside no fato de que são parte da história desse povo Tupi amazônico. São a materialização de aspectos do seu modo de vida e, ao mesmo tempo, testemunhos dos processos de transformação que os Asurini vêm passando desde o contato (Foto 1 ).

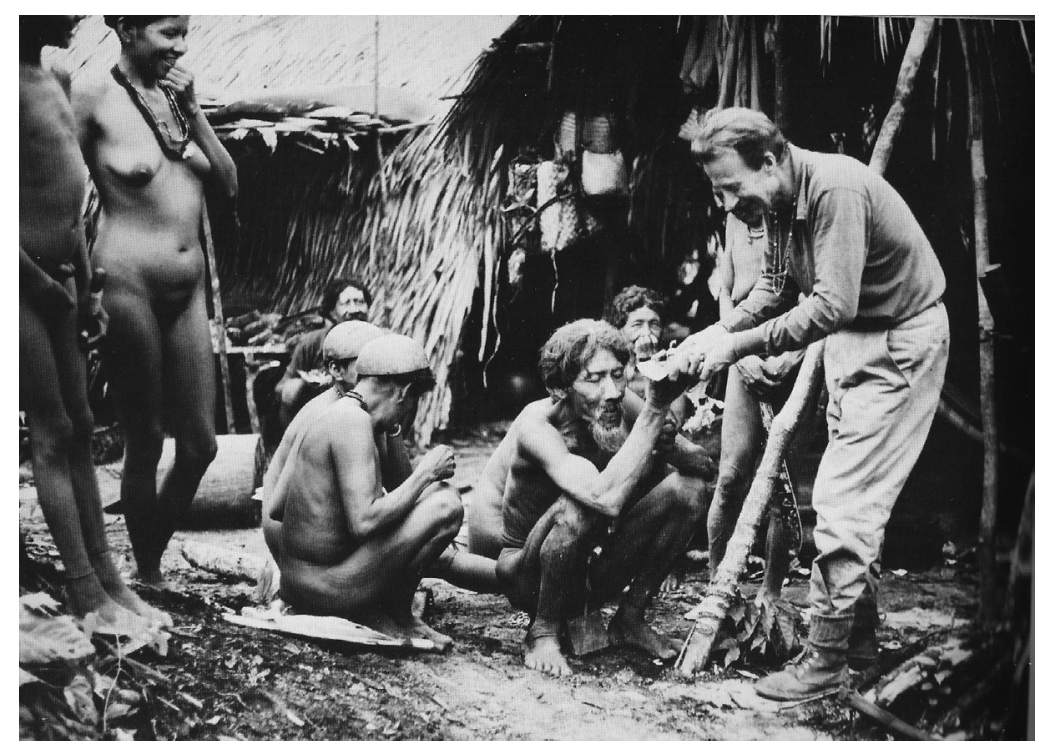

Foto 1 - Anton Lukesh entre os Asurini do Xingu (1971) Fonte: Lukesh, 1976, p.50.

Uma coleção etnográfica pode ser vista como um documento que se presta a muitas possibilidades de leitura. Ela é formada a partir de uma determinada visão do coletor, num contexto complexo de interação com os produtores, e num momento histórico particular. Ao mesmo tempo, é constituída por objetos que possuem uma história e uma realidade próprias, cujos significados são múltiplos, e que não se reduzem, evidentemente, à lógica institucional dos museus e ao sistema de classificação museológica. A percepção dessas diferentes dimensões de significado possibilita uma análise em diferentes níveis e a partir de múltiplos olhares (Silva; Gordon, 2011).

Atualmente, tem havido um crescente reconhecimento da importância de se trabalhar com os objetos etnográficos em museus, na medida em que se reconhece que eles permitem acessar 
diferentes aspectos da vida social, do universo simbólico e da percepção estética daqueles que os produziram (Ribeiro; Van Velthem, 1998; Barcelos Neto, 2004; Silva; Gordon, 2013). Nos últimos anos, os estudos de coleções etnográficas também têm contemplado a discussão sobre os coletores e suas motivações, e sobre o contexto histórico em que uma determinada coleção foi formada e posteriormente conservada institucionalmente, bem como sobre o papel dos curadores nos museus. Nesse caso, os objetos são acrescidos de outras camadas de significado, enriquecendo nossas possibilidades de leitura e pesquisa a seu respeito (por exemplo: Grupioni, 1998; Nash; Feinman, 2003; Hallam, 2000; Shelton, 2000 ; Belk, 1999; Formaneck, 1999). No campo da antropologia, o interesse renovado na história e na cultura material coloca mais uma vez em cena a discussão sobre as relações entre etnografia e pesquisa documental. Ao mesmo tempo, os museus que outrora já foram identificados e criticados como instrumentos do colonialismo ocidental vêm sendo percebidos, cada vez mais, como locais de produção de conhecimento e um possível espaço de diálogo intercultural (Silva; Gordon, 2013).

O trabalho de curadoria que iniciei com a coleção Asurini no Weltmuseum pretende contribuir com esse esforço atual de reincorporar as coleções etnográficas na pesquisa antropológica em geral e nos estudos de cultura material em particular. Além disso, abriu a possibilidade de tentar promover o encontro dos Asurini do Xingu com os seus objetos. A curadora das Coleções Etnográficas Sul-Americanas, Cláudia Augustat, pretende realizar uma exposição desses objetos no Weltmuseum, em 2018. No entanto, ela pretende fazê-lo a partir de uma curadoria partilhada com os Asurini do Xingu. Assim, no próximo ano, iniciaremos um projeto de pesquisa com o Weltmuseum, que pretende promover a repatriação virtual dos objetos e identificar o interesse dos Asurini em realizar essa curadoria partilhada.

Durante o estágio de pesquisa junto ao Weltmuseum de Viena fotografei e registrei as características físicas dos objetos da coleção Asurini, bem como consultei as fichas catalográficas a fim de realizar uma análise preliminar: 1) agrupar os objetos em diferentes conjuntos artefatuais conforme as especificidades das técnicas de produção e matérias-primas (por exemplo: cerâmica, trançados, instrumentos musicais, utensílios e ferramentas, plumária, indumentária, armas); 2) dividir os objetos em categorias e tipos (por exemplo: adornos corporais, vasilhas cerâmicas, cestos, arcos, flechas etc.) e descrevê-los em termos de suas características morfológicas, técnicas e de matéria-prima; 3) descrever o uso (funcionalidade e gênero) dos objetos; 4) complementar a documentação museográfica sobre os objetos no Wel tmuseum.

A coleção de objetos dos Asurini do Xingu apresenta 86 objetos catalogados e bem conservados: adornos corporais feitos de penas (cocares, testeiras), de fibras de algodão (testeiras), de dentes e ossos de animais (colares, braceletes), de miçangas e alumínio (colares), de sementes (colares, braceletes); instrumentos musicais feitos de taquara (buzinas e flautas), de cabaça (maracás), de palha (apito), de osso (flautas); armas feitas de estipe de palmeira (arcos), de bambu (hastes e pontas de flecha), de madeira (pontas de flecha), de metal (pontas de flecha); utensílios e ferramentas em osso (escarificadores e furadores), em cerâmica (vasilhas), em unhas de animais (escarificador), em madeira (pentes, raspadores, pau de fogo, fuso, colher, banco), em pedra (machado encabado) e recipientes de cabaça; trançados (cestos vasiformes e estojiformes, peneiras, abanador); exemplares de matéria-prima (fios de algodão, casca de tauari, folhas de petima (tabaco), sementes, fibras vegetais).

Ela apresenta objetos extremamente interessantes para se pensar a conjuntura na qual estavam vivendo os Asurini, no início dos anos 1970, bem como para evidenciar os seus processos de transformação cultural e afirmação de identidade, desde o contato: 
1. Esses objetos remetem a aspectos da vida cotidiana e ritual dos Asurini e alguns são desconhecidos para mim, mesmo depois de 20 anos estudando a cultura material desse povo; (Foto 2)

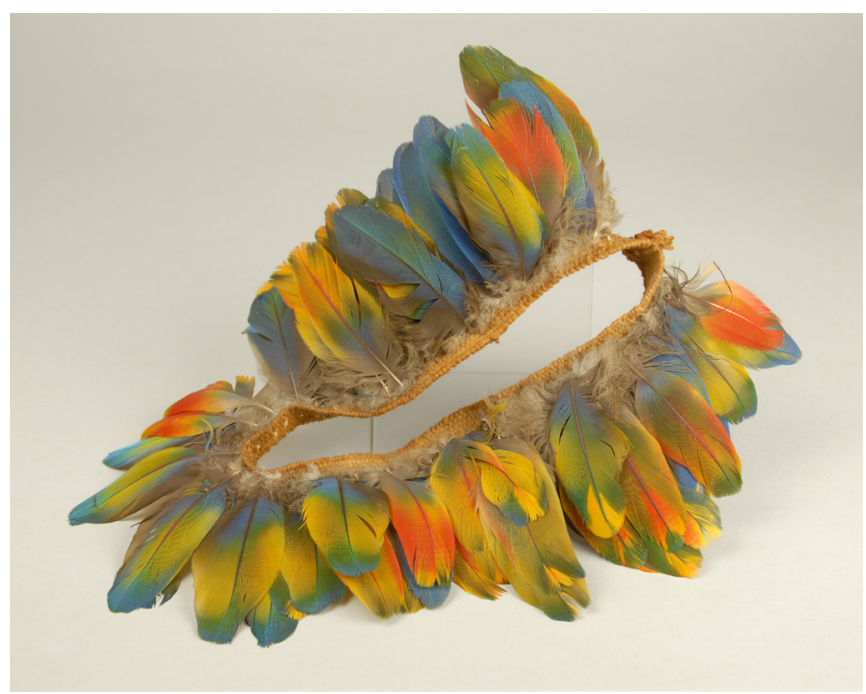

Foto 2 - Adorno de cabeça de uso ritual (atirau/moakara turiva). Acervo Weltmuseum. Fonte: Weltmuseum.

2. Quando se comparam alguns objetos desta coleção com a produção atual dos Asurini, vemos que alguns deles evidenciam o usual apuro estético e técnico pelo qual esse povo é reconhecido, desde o contato; (Foto 3 )

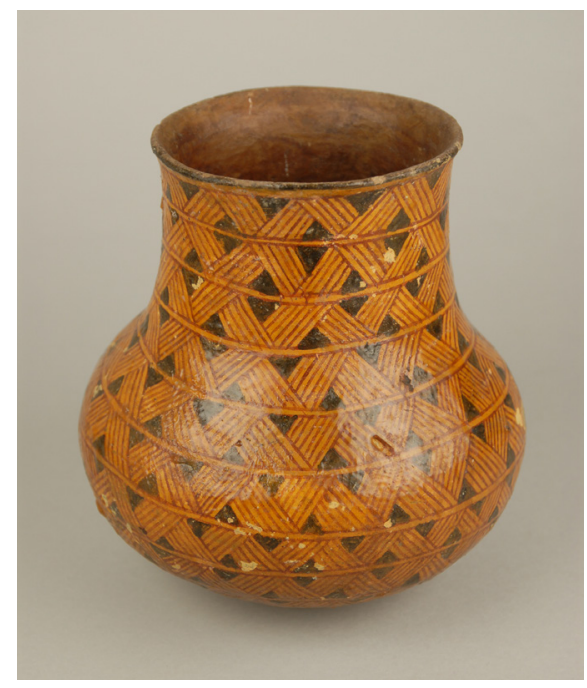

Foto 3 - Vasilha cerâmica para guardar mel e líquidos (japu) Acervo Weltmuseum. Fonte: Weltmuseum.
3. Alguns instrumentos (por exemplo, paus de fogo, ferramentas em osso e dentes de animais) não são mais usados atualmente, e isso é exemplar para se pensar a rapidez com que os Asurini se apropriaram das tecnologias ocidentais, depois do contato; (Foto 4)

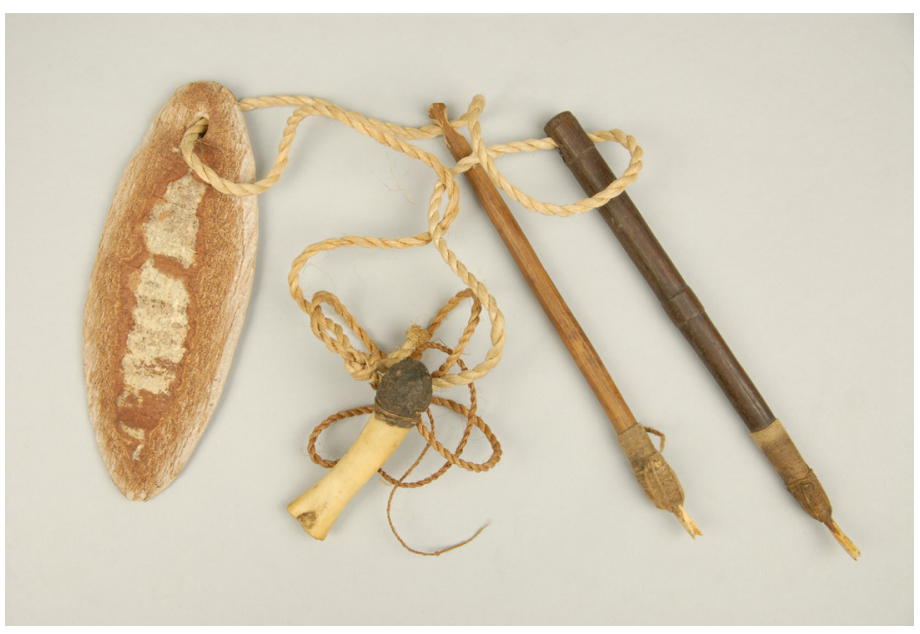

Foto 4 - Instrumentos para alisar, raspar e furar (takype e merirãña). Acervo Weltmuseum. Fonte: Weltmuseum.

4. Existem adornos corporais (por exemplo, colares) feitos com matérias-primas industrializadas, o que revela o quanto eles estavam em contato com a população local há muito tempo e o quanto eram criativos em transformar sua cultura material; (Foto 5)

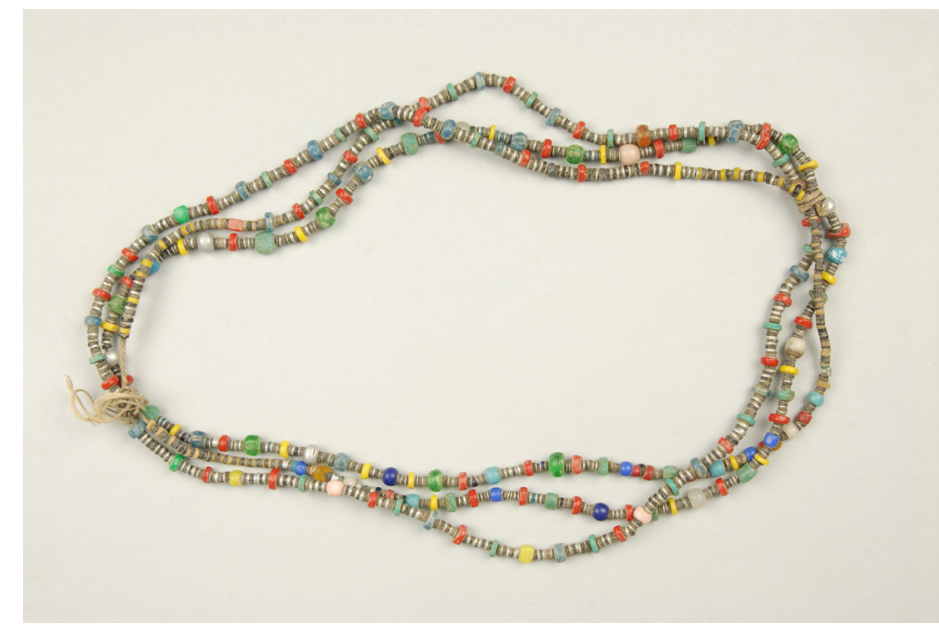

Foto 5 - Colares feitos de miçangas e contas de alumínio (mumbaka). Acervo Weltmuseum. Fonte: Weltmuseum. 
5. Esses objetos também revelam a capacidade de resistência desse povo diante da conjuntura na qual estavam inseridos. A região do baixomédio Xingu era considerada uma das principais fronteiras de expansão capitalista, nos anos 1970.

Cabe dizer que todas estas constatações deverão ser retomadas junto aos Asurini, na continuidade de um trabalho de curadoria partilhada desta coleção.

\section{Conclusão}

Várias populações indígenas não têm conhecimento de que vários objetos produzidos por seus antepassados estão armazenados em acervos de instituições museológicas no mundo todo. Na atualidade, informar os povos indígenas sobre os seus patrimônios culturais armazenados nas reservas técnicas dos museus tem sido um dos principais compromissos éticos dessas instituições. São essas ações que permitem aos povos indígenas requererem procedimentos curatoriais mais participativos, devolvendo a eles a agência sobre seus bens culturais quase sempre espoliados pelas investidas colonialistas (Peers; Brown, 2003; Marstine, 2011).

Várias experiências curatoriais têm demonstrado que ao interagirem com os objetos depositados em museus, as populações indígenas deixam claro que eles não remetem a um passado congelado e nostálgico, visto que continuam vivos no presente desses povos e remetem a histórias, mitos, canções, danças, pessoas e acontecimentos. São percebidos como objetos fundamentais nos seus processos de transmissão de saberes e produção da memória. Nesse sentido, o museu que "guarda" esses objetos é percebido como uma exterioridade a partir da qual eles também podem se autorrepresentar e afirmar a sua identidade. 0 que ele "guarda" não são os objetos em si, mas os saberes e as experiências neles materializados (Cruikshank, 1998; Nicks, 2003; Fienup-Riordan, 2003; Silva; Gordon, 2011).

Na medida em que os movimentos em defesa dos patrimônios materiais e imateriais indígenas ganham mais espaço, é premente a realização de pesquisas para documentar e registrar as manifestações culturais dessas populações (Gallois, 2006). Além disso, o processo de transformação cultural que está sendo vivenciado por essas populações também torna a manutenção de acervos etnográficos, nos museus, uma tarefa importante para os profissionais inseridos nesses contextos e para as próprias populações. Diferentemente das perspectivas colonialista e conservacionista - nas quais esses acervos eram vistos como índices da expansão ocidental pelo mundo e como testemunhos de modos de vida de populações fadadas ao desaparecimento -, eles agora servem como aportes das memórias e dos saberes indígenas.

Várias populações indígenas têm procurado os museus para (re)encontrar objetos e técnicas por vezes esquecidos ou abandonados no seu cotidiano, mas cujos significados ainda permanecem em outros objetos e em outros modos de fazer. Portanto, os museus têm papel importante, pois os acervos que eles guardam são constituídos de objetos potencialmente vivos e, enquanto existirem como realidade material, seus significados poderão ser sempre reelaborados e atualizados pelas populações indígenas.

\section{Agradecimentos}

Aos Asurini do Xingu pelos seus ensinamentos e paciência ao longo dos anos. À Claudia Augustat, curadora do acervo de etnologia americana do Weltmuseum e sua equipe, pela calorosa recepção. Ao CNPq pelo auxílio financeiro para a realização da curadoria. À Fapesp pelo auxílio financeiro para a realização das pesquisas na T.I. Koatinemo.

\section{Referências}

BARCELOS NETO, Aristóteles. Com os Indios Wauja: objectos e personagens de uma coleção amazônica. Lisboa: Museu Nacional de Etnologia, 2004.

BELK, Russell W. Collectors and Collecting. In: PEARCE, Susan M. (Ed.) Interpreting Objects and 
Collections. London: Routledge, 1999. p.317326.

CRUIKSHANK, Julie. The social life of stories: Narrative and knowledge in the Yukon territory. Lincoln: Nebraska University Press, 1998.

FIENUP-RIORDAN, Ann. Yup'ik Elders in museums: Fieldwork turned on its head. In: PEERS, Laura; BROWN, Alison K. (Ed.) Museums and Source Communities: A Routledge reader. London: Routledge, 2003. p.28-41.

FORMANEK, Ruth. Why they Collect: Collectors Reveal their Motivations. In: PEARCE, Susan M. (Ed.) Interpreting Objects and Collections. London: Routledge, 1999. p.327-335.

GALLOIS, Dominique T. Patrimônio cultural imaterial e povos indígenas. São Paulo: Iepé, 2006.

GRUPIONI, Luís Donisete B. Coleções e expedições vigiadas: os etnólogos no Conselho de Fiscalização das Expedições Artísticas e Científicas no Brasil. São Paulo: Hucitec; Anpocs, 1998.

HALLAM, Elizabeth. Texts, Objects and "Otherness": Problems of Historical Process in Writing and Displaying Cultures. In: HALLAM, Elizabeth; STREET, Brian V. (Ed.) Cultural Encounters: Representing “Otherness”. London: Routledge, 2000 .

LUKESH, Anton. Bearded Indians of the Tropical Forest: The Assurinis of the Ipiaçaba. Graz: Akademische Druck- und Verlags-Anstalt, 1976.

MARSTINE, Janet. The contingent nature of the new museum ethics. In: MARSTINE, Janet (Ed.) Redefining ethics for the twenty-first-century museum (The Routledge Companion to Museums Ethics). London: Routledge, 2011. p.3-25.

MüLLER, Regina. Os Asurini do Xingu (História e Arte). Campinas: Ed. Unicamp, 1990.

NASH, Stephen E.; FEINMAN, Gary M. Curators, Collections, and Contexts: Anthropology at the Filed Museum, 1893-2002. Fieldiana. Anthropology, N.S., n.36, 2003.

NICKS, Trudy. Introduction. In: PEERS, Laura; BROWN, Alison K. (Ed.) Museums and Source Communities: A Routledge reader. London: Routledge, 2003. p.19-27.

PEERS, Laura; BROWN, Alison K. (Ed.) Museums and
Source Communities: A Routledge reader. London: Routledge, 2003.

RIBEIRO, Berta. A Oleira e a Tecelã. Revista de Antropologia, v.26, p.25-61, 1982. .; VAN VELTHEM, Lúcia H. Coleções

etnográficas: documentos materiais para história indígena e a etnologia. In: CUNHA, Manuela C. da (Org.) História dos Índios no Brasil. São Paulo: Companhia das Letras, 1998. p.103-112.

SHELTON, Anthony Alan. Museum Ethnography: an Imperial Science. In: HALLAM, Elizabeth; STREET, Brian V. (Ed.) Cultural Encounters: Representing "Otherness". London: Routledge, 2000.

SILVA, Fabíola A. Território, lugares e memória dos Asurini do Xingu. Revista de Arqueologia, v.26, n.1, p.28-41, 2013.

.; BESPALEZ, Eduardo; STUCHI, Francisco. Arqueologia colaborativa na Amazônia: Terra Indígena Koatinemu, Rio Xingu, Pará. Amazônica. Revista de Antropologia, v.3, n.1, p.32-59, 2011.

.; GORDON, Cesar. Anthropology in the museum: reflections on the curatorship of Xikrin collection. Vibrant, v.10, p.425-468, 2013.

.; GORDON, Cesar (Ed.); SOUZA e SILVA,

Wagner (Fotografias). Xikrin: uma coleção etnográfica. São Paulo: Edusp, 2011.

; NOELLI, F. S. Mobility and territorial occupation of the Asurini do Xingu, Pará, Brazil: An archaeology of the recent past in the Amazon. Latin American Antiquity, v.26, n.4, p.493-511, 2015.

\footnotetext{
* Fabíola Andréa Silva é graduada em História pela Universidade do Vale do Rio dos Sinos (1988), mestre em Antropologia Social pela Universidade Federal do Rio Grande do Sul (1992), doutora em Ciências (Antropologia Social) pela Universidade de São Paulo (2000) e pósdoutorado em Arqueologia pela Universidade de São Paulo $(2002)$. Atualmente é professora e pesquisadora no Museu de Arqueologia e Etnologia da Universidade de São Paulo (MAEUSP). Tem experiência na área de Arqueologia e Antropologia, com ênfase em Etnoarqueologia e Etnologia Indígena, atuando nos seguintes temas: Cultura Material, Formação do Registro Arqueológico, Curadoria de Coleções Etnográficas, Arqueologia em Terra Indígena. Realiza pesquisa Etnográfica e Etnoarqueológica com os Povos Asurini do Xingu, KayapóXikrin, Terena e Kayabi.
} 


\title{
A fotorreportagem como projeto etnocida: o caso da índia Diacuí na revista 0 Cruzeiro
}

\author{
Helouise Costa* \\ Museu de Arte Contemporânea, Universidade de São Paulo (MAC-USP)
}

A revista 0 Cruzeiro publicou entre os anos de 1952 e 1953 uma série de fotorreportagens sobre a relação do sertanista Ayres Câmara Cunha com a índia Diacuí. A revista ajudou Ayres a obter autorização para o seu casamento civil e religioso com a índia e teve participação ativa no processo de aculturação a que ela foi submetida. A série abrange desde o noivado de Diacuí com o homem branco, passando por sua estadia no Rio de Janeiro para o casamento e seu retorno ao Xingu, até o desfecho trágico de sua história. 0 foco de nossa análise neste artigo é o modo de construção do discurso jornalístico da fotorreportagem, em sua estrutura narrativa própria, expandida aqui por um tipo de seriação que muito se aproxima do modelo da novela. ${ }^{1}$

Uma avaliação temática das fotorreportagens publicadas na revista o Cruzeiro ao longo das décadas de 1940 e 1950 nos permite identificar o papel exercido pela imagem do Outro nos meios de comunicação de massa então emergentes no Brasil. A alteridade estabelecia o contraponto necessário para a construção de representações sociais que se pretendiam hegemônicas e funcionavam como exemplos normativos. Naquele momento o Outro podia se materializar em diferentes tipos considerados desviantes - no doente, no louco, no presidiário, no negro, no índio, no malandro,

1. Este artigo, publicado inicialmente na revista Studium do Instituto de Artes da Unicamp, resultou de uma comunicação apresentada no XXVII Congresso Brasileiro de Ciências da Comunicação da Intercom em 2004. Para esta coletânea foram realizadas correções e atualizações pontuais que não modificaram a estrutura e os argumentos principais do artigo original. no comunista e no estrangeiro -, todos eles transformados em personagens de fotorreportagens ilustradas de cunho sensacionalista. ${ }^{2} \mathrm{~A}$ imagem do índio, em particular, foi explorada sistematicamente nesse contexto.

Já tivemos oportunidade de demonstrar que, subjacente ao conjunto de fotorreportagens de 0 Cruzeiro sobre os índios brasileiros, pode-se apreender um verdadeiro projeto de aculturação para as nações indígenas (ver Costa, 1994). 0 índio era considerado um empecilho para o avanço do progresso e sua imagem era incompatível com o modelo de nação desenvolvida apregoado pela revista. Inaugurada por Jean Manzon e David Nasser em 1944, essa vertente temática nos fornece exemplos contundentes do exercício da violência no processo de representação do Outro, fundamentada em relações de poder extremamente desiguais entre os detentores dos meios de representação e os representados. ${ }^{3}$ Sob esse aspecto destaca-se especialmente a série de fotorreportagens acerca do caso Diacuí, que em

2. Listei especificamente aqui os temas das fotorreportagens produzidas por Jean Manzon para O Cruzeiro entre 1943 e 1951 período em que o fotógrafo francês trabalhou para a revista dos Diários Associados. Em estudo mais recente, no entanto, observei que esses temas estiveram presentes também em fotorreportagens produzidas por outros fotógrafos da revista. Ver: Costa, 1997 e 2012

3. A primeira fotorreportagem sobre a temática do índio foi "Enfrentando os chavantes!". Texto: David Nasser. Fotos: Jean Manzon. O Cruzeiro, 24 jun. 1944, p.46-62 e 96, 100, 106. Embora haja fotografias de índios publicadas em 0 Cruzeiro antes disso, foi somente a partir de 1943 que a revista adotou o modelo da fotorreportagem internacional, segundo o qual a fotografia deixava de ter um papel meramente ilustrativo e passava a construir um discurso especificamente visual sobre os acontecimentos. Interessa-me aqui analisar somente as fotorreportagens. Sobre a temática indígena em 0 Cruzeiro ver: Costa, 1994; Costa; Burgi, 2012, p.42-77. 
razão de suas peculiaridades amplia a abordagem da temática indígena proposta inicialmente pela revista, já que trata também da miscigenação e das relações de gênero. A riqueza desse conjunto de fotorreportagens certamente possibilita inúmeros enfoques oriundos de diferentes disciplinas. ${ }^{4}$ Neste artigo manteremos o nosso interesse, já materializado em outros estudos, no modo de construção do discurso jornalístico da fotorreportagem pensada no campo da cultura visual.

Podemos identificar na revista o Cruzeiro diversos exemplos em que a narrativa não se restringia apenas a uma única fotorreportagem, mas se desdobrava em séries de média e longa duração. Se o modelo da fotorreportagem introduziu uma nova noção de tempo por meio de um modo específico de edição das imagens, as sequências de fotorreportagens sobre um mesmo tema expandiam ainda mais essa temporalidade, incorporando um atributo característico de certos tipos de ficção que é a construção em capítulos. Como estratégia comercial a publicação de séries estimulava o consumo da revista e induzia o público a colecioná-la.

Quando uma história se mantém no foco de interesse do público, é quase certo virar uma 'reportagem-novela'. Reproduz-se então a mesma fórmula do folhetim, que veio a dar no romance... impossível esquecer David Nasser e suas séries de reportagens, publicadas semanalmente pela revista 0 Cruzeiro, entre as quais se destacaram 'O caso Aída Curi', '0 crime do Sacopã', e tantas outras. (Sodré, 1971)

No que se refere à reprodução da fórmula do folhetim, um dos melhores exemplos talvez tenha sido o da série de fotorreportagens sobre a índia Diacuí. Diferentemente de "O caso Aída Curi" e

4. Os artigos de Tracy L. Devine Guzmán e de João Veridiano Franco Neto oferecem abordagens distintas do caso Diacuí vindas do campo da antropologia. O primeiro analisa a história da índia em relação ao mito da Iracema, personagem de um romance de José de Alencar, enquanto o segundo busca recuperar o ponto de vista dos índios Kalapalo sobre o casamento. Ver: Guzmán (2005); Franco Neto (2008). de "0 crime do Sacopã", séries que se debruçaram sobre assassinatos de grande repercussão e acompanharam o desdobramento dos respectivos processos criminais, o que se apresentava ao leitor no caso Diacuí tinha o sabor de um acontecimento em pleno curso, palpitante de polêmica e atualidade, como se fosse uma espécie de novela da vida real. ${ }^{5}$ Já ciente, há quase uma década, do poder de mobilização da temática indígena junto ao seu público, a revista decide investir maciçamente na cobertura do suposto envolvimento amoroso entre Ayres e Diacuí, impedidos de contrair o matrimônio devido à legislação vigente. Materializava-se, assim, o mito do amor impossível que para sua consumação precisava vencer os mais difíceis obstáculos. Vejamos como o episódio foi apresentado pela primeira vez ao público de o Cruzeiro:

Aqui está um curioso caso de amor à primeira vista, de onde se conclui que a vida na selva, se é rude e áspera, nem sempre endurece o coração humano. Ayres Câmara Cunha, funcionário da Fundação Brasil Central, foi transferido para um posto daquela entidade, próximo a uma aldeia da tribo dos Kalapalos. Conheceu ali uma jovem índia, Diacuí, por quem imediatamente se apaixonou. Ayres não falava o kalapalo e Diacuí muito menos o português, mas isso não representou obstáculo para que os dois se entendessem. Os olhos da indiazinha dispensavam as palavras: deles escorria uma ternura mansa, levando ao coração do homem branco a certeza de que era correspondido no seu amor. E Aires não hesitou: pediu Diacuí em casamento. Os maiorais da tribo, não duvidando dos sentimentos dele, concordaram com a união dos namorados. Mas eis que uma nuvem veio toldar a felicidade dos dois jovens, sob a forma de um artigo dos estatutos do Serviço de Proteção aos Índios, que proíbe a ligação entre civilizados e

5. Roberta Barros de Andrade afirma que "o princípio da realidade torna-se ... uma das razões do prazer que as audiências encontram ao assistir a uma telenovela". Nada melhor, portanto, para ampliar esse princípio de realidade do que acompanhar o desdobramento de um acontecimento real, na forma seriada, como foi o caso da índia Diacuí. Ver: Andrade, 2003, p. 58 . 
selvagens. Chamado ao Rio para prestar esclarecimentos, Aires nada negou, deixando falar bem alto o seu coração. E através da imprensa lançou um dramático apelo às autoridades, no sentido de instituírem uma cláusula no regulamento do SPI, permitindo o casamento de brancos com índios. Na foto, Ayres ao lado de Diacuí, num flagrante que lhe aviva as saudades da mulher amada. A índia continua a esperá-lo na selva, sem saber que os separam, com mais força do que as léguas de mata, as leis feitas pelos homens. ${ }^{6}$

Essa apresentação consta na seção intitulada "Um fato em foco", na qual o Cruzeiro publicava semanalmente uma fotografia acompanhada de um pequeno comentário. Em geral as imagens selecionadas revestiam-se de um interesse particular, seja em função da raridade ou do caráter inusitado do assunto tratado. 0 exemplo em questão não foge à regra (Figura 1 ). A foto mostra o casal de corpo inteiro, posando em frente a uma cabana rústica. A índia está nua, ostentando apenas um colar e um delicado adorno próximo à virilha, que não chega a lhe cobrir a genitália. Ao seu lado vê-se o sertanista, que por sua vez está completamente vestido, trajando camisa e calça comprida. A dicotomia entre os dois, já enfatizada no texto, é reforçada também pelas expressões faciais: enquanto ele sorri numa pose calculada, a índia tem a fronte franzida, mostrando-se pouco à vontade ao lado do homem branco. Essa seção prepararia o público para a fotorreportagem que viria logo adiante, na mesma edição de o Cruzeiro, intitulada "Minha noiva é uma índia”. 7 Diacuí mostra-se agora familiarizada com a câmera fotográfica, para a qual sorri, em situações diversas, sem nenhum constrangimento, ostentando vistosos colares de contas no pescoço, que lhe teriam sido presenteados por Ayres (Figura 2).

Podemos identificar nesses dois exemplos um forte sensacionalismo por parte de O Cruzeiro

6. "Um fato em foco". O Cruzeiro, 1 nov. 1952, p.30-31. Foto Diário da Noite.

7. O Cruzeiro, 1 nov. 1952, p.106-108. Texto: Romildo Gurgel. Fotos: Gilberto Butowsky.

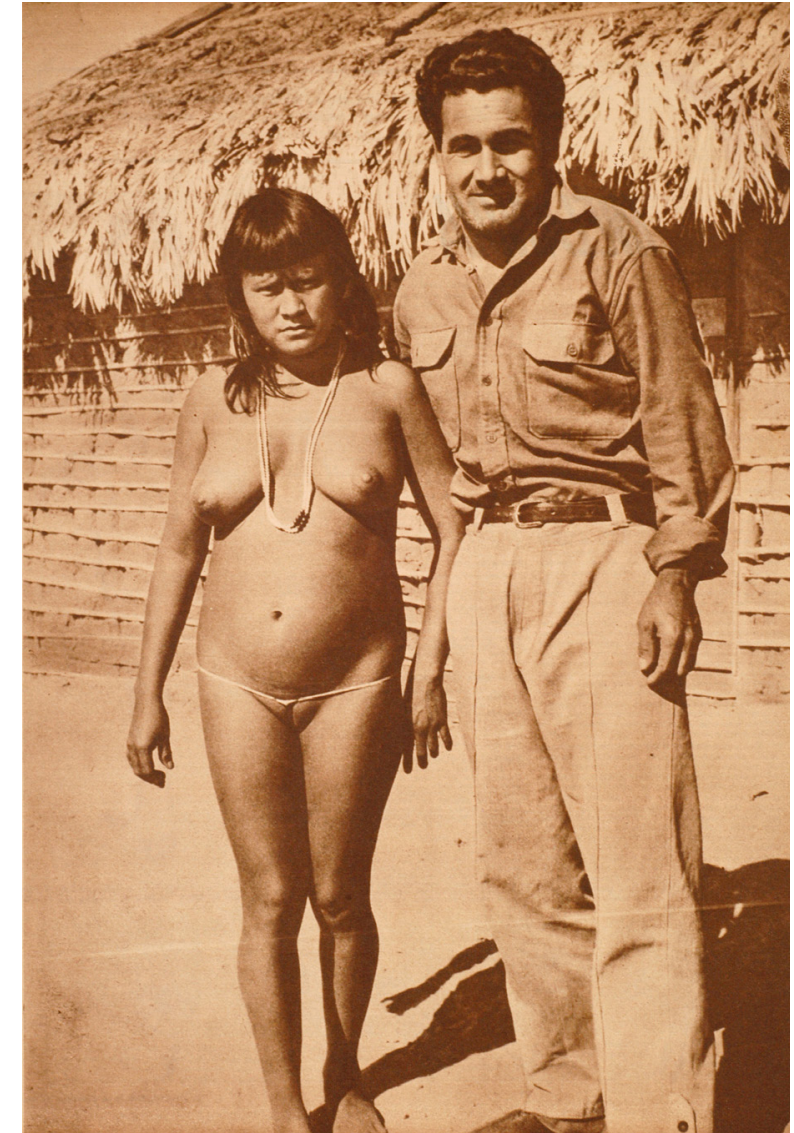

Figura 1 - Um fato em foco, O Cruzeiro, 1 nov. 1952.

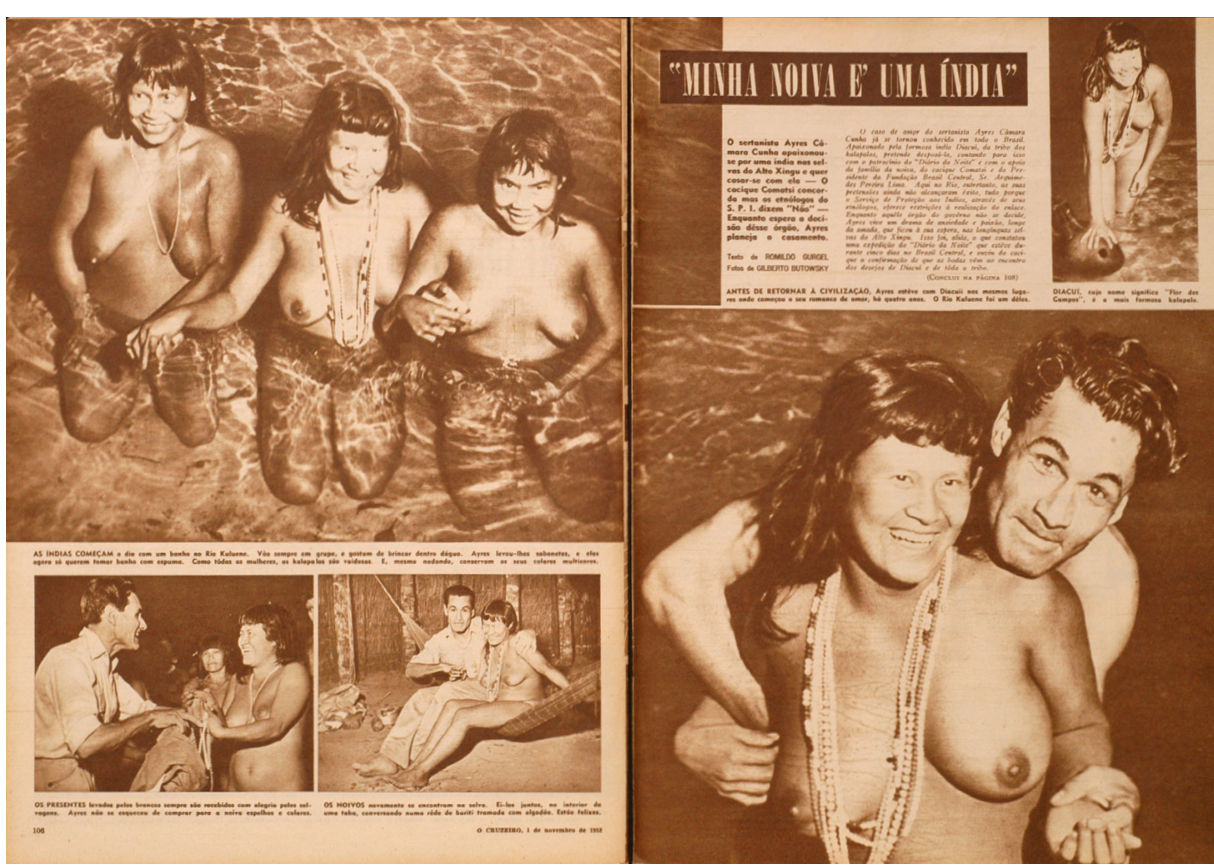

Figura 2 - Minha noiva é uma índia. O Cruzeiro, 1 nov. 1952, p. 106-107 
na abordagem da temática indígena. Num momento em que a nudez era alvo certo de censura à imprensa, a revista consegue burlá-la, exibindo o nu sob o pretexto do interesse etnográfico. A exploração da nudez dos indígenas recaía mais diretamente sobre o corpo da mulher, mostrado ao natural nas mais variadas posições, ao passo que o nu masculino explícito geralmente era evitado pelo próprio fotógrafo ou censurado na edição da fotorreportagem. ${ }^{8}$ Nas primeiras aparições de Diacuí a exibição do seu corpo é ostensiva, como na foto principal de "Minha noiva é uma índia”, em que o sertanista posa atrás dela, segurando-lhe os braços, de modo a deixá-la totalmente a mercê do olhar do fotógrafo e, em última instância, do leitor. Na verdade, essa imagem pressupõe uma cumplicidade entre o sertanista e o público masculino da revista, com quem ele parece compartilhar a fantasia colonialista da posse sexual da mulher indígena pelo homem branco. A nudez de Diacuí, ressaltada pela exibição de seus seios em primeiro plano, remete o espectador a uma sexualidade livre e primitiva, que há muito permeia o imaginário ocidental acerca dos "selvagens", em especial acerca da mulher, subjugada à condição de fêmea do homem. Posicionada em meio ao diálogo silencioso entre essas duas instâncias masculinas, Diacuí é apresentada como um verdadeiro troféu nas mãos do homemcaçador. Nesse contexto, a sua postura corporal e o seu sorriso largo viriam apenas atestar a libidinosidade supostamente inata às índias, além de sugerir que talvez já houvesse uma relação íntima entre ela e o sertanista.

Em que pese o voyeurismo das primeiras fotorreportagens sobre o envolvimento da índia

8. No momento da edição, a censura se dava por meio de interferências no negativo fotográfico ou velamentos realizados na superfície das cópias fotográficas a fim de ocultar os órgãos genitais. Um bom exemplo aparece na fotorreportagem "A conquista da Serra do Cachimbo". 0 Cruzeiro, 20 fev. 1954, p.84-88. Nela há uma foto de três índios adultos, castrados por meio da raspagem da superfície da imagem. Resultado de um ato de censura nada sutil, a imagem talvez tenha chamado mais a atenção do leitor do que se tivesse sido apresentada ao natural, uma vez que evidenciava o uso de certos procedimentos editoriais que colocavam em xeque a própria credibilidade do registro fotográfico e, consequentemente, da revista. com o sertanista, é importante assinalar que 0 Cruzeiro não se colocaria apenas como observadora passiva do desenrolar do caso Diacuí, mas seria um de seus principais agentes. Assis Chateaubriand, dono da empresa à qual pertencia a revista, iria empenhar-se pessoalmente em viabilizar a união legal de Ayres e Diacuí, patrocinada oficialmente pelo Diário da Noite, jornal de sua rede de comunicações. 0 seu primeiro passo foi promover a viagem de Diacuí e de mais três índios de sua etnia, entre os quais o cacique dos Kalapalos, ao Rio de Janeiro. Documentada na reportagem "Kalapalos invadem a cuiabá dos arranha-céus", ${ }^{9}$ a viagem foi transformada pelos Diários Associados num grande acontecimento que envolveu a visita do casal a diversas autoridades políticas e religiosas locais. Dizendo-se descendente dos índios Caetés, Chateaubriand afirma que "o Brasil precisa de sangue de índio" e justifica: "Como iria eu achar absurdo o casamento se ele me lembra a arrancada desbravadora dos mamelucos do século XVI?". ${ }^{10}$ A autorização para o casamento, porém, seria negada pelo Serviço de Proteção aos Índios (SPI), devido aos riscos do choque cultural a que a índia viria a ser submetida. ${ }^{11}$ Apesar da negativa, Chateaubriand não se daria por vencido e, graças às suas influências, iria obter o aval do então ministro da Agricultura, João Cleofas, para o seu intento, já que o SPI era subordinado ao seu ministério. ${ }^{12}$ Do mesmo modo, conseguiria da Igreja a permissão para o enlace religioso. Ao empresário importava tirar o maior proveito possível da situação, o que se traduzia

9. o Cruzeiro, 29 nov. 1952, p.100-101, 104 e 106. Texto: Romildo Gurgel e Ubiratan de Lemos. Fotos: Badaró Braga. Instalar "selvagens" nas grandes metrópoles e divertir-se com seu espanto e desconforto diante do cotidiano "civilizado" é uma prática antiga, que remonta às práticas coloniais e aos primórdios da Antropologia e que vemos reeditada aqui como espetáculo de massa.

\section{Ibidem}

11. Ayres afirma que foi desaconselhado pessoalmente pelos etnólogos do SPI, Darcy Ribeiro e Eduardo Galvão, a levar adiante o casamento. Ver: Cunha, 1976, p.56-57.

12. Segundo levantamento da jornalista Rebeca Kritsch, uma das versões que circulou na época aventava que a aprovação do casamento fora dada em troca do apoio dos Diários Associados à candidatura do ministro ao governo de Pernambuco. Sobre a polêmica suscitada pelo casamento de Diacuí ver também Moraes, 1994, p.576. 
principalmente em lucros financeiros, tanto por intermédio de patrocinadores interessados em conseguir visibilidade para seus produtos e serviços às custas do caso Diacuí, quanto pela venda de exemplares da revista para um público numeroso. Sendo assim, Chateaubriand não pouparia esforços para ser fotografado ao lado de Diacuí nas mais diversas situações, prontificando-se até mesmo a figurar como seu padrinho de casamento. ${ }^{13}$

Ayres Câmara Cunha, por sua vez, explicitaria seus propósitos de modo mais direto e pragmático, assegurando a todos a sua intenção de morar definitivamente no Xingu, junto aos índios, para exercer o seu papel de fato e de direito como colonizador:

Ao lado de Diacuí, ensinarei os índios a falar o português e a fazer agricultura, criação, etc. Estou certo de que, em pouco tempo, civilizarei toda a tribo. Conto para isso, com a ajuda dos meus amigos brancos e com a inteligência excepcional dos kalapalos. ${ }^{14}$

A metamorfose pela qual passaria Diacuí ao ser levada para o Rio de Janeiro seria documentada passo a passo pela revista o Cruzeiro. A extensão de sua transformação pode ser aferida já na foto de abertura da reportagem "Kalapalos invadem a “cuiabá' dos arranha-céus". ${ }^{15}$ Trajando um vestido estampado, complementado por sandálias escuras, a índia posa sorridente, tendo o rosto coberto por uma pesada maquiagem (Figura 3 ). Cinco fotos sequenciais mostram as diversas etapas do tratamento a que ela fora submetida para conseguir a nova aparência, imagens que sintomaticamente assemelham- se ao registro das diferentes etapas de uma operação cirúrgica. A legenda nos explica

13. Fernando Moraes confirma o grande interesse que Chateaubriand tinha pelos índios e apresenta em seu livro fotografias do empresário em visita a uma aldeia Txucarramãe. Numa delas Chateaubriand posa nu ao lado de um guerreiro daquela etnia e em outra aparece com uma tanga de penas, cocar e flecha na mão, de braço dado com uma jovem índia. Ver: Moraes, 1994, p.576-579.

14. "Flores de laranjeiras para a "flor dos campos". Texto Romildo Gurgel e Ubiratan de Lemos. Fotos: Badaró Braga. 0 Cruzeiro, 6 dez. 1952, p.16.

15. O Cruzeiro, 29 nov. 1952, p.100-101, 104-108. Texto: Romildo Gurgel e Ubiratan de Lemos. Fotos: Badaró Braga. que a maquiagem fez os traços fisionômicos de Diacuí ganharem "um refinamento que ela até então desconhecera" e prevê que em pouco tempo ela estaria sendo confundida "com qualquer grã-fina de Copacabana”. Ademais, o texto nos assegura que o encontro da índia com a moderna tecnologia dos cosméticos não deveria nos causar estranhamento:

Diacuí e Helena Rubinstein são dois nomes aparentemente incompatíveis, parecendo entre eles haver um abismo de séculos. Mas os extremos se tocaram e deu-se o milagre. A beleza primitiva de Diacuí transfigurou-se, emergindo da espuma de múltiplos cremes e sabonetes como a de uma Vênus do século XX.

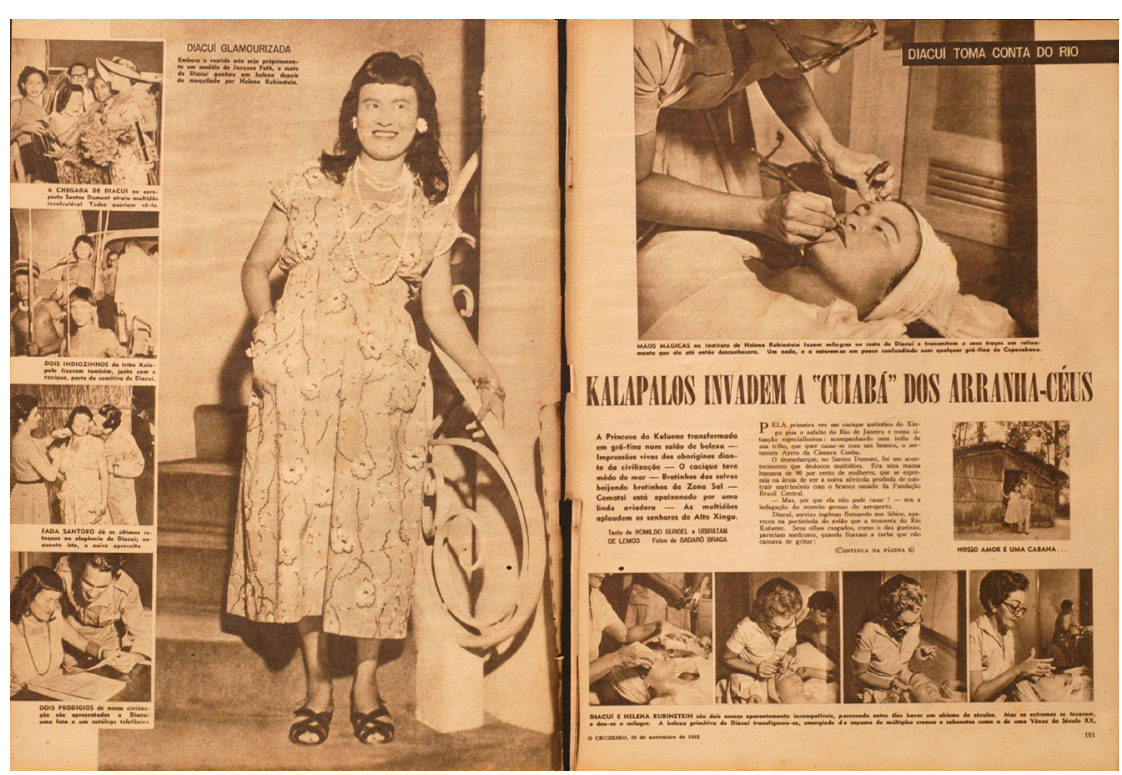

Figura 3 - Kalapalos invadem a 'cuiabá' dos arranha-céus. 0 Cruzeiro, 29 nov. 1952, p.100-101.

Nas fotorreportagens seguintes a revista nos fará acompanhar os percalços da índia em seu contato com os grandes prodígios da nossa civilização. ${ }^{16}$ 0 fogão a gás, "muito diferente das fogueiras primitivas dos Kalapalos”, a máquina de costura, "com a qual confeccionará os seus vestidos de agora

16. As fotos de Diacuí aprendendo a cozinhar em um fogão a gás aparecem em: "Flores de laranjeiras para a "flor dos campos'". Texto: Romildo Gurgel e Ubiratan de Lemos. Fotos: Badaró Braga. O Cruzeiro, 6 dez. 1952, p.10-16. As demais fotos analisadas foram publicadas em: "Abençoado por Deus o casamento da índia com o branco”. O Cruzeiro, 13 dez. 1953, p. $12-15$. 
em diante", o relógio de pulso, no qual contará "todos os minutos que a separam do casamento com Ayres", além do "famoso livro Beleza e personalidade - chave do êxito da mulher civilizada" (Figura 4). É particularmente significativa a fotografia em que Diacuí supostamente estaria lendo o imprescindível manual. Preparada para a pose, ela aparece sentada numa cadeira com o livro aberto à sua frente, simulando a leitura. No entanto, por alguns segundos a cena foge ao controle do fotógrafo e a imagem final mostra-nos Diacuí com as pálpebras fechadas. Ao congelar esse ínfimo instante a fotografia materializa uma realidade indisfarçável: apesar de todos os esforços a índia não consegue ter olhos para a cultura ocidental, nem tampouco tem condições de se enquadrar no padrão de feminilidade que lhe está sendo imposto. Superado o lapso, podemos também observar Diacuí escovando os dentes, penteando os cabelos e calçando sapatos. Todos esses pequenos atos cotidianos fazem parte da sua preparação para os três grandes ritos de passagem que irão introduzi-la definitivamente no universo da civilização: o batismo cristão, o casamento civil e a cerimônia religiosa de consagração do matrimônio. ${ }^{17}$ Nesse ponto a série chega ao seu clímax, ao esperado momento do final feliz, detalhadamente relatado na fotorreportagem "Abençoado por Deus o casamento da índia com o branco": ${ }^{18}$

Diacuí, no seu soberbo vestido de penas de garça, foi sacudida por uma onda humana de mais de 10 mil pessoas - Chuva de flores sobre os noivos e o Sr. Assis Chateaubriand - Uma senhora, entusiasmada, arrancou a anágua da noiva kalapalo, enquanto o povo, dentro da Igreja, vivava o casal mais famoso do ano - 0 cacique Comatsi e os dois outros jovens de sua tribo, de ternos de linho e gravata, abraçaram centenas de 'caraíbas'.

A fotorreportagem mostra diversas cenas do casamento e da multidão na igreja da Candelária, além de uma foto de corpo inteiro de Diacuí um tanto constrangida no volumoso vestido de noiva, recoberto de penas de aves, feito especialmente

17. Cenas do batismo de Diacuí aparecem nessa mesma fotorreportagem. O Cruzeiro, 6 dez. 1952, p.10-16.

18. O Cruzeiro, 13 dez. 1952, p.8-16. Texto: Romildo Gurgel e Ubiratan de Lemos. Fotos: Badaró Braga e Indalécio Wanderley.

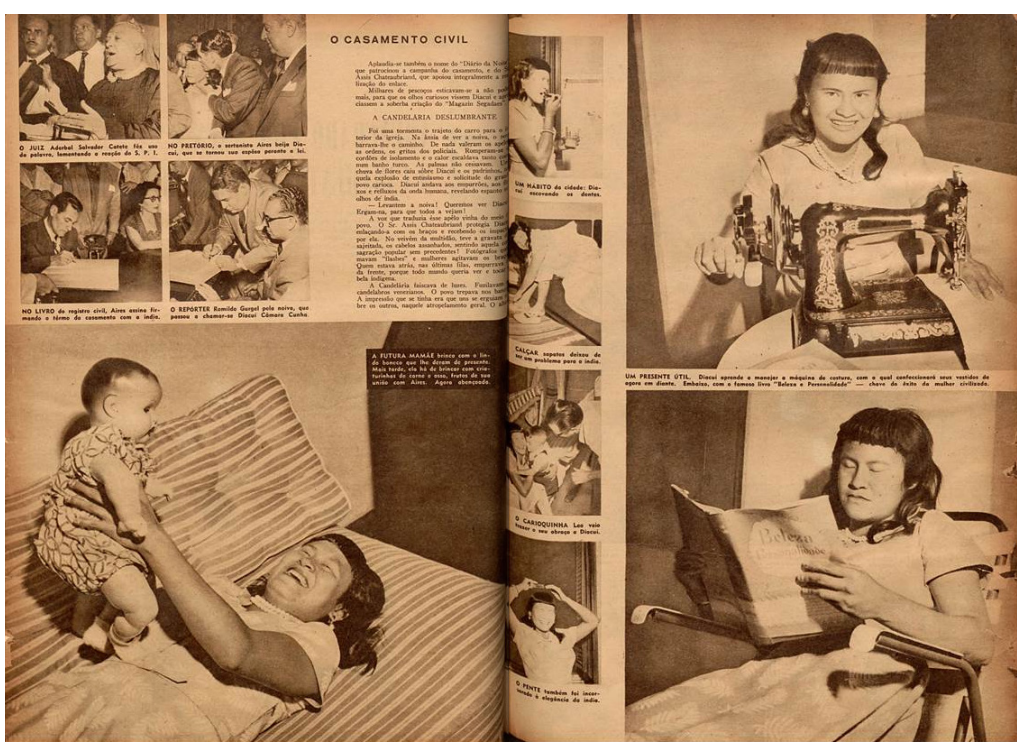

Figura 4 - Abençoado por Deus o casamento da índia com o branco. O Cruzeiro, 13 dez. 1953, p.12-13.

para ela (Figura 5). Não satisfeita apenas com a cobertura do casamento, a revista o Cruzeiro iria acompanhar a volta dos noivos ao Xingu. "Lua de mel num palácio de sapé” nos mostra uma Diacuí civilizada que "não quer mais apresentar-se despida ante os seus irmãos de tribo". ${ }^{19}$ Ela passa a usar um maiô de duas peças para banhar-se no rio ao lado do marido e apresenta-se nas fotos sempre vestida. A reportagem conta que os recém-casados, em seu retorno, levaram quatrocentos quilos de presentes para os Kalapalos, além das lembranças do casamento. Numa das fotos Diacuí exibe às mulheres o seu vestido de noiva, enquanto em outras imagens diversos índios aparecem tentando provar as roupas que acabaram de ganhar. 0 resultado, nos dirá o repórter, é que "toda a tribo dos Kalapalos quer imigrar para o Rio de Janeiro".

0 público de 0 Cruzeiro demoraria 8 meses para voltar a ter notícias de Ayres e Diacuí após a cobertura da lua de mel do casal. No mês de agosto de 1953 uma reportagem bombástica iria dar conta da tragédia que se abatera sobre a índia: "Abandonada pelo branco morreu Diacuí". ${ }^{20}$ Essa

19. O Cruzeiro, 27 dez. 1952, p.130-135. Texto: Ubiratan Lemos. Fotos: Indalécio Wanderley.

20. O Cruzeiro, 22 ago. 1953, p.8-13. Texto: Ubiratan Lemos. Fotos: Indalécio Wanderley. 


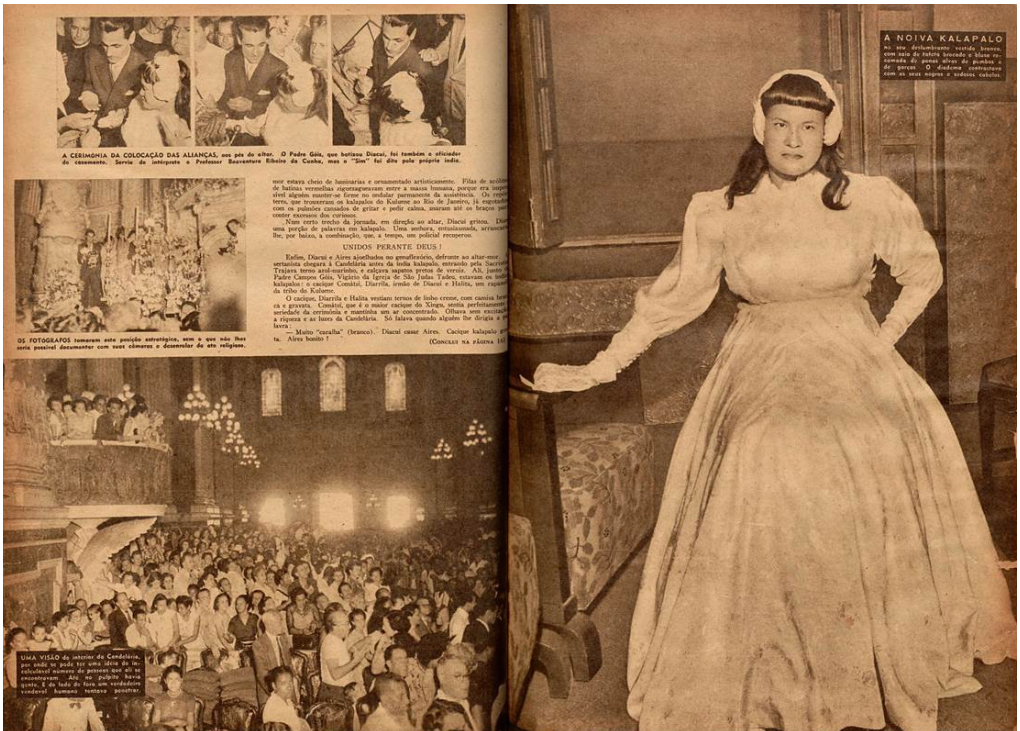

Figura 5 - Abençoado por Deus o casamento da índia com o branco. O Cruzeiro, 13 dez. 1953, p.14-15.

fotorreportagem é emblemática dentro da série, seja do ponto de vista da linguagem fotográfica, da edição e de sua perfeita adequação ao modelo da novela, ${ }^{21}$ seja na explicitação do caso Diacuí como um exemplo do devastador poder de manipulação da mídia sobre a vida das pessoas. São seis páginas nas quais se estabelece uma narrativa expandida no tempo e no espaço por meio de recursos de flash-back (Figura 6). Imagens já empregadas em reportagens anteriores são apropriadas no novo contexto, estabelecendo um diálogo com a memória do público e reforçando a ideia de que se trata de mais um capítulo da conhecida novela. Logo nas duas páginas de abertura, a imagem do sertanista junto ao túmulo da índia contrasta com uma das fotos do casal tirada durante o casamento. Seguindo esse mesmo princípio, a revista reutiliza uma fotografia de Diacuí da época de sua estadia no Rio de Janeiro, na qual ela aparece brincando com um boneco, como contraponto à imagem do bebê recém-nascido que sobrevivera à morte da mãe, decorrente de complicações no trabalho de parto.

21. Ao analisar a telenovela Roberta Barros de Andrade afirma que "A característica básica do gênero é ... o convite implícito no texto à especulação sobre julgamentos morais e/ou dilemas emocionais das personagens", op. cit., p.52. É o que vemos claramente ao longo de toda a série de fotorreportagens sobre o caso Diacuí e que se torna mais explícito nesta última.
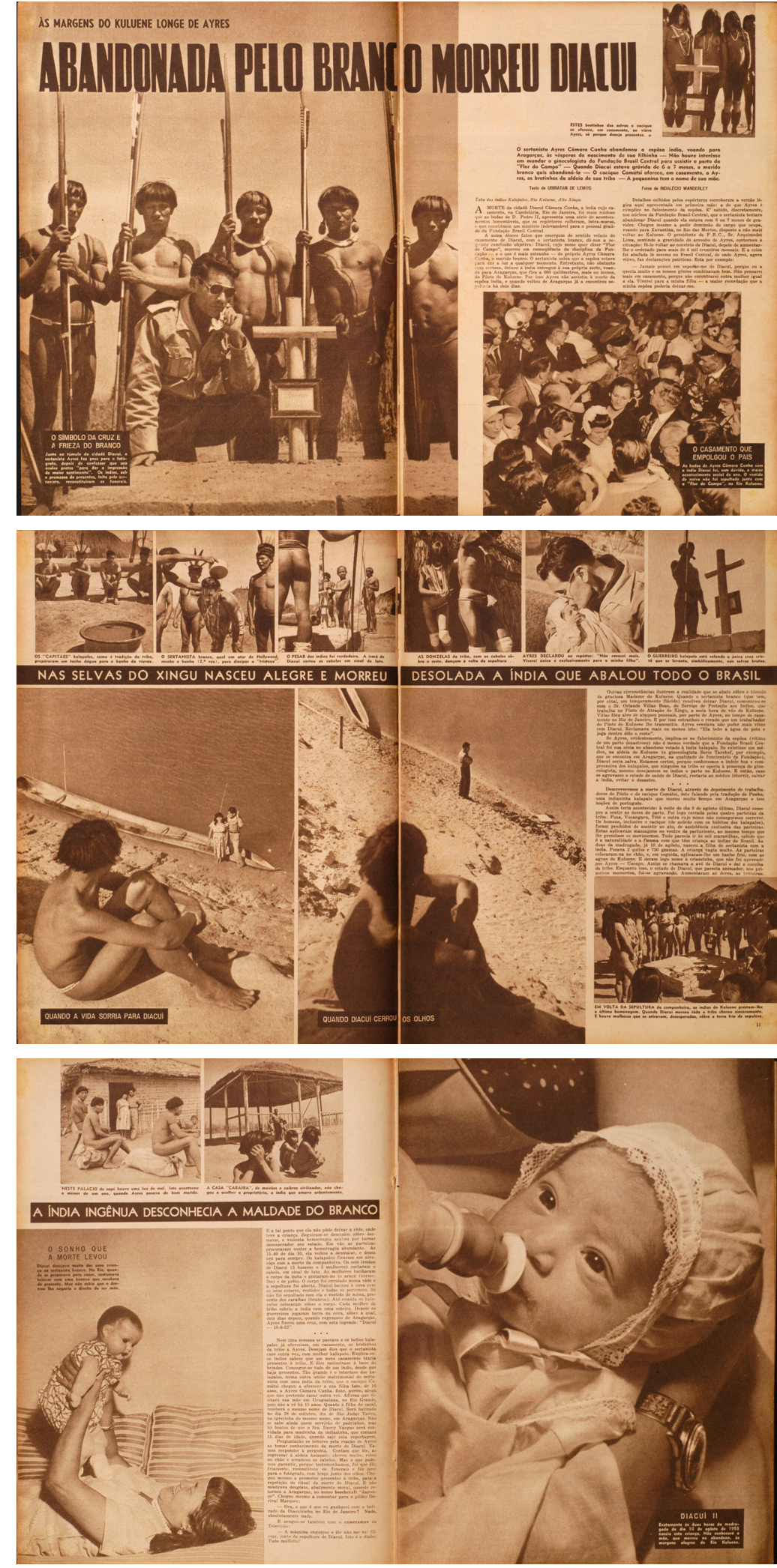

Figura 6 - Abandonada pelo branco morreu Diacuí. O Cruzeiro, 22 ago. 1953, p.8-13 
0 recurso ao contraste entre duas realidades opostas não seria utilizado somente pela edição. o próprio fotógrafo iria construir contraposições igualmente dramáticas. Tomando como referência uma das fotografias publicadas na reportagem sobre a lua de mel do famoso casal, Indalécio Wanderley atualiza a cena. Na primeira imagem vemos, ao longe, os recém-casados abraçados na beira do rio, sendo observados, supostamente às escondidas, por um índio situado sobre uma elevação em primeiro plano. É como se o fotógrafo colocasse o público na posição voyeurista ocupada pelo índio. Já na segunda foto, tomada no mesmo local onde produziu a cena anterior, Indalécio nos mostra Ayres solitário, sendo observado por um índio que posa na mesma posição. Enquanto na primeira imagem a figura do índio era banhada de luz, na segunda aparece obscurecida por uma sombra. Enquanto a primeira foto nos remete à ideia de mobilidade, em função da canoa atravessada em diagonal junto ao casal, a segunda sugere imobilidade e estagnação, não só pela postura introspectiva de Ayres, mas também pela canoa que por pouco não desaparece no extraquadro.

O sertanista, anteriormente tão elogiado pelos repórteres de o Cruzeiro, é descrito agora como dono de um "temperamento flácido". Deixando-se fotografar em poses afetadas ao lado do túmulo da ex-esposa ou beijando a filha que repousa em seu colo, 22 Ayres inadvertidamente torna-se alvo fácil da mordacidade da revista que o acusa de ser o grande responsável pela morte de Diacuí. Esse ataque passional contra o sertanista atingiria também a Fundação Brasil Central. Mesmo um ano após a morte da índia, a posição de o Cruzeiro a respeito dos acontecimentos se manteria inal terada:

0 aspecto pouco esclarecido do romance é o da morte da silvícola, cujas circunstâncias condenam o marido branco e a Fundação Brasil Central, na pessoa do seu presidente Sr.

22. A filha do casal, também batizada Diacuí, foi levada por Ayres para ser criada pela mãe dele em Uruguaiana, no Rio Grande do Sul, cidade natal do sertanista. Ayres Cunha morreu em 1997, aos 81 anos. Ver: "Diacuí é uma menina feliz". O Cruzeiro, 15 fev. 1958; "A filha de Diacuí: o romance da selva 20 anos depois”, 14 fev. 1973.
Arquimedes Lima. Lembramos, quando de nossa viagem ao território kalapalo, a frieza de Ayres, ao mandar os índios reconstituírem os funerais de Diacuí, para que ele aparecesse, ao lado do túmulo, fingindo chorar, com o lenço enxuto tapando os óculos "ray-ban" ... E recordamos que Diacuí, às vésperas de dar a luz à filhinha, fora abandonada por Ayres, que tomou um avião e voou para Xavantina, a 600 quilômetros de distância. Se o marido branco quisesse, ser-lhe-ia fácil providenciar a ida à taba de Diacuí, do ginecologista Boris Tarekof, da Fundação Brasil Central, o que representaria vida para a Madame do Kuluane. Só não o fez, porque não lhe interessava, e Diacuí, morreu à míngua, vítima de tenaz hemorragia. ${ }^{23}$

Se até aqui demos voz exclusivamente à revista o Cruzeiro, passaremos à análise de uma outra versão dos acontecimentos, dada por seu principal protagonista.

A resposta de Ayres Câmara Cunha às acusações que lhe foram imputadas pelos Diários Associados viria formalmente muitos anos mais tarde nas páginas de seus livros de memórias. ${ }^{24}$ Um deles, em particular, foi totalmente dedicado à história da índia Diacuí. Como não é nosso objetivo fazer uma análise detalhada dessa publicação, nem julgar o comportamento do sertanista, iremos nos deter nas informações que de algum modo nos auxiliem a esclarecer questões referentes às fotorreportagens. ${ }^{25}$

De início cabe destacar que o sertanista era o responsável pelo posto da Fundação Brasil Central instalado na região em que se localizava a comunidade dos Kalapalos, à qual pertencia

\section{3. "Um fato em foco". O Cruzeiro, 21 ago. 1954. Foto:} Indalécio Wanderley.

24. Não foi possível saber exatamente quantos livros Ayres Câmara Cunha publicou. Levantamos quatro títulos e tivemos acesso a dois deles: A história da índia Diacuí (1976) e Nas selvas do Xingu (1969).

25. Cabe apenas ressaltar que na versão do sertanista a morte da índia foi uma fatalidade, uma vez que ele teria viajado apenas por 4 dias para comprar provisões, período no qual Diacuí veio a falecer. 
Diacuí, e já vivia com ela quando decidiu solicitar autorização para o casamento. ${ }^{26}$ Tal situação pode ser comprovada por meio do parecer emitido pelo ministro da Agricultura para justificar a sua anuência à união legal entre a índia e o sertanista.

0 fato consumado, porém, e que não pode ser remediado com soluções teóricas, é que o recorrente e a índia já têm vida em comum há longo tempo, conforme consta do processo, de sorte que o casamento para que o recorrente solicita permissão, vem enquadrá-los nas normas do direito e da moral, tornando legítima uma situação existente. ${ }^{27}$

Segundo consta, uma sindicância interna realizada na Fundação Brasil Central condenou Ayres por manter um relacionamento considerado impróprio com a índia. Ameaçado de perder seu emprego e ser expulso do Xingu, o sertanista teria encontrado no casamento uma saída para reverter a situação ${ }^{28}$. Essa informação, que não circulou na imprensa na época do casamento, nos autoriza a avançar em nossa análise das fotorreportagens, pois confirma que tudo nelas foi encenado para a mídia. A artificialidade que percebemos à primeira vista é ainda maior do que se poderia supor, e muitas informações que poderiam revelar a real condição em que vivia o casal são omitidas nas fotorreportagens. A cabana, situada no fundo da primeira foto dos dois publicada em 0 Cruzeiro (Figura 1), por exemplo, era a casa de taipa coberta de palha, construída próxima às habitações dos Kalapalos, onde Ayres morava com Diacuí. ${ }^{29}$

26. No livro A história da índia Diacuí, várias pistas indicam que Ayres e Diacuí já viviam juntos antes do casamento legal. Ver: Cunha, 1976, p.43-50 e 84.

27. 0 parecer do ministro da Agricultura pode ser consultado em: Cunha, 1976, p.43-50 e 84.

28. Segundo relatório anual da CNPI, de 1952, Ayres Cunha, juntamente com outros funcionários, era acusado de forçar as índias do Alto Xingu à prostituição. Ver: Freire, 1990, p.233. 29. Cunha, 1976, p.95-96. Não podemos deixar de assinalar também que em seu relato tardio sobre sua estadia no Rio de Janeiro com Diacuí, o sertanista afirma ter traduzido as falas da índia em diversas ocasiões, o que contradiz a versão apresentada pela revista, e pela imprensa em geral, de que eles não conseguiam se comunicar verbalmente.
As situações estrategicamente planejadas e os altos recursos financeiros disponibilizados para a realização da série de fotorreportagens sobre o caso Diacuí nos permitem verificar que o papel exercido pelos Diários Associados no episódio esteve longe de ser isento. Embora o sertanista não esclareça suas relações de bastidores com Assis Chateaubriand, deixa transparecer que era pressionado por ele a tomar determinadas atitudes: "Foi então que resolvi, aconselhado, ou melhor, instigado pelos Diários Associados, constituir dois grandes juristas para defenderemme (sic)". ${ }^{30}$ Diante desse quadro, nos é lícito supor que o destino da índia talvez tivesse tomado outro rumo, caso Assis Chateaubriand não tivesse decidido investir na cobertura jornalística de sua história. Devemos reconhecer, no entanto, que a atuação da revista no episódio pautou-se, ao menos no nível do discurso, por certos ideais humanistas vigentes na época.

0 apoio do governo e da Igreja ao casamento da índia estaria imbuído da intenção de dar-lhe acesso a uma nova condição de vida, pretensamente mais digna e condizente com o tipo de assimilação cultural que se esperava poder estender a toda a população indígena do país. Era, portanto, uma atitude perfeitamente legítima do ponto de vista de seus protagonistas. Como aponta Pierre Clastres, a negação das culturas ditas primitivas em prol de sua assimilação à cultura ocidental tem se revestido dos mais nobres ideais ao longo da história: "Trata-se de uma negação positiva, na medida em que quer suprimir o inferior enquanto inferior para alçá-lo ao nível de superior. Suprime-se a indianidade do índio a fim de fazer dele um cidadão brasileiro". Segundo essa lógica aquela era “uma tarefa necessária, exigida pelo humanismo inscrito no coração da cultura ocidental" (Clastres, 1982, p.55).

As fotorreportagens sobre Diacuí funcionaram como veículos de uma verdadeira missão civilizatória, materializando o tipo de relação entre brancos e índios proposto naquela ocasião por diversas instâncias institucionais. Endereçadas a um público de massa, transformaram o processo de aculturação da índia num espetáculo, encenando preceitos morais

30. Ibidem, p. 80 . 
bem definidos por intermédio de seus personagens. 0 homem branco encarnaria a civilização ocidental, masculina em sua essência, traduzida no arquétipo do colonizador. As etnias indígenas minoritárias estariam sendo representadas por Diacuí, que na sua condição feminina materializaria a inferioridade dessas culturas e sua pretensa vocação à

subserviência. Diacuí é duplamente enquadrada como Outro: enquanto selvagem e enquanto mulher. 0 casamento seria a submissão consentida dos povos indígenas aos desígnios do homem branco, apontando para o tipo de aliança desigual que se pretendia estabelecer entre esses opostos. Mais que isso: simbolizaria o reconhecimento da superioridade do branco, constituindo-se no passaporte simbólico para o ingresso dos índios num mundo supostamente melhor. Por fim, a miscigenação seria uma poderosa arma de branqueamento da população indígena, como mostra a foto da pequena Diacuí paramentada como um bebê civilizado, que fecha a última reportagem da série. ${ }^{31}$

Neste ponto não podemos deixar de considerar que o conceito de etnocídio, tal qual nos apresenta Pierre Clastres, é uma ferramenta teórica extremamente eficaz para nos auxiliar a refletir sobre o desfecho do caso Diacuí:

\begin{abstract}
Se o termo genocídio remete à ideia de 'raça' e ao desejo de extermínio de uma minoria racial, o termo etnocídio acena não para a destruição física dos homens (nesse caso permaneceríamos na situação genocidiana), mas para a destruição de sua cultura. 0 etnocídio é, portanto, a destruição sistemática de modos de vida e de pensamento de pessoas diferentes daquelas que conduzem a empresa da destruição. Em suma, o genocídio assassina os povos em seu corpo e o etnocídio os mata em seu espírito.
\end{abstract}

31. O processo de branqueamento não se deu apenas no plano simbólico da fotorreportagem. A filha do casal foi deliberadamente afastada de seus parentes Kalapalos por seu pai e chegaria à idade adulta sem nenhuma identificação com sua ascendência indígena. Ver entrevista com Diacuí Cunha Dutra em Kritsch, 2000, p.D10. Somente em março de 2015 Diacuí veio a conhecer seus parentes no Xingu por iniciativa de um jornalista de Uruguaiana. Ver: http://g1.globo.com/ rs/rio-grande-do-sul/jornal-do-almoco/videos/v/vida-deayres-camara-cunha-e-da-india-diacui-sao-temas-de-estudo-emuruguaiana-no-rs/4061372/; Acesso em: 1 jun. 2016.
Em um e outro caso trata-se de morte, mas de uma morte diferente. (Clastres, 1982, p.53)

0 desenrolar dos acontecimentos do caso Diacuí se encarregaria de evidenciar as contradições do projeto etnocida no qual ela foi envolvida com seu povo. Mesmo que consideremos a morte da índia como fruto de uma fatalidade - já que a eliminação física do Outro não faz parte do projeto etnocida -, ela subverteu o final feliz da fotorreportagem-novela encenada pela revista o Cruzeiro, expondo de maneira imprevista a violência extrema que se ocultava sob as boas intenções de seu discurso.

\section{Referências}

ANDRADE, Roberta Manuela B. de. O fascínio de Scherazade: os usos sociais da telenovela. São Paulo: Annablume, 2003.

CLASTRES, Pierre. Arqueologia da violência: ensaio de antropologia política. São Paulo: Brasiliense, 1982 .

COSTA, Helouise. Um olhar que aprisiona o outro. 0 retrato do índio e o papel do fotojornalismo na revista 0 Cruzeiro. Imagens, Campinas, n.2, p.82-91, ago. 1994.

Palco de uma história desejada: o

retrato do Brasil por Jean Manzon. Revista do Patrimônio Histórico e Artístico Nacional, Rio de Janeiro, n.27, p.138-159, 1997.

.; BURGI, Sergio. As origens do

fotojornalismo no Brasil: um olhar sobre 0

Cruzeiro, 1940-1960. Rio de Janeiro: Instituto Moreira Salles, 2012.

CUNHA, Ayres Câmara. Além do Mato Grosso. São Paulo: Clube do Livro, 1974.

Entre os índios do Xingu: a verdadeira

história de Diacuí. São Paulo: Livraria

Exposição do Livro, 1960.

A história da índia Diacuí: seu

casamento e sua morte. São Paulo: Clube do

Livro, 1976.

Nas selvas do Xingu. São Paulo: Clube do

Livro, 1969. 
FRANCO NETO, João Veridiano. O casamento de Jakuí Kalapalo e Ayres Câmara Cunha: cosmologia do contato do Alto Xingu. Temáticas, Campinas: Unicamp, v.31/32, p.51-89, 2008.

FREIRE, Carlos Augusto da Rocha. Indigenismo e Antropologia. 0 conselho Nacional de Proteção aos índios na gestão Rondon (1939-1955). Dissertação (Mestrado em Antropologia Social) Museu Nacional, Universidade Federal do Rio de Janeiro. Rio de Janeiro, 1990.

GUZMÁN, Tracy L. Devine. 'Diacuí killed Iracema': Indigenism, Nationalism and the Struggle for Brazilianness. Bulletin of Latin American Research, v.24, n.1, p.92-122, 2005.

$\mathrm{KRITSCH}$, Rebeca. No Xingu nasceu o romance mais famoso dos anos 50 entre um branco 'civilizado' e uma 'selvagem' índia. O Estado de S. Paulo, 27 ago. 2000, p.D10.

MORAES, Fernando. Chatô, o rei do Brasil. São Paulo: Companhia das Letras, 1994.

MOURA, Carlos Eugênio M. Estou aqui. Sempre estive. Sempre estarei: indígenas no Brasil. Suas imagens, 1505-1955. São Paulo: Edusp, 2012.

SODRÉ, Muniz. A comunicação do grotesco: introdução à cultura de massa brasileira. Petrópolis: Vozes, 1971.

TODOROV, Tzvetan. A conquista da América: a questão do outro. São Paulo: Martins Fontes, 1993.

\footnotetext{
* Helouise Costa é professora associada, docente e curadora do Museu de Arte Contemporânea da Universidade de São Paulo (MAC-USP). Atua como professora e orientadora no Programa de Pós-GRaduação Interunidades em Museologia e no Programa Interunidades em Estética e História da Arte, ambos da USP.
} 


\title{
Leituras visuais da criança indígena: uma abordagem para além da estética e do racismo
}

\author{
Josué Carvalho* \\ Universidade Federal de Minas Gerais (UFMG)
}

As práticas culturais de cunho indenitário de um indivíduo ou um povo, graças ao avanço das diferentes linguagens tecnológicas, têm sido apresentadas e representadas ao mundo na velocidade da luz. Visualmente falando, basta apenas um flash seguido de alguns clicks, e upload e download são possíveis. Esse instigante universo tecnológico (fotografia, vídeo,

internet) tem ganhado cada vez mais espaço no material base de etnógrafos em seus trabalhos de campo; já não é mais novidade perceber diários de campo sendo registrados diariamente na rede. Pink ressalta que:

Photography, video and electronic media are becoming increasingly incorporated into the work of ethnographers: as cultural texts; as representations of ethnographic knowledge; and as sites of cultural production, social interaction and individual experience that themselves form ethnographic fieldwork locales. (Pink, 2001, p.2)

É impossível negar que o uso dessas tecnologias tem contribuído para análises cada vez mais fidedignas sobre sujeitos e objetos de estudos, porém, o uso dessas mídias, uma vez lançado na rede, produz significados múltiplos, ou seja, o uso deliberado desses meios pode ser como uma faca de dois gumes. Estou me referindo grosso modo ao que se pode chamar de antropologia visual. MacDougall (1998) sugere a existência de diferentes interesses no uso da antropologia visual, seja como técnica de pesquisa, campo de estudo, ferramenta de ensino, seja também como meio de publicação ou nova forma de abordagem do conhecimento antropológico.
Neste ensaio sinalizo o uso da tecnologia, a partir da fotografia exposta na rede (universo virtual) e com possibilidades de discussões no campo da museologia, no que se refere à representação e apresentação de crianças indígenas, uma vez que os olhares para essas crianças têm se intensificado nas diferentes áreas do conhecimento. Estudos etnográficos, advindos dos mais diferentes sentimentos e fins, ora para entender a criança indígena em seu contexto, ora pela simples procura do belo étnico.

\section{0 lugar de onde falo e as crianças Kaingang}

A Terra Kaingang Nonoai está situada no nordeste do Rio Grande do Sul, na divisa com o estado de Santa Catarina e a 150 quilômetros do país vizinho, a Argentina. No presente a T.I. Nonoai comporta uma população de aproximados $3 \mathrm{mil}$ Kaingang, numa área de cerca de 40 mil hectares entre mata nativa e área de livre plantio, comporta quatro aldeamentos: aldeia Posto Kaingang (município de Nonoai, ao leste), aldeia Pinhalzinho (município de Planalto, ao norte), e aldeias Bananeiras 1 e 2 (pertencentes ao município de Gramado dos Loureiros, ao sul).

Os Kaingang sozinhos representam cerca de $50 \%$ de toda a população dos povos de língua Jê (Tronco Macro-Jê), e estão entre os cinco povos indígenas mais populosos do Brasil. Essa língua possui cinco dialetos regionais. O Kaingang e o Xokleng formam o conjunto restrito das línguas e culturas Jê do Sul (D’Angelis, 2002). Nessa 
região, além da língua Kaingang, temos também alguns dialetos do Guarani falados em diversas comunidades. Recentemente, foram detectados alguns descendentes do povo Xetá, mas restavam apenas três falantes da língua.

$\mathrm{Na}$ T.I. Nonoai as interlocuções dos indígenas com o museu são bastante recentes. A noção nessa T.I. sobre museus inicia-se em 1994, quando foi construído pelo Departamento Autônomo de Estradas de Rodagem do estado do Rio Grande do Sul (Daer) - Centro Cultural Kaingang e Guarani, como medida compensatória pelo fato de a rodovia RS-360 atravessar a aldeia. Porém, o centro cultural não deu certo por falta de investimentos para manutenção, seja no que se refere a pessoal técnico capacitado para gerir o centro cultural, como por falta de pesquisadores indígenas e não indígenas com conhecimento para tal. No presente encontra-se depredado, sem condições de abrigar artefatos de qualquer natureza.

Só no presente integrantes da T.I. Nonoai passaram a considerar como necessário o processo de musealizar aspectos da sua cultura, antes disso não havia o interesse por acreditarem que a cultura e os costumes nessa T.I. estavam bastante intactos, principalmente no que se refere à língua Kaingang e à confecção de artefatos tradicionais. Essa preocupação foi motivada não apenas, mas principalmente, pela participação de alguns indígenas e lideranças em processos de musealização promovidos pelo Museu Histórico e Pedagógico Índia Vanuíre, a exemplo das Oficinas de Troca de Saberes entre Mulheres Kaingang, do processo de curadoria da coleção Lyfãy Kanhgág e outros trabalhos, que se encontram disponíveis nesse museu. Quando os indígenas da T.I.

Nonoai envolvidos nos processos de musealização visualizaram seus artefatos e memórias no museu, passaram a percebê-lo diferentemente, como afirmou o líder espiritual Jorge Garcia, em visita ao museu em 2014: “aqui também, esse espaço é um velho Kaingang, lugar de sabedoria, aqui os mais novos encontram repostas, o museu são os velhos Kaingang ensinando sobre o conhecimento dos antigos, como guardar os costumes e levar adiante o conhecimento dos índios".
Mas a questão, aqui, é sobre as crianças e não sobre as concepções indígenas de museus, embora esse seja um tema bastante pertinente. É sobre as concepções e formas de apresentação Kaingang de suas crianças frente às formas de apresentação e representação em diferentes espaços e contextos, sobretudo por pesquisadores ou pessoas que têm pouco ou nenhum conhecimento da realidade e, principalmente, das formas indígenas de apresentar e representar suas crianças, tendo como suporte a fotografia e o audiovisual. Não se trata de um estudo comparativo, mas sim explanativo, com intuito de lançar outros olhares para as crianças indígenas, sobretudo crianças Kaingang, e para as formas como são concebidas no interior das aldeias.

Quando nossos avós e outros velhos se referiam a nós, quando crianças na aldeia, nos chamavam pelo nome dado na língua Kaingang, e quando esqueciam o nome, diziam apenas Kãxit (filho), Un Xî̀ (filho recém-nascido) ou Kãxit Xî (filho pequeno). Na língua Kaingang, essas três variantes seriam a tradução mais próxima do que se entende como criança na cultura dominante, e se apresentam de forma a separar papéis e modos de interação de acordo com a idade em que a criança está. Porém, no decorrer do estudo, nos diferentes contextos, percebemos que ser um Kãxit Kaingang não está apenas ligado a uma questão de idade numérica, pois a marcação das fases da vida nesse formato não era conhecida e só passou a vigorar na aldeia a partir do contato com o não Kaingang.

A palavra "criança" não é um termo comum utilizado nas famílias e na aldeia para referirse aos Kãxit na língua Kaingang. Em outras possibilidades de entendimento sobre a fase que vai desde o nascimento até o tornar-se adulto, a palavra Kãxit também significa filho (como as outras duas denominações a seguir), e só é usada nesse intervalo da vida. Por exemplo: pai ou mãe, embora tenham dado um nome na língua Kaingang (nome do mato), e no presente um nome também na língua portuguesa, quando se referem a seus filhos (na língua Kaingang) usam as três nomenclaturas que demarcam três fases da vida do que entendemos convencionalmente como criança, a saber: 
Un Xi: fase até os 3 anos de idade;

Kãxit Xi: fase entre os 3 e 8 anos de idade, não são Kãxit, porque são pequenos exclusivamente em termos de altura e ainda são bastante dependentes de suas mães, mas são grandes em termos de altura para serem Un $X \hat{\imath}$.

Kãxit: fase ligeiramente anterior ao momento em que se tornará um adulto (menstruação para a menina, ejaculação para o menino), intermediário entre 8 e 13 anos de idade. Os Kãxit são, em outras palavras, pequenos adultos, mas com maturidade insuficiente para um adulto, porém, já não cabe mais a eles a ideia de pequeninos e indefesos: já respondem parcialmente por seus atos e já fazem as tarefas de um adulto.

Os pais usam expressões como: este é meu Kãxit, Kãxit $X \hat{i}$ ou Un $X \hat{i}$, ao apresentar seus filhos a outros pais do mesmo grupo. Caso os pais de uma família de fora (mas também família de Kaingang) queiram saber sobre os filhos do seu parente ou vizinho Kaingang, usarão a terminologia teu Kãxit, Kãxit Xî ou Un $X \hat{i}$. Já entre irmãos, o termo mais utilizado ao se referir às crianças pequenas é o que faz referência ao recém-nascido até os 3 anos de idade (Un $X \hat{1}$ ). Após essa fase os irmãos mais velhos, assim como outros integrantes da mesma idade em contextos diversos no interior da aldeia, e principalmente adultos que ainda não são pais, vão se referir às crianças dos outros e seus irmãos pelos respectivos nomes, sobretudo ao nome dado na língua Kaingang (nome do mato) e, em segundo plano, na língua portuguesa. 0 nome na língua portuguesa será também o primeiro nome apresentado pela família e pela comunidade de um modo geral ao fóg (essa palavra em Kaingang quer dizer 'não índio') ou aos Kaingang que não dominam a língua Kaingang, quando estes querem saber mais sobre as crianças nas famílias Kaingang.

De volta à ideia de em algum momento sermos chamados de criança mesmo sendo adultos, percebo no interior das famílias Kaingang o termo criança (em português) ser utilizado em conversas diversas entre adultos e principalmente adolescentes e ou pré-adolescentes, mas, quando usam essa palavra percebo que não se trata de uma referência às crianças Kaingang e sim ao termo e o ser criança como entendemos na cultura dos fóg. A palavra criança é utilizada em forma de brincadeiras e ou repreensões, quando um adulto quer chamar a atenção do outro para algo que não está certo, ou por simples zombarias no caso entre adolescentes e pré-adolescentes. Algumas palavras são proferidas da seguinte maneira:

- Você está parecendo uma criança porque não sabe fazer

- Você está falando mais que uma criança;

- Pare de ser como criança;

Dessa forma, percebo que a palavra criança tem também caráter pejorativo, quando se tem a intensão de reprimir o outro, pura e exclusivamente, sobretudo pela visão que se tem de criança como a criança ocidental que, como se sabe, destoa total ou quase totalmente do que o sujeito dessas idades representa e é na cultura Kaingang. Ninguém gosta de ser considerado uma criança, nem mesmo os Kãxit (que seriam também crianças). No campo, registro um Kãxit indignado por ter sido chamado de criança por seu irmão mais velho, uma indignação que resultou em luta corporal entre os dois. 0 irmão mais velho o havia chamado de criança porque não queria que ele o acompanhasse na pescaria onde o rio era mais fundo. Diante da insistência, o irmão mais velho disse "pare de ser criança”, e imediatamente o irmão menor começou a chorar e respondeu: "eu não sou criança, não sou fóg”, e partiu para luta corporal com o irmão mais velho, que ria e apenas se defendeu até conseguir segurar o menor.

A demarcação da ideia de ser criança tal como a entendemos na cultura dominante também me parece alheia em momentos de reuniões entre as lideranças e toda a comunidade, assim como nos acertos entre brigas de casais e desentendimentos diversos dentro da aldeia. Numa ocasião acompanhei uma reunião que tratava de um acerto entre um casal. A liderança da aldeia havia sido chamada para fazer o acerto do descasamento (como são entendidos dentro da aldeia casais que não querem mais ser casados); antes, porém, tinha a intenção de aconselhar o casal para que o descasamento não acontecesse. Numa das falas o conselheiro, um ancião com cerca de 80 anos, disse ao casal: "vocês parecem criança, não 
sabem nada, só brigam, os Un $X \hat{\imath}$, os Kãxit são mais sábios, aprendam com eles, vocês estão deixando eles com vergonha dos pais deles”. Percebo que, ao usar criança, o ancião está fazendo referência a gentes que são causadoras de desordem ou, na melhor das hipóteses, despreparadas para o que estão vivendo, características que não cabem aos Un $X \hat{\imath}$, Kãxit $X \hat{i}$ e Kãxit (seus filhos). A referência aos Un $X \hat{\imath}$, Kãxit $X \hat{i}$ e Kãxit retira deles a ideia de imaturos e incompletos, uma vez que pela atuação, embora não com estas palavras, já sejam compreendidos como sujeitos sociais.

0 uso da palavra criança se refere às formas como a percebemos na cultura dominante (alguém que precisa de instrução) ou apenas uma maneira de desqualificar o adulto, chamando a atenção para a criança que ele deveria deixar de ser, na esfera daquilo que não lhe cabe mais. Porém, ao dizer que os Un Xî e Kãxit são mais sábios e que os pais deveriam aprender com eles, passa-se da ideia da criança como se entende na cultura

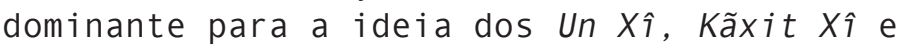
Kãxit, que, nesse entendimento e contexto, são tidos como os sábios da família. Dessa maneira é possível perceber claramente que o emprego da palavra criança pelo Kaingang é destoante e não se refere aos Un Xî̀, Kãxit Xî̀ e Kãxit.

Se há uma divergência de aplicação da palavra criança, seria possível dizer que na cultura Kaingang essa palavra tal qual a conhecemos, logicamente a partir de teorias diversas, não caberia aos Un Xîn, Kãxit Xî e Kãxit? Quem seriam os Un Xî̀, Kãxit Xî̀ e Kãxit, como vivem, são seres completos, adultos em miniatura? 0 que, afinal de contas, os define como Un $X \hat{\imath}$, Kãxit $X \hat{\imath}$ e Kãxit, se os velhos Kaingang não os enquadram linguisticamente ao se referir a eles na língua dominante como uma criança no modo convencional como a percebemos no mundo fora da aldeia? Qual - peso da língua Kaingang na significação das palavras, da vida cotidiana do grupo?

Também, percebo ${ }^{1}$ que a referência aos Un Xî, Kãxit $X \hat{\imath}$ e Kãxit usando a palavra criança acontece

1. Ao longo da escrita usarei a palavra perceber, "percebo", no sentido de observação, uma vez que o estudo aqui proposto reúne grande conjunto de minhas observações no campo. apenas quando a fala é na língua portuguesa; há um enquadramento de significado dos Un $X \hat{\imath}$, Kãxit Xî̀ e Kãxit (filhos) no termo criança mas, a partir dos exemplos trazidos, esse enquadramento ocorre exclusivamente ao referenciá-los na língua portuguesa, ou seja: há uma possibilidade de entendimento de que, ao falar dos seus na língua do outro, há um movimento de se fazer ser entendido nessa língua, na outra cultura que não a sua; significa dizer que Un Xî̀, Kãxit Xî̀ e Kãxit são entendidos como crianças no intermédio da língua Kaingang para a língua portuguesa, em que o câmbio linguístico se faz necessário como campo de produção de sentido no diálogo com sujeitos da cultura dominante que não conheçam "as crianças" que existem na sociedade Kaingang. Mas o caminho seguro do entendimento dessas fases só se dá em termos linguísticos na língua Kaingang, que vai também implicar não apenas uma questão linguística, mas de vida, interna ao povo. ${ }^{2}$

0 estudo que trago aqui é parte de minha pesquisa de doutorado em Educação, Cultura e Movimentos Sociais, recém-finalizado, pela Universidade Federal de Minas Gerais (UFMG) ${ }^{3}$ e versa sobre a criança indígena Kaingang do Sul e Sudeste do Brasil contemporâneo, as práticas de aprendizagem da língua e da cultura tradicional em seu cotidiano e as linguagens de representação e apresentação das crianças dentro e fora de seu contexto. Meus estudos sobre as crianças Kaingang já duram aproximados 10 anos, e neles busco percebê-las em seus contextos próprios, com olhar atento às suas práticas cotidianas, suas culturas e suas interações sociais.

Nesse intervalo de tempo, muitos registros foram feitos em diferentes mídias (fotografia, audiovisual e sonora) sobre as "criancices das crianças”, por assim dizer. Também procurei perceber como acontece a representação da criança por ela mesma (autorrepresentação) principalmente a partir da oralidade e da fotografia. Tal perspectiva representa o primeiro momento deste

2. Outras definições internas sobre as crianças e jovens: se for filho: káxit; se for qualquer criança: nhyr xin; rapaz: kovem; moça: xhay hã ou toton.

3. Bolsista CNPq (processo 147639/2014-@) e Capes (projeto 14792-0E2012). 
ensaio, para, só após entendermos a criança indígena em seu contexto, discorrermos sobre as "leituras visuais da criança indígena: uma abordagem para além da estética e do racismo étnico em fotografias infantis.

Assim como toda criança indígena, as Kaingang estão em todos os lugares o tempo todo: em grupos, fazendo alguma coisa, cumprindo alguma tarefa a pedido dos pais e ou interagindo consigo mesmas e com outros elementos da natureza - segundo os líderes espirituais (kujá), elas nunca estão sozinhas, estão o tempo todo em processo de aprendizagem, e recriando coisas em seu intelecto para posteriormente expressar essas coisas apreendidas em forma de gestos, palavras, cantos, danças, imitações e ou criancices. Elas estão sempre em processo de apreensão e transmissão de saberes próprios e daqueles adquiridos dos pais, na aldeia e, em alguns casos, quando muito sensíveis, de origem kujá (linhagem de líder espiritual): elas também apresentam e representam o saber adquirido dos espíritos.
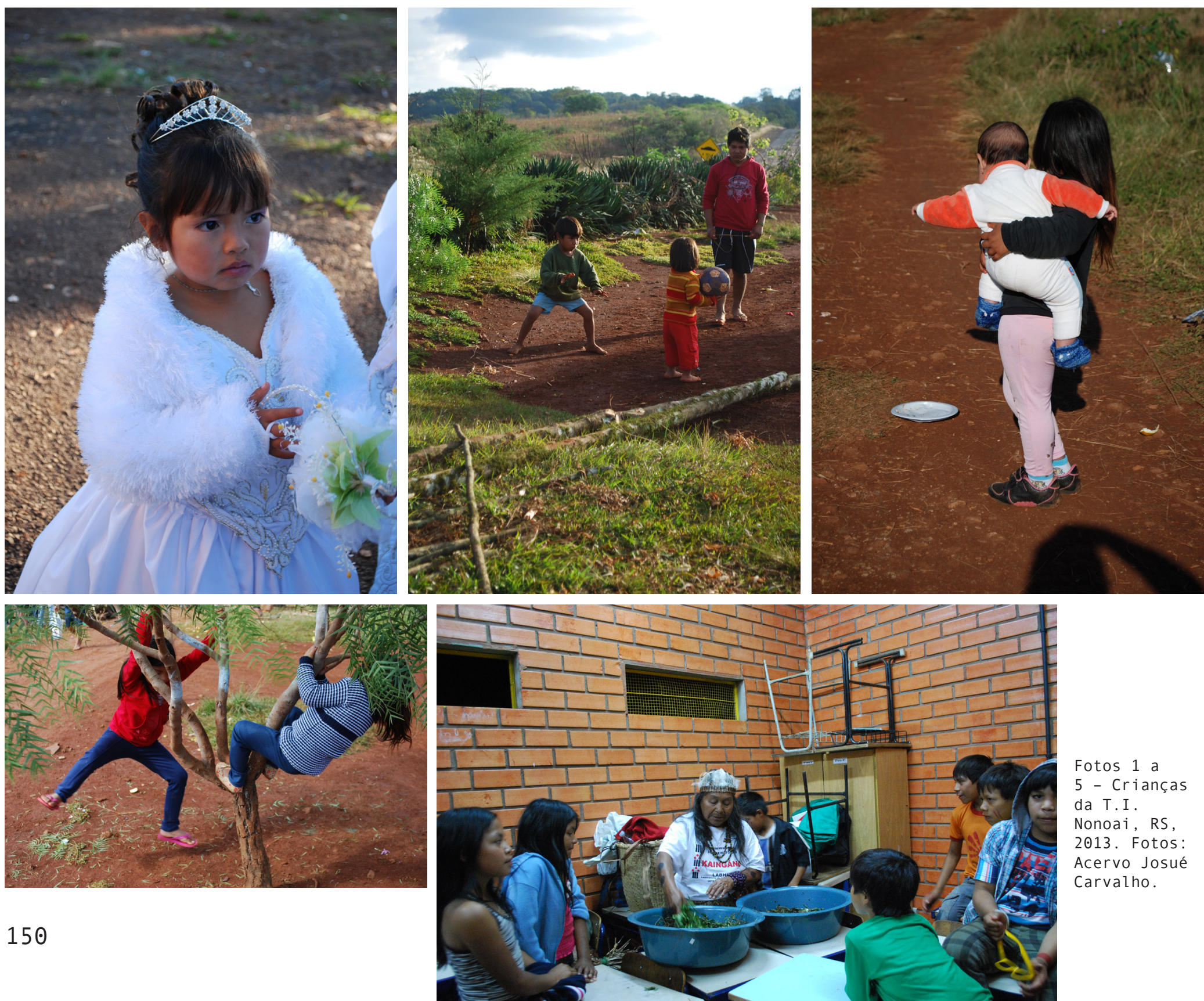

Fotos 1 a 5 - Crianças da T.I Nonoai, RS 2013. Fotos: Acervo Josué Carvalho. 


\section{Leituras das outras linguagens de representação da criança indígena}

Todos sabemos que, em diferentes contextos e sociedades culturais, as crianças estão em toda parte; todos temos, desejamos ou não desejamos ter crianças. Segundo Cohn (2005, p.33), "poetas românticos falam com nostalgia de seu tempo de criança. É como se tudo já fosse sabido, como se não houvesse espaço para dúvidas ... A criança pode ser a tábula rasa a ser instruída e formada moralmente, ou o lugar do paraíso perdido, quando somos plenamente o que jamais seremos de novo".

0 tempo todo somos (não apenas as crianças) observados por diferentes olhares, em diferentes ângulos, cada olhar que se fecha e abre é como um flash que registra, que eterniza momentos na memória e ou simplesmente não captura nada: a questão é que cada olhar irá para uma direção, a partir dele defendemos teses, chegamos a conceitos e ou pré-conceitos.

Mas o universo da criança indígena, como os diferentes olhares as têm representado através de lentes fotográficas? Como na contemporaneidade os flashes fotográficos se inserem no universo da criança indígena e tecem leituras visuais sobre ela? Estariam os flashes traçando uma leitura do tempo atual da criança indígena, ou a remetendo com seu povo a um tempo remoto que encontramos apenas na literatura da história do descobrimento do Brasil? Qual o papel dos diferentes campos do conhecimento, da antropologia visual, da educação e da museologia ao representar a criança indígena, de modo que o belo não seja o estético, os traços, o "parecer ser", quando a criança apenas "é o que é"?

Neste momento o tema do racismo e do preconceito volta à ordem do dia, em diferentes contextos e formas, como nos fatos recentes que causaram alvoroço em rede nacional, pelos mais diferentes meios e veículos de comunicação - caso do goleiro negro chamado de macaco; caso do galpão incendiado antes de sediar um casamento gay e, principalmente, o caso da morte do menor Vitor Kaingang, degolado enquanto era amantado no seio de sua mãe, fatos registrados no sul do país - entre outros inúmeros casos de racismo e preconceito contra a pessoa e sua forma de simplesmente ser e existir. Somos instigados a saber como, afinal de contas, as imagens enunciam as crianças indígenas no presente.

Segundo dados da ONU (2009), no Brasil vivem 31 milhões de meninas e meninos negros e $140 \mathrm{mil}$ crianças indígenas. Eles representam $54,5 \%$ de todas as crianças e adolescentes brasileiros (IBGE, 2009). Essas crianças diariamente são vítimas, nos diferentes campos do país, de atos de racismo e preconceito, e na maioria das vezes por sua raça e cor, que fogem ao biótipo pretendido para a sociedade nacional. Outro

fator importante é a forma como tais crianças e a cultura de seu povo são apresentadas à sociedade pelos diferentes meios de comunicação, nesse caso em específico pelo meio visual. Há uma tendência em explorar o belo como exótico, os traços de pertença, as pinturas corporais, a cor da pele e do cabelo, o delinear dos olhos, das curvas ou, quando não se destacam esses estereótipos, traz-se uma leitura da criança na representação da miséria em termos econômicos e ou num modo atrasado de viver e "educar" a criança.

Ao pensar este ensaio, busco visualizar a criança indígena vivendo no hoje, através da lente do tempo, ou seja, uma criança que pertence a um povo (indígena) que também foi vítima não passiva, mas fortemente ativa, no impacto da globalização, do encontro com o outro. Recusome a produzir mais um ensaio em que a cultura do povo indígena seja vista como estática, como se ao índio não coubesse o presente. Sinalizo que não há mais tempo para ignorar o presente, ignorar que o povo indígena também é senhor de seu tempo e, portanto, contemporâneo.

Segundo Menezes (1997, p. 76), “não há sentido imanente nas coisas físicas, nós é que o produzimos, uma ideia sem suporte sensorial fica aprisionada na mente. A estética (no sentido etimológico, de percepção) é a base da vida social”. Uma criança indígena não é só estética, estereótipo, ou o lugar do mundo perdido ao qual os adultos não têm mais acesso, ela é também um sujeito do seu contexto e da sociedade; representa cultura que é algo que se vive. 
Muitos grupos de crianças indígenas no Brasil em suas aldeias, assim como a criança Kaingang, desde que nascem estão à mercê de dois mundos: o seu e o mundo dos fóg (como é chamado o não índio). De um lado, vivem na sua cultura como algo herdado, sem a preocupação de ser ou deixar de ser quem são (criança), mas no desenrolar da vida se veem obrigadas a afirmar-se como índio, ora para dentro do grupo, ora para fora dele. Algumas crianças, cujos nomes não citarei, relatam a dificuldade de ser apenas uma criança hoje:

Eu tenho 8 anos, meu pai não é índio, só minha mãe que é, eu não conheço meu pai, só sei porque tenho a cor branca como ele. Fora da área dizem que não sou índio e até dentro da aldeia também dizem, mas eu só conheço minha família de índio. Eu sei que sou índio, eu falo a língua, os parentes da minha mãe são, então eu também sou, porque nasci na aldeia e aprendi coisas de índio com meu avô, então eu sou um índio. ${ }^{4}$

Quando tem gincana e a gente vai à escola dos brancos eles dizem que nós não somos mais índios, só porque queremos estudar. Eu queria saber: por que na cabeça dos brancos o índio não pode estudar que já deixa de ser indio ${ }^{5}$

Eles dizem que nós nem tomamos banho e que temos celular, dizem que índio são os do Amazonas, porque eles vivem pelados e sempre pintados nas fotos. ${ }^{6}$

É a esse universo de imagens avessas que a criança indígena está exposta no presente, à mercê de discursos de outras crianças que deveriam apenas estar preocupadas em brincar, socializar, o que é natural no período do ser criança. Pergunto-me de onde vêm essas afirmações estereotipadas do pertencimento étnico. Estariam as imagens, as literaturas, a mídia visual, as exposições museológicas e a educação a contribuir

4. Criança Kaingang, 8 anos, T.I. Vanuíre, Arco Íris, SP.

5. Criança Kaingang, 10 anos, frequenta na escola o $5^{\circ}$ ano na escola indígena, T.I. Nonoai, Nonoai, RS.

6. Criança Kaingang, 11 anos, frequenta $06^{\circ}$ ano em escola municipal, T.I. Conda, Chapecó, SC. com esse sentimento racista e preconceituoso? Ora, se em pleno século XIX esse ainda é o discurso sobre o índio, posso afirmar que o conceito de evolução não surtiu efeito para o fóg com esse discurso. Não cabe aqui uma defesa e ou tendência de lados, instiga-se à análise, sobretudo, da evolução ou degradação do pensamento, da sociedade em diferentes contextos.

No relato também percebemos que o preconceito não vem apenas de fora, a reprodução do preconceito também acontece de índio para índio, como vemos em outro depoimento:

Quando eu era criança, tinha poucos brancos na aldeia, logo depois eles foram chegando, trouxeram a escola, entraram na cabeça da liderança e diziam que a escola era para nós índios, eu não fui à escola, mas meus filhos tiveram que ir. Desde pequena eu ouvia os brancos dizerem que os índios não prestavam, que eram vagabundos, então quando meus filhos ficaram com idade de ir na escola eu não deixei, então fui castigada, fiquei no tronco meio dia, tenho a marca na minha perna até hoje. Na escola meus filhos não poderiam falar a língua indígena, se falasse era castigado, eu fiquei brava com o meu povo por deixar aquilo acontecer e não ensinei mais a língua indígena para meus filhos. Ensinei eles a serem como os brancos, mas hoje vejo que também errei, porque meus netos não sabem direito, mas não foi porque eu não quis, eu só queria que meus filhos não sofressem por ser índio, agora às vezes eles sofrem porque não sabem falar a língua e aí os brancos dizem que eles não são mais índios e os índios dizem que eles são precisam aprender. ${ }^{7}$

0 que percebemos não é uma mera reprodução interna do "preconceito" e, talvez, nem possa ser entendido como tal, se em um momento o índio foi obrigado a deixar de ser índio, como era o plano de Brasil até meados dos anos 1970. Em outro momento, ele se vê obrigado a se manter como tal, porém, já com rupturas gravíssimas em suas formas próprias de viver e cultivar seus costumes herdados de geração a geração.

7. Anciã Kaingang, 90 anos, T.I. Nonoai, Nonoai, RS. 
Vou entender nesse contexto (em que existe a possível reprodução do preconceito interétnico) um alerta aos mais novos da aldeia, uma forma que o velho percebeu de instigar o próprio índio a revitalizar o seu legado cultural. Na T.I. Nonoai, onde acompanho com mais afinco as práticas de transmissão e aprendizagem da língua e da cultura tradicional, registro alguns momentos que vou assimilar como performáticos no processo de apresentação interna e externa dos costumes Kaingang, certos rituais de passagens, como:

Casamento Kaingang: a base desse casamento é a união das duas metades cosmogâmicas, só pode acontecer entre pessoas de marcas diferentes, ou seja, Kamé (representa os motivos da lua, traços abertos, compridos), Kanhrú (representa só motivos do sol, traços arredondados, fechados); essa identificação é comum aos grupos Jê, entretanto cada povo tem sua forma de entender esse processo.

Apresentação da menina como mulher: uma vez ao ano acontece uma grande festa de apresentação da menina como mulher à aldeia; toda menina ao passar pela primeira menstruação deve ir à busca, com suas avós e irmãs mais velhas, de seus conhecimentos sobre o que é a mulher Kaingang; deve aprender sobre as pinturas corporais, reverência aos irmãos mitológicos da origem do Povo Kaingang (Kamé e Kanhrú) e preparar, a partir da natureza, vestimentas para apresentar-se no dia marcado (geralmente acontece no mês de maio, época da colheita do pinhão). Toda a aldeia comparece à festa, inclusive as crianças; a menina se apresenta hoje num desfile vestida com seu traje típico, deixando em evidência suas pinturas corporais; através da pintura corporal ela mostra a seu futuro marido a que metade pertence: os meninos da mesma metade as tratarão como irmã, nunca como possível esposa. No final do desfile uma das meninas será escolhida a mais bela índia da aldeia.
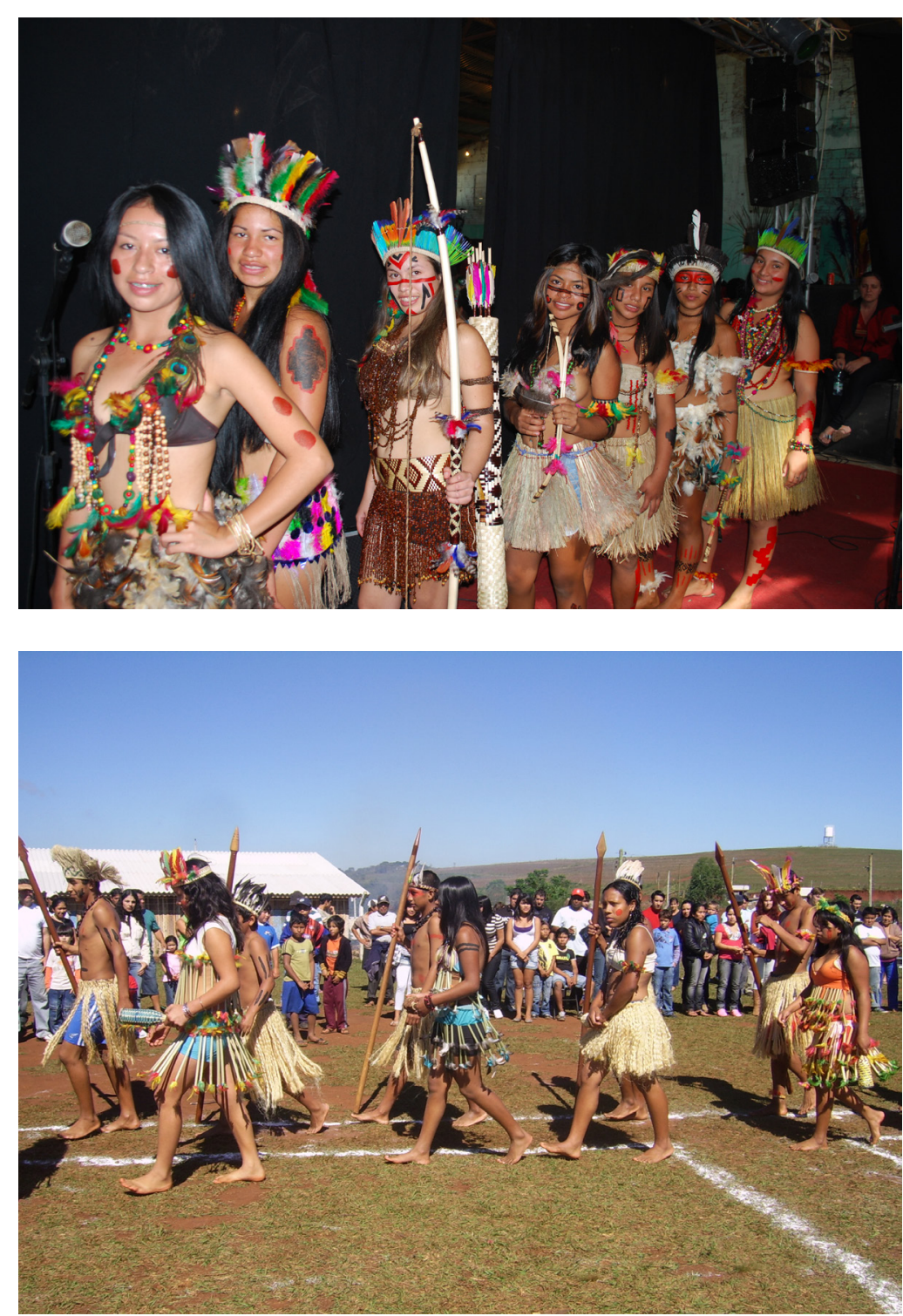

Fotos 6 e 7 - Índias Kaingang, T.I. Nonoai, RS, maio de 2014 Fotos: Acervo Josué Carvalho.

Não é a beleza da mulher Kaingang que conta, mas como ela representa o conhecimento que aprendeu com suas avós, a forma como traz a pintura corporal em seu corpo e faz referência aos que já morreram, isso é a beleza da mulher Kaingang, ela tem uma cultura e está representando a cultura do Kaingang. ${ }^{8}$

8. José Oreste do Nascimento, cacique da T.I. Nonoai, RS. 
0 movimento de apresentação da menina como mulher é coordenado pela escola a pedido da liderança e dos mais antigos da aldeia. É interessante aqui uma relação: tratando-se de escola indígena, há novas possibilidades no âmbito escolar, com a apropriação da escola pelo Povo Kaingang, no reverso do que foi a instituição escola dentro das aldeias há algumas décadas, quando sua função era estar a serviço do Estado para manter uma política integracionista vigente no Brasil até recentemente, a qual desconsiderava a cultura que não fosse a hegemônica; não reconhecia, nem atribuía valor algum à cultura indígena, nem a reconhecia como etnia diferenciada com identidade própria, fato que toma outros rumos com a Constituição Federal de 1988.

A Constituição Federal de 1988, a lei maior do Brasil, inaugura no cenário nacional o reconhecimento de que a diversidade cultural é um bem jurídico a ser protegido pelo Estado brasileiro e estabelece o respeito às organizações sociais, línguas, crenças e tradições dos povos indígenas em consonância com seus artigos 215 e 231. 0 indígena deixa de ser considerado um semicapaz, para também ser um sujeito ativo em diferentes contextos.

\section{A mirada da antropologia para a criança indígena}

Em seus estudos sobre concepções indígenas de "infância" no Brasil, Tassinari (2007) registra que a mirada da Antropologia para as crianças indígenas em nosso país é muito recente e podese dizer que "embora as crianças sejam aquelas que mais pacientemente nos acolhem nas aldeias, temos nos dedicado muito pouco à interlocução com elas". Ainda segundo a autora:

Ao fazer uma revisão das etnografias sobre duas populações indígenas (Qom e Mbyá), Enriz, Palácios e Hecht (2007) encontraram pouquíssimas descrições das dinâmicas cotidianas infantis. Perceberam que essas etnografias se referem às atitudes dos adultos nos cuidados relativos à gestação, ao parto e ao recém-nascido e, em seguida, tratam dos ritos de iniciação dos jovens para sua integração ao mundo adulto. Portanto, entre o nascimento e a vida adulta, há um grande vazio de informações. Pode-se dizer que esse vazio é constante nas etnografias sobre povos indígenas da América do Sul em geral. Segundo Nunes (2005), essa ausência de informações sobre as crianças decorre do 'adultocentrismo' que marca o pensamento ocidental, dificuldade que não é compartilhada pelas sociedades indígenas, que reconhecem a autonomia e a legitimidade das falas infantis. (Tassinari, 2007, p.12)

Nesse sentido, podemos perceber a importância de olhares em que seja possível visualizar a criança como um agente, sujeito, um ator fundamental na estrutura familiar e social de um grupo indígena, não como mera representante do belo diferente e ou outro sentimento que a tire do seu posto de ser apenas uma criança, com formas diferentes de expressar e viver em sociedade. Em tal perspectiva, Borba afirma que:

\section{A concepção da criança como sujeito, no entanto, vai além da noção de que as crianças possuem uma subjetividade, estendendo-se para a compreensão de que elas são sujeitos ativos na sociedade em que se inserem e de que seus conhecimentos, sentimentos e valores devem ser levados em conta na pesquisa, ou seja, as crianças devem ser ativas e participantes também no processo de pesquisa. (Borba, 2006, p.58)}

Durante muito tempo as crianças indígenas foram subjugadas nos estudos etnográficos, a maioria das vezes aparecendo apenas para compor a análise da organização do grupo doméstico e/ou remissões às fases do ciclo de vida do indivíduo. Para Nunes (2002), o ponto de partida desses estudos não era a criança, mas qualquer outro tema que, às vezes, adentrava na temática da infância indígena apenas para auxiliar a elucidação da questão central.

Qual era a perspectiva analítica desses estudos etnográficos sobre as crianças indígenas? Em primeiro lugar, elas não eram ouvidas, ou seja, as perguntas não lhes eram feitas diretamente, 
nem o que falavam detinha qualquer importância para compor o diário de campo dos pesquisadores. Em segundo lugar, a forma de aprendizagem na interação com o mundo adulto era analisada pelo viés da imitação: cabia às crianças indígenas, no entender dos etnógrafos, o papel de meras reprodutoras passivas das tradições culturais. Em terceiro lugar, estabeleciam-se comparações culturais inadequadas, pois assimetricamente mediadas pelo paradigma da infância universal, potencialmente restritivo da lente analítica adequada para a elaboração de reflexões sobre a construção sociocosmológica e identitária das crianças indígenas que começassem por questionar as normalidades ocidentais impostas e os espaços políticos, jurídicos e éticos propícios para o diálogo democrático e intercultural.

Não há novidade alguma em afirmar que a dimensão do "ser criança” entre povos indígenas não segue as mesmas diretrizes e concepções valorativas e culturais das sociedades ocidentais, sobretudo quanto às questões relativas ao corpo e à pessoa. De acordo com Rosa (2008), em seus estudos (antropológicos) entre os Kaingang (sujeitos em análise neste estudo), as práticas cotidianas relativas ao "fazer-se uma pessoa Kaingang" perpassam a lógica da relação dos sujeitos com seus ambientes de vida. Assim, o corpo é entendido não somente como suporte identitário ou de afirmação de papéis sociais, mas também como instrumento e atividade que articula significações sociais e cosmológicas, local da justaposição entre pessoa, corpo e sujeito indígena. Ainda segundo a autora

a individualidade do corpo depende do processo de socialização desde o qual o sujeito constitui suas relações... Como meio de incorporação dos valores e símbolos culturais, o corpo é socialmente produzido pelo tratamento corporal que the apropria os códigos relativos às mensagens específicas sobre modos, estados e estágios de desenvolvimento do ator social. (Rosa, 2008, p.111)

Ao pensar este estudo sinalizo para a reflexão sobre questões como: quais consequências de cunho epistemológico e ou social decorrem das formas de representar as crianças indígenas através do vídeo, da internet, de fotografias, em estudos de pesquisadores e mesmo em exposições museais? Qual o papel dos diferentes campos do conhecimento, da educação, da antropologia visual e da museologia nesta tarefa? E, afinal, quais verdades enunciam as crianças indígenas hoje?

Em pesquisa na web, arrisco dizer que no que compete ao Povo Kaingang, em redes sociais, a apresentação da criança é mínima. Dos mais de 800 perfis pesquisados em meu perfil pessoal https:// WWW.facebook.com/indio.kanhgag\#, foi possível perceber as formas como as crianças indígenas são apresentadas pelos próprios Kaingang, ou melhor dizendo: não há uma representação. As imagens expostas na rede sobre a criança a remetem a seus contextos originais, e dificilmente despertam a atenção para o lado estético da criança na imagem, o que conversa com que os antigos afirmam: "o adulto tem que respeitar as crianças, porque ele já viveu mais que ela, ele tem que ser o exemplo dela, uma criança bonita é aquela que sabe a cultura, não é o que ela apresenta por fora". 9

Há uma representação da criança em contexto, em suas práticas cotidianas e não de forma performática; para o Povo Kaingang, em depoimentos dos velhos, a pintura corporal é algo sagrado, faz referência aos antepassados:

nós, índios Kaingang, não vivemos o tempo todo pintados ou com trajes de rituais; rituais são sagrados, são feitos para o Povo Kaingang, e é nesse momento que o índio precisa estar de acordo desde a pintura corporal. Cada pessoa é diferente uma da outra, mesmo os índios, o índio não pode só ser índio porque está de cocar, pintado, pelado ou se parece com índios de quando o Brasil foi descoberto. Nunca teve um índio igual, isso é uma forma preconceituosa usada pelo branco para atacar o índio. ${ }^{10}$

9. Líder espiritual Kaingang, 96 anos, T.I. Nonoai, RS, registro em agosto de 2013.

10. Artesão Kaingang, 60 anos, T.I. Iraí, RS, registro em outubro de 2013. 


\section{Considerações finais}

Qualquer sistema de linguagem na apresentação e representação do outro ou de si constitui-se da linguagem, do autor e do leitor. As teorias que gravitam em torno desse tripé têm por objetivo a fruição, a interpretação ou a produção das representações. Vamos pensar a representação visual da criança indígena pelo viés da "estética da recepção" que surge com o desejo explícito de conceder ao leitor o seu devido lugar. Ela subverte o exclusivismo da teoria da estética tradicional, uma vez que entende a leitura de algo como processo de produção, recepção e comunicação, ou seja, uma relação dinâmica entre autor, imagem, leitor e o sentido daí resultante.

Ao apresentar a criança indígena, seja pelo viés da antropologia visual, da educação ou da museologia, estamos também possibilitando ao receptor/leitor outras leituras, literaturas. Ao apresentar algo, a lógica da estética da recepção sugere que o processo de leitura sobre o outro ou de si é de duplo sentido: uma produção de sentidos implicada pela obra e o horizonte projetado pelo leitor de determinada sociedade. Zilberman (1989) defende que as abordagens da estética da recepção levam em conta as condições sócio-históricas das diversas interpretações textuais pelo universo de leitores possíveis. 0 discurso se constitui, através de seu processo receptivo, como pluralidade de estruturas de sentido historicamente mediadas.

Sem destoar do passado histórico, o presente é marcado por tempos de grandes conflitos entre índios e não índios, como os casos da usina hidrelétrica de Belo Monte no rio Xingu, Pará, da luta indígena pela preservação do antigo Museu do Índio nos arredores do Estádio do Maracanã, no Rio de Janeiro, e dos 27 índios Guarany-kayoa mortos no Mato Grosso do Sul em 2012, advindos de confrontos com colonos e fazendeiros na luta pela preservação de seus espaços territoriais. Sujeitos de suas culturas, as crianças estão à mercê desses confrontos e são alvo, com os seus, de todo tipo de preconceito afetando sua integridade emocional e física.
As imagens produzidas sobre as crianças antes de tudo precisam colocá-las no lugar de crianças: embora sejam também sujeitos ativos e reprodutores de culturas, são apenas crianças. Em antropologia visual, o debate precisa sair das ferramentas tecnológicas para o campo da representação do outro, a tecnologia é apenas um instrumento, o que está em jogo vai muito além disso, representam-se formas únicas de se apresentar e viver em sociedade.

A antropologia visual, a educação e a museologia são um campo do conhecimento, não um organismo, e não se trata de uma instituição universal, apesar de sua tamanha abrangência e relevância. Precisamos ter claro que as culturas são também recicláveis, não são estáticas, mesmo que guardem vestígios de um tempo que no presente pode não existir mais. Arrisco-me a dizer que para fazer uma antropologia visual representativa de fato, as imagens precisam capturar mais que traços estéticos, biótipos indígenas, pois, como diz Viveiros de Castro (2016),

índio não é uma questão de cocar de pena, urucum e arco e flecha, algo de aparente e evidente nesse sentido estereotipificante, mas sim uma questão de "estado de espírito". Um modo de ser e não um modo de aparecer.

As imagens da criança indígena precisam se desvincular da tendência do estereótipo, do selvagem, do exótico, porque nesse sentido produz-se preconceito num universo que não está preparado para lidar com ele, e é criminoso. $\mathrm{Na}$ entrevista à revista Veja em 3 de maio de 2010, o antropólogo Eduardo Viveiros de Castro chama a atenção para a problemática das ideias distorcidas sobre o índio:

A questão de quem é ou não é índio reaparece agora, mas por outras razões. Algumas pessoas ligadas à questão indígena têm por vezes a impressão (ou pelo menos eu tenho a impressão de que elas têm a impressão) de que nós, índios e antropólogos, fomos um pouco vítimas de nosso próprio sucesso. Antigamente, muitos coletivos indígenas sentiam vergonha de sê-lo, e o governo tinha todo interesse em aproveitar essa vergonha inculcada sistemicamente, 
tirando as consequências jurídico-políticas, digamos assim, do eclipsamento histórico da face indígena de várias comunidades “camponesas” do país. Agora, ao contrário, "todo mundo quer ser índio" - dizemos, entre intrigados e orgulhosos. Talvez mais intrigados que orgulhosos.

Isso não quer dizer que todo mundo possa ser índio, porque só é índio quem é. Representar a criança indígena dos ângulos em que ela está sendo representada hoje (pelo viés do estereótipo anacrônico de representação vigente: a criança imaculada, imageticamente performática, ou na miserabilidade etc.) não retrata a representação do imaginário real por se tratar de um movimento de vaidade estética e não de representação ideológica da criança indígena. A criança indígena não vive numa redoma, vive em variados contextos e lugares, é também agente ativa desses contextos, circula pelos diferentes mundos culturais, é fruto de uniões entre índio e não índio, não pode estar preocupada em ser ou não ser.

Dada a multiplicidade de lugares em que elas estão inseridas hoje, ter o foco apenas nos traços exteriores é ignorar e instigar o preconceito e o racismo, ideias estereotipadas sobre a criança indígena. A criança indígena na contemporaneidade é também fruto de outras relações, como a união entre um índio e um não índio, entretanto vive desde seus primeiros momentos na aldeia e tem a filosofia indígena a partir dos ensinamentos de seus ancestrais índios, nesse sentido o estereótipo não a desqualifica como uma criança indígena.

As imagens não podem ser um parâmetro de configuração e ou verificação no que concerne à questão "ser ou não indígena" quando incidem sobre as crianças miscigenadas ou não. Ademais, é necessário perceber a criança como indígena, com olhar livre dos estereótipos, pois o que não é percebido não existe.

Os estudos vinculados ao campo do conhecimento, sejam da antropologia visual, educação ou museologia, mediados pelas tecnologias visuais, como a fotografia e o vídeo, possibilitam ao pesquisador registros de campo que apenas sua memória e anotações escritas ou em áudio não conseguiriam capturar, os detalhes do universo estudado. Ao estudar a cultura do outro, nesse caso específico, os estudos precisam se desvincular de imagens estereotipadas, ou contribuir para a criança dessas imagens: o olhar para a cultura do índio e de suas crianças precisa caminhar paralelo com o tempo, não se trata de uma imagem estereotipada do índio, trata-se de uma imagem da vida do índio guardião de um legado cultural único, porém, em movimento natural com o tempo e as complicações deste.

\section{Referências}

ALMEIdA, Ana Nunes de. Para uma sociologia da infância: jogos de olhares; pistas para investigação. Lisboa: ICS - Impressa de Ciências Sociais, 2009.

AMBROSETTI, Juan B. Los índios Kaingángues de San Pedro (Misiones). Revista del Jardin Zoológico de Buenos Aires, Buenos Aires, v.2, n.10-12, p. 305-387, 1894 .

BIGG-WITHER, Thomas P. Novo caminho no Brasil Meridional: a provincia do Paraná. Três anos de vida em suas florestas e campos. 1872-1875. Trad., introd. e notas de Temistocles Linhares; nota biográfica de Newton Carneiro. Rio de Janeiro: J. Olympio Ed., 1974. (Documentos Brasileiros, 162).

BORBA, Ângela Meyer. Culturas da Infância nos espaços tempos do brincar. Tese (Doutorado em Educação) - Faculdade de Educação, Universidade Federal Fluminense. Niterói, 2006.

BORBA, Telêmaco M. Breve notícia sobre os índios Caingangs, acompanhada de um pequeno vocabulário da língua dos mesmos indígenas e da dos Cayguás e Chavantes. Revista Mensal da Secção da Sociedade de Geographia de Lisboa, Rio de Janeiro, n.2, p.20-36, 1883.

BRASIL. Lei de Diretrizes e Bases da Educação 9.394/6. 1996.

BRASIL. Ministério da Educação (MEC). Referencial Curricular Nacional para a Escola Indígena. 1998.

CASTRO, Eduardo Viveiros de. No Brasil todo mundo é índio, exceto quem não é. Revista Veja 
online, 3 maio 2010. Disponível em: http:// veja.abril.com.br/noticia/brasil/brasil-todomundo-indio-quem-nao.

Os Pronomes Cosmológicos e o

Perspectivismo Ameríndio. Mana, Rio de Janeiro, v.2, n.2, p.115-143, 2006.

COHN, Clarice. A criança indígena: a concepção Xikrin de infância e aprendizado. Dissertação (Mestrado em Antropologia Social) - Universidade de São Paulo. São Paulo, 2000.

Antropologia da criança. Rio de Janeiro: Jorge Zahar, 2005.

IBGE. Instituto Brasileiro de Geografia e Estatística. PNAD 2009. Crianças - população de até 17 anos. Brasília, 2009.

MABILDE, Pierre François Alphonse. Apontamentos sobre os indígenas selvagens da nação "Coroados" que habitam os sertões do Rio Grande do Sul, pelo Tenente-coronel P. F. Affonso Mabilde (1866). Annuario do Estado do Rio Grande do Sul. Porto Alegre, ano XIII, p.145-167, 1897.

MACDOUGALL, David. Film, Ethnography, and the Senses: The Corporeal Image. Princeton \& 0xford: Princeton University Press, 2006.

MELLO, Marcos. Reconstrução curricular via pesquisa da realidade e tema gerador. Porto Alegre: Secretaria Estadual de Educação; CORAG, 2002. (Cadernos Pedagógicos Seduc-RS).

MENEZES, Philadelpho (Org.) Signos Plurais. São Paulo: Experimento, 1997.

NUNES, Angela. No tempo e no espaço: brincadeiras das crianças A'uwe-Xavante. In: SILVA, Aracy Lopes da; NUNES, Angela; MACEDO, Ana Vera Lopes da Silva (Org.) Crianças indígenas: ensaios antropológicos. São Paulo: Global, 2002. p.64-99.

NUNES, Angela. A sociedade das crianças A'uwêXavante - por uma antropologia da criança. Dissertação (Mestrado em Antropologia Social) Universidade de São Paulo. São Paulo, 1997.

PINK, Sarah. Doing Visual Ethnography: Images, Media and Representation in Research. London: Sage, 2001.

ROSA, Patrícia C. "Eu também sou do mato": a produção do corpo e da pessoa Kaingang. In: POVOS INDÍGENAS na Bacia Hidrografia do Lago Guaíba. Porto Alegre: Prefeitura municipal de Porto Alegre/ Núcleo de Políticas Públicas para os Povos Indígenas, 2008. p.109-121.

TASSINARI, Antonella. Concepções indígenas de infância no Brasil. Revista Tellus, Campo Grande, ano 7, n.13, p.11-25, 2007. Escola indígena: novos horizontes teóricos, novas fronteiras de educação. In: LOPES DA SILVA, Aracy; LEAL, Mariana Kawall Ferreira (Orgs.). Antropologia, História e Educação - A questão indígena e a escola. São Paulo: Global, 2001, p. 44-70.

TYLER, Stephen A. Post-modern Ethnography: From Document of the Occult to Occult Document. In: CLIFFORD, J.; MARCUS, G. E. (Ed.) Writing culture: the poetics and politics of ethnography. Berkeley: University of California Press, 1986. p.122-140.

VEIGA, Juracilda. Revisão Bibliográfica Crítica sobre Organização Social Kaingang. Cadernos do Ceom, Chapecó, SC: Unoesc, n.8, 1992.

WATSON-GEGEO, K. A. Ethnography in ESL: defining the essentials. Tesol Quartely, Alexandria, v.22, n.4, p.575-592, Dec. 1988.

WIESEMANN, Ursula. Dicionário Kaingáng-Português, Português-Kaingáng. (1.ed. 1971). Rio de Janeiro: Summer Institute of Linguistics (SIL), 1981.

ZILBERMAN, Regina. Estética da recepção e história da literatura. São Paulo: Ática, 1989.

\section{Sites}

https://www.flickr.com/photos/ resarmento/5650457645/in/photostream/; Acesso em: 17 out. 2014 .

http://lutadeclasses.blogspot.com.br/2012/01/ madeireiros-queimam-crianca-indigena-no.htm l ; Acesso em: 17 out. 2014.

\footnotetext{
* Josué Carvalho é publicitário graduado pela Universidade Comunitária da Região de Chapecó (UnoChapecó), mestre em Memória Social pela Universidade Federal do Estado do Rio de Janeiro (UniRio) e doutor em Educação, Cultura e Movimentos Sociais pelo Programa de Pós-Graduação em Educação da Universidade Federal de Minas Gerais (UFMG). Docente Convidado em Licenciatura Intercultural Indígena do Sul da Mata Atlântica na UFSC. Pesquisador Kaingang.
} 


\title{
Museus e indígenas - novos procedimentos para uma nova política: a gestão de acervos em discussão
}

\author{
Juliana Dal Ponte Tiveron* \\ José Francisco Miguel Henriques Bairrão** \\ Faculdade de Filosofia, Ciências e Letras de Ribeirão Preto, Universidade de São Paulo (FFLCLRP-USP)
}

\section{Pesquisa em Psicologia e Instituição Museal}

Há aproximadamente 2 anos tem sido realizada a pesquisa ${ }^{1}$ (inicialmente mestrado, e agora doutorado), chamada "Etnocídio e Memória Social: a aldeia dos Mortos no Sertão Paulista”, orientada pelo Prof. José Francisco Miguel Henriques Bairrão, na T.I. Vanuíre e na T.I. Icatu. Basicamente, tal estudo objetiva delinear os efeitos subjetivos atuais do processo de colonização do oeste do estado de São Paulo, de modo mais veemente com a população indígena Kaingang, ${ }^{2}$ afetada diretamente pelas políticas do Serviço de Proteção aos Índios (SPI). Antes dos aldeamentos do SPI (hoje chamados Território Indígena Vanuíre e Território Indígena Icatu), muitos foram os indígenas mortos por conflitos com os colonizadores, principalmente com a construção da estrada de ferro Noroeste do Brasil.3 Porém, com os aldeamentos, muitos foram os que morreram por doenças contagiosas, e os que sobreviveram, além de sofrerem com a perda de seus entes, também tiveram de lidar com mudanças radicais nos seus modos de vida.

1. Agradecemos à Fapesp o incentivo na realização desta pesquisa (processo 2015/04974-5).

2. Povo pertencente à família linguística Jê. Vive em áreas hoje denominadas estado de São Paulo, Paraná, Santa Catarina e Rio Grande do Sul. Atualmente estimam-se, no total, 32 T.I. Kaingang (dado disponibilizado no site do Instituto Socioambiental: http://pib.socioambiental.org/pt/povo/ kaingang/286; Acesso em: abr. 2016.

3. Para mais informações acerca da construção dessa ferrovia consultar Moratelli (2009).
A queda populacional repentina dificultou a transmissão de saberes dos mais velhos aos mais jovens, ao passo que a política indigenista em voga preocupava-se em integrá-los à sociedade brasileira. Com isso, os indígenas passaram a realizar trabalhos agrícolas e manejo de animais, a ter de priorizar a aquisição de comida, ao invés da caça, a lidar com a ilegitimidade de seus rituais, regras de casamento, suas leis e modos punitivos, bem como a não legitimidade de seu idioma.

Embora o cenário relatado inspire terror e convide ao assombro, sua finalidade é outra. Não se busca analisar mudanças culturais Kaingang para, então, afirmar que são aculturados, e sim comunicar uma reconciliação com a ideia da morte, por via da etnopsicologia.

Porém, faz-se aqui uma ressalva: Manuela Carneiro da Cunha (1978) salienta que, para os indígenas, a partida para o mundo dos mortos é compreendida pelos vivos como uma traição e um rompimento. Com isso, os mortos são excluídos da sociedade dos vivos e são considerados como inimigos, estabelecendo-se, assim, uma enfática distinção entre eles e os vivos. ${ }^{4}$

Práticas como a destruição dos bens do morto e o não pronunciamento de seu nome são realizadas pelos

4. Vale mencionar que a autora realizou seu estudo com o povo Krahô, pertencente à família linguística Jê. Com os Ramkokamekrá-Canela, os Apanyekrá-Canela, Pikobye e Krikati, e povos chamados de Timbira Orientais, compõem a subdivisão dos Jês setentrionais (Cunha, 1978). 
seus parentes. Veiga (2000), por exemplo, refere que os Kaingang, além de se desfazerem dos objetos pessoais, também sacrificavam os animais, destruíam as roças e quebravam as panelas, na tentativa de eliminar tudo o que pudesse fazer o morto voltar para buscar os seus entes (o que acarreta a morte de seus familiares), por sentir a falta deles.

Nesse sentido, a psicologia e a instituição museal vivem o mesmo impasse: como proceder junto aos indígenas, se os seus mortos, para eles, precisam ser esquecidos?

\section{Etnopsicologia}

Parte-se do pressuposto de que a morte e o morto são fundamentais para os vivos. Como diz Bairrão (2012, p.30): "Os vestígios do morto são o que se conserva e transmite entre gerações". Eles são o que, comumente, se denomina por cultura. Tal etnopsicologia, amparada pela teoria psicanalítica, entende que, por trás de uma cerâmica, um canto, uma dança, arco e flecha, um prato típico, um esqueleto, um túmulo, e até mesmo de uma palavra, sempre está o morto. A cultura, em última instância, é a marca da presença dos mortos, e, portanto, é o morto que dá contorno ao sujeito e delimita o vivo.

Sabe-se que o museu apresenta coleções compostas por objetos que são adquiridos, expostos, resguardados e conservados porque transmitem o patrimônio material e imaterial da humanidade. Sendo assim, a partir dessa etnopsicologia, pode-se compreender o museu como um espaço que apresenta mais expressamente os vestígios do morto, ou melhor, o próprio morto. De certo modo, o museu pode ser considerado, então, como um grande cemitério (independentemente da presença ou não de esqueletos). A ousadia deste viés de pesquisa está, portanto, em última instância, em fazer sobressair o morto, ou melhor, permitir que o morto seja escutado.

Uma das pontes que se pode construir entre etnopsicologia e instituição museal deve-se à importância que ambas concernem à transmissão da cultura, sobretudo, a transmissão da cultura indígena. Presume-se, com isso, que ambas as áreas de saberes irão de algum modo se aproximar, com os indígenas, da relação estabelecida por eles com seus mortos, com a sua cultura. Pontuase, então, que não há como delinear uma política de gestão de acervo se não for considerar o que os indígenas enunciam sobre o morto e, ainda, o que o morto diz.

Posta a importância da morte para esta vertente da etnopsicologia, e o modo pelo qual o museu é entendido por ela, bem como a interface que se pode fazer com tal instituição, segue-se, no sentido de apresentar o grande impasse, tanto para a pesquisa em etnopsicologia, quanto para o trabalho da instituição museal: tendo em vista que para os indígenas os mortos são considerados inimigos e não podem ser lembrados, quais são os procedimentos a que podemos recorrer?

\section{0 fazer Kaingang e o fazer Pesquisa}

De modo geral, o fazer artefato (cerâmica, kuru kucha), ${ }^{5}$ a comida, o dançar e cantar no idioma traz lembranças dos mortos, já que foi com estes que se aprendeu a ser Kaingang. Mesmo que não se pretenda, as memórias são reavivadas e atualizadas na ação. Quando se faz um convite para que os indígenas fabriquem algum artefato, cantem, dancem ou façam alguma comida, se faz, inevitavelmente, um convite para que eles se lembrem dos mortos.

Participar das atividades (cantar, cozinhar, fabricar cerâmica) junto aos indígenas é se deixar fazer Kaingang. Ser Kaingang é ser feito como tal, ou seja, cotidianamente, e em ação, e pelas lembranças dos mortos no próprio corpo. A transmissão da cultura, assim, ocorre na realização de alguma ação e resulta no vaso de cerâmica, trançado, numa música, em um remédio, e numa comida típica. Aquele que participa das atividades relacionadas com a cultura é modelado, e está sendo feito para pertencer ao grupo.

5. Trata-se de um artefato feito de fibra vegetal que apresenta a função de cobrir e proteger, portanto, pode ser usado como roupa, esteira, rede e cobertor. 
Nesse sentido, ao mesmo tempo em que se faz a pesquisa também a pesquisadora está sendo pesquisada e feita pelo campo. Por mais que ambos (pesquisadora e indígenas) falem a língua portuguesa, muitas palavras usadas por ela são desconhecidas pelos indígenas, e vice-versa. 0 que se pode fazer, neste caso, é escutar e dar voz aos termos empregados pelos indígenas. Trata-se, então, de evidenciar a importância dos enunciados dos Kaingang, que são produzidos por eles e não são redutíveis ao verbal. Isso porque há um saber corporal necessário para se locomover dentro da mata e para fazer atividades relacionadas à cultura, há avisos que são dados por animais, como os pássaros, avisos que são dados em sonhos, além de comunicação com antepassados e animais na garantia de própria proteção e proteção de outrem.

Apresentam-se a seguir os termos que mais se repetiram nos enunciados Kaingang, por enquanto, e que, portanto, parecem ser fundamentais:

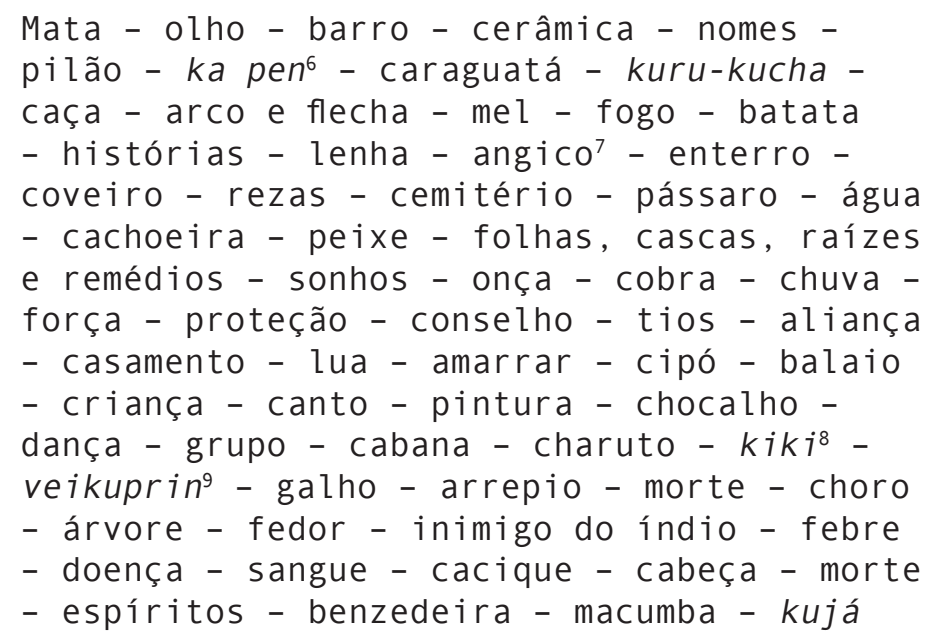

Não visamos traduzir os significados de cada um desses termos (descrevem-se através de notas

6. Pinça feita de madeira usada para colocar e retirar algo (alimentos ou mesmo a cerâmica) na fogueira.

7. Uma árvore bastante apreciada pelas qualidades de sua madeira.

8. Bebida feita a base de mel, tendo sido mencionado pelos Kaingang de Vanuíre a presença, em sua composição, de frutos de uma palmeira.

9. Espíritos que podem estar, por exemplo, em uma mata. informações básicas sobre os termos em Kaingang, apenas para situar o leitor, e de forma alguma tais descrições atendem ou encerram os sentidos dados a eles pelos remanescentes), e sim apresentá-los como rastros do caminho pelo qual a pesquisa está sendo conduzida. Vale indicar que o termo kujá (xamã) parece não ser empregado pelo dialeto Kaingang do estado de São Paulo, porém está sendo muito usado no processo deste estudo para se referir ao kujá Jorge Garcia da T.I. Nonoai, do Rio Grande do Sul, o qual já esteve em visita ao Museu Índia Vanuíre e, assim, conheceu alguns remanescentes indígenas. Indica-se que há combinatórias entre esses termos que precisam futuramente ser mais fortemente refletidas, tanto por esta quanto por pesquisas vindouras.

Ao mesmo tempo em que há termos que se repetiram, há também histórias que são recontadas constantemente. Sempre é interessante ouvi-las, pois a cada vez que são recontadas se agregam termos novos, ou seja, são sempre contadas com riqueza de detalhes, e, frequentemente, são incluídos termos que estão disponíveis no ato de contá-las. Um desavisado suporia se tratar de uma mentira (ou que o contador da história é um mentiroso), já que, antes, a narrativa foi contada de uma forma e agora se contou de outra maneira. No entanto, o que se evidencia é o quanto o passado inclui o presente e o presente inclui o passado. Ou melhor, as fronteiras estabelecidas entre presente e passado não são colocadas pelos Kaingang. Ressalta-se, então, que não considerar o aspecto da inclusão de novos elementos no que, na maioria das vezes, se denomina como tradição é não considerar o tempo Kaingang. Então, os verbos que supostamente precisariam estar conjugados no passado são conjugados no presente. Os verbos das narrativas que remetem a alguém que já morreu também são conjugados no presente. Na língua portuguesa oficial seria: "minha mãe contava" (visto que a mãe está morta), ao passo que se diz em Kaingang: “a mãe conta”.

Dessa forma, dois procedimentos têm sido fecundos: acompanhar e participar das atividades referentes à fabricação de tudo que envolve a cultura, bem como escutar os enunciados Kaingang, pois ambos os procedimentos se relacionam com o 
morto, já que o primeiro traz a lembrança dele no corpo e é o que possibilita a criação de algo novo, e o segundo o invoca ao presente. Sendo assim, nesses dois casos os mortos parecem estar apoiando a continuidade da cultura, ao invés de serem esquecidos.

\section{Morto: qual o seu nome?}

Tem-se percebido que, se o nome do morto não pode ser pronunciado, uma saída encontrada pelos Kaingang é dizer o nome de "brasileiro" ou o apelido, e não o nome indígena do morto. Porém, se por um lado tal medida visa prevenir os vivos dos perigos dos mortos, por outro impede que circulem os nomes dos antepassados, sob o risco de serem esquecidos, e até mesmo não serem usados nas novas vidas (crianças serem assim nomeadas).

Elencam-se, a seguir, quatro ditos interessantes para reflexão:

1) Em conversa com o Kaingang mais idoso de Vanuíre, este afirma com convicção: "acabou os homens Kaingang, só ficaram as mulheres";

2) À pesquisadora foi indagado se sabia os nomes das antigas lideranças Kaingang. Disse que apenas conhecia o nome Iacri. Recebeu na sequência da conversa a resposta: "então você não sabe nada: há Lacri, Ienkri, Lenkri”;

3) Em conversa com um Kaingang, este, após dizer o nome indígena de seu avô e explicar o significado, faz a seguinte pergunta: "você vai esquecer o nome dele?" :

4) Em conversa com outro indígena, este diz e explica seu nome em Kaingang e depois pergunta: "você vai esquecer o meu nome?".

Todos os envolvidos nessas quatro conversas, sejam vivos ou mortos, eram homens. Nesse sentido, indaga-se: por que o homem Kaingang está sendo considerado como inexistente? Estariam, de fato, todos mortos? Por que os homens atuais não podem ser considerados mais Kaingang? Possivelmente, o que se está dizendo não envolve uma questão de gênero e sim da característica guerreira Kaingang, ou seja, a valorização do homem enquanto guerreiro. Assim, homens são os que fazem a guerra e são os caçadores. São, dessa forma, os que matam, e também os que provavelmente morrem cedo, aumentando a chance se suas esposas se tornarem viúvas. Nesse sentido, se não há guerreiros, não há mais homens Kaingang .

Atualmente, os homens Kaingang que mais apresentam características belicosas - ou seja, qualidades guerreiras - estão solteiros ou divorciados. Anteriormente, matar alguém, para os Kaingang, era motivo de prestígio; hoje, há o Estado que aprisiona e pune com suas leis. Então, como ser homem Kaingang atualmente, se há risco de ser preso, ficar solteiro, e ainda há o risco de ser morto?

Pelo visto, o Estado se esquece de todos os guerreiros Kaingang que morreram defendendo seus territórios e seu grupo. Se há algo que a psicologia e a instituição museal podem trabalhar de modo ainda mais próximo - além dos registros dos processos da confecção de artefatos, culinária, canto e dança -, é a restituição dos nomes dos grandes líderes Kaingang, para então homenageá-los e, também, reconhecermos os nomes Kaingang e os guerreiros que ainda estão ao nosso lado.

\section{0 morto e as crianças}

Juracilda Veiga (2000) encontrou em seu estudo uma distinção entre "espírito do vivo", que é chamado de kumba, e "espírito do morto", que é chamado de kupring (sombra). Ademais, Weinkupring iamo é a aldeia dos espíritos ou aldeia dos mortos. Para esse local se dirigem os espíritos dos mortos e desse local vêm os espíritos das futuras crianças. A autora pontua que, antes de chegar à aldeia dos mortos, o espírito pode permanecer um tempo andando e protegendo seus parentes, até que definitivamente viaje para lá. Músicas podem ser cantadas para ajudar a direcionar o morto para sua nova morada. Os que 
se perdem na mata, os que estão sozinhos e os que pensam muito nos mortos também podem chegar à aldeia dos mortos. Além disso, um susto ou o sentimento de tristeza podem acarretar a perda da alma de um vivo, que abandona seu corpo e se perde na aldeia dos espíritos. Por isso, tal vivo fica triste e doente. Então, o que especificamente distingue o espírito do vivo e o do morto?

Em relação ao modo de vida na aldeia dos mortos, ela parece conservar todas as características e atividades que os Kaingang realizavam no passado. As diferenças se dão num nível temporal: se é dia no mundo dos vivos, no mundo dos mortos é noite; se chove em um, no outro faz sol. Diferenciam-se também pelo fato de os mortos não se interessarem por ter filhos, e por sempre estarem em festas, com muitas músicas e comidas.

Os kujás (xamãs), segundo ela, são capazes de ir até o mundo dos espíritos e resgatar as almas que ali se encontram, ou seja, são os responsáveis por fazer a mediação entre o mundo dos vivos e o mundo dos espíritos, desde que a alma que para lá viajou não tenha ingerido nenhuma comida oferecida pelos mortos. Para tanto, são ajudados por espíritos de animais que indicam as plantas que garantem a cura dos doentes, fazem sopros com tabaco e alucinógenos e benzimentos. A saúde, portanto, é um processo de fixação da alma no corpo. Há vários relatos de pessoas que foram até o mundo dos espíritos e conseguiram retornar com a ajuda dos kujás. Rosa (2005) pontua que além do espírito animal da floresta (por exemplo, tigre, gavião, coruja), os kujás também podem ser ajudados pelo espírito vegetal da floresta (Maria da Erva, planta) e por santos do panteão do catolicismo popular regional (Nossa Senhora Aparecida, Santo Antônio, Divino Espírito Santo, São João Maria).

Além disso, são os kujás que nomeiam as crianças, dando-lhes um nome de algum antepassado. Vale

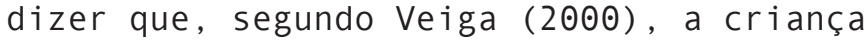
encarna o espírito de algum antepassado, e através do nome recebe a respectiva alma daquele, de modo que assim o antepassado torna-se vivo, novamente. 0 nome é escolhido a partir do momento em que o kujá sente a falta de um dos mortos na aldeia dos espíritos, sendo este o sinal de que ele encarnou em uma criança. Parece haver, então, uma ligação entre "mundo dos mortos -crianças nome dos mortos”.

Posto isto, o que Veiga (2000) nos ajuda a compreender em sua análise sobre a aldeia dos mortos, os kujás e a nomeação de uma criança poderia ser: um jeito propício de se esquecer o morto, ou seja, o que completa totalmente o seu esquecimento, é vê-lo como alma de uma criança, e nomeando-a com o nome do morto?

\section{Se não for o ritual do Kiki, o que será?}

Cabe salientar que há especificidades entre os Kaingang do Sul e os remanescentes da T.I. Vanuíre e T.I. Icatu. A nomeação de uma criança e os procedimentos de curas foram, até há pouco tempo, realizados por mulheres, que não eram chamadas de kuiãs e sim de benzedeiras.

A festa do Kiki ou ritual do Kiki é comumente referida na literatura como evento Kaingang no qual as pessoas se juntavam e consumiam uma bebida típica feita de milho ou flor de palmeira (Manizer, 2006; Gonçalves, 1993; Barbosa, 1913), realizavam danças que faziam referências aos seus nomes, contavam sobre viagens e caçadas, e sobre suas tradições. Enfim, tratava-se de um ritual com função de homenagear os mortos. Porém, esse ritual deixou de ser realizado pelos Kaingang no estado de São Paulo, desde 1940, como explica Ribeiro (1996):

Junto aos Kaingáng de São Paulo e aos Xogleng de Santa Catarina, O SPI se viu obrigado, logo após a pacificação, a compelir os índios ao abandono de cerimônias tribais da maior importância (as únicas que reuniam toda a tribo, fazendo confraternizar os grupos em conflito), para evitar toda aglomeração e frustrar as oportunidades de contágio. Essas cerimônias duravam vários dias e noites, em que cantavam, dançavam e consumiam grande quantidade de bebidas fermentadas. No passado não apresentavam 
o menor inconveniente, mas agora pareciam predispor os índios para gripe. Após cada uma delas, recrudesciam os acessos de gripe, muitas vezes fatais. (Ribeiro, 1996, p.307)

Para os Kaingang, lembrar seus mortos faz adoecer os vivos, visto que se espera que estes se esqueçam dos entes que faleceram. Questiona-se: será que realmente são os Kaingang que buscam esquecer seus mortos ou é um modelo de vida imposto a eles para se esquecerem? Há uma relação entre mortos e doença, indubitavelmente. Mas, como explicar o que antes era uma festa para os mortos ter se tornado um medo de adoecer, a não ser levando em consideração o histórico de tentativas de fazer esses indígenas deixarem de serem indígenas? Sendo assim, seriam os mortos Kaingang que causam as doenças, ou a história e a política de nossa sociedade brasileira que os fazem adoecer?

Nesse sentido, Manuela Carneiro da Cunha (1978), em seus estudos com os Krahô conclui que a permanência cultural daqueles indígenas não estava na manutenção de seus rituais ou nos casamentos entre seus pares, como se pode acompanhar neste trecho: "Restringir-se a consanguinidade e a esfera ritual é, pois, nos termos krahô, cristalizar a sociedade no que ela tem de permanente, no que a faz perdurar igual a si própria e, consequentemente, negar-lhe o aspecto dinâmico contido na aliança” (p.72).

Essa autora afirma que a permanência estava na nomeação. Sendo assim, hoje não há mais Kiki e talvez nem casamentos que obedeçam às regras de parentesco, efetivamente, mas ainda há nomes a serem homenageados e dados às nossas crianças: os nomes dos mortos.

\section{Agradecimentos}

Aproveitamos a oportunidade para agradecer aos Kaingang colaboradores deste estudo, bem como ao Museu Índia Vanuíre (ACAM Portinari), que por intermédio da Profa. Dra. Marília Xavier Cury nos convidou para apresentar o conteúdo (agora escrito) no IV Encontro Paulista Questões Indígenas e Museus - V Seminário Museus,
Identidades e Patrimônios Culturais. Agradecemos aos participantes desse encontro o debate instigante e as valiosas contribuições versadas à reflexão sobre o morto para os povos indígenas.

\section{Referências}

BAIRRÃO, José Francisco M. H. A eloquência do morto: senciência e inclusão na umbanda. Tese (Livre-Docência) - Faculdade de Filosofia, Ciências e Letras de Ribeirão Preto, Universidade de São Paulo. Ribeirão Preto, 2012.

BARBOSA, Luis Bueno Horta. A pacificação dos índios Caingangues paulistas: hábitos, costumes e instituições desses índios. In: O PROBLEMA indígena do Brasil. Rio de Janeiro: Imprensa Nacional; Conselho Nacional de Proteção aos Índios, 1913. p.34-72.

CUNHA, Manuela Carneiro da. Os mortos e os outros: uma análise do sistema funerário e da noção de pessoa entre os índios Krahó. São Paulo: Hucitec, 1978.

GONÇALVES, Marco Antonio. Etnografia e indigenismo: sobre os Kaingang, os OfaiéXavante e os Índios do Pará. Campinas: Ed. Unicamp, 1993.

LOURENÇO, Marília Sene de. A presença dos antigos em tempos de conversão: etnografia dos Kaingang do Oeste Paulista. Dissertação (Mestrado em Antropologia Social) - Universidade Federal de São Carlos. São Carlos, 2011.

MANIZER, Henri H. Os Kaingang de São Paulo. Campinas: Curt Nimuendajú, 2006.

MELATTI, Delvair Montagner. Aspectos da organização social dos Kaingang paulistas. Brasília: Funai, 2009.

MORATELLI, Thiago. Os trabalhadores da construção da Estrada de Ferro Noroeste do Brasil: experiências operárias em um sistema de trabalho de grande empreitada (São Paulo e Mato Grosso, 1905-1914). Dissertação (Mestrado) - Instituto de Filosofia e Ciências Humanas, Universidade Estadual de Campinas. Campinas, 2009.

PINHEIRO, Niminon S. Vanuíre: conquista, 
colonização e indigenismo: oeste paulista, 1912-1967. Tese (Doutorado em História)

- Universidade Estadual Paulista Júlio de Mesquita Filho. Assis, 1999.

RIBEIRO, Darcy. Os Índios e a Civilização: a integração das populações indígenas no Brasil moderno. São Paulo: Companhia das Letras, 1996.

RODRIGUES, Robson Antonio. Os caçadores-ceramistas do sertão paulista: um estudo etnoarqueológico da ocupação Kaingang no vale do Rio Feio/ Aguapei. Tese (Doutorado em Arqueologia) Museu de Arqueologia e Etnologia, Universidade de São Paulo. São Paulo, 2007.

ROSA, Rogério Reus G. da. O Território Xamânico Kaingang Vinculado às Bacias Hidrográficas e à Floresta de Araucária. Cadernos do Lepaarq, v.2, n.4, 2005.

VEIGA, Juracilda. Aspectos fundamentais da cultura Kaingang. Campinas, SP: Curt Nimuendajú, 2006.

- Cosmologia e práticas rituais

Kaingang. Tese (Doutorado) - Departamento de Antropologia, Instituto de Filosofia e Ciências Humanas, Universidade Estadual de Campinas. Campinas, 2000.

Organização Social e Cosmovisão Kaingáng: uma introdução ao parentesco, casamento e nominação em uma Sociedade Jê Meridional. Dissertação (Mestrado) - Departamento de Antropologia, Instituto de Filosofia e Ciências Humanas, Universidade Estadual de Campinas. Campinas, 1994.

* Juliana Dal Ponte Tiveron é graduada em Psicologia pela Universidade de São Paulo (USP) e doutoranda no Programa de Pós-Graduação em Psicologia pela Faculdade de Filosofia, Ciências e Letras de Ribeirão Preto da Universidade de São Paulo (FFCLRP-USP).

** José Francisco Miguel Henriques Bairrão é doutor em Filosofia pela Universidade Estadual de Campinas (Unicamp), Professor Associado ao Departamento de Psicologia da Faculdade de Filosofia, Ciências e Letras de Ribeirão Preto da Universidade de São Paulo (FFCLRP-USP) e coordenador do Laboratório de Etnopsicologia na FFCLRP-USP. 


\title{
Xamanismo indígena e cultura brasileira
}

\author{
Laercio Fidelis Dias* \\ Universidade Estadual Paulista Júlio de Mesquita Filho (Unesp)
}

\section{Introdução: dos termos Xamã e Pajé}

0 xamanismo pode ser definido como uma instância social que lida, essencialmente, com questões da esfera do político; com o gerenciamento de assuntos ligados à constituição e ao bem-estar da sociedade e da cultura. É uma forma de "atualização, concretização, cristalização da compreensão das relações entre o mundo dos espíritos e o mundo dos seres humanos" (Brunelli, 1996, p.234).

Os termos xamã e pajé, bem como xamanismo e pajelança, serão tomados como equivalentes neste artigo. Xamã é uma palavra de língua siberiana tunge e indica o mediador entre o mundo humano e o mundo dos espíritos (Langdon, 1992, p.20; 1996, p.12). Métraux (1944, apud Langdon, 1996, p.14) sugere que pajé, por sua vez, deriva do termo piai das línguas tupi e caribe para designar o xamã sul-americano. A diferença entre o xamã siberiano e o sul-americano é que o poder do primeiro advém de voos extáticos e, o do segundo, de plantas psicoativas, principalmente, tabaco e bebidas (Viertler, 1981, p.301, apud Langdon, 1996, p.15). Os xamãs nas sociedades indígenas sul-americanas quase sempre são homens. Os Guajiro, na Colômbia e na Venezuela, são a exceção apontada por Perrin (1992, p.103), já que entre este grupo $80 \%$ dos xamãs são mulheres.

Conforme enfatiza Langdon (1996, p.28),

0 xamanismo é uma importante instituição nas sociedades nativas da América do Sul. Ele expressa as preocupações gerais destas sociedades. Seu objetivo principal é descobrir e lidar com as energias que existem por trás dos eventos cotidianos. Nos ritos, estas concepções gerais de ordem são representadas, tornadas manifestas, e recriadas. 0 xamã interage com estas energias através da experiência extática, através dos sonhos, ou dos transes induzidos por substâncias ou outras técnicas, servindo como mediador entre domínios humanos e extra-humanos.

\section{Povos ameríndios e ocupação da América}

A origem dos povos indígenas é cercada de controvérsias. Os povos indígenas que atualmente moram no Brasil são remanescentes de um enorme contingente populacional constituído, principalmente, por grupos do tronco linguístico tupi. As estimativas não são muito precisas, e há controvérsias em torno delas. Entretanto, calcula-se que havia aproximadamente de 2 a 4 milhões de índios só no território que conhecemos como Brasil (ISA, 2016).

Na época do "descobrimento", esses povos estavam dando os primeiros passos na domesticação de plantas: mandioca, milho, batata-doce, cará, feijão, amendoim, tabaco, abóbora, urucu, algodão, carauá, cuias e cabaças, pimentas, abacaxi, mamão, erva-mate e guaraná. A mandioca teve papel de destaque porque, para ser conservada, não precisava ser colhida e estocada, pois mantém-se viva na terra durante meses. De qualquer forma, sendo uma planta venenosa, além de cultivada, a mandioca precisa ser adequadamente tratada para 
que o ácido cianídrico seja extraído, tornando-a comestível. A prática da agricultura garantia um provimento de alimentos mais regular durante o ano todo, o que não era possível quando se depende quase que exclusivamente da caça, pesca, coleta e das variações sazonais de oferta de alimentos. A principal consequência de tais mudanças na organização social dos povos indígenas é a passagem de um estilo de vida nômade para outro mais sedentário, além do crescimento populacional (Ribeiro, 1996).

A origem dos povos indígenas é também cercada de controvérsias. A teoria mais conhecida para explicar as primeiras migrações feitas pelo homem em direção à América diz que a única rota possível seria por terra. Assim sendo, para alcançar a América, o homem teria passado da Ásia para o Alasca através da Beríngia. Essa passagem teria sido possível durante períodos em que os níveis do mar estivessem bem abaixo, aproximadamente 50 metros, dos atuais, possibilitando o trânsito a pé nas planícies que formam o fundo do Mar de Bering. A diminuição dos níveis do mar teria sido provocada por uma glaciação ocorrida por intervalos entre aproximadamente $35 \mathrm{mil}$ e $12 \mathrm{mil}$ anos atrás. Em seguida, o homem teria se espalhado pelo continente americano do norte para o sul (Guidon, 1998). ${ }^{1}$

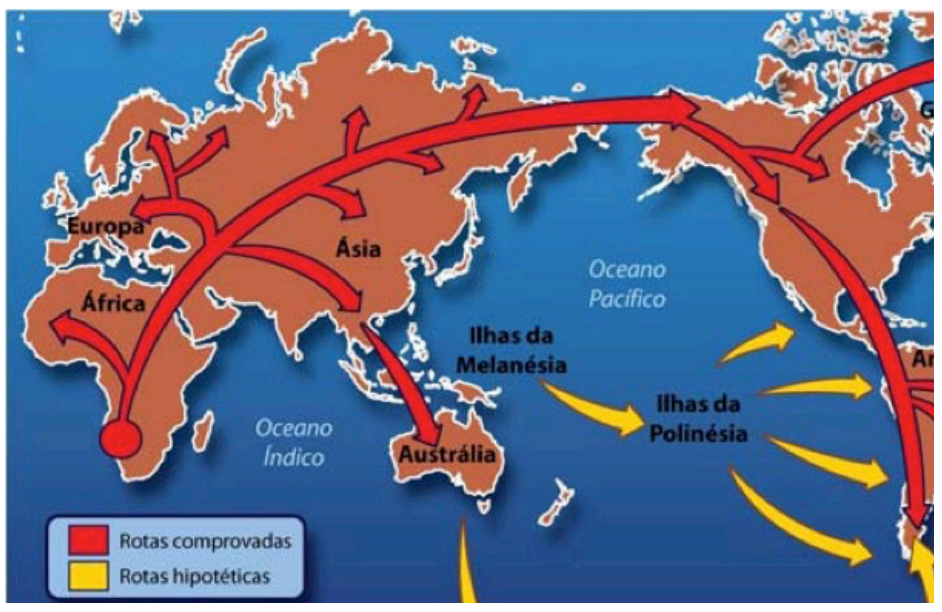

Mapa 1 - Rota de migração para as Américas. Fonte: Lookfordiagnosis, 2016.

1. Para uma discussão mais aprofundada sobre a questão consultar Silva e Rodrigues-Carvalho (2006) e Neves e Piló (2008).

\section{História, xamanismo e povos ameríndios}

Quando se trata de índios é necessário fornecer alguns esclarecimentos prévios que contribuam para a melhor compreensão dos povos indígenas no Brasil. O primeiro esclarecimento refere-se ao termo “índio". Essa designação genérica pressupõe que os índios são todos iguais e ignora o fato de que as maneiras como os diferentes povos indígenas constroem as suas casas, organizam as suas atividades de subsistência, realizam festas e rituais, diferem, significativamente, uma da outra. Essas diferenças são dinamizadas por fatores internos às culturas, por movimentações dos grupos pelo território, por intercâmbios amistosos dos grupos entre si e, também, por conflitos e guerras. 0 “índio" genérico não existe. Existem os Kayapó, os Yanomami, os Bororo, os Guarani, os Karipuna, os Palikur etc. As estimativas atuais indicam que no Brasil existem em torno de 240 grupos indígenas e, segundo o IBGE (2010), somam 896.917 pessoas. Destes, 324.834 vivem em cidades e 572.083 em áreas rurais, o que corresponde aproximadamente a $0,47 \%$ da população brasileira, e estão distribuídos em aproximadamente $12 \%$ do território nacional.

Toda essa dinâmica sociocultural e geográfica refletese na dinâmica dos sistemas xamânicos ameríndios.

Isso torna difícil uma boa e adequada caracterização dos sistemas xamânicos ameríndios. Pode-se aproximálos, ainda que de modo um tanto estereotipado, ao animismo, totemismo e xamanismo siberianos.

Animismo designa uma manifestação imanente a todos os elementos do Cosmo, da natureza, dos seres vivos e fenômenos naturais. Todos esses elementos têm ânima (Tylor, 1920). Pela lógica do animismo, todos os elementos são passíveis de sentimentos, vontades, desejos, emoções e mesmo inteligência. Em síntese, para o animismo todas as coisas são vivas, conscientes e têm ânima (ibidem).

Totemismo é um sistema classificatório social e simbólico, baseado nas relações de pertencimento e distinção (Durkheim, 1995). A lógica totêmica é uma lógica de continuidade entre domínios opostos que são natureza e cultura (Lévi-Strauss, 1975). 
No totemismo há uma continuidade postulada na associação de um elemento da natureza (animal, vegetal ou fenômeno meteorológico) com um grupo social humano (ibidem).

Sem pretender interpretações definitivas, entretanto, podem-se identificar alguns elementos em comum no xamanismo das Terras Baixas sul-americanas (Langdon, 1992; 1998): crenças em seres celestes; crenças em espíritos celestes; esses seres e espíritos intervêm na vida humana e do xamã; o contato e domínio desses espíritos são a fonte de poder xamânico; o acesso ao domínio onde estão esses espíritos se dá por meio do transe extático e consumo de tabaco e/ou plantas alucinógenas; os sentidos dos ritos xamânicos podem ser socioeconômicos, ou seja, ligados à pesca, caça, guerra, às doenças, à proteção, sorte etc.; podem estar ligados à esfera do político (agressões xamânicas); podem estar ligados à arte (xamã aprende nos sonhos os motivos estilísticos que decoram os objetos de cultura material); podem estar ligados a festividades profanas ou sagradas (Turé no Uaçá) (Dias, 2013); há ritos xamânicos ligados à etiologia, à nosologia e ao tratamento das doenças (doenças aqui sempre pensadas como desequilíbrio das relações sociocosmológicas A doença não acorre apenas no corpo biológico, mas na tríade que envolve o corpo individual, social e político).

Cinco elementos, assim, sintetizam o xamanismo:

1) “0 xamanismo é uma importante instituição nas sociedades nativas da América do Sul. Ele expressa as preocupações gerais destas sociedades. Seu objetivo principal é descobrir e lidar com as energias que existem por trás dos eventos cotidianos" (Langdon, 1998, p.28);

2) "Nos ritos, estas concepções gerais de ordem são representadas, tornadas manifestas, e recriadas. 0 xamã interage com estas energias através da experiência extática, através dos sonhos, ou dos transes induzidos por substâncias ou outras técnicas, servindo como mediador entre domínios humanos e extra-humanos" (Langdon, 1998, p.28);

3) o xamanismo, pode-se dizer, é um operador da Cosmologia do grupo;
4) As cosmologias indígenas representam modelos complexos que expressam suas concepções a respeito da origem do Universo, de todas as coisas que existem no mundo e de como elas estão articuladas;

5) Os mitos, considerados individualmente, narram a origem do homem, das relações ecológicas entre animais, plantas e outros elementos da natureza, da origem da agricultura, da metamorfose de seres humanos em animais, da razão de ser de certas relações sociais culturalmente importantes etc.

\section{Legado indígena à cultura brasileira}

0 povo brasileiro surge da confluência, do entrechoque e amálgama do português colonizador, de povos indígenas e do negro africano (Ribeiro, 1996). A confluência de tantas e tão variadas matrizes formadoras poderia ter resultado numa sociedade multiétnica e dilacerada, mas ocorreu justamente o contrário: sobreviveram na fisionomia somática e no espírito dos brasileiros os signos de sua múltipla ancestralidade (ibidem).

Mas elas não se diferenciaram em minorias raciais, culturais ou regionais antagônicas (Ribeiro, 1996). Essa unidade básica não significa uniformidade. Três fatores concorrem para que a unidade seja heterogênea:

1) Fator ecológico que fez surgir paisagens humanas distintas onde as condições de meio ambiente obrigaram a adaptações regionais;

2) Fator econômico que criou diferentes formas de produção, que, por sua vez, conduziram a especializações funcionais e aos seus correspondentes gêneros de vida;

3) Fator imigratório, especialmente europeu, árabe e japonês, que introduziu novos contingentes humanos que colocam um ingrediente novo na unidade, sem desfazê-la. 
E que fatores concorreriam para manutenção da unidade básica? Enveredar agora para uma discussão sobre a identidade nacional brasileira nos faria perder o foco. Por que mencionar a questão da unidade ou identidade nacional para refutar e não enfrentá-la? Porque há um fator crucial na construção da identidade nacional que nos possibilita ver claramente a influência indígena na cultura brasileira. É o fator religioso, seja pela presença na Igreja Católica, dos jesuítas, em especial, na conversão dos índios, e dos imigrantes europeus na construção de um povo de fé majoritariamente cristã/católica.

Quando se observa o catolicismo popular amazônico, o legado indígena a essas manifestações religiosas é nítido. O catolicismo amazônico resulta da confluência de pelo mesmos três tradições (Maués, 2005): tradição portuguesa, xamanismo indígena (ou pajelança) e tradições africanas.

Quais seriam as características desse catolicismo que revelariam as influências xamânicas?

1) 0 catolicismo popular amazônico é centrado na crença e culto dos santos;

2) Em Itapuá, nordeste do Pará, São Benedito é considerado bastante milagroso;

3) Recorre-se ao santo em casos de doenças, objetos perdidos, quando os pescadores estão no mar, não necessariamente em situações de perigo;

4) O Menino Deus é outro "santo" muito cultuado, já que é o padroeiro da povoação;

5) Numa concepção mais próxima do catolicismo oficial, sabe-se que o Menino Deus é Jesus menino, isto é, a segunda pessoa da Santíssima Trindade.

As crenças do catolicismo popular amazônico mais vinculadas ao xamanismo indígena (pajelança rural/cabocla) referem-se aos "encantados" (Maués, 2005). Encantados são pessoas que, ao contrário dos santos, não morreram, mas se encantaram. Nesse processo não interfere nenhum mérito moral, como no caso dos santos, que são frequentemente pensados como pessoas que praticaram o bem enquanto eram vivas (ibidem). As pessoas se encantam porque são atraídas por outros encantados para o "encante", seu local de morada.

0 encante se encontra "no fundo" dos rios, lagos, igarapés, "atrás do sol” etc. Para que alguém seja levado para o fundo, por um encantado, é preciso que este "se agrade" da pessoa, por alguma razão.

É comum a ideia de que, se alguém for levado por algum encantado para visitar o encante, deve evitar comer as coisas que the são oferecidas, caso contrário se encantará, não podendo mais viver no mundo da superfície, como os demais seres humanos (Maués, 2005). Há também a ideia de que os grandes pajés são levados pelos encantados para o fundo, onde aprendem sua arte; mas, neste caso, eles retornam à superfície, como xamãs, para poder praticar a pajelança (ibidem). No caso do pajé, no Uacá, se a comida for outra pessoa, e ele aceitar, pode se tornar um pajé mau, capaz de matar as pessoas.

Os encantados são normalmente "invisíveis" aos olhos dos simples mortais (Maués, 2005). Mas podem manifestar-se de formas diversas. Basicamente três:

1) São chamados de bichos do fundo quando se manifestam nos rios e igarapés, sob a forma de cobras, peixes, botos e jacarés, e provocam doenças (Maués, 2005);

2) Sob a forma humana, nos manguezais ou nas praias; visagens; neste caso, eles frequentemente aparecem como se fossem pessoas conhecidas, amigos ou parentes, e desejam levar as pessoas para o fundo;

3) Permanecem invisíveis e incorporam-se nas pessoas, quer sejam aquelas que têm o dom "de nascença" para serem xamãs, quer sejam as de quem "se agradam", quer sejam os próprios xamãs (pajés) já formados: neste caso, são chamados de caruanas (Karuanãs, em patois), guias ou cavalheiros. 
Ao se manifestarem nos pajés, durante as sessões xamanísticas, os caruanas vêm para praticar o bem, sobretudo para curar doenças.

As concepções ligadas à pajelança (encantados) podem ser comparadas a diversas formas de xamanismo (Maués, 2005), exceção feita ao xamanismo clássico siberiano. Nesse caso, o xamã viaja ao mundo dos espíritos, onde combate os agentes causadores do infortúnio, e o fenômeno da incorporação tem menor importância.

No caso da pajelança, a incorporação é crucial. 0 encantado ou caruana é quem cura. o corpo do pajé é tomado pela entidade. Os pajés consideram suas práticas parte integrante do catolicismo que praticam; aliás, eles se apresentam como "católicos".

Santos e encantados são ambíguos, pois transitam por domínios distintos (Maués, 2005). É por essa ambiguidade que podem realizar a mediação entre seres humanos e o mundo sobrenatural.

Santos, entretanto, são menos ambíguos. Santos viveram neste nosso mundo. Por processos diversos se santificaram após a morte: praticaram o bem; sofreram; morreram subitamente; tiveram - corpo conservado por muitos anos após a morte (Maués, 2005)

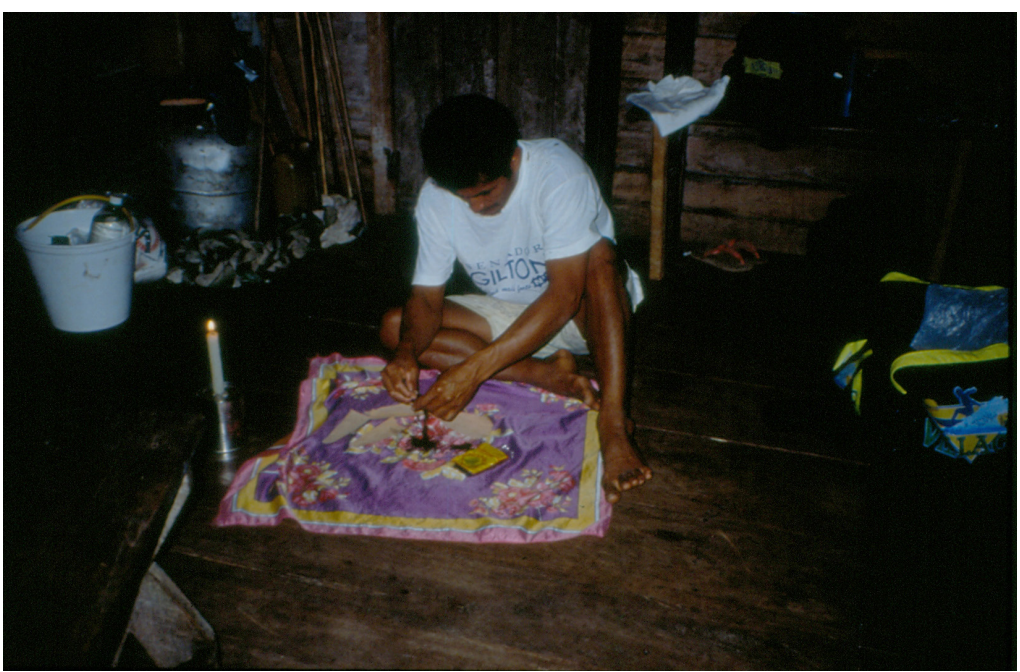

Foto 1 - 0 palika, auxiliar do xamã, prepara o cigarro que o xamã consumirá durante a sessão xamânica, 1996. Foto: Laércio Fidelis Dias.
Encantados, por sua vez, são mais ambíguos. Não são pensados como espíritos. São pensados como seres humanos com poderes excepcionais (Maués, 2005). Podem manifestar-se como humanos ou animais. Incorporam em pessoas comuns, apesar de se manterem como seres humanos durante a incorporação (ibidem). Não é a alma ou espírito do caruana que incorpora nos pajés, mas o encantado por completo: espírito e matéria.

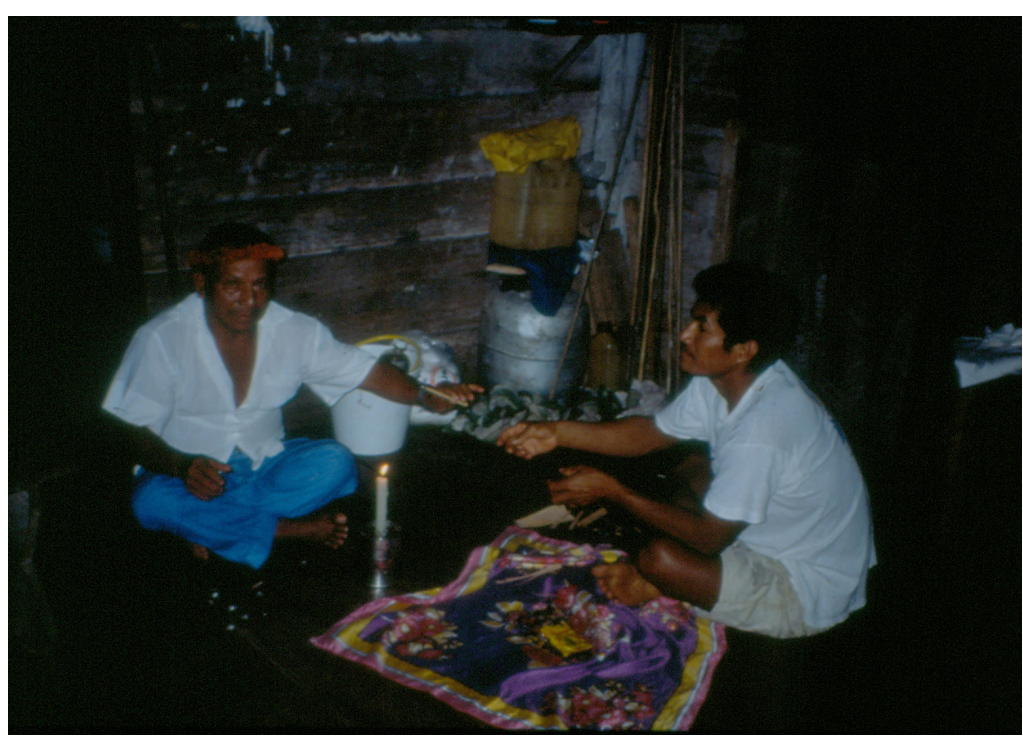

Foto 2 - 0 palika, auxiliar do xamã, entrega o cigarro ao xamã, 1996. Foto: Laércio Fidelis Dias.

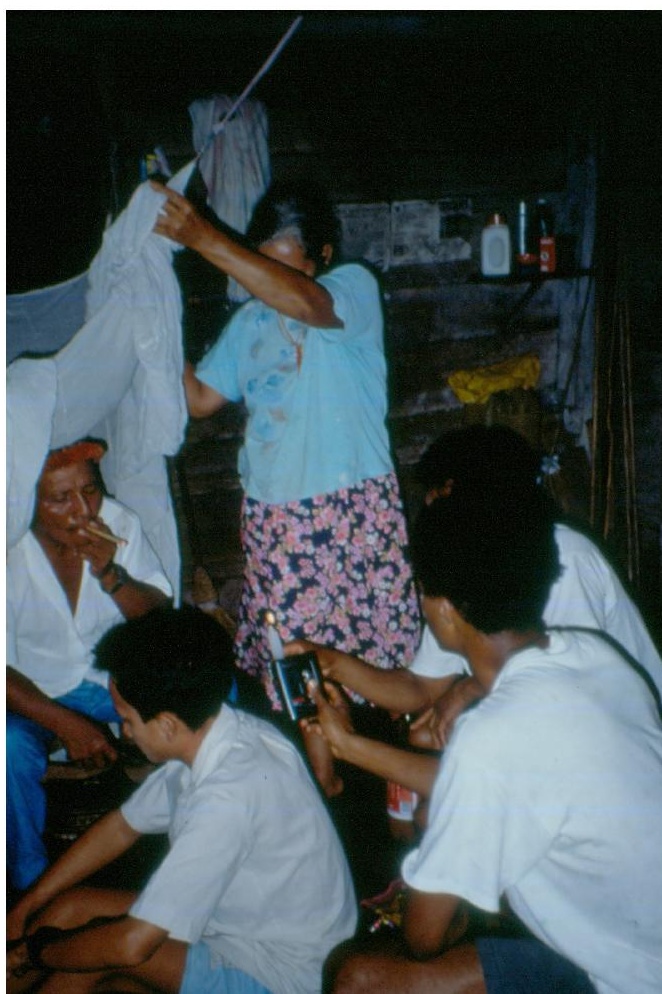

Foto 3 - Com o cigarro já acesso, o xamã, sentado em seu banco ritual. prepara-se para o início da sessão, 1996. Foto: Lux Boelitz Vidal. 


\section{Referências}

BRUNELLI, Gilio. Do xamanismo aos xamãs: estratégias Tupi-Mondé frente à sociedade envolvente. In: LANGDON, E. Jean Matteson (Org.) Xamanismo no Brasil: novas perspectivas. Florianópolis: Ed. UFSC, 1996. p. 233-266.

CUNHA, Manuela Carneiro da. Introdução a uma história indígena. In: . (Org.) História dos Índios no Brasil. São Paulo: Fapesp; Companhia das Letras; Secretaria Municipal de Cultura (SMC), 1998.

DIAS, Laércio Fidelis. Consumo de bebidas alcoólicas entre os povos indígenas do Uaçá. In: SOUZA, Maximiliano L. P. de. (Org.) Processos de alcoolização indígena no Brasil: perspectivas plurais. Rio de Janeiro: Ed. Fiocruz, 2013. v.1, p.107-124.

DURKHEIM, Émile. Algumas formas primitivas de classificação. In: RODRIGUES, José Albertino (Org.) Durkheim. São Paulo: Ática, 1995. (Grandes Cientistas Sociais).

GUIDON, Niéde. As Ocupações Pré-Históricas do Brasil (excetuando a Amazônia). In: CUNHA, Manuela Carneiro da (Org.) História dos Índios no Brasil. São Paulo: Fapesp; Companhia das Letras; Secretaria Municipal de Cultura (SMC), 1998 .

LANGDON, E. Jean Matteson. Introduction: Shamanism and Anthropology. In: LANGDON, E. Jean Matteson; BAER, Gerhard (Ed.) Portals of Power. Albuquerque: University of New Mexico Press, 1992

Introdução: Xamanismo - velhas e novas perspectivas. In: LANGDON, E. Jean Matteson (Org.) Xamanismo no Brasil. Florianópolis: Ed. UFSC, 1996.

LÉVI-STRAUSS, Claude. Totemismo hoje. Petrópolis: Vozes, 1975.

MAUÉS, Raymundo Heraldo. Um aspecto da diversidade cultural do caboclo amazônico: a religião. Estudos Avançados, v.19, n.53, 2005. Disponível em: www.scielo. br/scielo.php?script=sci_arttext\&pid $=\mathrm{S} 0103-40142005000100016$.
MÉTRAUX, Alfred. Le shamanisme chez les Indiens de l'Amerique du Sud tropicale. Acta Americana, II, México, p.197-219, 320-341, 1944.

NEVES, Walter Alves; PILÓ, Luís Beethoven. o Povo de Luzia: em busca dos primeiros americanos. São Paulo: Globo, 2008.

PERRIN, Michel. The Body of the Guajiro Shaman. In: LANGDON, E. Jean Matteson; BAER, Gerhard (Ed.) Portals of Power. Albuquerque: University of New Mexico Press, 1992.

RIBEIRO, Darcy. O Povo Brasileiro: a formação e o sentido do Brasil. São Paulo: Companhia das Letras, 1996.

SILVA, Hilton P.; RODRIGUES-CARVALHO, Claudia (Org.) Nossa origem: o povoamento das Américas: visões multidisciplinares. Rio de Janeiro: Vieira e Lent, 2006.

TYLOR, Edward B. Primitive Culture. (1871). New York: J.P. Putnam's Sons, 1920.

VIERTLER, Renate B. Implicações de alguns conceitos utilizados no estudo da religião e da magia de tribos brasileiras. In: HARTMAN, Thekla; COELHO, Vera Penteado (Org.) Contribuições à Antropologia em Homenagem ao Professor Egon Schaden. São Paulo: Universidade de São Paulo, Fundo de Pesquisa do Museu Paulista, 1981.p.305-318. (Coleção Museu Paulista, Série Ensaios, 4).

* Laercio Fidelis Dias é graduado em Ciências Sociais pela Universidade de São Paulo (USP), mestre e doutor em Antropologia Social também pela Universidade de São Paulo. Atualmente é Professor Doutor do Departamento de Sociologia e Antropologia e Programa de Pós-Graduação em Ciências Sociais, Vice-Coordenador do curso de Relações e Internacionais e Vice-Chefe do Departamento de Sociologia e Antropologia, na Universidade Estadual Paulista "Júlio de Mesquita Filho" (UNESP), campus Marília. Desenvolve pesquisa na área de Antropologia, com ênfase em Antropologia da Saúde e Médica, e Etnobiologia atuando nos seguintes temas: etnomedicina, itinerário terapêutico, transição da saúde, bebidas alcoólicas. 


\title{
Museu Kaingang, Krenak e Terena: o problema da temática do concreto na exposição indígena museográfica
}

\author{
Niminon Suzel Pinheiro* \\ Centro Universitário de Rio Preto (Unirp)
}

A capacidade visual é muito mais ampla do que aquelas transmitidas elou assimiladas pelos outros sentidos.

João Gomes Filho, 2000

Acredito que despertar os sentidos é um dos objetivos dos museus. 0 sentido que a visão pode despertar, dentre todos, tem importância especial na contemporaneidade pois por meio dela somos capazes de sensibilizar outros sentidos numa multiplicidade de perspectivas. Como captar na exposição museográfica a intensidade da vida? Esse problema me intrigou desde que conheci os índios Krenak de Vanuíre, em 1987. Nessa época eles haviam construído o "museuzinho", que era espaço de estada obrigatória para se começar a entender a memória indígena Krenak em Vanuíre. Estada porque não era um lugar de passagem, mas de absorção pela contemplação de uma história de vida singular.

0 interesse pela temática indígena museográfica se acentuou com a pesquisa e construção do Museu Trilha "Picada das Mulheres", museu a céu aberto construído por Deolinda Pedro e Neusa Umbelino, com ajuda de um homem. 0 trabalho era duro, mas a ideia da possibilidade de comunicação entre indígenas e não indígenas deu força e a temática indígena se concretizou na trilha que, com as duas mulheres, recriava a vida do índio na mata.

As experiências de convívio com os indígenas das Terras Indígenas (T.I.) Icatu (Braúna, SP), Vanuíre (Arco Íris, SP), Apucaraninha (Londrina, PR), principalmente, mas também as cinco Terras Indígenas na área Kopenoti - Nimuendaju (Avaí, SP) e as Tupi-Guarani do litoral e de Barão de Antonina (Barão de Antonina, SP), se mostraram profícuas na compreensão do interesse e da importância da construção de museus indígenas. As exposições museográficas indígenas podem ser escoras de ideias, de sistemas, de habilidades próprios de cada etnia. Nelas se tecem histórias e processos vivenciados pelos indígenas numa comunicação basicamente visual, tangível e oral. Esses elementos se concretizam em círculos, vibrações, movimentos orgânicos, pesquisas viscerais, curas xamânicas, mitos escatológicos, aparições espirituais e retóricas circulares.

Por conta desse último ponto, a retórica circular, é imprescindível que os guias e condutores dos visitantes pela exposição sejam das comunidades que estão sendo representadas pela exposição. Se possível, pessoas que participaram da sua criação.

Em 2015, durante o processo dos trabalhos na Mesa temática "Indígenas nos Museus: as visões da cultura”, IV Encontro Paulista Questões Indígenas e Museus (Tupã, jul. 2015), à tarde, quarta apresentação, e após palestra instigante do pesquisador e doutorando indígena Josué Carvalho, nos reunimos diante da assistência. Formávamos um grupo de 23 indígenas das T.I. Icatu, Vanuíre, Kopenoti e Nimuendaju.

A experiência que se seguiu foi emocionante e ilustrativa. Por meio dela foi possível conhecer aspectos próprios da relação emocional dos indígenas com os objetos e ideias expostos por eles. Foi possível presenciar a manifestação das diferentes memórias, dos elementos da natureza interagindo com o cotidiano indígena, a importância das ações políticas para a continuidade da vida indígena no seu cotidiano, inserida na sociedade capitalista. 
A atividade levada a termo durante a realização da Mesa baseou-se no método empregado por Pinheiro na alfabetização indígena de adultos bilíngues (Apucaraninha, PR). Esse método foi criado pela autora a partir da pesquisa com os seguintes métodos e teorias de aprendizagem e de análise de evidências históricas e antropológicas: História Oral; análise de documentos escritos e iconográficos; práticas da educadora australiana Ashton-Warner,

estruturadas na teoria Organic Reading; técnicas de aprendizagem, aperfeiçoamento e controle das emoções utilizadas no método Kumon; e, também, a experiência da autora Pinheiro na construção de sua própria família, que é bilíngue, e na sua pesquisa com a temática da memória indígena. Todos esses conhecimentos, teóricos e práticos, favoreceram o entendimento de que os indígenas do oeste de São Paulo e do norte do Paraná se apropriam das palavras e dos conceitos com parcimônia e com a consciência de sua devida acuidade na realização da vida indígena.

Como resultado do exposto acima, o método utilizado durante a apresentação facilitou aos indígenas a expressão, com naturalidade. Foi possível obter sensível percepção, pelos participantes e ouvintes, da relação entre o pensamento, a escrita e a fala. As experiências gravadas no corpo físico e psíquico dos indígenas puderam vir a público pela mediação da palavra focada, do concreto do objeto visível e conhecível por todos numa experiência orgânica: tais palavras como o fogo, o cocar, a zarabatana, o território, o milho tchantchan (preto) etc. se constituíram em janelas que se abriram para os valores e a ética inerentes à alteridade indígena dessas etnias.

Ciente da relação orgânica que o indígena evidencia na comunicação entre seu pensamento, sua escrita e sua fala, foi possível conhecer um pouco mais dos interesses dos indígenas. Interesses que podem permear o planejamento das exposições indígenas, e essa descoberta pode contribuir com a elaboração ou a seleção da temática e do método didático-pedagógico da(s) arte(s) a ser(em) musealizada(s) em um Museu Indígena na área etnogeográfica em estudo.
Segue a descrição da Mesa apresentada.

Dispusemos o grupo em forma de ferradura e, do centro, pedimos aos participantes que pensassem uma palavra e a escrevessem na folha de sulfite (meia folha). Uma única palavra! Escrita essa palavra na folha em branco, os participantes escreveram seus nomes no canto direito superior, e o papel foi dobrado. Terminado isso, voltouse para o grupo, o primeiro abriu seu registro e o leu aos colegas. Ao fazer isso, ele se sentiu motivado para explicar todas as possibilidades afetivas, de habilidades, sensitivas, cômicas, trágicas, de advertência, de cura, filosóficas, de superação ou preservação que a palavra carrega com ela. Há um tipo de motivação para a expressão oral, algo raro de se obter dos indígenas, pois eles costumam ser parcimoniosos no uso da palavra falada.

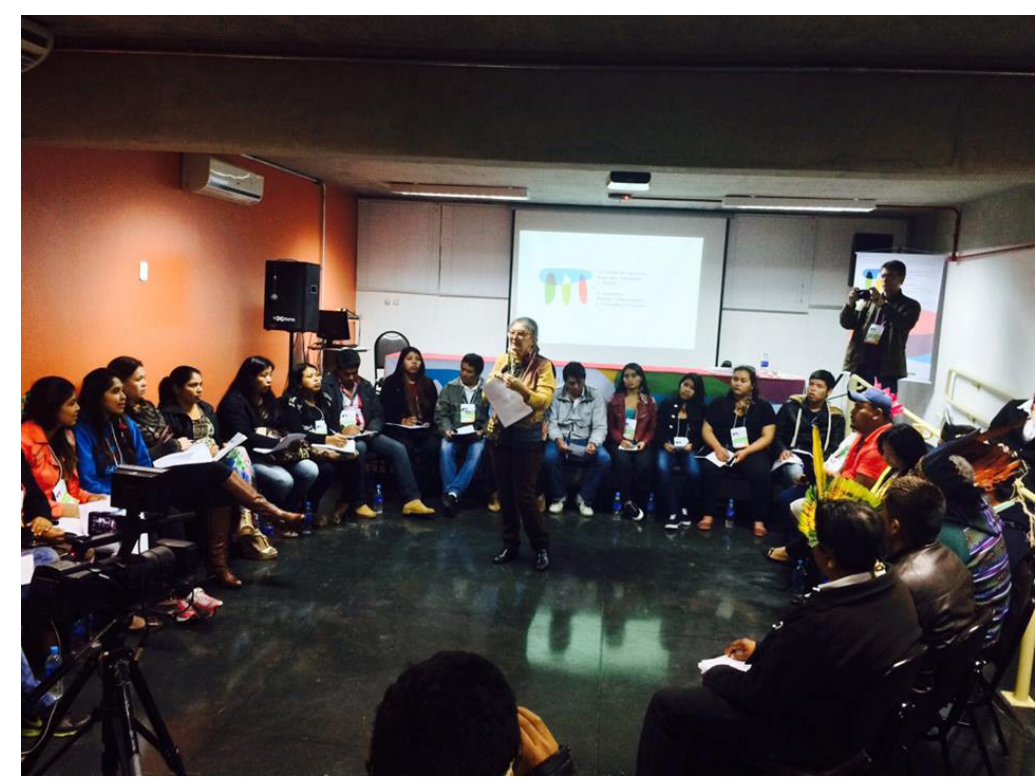

Foto 1 - Formação do grupo, 2015. Foto: Acervo Museu Histórico e Pedagógico Índia Vanuíre.

Esse tipo de abordagem orgânica se mostra sistêmico, não cartesiano. Tal como é a vida do índio! Muitos conhecimentos, de diversas áreas, foram expostos oralmente pelos participantes.

Vejamos uma lista com os nomes e as palavras orgânicas escolhidas pelos participantes, na ordem exposta: 


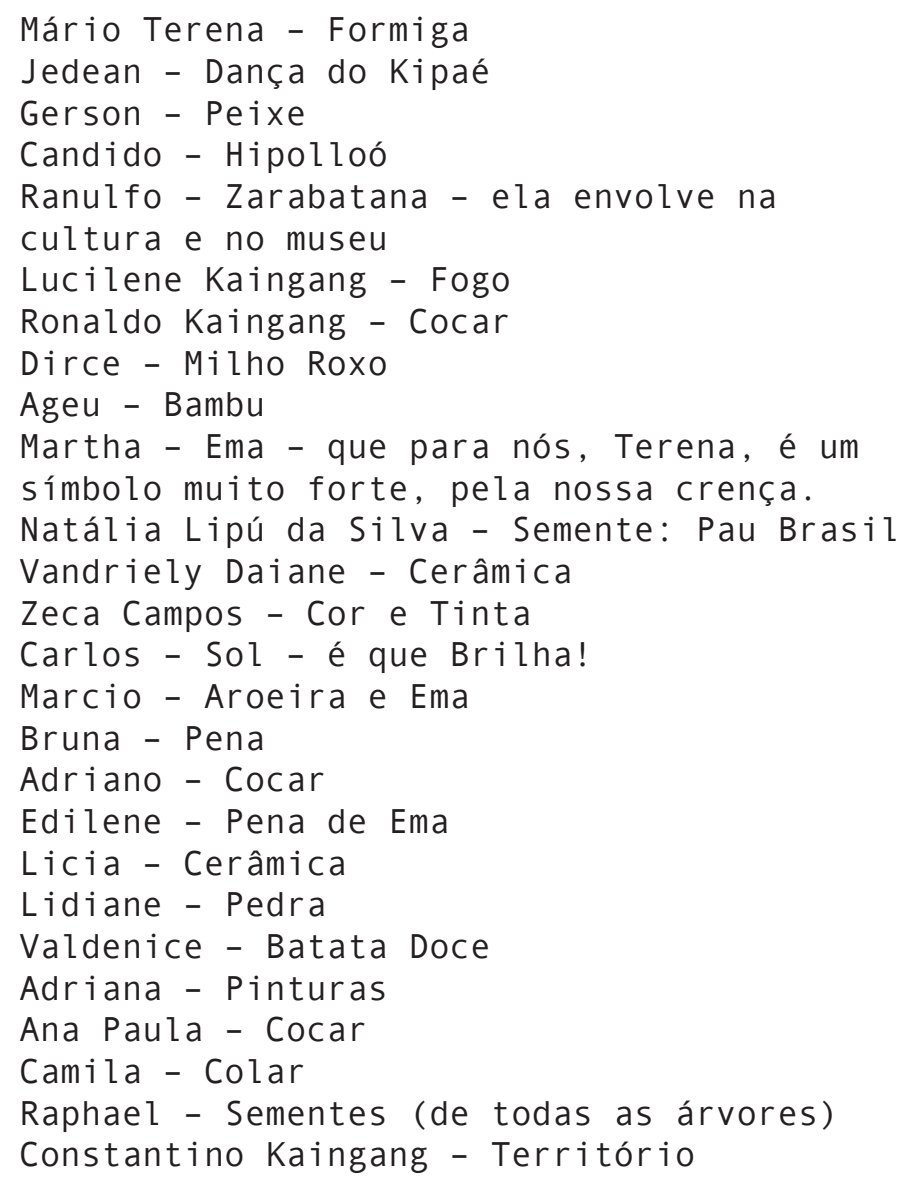

Ao elaborar a dinâmica pensamos que ao final poderíamos ter elementos significativos para falar sobre a importância da proteção das terras indígenas para os indígenas. Quão grande foi nossa surpresa no momento em que Constantino Kaingang abre sua folha e lê a palavra "Território". Esse fato nos propiciou a vivência de um momento no qual os próprios indígenas, ao final da atividade, apontaram o sentido da temática museográfica indígena, o sentido da memória e da luta atual dos indígenas: a certeza de poder habitar suas terras e aí construir ou dar continuidade à sua cultura e vivenciar a alteridade étnica.

Todas as palavras escritas e depois comentadas pelos participantes estão de acordo com os três desafios do museu, na atualidade, colocados pela pesquisadora e diretora do MAE-USP, Maria Cristina Oliveira Bruno (2015). Isto é, o desafio da condição humana, pois a temática deve estar relacionada à contemporaneidade, à relação do ser humano com as questões de seu tempo histórico. Nesse sentido, as palavras e seus comentários estão firmemente ancorados no cotidiano indígena das etnias ali presentes. O segundo desafio, a questão do respeito. Respeito ligado ao social, ao cultural e ao ambiental, a tolerância e a convivência de seres humanos, a fauna e a flora. Isso também foi contemplado pelos indígenas na "ferradura filosófica". O terceiro desafio concerne à inovação. Nesse quesito, a inovação se apresenta principalmente na capacidade de sintetizar em uma palavra, relativa à tradição, uma forma de resistência da cultura indígena na sociedade mais ampla e no fortalecimento da identidade indígena (que pode ser representada em um artefato propriamente dito - cocar, alimento, colar - ou um elemento menos objetivo como fogo, formiga, milho roxo, brilho do sol ou as sementes).

Conforme a pesquisadora mencionada, o acervo de uma exposição indígena pode ter múltiplas origens, ser múltiplo, mas sua explicação é universal visto estar relacionada à condição humana. Condição essa que celebra, que sofre, que nasce e que é singular, posto que ela é, além de universal, também local e advinda do convívio.

Outro aspecto é a educação. No caso indígena, a arte sempre está relacionada à dinâmica da sociedade, suas transformações e permanências. Para isso a curadoria deve ser ou indígena ou compartilhada. 0 indígena não deve de forma alguma ficar de fora da curadoria em uma exposição indígena. As referências e as relações dos artefatos entre si e das ideias ali expostas devem seguir uma lógica que, para o não indígena, é, muitas vezes, surpreendentemente impensável. Esse fato contribui para a experiência da alteridade, para a educação do povo ali representado e a obtenção do respeito dos visitantes.

O Brasil é um país que se constrói com as experiências de povos e culturas diversos, que já tinha uma (ou várias!) história(s) e várias memórias antes da invasão europeia. A conexão entre a História do Brasil e a dos indígenas précabralinos aparece, a todo momento, na produção atual dos indígenas: culinária, artesanal, educacional, artística, musical, no vestuário, no penteado, na apreciação do mundo, na explicação 
para os fatos, no convívio etc. No entanto, uma exposição que não leve em conta essa problemática do vínculo entre a nação brasileira e a

identidade indígena, identidade que nos remete à memória anterior à conquista, deixa de valorizar a perspectiva do indígena com relação aos temas universais da humanidade.

Perdemos todos com isso, pois a exposição perde a oportunidade de se mostrar viva, os indígenas são apagados da proposta, traços de eurocentrismo deixam de ser questionados, e a sociedade visitante é privada da experiência real da alteridade.

Para terminar, lamento não ter escrito imediatamente o que cada participante da Mesa relatou sobre sua palavra orgânica, mas isso não foi perdido pois está gravado e filmado e pode ser resgatado nos arquivos audiovisuais do Museu Índia Vanuíre, em Tupã. No entanto, relato fragmentos de uma longa conversa, recente, que tivemos - eu, Deolinda Pedro e Neusa Umbelino - sobre algumas palavras orgânicas mencionadas durante a realização da Mesa.

\section{- As sementes são importantes para o} índio, todas elas. Isto porque o índio trabalha com a semente, com a taboa, com o coqueiro. Mesmo o índio que não tem mais sua mata para retirar a semente, ele busca na mata do fazendeiro, nas ruas das cidades e em todo lugar onde tem semente. As sementes vermelhas são importantes porque mostram a cor vermelha. 0 vermelho é o índio guerreiro, índio lutador, que tem força e coragem. Como que pode dar sementes vermelhas, né? É para o índio mesmo!

- Hoje as abelhas não fazem mais casa no pau. Hoje não tem mais aquela madeirona grossa. As abelhas gostam das madeiras grossas. Elas faziam aí sua casa e nesse pau grosso elas davam muito mel. Meu pai tirava 15 a 20 litros de mel do meio da mata, quando ele achava um pau grosso desses, cheio de mel. Hoje não tem mais pau para elas e é difícil encontrar abelhas.
- Quando nós íamos pescar, todos juntos, no rio, minha mãe falava: enquanto os homens vão pescar, nós, mulheres, vamos catar lenha e fazer a fogueira. Preparava a fogueira, punha o fogo e colocava duas forquilhas. Preparava um espeto com a ponta bem afiada e assim que os homens pescavam um peixe grande eles mandavam pra nós. A gente tirava a barrigada, as escamas, e colocava no espeto, bem firme e punha no fogo. Nós já levávamos o yamim (pão Kaingang feito de milho preto) pronto e todos comiam com peixe. Depois, minha mãe ia coletar coquinho. Aquele coquinho alaranjado e pequeno. Nós levávamos muitos daqueles coquinhos. Minha mãe levava um balde cheio pra casa e lá chegando, minha mãe pilava os coquinhos e tirava o caldo deles e dava para nós bebermos. Não era um copinho não! Era um caneco grande para cada um de nós beber. Éramos uns quatro ou cinco netos perto dela e todos tomavam. Era gostoso! Tão docinho e grosso aquele caldo do coquinho.

- 0 fogo é muito importante para o índio! A fogueira aquece o índio! E toda caça, o índio traz pra fogueira!

- De dia, quando está frio o índio se esquenta no Sol, de noite no fogo. 0 índio precisa muito do sol pra se aquecer, se esquentar no sol, é assim que o índio se livra do frio!

- 0 peixe foi sempre a comida do índio, o índio começou a viver comendo peixe, as avós dando peixe para os filhos, para os netos. Nunca dava arroz, macarrão, essas comidas que hoje dá.

- o caldo de peixe é muito gostoso. Coloca na panela água, sal e peixe, pode ser aquele lambari, lambarizão, bagre, peixe do rio. Cozinha bem e come o peixe com o yamim. o caldo é servido separado, para quem quiser. Meu pai gostava era do caldo!

- 0 yamim torrado, com caldo de peixe, é muito gostoso! Como se faz o yamim? Debulha o milho preto, deixa de molho por dois ou três dias, soca no pilão, coa 
na peneira, molha como se faz pirão e depois prepara o bolo dele para fritar ou cozinhar na folha de bananeira [Deolinda]. Debulha o milho preto, deixa de molho três dias (não precisa trocar a água), soca no pilão, coa na peneira, soca outra vez, deixa mais três dias (ou dois). Quando estiver pronto (macio), coloca na panela de ferro e torra. Fica muito gostoso! Pode comer com carne, peixe [Neusa].

- Quando éramos crianças, nosso pai curava a gripe com fumo. Ele colocava um pouco de fumo na chapa do fogão a lenha, esperava ele torrar, tirava e fazia o pozinho dele na palma da mão. Dava para nós, pondo no nariz, e nós cheirávamos aquele pó de fumo. Espirrava muito! Daí a gripe foi embora!

- A dança é muito importante para o índio! A dança indígena faz bem pro índio, ele pode mostrar como é a dança do índio numa apresentação. Ele mostra a dança para o não índio numa comemoração, numa celebração. 0 índio gosta também do forró. Forró é bom pra trazer energia, é bom pra dançar!

- A zarabatana era a ferramenta da caça do índio, eles usavam para matar o peixe e outros animais pequenos.

- o cocar é para apresentar e comemorar. 0 índio usava para cerimônias, não era para o dia a dia.

- Milho roxo, comida indígena muito importante para nós indígenas. Era a comida mais forte que o índio comia, o índio que podia ter o yamim nunca trocava ele por comida outra.

- 0 bambu é bom pra fazer flecha, cesto e as armas indígenas. Ele é muito importante!

- A ema é uma ave importante pois tem até as brincadeiras de ema. As crianças e adultos brincam dessa brincadeira. Forma uma roda e fica um no meio, esse é a ema que vai ouvir que madeira cada um vai ser. Depois a ema sabe qual a madeira mais fraca e ela vai tentar sair do círculo forçando os braços dos índios que estão no círculo. Forçando a madeira fraca! Até que ela, a pessoa que é a ema, rompe um deles e sai correndo campo afora e todos correm atrás dela até pegar. 0 que pega a ema fica no meio pra contar histórias. Histórias de índios!

- As madeiras fracas são taboca, mamona, figueira, o jambo, amora, pau-brasil. As madeiras fortes são a aroeira, o cedro e a peroba. A aroeira, que é madeira dura, nunca morre! Nunca seca! Nós morremos e ela fica! Nunca apodrece! 0 índio fazia pilão com ele!

- A cerâmica era muito importante para as índias. Hoje usa muito outras panelas. As mulheres faziam panelas para fazer feijão, yamim, arroz, pote para segurar água, pois o pote gelava a água mais que uma geladeira. 0 barro do rio, o barro tchatcha, barro preto, é muito bom. Era muito difícil de achar. Para achar o barro preto, o índio vai no rio! Colhe o barro! Traz o barro em casa! Maceta o tijolo para tirar o pó, mistura com o barro preto e amassa, amassa e depois vai dando a forma: um pote, uma panela, um bule. Eu [Deolinda Pedro] cozinhava feijão numa panela feita pela minha avó Chica, mãe da mãe Catarina Campos Lenri.

- Minha mãe Tereza Maria Leri [mãe de Neusa Umbelino] fazia os potes Kaingang e colocava o yamim dentro deles. Ali o yamim ficava conservado, não estragava. Fazia um pote grande, daqueles Kaingang, preto, comprido, sabe? Que tem no Museu! Lá colocava mel também!

- A pintura? A tinta dos Kaingang é só preto mesmo!

- As penas usa pra fazer cocar. Cocar é o pajé que usa. Ele usa para benzer, fazer as orações dele. Para benzer tem que ter fé, cachimbo, cocar e colar. Antigamente não tinha esses colares. Agora é que o índio faz esse colar com sementes. Era mais colar de pena, amarradas em duas voltas [Neusa]. 
- As penas de Ema, o índio fazia saia com elas. Meu finado avô Antonio Pedro, Terena, só fazia a saia com pena de ema. E era bonito! Muito bonito! [Deolinda].

- As pedras são muito boas para alisar as cerâmicas, em Kaingang chama pororo.

- Gostoso é a batata-doce. Os índios gostavam de assar na fogueira, era a principal comida indígena. Muito bom pra comer com mel, mel de abelha. Meu pai colocava na fogueira batata-doce, mandioca. Mandioca também põe na fogueira. Fica gostoso! Corta no meio e põe mel, hummmm!

- 0 índio precisa da sua Terra para plantar mandioca, abóbora, batata-doce, lengró, feijão, guerentim, arroz.

- Lengró Ton! Não tem feijão!

- Foc tarrah curutim lengró coia! Venha logo comer feijão!

- Foc coré - mulher branca ruim.

- Foc mahã - mulher branca bom.

- Ian cupri - mãe branca.

- Iok cupri - pai branco - iok tchatcha pai preto.

Essa conversa animada teve também muitas risadas, muitos momentos de lembranças da infância e da mocidade. Lembranças dos mais velhos que se foram, principalmente da Dona Catarina Campos Lenri, a quem nós gostaríamos de dedicar essas palavras finais de Dona Deolinda e Dona Neusa.

\section{Referências}

ASHTON-WARNER, Sylvia. Teacher. New York: Bantam Books, 1971

BRUNO, Maria C. 0. Museu de Arqueologia e Etnologia da USP. (Palestra). In: ENCONTRO PAULISTA QUESTÕES INDÍGENAS E MUSEUS, 4.; SEMINÁRIO MUSEUS, IDENTIDADES E PATRIMÔNIOS CULTURAIS, 5., Museu Índia Vanuíre, Tupã, 30 jun. 2015.

CUNHA, Manuela C. da. O futuro da questão indígena. IN: SILVA, Aracy Lopes; GRUPIONI, Luís Donisete B. (Coord.) A Temática indígena na escola: novos subsídios para professores de $1^{\circ}$ e $2^{\circ}$ graus. Brasília: MEC; MARI; Unesco, 1995 .

FERREIRA, Marieta de M. (Coord.) Entre-Vistas: abordagens e usos da História Oral. Rio de Janeiro: Ed. FGV, 1994.

GOMES FILHO, João. Gestalt do objeto: sistema de leitura visual da forma. São Paulo: Escrituras, 2000 .

KUMON, Toru. Estudo gostoso de matemática: o segredo do método Kumon. São Paulo: Kumon, 1995.

MONTEIRO, John M. (Coord.) Guia de Fontes para a História Indígena e do Indigenismo em arquivos Brasileiros. São Paulo: NHII-USO; Fapesp, 1994.

PINHEIRO, Niminon S. Ensino de História nas Aldeias Indígenas - Produção de Textos de Etnohistória Kaingang para a Alfabetização nos Postos Indígenas Apucaraninha (PR) e Vanuíre (SP). In: BITTENCOURT, C. M. F. (Org.) II Encontro "Perspectivas do Ensino de História", Anais. São Paulo: FEUSP, 1996.

\footnotetext{
* Niminon Suzel Pinheiro é mestre em História e Movimentos Sociais e doutora em História e Sociedade pela Universidade Estadual Paulista Júlio de Mesquita Filho (Unesp), campus Assis, com pós-doutorado em Antropologia pela Unesp campus Marília. Atualmente é professora no Centro Universitário de Rio Preto (Unirp).
} 


\title{
Meruri 2015: do território cultural ao território dos entraves morais
}

\author{
Aramis Luis Silva* \\ Universidade Federal de São Paulo (Unifesp) e Centro Brasileiro de Análise e Planejamento (Cebrap)
}

Este texto está articulado em torno de informações relacionadas à última viagem de campo da pesquisa "Lendo Museus Salesianos", vinculada ao Projeto Jovem Pesquisador "Alteridade e Mediação: processos de construção do 'outro' em universos católicos e protestantes no Brasil e na África”, encerrado no primeiro semestre de 2015. Essa viagem foi realizada entre os dias 24 de janeiro e $1^{\circ}$ de fevereiro de 2015, na Missão Salesiana do Sagrado Coração de Jesus de Meruri, junto aos índios Bororo da Terra Indígena homônima, no Sudoeste do Mato Grosso. Nossa intenção, aqui, é iniciar a sistematização de um universo de dados e apontamentos dessa última experiência de campo, confrontando com resultado de pesquisas anteriores, a fim de suscitar um debate sobre pertinências e urgências de pesquisas futuras enquadradas sob a específica maneira de abordar o fenômeno sociocultural que apresentaremos a seguir.

Estávamos justamente encerrando o processo de revisão de dados e elaboração textual dos resultados da pesquisa "Lendo Museus Salesianos" 2 quando fomos surpreendidos com uma notícia que definiu os contornos desse texto: depois de longos (e indesejados) 7 anos de ausência,

\section{Bolsa Fapesp (processo 2008/10758-0).}

2. Os esforços decorrentes do projeto "Lendo Museus

Salesianos" acabaram sendo trabalhados em um capítulo de livro e um artigo de periódico: "Patrimônio etnográfico salesiano na América do Sul: entre a ciência e a religião" (na coletânea precedente a essa mesma série de publicações) e "Quando as musas vestem o hábito - diálogo entre Antropologia, Museologia e História à soleira dos museus missionários" (Revista Museologia \& Interdisciplinaridade, criada pelo Curso de Museologia e vinculada ao Programa de Pós-Graduação em Ciência da Informação da Universidade de Brasília). uma nova viagem de campo à Missão Salesiana do Sagrado Coração de Meruri havia sido finalmente autorizada pela congregação religiosa católica de origem italiana. Um fato surpreendente e significativo. Meruri não só é parte do território de missão salesiana de onde proveio grande parte das coleções etnográficas brasileiras postas em observação ao longo desse projeto, como também foi o ponto de partida da nossa trajetória de pesquisa, desde o mestrado e o início do doutorado, quando realizamos nossa última estadia nesse campo.

\section{Por que Meruri é central?}

Meruri, um enclave indígena e missionário atualmente cercado por bois e soja do agrobusiness nacional no Sudeste do estado do Mato Grosso, pode ser entendida como o fio da meada de uma pesquisa que nos conduz até o projeto "Lendo Museus Salesianos". Tratase de uma nomenclatura referente a um sistema que se desdobra em dois eixos histórica e sociologicamente imbricados e indissociáveis, como já atestaram alguns autores (Novaes, 1993; Evangelista, 1996; Montero, 2012).

Condição sistêmica que se reflete até mesmo no espaço. De um lado está a Missão Sagrado Coração de Meruri, um complexo arquitetônico multifuncional erigido pela Congregação Salesiana a partir de 1902 junto aos índios Bororo da região dos Rios Garças. De frente à missão, compondo um enorme quadrilátero com fileiras de casas de alvenaria perfiladas, a aldeia indígena de Meruri, a mais antiga e maior entre as quatro 
aldeias que compõem a Terra Indígena homônima. São as outras: Garças, Nabureau e Koge Kureu. ${ }^{3}$

Ao pé do morro do qual emprestou seu nome e à beira do Rio Barreiro, Meruri, com uma população de cerca de 450 residentes em casas organizadas por famílias nucleares, abriga, além do complexo missionário, instalações e postos de trabalho referentes a órgãos federais (Fundação Nacional do Índio - Funai e Secretaria Especial da Saúde Indígena - Sesai do Ministério da Saúde) e do estado do Mato Grosso (Escola Indígena de Meruri, sob administração da Secretaria de Estado da Educação - Seduc). Essa característica lhe assegura a afluência dos homens e mulheres Bororo que habitam ou percorrem a região.

Diversas vezes usada como plataforma empírica para pesquisas de múltiplas disciplinas interessadas em fenômenos que gravitam em torno daquilo que pode ser descrito como interações interssocietárias, Meruri teve sua história e seus quadros de configurações de relações sociais revistos de forma mais sistemática em trabalhos antropológicos e historiográficos. Depois de figurar em obras de autores que lançaram em décadas precedentes luzes sobre a histórica relação entre missionários e índios Bororo (Bordignon, 1986; Viertler, 1990; Novaes, 1993), dois trabalhos publicados no período de um ano voltaram a refletir nos anos 2000 sobre os ditames que organizaram essas relações e examinaram as configurações sociais delas derivadas.

Maria Augusta de Castilho, historiadora formada pela Universidade de São Paulo e docente da Universidade Católica Dom Bosco (UCDB), instituição de ensino superior administrada pela Missão Salesiana do Mato Grosso, publicou no ano 2000 Os índios e os salesianos na Missão dos Tachos, focando os anos iniciais da formação de Meruri. No ano seguinte, Antônio Hilário Aguilera, ex-missionário salesiano e atual professor de

3. Vale lembrar que além desse quarteto, o universo Bororo se estende por um conjunto de mais de uma dezena de aldeias Bororo espalhadas em um território descontínuo composto por seis Terras Indígenas demarcadas no estado do Mato Grosso. Além delas, duas em litígio. Para uma leitura etnológica acerca dos Bororo ver, principalmente, Crocker (1963). Viertler (1990) e Novaes (1993). antropologia da Universidade Federal do Mato Grosso do Sul (desligou-se da Congregação), lançou Currículo e cultura entre os Bororo de Meruri, obra na qual reconstitui a trajetória da missão salesiana até os anos 1990 a fim de situar as configurações relacionais simultâneas entre missionários e missionados que sustentaram a implementação e desenvolvimento da Escola Indígena de Meruri, instituição criada pela Missão.
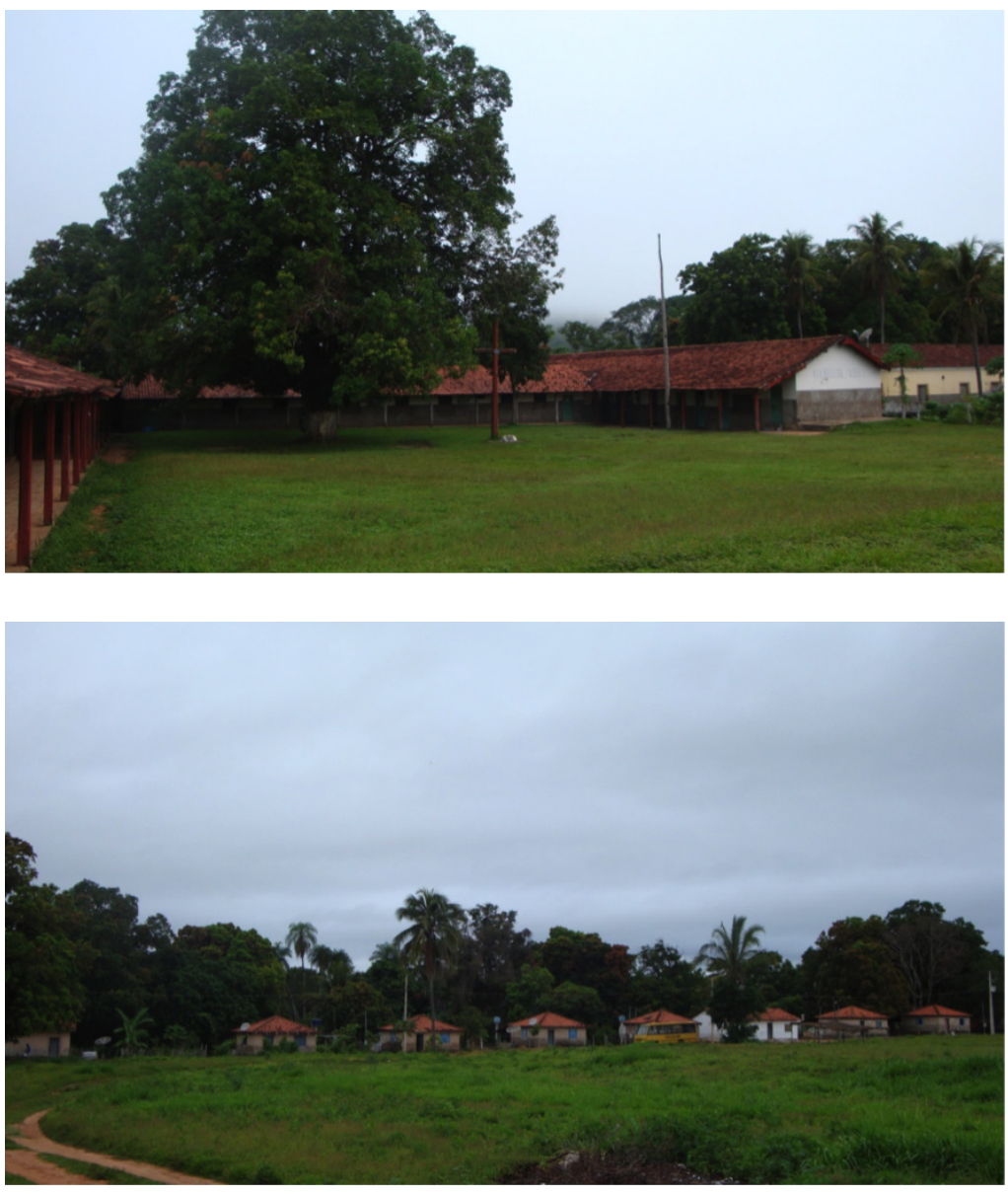

Fotos 1 e 2 - No alto, vista frontal da Missão do Sagrado Coração de Jesus. Acima, um dos três vértices de casas indígenas que formam o quadrilátero merurense. Fotos: Aramis Luis Silva.

Guarnecida pelo acúmulo de informações fornecidas pelos autores precedentes, bem como por outras fontes descobertas durante sua própria pesquisa de arquivo, Paula Montero revisitou novamente essa história em 2012 com o livro Selvagens, 
civilizados e autênticos - a produção das diferenças nas etnografias salesianas, desta vez com o objetivo de oferecer ao leitor o quadro conjuntural das relações que sustentaram a tessitura da escrita missionária, em parte enredada na história de Meruri.

A despeito da multiplicidade de inspirações teóricas, perspectivas temáticas e marcos temporais dos autores acima citados, todos convergem ao transformar Meruri em um palco de relações sociais cujos sentidos locais só podem ser compreendidos quando se consegue situar todos os agentes ali entrelaçados frente a quadros de referência que escapam aos limites da aldeia. Isto é, produções que nos fazem ver Meruri e suas sucessivas feições históricas como o pontomatriz resultante do entrecruzamento de linhas de forças que dizem respeito aos projetos de poder do Estado, da Igreja Católica, da Congregação Salesiana e, é claro, desse coletivo de homens e mulheres, reconhecidos e autoproclamados como "índios Bororo", que se articulam por redes indígenas que se estendem igualmente para além da Terra Indígena.

Foi desse modo que também abordamos Meruri e seu devir histórico quando estivemos lá pela primeira vez, em 2004, interessados em descrevê-la enquanto um campo de disputas simbólicas travadas em torno do desenvolvimento de dois projetos de intervenção sociocultural de viés culturalista (Silva, 2009). Estamos falando da criação e operação de um museu comunitário e da tentativa de construção de uma aldeia "tradicional" fora da aldeia de Meruri, que estaria articulada em torno de outro centro comunitário.

Mas, na direção contrária de conceber as disputas postas em cena a partir da observação dessas duas empreitadas culturais e museais enquanto simples enfrentamentos de forças antagônicas, iniciamos naquela época o mapeamento das redes sociais e dos fluxos de circulação de pessoas, coisas e discursos postos em ação em cada uma delas a fim de demonstrar que esses embates, travados ora veladamente ora abertamente, só ocorriam porque, após anos de história de missionação salesiana entre os Bororo, havia entrado em operação em Meruri uma gramática culturalista compartilhada por todos os agentes postos em relação, entre aqueles que se apresentam como aliados e, também, entre rivais.

Vejamos de forma sintética as configurações de tal campo, apresentando esquematicamente cada um desses projetos e as redes sociais que os sustentam.

\section{Uma aldeia, um passado e dois projetos de futuro}

Em meados dos anos 2000 , Meruri estava mobilizada em torno de dois projetos de intervenção cultural paralelos e correntes. Expressão cabal de processos de objetivação cultural, operava em cada uma das iniciativas em curso o suposto de que o "resgate", "revitalização" e/ ou "valorização" ${ }^{4}$ daquilo que era nomeado como "cultura Bororo" seria o motor para transformação de um quadro social marcado pela escassez econômica, acirramento dos problemas relacionados ao consumo excessivo de álcool (como mortes e violência) e um fenômeno descrito localmente como "perda” ou "descaracterização cultural". Cultura, tomada em uma forma substantivada, se impunha assim como peça de uma engenharia social.

A primeira iniciativa, um pouco mais antiga e ainda em pleno funcionamento nos dias de hoje, é o projeto do Museu Comunitário de Meruri, organizado desde 1999 por uma rede formada por intelectuais leigos interessados em conciliar produção acadêmica e intervenção social, missionários salesianos escalonados em níveis regional e internacional, e por expressiva parcela dos moradores indígenas de Meruri, como atesta a participação desse

4. As formulações sobre esse processo variam no transcorrer de cada uma das iniciativas, o que aponta para uma transformaça dos discursos que as sustentam. Gradativamente a ideia de perda, implícita em categorias como "resgate" e comprometida com um ideário de cultura enquanto um depositário estático de repertórios, vai sendo substituída por termos que apontam para quadros conceituais que incorporam a ideia de transformação cultural. Assim vão entrando em operação discursiva categorias como "revitalização" e "valorização". 
contingente nas agendas relacionadas a esse espaço cultural, como promoção de oficinas para confecção de artefatos, participação em concursos nacionais e apresentação em fóruns nacionais e internacionais. ${ }^{5}$

A segunda iniciativa, o projeto Meri Ore Eda, ${ }^{6}$ que, em princípio, envolvia a construção de uma nova aldeia e, dentro dela, também um espaço cultural com atividades voltadas para indígenas e não indígenas, esteve inicialmente articulado em torno de Paulo Meriekureu, liderança à época ligada ao Instituto de Tradições Indígenas - Ideti (organização pan-indigenista hoje extinta), apoiado por um pequeno grupo de familiares (do clã baadojeba), 7 alguns poucos aliados Bororo e pelo Ministério da Cultura (MinC), que tornou o projeto merurense em um modelo de política pública a ser adotada pela então recém-criada Secretaria da Cidadania e Diversidade Cultural do Ministério, então sob tutela do ministro Gilberto Gil e do secretárioexecutivo Juca Ferreira.

5. 0 processo de formação e consolidação desse espaço cultural enquanto um museu comunitário foi marcado por sucessivos fatos significativos. Em 2006, a experiência cultural merurense tornou-se o grande vencedor do Prêmio Cultura Viva, iniciativa do Ministério da Cultura para reconhecer e estimular as experiências societárias que, sob a ótica do júri, estariam alinhadas ao ideário das políticas públicas culturais a serem postas em cena pelo Estado: "cultura" como uma chave para o empoderamento e desenvolvimento de grupos sociais marginalizados. Ao consagrar-se vencedor, o museu de Meruri e seus agentes colocaram em marcha uma série de conexões com outros agentes e instituições, interessados em conhecer sua experiência. É interessante destacar que é durante esse processo de inserção nesse campo que os agentes envolvidos na experiência merurense aprendem a formular aquilo que estava sendo experienciado em termos museológicos. Essa trajetória envolveu exposições no Museu das Culturas de Gênova e apresentações orais sobre o projeto em arenas organizadas por instituições como a Universidade Autônoma de Barcelona, Espanha, e o Museu Nacional de História Natural Smithsonian, Washington, DC, Estados Unidos. No Brasil, em plena época de elaboração e configuração do Instituto Brasileiro de Museus (Ibram), autarquia que sucedeu o Instituto do Patrimônio Histórico e Artístico Nacional (Iphan) em 2009 nos direitos e obrigações relacionados aos museus federais, houve convites para participações em fóruns temáticos.

6. Meri Ore Eda pode ser traduzido por Filhos do Sol.

7. Aldeias Bororo foram tradicionalmente descritas pelas etnografias como unidades compostas por oito clãs, divididos em duas metades exogâmicas, Tugarege e Ecerae. 0 baadojeba é um desses oito clãs.
A seguir, vamos retraçar um breve perfil histórico dessas duas empreitadas para poder entender de que modo elas se entrelaçam atualmente na vida dos homens e mulheres de Meruri de 2015. Comecemos pelo projeto ligado aos salesianos. Em seguida, revisitemos o projeto de construção da aldeia Meri Ore Eda. Pedimos especial atenção para o trânsito de alguns dos agentes por entre esses dois projetos. Mais que um trânsito, precisamos identificar uma espécie de um curto-circuito significativo.

\section{O Museu Comunitário de Meruri}

A história do Museu Comunitário de Meruri está diretamente vinculada à trajetória profissional, acadêmica e indigenista de um agente capital: Aivone Carvalho Brandão, doutora em Semiótica pela Pontifícia Universidade Católica de São Paulo, que ao longo do percurso de construção e consolidação desse espaço cultural merurense galgará posições no interior de uma rede universitária (será contratada como docente da Universidade Católica Dom Bosco) e museológica (assumirá a função de diretora e curadora de museus salesianos dentro e fora de Meruri).

Em longa temporada na Itália, para onde viajara por questões pessoais, e interessada em continuar seus estudos acadêmicos iniciados no Brasil, Aivone decidiu seguir os conselhos de seu antigo vizinho de Brasília, o antropólogo Darcy Ribeiro: fazer dos museus italianos um meio para ela se aproximar daquilo que descreve como a "cultura Bororo", algo que já havia sido transformado em objeto de pesquisa em sua fase de mestrado, quando estudou o ritual fúnebre Bororo como "uma narrativa semiótica e cultural". ${ }^{8}$

Depois de breve passagem pelo Museu Nacional Pré-Histórico e Etnográfico Luigi Pigorini, de Roma, onde teceu relações e conheceu a pequena

8. Trata-se da dissertação de mestrado em Comunicação e Semiótica, Simbolismo e Narratividade no Ritual Funerário Bororo, defendida em 1994 na PUC-SP, sob orientação do Prof. Dr. Fernando Segolin. 
coleção Bororo da instituição, sua próxima paragem foi o Museu Colle Dom Bosco, museu missionário salesiano a cerca de 30 quilômetros de Turim, e dono da maior coleção etnográfica Bororo fora do Brasil. Chegando ao museu salesiano piemontês no final dos anos 1990, quando a instituição passava por reformulações institucionais e curatoriais, a pesquisadora teve a oportunidade de se engajar no processo de revisão das fichas catalográficas e reorganização expositiva do material etnográfico sul-americano. ${ }^{9}$

Foi durante esse período que essa agente gestou a ideia que implementaria ao regressar ao país, em 1999: apresentar as fotos das peças da coleção salesiana do Museu Colle $e^{10}$ para os alunos da Escola Indígena de Meruri como parte de um processo de "resgate"/ "revitalização"/ "valorização cultural" a ser documentado em uma tese de doutorado. ${ }^{11}$ A mecânica era relativamente simples: mostrar as imagens das peças aos alunos do ensino fundamental a fim de estimulá-los a descobrir seus usos contextuais, principalmente rituais, por meio de consultas a fontes como a Enciclopédia Bororo, escrita pelos missionários César Albisetti e Ângelo Venturelli, ou em conversas com os mais velhos da aldeia. Os trabalhos renderam desenhos nos quais estudantes criaram cenas para contextualizar as peças. Esses trabalhos se encontram hoje no arquivo da instituição merurense.

Funcionando para ela com um acesso à aldeia, a escola de Meruri recebeu de bom grado o projeto dessa agente. À época, é importante saber, a instituição continuava sob administração

9. Coleções salesianas sul-americanas do Colle dizem respeito a peças, além dos Bororo; dos Xavante; dos povos do noroeste amazônico, com destaque para os Tucano; dos Jivaro (Ashuar), do Equador; dos Yanomani da Venezuela; de populações do Chaco Paraguaio; e da Terra do Fogo (Selknan, Tehuelche, Yamana e Alakaluf).

10. Cópias das fichas catalográficas de todas as peças Bororo sob guarda do Museu do Colle se encontram no arquivo de Meruri

11. Menção ao trabalho de doutoramento em Comunicação e Semiótica, "0 museu na aldeia: comunicação e transculturalismo no diálogo museu e aldeia", defendido na PUC-SP, em 2003. Esse material é analisado detalhadamente em trabalho anterior (2015). dos padres salesianos ${ }^{12}$ e estava recebendo as primeiras levas de docentes Bororo graduados (ou em vias de) pelos programas especiais de formação de professores indígenas com titulação universitária da Universidade Católica Dom Bosco (UCDB) e a da Universidade do Estado do Mato Grosso (Unemat). ${ }^{13}$

Da perspectiva dos religiosos da missão de Mato Grosso, além de chancelado e financiado pelo comando central salesiano de Roma, o projeto dessa agente situada para além do universo missionário fazia do patrimônio museológico e do conhecimento etnográficos acumulados durante o trabalho de evangelização no Brasil um instrumento para colocar em novos termos a validade moral da ação evangelizadora salesiana. Se hoje a própria instituição reconhece os efeitos deletérios da ação missionária anterior, justificáveis segundo seus agentes pela necessidade de salvaguardar vidas ameaçadas por outras frentes de contato da expansão nacional, ${ }^{14}$ seria o espólio intelectual desse mesmo passado que estaria atualizando o trabalho de missionação frente a uma nova teologia missiológica interessada em compatibilizar expressões culturais nativas com os ditos valores universais do evangelho. Uma operação, de acordo com as diretrizes de uma antropologia católica difundida em cursos de formação missionária, que precisaria

12. Apesar de já ter sido formalmente incorporada à rede de escolas indígenas do estado do Mato Grosso, a escola de Meruri em 1999 continuava tendo como diretores nomes ligados à organização religiosa. À época, os salesianos diziam que aguardavam os Bororo se capacitarem para assumir essa tarefa. Fato ocorrido anos mais tarde, quando Marcos Obokadugue torna-se o primeiro diretor indígena da escola.

13. Esse processo de formação universitária não só é contínuo como se aprofundou. Além de novas levas de professores que continuam chegando de outras instituições, como a Universidade Federal do Mato Grosso, para ocupar novas posições de docência na Escola de Meruri, alguns desses primeiros professores já estão realizando cursos de pós-graduação. Além disso, Meruri assiste a uma leva de estudantes que estão se especializando em outras áreas de conhecimento. Atualmente, a aldeia conta com indígenas matriculados em cursos como Odontologia, Direito e Medicina. por exemplo.

14. Referência aos conflitos fundiários entre índios Bororo, fazendeiros e garimpeiros, frente aos quais os salesianos se estabeleceram como importantes aliados dos Bororo na conquista de parte do seu território tradicional na região da Bacia do Garças. 
ser conduzida à luz dos conhecimentos etnológicos previamente acumulados. Vale destacar ainda que - trabalho pedagógico e culturalista proposto por essa agente seguia alinhado com o ideário e a metodologia de outras iniciativas missionárias aplicadas poucos anos antes na aldeia, como as oficinas para recuperação de arte plumária, ministradas pelo salesiano Mário Bordignon.

Em contrapartida, a figura dessa agente, vista localmente não como uma religiosa, mas uma "pesquisadora", isto é, uma especialista em "cultura Bororo", também foi bem-recebida por esse novo corpo docente de Meruri que, trazendo novas informações das redes pan-indígenas ou indigenistas associadas aos seus centros de formação universitária, colocavam em circulação na aldeia uma série de formulações sobre o protagonismo indígena e os modos de relacionamento entre populações nativas e a dita sociedade branca. Isso dizia respeito especialmente a uma nova forma de encarar as constantes visitas de pesquisadores em Meruri, como dissemos acima, sempre no mapa das reflexões voltadas a temáticas tensionadas pela interculturalidade.

No cabedal discursivo desses professores, muitos deles interessados em fundir a figura da docência indígena com a da "liderança cultural”, tornaram-se comuns fraseados como "Hoje nós somos produtores do nosso conhecimento"; "Somos nós que vamos fazer as pesquisas sobre nosso povo e cultura e não alguém que vem de fora"; "Acabou-se o tempo em que vinha pesquisador levar nossas riquezas e não nos dava nada em troca". Assim, frente a esse ideário, a figura de Aivone parecia representar algo compatível e desejável. Trazendo em sua bagagem imagens de um acervo museológico até então inacessível aos índios Bororo e com a proposta de convertê-las em peças estratégicas de uma ação acadêmica que beneficiaria antes de tudo os próprios indígenas postos em observação, ela chegava diante dos olhos desses novos professores da aldeia como a encarnação desse novo pesquisador, alinhada, mesmo que de forma um tanto caricatural, à novíssima pauta do indigenismo nacional.

A pesquisadora, que acabou sendo incorporada ritualmente à comunidade indígena merurense como uma mulher pertencente à metade Ecerae, no clã dos bokodori, sob o nome de Kogebo Jokiudo (Rio de Peixe Dourado), ${ }^{15}$ no percurso de se autoproduzir intelectualmente enquanto uma agente museal engajada nas questões indigenistas, construiu uma relação triádica que permitiu sua inserção e circulação no campo merurense entre salesianos e os Bororo. Com o beneplácito dos salesianos de Roma, galgou posições importantes dentro da Missão Salesiana do Mato Grosso, tornando-se docente contratada pela Universidade e, mais tarde, a pessoa designada a comandar a reforma milionária do velho Museu Dom Bosco de Campo Grande, renomeado Museu das Culturas Dom Bosco. ${ }^{16}$

Em relação aos Bororo de Meruri, essa agente trabalhou em diversas frentes para que seu projeto acadêmico e pessoal fosse posto, segundo a sua ótica, a serviço dos interesses da população. Contando com financiamento internacional dos salesianos, por exemplo, garantiu a reforma da quase totalidade das então setenta casas de alvenaria de Meruri que estavam praticamente em ruínas ao incluir em seu projeto de "revitalização cultural" uma "oficina de mutirão" a fim de verificar a operacionalidade da "reciprocidade clânica” entre as duas metades exogâmicas Bororo (tugarege e ecerae), assim como ela descreve em sua tese. Disponibilizando material de construção, empreiteiro e pedreiros, a agente teria documentado a contribuição dos grupos de famílias no processo de reforma de cada casa.

Com adesão expressiva dos moradores ao seu projeto acadêmico e social, as oficinas de desenhos logo se desdobraram em novas atividades: em oficinas de confecções de peças criadas a partir dos modelos fotográficos e dos demais dispositivos pedagógicos (consultas à Enciclopédia Bororo e aos mais velhos). Na sequência, a ideia de transformar uma das salas do velho prédio da missão em sede das atividades culturais e abrigo das peças logo amadureceu na

15. Pessoas que são encaradas como importantes aliados são ritualmente incorporados ao universo social Bororo. Uma vez que o universo encontra-se completamente dividido entre as classes de primazia Bororo, os brancos, os braido, em Bororo, são concebidos como pertencentes aos bokodori. Ao ser incorporado pelos Bororo, um braido entra no clã bokodori. 16. Sobre esse museu, ver Mapa de viagem de uma coleção etnográfica (Silva, 2011). 
criação de um centro cultural, que mais tarde se tornaria o Museu Comunitário de Meruri, uma instituição posteriormente conhecida como um museu não de peças, mas da técnica.

Suas coleções, que deveriam ser constantemente recriadas em oficinas interessadas em multiplicar o domínio de suas técnicas de produção entre os Bororo, estariam disponíveis para empréstimo para serem usadas em funerais, missas inculturadas e eventos públicos fora da aldeia, como os Jogos Mundiais dos Povos Indígenas. Assim elas ganhavam vida para além da sua função museal de encarnar a si mesmas como peças de museu. Enfim, para coroar esse processo de transmutação de uma experiência pedagógica em um projeto museológico, em 2001 foi trazido do Museu Colle um conjunto de artefatos que estavam guardados na reserva técnica da instituição italiana para ocupar dali em diante a posição de “coleção histórica” do museu de Meruri. ${ }^{17}$

\section{Uma aldeia para resgatar a cultura e a religião Bororo}

Da aldeia Meri Ore Eda, projeto de "resgate da cultura Bororo" concebido pelo líder Bororo Paulo Meriecureu, apoiado pelo Instituto das Tradições Indígenas (Ideti) e à época aventado para se tornar um dos múltiplos pontos de cultura do Ministério da Cultura, ${ }^{18}$ resta hoje apenas o esqueleto do grande baito, a casa dos homens Bororo, a sobra daquilo que o fogo da queimada xavante não consumiu. ${ }^{19}$

17. Essa coleção foi transformada em tema da tese Mapa de viagem de uma coleção etnográfica (Silva, 2011).

18. "Ponto de cultura" é o nome dado aos núcleos de atividades culturais desenvolvidos por entidades comunitárias ou governamentais com financiamento e apoio institucional do Ministério da Cultura (MinC). Atrelado ao Programa Cultura Viva do MinC, trata-se dos pontos focais de uma rede posta em construção, base de uma política pública implementada desde o primeiro mandato do governo Luís Inácio Lula da Silva baseada na ideia de que o empoderamento cultural de comunidades tradicionais ou específicos grupos sociais à margem do establishment seria um veículo promotor de desenvolvimento sociopolítico e econômico.

19. Com situação fundiária praticamente estável desde a demarcação de terras posta em curso em 1975 pela trágica história conhecida com a "Chacina do Meruri", na qual
Instalada propositalmente longe da aldeia de Meruri - para que a distância física marcasse também a distância ideológica da missão - e próximo da divisa da T.I. de Meruri com a T.I. São Marcos dos Xavantes - para funcionar também como uma sentinela para monitorar e impedir as constantes invasões dos antigos inimigos nas terras dos Bororo -, Meri Ore Eda praticamente não saiu do papel, apesar do estardalhaço do seu lançamento oficial, em abril de 2004. Na ocasião, o próprio ministro Gilberto Gil, acompanhado de representantes da Organização das Nações Unidas para Educação, Ciência e Cultura (Unesco), da Organização das Nações Unidas para Alimentação e Agricultura (FAO) e de representantes do governo do estado do Mato Grosso, compareceu em cerimônia pública promovida na Terra Indígena para ratificar oficialmente o apoio do Ministério a uma experiência local que deveria ser vista ali como um modelo de política pública a ser replicada por todo o país.

A única instalação da nova aldeia a ser construída foi a casa central Bororo, descrita pela etnografia sobre esse povo como o lócus da produção e reprodução do masculino e dos ordenamentos de poder a ele associado (ver, por exemplo, Viertler, 1990). Uma vez enquadrada pela antiga etnografia salesiana como núcleo desagregador da família por expressar uma sobrevivência do matriarcado (Albisetti; Colbachini, 1942) e tida como espaço de influência dos baire, os xamãs Bororo, é importante lembrar, essa instituição tornou-se no início do século XX alvo de intervenções missionárias (Novaes, 1993). 0 objetivo era convencer os Bororo de que essa casa e todas as práticas rituais a ela associadas deviam ser extirpadas da vida social

fazendeiros e posseiros mataram o então diretor da missão Padre Rodolfo Lukenbein e o índio Simão Bororo, Meruri está sendo tensionada pelas constantes investidas dos vizinhos Xavante, residentes na Terra Indígena de São Marcos, limítrofe às terras Bororo. Pressionados pelo forte crescimento populacional, faccionalismo que pulveriza suas aldeias e escassez de áreas de caça, os grupos Xavante têm se instalado periodicamente à revelia dos Bororo em Meruri, gerando atritos. Lembrados como tradicionais inimigos, os xavantes, ou kaimos, os inimigos Bororo, são encarados com desconfiança e ressentimento. Para se tomar dimensão das tensões entre os grupos, recentemente houve uma verdadeira histeria quando estourou pela aldeia um boato de que os Xavantes estavam chegando para invadir Meruri. Famílias correram para a escola, para se abrigar e se esconder. 
dos indígenas. Desse modo, assentado sobre tantas histórias e referências, agora transformado em símbolo, o baito de Meri Ore Eda foi levantado quando houve a primeira e única destinação de recursos para o projeto: 500 mil reais.

Todavia, outros montantes necessários para levar a aldeia Meri Ore Eda adiante não vieram, para desgosto do líder Bororo, que também se ressentia do descrédito de parcela de moradores de Meruri frente ao seu projeto. Segundo ele, os Bororo de Meruri estavam habituados a viver em uma vila de padres e não compreendiam que essa era a raiz de todos os males. Como defendia Paulo, eles só recuperariam sua cultura e ganhariam um novo futuro quando rompessem com uma relação já centenária marcada pela dependência econômica, política e espiritual.

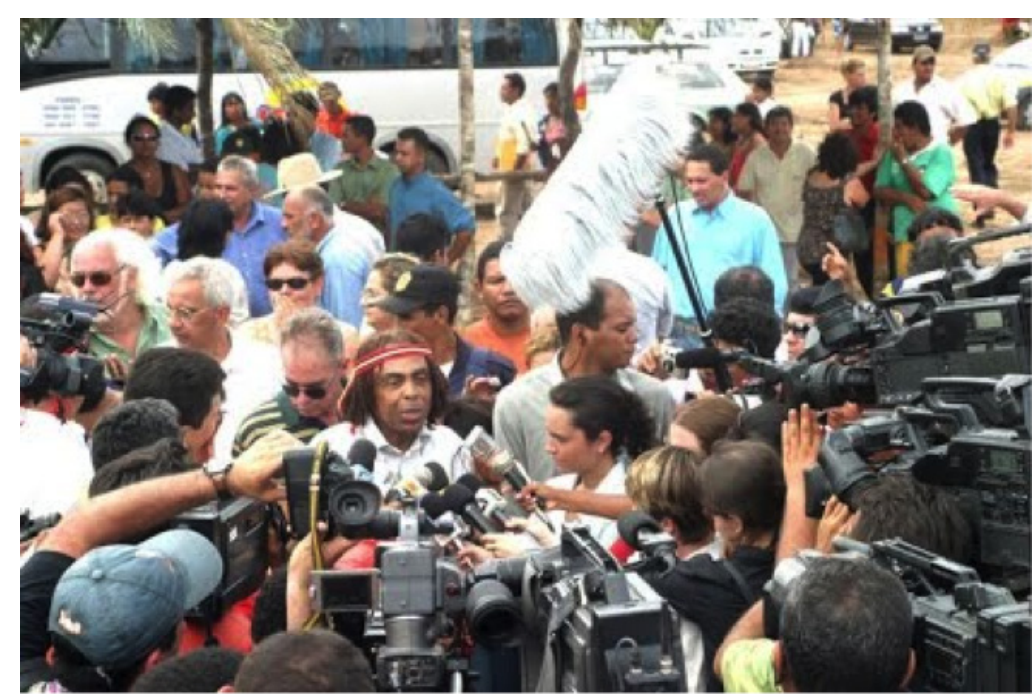

Foto 3 - O então ministro Gilberto Gil, em Meruri durante o lançamento da aldeia Meri Ore Eda. Junto a ele, representantes da Unesco, da FAO e do governo do estado do Mato Grosso. Fonte: MinC.

A ideia de Paulo era criar uma aldeia autossustentável e, segundo ele, sede do verdadeiro centro cultural Bororo, uma unidade criada e mantida por indígenas que funcionaria para ser um lugar de "resgate e novas ideias", 20

20. Trecho extraído do site de Fabrício Pedroza, arquiteto (e amigo pessoal de Paulo Meriecureu) que assinou o projeto arquitetônico. Disponível em: http://www. fabriciopedroza.com. br/projeto-meri-ore-eda-para-o-povo-bororo-2004-2005; Acesso em: mar. 2015 . com as adaptações necessárias para guardar acervos de vídeo, foto e textos. Um espaço equipado com tecnologias de telecomunicação e informação e com auditório para apresentações para grandes plateias. Meri Ore Eda nasceria assumindo como sua força motriz, além dos enormes painéis fotovoltaicos a serem instalados sobre o centro cultural, uma entidade tomada naquele projeto como autoevidente: a cultura Bororo.

Ao inscrever essa dita cultura em materiais audiovisuais e textuais produzidos pelo centro cultural, ela se tornaria matéria-prima para uma série de produtos que foram pensados como comercializáveis em um mercado de bens simbólicos. Em diferente instância, a cultura em sua forma objetivada serviria também de sustentáculo para outra frente econômica da aldeia: o turismo.

Ao redor da casa dos homens seriam construídas as oito casas clânicas Bororo, que tanto serviriam de abrigo aos visitantes pagantes como forjariam junto à casa dos homens o espaço social Bororo no qual iriam transcorrer rituais, danças e cantos coreografados para serem apresentados àqueles interessados em conhecer como seria a dita cultura Bororo. Num círculo posterior a essas ditas casas tradicionais, mais oito casas clânicas de alvenaria, com todo o conforto que a modernidade fosse capaz de oferecer. Nessas casas morariam os Bororo de Meri Ore Eda, pessoas interessadas em fazer da recuperação dessa dita cultura nativa o seu modo de sobrevivência. 0 abastecimento de alimentos seria proveniente de roça comunitária e de projetos paralelos como o de piscicultura.

Assim, como defendia Paulo, no mesmo instante em que os Bororo teriam de se preparar para serem capazes de viver a cultura Bororo na prática diante dos olhos dos turistas, essa seria também para eles uma oportunidade para reaprenderem aquilo que teriam perdido em anos de convívio com os padres salesianos. Um trabalho de resgate cultural sustentado por meio de pesquisas nas etnografias acadêmicas e missionárias, como a própria Enciclopédia Bororo - e o seu exemplar já havia sido levado para Meri Ore Eda, para eventuais consultas. Em síntese, esse era o núcleo da intervenção didática e sociológica de Paulo. 


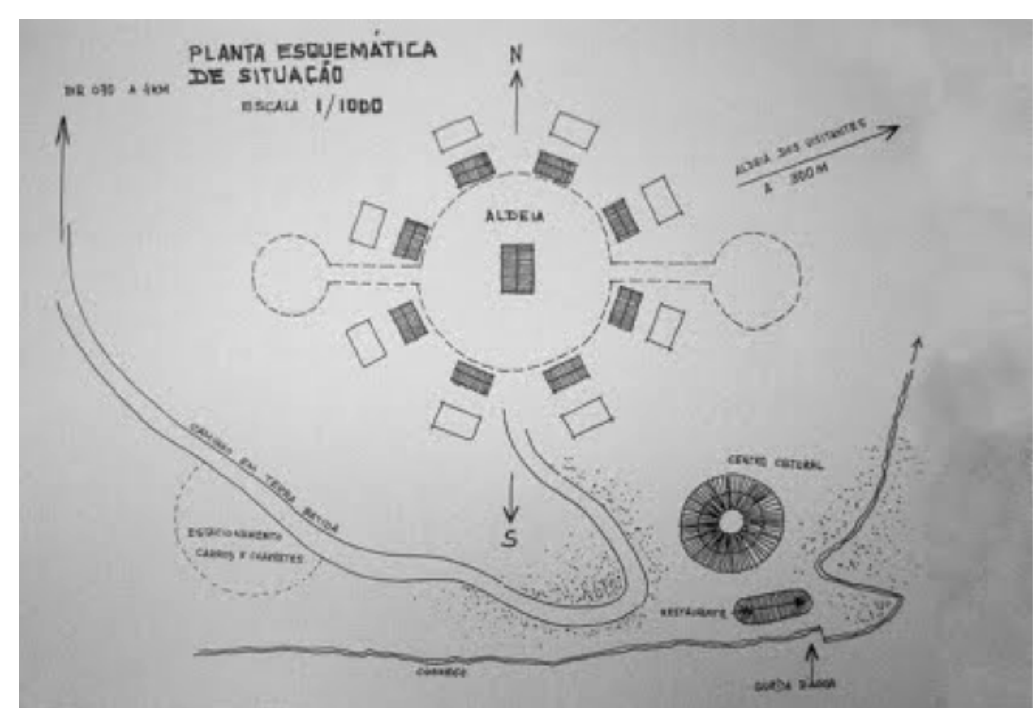

Foto 4 - Planta de Meri Ore Eda. Fonte: site de Fabrício Pedroza.

Todavia, se agentes ligados aos padres o acusavam de pouco conhecimento sobre a tradição Bororo, em parte por ter morado anos fora da aldeia quando jovem, Paulo dizia que a sua legitimidade estava no sangue que corria em suas veias. Mais que um Bororo, o líder indígena conhecido no mundo indigenista fora de Meruri como Paulo Bororo gostava de lembrar aos seus interlocutores que ele era um baadojeba, isto é, do clã do qual provinham os grandes chefes Bororo.

Uma posição de radicalidade em relação à descendência, aliás, que o levaria a propor posições extremas, como a proibição de mestiços em Meri Ore Eda. Para ele, Meruri, vista como a menos Bororo das aldeias Bororo, que até hoje tem como cacique Lourencinho, um dos filhos de Ana Preta, senhora negra da qual atualmente mais de 50 pessoas da aldeia descendem, era a pura prova daquilo que a mestiçagem poderia fazer para os Bororo. Informado por quadros de referência heterodoxos, Paulo se defendia dizendo não ser racista, apesar de apostar em que a mestiçagem produzia sim aberrações e elas precisavam ser enfrentadas com a proteção da cultura Bororo, que naqueles instantes surgia em seus discursos com sucedânea de uma raça Bororo.

Crítico veemente das missões católicas, Paulo planejava blindar Meri Ore Eda da influência salesiana ou de qualquer religião relacionada àquilo que ele descrevia como o mundo branco. Segundo ele, mais que uma cultura, os Bororo precisavam recuperar sua religião, que teria sido, tal qual a língua Bororo, quase que totalmente apagada em Meruri por conta da história missionária. Por delicadeza, os padres salesianos não estariam proibidos de conhecer a nova aldeia ou fazer visitas informais. Todavia, estavam absolutamente vedados proselitismos e funções religiosas entre os antigos missionados, fiéis que se destacam, aliás, pelo fervor em Nossa Senhora Auxiliadora, um culto devocional mariano implementado mundialmente pelo fundador dos salesianos, o padre São João Bosco.

Segundo o líder, uma vez desafiados a redescobrirem a sua cultura, em sua chave, concebida como um conjunto de conhecimentos expressos nas formas de mitos, ritos, cantos e histórias pregressas, os Bororo que se engajariam em Meri Ore Eda também estariam imbuídos de buscar nas mesmas fontes de pesquisa informações que lhes permitissem reconstituir o que teria sido a sua religião, ali expressa da mesma forma objetiva que a "cultura Bororo".

À época do lançamento de Meri Ore Eda, Paulo não sabia o que poderia ser essa religião. Mas em conversas com outros indígenas, dizia, havia descoberto que os Bororo descendiam dos Inca, ${ }^{21}$ segundo ele, um povo indígena que cultuava o sol. Para Paulo a informação fazia sentido, uma vez que Meri, grande herói mítico Bororo, era nada menos que a encarnação em forma de gente do sol. Mesmo sem constar formalmente no projeto entregue ao Ministério, Paulo em conversas informais contava que pretendia construir uma espécie de pirâmide para os Bororo cultuarem o seu Deus-Sol, bem distante das feições do Deus cristão, mesmo que ele fosse pintado com cara de índio no altar da capela de Meruri.

21. Informação não referendada pela etnografia. Um dado relevante, a saber. À época dessas investidas de Paulo acerca das suas origens religiosas, os missionários salesianos empreenderam uma viagem à Bolívia, em busca de renascentes de supostos índios Bororo na região da fronteira do Brasil. Lá encontraram uma senhora que, segundo os missionários, falava língua muito próxima à dos Bororo do Brasil. 


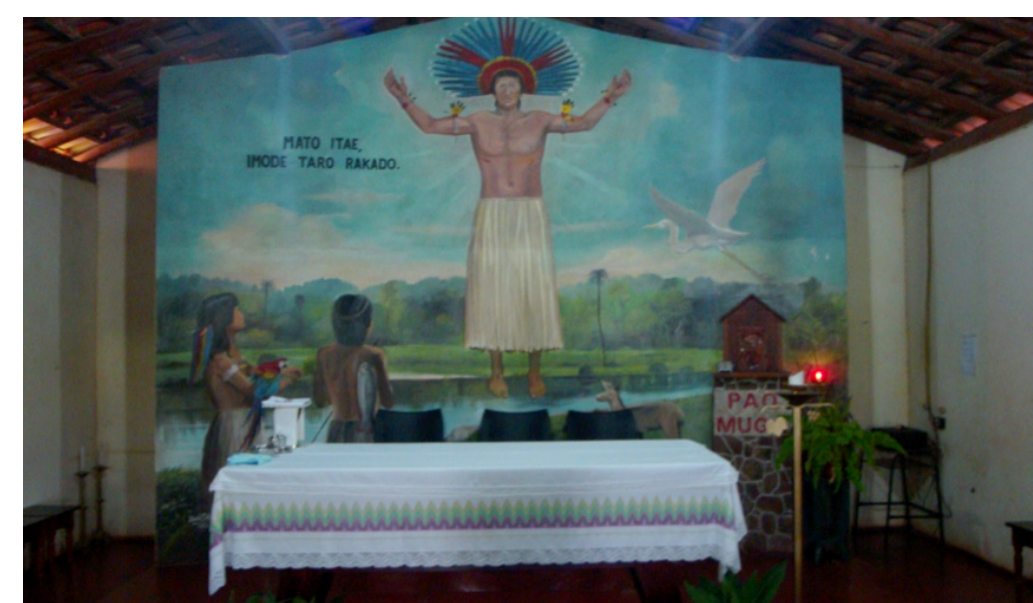

Foto 5 - Jesus Bororo, no painel pintado no altar da capela da Missão do Sagrado Coração de Jesus de Meruri, 2015. Foto: Aramis Luis Silva.

Paulo, contudo, não pôde levar seu projeto adiante. Trabalhando dias a fio quase solitariamente para levantar Meri Ore Eda, pois os "parentes" que se prontificaram a aderir à sua empreitada não podiam ainda se desvencilhar de Meruri todo o tempo, levantou apenas a casa dos homens e a cobriu com palha. Nem dinheiro nem gente vieram para dar vida a sua aldeia, a realização do seu projeto político. Desgostoso, Paulo teria voltado a beber, prática tida como viciosa, com a qual havia muito ele se debatia. Usava a sua questão com a bebida, aliás, como exemplo do poder desagregador da perda cultural que ele tanto queria combater. Em 2006, o líder Bororo foi vitimado por uma doença fulminante. Para os amigos mais próximos, como o arquiteto Fabrício Pedrosa, que o ajudara a colocar Meri Ore Eda no papel, ele morrera de tristeza. Na boca miúda de Meruri, da doença da bebida.

\section{Mas afinal, e os Bororo? De que lados estão, se isso existe?}

Discretos, os moradores de Meruri poucas vezes se permitem maldizer alguém diante daqueles com quem não têm tanta familiaridade. Excetuando as conversas feitas ao pé da orelha, mesmo assim meio constrangidos, eles preferem manifestar posições em relação a determinadas pessoas ou questões agindo, ou, de forma mais eficaz, não agindo. Desse modo, no transcorrer dos dois projetos culturais postos em curso em Meruri, a maneira mais elucidativa de compreender as adesões dos agentes Bororo em relação aos dois projetos foi observar seu modo de interação com ambos.

Todavia, vale um alerta em relação à forma de enquadrar os agentes indígenas de Meruri conclamados a se engajar nesse ou naquele projeto de "revitalização cultural". Muito mais que simples partícipes, assim como cada uma das iniciativas pretendia representá-los em suas aparições públicas - afinal, ambos os projetos pretendiam ser reconhecidos interna e externamente como o legítimo espaço cultural "dos Bororo" -, eles precisam ser encarados como ativos membros de uma espécie de plateia de espetáculos interativos metalinguísticos. Isto é, espetáculos feitos para produzir suas plateias internas no mesmo instante em que eles visam representá-las para espectadores externos.

Ambos os projetos de fato obtiveram importantes reconhecimentos para além dos limites de Meruri, o que atesta que eles foram capazes de mobilizar em diversos graus de intensidade redes internas capazes de representar para além da Terra Indígena "o povo e a cultura Bororo". Contudo, o mais interessante é notar uma operação posta em movimento nesse jogo de adesões sociais e engajamentos discursivos enquanto essas redes ocultavam o sistema que as amalgamava e as constituía: uma aldeia indígena, na qual a operação de salvamento de uma cultura se metamorfoseia na salvação de uma religião, justaposta a uma missão católica, na qual a prática religiosa se transfigura na salvação de uma cultura.

Desembaralharemos a seguir os fios que organizam essa imagem ao examinarmos brevemente a movimentação de alguns agentes Bororo em torno desses dois projetos. Comecemos à luz do museu comunitário indígena-salesiano para deliberadamente voltarmos a embaralhá-lo com a aldeia cultural do finado Paulo, ainda viva atualmente na memória e nas intenções de alguns agentes que a percebem como a alternativa antípoda do museu comunitário. 
No transcorrer do processo gerativo do museu de Meruri, uma instituição que se representa como comunitária, foi preciso arregimentar mais do que participantes e/ou animadores de oficinas culturais. Foi necessário produzir agentes capazes de encarnar e encenar a sua "verdade pública”: um museu indígena instalado em uma missão a serviço dos interesses "da cultura e sociedade Bororo".

Numa frente, isso se deu pelo gradativo processo de formação de agentes curatoriais indígenas, que culminou numa relação de profissionalização que perdura até hoje. Noutra, em um forte diálogo com os professores indígenas em pleno processo de formação acadêmica e de autoconstrução como novos agentes sociais Bororo: o de líderes culturais, como já mencionado. Foram alguns desses agentes que assumiram a função de porta-vozes do museu de Meruri em aparições públicas institucionais ou ocasiões de visitas de relacionamentos, como aquela que fizeram a Lévi-Strauss em Paris, entre o fim de 2004 e o início de 2005 , durante a viagem à Europa empreendida para promover a exposição Io Sono Bororo no Museu das Culturas Castelo D'Albertis, em Gênova. ${ }^{22}$

Integraram essa comitiva quatro indígenas de Meruri, cujas trajetórias relacionadas aos projetos culturais consideramos emblemáticas: Leonida Akiri Ekureudo, Agostinho Eibajiwu, Gerson Mariano Ekureu e Kleber Moritororeu. Em nosso entender, tais trajetórias expressariam múltiplas perspectivas de entendimento sobre o museu, ora convergentes ora divergentes, que nos permitem situar os possíveis lugares que as experiências culturais assumem frente ao atual quadro de relações merurenses. Em nosso retorno a Meruri de 2015, passados exatamente 10 anos da viagem à Europa, revisitamos e entrevistamos cada um desses agentes a fim de compreender o lugar que esse centro de cultura tomou em suas biografias. ${ }^{23}$

22. Exposição Io sono Bororo - Un popolo indígeno del Brasile tra riti e 'futebol' está registrada em um interessante livro homônimo editado em italiano.

23. As informações a seguir foram capturadas do caderno de campo. A transcrição das entrevistas se encontra em processo.
Leonida Akiri Ekureudo (11/04/1964), índia Bororo do clã apiborege, mãe de três filhas adultas e nora de Antonio Kanajó - na época da criação do museu comunitário de Meruri o último renascente de uma geração de velhos conhecedores daquilo que é descrito no campo como "a tradição Bororo" -, até hoje se ocupa das coleções guardadas no Museu Comunitário de Meruri. Ativamente engajada na série de oficinas culturais postas em marcha pelo museu, Leonida todas as manhãs, como uma funcionária contratada pela instituição, ${ }^{24}$ chega de moto, trazida pelo marido, para abrir ao eventual público a sala Koge ekureu, espaço reservado para guardar e exibir as peças. ${ }^{25}$ Cabe a ela também, agente que acabou se tornando amiga e "comadre" da pesquisadora Aivone, o combate ao pó e aos parasitas que investem sobre a frágil matéria-prima de múltiplas fontes orgânicas que compõe os artefatos (plumas, trançados de fibras vegetais, ossos, sementes etc.). Leonida faz isso, em parte, valendo-se dos conhecimentos das oficinas de restauro que recebeu como uma das etapas pedagógicas do seu processo de formação como curadora indígena. ${ }^{26}$ Seu diploma está à mostra, afixado em uma das paredes do museu. É tarefa dela, ainda, o restauro de eventuais exemplares danificados, quando saem da aldeia na condição de empréstimos. Nessas ocasiões,

24. 0 Museu Comunitário de Meruri institucionalmente faz parte do Museu das Culturas Dom Bosco, sediado em Campo Grande. Por sua vez, o museu é um órgão da Pró-Reitora de Pós-Graduação e Pesquisa da Universidade Católica Dom Bosco, esta, administrada pela missão. Logo, os curadores indígenas de Meruri fazem parte do quadro de funcionários de museu de Campo Grande.

25. Apesar de tratarem outra sala entre o espaço expositivo e a Biblioteca Simão Bororo como reserva técnica, nela ficam depositados apenas os couros de onça, utilizados durante os ciclos fúnebres. Assim, quase a totalidade de peças, sejam as produzidas nas oficinas sejam as expatriadas da Itália, ficam em contínua exibição. As peças das oficinas ficam afixadas em oito estruturas de palhas a simbolizar as casas clânicas, de acordo com o sistema de primazia Bororo. As peças da coleção histórica ficam dispostas em uma vitrine octogonal, no centro da sala, representando a casa dos homens. A expografia visa representar a planta tradicional da aldeia Bororo, espaçosímbolo de uma cosmologia que situa os Bororo no mundo (Silva, 2015).

26. Os cursos de formação contaram com apoio de profissionais ligados a entidades como o Museu de Arqueologia e Etnologia da Universidade de São Paulo (MAE-USP). 
geralmente ela efetua a concessão de uso mediante uma condição: ir com as comitivas merurenses aos locais de destino a fim de assegurar a segurança material das peças.

Em janeiro de 2015, uma decisão de Leonida ajudou a evidenciar uma tensão incrustada no coração do espaço cultural de Meruri: o museu comunitário, afinal, é dos Bororo ou dos padres salesianos? Ao receber a solicitação de empréstimo de peças do acervo para serem usadas pela seleção Bororo, em setembro, em Tocantins, na primeira edição dos Jogos Mundiais dos Povos Indígenas, Leonida adiantou que não iria entregá-las. Cansada e se sentido adoentada, a curadora não estava disposta a seguir com os demais Bororo para os jogos. E sem ela, as peças não poderiam ir. Segundo a agente, se até mesmo quando ela está presente nos eventos são registrados danos ou extravios, o que aconteceria com as peças sem a sua presença?

Para alguns, a justificativa é legítima. Leonida, uma das poucas mães das almas de Meruri, ${ }^{27}$ há anos dedica-se não somente àquele acervo, mas também à "sobrevivência da cultura Bororo". Isto é, não só conheceria o acervo como uma coleção museológica dependente de técnicas específicas para conservação e restauro, mas também dominaria seus contextos de uso tradicional. Todavia, para outros, como para aqueles que agora se sentem alijados por saber que eventualmente poderão ter de comparecer a um evento pan-indígena de tal importância e magnitude desprovidos dos sinais diacríticos Bororo (reivindicavam principalmente os pariko, os cocares Bororo), a posição da curadora não se sustenta. As peças seriam do povo Bororo de Meruri e devem ser usadas por eles, da maneira que julgarem cabível. Se Leonida quiser ir para maximizar o cuidado, bem. Se não pode ou não quer ir, que as peças viajem sob os cuidados de outros Bororo. A polêmica está armada.

27. Mãe das almas diz respeito a uma função ritual. Tratase de uma mulher Bororo que se tornou representante de um morto, simbolizado por pequenas cabaças (poware aroe). Na realização de cada novo ritual, as mães das almas levam nos rituais fúnebres tais cabaças. Cada uma delas representa a garantia da visita e presença desses mortos na aldeia durante os rituais.
Leonida se ressente dessa segunda posição, já manifestada em outras ocasiões. Segundo ela, menos por motivos pessoais relacionados ao reconhecimento pelo seu trabalho, e mais por preocupação com o acervo e com a viabilidade da existência do próprio museu. As últimas oficinas foram realizadas em 2005, quando se organizou a exposição em Gênova. Enquanto um dos alicerces da proposta museológica continuava de pé - um acervo vivo, integrado à vida social de Meruri -, o outro, a contínua promoção de oficinas como fonte de produção de novos itens e propagação das técnicas de confecção entre os merurenses, não havia sido levado adiante. Sem oficinas não havia novas peças. E sendo as já existentes disponibilizadas ao uso, elas estavam em constante risco e, para piorar a situação, o acervo estava minguando.

Não sabemos, por enquanto, da resolução desse conflito. Contudo, ele já nos permitiu rever a complexa rede merurense em movimento. Leonida, interessada em garantir a segurança das peças em nome da cultura Bororo, foi procurar o diretor da Missão Sagrado Coração de Jesus de Meruri, o padre Osmar Resende. Segundo ela, são os padres que pagam para que cuide do acervo, portanto o padre vai decidir se as peças feitas pelos Bororo para serem usadas pelos Bororo poderão correr o risco de deixar de existir justamente pelas mãos dos próprios Bororo.

Agostinho Eibajiwu (19/11/1964), Bororo do clã iwagudu e outro agente museal indígena formado nesse processo museológico posto em curso na aldeia, mantém posição discreta em relação à polêmica. Acredita que as peças precisam ser preservadas, mas também entende que os Bororo que irão para o Jogos Mundiais Indígenas ficariam muito aborrecidos em não poder usá-las. Posição resolutiva ele não tem, talvez como reflexo de uma harmônica divisão de trabalho. "Leonida se ocupa das coleções e eu não me meto no trabalho dela. Eu me ocupo da biblioteca e do arquivo e ela não se mete no meu trabalho", conta Agostinho, filho de um grande chefe cultural Bororo da aldeia de Tadarimana e agente que diz ter-se engajado inicialmente no projeto de construção do museu comunitário de Meruri por ter visto nele uma oportunidade de conhecer a 
cultura Bororo da qual lamenta não ser um grande conhecedor.

Enquanto Leonida trabalha no período da manhã, no período vespertino é a vez de Agostinho atravessar a pé cerca de 400 metros de areal para entrar em cena, desta vez, junto aos acervos bibliográficos e arquivísticos da instituição, abertos a consultas de interessados, geralmente alunos da escola que os usam como fontes bibliográficas para realização de eventuais trabalhos escolares. Outro motivo frequente de visitas ao museu é seu acervo de fotos e vídeos, que registram agendas importantes da aldeia de Meruri, como a realização de missas inculturadas, em função de visitas da hierarquia da missão ou de datas comemorativas; registros de funerais, principalmente os realizados na aldeia Garças; ${ }^{28}$ participações dos moradores de Meruri em festividades para os quais os Bororo são convidados, como agendas relacionadas ao Dia do Índio; e também atividades relacionadas diretamente ao espaço cultural, como as imagens da cerimônia do Prêmio Cultura Viva, que elegeu - Museu Comunitário de Meruri como o grande vencedor do Programa Cultura Viva, do Ministério da Cultura. ${ }^{29}$

Em janeiro de 2015, Agostinho estava ocupado com uma demanda da diretoria da Missão Salesiana do Mato Grosso: organizar as mais de mil fotos do acervo fotográfico de Meruri, primeiro passo para a digitalização do conjunto. Pacientemente, Agostinho todas as tardes tirava das caixas centenas de fotos para ir agrupando em pilhas temáticas, enquanto as crianças e senhoras que cruzavam a missão paravam para ordenadamente mexer nas pilhas e vasculhar por conhecidos estampados nas imagens. 0 trabalho de digitalização ia demorar. Alguém havia desconfigurado o computador do centro cultural. Os padres teriam de mandar de Campo Grande um novo computador e, enquanto isso, Agostinho e os demais ficavam se deleitando com as imagens.

28. Não são realizados funerais Bororo na aldeia de Meruri. 29. Sobre esse evento, ver "Entreato" da tese Mapa de viagem de uma coleção etnográfica (Silva, 2011). Nesse capítulo a cerimônia de entrega do prêmio é etnografada.
Segundo o curador, a participação na história do espaço cultural de Meruri foi crucial em sua vida, sempre desvencilhada de mulheres ou filhos. 0 principal benefício, sob a ótica de Agostinho, foi poder "rodar o mundo" ao fazer parte de algumas das comitivas do Centro que viajaram para representar a instituição, e, acima de tudo, ter tido a chance morar por vários anos fora da aldeia. Uma vez tendo seus pedidos aceitos pela professora Aivone, que à época já havia se tornando a diretora do Museu das Culturas Dom Bosco, em Campo Grande, Agostinho mudou-se para essa capital para desempenhar as atividades de curador indígena junto à coleção da instituição então recém-modelada. Livre pela cidade onde morou sozinho e com mais disposição para enfrentar o vício do álcool, sua principal tarefa no museu era receber o público e atuar como monitor. Sobre eventuais dificuldades em relação à falta de conhecimentos aprofundados sobre a dita "cultura Bororo", Agostinho, bem-humorado e maliciosamente, nos lembra que não era nada grave, afinal, falava com gente que sabia muito menos do que ele e que jamais poderia perceber quando ele, eventualmente, tinha de pedir auxílio para a sua imaginação.

Sobre o futuro do Museu Comunitário de Meruri tem poucas certezas, para o bem ou para o mal: "Ele continua sim, eu acho". Já sobre o seu futuro no museu ele tem certeza de não ter muito mais o que fazer ali. Em janeiro, aguardava a resposta da Secretaria Especial da Saúde Indígena (Sesai) sobre sua eventual contratação. Agostinho ia trocar o museu comunitário por uma ambulância (também de uso comunitário, afinal). Segundo ele, além de pagarem um pouquinho mais, ainda teria direito a folgas durante a semana, que o espaço cultural merurense não dava aos seus curadores.

Gerson Mariano Ekureu $(09 / 04 / 1975)$, Bororo do clã abiborege, mora no início de 2015 em Barra do Garças, cidade à beira da confluência dos rios Garças e Araguaia, na divisa dos estados de Mato Grosso e Goiás. Para lá se mudou temporariamente para cursar sua pós-graduação em pedagogia, no campus local da Universidade Federal do Mato Grosso (UFMT). Aos fins de semana regressa para Meruri, num percurso de 2 horas. 
Ex-seminarista salesiano e um dos primeiros professores indígenas de Meruri formado pelo Projeto Tucum e mais tarde pela Faculdade Indígena Intercultural (especializado no ensino de matemática), Gerson esteve ligado ao grupo de professores que se envolveram mais diretamente com as atividades do museu comunitário de Meruri na época da sua criação. Gerson foi, aliás, um dos nomes mais requisitados para viajar com a equipe do museu para falar sobre a experiência cultural que estava sendo desenvolvida na sua aldeia. Para a Europa embarcou com o quarteto completo (Agostinho, Leonida, Kleber e Toninho, mais os acadêmicos não indígenas). Para Washington DC, com os parceiros não indígenas e Agostinho.

Na época das viagens, a explicação para o engajamento no projeto era inequívoca: o "resgate" da cultura Bororo, cada vez mais ameaçada de sumir não só de Meruri, mas do Brasil, era também uma missão religiosa. Sem anunciar conflitos com o seu cristianismo e catolicismo, Gerson defendia que a "cultura Bororo" precisava ser vista antes de tudo como a "religião Bororo", afinal, todos os sentidos sobre o que e como deveria ser a vida dos homens no mundo e no além-mundo estavam inscritos nessa cultura. Indo além, toda forma de os Bororo se relacionarem com a natureza e com o sagrado também estavam organizadas pelo conjunto de ritos e mitos que compunham aquela cultura a ser preservada. Logo, para Gerson, parecia compatível a formação de tal aliança: índios Bororo, padres e intelectuais, todos juntos e engajados em prol de uma causa única: a cultura Bororo, totalidade possível de ser apreendida pela perspectiva da ciência (que a entendia como cultura) e da religião cristã (que reconhecia nos Bororo uma fonte própria de sabedoria para se lidar com algo universal, o sagrado).

Contudo, foi na docência indígena que Gerson apostou como caminho para realização desse projeto cultural e religioso. Depois da obtenção de dois diplomas universitários, ambos talhados especificamente para público indígena, Gerson achou que era hora de enfrentar o mundo dos brancos de outra forma - a de dentro. Ainda intimidado por ser o único aluno indígena da classe, ainda mais em uma das cidades-polo do agrobusiness nacional, o professor indígena engajado na causa cultural Bororo dedica-se agora a produzir artigos ainda não publicados. Seu tema: a descrição etnográfica dos vários mitos e ritos do seu povo. Para ele, a primeira publicação funcionará como um batismo de fogo.

Kleber Moritororeu (02/06/1979), outro orgulhoso descendente do clã baadojeba, linhagem dos grandes chefes Bororo, é sobrinho de Paulo Meriekureu, o idealizador da aldeia Meri Ore Eda. Também ex-seminarista e professor de biologia formado na Universidade Católica Dom Bosco (UCDB), com bolsa concedida pela Missão Salesiana do Mato Grosso, na época da criação do museu de Meruri Kleber se descrevia como um agente com um pé no projeto financiado pelos padres e com outro no projeto do seu tio. Segundo ele, tudo valia a pena frente a um fim maior convergente: a salvaguarda da cultura Bororo, uma fonte de "sabedoria milenar" ameaçada de extinção, como ele a descreve até hoje.

Kleber tinha posições semelhantes à de Gerson, o outro professor indígena. Todavia, distinguiu-se pela radicalidade. Ele também concebe "a cultura Bororo" como a sua "religião". Mas essa religião não só seria incompatível com o cristianismo dos salesianos, vistos, assim como dizia seu tio, como um dos responsáveis pela destruição da cultura Bororo, como ela demandaria outras formas de recuperá-la, para além das abordagens, diríamos, bibliográficas e patrimonialistas de Gerson. Para Kleber, a religião Bororo precisava ser encarnada em sua vida. E isso significaria um caminho biográfico e espiritual que o levaria a se tornar um baire, xamã Bororo inexistente há décadas em Meruri.

Após a viagem à Europa, época em que Kebler ainda tentava se equilibrar entre os dois projetos em curso na aldeia, o então jovem professor indígena planejava partir para Perigara, onde habitava, segundo ele, o último baire Bororo. Seu plano era se transformar em um xamã, realizar aquilo que ele percebia ser um chamado, como gostava de lembrar, que havia começado quando folheara Tristes Trópicos de Claude Lévi-Strauss, na época da sua formação universitária. Desde então 
ficava imaginando: seria possível tudo voltar a ser como antes? A imagem dos homens e mulheres nus o impressionaram. Para ele, eram a expressão da liberdade e autenticidade Bororo, longe das "garras da religião dos padres".

Essa viagem nunca aconteceu, o velho baire Bororo citado já está morto, e a relação de Kleber com a missão, inicialmente marcada por uma ambiguidade na qual tentava se equilibrar entre a gratidão pela sua formação e uma crítica revisionista dos efeitos que ela teria exercido sobre os Bororo, parece ter evoluído para um conflito mais aberto. A própria professora fundadora do processo museal local, que sempre fora vista por todos os agentes Bororo como uma aliada salesiana, mas jamais confundida com um deles, também já havia se tornado alvo de seus ataques. Para Kleber, ela era uma espécie de religiosa disfarçada.

Assim como seu tio Paulo, Kleber passou a denunciar os missionários como representantes de uma herança maldita de intervenções e subjugações seres dependentes. Atualmente diretor eleito da Escola Indígena de Meruri, a crítica de Kleber subiu em tom, escala e amplitude, ainda mais com a publicação do livro a Linha de pó - A cultura Bororo entre tradição, mutação e autorrepresentação, de Massimo Canevacci, autor que o retratou não só como um agente expressivo da autorrepresentação Bororo, mas também como um novo líder a apontar novos caminhos para os antigos missionados salesianos.

Uma vez que o antropólogo italiano fora trazido à aldeia para sua experiência etnográfica e hospedado na missão de Meruri pela própria equipe do Centro de Cultura, ${ }^{30}$ seu livro provocou mal-estar entre os missionários. Na obra, foram chamados de ingênuos, praticantes de um revisionismo histórico que teriam transformado os Bororo de Meruri em

parcial, e reafirmou-se a acusação de colonialismo espiritual, mesmo que em versão liberal. Em meio a essa operação, Kleber Moritotoreu, descrito no livro como um videomaker que toma em suas mãos "a sua câmera de vídeo digital como uma arma" (Canevacci, 2012, p.46), é construído como herói de uma resistência cultural, atento aos efeitos de um catolicismo que teria um efeito devastador ao destruir "visões, ritos, história e a cultura". Segundo Kleber, os Bororo têm a sua própria religião e seus rituais. Sendo assim, "não podemos assistir à sua dissolução. E o meu instrumento fundamental é este", a gravação de vídeos, que tanto fascinara o antropólogo italiano, como expressa em seu depoimento no livro.

Num trocadilho com o livro do seu amigo e admirador, Kleber, que não abandonou seu projeto de se tornar baire, coloca-se não em uma linha de pó, limite imaginário que o separa dos padres, - símbolo mais próximo para ele do que seria o mundo dos brancos. Kleber se coloca em linha de fogo. A missão obviamente se ressente daquilo que lê como impropérios proferidos de alguém de quem esperava, no mínimo, consideração.

Todavia, para os padres, a validade das suas posições pode ser medida pela moralidade do seu projeto. Kleber, ao se produzir como baire, decidiu há quase uma década desposar uma segunda mulher, segundo ele, uma prerrogativa das figuras xamânicas, como, aliás, atestariam as etnografias, ele sustenta. Mas, para os salesianos, se não bastasse a bigamia acionada como argumento cultural, haveria um segundo agravante, que ao mesmo tempo serviria para lançar por terra o projeto religioso concorrente. Kleber decidiu fazer de segunda esposa a sua enteada, uma menina menor de idade, com a qual está casado até hoje e já tem mais de dois filhos. O cenário do confronto cultural e moral está armado.

\section{Considerações finais}

Comunitario de Meruri, iniciou sua aproximação com Massimo Canevacci quando ela ainda estava na Itália. Interessada en desenvolver um projeto de pós-doutorado com o antropólogo vinculado à universidade La Sapienza, de Roma, Aivone convidou Massimo para participar de um ritual fúnebre, que seria realizado na aldeia Garças. Foi dessa experiência etnográfica que nasceu o livro A linha de pó - A Cultura Bororo entre a tradição, mutação e autorrepresentação, publicado em 2012 .

A viagem realizada a Meruri em 2015 teve três objetivos: revisitar o museu comunitário da aldeia e verificar se e de que modo ele continuava em operação; pesquisar pela primeira vez o 


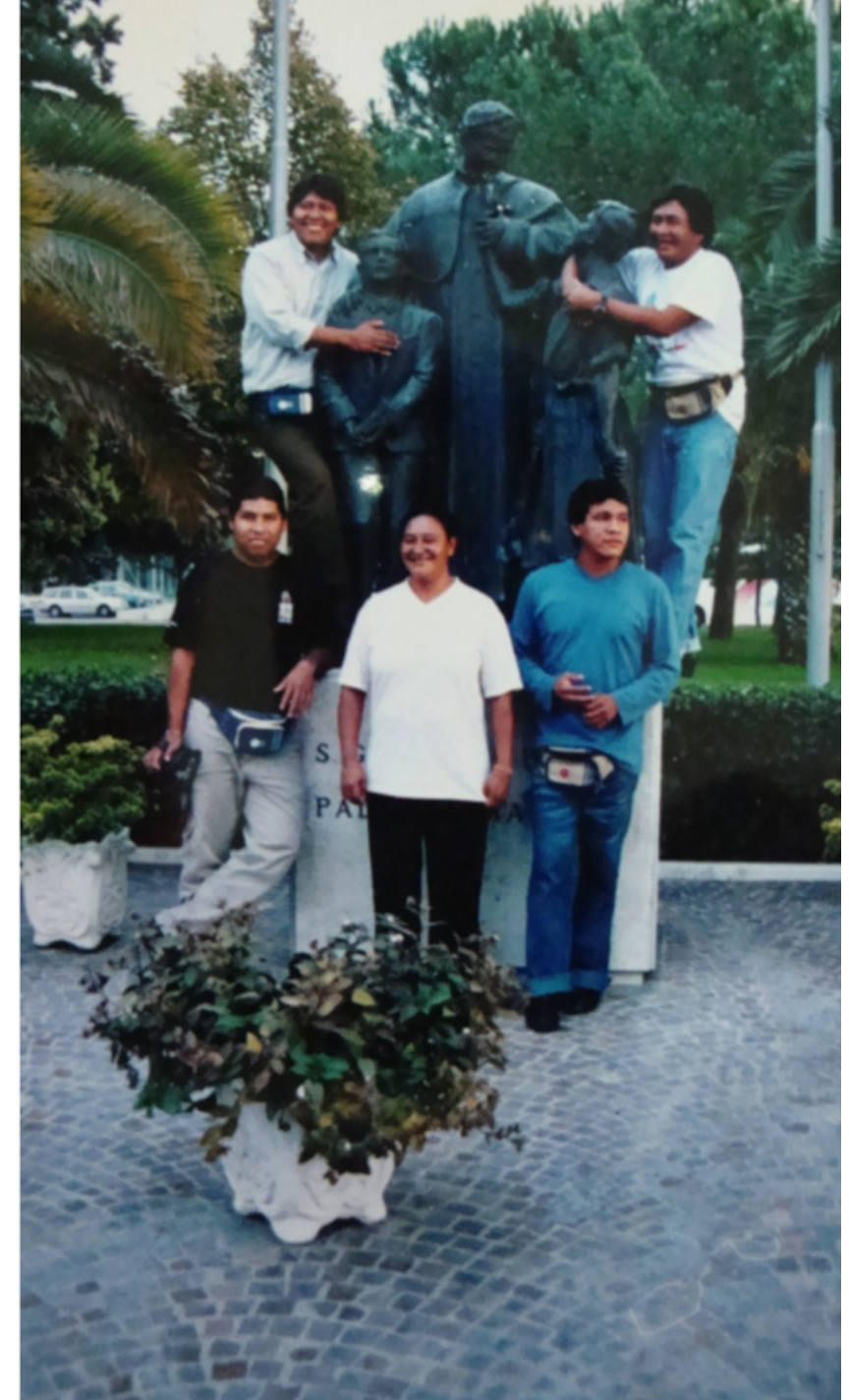

Foto 6 - Comitiva de Meruri em visita à Europa. Embaixo, à direita: Kleber e Leonida. No alto, Gerson e Agostinho. Foto: Acervo do Museu Comunitário de Meruri.

arquivo da instituição, acervo a que nunca tivemos acesso; e reencontrar e entrevistar alguns dos personagens do mundo Bororo que estiveram diretamente ligados à construção do espaço museológico.

Durante todo o percurso do mestrado e início do doutorado, a escolha de focar na comparação de dois projetos culturais concorrentes em curso na aldeia mostrou-se politicamente complicada. Pairavam sempre sobre as pesquisas a atenção e expectativas relacionadas a possíveis adesões e colaborações relacionadas ao processo de legitimação de ambas as experiências. Uma vez concluído o mestrado, a alternativa imposta para concretização da fase do doutorado foi um afastamento do campo. Foi desse modo que entramos no mundo das coleções e análises expográficas.

Todavia, uma vez interessados nos processos de mediação cultural, nada mais óbvio que entender a vontade e pertinência de voltar a campo a fim de adensar uma análise de mediação que precisa levar em conta todas as vozes constitutivas do fenômeno observado. Não a fim de perseguir o ponto de vista Bororo, esforço do qual insistimos em nos distanciar, afinal, a produção dessa "perspectiva Bororo" é um efeito dos jogos de força que nos propusemos a observar (o trabalho último das experiências culturais postas em cena é a produção e exibição pública "da perspectiva Bororo"). A intenção sempre foi observar de mais perto as interações, para que pudéssemos observar estratégias sendo modeladas e reajustadas a cada próximo lance do jogo que reconfigurava continuamente a partida que estava sendo jogada.

Voltar a Meruri quase 10 anos mais tarde nos permitiu observar que o sistema aldeia-missão de fato é operante e precisa ser mais bem compreendido. Ao contrário de simplesmente observarmos mundos outros mecanicamente justapostos (missão salesiana e aldeia Bororo), a controvérsia em torno de como se deve recuperar e/ou preservar a dita cultura Bororo continua sendo travada a partir de uma arena compartilhada onde todos falam uma língua (culturalista) simbiótica. Os significados acerca do que se pretende dizer com uma série de categorias comumente acionadas flutuam em função de contextos de enunciação, repertórios de referência e habilidades retóricas. Todavia, em Meruri, observa-se que alguns códigos de mediação estão postos e em pleno funcionamento. Ninguém, seja padre católico, intelectual engajado, professor Bororo universitário ou professor xamã, se constrói alheio a termos como cultura e religião. Ironicamente, no momento em que alguns agentes Bororo anunciam os estertores da missão entre os indígenas de Meruri, nem imaginam que assim o fazem indicando uma espécie de triunfo do sonho evangélico católico. Em Meruri, religião está por toda parte. Na modesta capela de Meruri, que só se enche em batizados e aos domingos, nos artigos de Gerson, nas coleções de Leonida e até na bigamia de Kleber. 


\section{Referências}

ALBISETTI, César; COLBACHInNI, Antonio. Os Bororo Orientais. São Paulo: Cia. Ed. Nacional, 1942. (1.ed. italiana, 1925).

BORDIGNON, Mário. Os Bororo na história do Centro oeste brasileiro: 1716-1986. Campo Grande: Missão Salesiana de Mato Grosso, 1986.

CANEVACCI, Massino. A linha de pó: a cultura bororo entre a tradição, mutação e autorepresentação. São Paulo: Annablume, 2012.

CASTILHO, Maria Augusta de. Os índios e os salesianos na Missão dos Tachos. Campo Grande: Ed. UCDB, 2000.

NOVAES, Sylvia Caiu. Jogos de espelhos: imagens da representação de si através dos outros. São Paulo: Edusp, 1993.

MONTERO, Paula. Selvagens, civilizados e autênticos: a produção das diferenças nas monografias salesianas no Brasil. São Paulo: Edusp, 2012

SILVA, Aramis Luis. Deus e o Bope na terra do sol. São Paulo: Humanitas, 2009.

Mapa de viagem de uma coleção etnográfica: a aldeia bororo nos museus salesianos e o museu salesiano na aldeia bororo. Tese (Doutorado em Antropologia Social) - Universidade de São Paulo. São Paulo, 2011.

VANGELISTA, Chiara. Missões Católicas e políticas tribais na frente de expansão: os Bororo entre o século XIX e o século XX. Revista de Antropologia, São Paulo, v.39, n.2, p.165-197, 1996.

VIERTLER, Renate B. As duras penas: um histórico das relações entre os índios Bororo e "civilizados" no Mato Grosso. São Paulo, FFLCH/ USP, 1990.

\footnotetext{
* Aramis Luis Silva é mestre e doutor em antropologia social pela Universidade de São Paulo (USP). Atualmente é pós-doutorando do Departamento de Ciências Sociais da Universidade Federal de São Paulo (Unifesp, Bolsa Capes) e pesquisador do Centro Brasileiro de Análise e Planejamento (Cebrap). A pesquisa "Lendo Museus Salesianos" contou com financiamento Fapesp.
} 


\title{
"O passado vai tá sempre na frente do presente": museus indígenas em rede, etnografia em processo ${ }^{1}$
}

\author{
Alexandre 0 liveira Gomes* \\ Universidade Federal de Pernambuco (UFPE)
}

O meu pai é rei na terra

0 meu pai é rei no mar $(2 x)$

Ando com os mensageiros

Foi meu pai quem me mandou $(2 x)$

Eu sou índio, eu sou guerreiro

Eu sou índio curador $(2 x)$

(Toré entoado na abertura do IV Encontro Paulista Questões Indígenas e Museus)

Na manhã do dia 30 de junho de 2015, iniciávamos as atividades do IV Encontro Paulista Questões Indígenas e Museus, no auditório do Museu Histórico Pedagógico Índia Vanuíre, na cidade de Tupã, região do oeste paulista. No ano anterior, havíamos comparecido à terceira edição do evento - uma comitiva representando os processos museológicos entre populações indígenas no Nordeste - com três pessoas ${ }^{2}$ e, àquele momento, estávamos presentes com quatro participantes: além de mim e Suzenalson Santos, Ronaldo França de Siqueira (Museu Kapinawá, Buíque, PE) e Heraldo Alves, o Preá (Museu Indígena JenipapoKanindé, Aquiraz, (E), todos eles gestores de museus indígenas entre seus povos e importantes lideranças no debate sobre museus indígenas em seus estados.

Como abertura do encontro, a professora Marília Xavier Cury, uma das idealizadoras

\section{0 presente trabalho foi realizado com apoio do CNPq.} (processo 141309/2014-8)

2. Estivemos com o professor Suzenalson da Silva Santos, coordenador pedagógico do Museu dos Kanindé (Aratuba, CE), representando os museus indígenas no Ceará, e o antropólogo Wilke Torres de Melo, do povo Fulni-ô (Águas Belas, PE), representando os processos museológicos indígenas em Pernambuco. e organizadoras, convidou os indígenas para conduzirem um momento ritual. Aos três representantes do Nordeste, reuniram-se lideranças dos povos da região, os Kaingang, Krenak, Terena e Guarani, que atenderam ao convite, formando um semicírculo defronte ao público. Sob o ritmo das maracas, entoaram alguns cânticos, o primeiro dos quais serve de epígrafe a este texto.

Meses antes, em dezembro de 2014, havíamos recebido d. Dirce Jorge Lipu Pereira (povo Kaingang, SP) na condição de palestrante, no II Encontro de Museus Indígenas em Pernambuco, ${ }^{3}$ no Recife e, em maio de 2015, sua filha, Lucilene de Melo, havia estado conosco no I Fórum de Museus Indígenas do Brasil, na aldeia Sítio Fernandes, dos Kanindé, em Aratuba, CE. ${ }^{4}$ Após a palestra de encerramento da programação do primeiro dia deste último encontro, ministrada pela professora Marília, o pajé Barbosa, do povo Pitaguary, CE, direcionou-se à mesa, retirou a palestrante de sua cadeira, sentou-se e proferiu comentários sobre diversos acontecimentos do dia de atividades e as questões tratadas pela professora, à moda de um "encantado-debatedor".

3. No dia 5 de dezembro de 2014, d. Dirce participou do painel "Curadoria compartilhada entre-olhares: experiências e desafios para a gestão de acervos”, com Marília Xavier (USP), Renato Athias (UFPE), Wilke Melo (Nepe-UFPE), Nilvania Barros (Ufam), Cláudia Lopez (Museu Paraense Emílio Goeldi-MPEG), João Paulo Vieira (Ibram) e Heraldo Alves (Museu indígena Jenipapo-Kanindé).

4. No dia 16 de maio de 2015 , Lucilene participou da " 1 a Sessão de trocas de experiências entre museus indígenas”, com - Cacique João Venâncio (Tremembé, CE), Ronaldo Siqueira, Heraldo Alves (Museu Indígena Jenipapo Kanindé, CE), Fabricio Narciso Karipuna (Museu Indígena Kuahí, AP) e Rosa Veras (Museu Indígena Potiguara, CE). 
0 passado sempre vaj tá na frente do presente. Isso se chama museu. Muito bom, obrigado. Até outro tempo. É um prazer de ver esses debates, porque sem história não tem cultura, cultura é aquilo... A vida foi do antigo, hoje, já é a história. Muito bom, muito bom, agradeço...

Identificou-se, em seus quase 10 minutos de comentários, em aparente estado de transe, como "vindo de Kapinawá", tal como Ronaldo França de Siqueira, representante dos museus indígenas de Pernambuco que estava participando do encontro e se emocionou com as palavras do "encantadodebatedor", que falava de furnas, pedras, "cacos" e caça das matas, temas tão comuns entre seu povo.

Pouco depois de nossa estadia em Tupã, voltaríamos a nos encontrar com Lucilene, desta vez na aldeia Malhador do povo Kapinawá, no I Encontro de Formação em Museologia para povos indígenas em Pernambuco, ${ }^{5}$ realizado entre 20 e 24 de julho de 2015. Nesse encontro foi inaugurado o Museu Kapinawá.

Uma intensa agenda de encontros foi promovida mediante parcerias entre diversos povos, associações indígenas, universidades e outros parceiros, durante os anos de 2014 e 2015 , o que favoreceu e fortaleceu a aproximação e o diálogo entre diversos atores sociais e coletividades étnicas envoltos em questões museológicas. Esses momentos, além de envolverem a troca de conhecimentos científicos e tradicionais, a apresentação de pesquisas e os respectivos debates sobre questões epistemológicas e teóricometodológicas, já habituais, são oportunidades riquíssimas e singulares para a observação e o acompanhamento das interações resultantes do contato entre representantes de processos museológicos entre populações indígenas de diversos locais do território brasileiro.

Nosso envolvimento com a temática da história e memória indígena iniciou-se no início dos anos $2000 \mathrm{e}$, posteriormente, como integrante

5. No dia 22 de julho de 2015 , Lucilene participou da mesaredonda "Os museus, a educação diferenciada e o movimento indígena”, com Ronaldo Siqueira e Suzenalson Santos. do Projeto Historiando, ${ }^{6}$ no estado do Ceará. A partir de meados de 2006 , esse envolvimento se consolidou em algumas direções, que se fortaleceram nos 10 anos seguintes mediante atuação em distintas áreas. Inicialmente, na perspectiva de uma militância de cunho indigenista, pela realização de diálogos e atividades junto ao movimento indígena sobre questões relativas ao patrimônio cultural, à memória e aos museus/museologia. Concomitantemente, a partir de nossa atuação no Museu do Ceará e no Sistema Estadual de Museus do Ceará (SEM-CE), entre 2000 e 2010 , na arena das políticas públicas culturais, em especial, as museológico-patrimoniais voltadas à diversidade étnica. Ao retornarmos à Universidade (no caso, para a UFPE, em Recife), após 6 intensos anos de atividades entre populações indígenas e outros grupos tradicionais em seus territórios, ressignificamos essas experiências de pesquisaação, ${ }^{7}$ transformando-as em objeto de pesquisa

6. O Projeto Historiando surgiu na cidade de Fortaleza, em 2002, idealizado por mim e pelo historiador João Paulo Vieira. Foi fundado sob princípios da história social e da pedagogia paulofreiriana e libertária, caracterizandose pelo formato de ação educativo-comunitária sobre a memória e o patrimônio cultural local, com o objetivo de fomentar o debate sobre a construção social da memória na ótica dos movimentos e organizações da sociedade civil, muitas vezes atuando mediante procedimentos museológicos/ museográficos, aprendidos na lide cotidiana dos museus. Nossa atuação configurou-se para além das instituições educacionais formais, concretizando parcerias com ONGs, associações de moradores, grupos comunitários, povos indígenas, pescadores e marisqueiros, populações tradicionais etc., dos mais diversos matizes e formatos organizativos. Com atividades de identificação, pesquisa e gestão do patrimônio cultural local, desenvolvemos procedimentos metodológicos colaborativos que possibilitaram a organização de oficinas educativas de pesquisa em memória e inventários participativos, cursos de formação, a montagem de exposições e a publicação de materiais didáticos, viabilizando mobilizações coletivas para as demandas do patrimônio, entre outras atividades correlatas (Gomes, 2012; Gomes; Vieira Neto, 2009). Um dos resultados mais expressivos das atividades do Projeto Historiando foi a organização, em outubro de 2011, da Rede Cearense de Museus Comunitários (RCMC) (Gomes; Vieira Neto, 2014).

7. Entre especialistas, considera-se como um dos pioneiros no uso e conceituação da noção de pesquisa-ação Kurt Lewin, que realizou estudos organizacionais e educacionais nos Estados Unidos do pós-guerra (Toledo; Jacobi, 2013, p.157). Segundo Toledo e Jacobi, "Metodologias de pesquisa de caráter participativo ganham repercussão mundial tanto na área científica como no campo político, a partir do Primeiro Simpósio Mundial sobre Pesquisa Participante, realizado 
histórica e antropológica, com foco na relação entre memória, museus indígenas e etnicidade. Por fim, esse envolvimento também tomou forma no exercício da docência, com destaque para a atuação junto aos cursos de Museologia (UFPE) e, em especial, nas Licenciaturas Interculturais Indígenas (da UFC e da UFPE) e nas Especializações em História e Culturas dos Povos Indígenas (na UFPE e na UFRPE); e enquanto facilitador de diversos processos formativos, exposições, encontros e demais atividades educativas não formais sobre museus, patrimônio cultural e memória indígenas, em parceria com organizações indígenas e entidades indigenistas.

No âmbito local, nossas experiências situamse nos estados do Ceará e de Pernambuco. No regional, os representantes de populações indígenas que desenvolvem processos museológicos nesses dois estados têm efetuado uma importante discussão junto ao movimento indígena, às entidades indígenas, ao Estado e aos cursos de Licenciatura Intercultural, entre outras instâncias, sobre o protagonismo indígena na construção de representações sobre si que se materializam na organização de museus indígenas, casas de memória e/ou exposições museológicas em seus territórios. No âmbito nacional, o diálogo contínuo e permanente que vem sendo travado pelos indígenas desses estados tem envolvido e se entrelaçado com as demandas e situações de outros grupos indígenas - como os povos do oeste paulista. Uma parte desses diálogos interculturais está sendo efetuada no que passou a ser denominado, em dezembro de 2014, durante o II Encontro de Museus Indígenas em Pernambuco, de Rede Indígena de Memória e Museologia Social.

Este breve artigo visa apresentar,

sinteticamente, a construção dos museus indígenas como objeto de pesquisa histórico-antropológica

em Cartagena, Colômbia, em 1977 (Fals Borda, 1986), e fundamentam-se na preocupação de garantir a participação ativa dos grupos sociais no processo de tomada de decisões sobre assuntos que lhes dizem respeito, com vistas à transformação social, não se tratando, portanto, de uma simples consulta popular, mas sim do envolvimento dos sujeitos da pesquisa em um processo de reflexão, análise da realidade, produção de conhecimentos e enfrentamento dos problemas" (2013, p.156). e alguns apontamentos etnográficos sobre a constituição de uma articulação em rede de contatos e interlocuções entre representantes de populações indígenas que vivenciam processos museológicos em seus territórios.

\section{Museus indígenas como objeto de estudo histórico e antropológico}

Estudei no mestrado a experiência museológica dos Kanindé de Aratuba, CE, o segundo museu indígena criado no Brasil (1995), após o Museu Magüta, dos Tikuna (AM), de 1990 (Gomes, 2012). Debrucei-me sobre a relação entre a mobilização étnica, o processo de musealização e a construção social da memória indígena, considerando que a organização do Museu dos Kanindé é concomitante ao processo de emergência étnica/etnogênese. Atribuo à prolongada reflexão sobre as experiências ali vivenciadas um fator crucial no desenvolvimento da noção de etnomuseografia, que nasceu da fusão da observação participante no trabalho de campo com a utilização de métodos museográficos na construção de dados para a escrita etnográfica, que estão associados ao processo de constituição da representação em primeira pessoa, efetuada na ação museológica indígena, outra noção em desenvolvimento.

A constituição dos museus e processos museológicos indígenas como objeto de estudo, em nosso horizonte, parte de uma articulação analítica de dois campos interconectados: o político e o profissional. Em nível teóricoconceitual, esse diálogo tem privilegiado uma perspectiva interdisciplinar a partir de três vieses que partem de nossa formação e atuação. Inicialmente, na perspectiva da História, compreendendo os museus indígenas como espaços de construção social da memória e de escrita da história (contada) em primeira pessoa, na medida em que constituem campos privilegiados para a elaboração de narrativas sobre si e a construção de autorrepresentações (poderíamos destacar, também, esses espaços como formadores de acervos documentais e fontes históricas). $\mathrm{Na}$ perspectiva da Antropologia, com foco na 
etnografia dos museus indígenas, tentando entender os sentidos atribuídos à memória nesses processos museológicos, com ênfase, dentre outros aspectos, na formação de acervos, nas práticas de colecionamento e nas dinâmicas políticas envoltas na constituição dos museus indígenas. Por fim, atuamos numa perspectiva museológica, na medida em que, ao longo de nossa trajetória, temos desenvolvido continuamente práticas museológicas participativas, visando a organização e o fortalecimento dos museus indígenas - o que vem apresentando resultados interessantes no que se refere à formação de indígenas para a gestão museológica, o fortalecimento desses processos e a formação em rede. Portanto, podemos, resumidamente, considerar que nos situamos na interface entre pesquisa histórico-etnográfica e a ação museológica colaborativa, entre a assessoria técnico-política e a etnomuseologia.

Entre 2006 e 2016, estivemos envolvidos numa série de atividades sobre a temática dos museus indígenas, seja na assessoria à criação e fortalecimento de algumas dessas experiências, seja atuando na formação dos índios para a gestão e/ou na organização de exposições colaborativas, na elaboração de materiais didáticos/cartilhas, articulando esses processos às ações de turismo comunitário, atuando na arena das políticas públicas, entre tantas outras. ${ }^{8}$

8. Algumas das mais importantes atividades ao longo deste período, à nível local/regional, foram: a realização do curso/pesquisa Historiando os Tapeba, no Memorial Tapeba Cacique Perna-de-Pau (Caucaia, CE), em 2006/2007; a organização da Oca da Memória (Poranga, CE), em 2007/2008; a organização do Museu Indígena Jenipapo-Kanindé (Aquiraz, CE), em 2009/2010; a publicação do livro Museus e memória indígena no Ceará: uma proposta em construção (Gomes; Vieira Neto, 2009); a realização da pesquisa e a escrita da dissertação de mestrado em Antropologia (PPGA-UFPE) intitulada "Aquilo é uma coisa de índio: objetos, memória e etnicidade entre os Kanindé no Ceará", entre 2009 e 2012; a atuação como docente no curso de Museologia do Departamento de Antropologia e Museologia da UFPE, período no qual desenvolvi a concepção metodológica e fui coordenador técnico do Projeto de Extensão Museus Indígenas em Pernambuco (2011/2013); a realização de três Encontros de formação de gestores indígenas do Ceará; a criação da Rede Cearense de Museus Comunitários (2013); a realização do I e do II Encontros de Museus Indígenas em Pernambuco (em 2012 e 2014, respectivamente); a co-orientação de quatro monografias de bacharelado em Museologia que versam direta ou indiretamente sobre o universo em questão, entre 2013 e 2016 (Silva, 2013; Cavalcanti, 2014; Mendes, 2014;
Na perspectiva de aprofundar uma antropologia dos museus indígenas, alicerçada no acompanhamento desses processos por meio de observação participante e ação museológica, em nível teórico objetivamos desenvolver alguns conceitos que nos possibilitem compreender os fluxos culturais e os processos de tradução ${ }^{9}$ e apropriação ${ }^{10}$ dos museus no horizonte semântico indígena. Nesse sentido, na intersecção entre História, Antropologia e Museologia, abordamos questões relativas à oralidade e cultura material/objetos à luz das modernas teorias sobre etnicidade. ${ }^{11}$ Reunindo reflexivamente a pesquisa etnográfica ao desenvolvimento de procedimentos museográficos, delineamos as noções de ação museológica indígena e etnomuseografia.

Silva, 2016); e, mais recentemente, a realização do I Encontro de Formação em Museologia para Povos indígenas em Pernambuco quando, no dia 24 de julho de 2015, ocorreu a inauguração oficial do Museu Kapinawá. Para maiores detalhes acerca destes processos, consultar: Gomes e Vieira Neto, 2009; Gomes, 2012; Gomes e Vieira Neto, 2014 e Gomes, 2016.

9. Sobre a noção de tradução, destacamos a edição especial de HAU: Journal of Ethnographic Theory, v.4, n.2, de 2014, em especial o artigo introdutório dos organizadores, William Hanks e Carlo Severi, Translating worlds: the epistemological space of translation. Em nossa perspectiva, a tradução do "museu" para a realidade dos povos indígenas, ao evidenciar um processo de apropriação, é resultante do diálogo entre categorias nativas indígenas, os processos e interações sociais que resultam nas práticas de colecionamento indígenas e seus "regimes de memória". Segundo Johannes Fabian, um regime de memória é "uma arquitetura da memória, internamente estruturada e limitada ... que tornaria possível a alguém contar histórias sobre o passado" (Fabian apud Oliveira, 2012, p. 201)

10. Apropriação é uma noção aqui utilizada no sentido do uso antropofágico da ferramenta "museu" - como instituição ou processo - no horizonte semântico de populações indígenas. Por uso antropofágico, entendemos o processo de "deglutição", que seria a apropriação e a ressignificação de acordo com suas categorias culturais. Portanto, é uma noção correlata à de tradução, no sentido aqui proposto.

11. Nos referimos às modernas abordagens antropológicas sobre etnicidade e relações interétnicas, fortemente influenciadas pelo texto de Fredrik Barth (a introdução à coletânea "Grupos étnicos e suas fronteiras", de 1969), pela noção de comunidade étnica, de Max Weber (1991), pelo conceito de "invenção de tradições" (Hobsbawm; Ranger, 1984), entre outros autores paradigmáticos (Abner Cohen, Erving Goffman e George Balandier, por exemplo) e, em nível nacional, pelos trabalhos de Manuela Carneiro da Cunha (a noção de sinal diacrítico, por exemplo) e, no Nordeste, pelos textos e livros de João Pacheco de Oliveira (1999, 2004 e 2011). 
Seria um erro heurístico reduzir as práticas sociais vinculadas aos museus indígenas a um aparato teórico ou técnico-científico concebido como um a priori ao seu entendimento ou, mesmo, à sua realização. Não é possível reduzir as experiências dos sujeitos à teoria social. Não é possível compreender as experiências museológicas dos povos indígenas simplesmente por meio de sua confrontação com categorias teórico-metodológicas ou modelos analíticos forjados noutros contextos. Por um lado, os fenômenos sociais de criação de museus entre populações indígenas aproximam-se do que consideramos, em Museologia, como processos de musealização; por outro, diferenciam-se tenazmente desses por conta das especificidades e diversidade cultural de cada povo e/ou das diferentes apropriações das noções de "cultura" e/ou "memória", de acordo com cada contexto étnico e do conjunto de interações sociais entre os quais florescem os processos museológicos indígenas.

Um caminho muito mais proveitoso, pelo qual optamos, foi direcionar nossos esforços analíticos para um salutar confronto entre as categorias nativas das práticas de colecionamento indígenas - a serem identificadas (pela etnografia) e compreendidas (pela análise antropológica), caso a caso - e as categorias conceituais oriundas da Antropologia e da Museologia.

No encontro entre categorias nativas e esse cabedal analítico fundamentamos a noção de ação museológica indígena, utilizada como categoria de classificação social de determinadas práticas de colecionamento e musealização, protagonizadas por indivíduos e coletividades étnicas e vinculadas aos museus e processos museológicos indígenas, visando a construção de representações sobre si por meio de diversas formas de "tradução" e "apropriação". Esse protagonismo indígena evidencia um confronto entre concepções distintas de "patrimônio" e "museu", percebidas, dentre outros aspectos, nos sentidos que um processo de musealização adquire quando, ao invés de representações sobre um "outro" pesquisado, volta-se para a construção de representações sobre si e de discursos contra-hegemônicos às narrativas oficiais (Gomes, 2012; Velthen, 2012). Na medida em que a ação museológica indígena se constitui enquanto práxis de tradução, a diversidade de modos de tradução representa a multiplicidade de possibilidades de apropriação da "musealização" e dos "museus" entre coletividades étnicas, ou seja, de desenvolvimento de seus processos museológicos para a constituição de representações sobre si.

A noção de "ação museológica indígena" está associada à de "etnomuseografia", ambas com o objetivo de aprimorar um arcabouço teóricometodológico de pesquisa de campo que reúne observação participante e ação museográfica, refletindo sobre nossa participação na construção dessas representações e práticas sociais, com - cuidado de nem minimizar essa presença nem resumi-la à autoetnografia. "Suppose you reflect and write only on your own experience? Well, if you are an ethnographer, then that's auto ethnography” (Ingold, 2014, p.384-385). Tim Ingold critica um projeto antropológico atual que, a seu ver, tornou a disciplina "the study of its own ways of working”, provocando-nos a exercitar mais antropologia, como forma de compreensão do mundo, que etnografia, descrição dos processos de pesquisa (Ingold, 2014, p.383).

Como transformar esses procedimentos museográficos em ferramentas para a construção de dados de uma pesquisa de campo com observação participante, em processos museológicos colaborativos? E, mais, como analisar a descrição etnográfica do próprio processo de compartilhamento, apropriação e tradução de procedimentos museográficos às realidades indígenas?

Assim, metodologicamente a noção de etnomuseografia nasce desse confronto entre trabalho de campo com observação participante e a descrição etnográfica do processo de compartilhamento de práticas e ferramentas museográficas junto a populações indígenas. Utilizamos o termo etnomuseografia, portanto, em dois sentidos:

a) Como ferramenta de pesquisa-ação que fomenta a autorrepresentação e a construção de narrativas sobre si entre as populações indígenas em processos museológicos colaborativos; 
b) Como uma perspectiva teórico-metodológica para a realização da observação participante nas pesquisas de campo e na construção de dados, fontes e informações para a descrição etnográfica dos processos museológicos indígenas.

Aliamos estes dois vieses: o museográfico

- fomentar variadas formas de produzir, tecnicamente, a autorrepresentação (ou representação sobre si) - e o etnográfico, ao propiciar a construção de dados e relatos textualizados para a análise dos processos oriundos dessa experiência, como resultados da observação participante na pesquisa de campo.

Ao refletir sobre minhas práticas de observação participante, descrição etnográfica e compreensão antropológica, considero que o uso e compartilhamento de técnicas da museografia e sua tradução para cada realidade indígena proporcionam situações privilegiadas para a descrição etnográfica das formas de apropriações efetuadas pelos indígenas protagonistas dos processos museológicos na construção de suas autorrepresentações. Nessa construção analítica, que vem crescentemente deslocando-se de experiências situadas em contextos microlocais para a observação de processos de interação entre representantes de diversos povos e os fluxos resultantes desses contatos entre indígenas de variados lugares que estão envolvidos nas questões museológicas, algumas problemáticas começaram a sobressair, entre estas: os sentidos da memória nos processos de autorrepresentação materializados nos museus indígenas; o significado para os indígenas do desenvolvimento de práticas colaborativas de pesquisa, salvaguarda e comunicação de referenciais de "patrimônio", "cultura" e "memória", ou seja, os usos indígenas dessas noções e suas relações com categorias nativas preexistentes e/ou forjadas nesses contextos de interação social; as diversificadas concepções de "objeto" ("patrimônio" e "acervo") e a questão da (i)materialidade e da agência; a relação das dimensões do "sagrado" e da "espiritualidade" com os processos museológicos indígenas de autorrepresentação; o diálogo com o Estado e com as agências mediadoras (atores, grupos e instituições) nos processos museológicos indígenas; e, por fim, as trocas e fluxos culturais oriundos da aproximação dos representantes nos processos de articulação em rede, que tem entre seus resultados a constituição da Rede Indígena de Memória e Museologia Social.

\section{Etnografia de uma organização em rede}

De que maneiras os relacionamentos sociais estão conectados uns com os outros? Como é que a situação em que duas pessoas em contato direto conhecem os mesmos outros se compara com aquela em que elas conhecem outros diferentes? (Hannerz, 2015, p.178)

Independentemente do que mais faz a etnografia, ela traduz experiência em texto. Há vários modos de realizar essa tradução, modos que trazem significativas consequências éticas e políticas. (Clifford, 2011, p.81)

0 quadro atual vem desenhando uma aproximação cada vez maior entre representantes de povos indígenas de várias regiões brasileiras que vivenciam processos museológicos em seus territórios.

Apesar da carência de realização de ações em âmbito nacional, tendo em vista a extensão do território brasileiro, a ausência de uma instância centralizada e as dificuldades financeiras e de comunicação dos museus indígenas entre si - o que vem sendo cada vez mais superado com o advento e a disseminação da internet nas aldeias -, nos últimos anos muitas ações fomentaram a constituição dessas redes de trocas de informações e contatos. Viemos registrando esses momentos, coletando dados e participando de alguns desses processos a partir de 2009 , quando se tornaram cada vez mais frequentes as discussões sobre as possibilidades de organização em rede para os museus indígenas.

Desde então, foram realizados alguns encontros que constituem momentos cruciais na aproximação de muitos dos atores sociais e coletividades 
étnicas que protagonizam processos museológicos indígenas em diversos locais do Brasil, do Oiapoque (AP) a Aratuba (CE), passando por Tupã $(S P)$, Buíque (PE), Benjamin Constant (AM) e Rio de Janeiro (RJ). Consideramos esses encontros parte de uma pesquisa etnográfica sobre os museus indígenas, para a qual são campo privilegiado, constatando pela observação participante que constituem oportunidades fundamentais para a compreensão dos processos de articulação nacional, de trocas e fluxos culturais e de fortalecimento do diálogo dessas iniciativas com - Estado brasileiro na proposição de políticas culturais adequadas às especificidades dos museus entre as populações indígenas.

Uma das primeiras tentativas de reunir representantes de museus e centros culturais geridos por populações indígenas de que temos conhecimento, em âmbito nacional, foi um encontro realizado em setembro de 2009, nas dependências do Museu Nacional (UFRJ). 0 evento, intitulado Seminário Experiências Indígenas com Museus e Centros Culturais, resultante de articulações efetuadas junto às instâncias do Ministério da Cultura (MinC), partindo do Grupo de Trabalho sobre Culturas Indígenas da então Secretaria da Identidade e da Diversidade Cultural (SIDMinC), foi organizado mediante parceria entre o Museu Magüta, o Museu Rondon e o Museu Nacional. A partir de então, um conjunto de atividades contínuas e periódicas, em processo crescente de aproximação, passaram a acontecer. Algumas ocasiões foram marcantes na criação desse diálogo interétnico que está em curso, nos níveis local, regional e nacional. Foram ocasiões como:

- Os encontros da Rede Cearense de Museus Comunitários e os cursos de gestores de museus indígenas no Ceará (2011/2014). 0 I Encontro de gestores de Museus Indígenas do Ceará ocorreu em outubro de 2011 , promovido pelos povos Kanindé, Tapeba, Pitaguary e Jenipapo-Kanindé, em parceria com o Projeto Historiando e o Centro de Defesa e Promoção dos Direitos Humanos (CDPDH) da Arquidiocese de Fortaleza. Em dezembro de 2012 foi realizado o II Encontro de Formação de Gestores de Museus
Indígenas do Ceará, nas dependências do Museu Indígena Jenipapo-Kanindé, com os coordenadores dos museus dos povos Jenipapo-Kanindé, Kanindé e Pitaguary, além de outros membros da RCMC. ${ }^{12} 0$ III Encontro aconteceu paralelamente ao I Fórum de Museus Indígenas do Brasil, em maio de 2015, no Museu dos Kanindé;

- As quatro edições do Encontro Paulista Questões Indígenas e Museus, realizadas sempre nas dependências do Museu Histórico Pedagógico Índia Vanuíre (na cidade de Tupã, SP), mediante parcerias que envolvem - Museu de Arqueologia e Etnologia da USP (MAE-USP), a ACAM Portinari e o Sistema Estadual de Museus de São Paulo (SisemSP). Cada um desses encontros tratou de temáticas afins ao universo da relação entre povos indígenas e museus. 0 primeiro encontro ocorreu entre $1^{\circ}$ e 3 de maio de 2012; o segundo, entre 6 e 8 de agosto de 2013; o terceiro, entre 28 de abril e $1^{\circ}$ de maio de 2014 (Museus e indígenas - Saberes e ética, novos paradigmas em debate), e o quarto, de 30 de junho a 2 de julho de 2015 (Direitos indígenas no museu - Novos procedimentos para uma nova política: a gestão de acervos em discussão). Esses encontros têm abarcado crescentemente mais grupos e priorizado uma ampliação dos debates para fronteiras nacionais e internacionais, fomentando aproximações fundamentais para a consolidação do processo de organização em rede em questão;

- 0 I e o II Encontros de Museus Indígenas em Pernambuco (dezembro de 2012 e de 2014). O primeiro foi o encerramento do Projeto de Extensão "Museus Indígenas em Pernambuco". A proposta que vem se consolidando é a periodicidade bienal desse evento, que também tem tido papel

12. Esse encontro contou com a presença do consultor francês Hugues de Varine, que estava publicando seu livro As Raízes do Futuro: o patrimônio a serviço do desenvolvimento local, em Fortaleza. Varine inseriu em seu blog um relato que contém suas impressões do encontro. Disponível em: http://WWW. worldinteractions.eu/article-musees-indigenes-du-ceara-114307857. html; Acesso em: 18 ago. 2014. 
importante como fomentador dos diálogos interétnicos e interinstitucionais que transitam na órbita dessa articulação em rede. ${ }^{13}$

- As reuniões e contatos ocorridos durante - V e o VI Fórum Nacional de Museus (Petrópolis, RJ, em 2012, e Belém, PA, em 2014), que podem ser considerados parte de um conjunto de aproximações provindas do contato entre as iniciativas indígenas contempladas no edital público Prêmio Pontos de Memória (Ibram) (2011, 2012 e 2014). Os representantes dos museus indígenas têm desempenhado papel importante no processo dialógico em curso desde 2012, em âmbito do DPMUS/Ibram/PPM, de constituição de mecanismos de gestão compartilhada e participativa do PPM;

- O seminário “Gestão de Acervos Culturais em Centros de Formação, de Documentação, de Cultura e Museus Indígenas no Brasil" (Museu do Índio-Funai, RJ, 17 a 20 de setembro de 2013 , em Saquarema, RJ) ${ }^{14}$

13. O Projeto de Extensão "Museus Indígenas em Pernambuco" reuniu estudantes de Museologia da UFPE e representantes dos povos Atikum (Carnaubeira da Penha), Truká (Cabrobó), Fulni-ô (Águas Belas), Pankará (Carnaubeira da Penha). Pankararu (Tacaratu), Entre-Serras Pankararu (Tacaratu) Kapinawá (Buíque), Pankaiwká (Jatobá), Pipipã (Floresta) e Kambiwá (Ibimirim). As atividades foram financiadas com recursos provindos do Programa de Extensão do MEC-Sesu (2011) e do Edital de Apoio para Ações Extensionistas ÉtnicoRaciais (ProExt/UFPE) (2012). Além de apontar diretrizes para políticas culturais e educacionais, as ações desenvolvidas apoiaram a formação de uma rede de contatos visando a troca de informações e experiências, mediante diálogo entre conhecimentos tradicionais e museológicos. Foram realizadas oficinas de diagnóstico museológico que identificaram patrimônios/saberes/memórias e sistematizaram um inventário de referências culturais, por meio de uma metodologia inspirada nas experiências oriundas do contexto cearense. As ações foram divididas em: formação de estudantes; Seminário de Planejamento; cursos Diagnóstico Museológico Participativo em áreas indígenas $(16 \mathrm{~h} / \mathrm{a})$. Como finalização desse projeto, foi realizado o I Encontro de Museus Indígenas de Pernambuco, entre 13 e 15 de dezembro de 2012; entre 3 e 5 de dezembro de 2014, realizamos o II Encontro de Museus Indígenas em Pernambuco, ambos em Recife.

14. Os participantes do encontro, que reuniu indígenas, entidades indigenistas, técnicos e servidores do Museu do Índio-Funai, redigiram um documento final, disponível em: http://bd.trabalhoindigenista.org.br/sites/default/ files /2014\%20Documento\%20F inal\%20Semin\%C3\%A1rio\%20Acervos.pdf ; Acesso em: $28 \mathrm{fev} .2016$. e demais atividades de salvaguarda e pesquisa efetuadas pelo Museu do Índio com diversas populações indígenas no Brasil; destacamos também o Curso Dimensões das Culturas Indígenas, que vem sendo realizado anualmente, e o Programa de Documentação de Línguas e Culturas Indígenas.

Entre 2014 e 2015, com o reencontro em várias oportunidades, representantes de processos museológicos do Ceará, de Pernambuco, do Rio de Janeiro, de São Paulo, do Amazonas e do Amapá, entre outros estados, vêm se aproximando e interagindo cada vez mais, no sentido da formação dessa rede de contatos e articulações. Acompanhamos a realização de seis encontros em diferentes locais do Brasil, nos quais foram discutidos os museus indígenas e o seu processo de organização coletiva, que foram fundamentais na constituição dessa rede de contatos específica, pautada na relação entre os povos e lideranças indígenas que desenvolvem processos museológicos em seus territórios. Em quatro deles, tivemos a elaboração coletiva de documentos públicos sobre a temática do patrimônio, memória e museologia entre populações indígenas. Foram eles:

- VI Fórum Nacional de Museus, de 24 a 28 de novembro de 2014, em Belém, PA;

- II Encontro de Museus Indígenas em Pernambuco, 3 a 5 de dezembro de 2014, no campus da UFPE, em Recife, PE; ${ }^{15}$

- I Fórum de Museus Indígenas do Brasil/III Encontro de Formação de Gestores de Museus Indígenas do Ceará, em 16 e 17 de maio de 2015, no Museu dos Kanindé, em Aratuba, $\mathrm{CE} ; 16$

15. O documento final do II Encontro de Museus Indígenas em Pernambuco, subdividido em três partes (Práticas museais e museus indígenas; Museus indígenas e políticas culturais; É possível uma rede nacional de museus indígenas?), foi assinado por 42 pessoas entre indígenas, pesquisadores, gestores públicos e estudantes.

16. No documento final do I Fórum de Museus Indígenas do Brasil foram sistematizadas demandas, propostas e diretrizes de políticas públicas para a memória, o patrimônio cultural e a museologia social. Está dividido em quatro partes (Gestão museológica e museus indígenas; Formação e capacitação; Sustentabilidade, fomento e financiamento; Articulação em rede), subdivididas em diretrizes, estratégias e 
- IV Encontro Paulista Questões Indígenas e Museus, no Museu Histórico-Pedagógico Índia Vanuíre, de 30 de junho a 2 de julho de 2015, em Tupã, SP; ${ }^{17}$

- I Encontro de Formação em Museologia para Povos Indígenas em Pernambuco, de 20 a 24 de julho, no Museu Kapinawá, em Buíque, $\mathrm{PE} ;{ }^{18}$

ações, assinado por 36 participantes que representavam 29 instituições afeitas ao campo indígena e indigenista.

17. O documento final do IV Encontro Paulista Questões Indígenas e Museus foi assinado por 28 pessoas,

representantes dos povos indígenas Kaingang, Terena, Krenak e Tupi-Guarani (SP); Karipuna e Galibi-Marworno (AP); Kanindé e Jenipapo-Kanindé (CE) e Kapinawá (PE), professores.

pesquisadores, estudantes, gestores públicos e privados. profissionais das áreas da educação e cultura, subdividido em considerações, moções, propostas e demandas. Entre as considerações, destacou-se o contexto de ataques recorrentes aos direitos dos povos indígenas adquiridos na Constituição Brasileira de 1988 e o desrespeito à Convenção 169-0IT; a interculturalidade, a especificidade e a diversidade cultural dos povos indígenas no Brasil; os violentos processos de etnocídio e genocídio que vêm acontecendo nas diferentes regiões brasileiras. E, entre as moções, transcrevemos: "1) Em repúdio à PEC 215 e a todas as propostas de modificação legislativa que afetam e modificam os direitos constitucionais dos povos indígenas; 2) Em apoio à iniciativa do Museu dos Povos Indígenas do Oiapoque - Kuahí, do município do Oiapoque (Amapá), que está fechado devido a problemas estruturais do prédio. É imperativo que as instalações físicas e o acervo sejam protegidos, por conta de sua relevância no cenário cultural e educacional no Brasil. Solicitamos a conclusão do processo de recuperação física do Museu; 3) Em apoio ao fortalecimento na preservação do Centro de Documentação do Projeto Xingu, juntamente à aquisição de um espaço físico para o Museu Professor Roberto Baruzzi-Escola Paulista de Medicina - Xingu (Unifesp)". O documento apresentou ainda as seguintes propostas: "1) Que a Secretaria de Cultura do Estado de São Paulo e a ACAM Portinari apoiem o deslocamento de representantes de comunidades indígenas do oeste paulista para o I Encontro de Formação em Museologia para Povos Indígenas em Pernambuco, para a realização de um intercâmbio com os demais povos indígenas participantes; 2)

Apoiar, de forma sistemática e permanente a realização de formações em Museologia para povos indígenas no oeste paulista, a partir do estabelecimento de diversas parcerias com o Museu Histórico-Pedagógico Índia Vanuíre; 3) A manutenção e ampliação dos programas de fomento diferenciado para as iniciativas de memória, patrimônio e museologia entre os povos e comunidades indígenas no oeste paulista; 4) Organização do Núcleo São Paulo da Rede Indígena de Memória e Museologia Social do Brasil".

18. O documento final do I Encontro de Formação em Museologia para Povos Indígenas em Pernambuco foi assinado por 63 pessoas, representantes dos povos indígenas Kapinawá, Truká, Fulni-ô, Xukuru, Pankararu (PE), Kanindé e Jenipapo-Kanindé (CE), Kaingang (SP), Karipuna (AP) e Kiriri (BA); e das
- V Encontro Internacional de Ecomuseus e Museus Comunitários, entre 14 e 17 de outubro de 2015, em Juiz de Fora, MG.

Foram seis encontros em 11 meses. Nos

questionamos sobre os significados locais dessas interações, na medida em que, além da observação participante nos encontros, temos acompanhado há alguns anos a trajetória de alguns de seus participantes, tendo como interesse compreender suas percepções dos processos e impactos dessas redes de trocas em suas realidades locais. Percebemos a noção de rede em duas perspectivas: como forma de organização social da interação entre os diferentes grupos, e, em termos teóricos, como ferramenta conceitual para a análise antropológica. ${ }^{19}$

Apesar de abrangermos campos de pesquisa situados em diferentes locais, em torno de problemáticas afins aos processos museológicos indígenas, as experiências efetuadas no Ceará e em Pernambuco têm sido pontos de partida e chegada de nossa abordagem. É com os indígenas desses dois estados que temos viajado para alguns encontros e organizado outros em suas aldeias e/ ou nas capitais, Fortaleza e Recife. É em suas aldeias que estamos circulando, em encontros, em pesquisas etnográficas, em atividades formativas, ministrando aulas ou acompanhando alguma ação importante.

instituições Núcleo de Estudos e Pesquisas sobre Etnicidade da Universidade Federal de Pernambuco (Nepe/UFPE), Museu do Homem do Nordeste da Fundação Joaquim Nabuco (MUHNE-Fundaj), Museu de Arqueologia e Etnologia da Universidade de São Paulo (MAE-USP) e Associação Nacional de Ação Indigenista (Anaí, BA). O documento, que reafirma o compromisso com o fortalecimento das culturas, memórias e lutas políticas dos povos indígenas, possui quatro encaminhamentos, relativos ao diálogo do Museu Kapinawá com o Museu Municipal de Buíque e com a UFPE, à consolidação de um núcleo em Pernambuco da Rede Indígena de Memória e Museologia Social, com a realização de uma reunião de articulação, no Território Indígena Xukuru (Pesqueira, PE); e a organização do II Fórum de Museus Indígenas do Brasil, na Aldeia Mina Grande, Território Indígena Kapinawá, no período de 18 a 22 de agosto de 2016. 19. Sobre a noção de rede para a análise antropológica, destacam-se os artigos clássicos de J. A. Barnes, “Redes sociais e processo político" (1969), e de Jeremy Boissevain, "Apresentando 'Amigos de amigos': redes sociais, manipuladores e coalizões" (1974), ambos publicados no Brasil em Feldman-Bianco (2010). Destacamos também um artigo de Ulf Hannerz, "Pensando com redes", de 1980 (Hannerz, 2015). 
Os indígenas do Ceará, onde o diálogo sobre os museus indígenas avançou muito nos últimos anos, têm se destacado no cenário brasileiro, inspirando iniciativas afins e desempenhando importante papel no que se refere à consolidação desse campo em nível nacional - com notório destaque no debate sobre políticas públicas culturais. Ainda em 2009, uma das propostas do documento final do seminário "Emergência étnica: índios, negros e quilombolas construindo seus lugares de memória" 20 propunha a "Criação da rede de museus indígenas no Ceará, que funcione através de um conselho formado pelas organizações das diversas etnias que compõem a rede e seus parceiros" (Gomes; Vieira Neto, 2009, p.215). Isso não ocorreu. Em 2011, com a ampliação e aproximação de uma diversidade de iniciativas, grupos e comunidades que desenvolviam processos museológicos em âmbito estadual, foi criada a Rede Cearense de Museus Comunitários (RCMC), com forte presença dos museus indígenas, englobando também comunidades da periferia urbana de Fortaleza, de pescadores e marisqueiras, de quilombolas, de assentados, além de ecomuseus e iniciativas participantes do Programa Pontos de Memória, Ibram, entre outras (Gomes; Vieira Neto, 2014)..$^{21}$

20. Esse Projeto foi realizado pela Secult-CE, por intermédio do Museu do Ceará, concebido para realizar uma consulta aos grupos étnicos acerca da elaboração de políticas públicas museológicas. Uma das motivações para esse debate foi uma proposta efetuada pelo órgão, em 2008, de organizar o Memorial das Culturas Indígenas do Ceará, um museu oficial do estado, com sede em Fortaleza, formado a partir da reunião de alguns acervos privados. Como já existiam diversas iniciativas museológicas indígenas, mediamos um diálogo com lideranças e entidades indigenistas, chegando-se à proposta de realizar um seminário propositivo para dialogar sobre tal questão de forma participativa, envolvendo estado e setores da sociedade civil. Os diagnósticos museológicos participativos foram realizados entre os povos indígenas: Kanindé (Aratuba), Tapeba (Caucaia), Tabajara e Kalabaça (Poranga), Tremembé (Itarema), Pitaguary (Pacatuba) e Tabajara/Potiguara/Gavião/Tubiba (Monsenhor Tabosa) (Gomes; Vieira Neto, 2009)

21. A Rede Cearense de Museus Comunitários (RCMC) foi a primeira rede de museologia social criada no Brasil. organizada em outubro de 2011, sob os princípios da horizontalidade, colaboração, descentralização, capilarização, autonomia e diversidade. Realizaram seu $1^{\circ}$ Encontro Estadual em maio de 2013 (Fortaleza, CE), no qual foi elaborada a "Declaração de princípios, objetivos e resoluções da RCMC”, que definiu missão, objetivos, princípios, modelos de gestão, estrutura e funcionamento.
Os representantes dos museus indígenas cearenses têm atuado fortemente e se tornado presença constante nos eventos museológicos nacionais. 0 diálogo para a construção de políticas museológicas participativas teve um marco no V Fórum Nacional de Museus (2012, em Petrópolis, RJ), quando foi criada, com o objetivo de dinamizar o processo de elaboração de mecanismos de gestão compartilhada do Programa Pontos de Memória (PPM) do Ibram a “Comissão para a Elaboração de Mecanismos para a Gestão Compartilhada/Participativa do Programa Pontos de Memória” (Cogepaco), a partir das demandas de iniciativas museológicas e museus comunitários participantes do Programa, reunindo representantes de instituições e redes de memória, patrimônio e museologia social brasileiras. A Cogepaco, que tinha como representante indígena Suzenalson Santos, reuniu-se nos 2 anos seguintes visando elaborar mecanismos para a implementação da gestão compartilhada. Durante o ano de 2014, foram realizadas consultas, nos estados, às iniciativas museológicas comunitárias contempladas nos editais Prêmio Pontos de Memória (2011 e 2012), acerca de proposições à minuta de uma portaria que visava instituir o Conselho de Gestão Compartilhada e Participativa do Programa Pontos de Memória. Em novembro de 2014, no VI Fórum Nacional de Museus em Belém, PA, oportunidade em que se discutiu a minuta de portaria para a instituição desse Conselho Gestor, além de Susenalson estiveram presentes Preá, Rosa Pitaguary e Nino Tikuna (AM). A Rede Indígena conquistou um assento permanente nesse Conselho Gestor, entre as vagas destinadas à sociedade civil, sendo Suzenalson Santos escolhido para representar os museus indígenas.

Apesar desse foco no Ceará, que temos acompanhado há mais tempo, o instigante quadro de diversidade étnica em Pernambuco tem apresentado vitalidade e dinâmica interessantes. Uma das principais e mais recentes novidades foi a criação do Museu Kapinawá (Buíque, PE), cuja trajetória acompanhamos desde 2012. Com o desempenho da função de coordenador-técnico do Projeto de

Mais informações disponíveis em: http://museuscomunitarios. files.wordpress.com; Acesso em: $24 \mathrm{fev} .2016$. 
Extensão Museus Indígenas em Pernambuco (20112013), a aproximação com os grupos indígenas em Pernambuco foi crescente, e aos poucos fui adentrando também esse outro contexto. Está acontecendo um importante processo de trocas e contatos entre participantes dos processos museológicos indígenas dos dois estados. No cenário pernambucano, é importante destacar as pioneiras iniciativas museológicas do povo Pankararu, em especial os museus indígenas na aldeia Brejo dos Padres (Tacaratu, PE): a Casa de Memória do Tronco Velho Pankararu e o MuseuEscola Pankararu. ${ }^{22}$

0 I Encontro de Museus Indígenas de Pernambuco, realizado em 2012 no Recife, foi o encerramento do referido projeto de extensão, constituindo um momento importante no conhecimento mútuo entre representantes de museus indígenas. Esse encontro foi estratégico na formação de uma articulação inicial em rede dos museus indígenas que havia até então. Esses contatos passaram, de um momento em que os representantes das iniciativas praticamente não se conheciam, para um outro, no qual esse reconhecimento mútuo deu vazão a constantes reencontros, oportunidades únicas para a percepção das trocas oriundas dessas interações, momentos em que os atores sociais indígenas foram/estão descobrindo objetivos e problemas comuns, criando laços afetivos em suas relações e planejando novas ações e atividades

22. A Casa de Memória do Tronco Velho Pankararu, como espaço de rememoração das lideranças e de mobilização indígena, destaca-se enquanto sentido atribuído pelos seus organizadores. Esse significado é constituído junto ao desejo de apropriação das representações construídas por outrem, pesquisadores ou não, invertendo os termos da interpretação de estudos/objetos/coleções para uma lógica discursiva em primeira pessoa. 0 início desse processo de musealização foi estimulado a partir da atuação do grupo de dança Pankararu Nação Cultural, que vem realizando um trabalho de pesquisa, divulgação e revitalização da chamada "dança do Búzio". Há uma importante relação entre a patrimonialização, desencadeada com o processo de musealização, e a revitalização de uma tradição adormecida. 0 desejo de retorno de acervos variados complementa-se à salvaguarda de imagens e de relatos orais, que realizam utilizando câmeras filmadoras e fotográficas, veiculando-as na internet como instância de circulação e articulação. Para mais informações, ver: Gomes e Athias, 2013. Para obter uma dimensão do trabalho desenvolvido pelo grupo Pankararu Nação Cultural, ver: http://pankararunacaocultural.blogspot.com.br/; Acesso em: 21 jan. 2015 . conjuntas. Aquele evento contou com a presença de representantes de nove estados brasileiros ( $P E$, CE, RJ, PB, AM, MA, BA, PI e SP), e de indígenas dos povos Pankaiwká, Pipipã, Atikum, Entre-Serras Pankararu, Pankararu, Fulni-ô, Truká, Kapinawá, Pankará e Kambiwá (PE), Jenipapo-Kanindé e Kanindé (CE), Pataxó (BA) e Tikuna (AM). Foram contatadas experiências presentes entre povos indígenas nos estados do Amapá (Núcleos museológicos indígenas do Amapá, vinculado à Universidade Federal do Amapá, Unifap) e Tocantins (Museu Iny Heto dos povos indígenas Javaé e Karajá, da Ilha do Bananal), que não puderam participar. Durante as atividades, fortaleceram-se os laços entre os representantes de comunidades e povos indígenas que vivenciam processos museológicos em seus territórios. Contou ainda com a participação marcante de dois experientes protagonistas na organização de museus indígenas no Brasil contemporâneo, além de lideranças destacadas entre seus povos: Nino Fernandes, um dos criadores do Museu Magüta do povo Tikuna (AM), e o cacique Sotero, criador do Museu dos Kanindé (CE). 0 evento, que contou com o apoio do Instituto Brasileiro de Museus (Ibram), reuniu, além de ouvintes e equipe técnica, cerca de 25 representantes de povos indígenas para a troca de saberes e o relato das experiências relativas à organização e gestão de processos museológicos indígenas. Realizouse uma mesa-redonda reunindo representantes de museus indígenas, articulação oriunda de uma reunião que havia acontecido em novembro de 2012 , aproximadamente um mês antes desse encontro, durante as atividades do V Fórum Nacional de Museus, em Petrópolis, RJ. ${ }^{23}$

23. Concomitante à discussão sobre a gestão compartilhada no âmbito do Programa Pontos de Memória, um primeiro encontro foi realizado entre os representantes dos museus indígenas que receberam financiamento do Prêmio em 2011 e outros que estavam presentes no encontro. As instituições participantes foram: Museu Magüta (AM), Museu Virtual dos Pataxó (BA), Museu Indígena Jenipapo-Kanindé (CE) Museu dos Kanindé (CE), Museu dos Pitaguary (CE), integrantes do grupo Raízes Históricas Indígenas (RJ), integrantes do Projeto Historiando (CE), integrantes Projeto Museus Indígenas em Pernambuco (UFPE), integrantes da Coordenação de Museologia Social da Executiva Nacional dos Estudantes de Museologia e representantes da Coordenação de Museologia Social e Educação do Departamento de Processos Museais do Ibram. 
Esses debates, que aconteceram entre Recife e Olinda, foram voltados à discussão sobre o universo dos museus indígenas, priorizando as trocas de experiências e o aprofundamento de questões como a diversidade de práticas museais e de perfis entre os museus indígenas no Brasil, assim como as diferentes modalidades de protagonismo indígena nos processos museológicos. Ao final, formou-se um grupo de trabalho para elaborar proposições, originando um documento que sistematizou desafios para a elaboração de políticas públicas e ações para os museus, a memória e o patrimônio cultural entre os povos indígenas.

Além dos museus no Território Pankararu, entre os Pipipã (Floresta), havia a experiência de um espaço edificado, porém inconcluso, do Museu Comunitário Pipipã. Entre os Fulni-ô, ganhava destaque a proposição de um processo de musealização do território, além da atenção especial dada à salvaguarda do Yaathê, sua língua materna. Entre praticamente todos os povos foram identificados processos de pesquisa e salvaguarda sobre aspectos da memória social e do patrimônio cultural, potenciais vetores da ação museológica indígena.

As ações daquele encontro foram realizadas no sentido de ampliar o debate sobre os museus indígenas, contribuindo para a superação do isolamento entre as iniciativas afins e aproximando-as para além dos municípios/estados. Junto às atividades dos museus indígenas em desenvolvimento no Ceará, que já possuíam um caráter permanente pelo menos desde 2009, no estado de Pernambuco aquele momento fortaleceu um cenário onde passou a ser cada vez mais constante o debate sobre os processos de autorrepresentação construídos pelos/nos museus indígenas.

Um dos três eixos temáticos que compunham o documento final do I Encontro de Museus Indígenas em Pernambuco tinha o formato de uma perguntaquestionamento: "É possível uma rede nacional de museus indígenas?". Como resposta, foram elencadas três propostas que, àquele momento, eram etapas estratégicas para a aproximação, que então se esboçava, entre lideranças e representantes de museus indígenas. Foram elas:
- Mapear a diversidade de processos museológicos provindos de iniciativas e com a participação de povos indígenas, apontando para as diferentes formas como as populações vêm protagonizando essas experiências e para os atores e organizações sociais envolvidos;

- Criar uma rede de contatos virtuais entre representantes de povos e museus indígenas, visando aproximar iniciativas afins e facilitar a articulação e a circulação de informações sobre a área museológica;

- Realização de um encontro nacional reunindo representantes de museus e processos museológicos indígenas, com o caráter de articulação, para a organização de uma rede de contatos entre os museus indígenas.

(Documento Final - I Encontro de Museus Indígenas em Pernambuco, 2012)

Exercitando um olhar retrospectivo, essas três propostas daquele documento, seguindo dinâmica e ritmo próprios, de algum modo foram realizadas. ${ }^{24}$ Em dezembro de 2014, realizamos o II Encontro de Museus Indígenas em Pernambuco, na UFPE, em Recife. Uma grande comitiva indígena do Ceará, composta por 11 pessoas, esteve presente, entre eles Nalson Kanindé, filho do cacique Sotero criador do Museu. Estivemos juntos na mesa-redonda “Museus indígenas, museus sobre indígenas: teoria antropológica e pesquisas etnográficas” e, tal qual noutras oportunidades em que o ouvi falando publicamente das atividades do Museu, narrava habilmente e fazia novos usos das categorias nativas utilizadas por eles para se referirem aos objetos, que eu havia identificado e analisado na dissertação. ${ }^{25}$ Falava dessas categorias com

24. A primeira delas, o mapeamento de museus e processos museológicos indígenas, à qual nos dedicamos na época, identificou 23 iniciativas entre 11 estados brasileiros, mais o Distrito Federal. A segunda vem se configurando lentamente, e acompanhamos muitos momentos nos quais esse processo foi debatido; a terceira concretizou-se em maio de 2015, em Aratuba, CE, com a realização do I Fórum de Museus Indígenas do Brasil, sediado no Museu dos Kanindé.

25. Essas categorias nativas são: Coisas dos índios: aquilo que seria pertencente aos índios, seja os do passado ou do 
a propriedade de quem as conhecia intimamente. embora tenha passado a utilizá-las somente após ter lido a pesquisa, revelando uma apropriação sui generis aos termos e à minha interpretação dada a eles, utilizadas ali no contexto de uma representação em primeira pessoa - dele falando sobre seu próprio povo, se autoapresentando, em um espaço acadêmico de antropologia, tão propenso a legitimar as representações sobre o outro. ${ }^{26}$

No término do II Encontro de Museus Indígenas em Pernambuco, Nalson tomou a frente e liderou um processo de formalização da articulação em rede que estava em construção havia alguns anos. Entre os povos envolvidos, destacamos os dos estados do Ceará, Pernambuco, São Paulo, Amazonas, Amapá e Rio de Janeiro. Como parceiro institucional, cada estado apresenta um contexto local bem específico, no qual destacam-se as parcerias com as universidades, centros de pesquisa, entidades indigenistas e/ou museus. ${ }^{27}$

presente; Coisas dos velhos (ou coisas dos antigos): aquilo que seria dos seus antepassados, parentes, pais, tios. avós e bisavós; Coisas das matas: usada para classificar o que é proveniente, literal e simbolicamente, das matas, da natureza, da floresta. Associam-se com os objetos produzidos a partir de técnicas artesanais ("manuais"), feitos com matérias-primas naturais (escultura em madeira) e também ao ato de caçar (os bichos), assim como à Caipora, pois todos são "coisas das matas" (Gomes, 2012, p.98-120).

26. Tal situação, na qual "Tanto os informantes quanto o pesquisador são leitores e 're-escritores' de uma invenção cultural" (Clifford, 2011, p.83), remete à narrativa citada por James Clifford, na qual um estudante de etnohistória africana fazia pesquisas de campo no Gabão, junto aos mpongué, grupo que, no início do século XIX, teve costumes e modo de vida registrados em um compêndio por um abade-etnógrafo. 0 pesquisador, que havia consultado tal publicação, a utilizou como parâmetro para fundamentar as perguntas que fazia ao chefe, através da listagem de termos religiosos, instituições e conceitos. "No início, as coisas correram fáceis, com a autoridade de mpongué fornecendo descrições e interpretações ... ou ainda observando que uma prática havia sido abandonada ... quando o pesquisador pergunta sobre uma certa palavra, o chefe parece em dúvida, meio perturbado. 'Um momentinho', diz ele animadamente, fugindo para dentro de casa, para voltar com uma cópia do compêndio ... Durante o resto da entrevista o livro ficou aberto em seu colo" (Clifford, 2011, p.82-83).

27. No Ceará, os apoiadores dos processos museológicos indígenas são a Rede Cearense de Museus Comunitários, o Projeto Historiando, o Museu do Ceará, o Centro de Defesa Promoção de Direitos Humanos da Arquidiocese de Fortaleza e a ONG Adelco no Estado de Pernambuco. Destacamos a atuação da UFPE, por meio do Núcleo de Estudos e Pesquisas sobre
A circulação e a troca de conhecimentos entre os indígenas nesses momentos propiciaram o amadurecimento coletivo de um grupo, ao mesmo tempo em que cada um deles continuava atuando em nível local, entre suas comunidades/povos e em suas cidades, no desenvolvimento de processos museológicos que estão em curso. Foi nesse contexto que surgiu o Museu Kapinawá.

A criação do Museu Kapinawá foi uma iniciativa de alguns professores desse povo e teve ações prévias apoiadas por projetos e ações do NepeUFPE e pelo Funcultura, fundo de apoio a projetos culturais da Secretaria da Cultura do Estado de Pernambuco, por meio da Fundação do Patrimônio Histórico e Artístico de Pernambuco (Fundarpe). Dois projetos aprovados no Funcultura foram fundamentais: "Kapinawá: museu povo conta e canta: memórias, samba de coco e furnas" (2011/2012), no qual foram realizados processos de formação com os professores em pesquisa, inventário do patrimônio cultural e arqueologia; e o projeto: "Meu povo conta: história e cultura Kapinawá na sala de aula”, que consiste no aprofundamento do processo de pesquisa protagonizado pelos professores indígenas para a elaboração de um livro didático, escrito pelos próprios índios, para ser utilizado como material didático nas escolas indígenas. ${ }^{28}$

Paralelamente a essas atividades, o Nepe-UFPE contribuiu com o "Projeto de Extensão Museus Indígenas em Pernambuco”, a partir de 2011/2012. Para o desenvolvimento das ações desse projeto,

Etnicidade (Nepe), o Museu do Estado de Pernambuco e o Conselho Indigenista Missionário (Cimi-NE); no estado de São Paulo, a atuação de profissionais vinculados ao Museu de Arqueologia e Etnologia (MAE-USP) e ao Museu Índia Vanuíre, além do Núcleo de História Indígena e do Indigenismo da USP e o Instituto Iepé; no Pará, destacam-se as diferentes parcerias dos povos indígenas com o Museu Paraense Emílio Goeldi, sobre questões museológicas e patrimoniais; no Rio de Janeiro, é já antiga a atuação do Museu do Índio-Funai e do Museu Nacional-UFRJ entre povos indígenas de diversos locais no território nacional.

28. É importante ressaltar que a produtora e proponente desses projetos é a antropóloga Lara Erendira, que também esteve realizando concomitantemente sua pesquisa que resultou na dissertação de mestrado Kapinawá é meu, já tomei, tá tomado: organização social, dinâmicas territoriais e processos identitários entre os Kapinawá, defendida em 2014 no PPGAUFPB . 
foram definidos articuladores locais por etnia. No povo Kapinawá, foi indicado justamente o professor de artes Ronaldo Siqueira, que ficou responsável pela organização da oficina na aldeia, atuando como dinamizador das atividades sobre memória e patrimônio, identificando potencialidades e planejando as ações museológicas. Desde então, Ronaldo foi participando de atividades afins ao universo dos museus indígenas, como formações, encontros e seminários; passou a ministrar palestras e circular entre outros povos e museus indígenas, tendo sido o maior entusiasta da criação do Museu Kapinawá. A criação desse Museu ocorreu no momento em que, paralelamente a essas interações, o povo Kapinawá começou a formar suas próprias coleções de documentos, fotos, objetos, vídeos, pesquisas de antropólogos, gravações musicais etc., e adaptou um espaço para funcionar como sede, numa antiga fazenda de gado retomada em 2011. A formação do acervo está em fase embrionária, tendo em vista que o espaço foi inaugurado oficialmente no dia 23 de julho de 2015, durante a realização do I Encontro de Formação em Museologia para Povos Indígenas em Pernambuco.

Em 2015, tanto o I Fórum de Museus Indígenas do Brasil (Aratuba, CE, maio de 2015), quanto o IV Encontro Paulista Questões indígenas e Museus (Tupã, junho/julho de 2015) e o I Encontro de Formação em Museologia para Povos Indígenas em Pernambuco (Buíque, PE), tiveram claramente objetivos de avançar no processo de articulação em rede, instituindo em suas programações momentos específicos para tratar das questões referentes à organização em suas diversas instâncias.

Além dos contatos entre os povos do oeste paulista e do Nordeste, duas outras aproximações importantes foram efetuadas nos últimos anos. Refiro-me aos diálogos entre os representantes dos processos museológicos indígenas do Ceará e de Pernambuco com integrantes do Museu Magüta e do Museu Kuahí dos Povos indígenas do Oiapoque. Nino Fernandes, coordenador do Museu Magüta, ${ }^{29}$ é

29. Na opinião da antropóloga Regina Abreu, o Museu Magüta representava perfeitamente um novo momento na história da relação entre antropologia e museus no Brasil (junto a outras experiências museológicas, como a dos Wajãpi, AP, e a do Museu da Maré, RJ), na medida em que "0 falar sobre o 'outro" presença certa nas edições do Fórum Nacional de Museus, estando presente nas reuniões ocorridas em 2012 e 2014, que congregaram os indígenas presentes ao evento. Em 2015, Fabrício Narciso (povo Karipuna), participou como palestrante do I Fórum Nacional de Museus Indígenas, em Aratuba; e Davi dos Santos (povo Galibi-Marworno), participou do IV Encontro Paulista Questões Indígenas e Museus, em Tupã (SP).

Nesse diálogo entre povos indígenas e instituições, uma temática comum às várias interações nos diferentes estados é, por um lado, o diálogo sobre as coleções etnográficas e os acervos indigenistas (objetos e documentos) e, por outro, a parceria para o desenvolvimento e fortalecimento dos processos museológicos indígenas (em questões que vão desde a formação de acervos, passando pela qualificação técnica para a gestão museológica, até a articulação em rede, a organização de encontros, o fomento e a mediação no diálogo com o Estado).

\section{A Rede Indígena de Memória e Museologia} Social não está sozinha nesse quadro nacional de organização da sociedade civil em redes territoriais e temáticas de memória, patrimônio e museologia social, que no Brasil começou apenas em 2011. Consiste em um fenômeno social e modelo organizacional recentes, o que inviabiliza, até mesmo, a avaliação de seu impacto em nível local, no diálogo entre sociedade civil e Estado e na execução e planejamento de políticas públicas. É fato que esse processo organizativo tem relação com as interações provenientes do âmbito estatal, embora seja simplista considerarmos que ocorre em função dessa relação, que na maior parte das vezes é descontínua e conflituosa, variando conforme fisiologismos políticos, alianças partidárias e alternâncias de grupos nos órgãos de gestão museológica.

é substituído por uma narrativa que mescla a construção da alteridade com a autorrepresentação e a construção de si, que identifico como 'alteridade mínima'” (Abreu, 2007. p.167-168). Identifica aquele museu indígena como algo novo "no panorama dos museus etnográficos. A experiência de um museu sobre índios, criado na confluência de um diálogo entre índios e antropólogos, merece ser registrada como um momento importante, de passagem para um novo estilo de museu etnográfico e de prática de colecionamento" (Abreu, 2007. p.167). 
Atualmente, existem no Brasil 11 redes temáticas e territoriais. São elas: a Rede Cearense de Museus Comunitários (CE), a Rede de Museus e Memoriais de Terreiros de Candomblé da Bahia (BA), a Rede Potiguar de Pontos de Memória e Museus Comunitários (RN), a Rede Indígena de Memória e Museologia Social, a Rede de Educadores de Museus do Maranhão (MA), a Rede São Paulo de Memória e Museologia Social (SP), a Rede de Museologia Social do Rio de Janeiro (RJ), a Rede de Pontos de Memória e Iniciativas de Memória e Museologia Social do Rio Grande do Sul (RS), a Rede de Pontos de Memória do Pará (PA), a Rede de Museus e Pontos de Memória do Sul da Bahia (BA) e a Rede Nacional LGBT de Memória e Museologia Social (G0). Essas redes congregam iniciativas que estão localizadas em diversos locais do território brasileiro, que possuem diferentes níveis temáticos de associação (étnico, no caso indígena; religioso, no caso da rede de terreiros, por exemplo) e espaços territoriais de abrangência (estados, como Ceará ou Rio de Janeiro, ou regiões, como o sul da Bahia). Seja quando estão agregadas por conta de uma temática afim, seja por conta da associação mediante pertencimento estadual (que acaba agregando iniciativas de diversas temáticas), as redes são fenômenos contemporâneos no cenário museológico que ainda carecem de análises e estudos interdisciplinares.

Nesse sentido, apresentamos dados etnográficos referentes a alguns momentos desse processo organizativo em voga: a formação de uma rede de museus indígenas (a Rede Indígena de Memória e Museologia Social do Brasil), ${ }^{30}$ com o surgimento de um grupo articulador que vem se constituindo pelo amadurecimento dos contatos entre gestores, integrantes de museus indígenas e pesquisadores/ instituições, por meio de diversos reencontros nos últimos 4 anos, o que está possibilitando a consolidação de um conjunto de atividades em diversos estados do território brasileiro.

30. A Rede Indígena de Memória e Museologia Social do Brasil tem uma página na rede social Facebook (https://WWw.facebook. com/rimemusbrasil/), que vem sendo importante ferramenta de articulação entre os representantes de iniciativas museológicas indígenas.

\section{Provocações finais: algumas considerações}

A junção de termos designativos aos processos de apropriação dos museus pelos índios já vem ocorrendo em círculos científicos e entre integrantes dos movimentos indígenas. Referidos também como museus tribais (Clifford, 2009; Scheiner, 2012), museus étnicos (Meneses, 1993, p.216) ou museus indígenas (Freire, 2009; Gomes, 2012; Vidal, 2008), problematizamos o significado desses processos museológicos e da própria noção de museus indígenas, como categoria nativa (usada pelos indígenas para definir determinados processos e práticas em que estão envolvidos), fenômeno social (resultado de práticas e relações sociais) e categoria de classificação (tipologia de museu).

As diversas apropriações da ideia de "museu", como instituição ou processo, são reinventadas em cada realidade. Traduções sobre si, na ótica dos diversos grupos étnicos, emergem para a construção de representações vinculadas ao diálogo com o outro ou para a compreensão de suas trajetórias enquanto coletividades. Mas quais os significados dessas experiências para seus protagonistas? 0 que essas populações fazem, muitas vezes, passa ao largo de um referencial conceitual da museologia ou da antropologia, e a própria noção de “índio” é problemática. Em algumas experiências no Brasil, uma intricada relação se destaca: a autorrepresentação enquanto parte das mobilizações políticas dos povos.

Pesquisar uma temática com a qual estou profundamente envolvido, considerando a vitalidade e dinâmica do campo, além de minha participação direta em grande parte das atividades, me fez constatar cabalmente que é impossível que o ritmo de análise siga o curso dos acontecimentos. A necessidade de objetificar questões e problemáticas, objetivos e metodologias, nos forçou a dar sentido a um conjunto ainda pouco ordenado de dados, fatos, experiências, encontros, documentos etc., vivenciados e construídos em diversos espaços, étnicos e institucionais, nas múltiplas, 
concomitantes e, por vezes, contraditórias condições de pesquisador, gestor público, professor, indigenista e assessor técnico dos processos museológicos indígenas.

Os fundamentos da formulação conceitual aqui proposta andam na contramão de uma "slavish adherence to the protocols of positivist methodology" (Ingold, 2014, p.384), na medida em que acreditamos ser "preciso desdogmatizar a metodologia e estimular a criatividade..." (Pires, 2010, p.44). O horizonte semântico desta abordagem requer, inevitavelmente, que esteja incorporada como parte da análise a interação entre antropólogo e nativo na construção da realidade social na qual o objeto é selecionado. Além da relação entre dados/evidências/ argumentos, refletir hoje sobre critérios de cientificidade e as formas de validação para o conhecimento antropológico se tornou um exercício importante e parte imprescindível na prática de uma antropologia reflexiva.

As questões teórico-metodológicas aqui postas surgiram do acúmulo de reflexões sobre as contínuas experiências junto aos processos museológicos indígenas nas variadas instâncias onde ocorreram (aldeias, espaços e órgãos públicos, escolas, universidades, movimento indígena etc.) - com uma definição crescente dos museus indígenas como objeto de estudos antropológicos. Estudos que avançam para além de abordagens culturalistas, estruturais ou funcionais, como atestam uma série de análises que redirecionam esforços para a compreensão dos "empréstimos e apropriações culturais, resultantes de situações de contato e das redes de troca" (Velthen, 2012, p.56). Se "A tarefa da antropologia agora é a indigenização da modernidade" (Sahlins, 1997a, p.53), acreditamos que por meio desses museus se constrói uma "antropologia nativa" (Abreu, 2007) que antropofagiza meios, técnicas e processos de representação, cujos resultados são os diversos modos de apropriação e gestão indígena do patrimônio cultural e da memória social.

A perspectiva de compreender os processos de autorrepresentação nos direciona ao estudo da visão indígena sobre si e, consequentemente, sobre sua história e os sentidos que possuem suas memórias. 0 sentido atribuído aos objetos e memórias, quando ressignificados no colecionamento praticado nos museus indígenas, é produto de uma estratégia retórica que textualiza a experiência sobre si, reordenando discursos de poder representacional e estabelecendo contranarrativas (Gomes, 2012).

Quais as especificidades dos museus indígenas? Se, por um lado, é necessário certo distanciamento para a compreensão dos processos sociais, por outro, não há estudo da realidade sem aproximação, interesse, vinculação e envolvimento. Não ser neutro "não implica, no contexto dessa combinação particular, pôr-se a reboque do grupo ou aceitar tudo a partir de um ponto de vista determinado ... objetivação não é incompatível com a participação, mas somente com a participação apologética” (Pires, 2010, p.83). Afinal, como afirmava Simmel, já em 1908, "A objetividade não se define em nenhum caso como ausência de participação; senão, nós estaríamos completamente fora da relação, seja ela objetiva ou subjetiva. Ela é um tipo particular de participação..." (apud Pires, 2010a, p.82-83).

À guisa de provocação final, uma pergunta fundamental: é possível falar do surgimento de uma "museologia indígena” no Brasil?

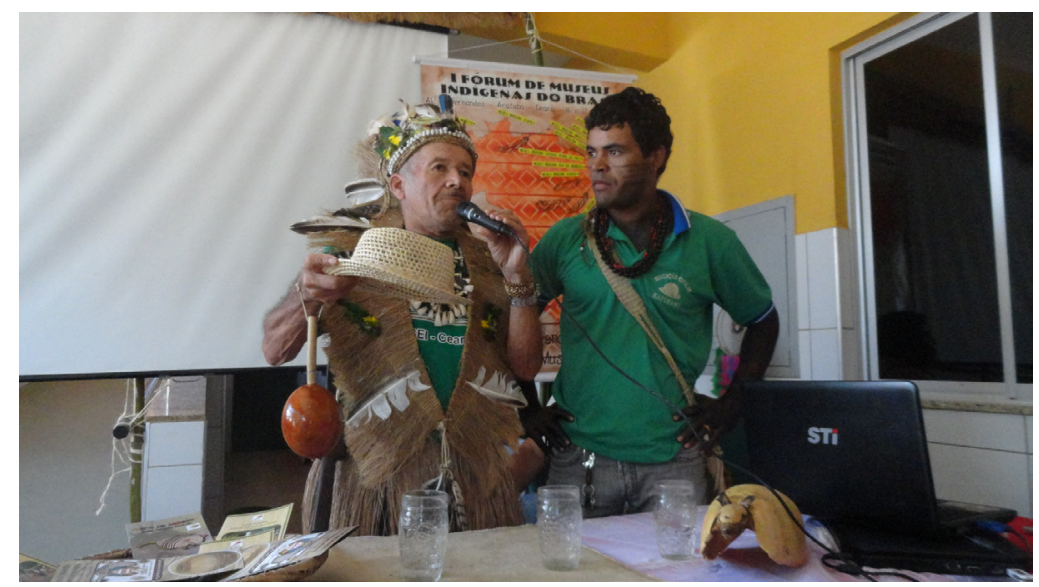

Foto 1 - Cacique Sotero e Ronaldo Siqueira trocam objetos Kanindé e Kapinawá (I Fórum Nacional de Museus indígenas), 2015. Foto: Alexandre Oliveira Gomes. 

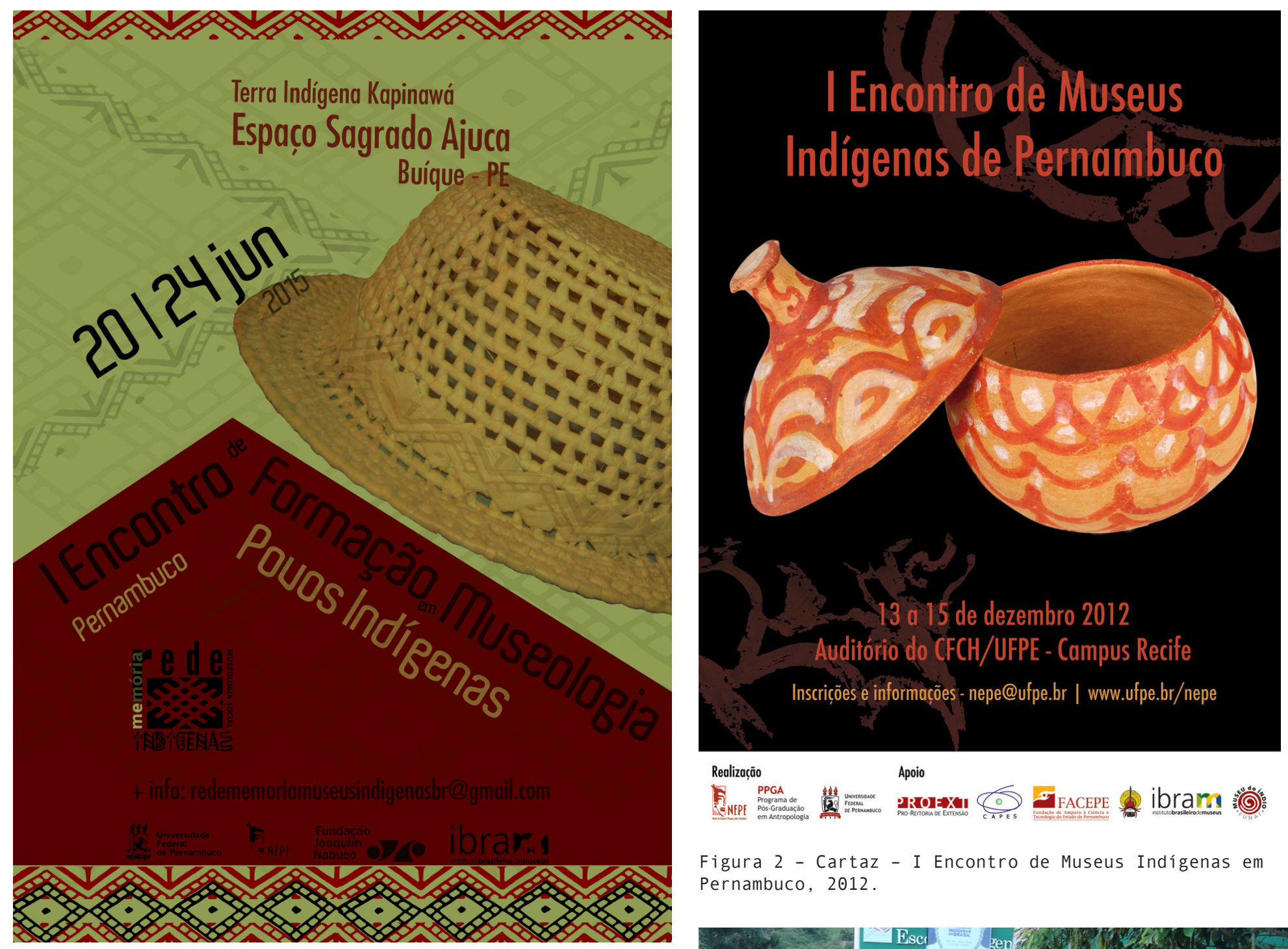

Realização

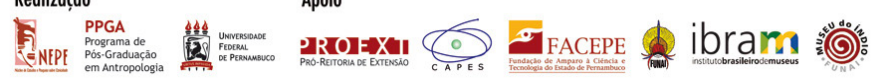

Figura 2 - Cartaz - I Encontro de Museus Indígenas em Pernambuco, 2012

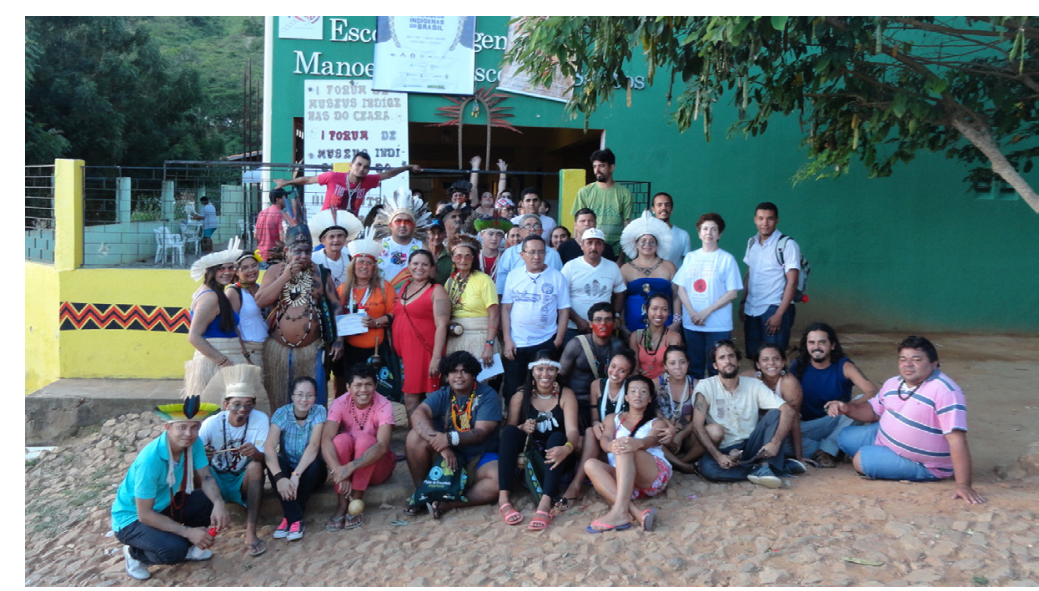

Figura 1 - Cartaz - Formação em Museologia para povos indígenas, Pernambuco, 2015.

Foto 2 - Fórum de Museus Indígenas, Aratuba, Ceará, 2015. Foto: Acervo Alexandre Oliveira Gomes. 


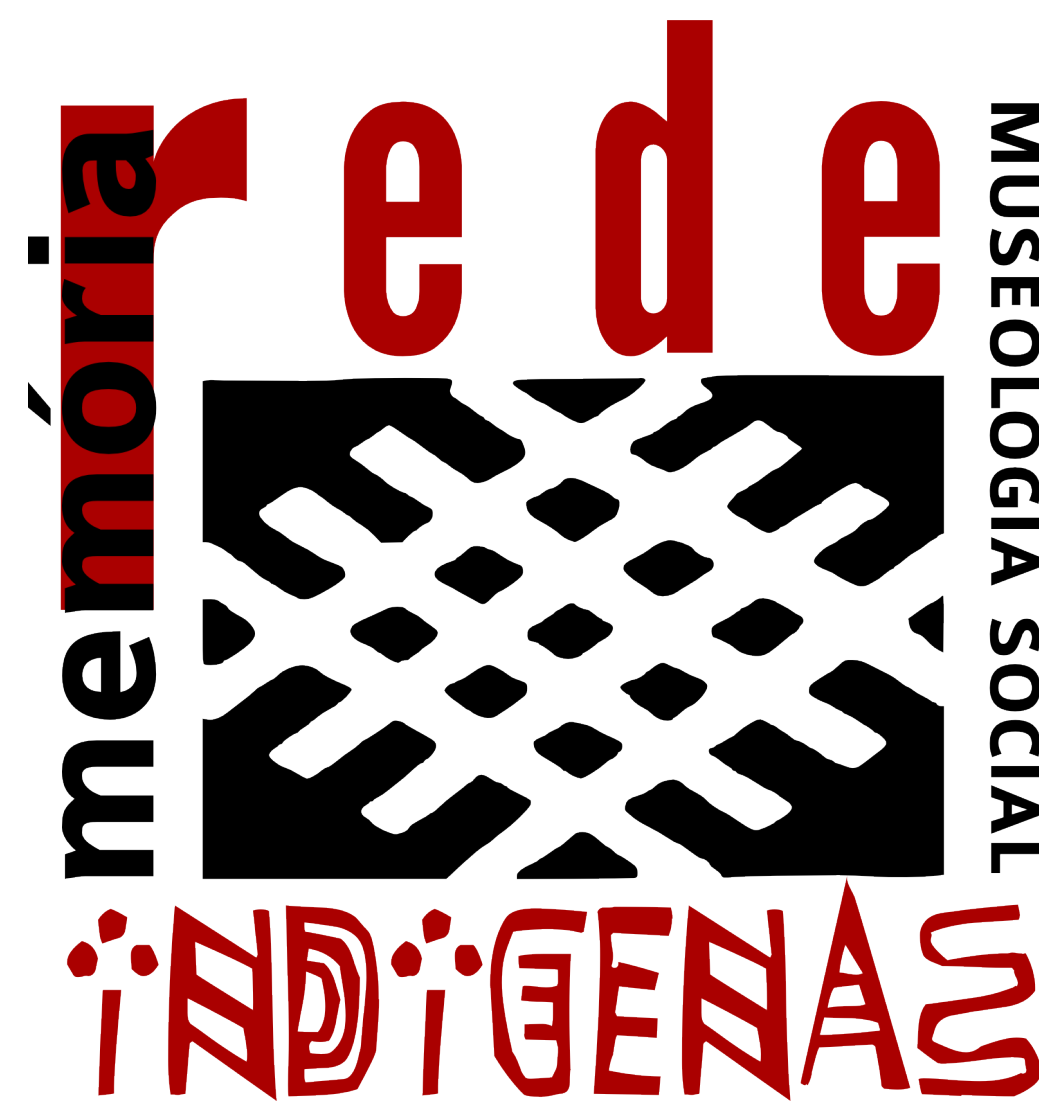

Figura 3 - Logomarca da Rede Indígena.
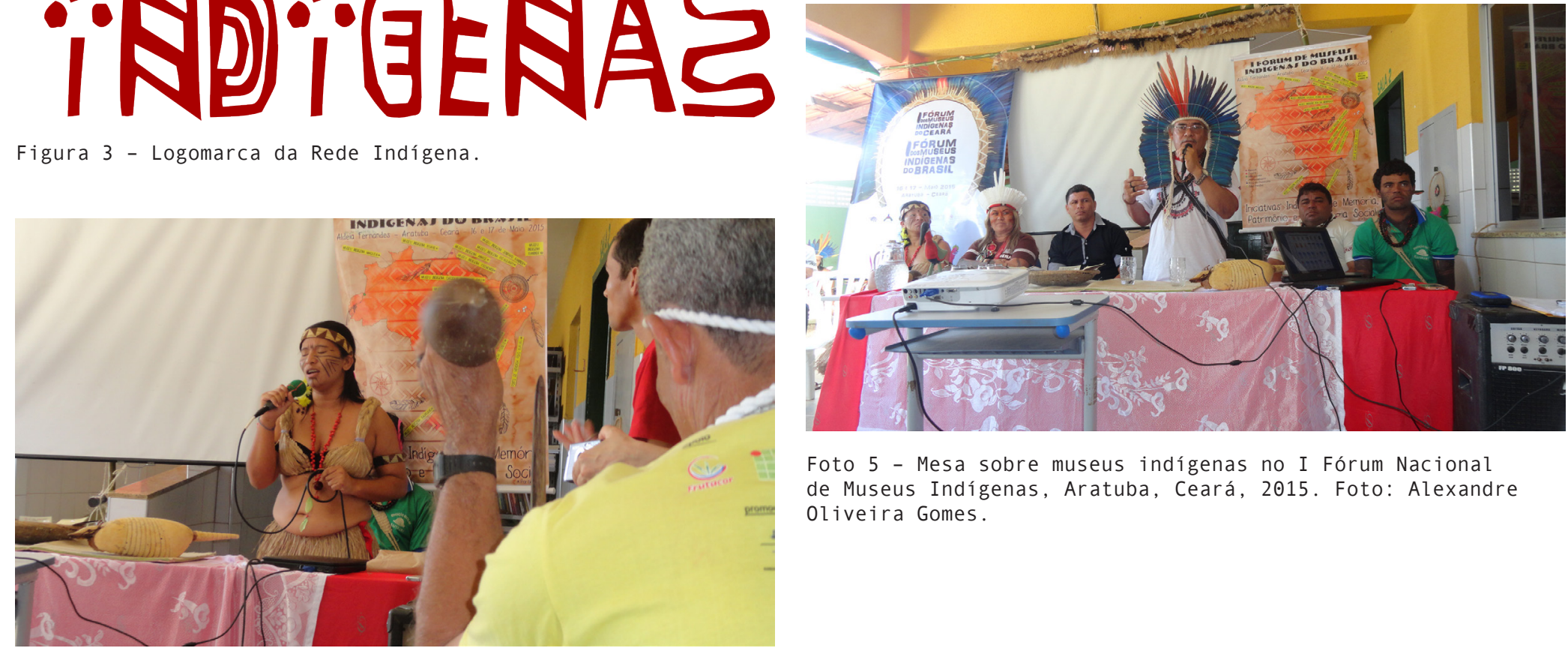

Foto 5 - Mesa sobre museus indígenas no I Fórum Nacional de Museus Indígenas, Aratuba, Ceará, 2015. Foto: Alexandre Oliveira Gomes.

Foto 3 - Lucilene de Melo, Kaingang de São Paulo, palestrando no I Fórum Nacional de Museus Indígenas, 2015. Foto: Alexandre Oliveira Gomes. 


\section{Povos e Museus Indigenas em Pernambuco}

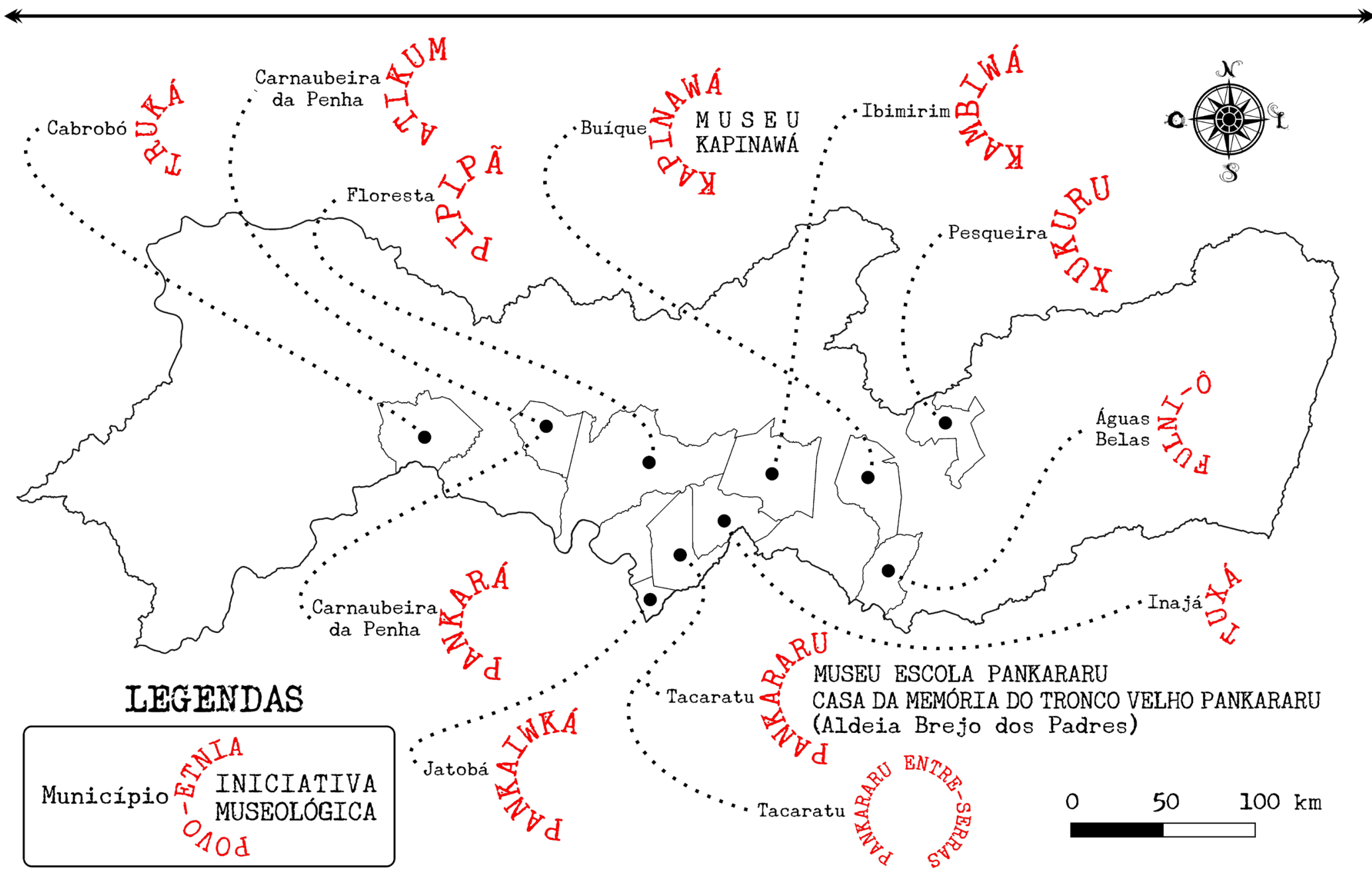

Mapa 1 - Museus e povos indígenas em Pernambuco. 


\section{Povos Indigenas no Ceará:}

\section{Organização, Memória e Luta}

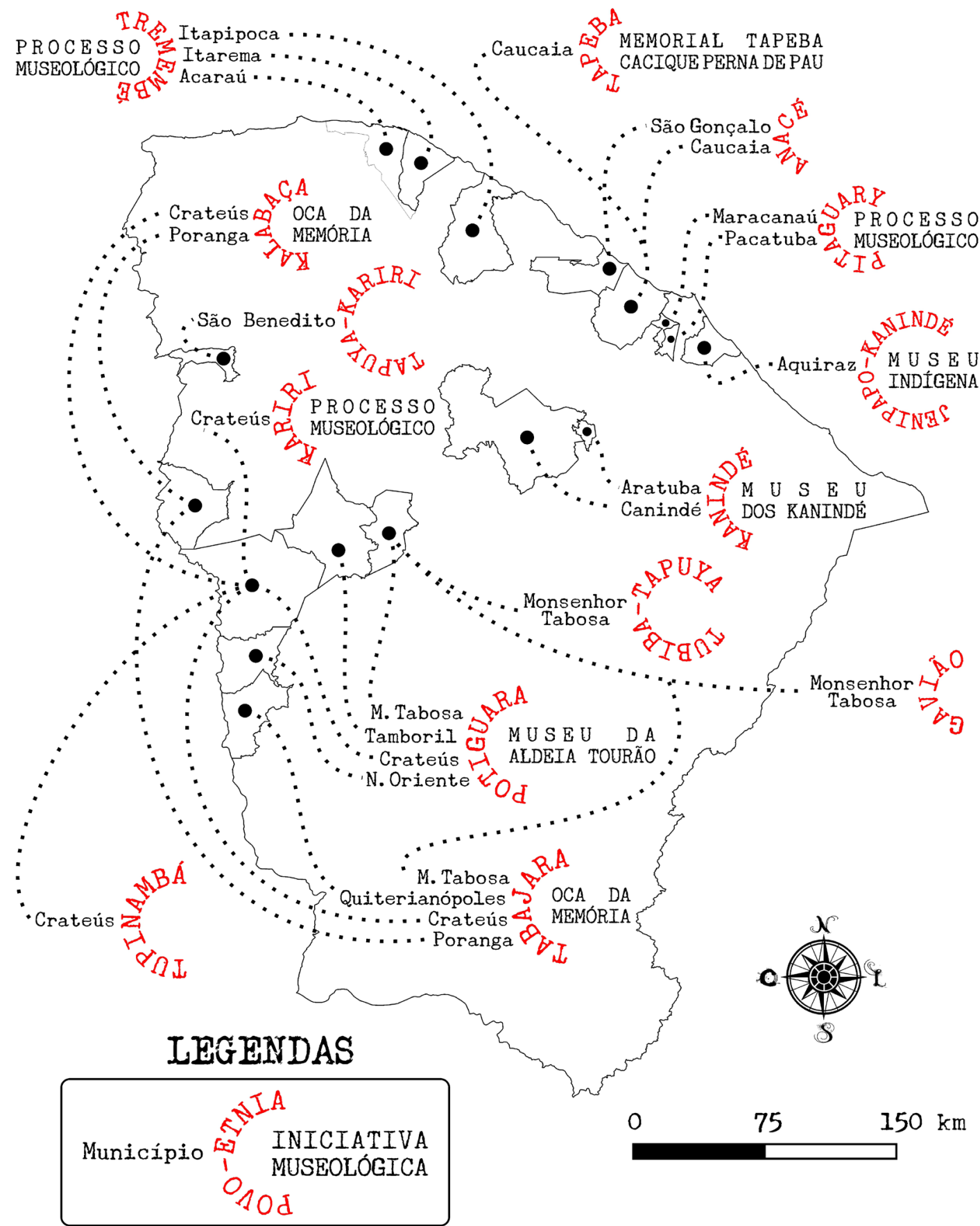

Mapa 2 - Museus e povos indígenas no Ceará.

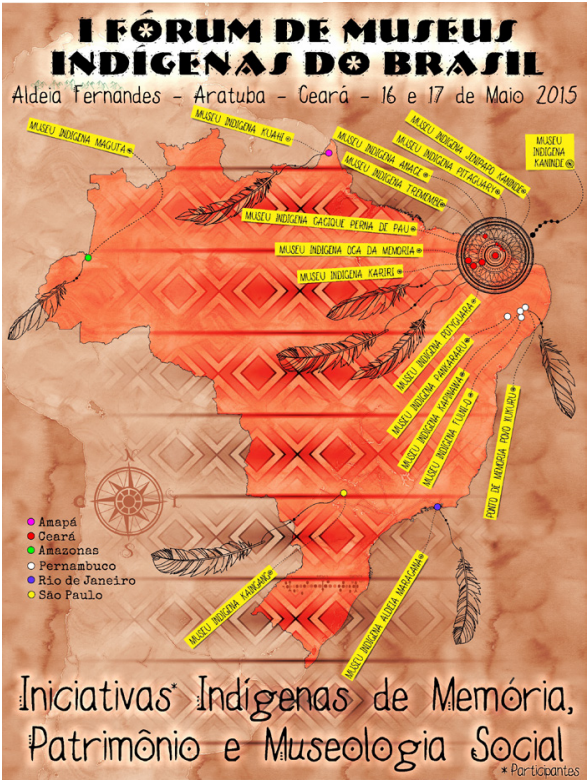

Figura 4 - Cartaz do I Fórum de Museus Indígenas do Brasil, 2015 


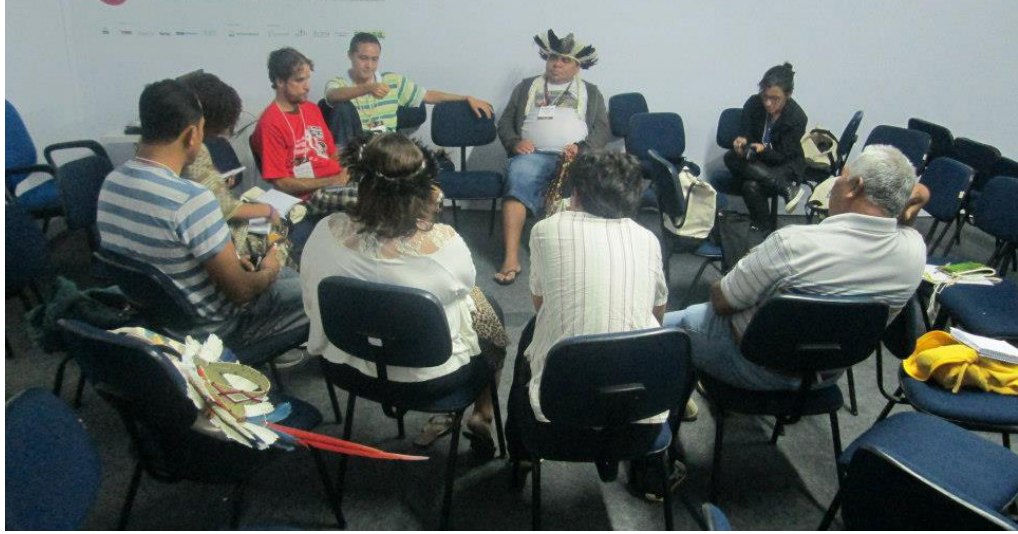

Foto 6 - Reunião no Fórum Nacional de Museus: representantes de Museus Indígenas do Brasil, 2013. Foto: Acervo Alexandre Oliveira Gomes.

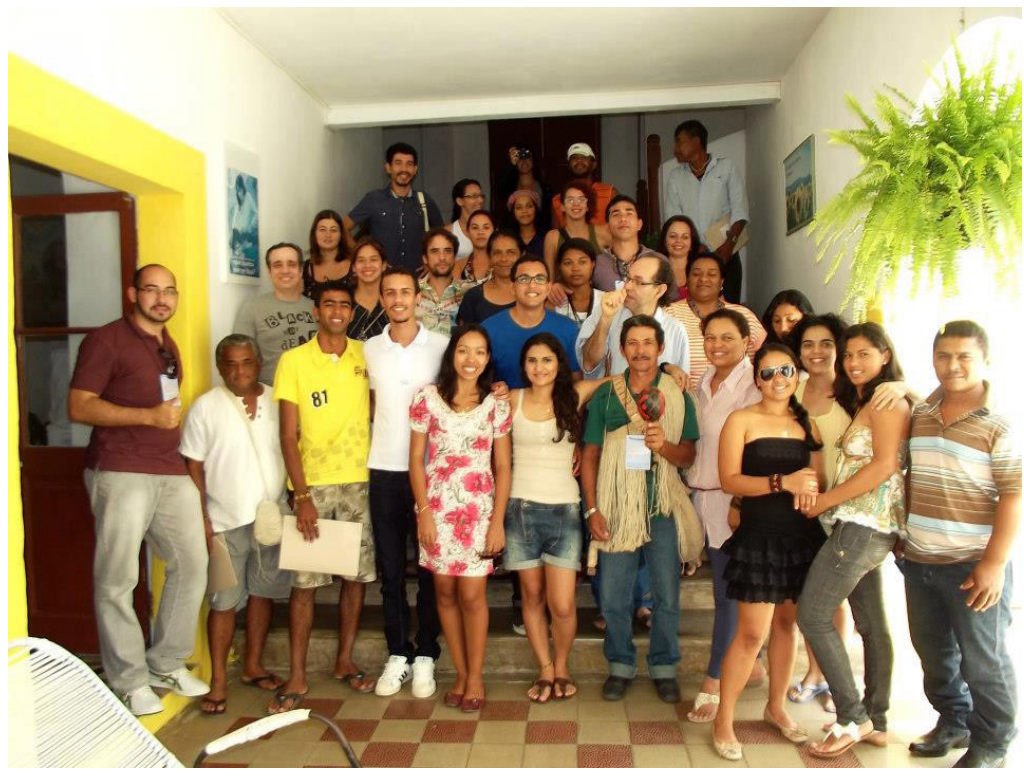

Foto 7 - Seminário de planejamento: Projeto Museus indígenas em Pernambuco, outubro de 2011. Foto: Acervo Alexandre Oliveira Gomes.

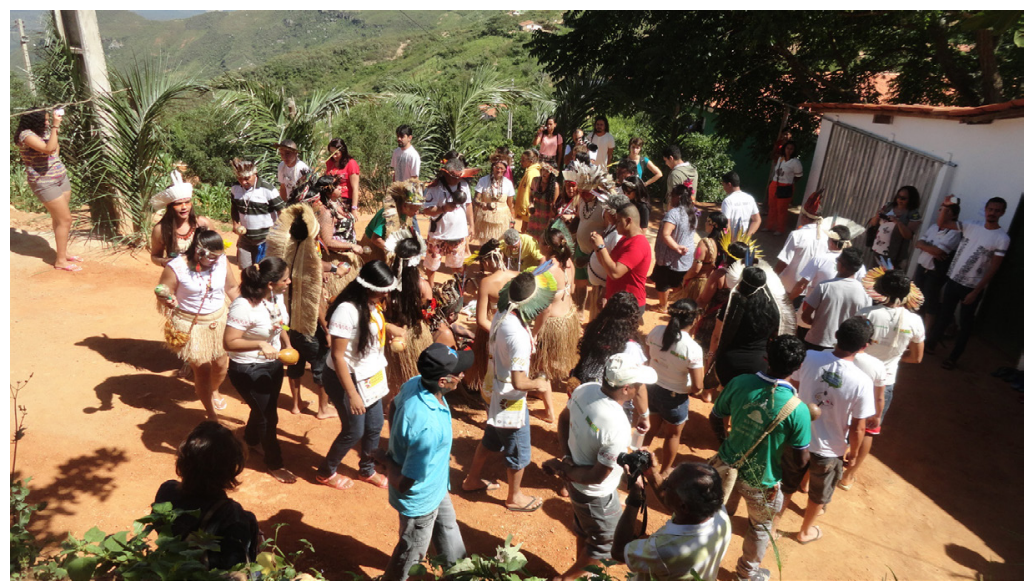

Foto 8 - Toré de abertura do I Fórum de Museus Indígenas do Brasil, Aratuba, Ceará, maio de 2015. Foto: Alexandre Oliveira Gomes.

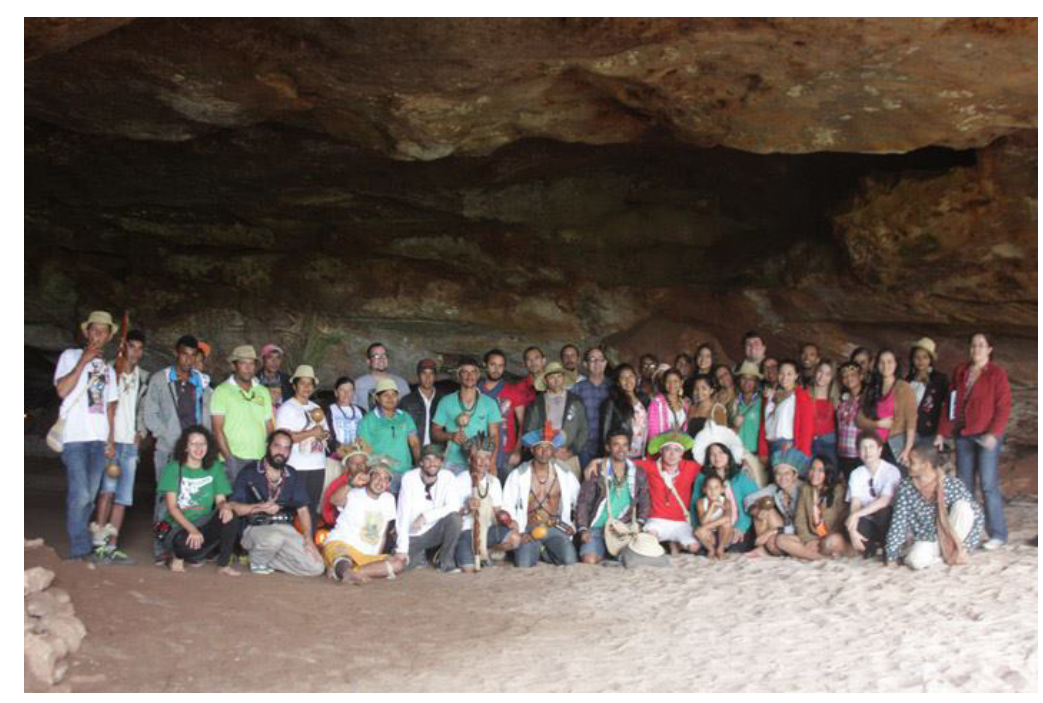

Foto 9 - Reunião da rede indígena no I Encontro de formação em Museologia para indígenas em Pernambuco, julho de 2015. Foto: Juliana Ferreira.

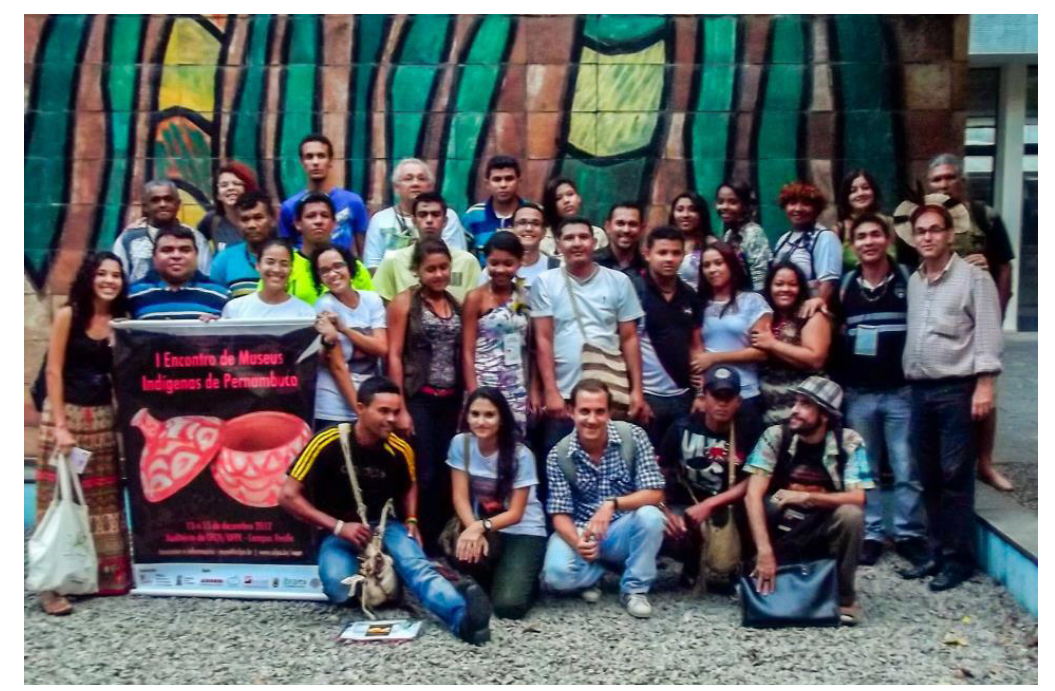

Foto 10 - I Encontro de Museus Indígenas em Pernambuco,

dezembro de 2011 (Museu do Homem do Nordeste). Foto: Acervo Alexandre Oliveira Gomes. 


\section{Referências}

ABREU, Regina. Museus indígenas no Brasil: notas sobre as experiências Tikuna, Wajãpi, Karipuna, Palikur, Galibi Marworno e Galibi Kali'na. In: FAULHABER, Priscila et al. (Org.) Ciências e fronteiras. Rio de Janeiro: Mast, 2012. p.285312 .

Tal antropologia, qual museu? In: ABREU, Regina; CHAGAS, Mário de Souza (Org.) Museus, coleções e patrimônios: narrativas polifônicas. Rio de Janeiro: Garamond; Minc/Iphan/Demu, 2007. p.138-178.

BARTH, Fredrik. Enduring and emerging issues in the analysis of ethnicity. In: VERMEULEN, Hans; GOVERS, Cora (Org.) The anthropology of ethnicity: Beyond Ethnic Groups and boundaries. Amsterdam: Het Spinius, 2000. p.11-32.

CLIFFORD, James. A experiência etnográfica: antropologia e literatura no século XX (org. José Reginaldo dos Santos Gonçalves). Rio de Janeiro: Ed. UFRJ, 2011.

Museologia e contra-história: viagens pela costa noroeste dos Estados Unidos. In: ABREU, Regina; CHAGAS, Mário (Org.) Memória e patrimônio: ensaios contemporâneos. Rio de Janeiro: Lamparina, 2009. p.254-302.

FELDMAN-BIANCO, Bela (Org.) Antropologia das sociedades contemporâneas. São Paulo: Ed. Unesp, 2010.

FREIRE, José Ribamar Bessa. A descoberta do museu pelos índios. IN: ABREU, Regina; CHAGAS, Mário (Org.) Memória e patrimônio: ensaios contemporâneos. Rio de Janeiro: Lamparina, 2009.

GOMES, Alexandre Oliveira. Aquilo é uma coisa de índio: objetos, memória e etnicidade entre os Kanindé do Ceará. Dissertação (Mestrado em Antropologia) - Universidade Federal de Pernambuco. Recife, 2012.

Por uma antropologia dos museus indígenas: experiências museológicas e reflexões etnográficas. In: CURY, Marília Xavier (Org.) Museus e indígenas: saberes e ética, novos paradigmas em debate. São Paulo: Secretaria da Cultura: ACAM Portinari: Museu de Arqueologia e Etnologia da Universidade de São Paulo. p. 133-155.
.; VIEIRA NETO, João Paulo. Museus e

memória indígena no Ceará: uma proposta em construção. Fortaleza: Museu do Ceará, 2009. .; VIEIRA NeTO, João Paulo. A Rede

Cearense de Museus Comunitários: processos e desafios para a criação de um campo museológico autônomo. In: CHAGAS, Mário (Ed.) Cadernos do Ceom, Chapecó: Unochapecó, ano 27, n.41, Museologia Social, p.389-413, 2014.

HANKS, William; SEVERI, Carlo. Translating worlds: the epistemological space of translation. Hau: Journal of Ethnographic Theory, Edinburgh: University of Edinburgh/ School of Social and Political Sciences v.4, n. 2, 2014.

HANNERZ, Ulf. Explorando a cidade: em busca de uma antropologia urbana. Petrópolis: Vozes, 2015.

INGOLD, Tim. That's enough about ethnography! Hau: Journal of Ethnographic Theory, Edinburgh: University of Edinburgh/School of Social and Political Sciences, v.4, n.1, p.383-395, 2014.

MENESES, Ulpiano Teixeira Bezerra de. A problemática da identidade cultural no museu: de objetivo (da ação) a objeto (do conhecimento). Anais do Museu Paulista, São Paulo: Museu Paulista, Nova Série, n.1, p.207$222,1993$.

OLIVEIRA, João Pacheco de. Ensaios de Antropologia Histórica. Rio de Janeiro: Ed. UFRJ, 1999.

A refundação do Museu Magüta: etnografia de um protagonismo indígena. In: MAGALHÃES, Aline Montenegro; BEZERRA, Rafael Zamorano (Org.) Coleções e colecionadores: a polissemia das práticas. Rio de Janeiro: Museu Histórico Nacional, 2012. p.201-218.

- (Org.) A presença indígena no Nordeste: processos de territorialização, modos de reconhecimento e regimes de memória. Rio de Janeiro: ContraCapa, 2011.

(Org.) A viagem de volta: etnicidade, política e reelaboração cultural no nordeste indígena. Rio de Janeiro: ContraCapa; Laced, 2004 .

PIRES, Álvaro. Sobre algumas questões epistemológicas de uma metodologia geral para 
as ciências sociais. In: - A pesquisa qualitativa: enfoques epistemológicos e metodológicos. Petrópolis: Vozes, 2010. p.4394.

SAHLINS, Marshall. 0 'pessimismo sentimental' e a experiência etnográfica: por que a cultura não é um 'objeto' em via de extinção (parte I). Mana - Estudos de Antropologia Social, Rio de Janeiro: Programa de Pós-Graduação em Antropologia Social do Museu Nacional (PPGASMN), UFRJ, v.3, n.1, p.103-150, 1997a.

SCHEINER, Tereza. Repensando o Museu Integral: do conceito às práticas. Boletim do Museu Paraense Emílio Goeldi - Ciências Humanas, Belém: MCTI/ Museu Paraense Emílio Goeldi, v.7, n.1, p.1530 , jan./abr. 2012.

TOLEDO, Renata Ferraz de; JACOBI, Pedro Roberto. Pesquisa-ação e educação: compartilhando os princípios na construção de conhecimentos e no fortalecimento comunitário para o enfrentamento de problemas. Revista Educação e sociedade, Campinas: Unicamp, v.34, n.122, p.155-173, 2013.

VARINE, Hugues de. As raízes do futuro: o patrimônio a serviço do desenvolvimento local. Porto Alegre: Medianiz, 2012.

VELTHEN, Lúcia Hussak Van. 0 objeto etnográfico é irredutível? Pistas sobre novos sentidos e análises. Boletim do Museu Paraense Emílio Goeldi. Ciências Humanas, Belém: MCTI/MPEG, v.7, n.1, p.51-66, jan./abr. 2012.

VIDAL, Lux Boelitz. 0 museu dos povos indígenas do Oiapoque - Kuahí. Gestão do patrimônio cultural pelos povos indígenas do 0iapoque, Amapá. In: BRUNO, Maria Cristina Oliveira; NEVES, Kátia Regina Felipini (Org.) Museus como agentes de mudança social e desenvolvimento. Propostas e reflexões museológicas. São Cristóvão: Museu de Arqueologia do Xingó, 2008. p. $173-182$.

\section{Documentos}

Políticas públicas para o patrimônio, a memória e os museus dos grupos étnicos e tradicionais do Ceará - Documento Final do Seminário emergência étnica: índios, negros e quilombolas construindo seus lugares de memória no Ceará, 2009

Documento Final do I Encontro de Museus Indígenas em Pernambuco, 2012

Documento Final do Seminário Gestão de Acervos Culturais em Centros de Formação, de Documentação, de Cultura e Museus Indígenas no Brasil, 2013

Documento Final do II Encontro de Museus Indígenas em Pernambuco, 2014

Documento Final do IV Encontro Paulista questões indígenas e Museus, 2015

Documento Final do I Encontro de Formação em museologia para povos indígenas em Pernambuco, 2015

\section{Sites}

http: //WwW.world-interactions.eu/article-museesindigenes-du-ceara-114307857.html

http://bd.trabalhoindigenista.org.br/sites/ default/files/2014\%20Documento\%2OF inal\%20 Semin\%C3\%A1rio\%20Acervos.pdf

http: //museuscomunitarios.files.wordpress.com

http: //pankararunacaocultural.blogspot.com.br/

https://WWw. facebook.com/rimemusbrasil

\begin{abstract}
* Alexandre Oliveira Gomes é mestre em Antropologia e doutorando no Programa de Pós-Graduação em Antropologia da Universidade Federal de Pernambuco (UFPE). Atua na Licenciatura Intercultural Indígena e no Núcleo de Estudos e Pesquisas sobre Etnicidade (Nepe) na UFPE.
\end{abstract}




\title{
Politique, représentation et dialogue aux Musées de la Civilisation: Premiers Peuples et muséologie autochtone au Québec
}

\author{
Jean Tanguay \\ Chargé de recherche, Les Musées de la Civilisation
}

De nos jours, le Québec compte près de 90000 autochtones répartis au sein de 11 nations distinctes: les Waban-Aki, les Anishinabeg, les Atikamekw Nehirowisiwok, les Eeyou (Cris), les Hurons-Wendat, les Innus, les Inuit, les Wolastoqiyik (Malécites), les Mi’gmaq, les Kanien'kehà:ka (Mahowks) et les Naskapis.

Avant de discuter des relations que les Musées de la Civilisation ont développées avec ces peuples par le biais de la muséologie, il me semble important de retracer brièvement leurs trajectoires historiques afin que vous puissiez en connaître un peu plus sur ces autres réalités autochtones nord-américaines.

\section{Rappel historique}

Comme vous le savez tous, l'histoire des Autochtones du Québec ne débute pas à l'arrivée des Européens au XVIe siècle. En fait, lorsque surviennent les contacts initiaux, cela fait plus de 11000 ans que des cultures migrent, se développent et se déploient graduellement dans toutes les régions du territoire. Libéré de ses glaces et de ses mers postglacières, ce territoire québécois deviendra hospitalier pour une diversité de groupes plus ou moins nombreux venus essentiellement du Maine (É-U), de l'Ontario et des Maritimes. Cette période historique plusieurs fois millénaire et qualifiée de "préhistoire" - ce qui laisserait entendre l'absence de l'histoire avant l'arrivée des Européens -, appartient donc à la trame historique la plus longue et encore largement méconnue de l'histoire du Québec. Nous sommes en présence d'un territoire habitable et habité par des populations qui prennent racine et présentent des caractéristiques culturelles variées. Très tôt, ces premiers occupants exploitent les ressources régionales et savent tirer profit des matières premières locales pour mener un mode de vie reposant sur la chasse, la pêche, la cueillette et, éventuellement, sur les activités agricoles. Le commerce n'est pas davantage introduit par le contact entre l'Ancien et le Nouveau Monde. Des réseaux d'échanges pré-contact sont bel et bien existants. Avec la colonisation du territoire et l'augmentation de la population, des traditions d'alliances animent bientôt les rapports entre ces peuples premiers, tout comme les conflits qui prennent forme bien avant le $X V I^{e}$ siècle. Bref, l'Européen n'a pas créé le Québec qui, depuis des millénaires, est un territoire autochtone riche et diversifiée.

\section{Et vinrent les premières îles flottantes: premiers contacts et premières alliances}

Il y a maintenant plus de 400 ans, les premiers occupants du Québec ont été les témoins de nouvelles migrations de peuples venus d'un autre continent. Normands, Basques, Français, Hollandais, Anglais, ont tous navigué avec le désir d'exploiter des ressources et souvent découvrir de nouvelles contrées aux multiples richesses. Les pêcheurs de morue et les chasseurs de baleine qui, les premiers, prirent connaissance de la nature du continent chargèrent leurs cales de navires des premiers biens nécessaires pour se procurer les fourrures des premiers occupants. À la recherche d'un nouveau passage vers l'Asie, les Français découvrirent 
un continent avec quantité de peuples dispersés sur un vaste territoire. Les mandataires officiels du roi établirent parfois maladroitement

les premiers échanges politiques. Négoce et diplomatie menèrent aux premières alliances franco-amérindiennes au début du XVIIe siècle. Les peuples premiers y virent l'occasion de se procurer de nouvelles curiosités qu'ils ne pouvaient le plus souvent reproduire, en plus de s'allier de nouveaux partenaires puissants dans leurs conflits nord-américains. Ils ne mesuraient peut-être pas pour autant l'impact que pourraient avoir ces premières alliances sur le destin de leurs nations. Les Européens, après les expérimentations du XVI e siècle, comprirent l'importance de s'allier les premiers occupants du pays pour explorer le continent, puis prétendre à une nouvelle souveraineté aux yeux des autres puissances européennes. Cela mena à la fondation d'une "nouvelle" France en Amérique. Aussi, ils crurent faire cuvre humanitaire en professant la foi au christianisme via l'action missionnaire. Commerce, exploration, colonisation et maintien d'un nouvel empire français en terre américaine motivèrent le renouvellement et la multiplication des alliances, et ce, tout le long des XVII e ${ }^{\mathrm{e}}$ XVIII e siècles.

\section{Des alliances qui ne sont pas sans conséquence}

C'est à partir de ces relations diplomatiques initiales que l'Européen et l'Amérindien s'engagent dans la négociation d'un destin commun. Ces rapports qui, à l'origine, se développent dans le cadre d'une logique et d'une pratique diplomatique amérindienne ne seront pourtant pas sans conséquence, à la fois pour les Français devenus Canadiens et les peuples autochtones. Des facteurs démographiques, les orientations économiques et la connaissance amérindienne du continent invitent à la négociation culturelle, ce qui impose aux nouveaux venus une adaptation à la réalité nord-américaine. Le territoire et ses ressources ainsi que la proximité des premiers occupants engendrent un phénomène important de canadianisation. Mais tout cela ne fera pas disparaitre pour autant les aspirations impériales de la France et des autorités coloniales. Modeler les esprits et les âmes par l'action missionnaire, intervenir dans l'ordre juridique par le pouvoir politique ne sont que quelques-unes des manifestations qui traduisent la volonté d'imposer d'importants traits de la culture européenne au sein des communautés amérindiennes, mais aussi, et dans une moindre mesure, chez les Inuit à compter du XVIIIe siècle. Épidémies, guerres, divisions, acculturation, migrations sont autant de mots qui évoquent les conséquences des alliances sur le destin de quantité de peuples. Les rêves d'empires bousculent et renversent ainsi le pays.

\section{De nouveaux alliés qui ne parlent pas le même langage}

L'histoire de L'Amérique du Nord-Est aux XVII et XVIII siècles est marquée par la transposition sur la scène coloniale des rivalités entre puissances européennes sur le vieux continent. La France et l'Angleterre souhaitent étendre leur prétention-souveraine sur le sol américain, et cela se traduit par de nombreux conflits auxquels participent les nations amérindiennes alliées. La Guerre de Sept Ans sera décisive à cet égard puisque les Britanniques vont finalement faire la conquête de la Nouvelle-France en 1760 . Les rapports que ces derniers établirent alors avec les anciens alliés amérindiens des Français auront des retombées importantes sur le plan politique et administratif. La période qui s'étend de 1760 à 1812 est d'abord marquée, de manière parfois hésitante et maladroite, par la transposition de la politique française à l'endroit des Autochtones, mais pour un temps seulement. Cela se traduit notamment par la conclusion de traités entre les autorités coloniales et amérindiennes au moment de la conquête, mais aussi par la poursuite du commerce et le maintien de la remise des présents du roi. Les Britanniques définissent toutefois une nouvelle approche basée sur la gestion administrative et bureaucratique des affaires indiennes puisqu'un agent agira dorénavant à titre de médiateur, en plus de recevoir les doléances des Autochtones.

La redéfinition des rapports historiques entre les autorités coloniales et le monde autochtone 
marquera d'une façon encore plus significative le XIXe siècle amérindien. Pour des raisons démographiques, la perte progressive du statut d'allié militaire et surtout la colonisation et l'exploitation des ressources forestières en territoire autochtone, s'ouvre une nouvelle ère durant laquelle le sort des premiers occupants allait être débattu sur bien des tribunes. Commissions, actes, débats, lois se feront parallèlement aux premières pétitions et revendications émanant des représentants autochtones. Tout ce processus aboutira à la création des premières réserves et l'adoption de la loi sur les Indiens en 1876. Les anciens alliés deviendront ainsi pupilles de l'État et les anciens présents seront dorénavant distribués à titre d'assistance publique. Il s'agit d'un siècle de dépossession et de mainmise de l'État sur le destin des Autochtones.

\section{Rallumer le feu}

L'expérience vécue au XIXe siècle marquera profondément les sociétés autochtones du Québec. Par la loi sur les Indiens, l'État fédéral canadien agit en quelque sorte comme si les Autochtones étaient des enfants et qu'il fallait encadrer toutes les sphères de leur existence. Cette mesure législative impose notamment un régime de tutelle définissant l'identité et l'appartenance nationale. Le gouvernement fédéral poursuivait ainsi une politique d'assimilation qui visait à faire des Autochtones des "citoyens ordinaires", ce qui était perçu, sur le plan idéologique du XIXe siècle, comme une action positive et quasi messianique. Les bancs rigides des écoles-pensionnats seront l'un des principaux moyens mis de l'avant pour "tuer l'indien dans l'indien" et ce, avec l'assistance des communautés religieuses qui croyait faire cuvre humanitaire. Les Amérindiens et les Inuits ont dû apprivoiser cette nouvelle réalité, faire les constats qui s'imposent et réagir. La première partie du $X X^{e}$ siècle est, à cet égard, une période de réveil où des leaders autochtones voudront rallumer le feu et lutter contre les politiques d'assimilation, afin de survivre en tant que peuples et de retrouver une participation active au sein de la réalité canadienne. La création d’organisations politiques, les jugements de cour, les revendications territoriales, les représentations sur la scène nationale et internationale, sont autant de démarches et moyens visant à rétablir les rapports historiques. Ces mouvements d'affirmation se poursuivent également sur le plan social et culturel, mais ils ne suffisent pas à faire disparâ̂tre les problèmes sociaux qui trouvent leurs principales racines dans le livre noir du XIXe siècle. L'autonomie politique et économique apparâ̂t comme la solution, ce qui passe d'abord par un processus de guérison. Tous s'entendent aussi sur la nécessité de se doter d'une assise territoriale, d'abolir la loi sur les Indiens, mais il reste à définir le cadre nouveau et les orientations que l'on souhaite pour l'avenir.

\section{Les Musées de la Civilisation et l'autochtonie}

Ouvert au public en 1988, le Musée de la Civilisation, un musée d'État québécois, a reçu le mandat de développer la collection ethnographique nationale et de diffuser la diversité des composantes de la réalité québécoise au pays et à l'étranger. Quatre autres lieux de diffusion et de conservation lui ont été confiés au fil des années, formant aujourd'hui un complexe muséal nommé les "Musées de la Civilisation".

Depuis plus de vingt-cinq ans, les Musées de la Civilisation initient, entre autres choses, des projets de diffusion visant à mieux faire connaître la diversité des réalités autochtones. Bien que l'attention et les efforts aient beaucoup porté sur une redécouverte de l'autochtonie québécoise, les regards institutionnels ont été orientés bien au-delà de nos frontières. Au cours des années, et en complète cohérence avec le projet culturel des Musées, il aura effectivement été question d'autochtonie internationale, dans le but de faire découvrir la diversité des réalités, tout comme de faire comprendre les similitudes dans 
les expériences vécues chez les Autochtones de bien des continents. Que ce soit par le biais d'expositions permanentes ou temporaires, de publications ou par de nombreuses activités éducatives et culturelles, les Musées ont su ainsi se positionner comme intermédiaires de premier plan. Leurs buts: susciter l'intérêt du public, combattre les préjugés et favoriser ainsi le dialogue entre Autochtones et allochtones.

En fait, cette volonté de créer des liens et de traiter de l'altérité autochtone prend toutes les allures d'une vocation institutionnelle. Elle a pris forme dès l'ouverture du Musée de la Civilisation en 1988 et, depuis, n'a jamais cessé d'alimenter la programmation offerte aux visiteurs. L'importance que l'institution accorde à la représentation des réalités autochtones s'exprime d'ailleurs très clairement dans sa politique en matière de relation avec les Premiers Peuples. ${ }^{1}$ Le Musée y affirme son intention:

- d'être un partenaire privilégié des peuples autochtones dans la protection et la mise en valeur de leurs identités;

- de contribuer à faire connaître les réalités, les patrimoines et les cultures des peuples autochtones et contribuer à leur rayonnement;

- de susciter la participation des groupes autochtones aux activités et aux projets du Musée de la Civilisation les concernant.

Cette politique se rattache à une initiative plus ancienne qui démontre l'engagement de l'institution envers ses partenaires autochtones. Elle a été élaborée dans le sillage d'une conférence nationale canadienne qui eut lieu à Ottawa en 1988, et au cours de laquelle les participants ont cherché à définir ce qui devait être fait pour favoriser un véritable partenariat entre les musées et les Premières Nations.

1. Politique du Musée de la Civilisation à l'égard des peuples autochtones. Musée de la Civilisation, 27 septembre 2012, p.5.

\section{Tourner la page... pour une nouvelle muséologie participative}

La Conférence Nationale d'Ottawa est considérée de nos jours comme un événement phare associé au développement de la muséologie autochtone canadienne. C'est au terme de cette rencontre que fut créé le groupe de travail sur les musées et les Premières Nations dont les activités allaient être parrainées par l'Assemblée des Premières Nations du Canada et l'Association des musées canadiens. Ce groupe composé de vingt-cinq individus, incluant plusieurs ainés autochtones, eut pour mandat de développer un cadre de travail et des stratégies éthiques permettant aux Autochtones et aux institutions culturelles de travailler ensemble pour mieux représenter l'histoire et les cultures des Premiers Peuples. $L$ 'exercice comporta des consultations régionales, la réception de nombreuses recommandations d'organismes et individus et des échanges menés lors de quatre réunions nationales du groupe de travail. Le rapport ${ }^{2}$ qui en résulte expose les enjeux et recommandations issus de ce projet. Aux fins de notre analyse, retenons les éléments suivants:

- Les liens entre l'héritage aborigène et la situation actuelle des Premières Nations doivent être démontrés et, en fait, les musées devraient devenir des forums pour la discussion des problèmes contemporains.

- Une participation accrue des Premières Nations au travail des musées est essentielle pour améliorer la représentation et l'interprétation de leur histoire et de leur culture.

- L'incorporation des Premières Nations aux équipes des musées aiderait à éduquer et à sensibiliser le personnel aux perspectives et aux philosophies autochtones aussi bien qu'aux intérêts des communautés autochtones.

2. Voir Tourner la page: Forger de nouveaux partenariats entre les musées et les Premières Nations, Rapport du Groupe de travail sur les musées et les Premières Nations, Assemblée des Premières Nations et Association des musées canadiens, Ottawa, 1992 . 
Ce rapport comporte également des recommandations quant au rapatriement d'objets, l'accès aux collections des musées, le soutien des institutions culturelles autochtones, la formation, etc.

Le contexte d'affirmation des Autochtones à l'échelle nationale et internationale contribue alors à la prise en compte de ces revendications sur le plan culturel. ${ }^{3}$ Rappelons que le dépôt du rapport se fait au lendemain de la Crise d’Oka au Québec, événement phare dans les luttes autochtones du XX siècle, et dont la médiatisation eut pour effet de ramener la "question indienne" dans l'actualité et, inévitablement sur les tables de travail des fonctionnaires. À cela s'ajoutent certains jugements de Cour qui imposent également de nouvelles façons de faire aux instances gouvernementales. La nécessité de consulter les Premiers Peuples notamment, oriente dès lors les actions gouvernementales. Les acteurs du développement culturel furent inévitablement invités à initier des démarches collaboratives avec les Premières Nations.

Au cours des années qui suivirent le dépôt du rapport, les recommandations incitèrent effectivement beaucoup d'institutions muséales à tourner la page et laisser place à une participation plus grande des Autochtones à leurs projets. Une nouvelle approche participative allait ainsi mener à quelques initiatives notables au Canada et en d'autres lieux à travers la planète. Pensons aux processus collaboratifs qui ont mené à la réalisation d'expositions à thématiques autochtones au Museum of Anthropology de Vancouver (1996), au Glenbow Museum de Calgary (2001), au National Museum of the American Indian à Washington (2004), ou encore au Melbourne Museum (2013). Parallèlement, on assiste également à l'ouverture de plusieurs institutions culturelles au sein des communautés autochtones au Québec. Il s'agit de Musées, mais aussi de centres culturels où se développe une "muséologie

3. Afin de connaître le contexte des revendications autochtones en ce qui concerne la muséologie canadienne, consulter Ruth B. Phillips, Museum Pieces. Toward the Indigenization of Canadian Museums, McGill-Queen's University Press, 2011. autochtone”. À titre d'exemple, mentionnons le Musée de Mashteuiatsh, le Musée Shaputuan de Uashat (Sept-Îles, Côte-Nord), le Musée huronwendat de Wendake, le Centre culturel des Innus (Ekuanitshit, Côte-Nord).

\section{Nous, les Premières Nations...}

Au Musée de la Civilisation, la réalisation de Nous les Premières Nations (1998-2013), la première exposition permanente consacrée aux Autochtones du Québec, s'inscrivait dans cette volonté de faire les choses autrement, en sollicitant la participation des Premières Nations et des Inuit. Le titre choisi pour cette première exposition laisse entendre que les Premiers Peuples se présentent aux visiteurs et qu'ils sont les principaux artisans de leur mise en scène. Or, la réalisation s'inscrit plutôt dans une volonté institutionnelle de représenter la diversité des réalités autochtones, en sollicitant une participation des Premières Nations et des Inuit. Le titre n'est donc pas révélateur d'une démarche de concertation impliquant les partenaires autochtones à toutes les étapes de réalisation. La concertation se distingue de la consultation en ce qu'elle ne se résume pas à une demande d'avis. Elle suppose la confrontation entre les parties, l'échange d'arguments, l'explicitation et la présentation des points de vue de chacun.

Essentiellement, cela a pris plutôt la forme d'un comité consultatif composé de représentants de différentes communautés dont le mandat fut de se réunir occasionnellement afin de se prononcer sur différentes questions soulevées par l'équipe de réalisation. Ce comité put valider entre autres certains éléments de contenu ou encore la façon dont les objets devaient être exposés en salle. Certains artisans ont également été invités à produire quelques pièces présentées dans l'exposition. C'est par le biais de ces échanges et avis qu'il fut décidé de ne pas aborder certains pans de la spiritualité traditionnelle, en l'occurrence le rituel de la tente tremblante chez les groupes algonquiens. Un premier pas était ainsi franchi de façon à donner une parole aux Autochtones et redéfinir ainsi la façon 
habituelle de réaliser une exposition sur les Premiers peuples.

L'exposition Nous, les Premières Nations eut une longue vie et, assurément un grand succès. Comme le démontrent les propos tenus par les visiteurs interrogés au terme de leur visite, cette exposition leur aura permis de découvrir des aspects qui leur étaient inconnus et d'approfondir certaines notions ou connaissances. Ceci étant dit, les propos des visiteurs nous révèlent également que l'exposition n'aura pas réussi à déconstruire les représentations négatives. Plusieurs des personnes interrogées ont répondu par la négative à la question de savoir si l'exposition avait contribué à modifier leurs représentations des Autochtones. ${ }^{4}$ La popularité du produit demeure toutefois un fait bien connu qui doit être souligné. Elle eut assurément le mérite de mettre en valeur la richesse de la culture matérielle des différentes nations autochtones du Québec ce qui est, en définitive, est une façon intéressante d'introduite le visiteur à la réalité autochtone. Le contenu textuel et les quelques entrevues diffusées sur écran permettaient également de se familiariser avec l'histoire, mais aussi certains enjeux contemporains, dont les revendications politiques et territoriales du $X X^{e}$ siècle. Pour les Premières Nations et les Inuit impliquées dans sa réalisation, Nous, les Premières Nations aura été une première réponse positive aux recommandations du rapport Tourner la page (1992). Un autre pas majeur, déterminant et même innovant allait être franchi aux fins du renouvellement de cette exposition quinze années plus tard.

\section{Quelques explorations temporaires...}

Les expositions temporaires auront également fourni des occasions de tisser des liens et de développer des collaborations avec les

4. Lucie Daignault et Pierre-Luc Collin (avec la collaboration de Geneviève Provencher-St-Cyr). Les expositions permanentes aux Musée de la Civilisation: attentes, pratiques et découvertes. Service de la recherche, de l'évaluation et de la veille muséologique, Musée de la Civilisation, 2010, p. 33 .
Autochtones. À titre d'exemple, pensons aux expositions $\mathbb{F} i l$ amérindiens, regards sur l'animal (1991); Rencontre des deux mondes (1992); Secrets d'Amazonie (1996) Iroquoiens du Saint-Laurent, peuple du mä̈s (2007). Il y a d'abord celles qui se consacre exclusivement aux Autochtones d'ici ou d'ailleurs et qui abordent une variété de sujets: cultures ancestrales, rapports coloniaux, luttes politiques, relations à l'animal, mythologie, production artistique et artisanale, portrait de femmes ou encore identités et stéréotypes. Ces expositions sont très instructives et de nature à compléter les contenus effleurés dans les expositions permanentes. En fait, elles ont la plupart du temps le défaut d'être temporaires puisque complémentaires... Il y a également ces autres expositions dans lesquelles la thématique autochtone est abordée sans en constituer le sujet principal. Pensons notamment à Imaginaires mexicains (1998), Or des Amériques (2008), Portés par le fleuve (2011). De la combinaison de toutes ces "initiatives temporaires", ressort assurément une représentation intéressante de l'autochtonie québécoise et internationale.

La volonté de traiter de l'autochtonie dans sa dimension plus internationale s'est d'ailleurs manifestée de façon récurrente. Les plus récents efforts ont été faits dans E TŪ AKE - MĀORIS DEBOUT (2012). Au fil des années, les contenus thématiques de plusieurs autres expositions ont été l'occasion d'aborder le sujet. Pensons notamment à Toundra, tä̈ga (1988), dans laquelle sont comparées des cultures autochtones au Canada et en URSS; pensons aussi à Nomades (1992) où est illustrée l'expression du nomadisme chez différents groupes à travers le monde. La diversité des réalités autochtones est ainsi mise en scène, ce qui permet de rendre compte des similitudes et des différences dans les expériences vécues.

Bref, que ce soit par la variété des thèmes abordés, la présentation d'innombrables objets et d'images de collections diverses, les expositions temporaires ont été des occasions de faire connaître des réalités autochtones du Québec, ainsi que de différents continents. Considérant que la population autochtone mondiale est 
composée de plus de 370 millions de personnes réparties dans quelque 70 pays, le sujet demeure, en définitive, inépuisable pour les Musées de la Civilisation. Au mois d'octobre 2015, nous poursuivrons cette exploration par l'exposition Lignes de vie. L'art des Autochtones d'Australie qui permettra aux visiteurs de s'imprégner à nouveau de l'univers de croyances et de l'histoire des Premiers Peuples d'un autre continent.

\section{"C'est notre histoire...", une nouvelle expérience muséale}

À compter de 2010, la décision fut prise de procéder au renouvellement de Nous, les Premières Nations. L'initiative allait être l'occasion pour les Musées de la Civilisation d'explorer une nouvelle approche afin de mieux représenter la diversité des expériences vécues par les Autochtones du Québec, à travers les millénaires. Pour ce faire, le Service des expositions et ses partenaires ont opté pour un processus collaboratif en investissant des efforts sans précédent pour susciter la participation des Autochtones, à toutes les étapes de réalisation du projet. Cette exposition devait ainsi laisser place à une variété de points de vue, notamment ceux de gens rencontrés dans les communautés, au regard de leurs réalités historiques et contemporaines. ${ }^{5}$

Le titre choisi, "C'est notre histoire, Premières Nations et Inuit au XXI ${ }^{\text {e }}$ siècle", laisse présager un contenu très affirmatif et engagé, par lequel les Autochtones présentent leur propre lecture de l'histoire, distincte de celle généralement

5. Cette nouvelle "muséologie participative" n'est pas que québécoise ou canadienne. Elle est tout autant étatsunienne qu'australienne et est en vogue au sein d'un nombre grandissant de pays. Elle résulte sans doute des revendications autochtones sur le plan culturel et, plus largement, de la reconnaissance des droits aborigènes par les grandes instances internationales. À propos des efforts d'intégration des Autochtones dans des projets d'expositions les concernant, consulter les articles suivant: Ronan, Kristine. 2014. Native Empowerment, the New Museology, and the National Museum of the American Indian. Museum \& Society. 12(1) 132-147; Witcomb, Andrea. 2014. "Regardez, écoutez, ressentez": l'exposition First Peoples au centre culturel Bunjilaka, Musée de Melbourne. Thema. La revue des Musées de la Civilisation 1: 63-106. contenue dans les livres d'histoire nationale. Qu'en est-il réellement? En fait, suivre le parcours de l'exposition c'est surtout pénétrer dans la diversité des points de vue sur une variété de thèmes, où s'entremêlent la parole autochtone et les connaissances issues des milieux académiques. C'est aussi pénétrer dans l'histoire pour mieux comprendre les enjeux contemporains. Cela passe par un dispositif parcours d'exposition - à travers lequel les visiteurs prennent connaissance de la diversité des identités nationales et régionales, de la diversité des modes de vie traditionnelle et actuelle, de la diversité des transformations culturelles, de la diversité des rapports avec les Euro-canadiens, de la diversité des conditions sociales et économiques, ou encore de la diversité des revendications. Tout cela est exposé à travers les différentes périodes de l'histoire: paléohistoire (ou préhistoire), période de contacts, période coloniale, période contemporaine, etc. L'exposition C'est notre histoire se distingue ainsi de Nous, les Premières Nations dans la mesure où les propos et témoignages nombreux des Autochtones donnent l'occasion aux visiteurs de pénétrer leurs intimités et de mieux saisir leurs lectures de l'histoire et la façon dont ils conçoivent leurs conditions d'Autochtones au XXIe siècle.

Dans C'est notre histoire, ce sont ces hommes et ces femmes qui relisent le passé, partagent le présent, mais surtout rêvent l'avenir. L'exposition s'appuie sur une riche collection. dont des cuvres contemporaines créées pour appuyer le propos. D'entrée de jeu, la section Ce que nous sommes aujourd'hui - La réserve, nos communautés plonge le visiteur dans la réalité actuelle des communautés, leurs modes de vie, leur héritage propre. Puis, Nos racines dévoile la longue traversée du territoire nordaméricain depuis 12500 ans, explicitant la grande diversité des cultures autochtones. La grande tourmente qui suit rend compte du choc des civilisations illustré par 400 ans de colonisation, de transformations et de résilience. La Décolonisation - la guérison fait état des revendications, des négociations politiques et culturelles, du combat pour la reconnaissance visant à rétablir les rapports 
historiques. Enfin, De quoi rêve-t-on pour l'avenir? porte sur les inquiétudes et les aspirations profondes de ces communautés.

Ce parcours d'exposition n'est pas révolutionnaire. Le caractère unique et distinctif de ce projet réside dans le processus même de réalisation: les Premières Nations et les Inuit n'ont pas seulement été consultés, ils furent partie prenante du concept, du choix des contenus et de la muséographie. Ce processus concertatif dura 38 mois. Les représentants désignés par chacune des Nations se sont réunis trois fois en une assemblée spéciale nommée Mamo ("ensemble", dans la langue des Atikamekw Nehirowisiwok). Ils y ont défini les attentes, la méthodologie et les thématiques. Au bout du compte, ils ont pu évaluer l'ensemble du processus.

Parallèlement, une équipe multidisciplinaire s'est déplacée dans chacune des Nations, dans des communautés, souvent distantes de centaines de kilomètres, colligeant un corpus documentaire et vidéographique exceptionnel. Les membres de l'équipe ont expérimenté les espaces et les modes de vie. Ils se sont intégrés à la vie quotidienne des communautés et ont suscité un climat de confiance, voire de confidence. Des ateliers de création furent conduits dans chaque nation et même à Québec dans les réserves des Musées de la Civilisation. En étroite collaboration avec La Bô̂te Rouge vif, le Musée a pu compter sur la participation de 500 personnes dans 18 communautés. Plus de 5000 pages de verbatim, 10000 photographies, 250 heures de vidéos constituent aujourd'hui la mémoire documentaire du processus. Des coffrets rassemblant tous les contenus colligés ont été remis à chacune des nations lors de l'inauguration.

Aborder le processus de réalisation de C'est notre histoire c'est également faire état des limites qu'imposent le médium exposition lorsqu'il est question de mettre en valeur la diversité culturelle des onze nations autochtones du Québec. Il s'agit d'un défi de taille que l'équipe de réalisation a tenté de relever tout en étant consciente des contraintes que cela devait imposer inévitablement. Il fallait donc accepter de s'en tenir aux thèmes unificateurs identifiés lors de la concertation dans les communautés, tout comme ceux issus de la recherche sur l'autochtonie. Il fallait également tenter de répondre aux souhaits des nations qui espéraient toutes voir leur propre trajectoire historique mise en espace. Enfin, il faillait surtout tenir compte des visiteurs qui ne devaient pas se sentir submergé par une masse d'informations susceptibles de leur faire perdre l'essentiel des messages que nous souhaitions tous leur transmettre.

De façon à ce que tous s'y retrouvent un peu, l'équipe de réalisation a privilégié un déploiement thématique qui reflète les expériences partagées par le plus grand nombre d'autochtones. Concrètement, le contenu met le plus souvent l'accent sur l'expérience d'une seule nation pour refléter une thématique qui concerne l'ensemble. À titre d'exemple, les transformations économiques du XIXe siècle ont pu être décrites par le développement du commerce de la vannerie chez les Waban-Aki (Abénaquis). À d'autres moments, les thèmes sont abordés sans pour autant se servir d'une expérience particulière. Un objet ou encore une cuvre d'art pouvait également suffire à illustrer un sujet.

En définitive, cette expérience muséale nous a enseigné que le médium exposition impose la plupart du temps le deuil des grands développements textuels, des thèmes que l'un jugera incontournables, de certaines précisions qui semblent à priori essentielles... Ce processus d'acceptation du fait qu'on ne peut tout dire dans une exposition concerne l'ensemble des membres de l'équipe de réalisation et, dans le cas qui nous occupe, les partenaires autochtones également. Dans ces circonstances, il faut se demander si refléter la diversité culturelle est un objectif plus réaliste que de représenter cette même diversité dans les limites parfois restreintes d'une salle d'exposition de 713 mètres. 2 Autrement dit, bien que l'exposition ait beaucoup à offrir aux visiteurs, il faut, la plupart du temps, considérer les efforts combinés de l'ensemble des médiums muséologiques (médiation culturelle et éducative, publications, colloques, etc.) pour approfondir des sujets 
aussi complexes que la diversité culturelle autochtone.

\section{L’important rôle de la médiation}

Parallèlement aux efforts investis en salle, la médiation éducative et culturelle développe des "moyens pluriels" afin de rejoindre différents publics et faire état, dans le cas qui nous occupe, de la diversité des réalités autochtones. La médiation précise souvent les contenus et élargit ainsi le champ des connaissances à transmettre aux visiteurs. Que ce soit par le biais de conférences, de projections (documentaires), de présentations artistiques, de différentes activités d'apprentissage, elle a contribué à mieux faire connaître et comprendre les cultures autochtones. L'accent a surtout été mis sur les Premières Nations et les Inuit du Québec bien que quelques activités aient été consacrées à d'autres manifestations de l'autochtonie sur la scène internationale. Des liens étroits se sont aussi développés au fil des années avec les artistes et auteurs autochtones qui ont trouvé dans nos murs l'espace de création et d'expression souhaité. La prise de parole a également été favorisée par le biais de témoignages traitant d'enjeux contemporains. Pensons notamment aux témoignages de survivants des pensionnats autochtones qui, en 2013, ont été présentés au Musée de la Civilisation; pensons aussi à la table ronde, "Les Autochtones et le Québec. Des premiers contacts au Plan Nord" (2014), consacré à l'héritage de la rencontre entre les mondes autochtones et allochtones.

\section{Objets autochtones et rayonnement culturel}

Les objets racontent, c'est un fait bien connu. Mais jusqu'à quel point leur donnons-nous la parole? Euvres humaines, ils sont assurément porteurs de sens et font rayonner les cultures au sein des institutions muséales. Ces témoins de civilisations provenant de nos collections auront sans aucun doute été les médiums les plus utilisés et les plus diffusés, aux fins de l'interprétation de la diversité culturelle autochtone d'ici et d'ailleurs. Indépendamment de leur rôle central dans une exposition thématique autochtone, les objets associés aux Premiers Peuples ont été également exposés dans bien d'autres expositions produites aux Musées de la Civilisation et ailleurs, depuis vingt-cinq ans. Lorsque les expositions abordent des thèmes qui rejoignent également les univers culturels autochtones, il est pratique courante d'insérer des objets inuit et amérindien pour en enrichir le contenu thématique et l'aspect visuel.

Les spécialistes de la conservation contribuent également à faire rayonner les cultures du Québec en essaimant les témoins matériels des Premiers Peuples en dehors de nos murs, aux fins d'une diversité de projets de mise en valeur, chapeautés le plus souvent par d'autres musées ou centres d'interprétation. Ces témoins culturels que sont les objets voyagent ainsi par prêts dans le réseau muséal national et international, ou autrement par le biais d'expositions itinérantes. Les Musées de la Civilisation ont aussi collaboré étroitement avec les Autochtones du Québec, en leur donnant accès aux collections nationales pour la réalisation de projets de mise en valeur, en plus d'être le partenaire de certaines nations dans leurs activités de collectionnement. Tout cela en poursuivant ses propres efforts d'enrichissement de la collection nationale afin qu'elle reflète la diversité des modes d'expression artistique. À ce sujet, soulignons les efforts significatifs qui ont été faits récemment par les Musées de la Civilisation pour acquérir des cuvres d'art contemporain. Cette production qui suscite de plus en plus d'intérêt auprès du public permettra de présenter des modes d'expression artistique qui traduisent l'identité et la culture des Premières Nations et des Inuit d'aujourd'hui.

Enfin, les collections de photos, estampes, tableaux, croquis, ou encore la riche collection de documents archivistiques et de livres rares et anciens servent couramment comme sources documentaires, en plus d'enrichir sur le plan visuel d'innombrables expositions, publications ou conférences consacrées aux Premières Nations et aux Inuit. De cette façon également, l'institution collabore à la recherche et à la diffusion de la diversité culturelle des Premiers 
Peuples. On se doit toutefois de constater que les moyens de diffusion de la culture matérielle et immatérielle des Autochtones se font peu en dehors des médiums traditionnels. Aussi, dans un avenir rapproché les Musées de la Civilisation devraient joindre les rangs des grandes

institutions qui ont démocratisé l'accès à leurs collections. Ces vitrines sur les objets sont de nature à satisfaire les visiteurs virtuels de toutes provenances, qu'ils soient amateurs ou spécialistes de disciplines diverses. Il s'agit d'un patrimoine collectif qui gagne en valeur, lorsqu'exposé aux yeux de l'humanité...

\section{Quelques éléments de conclusion}

Tel que nous venons de le constater, les Musées de la Civilisation ont toujours été animés par le désir de traiter de l'autochtonie et ont su mettre à la disposition des visiteurs un enseignement axé sur la découverte. Pour ce faire, l'institution a privilégié une mise en valeur dans l'espace physique du Musée, par le biais de deux expositions permanentes et de plusieurs temporaires.

Les Musées de la Civilisation souhaitent aussi poursuivre ses efforts pour une médiation participative sur le plan des idées, de la création et des activités muséales. Pour ce faire, on mise sur le maintien des relations que l'institution a su développer au cours des années avec plusieurs communautés autochtones. Celles-ci, faut-il le préciser, revendiquent plus que jamais d'avoir un mot à dire sur la mise en valeur de leur patrimoine. Cela implique notamment de laisser place à la parole et connaissance millénaire des Autochtones afin de donner un langage assurément riche à nos initiatives muséologiques.

La participation des Autochtones au processus de réalisation d'expositions est jugée nécessaire bien qu'elle bouscule les façons de faire des muséologues. Elle permet sans doute de pénétrer des univers sensibles et plus intimes qu'on peut qualifier de "révélateurs culturels". Les propos des Autochtones sur leurs réalités contemporaines ainsi que les connaissances millénaires dont ils sont souvent les dépositaires, nous invitent tout naturellement à les considérer comme des partenaires de choix dans la mise en valeur de leur patrimoine. Pour bon nombre d'autochtones, la muséologie participative est aussi perçue comme une démarche permettant de contrer une forme de colonialisme culturel. Traditionnellement, cette dernière aurait le plus souvent représenté les Premiers Peuples par le biais d'un "regard extérieur", insuffisamment imprégné de l'univers culturel des premiers concerné. Elle est motivée par l'idée que les Autochtones sont tout autant habilités que les muséologues - sinon plus - à définir ce qui doit les représenter aux yeux du public.

Mais représenter et préserver la diversité culturelle autochtone doit malgré tout reposer sur des objectifs réalistes. À priori, cela implique l'acceptation qu'on ne puisse tout dire et répondre à toutes les attentes que peuvent avoir les partenaires autochtones, les muséologues ainsi que les professionnels composant les comités scientifiques. Ceux-ci trouveront sans doute que les médiums propres à la muséologie ne peuvent répondre pleinement à la volonté d'affirmation identitaire des Premières Nations et des Inuit, tout comme ils ne peuvent représenter de manière exhaustive leur diversité culturelle, historique et actuelle; ils trouveront sans doute également que nos expositions comportent inévitablement un regard allochtone parfois déformant puisque souvent trop généralisant, mais ayant aussi l'avantage d'éviter les écueils de la partialité de certains discours.

Quoi qu'il en soit, la “nouvelle muséologie participative" n'en demeure pas moins positive et éclairante considérant qu'elle laisse place à entendre ce que l'autre veut dire et comment il souhaite être représenté. Le Musée laisse ainsi place à une nouvelle façon de faire tout en ne perdant pas de vue des objectifs qui lui sont propres. Au lendemain de cette extraordinaire expérience muséologique, le Musée veut instaurer des actions durables afin de poursuivre un dialogue permanent, en temps réel, entre les visiteurs et les communautés pour que 
l'exposition soit toujours vivante et pertinente. Dans un premier temps, l'institution a mis en circulation dans le réseau des musées autochtones une exposition intitulée Prenons tous place, qui en racontant le récit de la concertation retourne ainsi aux communautés la mémoire et les résultats de ce long travail collectif. 


\title{
Política, representação e diálogo nos Museus da Civilização: Primeiros Povos e museologia indígena no Québec
}

\author{
Jean Tanguay \\ Responsável pela pesquisa, Les Musées de la Civilization
}

Hoje em dia, o Québec conta com cerca de 90 mil indígenas distribuídos em 11 nações distintas: os Waban-Aki, os Anishinabeg, os Atikamekw Nehirowisiwok, os Eeyou (Cris), os Hurons-Wendat, os Innus, os Inuíte, os Wolastoqiyik (Malécites), os Mi'gmaq, os Kanien'kehà:ka (Mahowks) e os Naskapis.

Antes de discutir a relação que os Musées de la Civilization [Museus da Civilização] têm estabelecido com esses povos por intermédio da museologia, parece-me importante traçar brevemente suas trajetórias históricas para que possam conhecer um pouco mais dessas outras realidades dos indígenas norte-americanos.

\section{Recapitulação histórica}

Como todos sabem, a história dos indígenas do Québec não se inicia com a chegada dos europeus no século XVI. Na verdade, quando se verificam esses primeiros contatos, culturas haviam migrado, se desenvolvido e se espalhado em todas as regiões do território por mais de $11 \mathrm{mil}$ anos. Liberado de suas geleiras e de seus mares pósglaciais, o território quebequense tornara-se hospitaleiro para diversos grupos mais ou menos numerosos vindos essencialmente dos estados do Maine (É-U), do Ontário e das Províncias Marítimas do Canadá. Esse período histórico de vários milênios, qualificado de "pré-história" - o que nos levaria a pensar em uma ausência de história antes da chegada dos europeus pertence, portanto, à trama histórica mais longa e ainda muito pouco conhecida da história do Québec. Estamos diante de um território habitável e habitado por populações já enraizadas, apresentando características culturais variadas. Muito rapidamente, esses primeiros ocupantes irão explorar os recursos regionais e saber beneficiarse das matérias-primas locais, mantendo um modo de vida baseado na caça, na pesca, na colheita e, finalmente, nas atividades agrícolas. 0 comércio também não foi introduzido com o contato entre o Velho e o Novo Mundo. Redes de troca anteriores ao contato existem de fato. Com a colonização do território e o aumento da população, tradições de formação de alianças animam rapidamente as relações entre esses primeiros povos, assim como os conflitos que ganharam forma bem antes do século XVI. Em resumo, o europeu não criou o Québec, um território indígena rico e diversificado há milênios.

\section{E chegaram as primeiras ilhas flutuantes: os primeiros contatos e as primeiras alianças}

Há mais de 400 anos, os primeiros ocupantes do Québec testemunharam novas migrações de povos oriundos de outro continente. Normandos, bascos, franceses, holandeses e ingleses navegaram, todos com o desejo de explorar os recursos e muitas vezes de descobrir novas terras com riquezas diversas. Os pescadores de bacalhau e os caçadores de baleias, que foram os primeiros a tomar conhecimento da natureza do continente, carregaram os porões de seus navios com os primeiros bens necessários para adquirir as peles dos primeiros ocupantes. Procurando uma nova passagem para a Ásia, os franceses descobriram um continente com numerosos povos espalhados em um vasto território. Os mandatários oficiais do rei estabeleceram, por vezes de forma desajeitada, 
os primeiros intercâmbios políticos. Os negócios e a diplomacia levaram às primeiras alianças franco-ameríndias no início do século XVII. Os povos indígenas viram uma oportunidade para obter novas curiosidades que muitas vezes não podiam reproduzir, além de se aliar a novos e poderosos parceiros nos conflitos norteamericanos. Talvez não imaginassem o impacto que essas primeiras alianças poderiam ter no destino de suas nações. Após as experimentações do século XVI, os europeus entenderam a importância de se unirem aos primeiros ocupantes do país para explorar o continente, e então aspirar a uma nova soberania aos olhos das outras potências europeias. Isso irá levar à fundação de uma “nova” França na América. Também acreditavam estar fazendo um trabalho humanitário, já que professavam a fé no cristianismo por meio da ação missionária. Comércio, exploração, colonização e o estabelecimento de um novo império francês nas terras americanas foram o motivo da renovação e da multiplicação das alianças ao longo dos séculos XVII e XVIII.

\section{Alianças que não foram estabelecidas sem consequências}

Foi a partir dessas primeiras relações diplomáticas que o europeu e o ameríndio se comprometeram em negociar um destino conjunto. Mas essas relações que de início se desenvolveram no âmbito de uma lógica e de uma prática diplomática ameríndia não ficaram sem consequências, nem para os franceses, que haviam se tornado canadenses, nem para os povos indígenas. Fatores demográficos, as orientações econômicas e o conhecimento ameríndio do continente convidavam à negociação cultural, o que obrigava os recém-chegados a uma adaptação à realidade norte-americana. O território e seus recursos, bem como a proximidade dos primeiros ocupantes, irão gerar um fenômeno importante de canadianização. Mas tudo isso não fará desaparecer as aspirações imperiais da França e das autoridades coloniais. Modelar os espíritos e as almas pela ação missionária e intervir na ordem jurídica pelo poder político são somente algumas das manifestações que traduzem a vontade de impor traços essenciais da cultura europeia nas comunidades indígenas, mas também, e em menor medida, nos Inuítes a partir do século XVIII. Epidemias, guerras, divisões, aculturação, migrações, todas palavras que evocam as consequências das alianças no destino de muitos desses povos. Assim sendo, os sonhos de império agitam e derrubam o país.

\section{Novos aliados que não falam a mesma língua}

A história do nordeste da América nos séculos XVII e XVIII é marcada por uma transposição para a cena colonial das rivalidades entre as potências europeias do velho continente. A França e a Inglaterra desejam estender suas intenções de soberania sobre o solo americano, e isso se traduz pelos numerosos conflitos dos quais participam as nações ameríndias aliadas. A Guerra de Sete Anos será decisiva nesse sentido, já que os britânicos irão finalmente conquistar a Nova França em 1760. As relações que os britânicos estabeleceram então com os antigos aliados ameríndios dos franceses terão consequências importantes no plano da política e da administração. 0 período que se estende de 1760 a 1812 é num primeiro momento marcado, por vezes, de forma um tanto incerta e desajeitada, por uma transposição da política francesa para o trato com os indígenas, mas só por um período. Isso se traduz mais especificamente na conclusão de tratados entre as autoridades coloniais e ameríndias no momento da conquista, mas também na continuação dos negócios e na manutenção das remessas de presentes ao rei. Os britânicos irão definir, todavia, uma nova abordagem baseada na gestão administrativa e burocrática dos negócios indígenas, já que um agente atuará como mediador, além de receber as reclamações dos indígenas.

A redefinição das relações históricas entre as autoridades coloniais e o mundo indígena marcará o século XIX ameríndio de forma ainda mais significativa. Por motivos demográficos, pela perda progressiva do estatuto de aliado militar e, sobretudo, pela colonização e a exploração dos recursos florestais em território indígena, abrese uma nova era durante a qual o destino dos primeiros ocupantes seria debatido em numerosos fóruns. Comissões, atos, debates e leis vão 
aparecer em paralelo às primeiras petições e reinvindicações provenientes dos representantes indígenas. Todo esse processo resultará na criação das primeiras reservas e na adoção da lei sobre os índios, em 1876. Os antigos aliados vão então se tornar os pupilos do Estado, e os antigos presentes serão doravante distribuídos a título de assistência pública. Trata-se de um século de desapropriação e de tomada de controle sobre o destino dos indígenas pelo Estado.

\section{Reacender o fogo}

A experiência vivenciada no século XIX irá marcar profundamente as sociedades indígenas do Québec. Pela lei sobre os índios, o Estado federal canadense age de certa forma como se os indígenas fossem crianças necessitando um enquadramento em todas as esferas de sua existência. Essa medida legislativa impõe mais especificamente um regime de tutela definindo a identidade e o pertencimento nacional. 0 governo federal seguia, portanto, uma política de assimilação com o intuito de fazer "cidadãos ordinários" dos Indígenas, o que era visto, no plano ideológico do século XIX, como uma ação positiva e quase messiânica. Os bancos rígidos das escolas-internatos serão um dos principais meios valorizados para "matar o índio no índio", com a ajuda das comunidades religiosas que acreditavam fazer obra de caridade. Os ameríndios e os Inuítes tiveram de dominar essa nova realidade, fazer as constatações que se impunham e reagir. A primeira parte do século XX é, nesse aspecto, um período de despertar em que líderes indígenas vão querer reacender o fogo e lutar contra as políticas de assimilação para sobreviver, enquanto os povos tentam recuperar uma participação ativa na realidade canadense. A criação de organizações políticas, os julgamentos dos tribunais, as reinvindicações territoriais e as representações na cena nacional e internacional são ações e meios que visam ao restabelecimento das relações históricas. Esses movimentos de afirmação irão continuar também no âmbito social e cultural, mas não serão suficientes para fazer desaparecer os problemas sociais cujas principais raízes se encontram no livro negro do século XIX. A autonomia política e econômica aparece como a solução, o que parece ser, de início, um processo de cura. Todos estão também de acordo quanto à necessidade de se apropriar de uma base territorial e de abolir a lei sobre os índios, mas resta definir o novo quadro e as orientações desejadas para o futuro.

\section{Os Museus da Civilização e a autoctonia}

Aberto ao público em 1988, o Musée de la Civilization [Museu da Civilização], um museu estatal quebequense, recebeu o mandato de desenvolver o acervo etnográfico nacional e difundir a diversidade dos componentes da realidade quebequense no país e no exterior. Quatro outros espaços de divulgação e conservação lhe foram confiados ao longo dos anos e formam hoje um complexo museal designado de Musées de la Civilization [Museus da Civilização].

Há mais de 25 anos, os Museus da Civilização têm iniciado, entre outras atividades, projetos de divulgação visando tornar mais conhecida a diversidade das realidades indígenas. Embora a atenção e os esforços tenham sido muito focados em um redescobrimento da autoctonia quebequense, o olhar institucional enxergou muito além das nossas fronteiras. Ao longo dos anos, e em total coerência com o projeto cultural dos Museus, houve de fato uma ênfase na autoctonia internacional com o intuito de descobrir a diversidade das realidades, assim como de compreender as similitudes das experiências vivenciadas pelos indígenas dos demais continentes. Seja por meio de exposições de longa duração ou temporárias, publicações ou pelas muitas atividades educativas e culturais, os Museus souberam dessa forma se posicionar como intermediários decisivos. Seus objetivos: suscitar o interesse do público, combater os preconceitos e favorecer dessa forma o diálogo entre indígenas e alóctones.

Na realidade, essa intenção de criar laços e tratar da alteridade indígena assume inteiramente a forma de uma vocação institucional. Tomou forma desde a abertura do Museu da Civilização 
em 1988 e não cessou, desde então, de alimentar a programação oferecida aos visitantes.

A importância que a instituição dedica à representação das realidades indígenas se expressa, aliás, muito claramente na sua política em relação aos Primeiros Povos. ${ }^{1}$ São estas as intenções do Museu:

- ser um parceiro privilegiado dos povos indígenas na proteção e na valorização de suas identidades;

- contribuir para conhecer as realidades, os patrimônios e as culturas dos povos indígenas e contribuir para sua influência;

- suscitar a participação dos grupos indígenas nas atividades e nos projetos do Museu da Civilização a eles referentes.

Essa política está relacionada a uma iniciativa mais antiga que demonstra o engajamento da instituição para com seus parceiros indígenas. Foi elaborada após a realização de uma conferência nacional canadense em 0ttawa, em 1988, durante a qual os participantes buscaram definir o que se deveria fazer para favorecer uma verdadeira parceria entre os museus e as Primeiras Nações.

\section{Virar a página... para uma nova museologia participativa}

\section{A Conferência Nacional de Ottawa é} considerada hoje como um evento de destaque no desenvolvimento da museologia indígena no Canadá. Foi ao final desse encontro que se criou o grupo de trabalho sobre os museus e as Primeiras Nações, cujas atividades seriam patrocinadas pela Assembleia das Primeiras Nações do Canadá e pela Associação dos Museus Canadenses. Esse grupo, composto de 25 membros, incluindo vários anciãos indígenas, se propôs como missão desenvolver um modelo de trabalho e estratégias éticas que permitam aos indígenas e às instituições culturais trabalhar em conjunto para melhor representar a história e as

1. Política do Museu da Civilização perante os povos autóctones. Museu da Civilização, 27 set. 2012, p. 5 culturas dos Primeiros Povos. O exercício inclui consultas regionais, a recepção de numerosas recomendações de organismos e pessoas, além da troca de informações durante as quatro reuniões nacionais do grupo de trabalho. Seu relatório expõe os desafios e a problemática, bem como as recomendações obtidas do referido projeto. Para os fins de nossa análise, lembramos os seguintes elementos:

- As relações entre o legado aborígene e a situação atual das Primeiras Nações devem ser demostradas, e os museus deveriam se tornar fóruns de discussão sobre os problemas contemporâneos.

- Uma crescente participação das Primeiras Nações no trabalho dos museus se torna então essencial para melhorar a representação e a interpretação de sua história e cultura.

- A incorporação das Primeiras Nações às equipes dos museus ajudaria na educação e sensibilização dos funcionários em relação às perspectivas e filosofias indígenas, bem como aos interesses das comunidades indígenas.

Esse relatório contém, ainda, recomendações quanto ao repatriamento de objetos, o acesso aos acervos dos museus, o apoio às instituições culturais indígenas, a qualificação etc.

0 contexto de afirmação dos indígenas em escala nacional e internacional contribui então para levar em consideração essas reivindicações no plano cultural. ${ }^{3}$ É bom lembrar que o relatório foi registrado na sequência da Crise de Oka no Québec, evento de destaque nas lutas indígenas do século XX, cuja exploração

2. Cf Tourner la page: Forger de nouveaux partenariats entre les musées et les Premières Nations [Virar a página: forjar novas parcerias entre os Museus e as Primeiras Nações], Relatório do Grupo de trabalho sobre os museus e as Primeiras Nações, Assembleia das Primeiras Nações e Associação dos museus canadenses, Ottawa, 1992.

3. Para entender o contexto das reinvindicações dos nativos em relação à museologia canadense, consultar Ruth B.

Phillips, Museum Pieces. Toward the Indigenization of Canadian Museums, McGill-Queen's University Press, 2011. 
midiática permitiu trazer de volta a "questão indígena" na atualidade e, inevitavelmente, nas mesas de trabalho dos funcionários. A isso se acrescentaram certos julgamentos nos tribunais que impuseram também novas formas de procedimento nas instâncias governamentais. Desde então, a necessidade de consultar os Primeiros Povos orientou as ações governamentais de forma mais específica. E os atores do desenvolvimento cultural foram inevitavelmente incitados a iniciar ações colaborativas com as Primeiras Nações.

No curso dos anos seguintes à apresentação oficial do relatório, as recomendações incitaram de fato muitas instituições museais a virar a página e a abrir espaço para uma participação maior dos indígenas em seus projetos. Uma nova abordagem participativa iria assim levar a algumas iniciativas notáveis no Canadá e em outros lugares do planeta. Pensamos nos processos colaborativos que levaram à realização de exposições com temáticas indígenas no Museum of Anthropology de Vancouver (1996), no Glenbow Museum de Calgary (2001), no National Museum of the American Indian em Washington (2004), ou ainda no Melbourne Museum (2013). Em paralelo, assistimos também à abertura de várias instituições culturais dentro das comunidades indígenas do Québec. Trata-se de museus, mas também de centros culturais onde se desenvolve uma "museologia indígena". A título de exemplo, podemos mencionar o Museu de Mashteuiatsh,

o Museu Shaputuan de Uashat (Sete Ilhas, na Costa Norte), o Museu Huron-wendat de Wendake, e o Centro Cultural dos Innus (Ekuanitshit, na Costa Norte).

\section{Nós, as Primeiras Nações...}

No Museu da Civilização, a realização de Nous, les Premières Nation [Nós, as Primeiras Nações] (1998-2013), primeira exposição de longa duração dedicada aos indígenas do Québec, se inscreveu nessa vontade de agir de outra maneira, solicitando a participação das Primeiras Nações e dos Inuítes. 0 título escolhido para essa primeira exposição dá a entender que os Primeiros Povos que se apresentam aos visitantes são os principais artesãos de sua representação cênica. Ora, a realização se inscreve, sobretudo, numa vontade institucional de representar a diversidade das realidades indígenas, solicitando uma participação das Primeiras Nações e dos Inuítes. 0 título não revela, portanto, uma ação de acordo envolvendo os parceiros indígenas em todas as etapas da realização. 0 acordo se distingue da consulta na medida em que não se resume a uma solicitação de opinião. Supõe um confronto entre as partes, uma troca de argumentos, uma explicitação e apresentação dos pontos de vista de cada um.

Em essência, tomou mais a forma de um comitê consultivo composto por representantes de diversas comunidades, destinado a se reunir ocasionalmente para se pronunciar sobre diversas questões levantadas pela equipe de realização. Esse comitê pôde validar, entre outros, certos elementos de conteúdo ou ainda a forma de se expor os objetos em cada sala. Certos artesãos foram também convidados a produzir algumas das peças apresentadas na exposição. Foi por essas trocas de opinião que se decidiu não abordar certos lados da espiritualidade tradicional, como o ritual da tenda trêmula nos grupos algonquianos. Foi esse um primeiro passo no sentido de dar a palavra aos indígenas, redefinindo dessa forma a maneira habitual de se realizar uma exposição sobre os Primeiros Povos.

A exposição Nós, as Primeiras Nações teve vida longa e foi um grande sucesso. Como demostrado pelas respostas dos visitantes no fim da visita, essa exposição lhes permitiu descobrir aspectos antes desconhecidos e aprofundar certas noções ou conhecimentos. Mas os relatos dos visitantes nos revelam também que a exposição não conseguiu desconstruir as representações negativas. Várias pessoas entrevistadas responderam negativamente à pergunta sobre a contribuição da exposição para modificar suas representações dos indígenas. ${ }^{4}$ Sua popularidade permanece, todavia, como um fato bem conhecido, que se deve salientar. Teve certamente o mérito de valorizar a riqueza da cultura

4. Lucie Daignault e Pierre-Luc Collin (com a colaboração de Geneviève Provencher-St-Cyr). Les expositions permanentes aux Musée de la Civilisation: attentes, pratiques et découvertes. Serviço de pesquisa, avaliação e monitoramento museológico, Museu da Civilização, 2010, p. 33. 
material das diversas nações indígenas do Québec, o que definitivamente é uma forma interessante de introduzir o visitante à realidade indígena. 0 conteúdo textual e as poucas entrevistas apresentadas na tela permitiram a familiarização não só com a história, mas também com alguns dos desafios contemporâneos, incluindo reivindicações políticas e territoriais do século XX. Para as Primeiras Nações e os Inuítes envolvidos na sua realização, Nós, as Primeiras Nações foi uma primeira resposta positiva às recomendações do relatório Virar a página (1992). Outro grande passo, determinante e até inovador, seria dado ao final da renovação dessa mostra, 15 anos mais tarde.

\section{Algumas explorações temporárias...}

As exposições temporárias também fornecem oportunidades para formar laços e desenvolver colaborações com os indígenas. A título de exemplo, lembramos as exposições $\mathbb{E} i l$ amérindien, regards sur l'animal [0lhar ameríndio, visões sobre o animal] (1991); Rencontre des deux mondes [Encontro de dois mundos] (1992); Secrets d'Amazonie [Segredos da Amazônia] (1996); Iroquoiens de Saint-Laurent, peuple du maïs [Iroquoienses de Saint-Laurent, o povo do milho] (2007). Há em primeiro lugar aquelas que focam exclusivamente nos indígenas daqui ou de outras regiões e abordam uma variedade de assuntos: culturas ancestrais, relações coloniais, confrontos políticos, relações com o animal, mitologia, produção artística e artesanal, retrato de mulheres ou ainda identidades e estereótipos. Essas exposições são muito instrutivas e buscam completar os conteúdos abordados superficialmente em exposições de longa duração. Na realidade, na maioria das vezes elas têm o "defeito" de serem temporárias, já que são complementares... E há também outras exposições nas quais a temática indígena é contemplada sem constituir o assunto principal. Lembremos mais especificamente Imaginaires mexicains [Imaginários mexicanos] (1998), Or des Amériques [Ouro das Américas] (2008), Portés par le fleuve [Levados pelo rio] (2011). Da combinação de todas essas "iniciativas temporárias", sobressai certamente uma representação interessante da autoctonia quebequense e internacional.
A vontade de tratar da autoctonia na sua dimensão mais internacional se manifestou, aliás, de forma recorrente. Os esforços mais recentes foram feitos em E TŪ AKE - MĀORIS DEBOUT (2012). Ao longo dos anos, os conteúdos temáticos de várias outras exposições permitiram tocar no assunto. Lembremos, por exemplo, Toundra, tä̈ga [Tundra, taiga] (1988), na qual foram comparadas culturas indígenas no Canadá e na União Soviética; lembremos também Nomades [Nômades] (1992) onde se ilustrou a expressão do nomadismo nos diversos grupos ao redor do mundo. A diversidade das realidades indígenas é assim encenada, o que permite dar conta das similitudes e diferenças nas experiências vivenciadas.

Em resumo, seja pela variedade dos temas abordados, seja pela apresentação de inumeráveis objetos e imagens de acervos diversos, as exposições temporárias foram oportunidades para conhecer algumas das realidades indígenas do Québec e dos diversos continentes. Considerando que a população indígena mundial é composta de mais de 370 milhões de pessoas espalhadas por uns 70 países, o assunto permanece, em definitivo, inesgotável para os Museus da Civilização. No mês de outubro de 2015, poderemos continuar essa exploração com a exposição Lignes de vie. L'art des Autochtones d'Australie [Linhas de vida. A arte dos indígenas da Austrália], que permitirá aos visitantes se impregnarem novamente do universo de crenças e da história dos Primeiros Povos de outro continente.

\section{“Essa é nossa História...", uma Nova Experiência Museal}

Em 2010 tomou-se a decisão de renovar a exposição Nós, as Primeiras Nações. A iniciativa seria uma oportunidade para os Museus da Civilização explorarem uma nova abordagem, buscando melhor representar a diversidade das experiências vivenciadas pelos indígenas do Québec ao longo dos milênios. Para tanto, o Setor de Exposições e seus parceiros optaram por um processo colaborativo investindo esforços, sem precedente, para suscitar a participação dos indígenas em todas as etapas da realização do projeto. Essa exposição deveria, portanto, abrir 
espaço para inúmeros pontos de vista, sobretudo os das pessoas encontradas nas comunidades, no que se refere a suas realidades históricas e contemporâneas. ${ }^{5}$

0 título escolhido, C'est notre histoires, Premières Nations et Inuit au XXIe Siècle[Essa é nossa história, Primeiras Nações e Inuítes no século XXI], aponta para um conteúdo muito afirmativo e engajado pelo qual os indígenas apresentam sua própria leitura da história, distinta daquela geralmente contida nos livros de história nacional. Mas afinal, como é? $\mathrm{Na}$ realidade, seguir o percurso da exposição significa, antes de tudo, penetrar na diversidade dos pontos de vista sobre uma variedade de temas, onde se entrelaçam a palavra indígena e os conhecimentos oriundos da academia.

Significa também penetrar na história para melhor compreender os desafios e a problemática contemporâneos. Isso passa por um dispositivo - percurso de exposição -através do qual os visitantes tomam conhecimento da diversidade das identidades nacionais e regionais, da diversidade dos modos de vida tradicional e atual, da diversidade das transformações culturais, da diversidade das relações com os euro-canadenses, da diversidade das condições sociais e econômicas, ou ainda da diversidade das reivindicações. Tudo isso fica exposto nos diversos períodos da história: paleo-história (ou pré-história), período de contatos, período colonial, período contemporâneo etc. A exposição Essa é nossa história se distingue assim de Nós, as Primeiras Nações na medida em que as numerosas conclusões e testemunhos dos indígenas oferecem aos visitantes a oportunidade de conhecê-los

5. Esta nova "museologia participativa" não é quebequense ou canadense. É também estadunidense e australiana, e presente em um número crescente de países. Resulta, sem dúvida, das reivindicações autóctones no plano cultural e, mais amplamente, do reconhecimento dos direitos aborígenes pelas grandes instâncias internacionais. Quanto aos esforços de integração dos Autóctones em projetos de exposições concernentes a eles, consultar os seguintes artigos: Ronan, Kristine. "Native Empowerment, the New Museology, and the National Museum of the American Indian". Museum \& Society. v.12, n.1, p. 132-147, 2014; Witcomb, Andrea. "Regardez, écoutez, ressentez": a exposição First Peoples no Centro Cultural Bunjilaka, Museu de Melbourne. Thema. A revista dos Museus da Civilização, v.1, p. 63-106, 2014. de perto e melhor entender suas leituras da história e a forma como concebem suas condições de indígenas no século XXI.

Em Essa é nossa História, são esses homens e mulheres quem fazem uma releitura do passado e compartilham o presente, mas, sobretudo, sonham sobre o futuro. A exposição se funda numa rica coleção, cujas obras contemporâneas foram criadas para dar embasamento aos relatos. Desde o começo, a seção Ce que nous sommes aujourd'hui - La réserve, nos communautés [0 que somos hoje - A reserva, nossas comunidades] mergulha o visitante na realidade atual das comunidades, seus modos de vida, seu próprio legado. Mais tarde, Nos racines [Nossas raízes] desvendam a longa travessia do território norteamericano há 12.500 anos, explicitando a grande diversidade das culturas indígenas. La grande tourmente [A grande tormenta], que segue reflete o choque das civilizações ilustrado por 400 anos de colonização, de transformações e de resistência. La Décolonisation - la guérison [A Descolonização - a cura] relata as reivindicações e negociações políticas e culturais, a luta para o reconhecimento visando ao restabelecimento das relações históricas. Finalmente, De quoi rêvet-on pour l'avenir? [0 que sonhar para o futuro?] centra-se nas inquietações e aspirações profundas dessas comunidades.

Esse percurso de exposição não é revolucionário. o caráter único e distinto desse projeto reside no processo de realização em si: as Primeiras Nações e os Inuítes não foram somente consultados, foram partes integrantes do conceito, da escolha dos conteúdos e da museografia. Esse processo de preparação durou 38 meses. Os representantes designados pelas diversas Nações se reuniram três vezes numa assembleia especial nomeada Mamo ("juntos", na língua dos Atikamekw Nehirowisiwok). Definiram nelas as expectativas, a metodologia e as temáticas. Puderam, no final, avaliar o processo como um todo.

Em paralelo, uma equipe multidisciplinar se deslocou até cada uma das nações, até algumas comunidades, muitas vezes distantes centenas de quilômetros, juntando um corpo documental e 
videográfico excepcional. Os membros da equipe experimentaram os espaços e os modos de vida. Integraram-se à vida cotidiana das comunidades e estabeleceram um clima de confiança, e mesmo de troca de confidências. Ateliês de criação foram organizados em cada nação e mesmo no Québec, nas reservas dos Museus da Civilização. Em estreita colaboração com a organização La Bô̂te Rouge vif, - Museu pôde contar com a participação de 500 pessoas de 18 comunidades. Mais de 5 mil páginas de transcrições de falas, $10 \mathrm{mil}$ fotografias e 250 horas de vídeos constituem hoje a memória documental do processo. Kits reúnem todos os conteúdos que foram reunidos e entregues a cada uma das nações na inauguração.

Abordar o processo de realização de Isso é nossa história é também relatar as limitações impostas pelo meio de exposição quando se trata de valorizar a diversidade cultural das 11 nações indígenas do Québec. O desafio é enorme, e a equipe de realização tentou enfrentá-lo estando ciente das limitações inevitavelmente impostas. Era preciso, portanto, restringirse aos temas unificadores identificados durante a preparação nas comunidades, assim como aqueles oriundos da pesquisa sobre a autoctonia. Era também necessário tentar responder aos desejos das nações que esperavam todas ver sua própria trajetória histórica apresentada no espaço. Finalmente, era sobretudo necessário levar em conta os visitantes, que não podiam se sentir afogados na massa de informações, perdendo assim o essencial das mensagens que todos nós desejávamos transmitir.

Para que todos se reconhecessem um pouco na exposição, a equipe de realização privilegiou uma exibição temática que refletisse as experiências compartilhadas pelo maior número de indígenas. De forma concreta, o conteúdo salienta na maior parte do tempo a experiência de uma única nação para refletir uma temática que diz respeito ao conjunto. A título de exemplo, as transformações econômicas do século XIX foram descritas pelo desenvolvimento do comércio de cestaria nos Waban-Aki (Abénaquis). Em outros momentos, os temas foram abordados sem que se tivesse de focalizar uma experiência específica. Um objeto ou ainda uma obra de arte bastava também para ilustrar um assunto.

Definitivamente, essa experiência museal nos ensinou que o meio "exposição" impõe na maior parte das vezes a morte dos grandes desenvolvimentos textuais, dos temas que alguns julgam incontornáveis, de certas precisões que parecem a priori essenciais... Esse processo de aceitação do fato de que não podemos dizer tudo em uma exposição refere-se ao conjunto dos membros da equipe de realização e, no que nos diz respeito aqui, também aos parceiros indígenas. Nessas circunstâncias, é preciso perguntar se refletir a diversidade cultural é um objetivo mais realista do que representar essa mesma diversidade nos limites por vezes restritos de uma sala de exposição de 713 metros quadrados. Em outros termos, embora a exposição tenha muito a oferecer aos visitantes, prevê-se, na maioria das vezes, considerar os esforços combinados do conjunto dos meios museológicos (mediação cultural e educativa, publicações, fóruns etc.) para aprofundar assuntos tão complexos como a diversidade cultural indígena.

\section{0 importante papel da mediação}

Paralelamente aos esforços investidos na sala, a mediação educativa e cultural desenvolve "meios plurais" para reunir diferentes públicos e fazer um relato, no caso que nos toca, da diversidade das realidades indígenas. A mediação elucida muitas vezes os conteúdos, ampliando assim o campo de conhecimentos a serem transmitidos aos visitantes. Seja por meio de conferências, projeções (documentários), apresentações artísticas ou de diversas atividades de aprendizagem, ela contribui para melhor conhecer e compreender as culturas indígenas. 0 enfoque foi dirigido, sobretudo, às Primeiras Nações e aos Inuítes do Québec, embora algumas atividades tenham sido dedicadas a outras manifestações da autoctonia no âmbito internacional. Laços estreitos foram também consolidados ao longo dos anos com os artistas e autores indígenas que acharam, entre as paredes do nosso local, o espaço de criação e expressão desejado. A tomada de depoimentos foi também favorecida por testemunhos que tratavam dos desafios e 
da problemática contemporâneos. Lembremos, sobretudo, os testemunhos de sobreviventes dos internatos indígenas que, em 2013, foram apresentados no Museu da Civilização; podemos lembrar também a mesa-redonda intitulada "Os indígenas e o Québec. Primeiros contatos no Plano Norte" (2014), dedicada ao legado do encontro entre os mundos indígenas e alóctones.

\section{Objetos indígenas e irradiação cultural}

Que os objetos contam histórias é um fato bem conhecido. Mas até que ponto podemos dar-lhes a palavra? Eles são obras humanas, certamente são portadores de sentido e fazem irradiar as culturas nas instituições museais. Esses testemunhos de civilizações oriundos de nossas coleções irão beneficiar sem sombra de dúvida os meios mais utilizados e difundidos para permitir a interpretação da diversidade cultural indígena daqui e de outros lugares. Independentemente de seu papel central em uma exposição temática indígena, os objetos associados aos Primeiros Povos foram também expostos em inúmeras mostras produzidas nos Museus da Civilização e em outros espaços culturais nesses 25 anos. Quando as exposições abordam temas que reúnem também os universos culturais indígenas, é de praxe inserir objetos inuítes e ameríndios para enriquecer o conteúdo temático e o aspecto visual.

Os especialistas da conservação contribuem também para irradiar as culturas do Québec ao disseminar os testemunhos materiais dos Primeiros Povos além dos nossos muros, participando de inúmeros projetos de valorização, na grande maioria das vezes sob a supervisão de outros museus ou centros de interpretação. Esses testemunhos culturais que são os objetos viajam, assim, por empréstimos dentro da rede museal nacional e internacional, ou mesmo pelo viés das exposições itinerantes. Os Museus da Civilização trabalharam também em estreita colaboração com os indígenas do Québec, dando acesso às coleções nacionais para a realização de projetos de valorização, além de serem parceiros de algumas nações em suas atividades de colecionamento. Tudo isso para continuar seus próprios esforços de enriquecimento da coleção nacional para que reflita a diversidade dos modos de expressão artística. Sobre este assunto, é preciso ressaltar os esforços significativos feitos recentemente pelos Museus da Civilização para adquirir obras de arte contemporânea. Essa produção suscita cada vez mais o interesse do público e permitirá apresentar modos de expressão artística que traduzem a identidade e a cultura das Primeiras Nações e dos Inuítes de hoje.

Para concluir, as coleções de fotos, estampas, quadros, esboços, ou ainda o rico acervo de documentos arquivísticos e de livros raros e antigos servem hoje como fontes documentais, além de enriquecer o visual de numerosas exposições, publicações ou conferências dedicadas às Primeiras Nações e aos Inuítes. Assim sendo, a instituição colabora também para a pesquisa e difusão da diversidade cultural dos Primeiros Povos. É preciso, todavia, constatar que os meios de divulgação da cultura material e imaterial dos indígenas divergem pouco dos meios tradicionais. Também, em um futuro próximo os Museus da Civilização deveriam se juntar às fileiras das grandes instituições que democratizaram o acesso a suas coleções. Essas vitrines sobre os objetos destinam-se a satisfazer os visitantes virtuais de toda procedência, sejam eles amadores ou especialistas de disciplinas diversas. Trata-se de um patrimônio coletivo que ganha valor quando exposto aos olhos da humanidade...

\section{Alguns elementos para concluir}

Assim sendo, constatamos que os Museus da Civilização sempre foram animados pelo desejo de tratar a autoctonia e souberam disponibilizar aos visitantes um ensino centrado na descoberta. Para tanto, a instituição tem privilegiado uma valorização do espaço físico do Museu por meio de duas exposições permanentes e várias temporárias.

Os Museus da Civilização desejam também continuar em seus esforços para uma mediação participativa no plano das ideias, da criação e das atividades museais. Para tanto, apostamos na manutenção de 
relações que a instituição soube desenvolver ao longo dos anos com várias comunidades indígenas. Estas, é preciso assinalar, reivindicam mais do que nunca o direito à palavra sobre a valorização de seu patrimônio. Isso implica até mesmo dar espaço à palavra e ao conhecimento milenar dos indígenas a fim de que emprestem uma linguagem seguramente rica a nossas iniciativas museológicas.

Julga-se necessária a participação dos indígenas no processo de realização de exposições, embora ela abale os procederes dos museólogos. Essa participação permite, sem dúvida, adentrar os universos sensiveis e mais íntimos que podemos qualificar de "reveladores culturais". Os relatos dos indígenas sobre suas realidades contemporâneas, bem como os conhecimentos milenares dos quais são muitas vezes os depositários, nos convidam naturalmente a considerá-los como parceiros fundamentais na valorização de seu patrimônio. Para muitos indígenas, a museologia participativa é também percebida como um processo que permite contrariar uma forma de colonialismo cultural. Tradicionalmente, a museologia teria na maior parte do tempo representado os Primeiros Povos pelo viés de um "olhar externo", insuficientemente impregnado do universo cultural dos primeiros povos em questão. A museologia participativa é motivada pela ideia de que os indígenas são tão habilitados - talvez mais - quanto os museólogos para definir o que deve representá-los aos olhos do público.

Mas a representação e a preservação da diversidade cultural indígena devem, apesar de tudo, assentar-se em objetivos realistas. A priori, isso implica a aceitação de que não podemos dizer tudo e responder a todas as expectativas que possam ter os parceiros indígenas, os museólogos e os profissionais que compõem os comitês científicos. Estes certamente acharão que os meios próprios à museologia não podem responder plenamente à vontade de afirmação de identidade das Primeiras Nações e dos Inuítes, assim como não podem representar de forma exaustiva sua diversidade cultural, histórica e atual; certamente acharão também que nossas exposições comportam inevitavelmente um olhar alóctone por vezes deformante, já que muitas vezes demasiadamente generalizador, mas elas também apresentam a vantagem de evitar os riscos da parcialidade de alguns discursos.

Seja como for, a "nova museologia participativa" não é menos positiva e esclarecedora,

considerando que dá lugar a um entendimento do que o outro quer dizer e de como deseja ser representado. O Museu abre assim espaço para uma nova forma de implementação sem perder de vista os objetivos que lhe são próprios. Na sequência dessa extraordinária experiência museológica, - Museu quer instaurar ações duráveis para continuar um diálogo permanente, em tempo real, entre os visitantes e as comunidades, para que a exposição seja sempre viva e pertinente. Em um primeiro passo, a instituição colocou em circulação na rede dos museus indígenas uma exposição intitulada Prenons tous place [Assumamos todos o nosso lugar], que relata o processo de preparação e, assim, devolve às comunidades a memória e os resultados desse longo trabalho coletivo. 


\title{
ANEXO
}

\section{Memória}

\section{Encontro Paulista Questões Indígenas e Museus V Seminário Museus, Identidades e Patrimônios Culturais}

\author{
Direitos indígenas no museu - Novos procedimentos para uma nova \\ política: a gestão de acervos em discussão
}

\section{Local}

Museu Histórico e Pedagógico Índia Vanuíre

Endereço: Rua Coroados, 521 - Centro - Tupã - São Paulo

\section{Período}

30 de junho a 2 de julho de 2015

\section{Público}

Os eventos destinam-se a profissionais de museus, docentes e discentes de universidades e professores da rede pública de ensino. 0 evento tem a expectativa de reunir diversos profissionais ligados à ação museal e outros que usufruem dessa instituição por seu caráter patrimonial e educacional, em especial os formadores de opinião e agentes multiplicadores de novas atitudes com relação às culturas indígenas.

\section{Objetivos}

O IV Encontro Paulista Questões Indígenas e Museus e o V Seminário Museus, Identidades e Patrimônios Culturais têm como objetivos:

1. Discutir aspectos relativos à aquisição de coleções indígenas que venham a colaborar com a formulação de políticas públicas e institucionais;

2. Apontar procedimentos para a gestão documental de coleções oriundas de grupos indígenas contemporâneos;

3. Ver formas de correção e atualização de documentação de outros momentos passados;

4. Rediscutir a representação dos indígenas em exposições.

\section{Temas e recortes}

Estes temas são focos do evento:

- Museus, indígenas e Direitos da personalidade e autoral

- Museus, acesso à informação e as culturas indígenas

- A antropologia e os indígenas

- A museologia e os indígenas

- A visão dos indígenas sobre representações e narrativas de si nos museus

\section{Estrutura e estratégias}

Os eventos acontecem com a reunião de um grupo heterogêneo de profissionais e interessados, indígenas e não indígenas, para debates que se darão em:

- Conferência e palestras de temas e abordagens relevantes;

- Panorama e debates entre instituições para ampliação do tema, analisando-o a partir da práxis;

- Reunião de professores-pesquisadores indígenas;

- Reunião para levantamento de ideias para o I Encontro Nacional de Museus Indígenas. 


\section{PROGRAMAÇÃO}

\section{9 de junho, segunda-feira}

Chegada dos participantes

19h - Boas-vindas, apresentações e

confraternização

30 de junho, terça-feira

8h30 - Credenciamento

9h - Boas-vindas e abertura dos trabalhos

9h30 - Entrada no tema: Polúticas institucionais Angelica Fabbri e Luiz Antonio Bergamo (ACAM Portinari)

Maria Cristina Oliveira Bruno (MAE-USP)

Coordenação: Renata Vieira da Motta

11 - Conferência de abertura

Tema: Direitos Indígenas - contextos nacional e internacional

Márcio Santilli (Instituto Socioambiental)

Coordenação: Marília Xavier Cury

$12 \mathrm{~h} 30-\mathrm{Almoço}$

14 às $16 \mathrm{~h}$ - Mesa-redonda

Tema: As questões dos direitos, direitos indígenas e dos deveres do museu

Guilherme Carboni (Cesnik, Quintino e Salinas Advogados)
José Carlos Levinho (Museu do Índio, Funai)

Renata Vieira da Motta (UPPM-SEC)

Coordenação: Sandra Maria Christiani de La Torre

Lacerda Campos (MAE-USP)

16h - Café

$16 \mathrm{~h} 30$ às $18 \mathrm{~h} 30$ - Mesa redonda

Tema: Os indígenas e o museu, os indígenas no museu, museus indígenas

Suzana Primo dos Santos (Museu Paraense Emilio Goeldi)

Leandro da Cruz Silva (Projeto Xingu, Escola

Paulista de Medicina, Universidade Federal de São Paulo (Unifesp)

Alexandre Oliveira Gomes (UFPE)

Davidson Panis Kaseker (GT Sisem-SP)

Coordenação: Carla Gibertoni Carneiro (MAE-USP)

19h - Abertura da exposição autonarrativa

Fortalecimento da Memória Tradicional Kaingang De Geração em Geração, curadoria de José da Silva Campos, Ena Luiza Campos e Ana de Jesus (Kaingang da T.I. Vanuíre)

Apresentação cultural - Grupo Kaingang da T.I. Vanuíre liderado por Dirce Jorge Lipu Pereira

$1^{\circ}$ de julho, quarta-feira

$9 h$ - Palestra

Título: Política, representação e diálogo nos Museus da Civilização: Primeiros Povos e Museologia Indígena em Québec 
Jean Tanguay (Museus da Civilização, Québec, Canadá)

Coordenação: Angelica Fabbri (ACAM Portinari)

10h30 - Café

$11 \mathrm{~h}$ - Mesa-redonda

Tema: Pesquisa, pesquisadores e indígenas

Juliana Dal Ponte Tiveron (USP Ribeirão Preto)

Aramis Luis Silva (Unifesp)

Laércio Fidelis Dias (Unesp Marília)

Coordenação: Josué Carvalho (UFMG)

$12 \mathrm{~h} 30$ - almoço

14h - Encontro de Professores-pesquisadores indígenas do Oeste de São Paulo

Tema: A pesquisa na escola indígena e o papel dos museus

Professores indígenas das T.I. Icatu, Vanuíre e Araribá

Adriano César Rodrigues Campos (Escola Estadual Indígena Índia Maria Rosa, T.I. Icatu)

Carlos Roberto Indubrasil (Escola Estadual Indígena Índia Maria Rosa, T.I. Icatu)

Edilene Pedro (Escola Estadual Indígena Índia Maria Rosa, T.I. Icatu)

Lícia Victor (Escola Estadual Indígena Índia Maria Rosa, T.I. Icatu)

Márcio Pedro (Escola Estadual Indígena Índia Maria Rosa, T.I. Icatu)

Constantino Jorge da Silva (T.I. Vanuíre)

Lidiane Damaceno Cotuí (Escola Estadual Indígena Índia Vanuíre, T.I. Vanuíre)
Lucilene de Melo (T.I. Vanuíre)

Rosemeire Barbosa Dias (Escola Estadual Indígena Índia Vanuíre, T.I. Vanuíre)

Vagner Cecílio Damaceno (Escola Estadual Indígena India Vanuíre, T.I. Vanuíre)

Valdenice Cardoso Vaiti (Escola Estadual Indígena Índia Vanuíre, T.I. Vanuíre)

Alício Lipu (Escola Estadual Indígena Aldeia Ekeruá, T.I. Araribá)

Claudino Marcolino (Escola Estadual Indígena Aldeia Nimuendaju, T.I. Araribá)

Cleidenilson Alves Marcolino (Escola Estadual Indígena Aldeia Nimuendaju, T.I. Araribá)

Creiles Onório Marcolino da Silva Nunes (Escola Estadual Indígena Aldeia Nimuendaju, T.I. Araribá)

David Henrique da Silva Pereira (Escola Estadual Indígena Aldeia Ekeruá, T.I. Araribá)

Edileine da Silva Pereira (Escola Estadual Indígena Aldeia Ekeruá, T.I. Araribá)

Genilson Alves Marcolino (Escola Estadual Indígena Aldeia Nimuendaju, T.I. Araribá)

Gleidson Alves Marcolino (Escola Estadual Indígena Aldeia Nimuendaju, T.I. Araribá)

Jederson Marcolino Simão dos Santos (Escola Estadual Indígena Aldeia Nimuendaju, T.I. Araribá)

Luiza Lipu (Escola Estadual Indígena Aldeia Ekeruá, T.I. Araribá)

Moisés de Lima Camargo (Escola Estadual Indígena Aldeia Nimuendaju, T.I. Araribá)

Samuel de Oliveira Honório (Escola Estadual Indígena Aldeia Nimuendaju, T.I. Araribá)

Tiago de Oliveira (Escola Estadual Indígena Aldeia Nimuendaju, T.I. Araribá)

Valéria Érika da Silva Pereira (Escola Estadual Indígena Aldeia Ekeruá, T.I. Araribá)

Vanderson Lourenço (Escola Estadual Indígena 
Aldeia Nimuendaju, T.I. Araribá)

Vanessa Cristina Feliciano (Escola Estadual

Indígena Aldeia Nimuendaju, T.I. Araribá)

Wellington Marcolino (Escola Estadual Indígena

Aldeia Nimuendaju, T.I. Araribá)

Coordenação: Josué Carvalho (UFMG)

16h - café

16h30 - Mesa-redonda

Tema: Indígenas nos museus - as visões das culturas

Adriana Victor Campos Rodrigues (T.I. Icatu)

Adriano César Rodrigues Campos (Escola Estadual

Indígena Índia Maria Rosa, T.I. Icatu)

Ana Paula Victor Campos (T.I. Icatu)

Bruna Pedro (T.I. Icatu)

Camila Vaiti P. da Silva (T.I. Icatu)

Cândido Mariano Elias (T.I. Icatu)

Carlos Roberto Indubrasil (Escola Estadual

Indígena Índia Maria Rosa, T. I. Icatu)

Edilene Pedro (Escola Estadual Indígena Índia Maria Rosa, T.I. Icatu)

Lícia Victor (Escola Estadual Indígena Índia Maria Rosa, T.I. Icatu)

Márcio Pedro (Escola Estadual Indígena Índia Maria Rosa, T.I. Icatu)

Ranulfo de Camilo (T.I. Icatu)

Raphael Pedro Iaiati (T.I. Icatu)

Ronaldo Iaiati (T.I. Icatu)

Constantino Jorge da Silva (T.I. Vanuíre)

Dirce Jorge Lipu Pereira (Kaingang, T.I. Vanuíre)

Lidiane Damaceno (Escola Estadual Indígena Índia

Vanuíre, T.I. Vanuíre)

Lucilene de Melo (Kaingang, T.I. Vanuíre)

Valdenice Cardoso Vaiti (Escola Estadual Indígena
Índia Vanuíre, T.I. Vanuíre)

Ageu Cesar (Aldeia Ekeruá, T.I. Araribá)

Alício Lipu (Escola Estadual Indígena Aldeia

Ekeruá, T.I. Araribá)

Gedean Luiz (Aldeia Ekeruá, T.I. Araribá)

Gleidson Alves Marcolino (Escola Estadual

Indígena Aldeia Nimuendaju, T.I. Araribá)

Luiza Lipu (Escola Estadual Indígena Aldeia

Ekeruá, T.I. Araribá)

Mario de Camilo (Aldeia Ekeruá, T.I. Araribá)

Martha Pio (Aldeia Ekeruá, T.I. Araribá)

Natália Lipu da Silva (Aldeia Ekeruá, T.I.

Araribá)

Vandriele Daiane da Silva Pereira (Aldeia Ekeruá, T.I. Araribá)

Wellington Marcolino (Escola Estadual Indígena Aldeia Nimuendaju, T.I. Araribá)

Coordenação: Niminon Suzel Pinheiro (Centro

Universitário de Rio Preto)

18h - Café cultural

Lançamento do livro do II Encontro Paulista

Questões Indígenas e Museus

2 de julho, quinta-feira

9 h - Palestra

Título: Biografia de um Museu indígena: 0 Museu Kuahí dos Povos Indígenas do Baixo Oiapoque

Lux Vidal

Coordenação: Angelica Fabbri

10 h30 - café 
$11 \mathrm{~h}$ - Mesa-redonda

Tema: Formação, estudo e gestão de coleções museologicas

Ione Helena Pereira Couto (Museu do Índio)

Fabíola Andréa Silva (MAE-USP)

Edmundo Pereira (Museu Nacional, UFRJ)

Claudia Leonor López Garcés (Museu Paraense Emilio Goeldi)

Coordenação: Robson Antônio Rodrigues (Fundação Arapurã)

$12 \mathrm{~h} 30$ - almoço

14h - Mesa-redonda

Tema: Museus indígenas - novos referenciais para o debate

Davi Felisberto dos Santos (Museu Kuahí)

Diena Macial Sfair (Museu Kuahí)

Suzenalson da Silva Santos (Museu Indígena Kanindé)

Heraldo Alves (Preá) (Museu Indígena JenipapoKanindé)

José Ronaldo Siqueira (Museu Indígena Kapinawá)

Adriano César Rodrigues Campos (T.I. Icatu)

Creiles Onório Marcolino da Silva Nunes (Escola

Estadual Indígena Aldeia Nimuendaju, T.I Araribá)

Dirce Jorge Lipu Pereira (T.I. Vanuíre)

Lucilene de Melo (T.I. Vanuíre)

Coordenação: Fabíola Andréa Silva

16h - café 16h30 - Reunião de articulação da Rede de Museus Indígenas

Davi Felisberto dos Santos (Museu Kuahí)

Diena Macial Sfair (Museu Kuahí)

Suzenalson da Silva Santos (Museu Indígena Kanindé)

Heraldo Alves (Preá) (Museu Indígena JenipapoKanindé)

José Ronaldo Siqueira (Museu Indígena Kapinawá)

Adriano César Rodrigues Campos (Escola Estadual Indígena Índia Maria Rosa, T.I. Icatu)

Carlos Roberto Indubrasil (Escola Estadual Indígena Índia Maria Rosa, T.I. Icatu)

Edilene Pedro (Escola Estadual Indígena Índia Maria Rosa, T.I. Icatu)

Lícia Victor (Escola Estadual Indígena Índia Maria Rosa, T.I. Icatu)

Márcio Pedro (Escola Estadual Indígena Índia Maria Rosa, T.I. Icatu)

Lidiane Damaceno Cotuí (Escola Estadual Indígena Índia Vanuíre, T.I. Vanuíre)

Rosemeire Barbosa Dias (Escola Estadual Indígena Índia Vanuíre, T.I. Vanuíre)

Vagner Cecílio Damaceno (Escola Estadual Indígena Índia Vanuíre, T.I. Vanuíre)

Valdenice Cardoso Vaiti (Escola Estadual Indígena Índia Vanuíre, T.I. Vanuíre)

Claudino Marcolino (Escola Estadual Indígena Aldeia Nimuendaju, T.I. Araribá)

Cleidenilson Alves Marcolino (Escola Estadual Indígena Aldeia Nimuendaju, T.I. Araribá)

Creiles Onório Marcolino da Silva Nunes (Escola Estadual Indígena Aldeia Nimuendaju, T.I. Araribá)

Genilson Alves Marcolino (Escola Estadual Indígena Aldeia Nimuendaju, T.I. Araribá)

Gleidson Alves Marcolino (Escola Estadual Indígena Aldeia Nimuendaju, T.I. Araribá) 
Jederson Marcolino Simão dos Santos (Escola

18 h30 - Debate final Estadual Indígena Aldeia Nimuendaju, T.I. Araribá)

Moisés de Lima Camargo (Escola Estadual Indígena Aldeia Nimuendaju, T.I. Araribá)

Samuel de Oliveira Honório (Escola Estadual Indígena Aldeia Nimuendaju, T.I. Araribá)

Tiago de Oliveira (Escola Estadual Indígena Aldeia Nimuendaju, T.I. Araribá)

Vanderson Lourenço (Escola Estadual Indígena Aldeia Nimuendaju, T.I. Araribá)

Vanessa Cristina Feliciano (Escola Estadual Indígena Aldeia Nimuendaju, T.I. Araribá)

Wellington Marcolino (Escola Estadual Indígena Aldeia Nimuendaju, T.I. Araribá)

Alício Lipu (Escola Estadual Indígena Aldeia Ekeruá, T.I. Araribá)

David Henrique da Silva Pereira (Escola Estadual Indígena Aldeia Ekeruá, T.I. Araribá)

Edileine da Silva Pereira (Escola Estadual Indígena Aldeia Ekeruá, T.I. Araribá)

Luiza Lipu (Escola Estadual Indígena Aldeia Ekeruá, T.I. Araribá)

Valéria Érika da Silva Pereira (Escola Estadual Indígena Aldeia Ekeruá, T.I. Araribá)

Adriana Victor Campos Rodrigues (T.I. Icatu)

Ana Paula Victor Campos (T.I. Icatu)

Bruna Pedro (T.I. Icatu)

Camila Vaiti P. da Silva (T.I. Icatu)

Cândido Mariano Elias (T.I. Icatu)

Ranulfo de Camilo (T.I. Icatu)

Raphael Pedro Iaiati (T.I. Icatu)

Ronaldo Iaiati (T.I. Icatu)

Constantino Jorge da Silva (T.I. Vanuíre)

Dirce Jorge Lipu Pereira (Kaingang, T.I. Vanuíre) Lucilene de Melo (Kaingang, T.I. Vanuíre)

Coordenação: Alexandre Oliveira Gomes (Núcleo de Estudos e Pesquisas em Etnicidade - Nepe/UFPE) 


\section{Créditos do IV Encontro Paulista Questões Indígenas e Museus e V Seminário Museus, Identidades e Patrimônios Culturais (30 de junho e 2 de julho de 2015)}

\section{GOVERNO DO ESTADO DE SÃO PAULO}

Geraldo Alckmin

Governador do Estado

Marcelo Mattos Araujo

Secretário da Cultura

Renata Vieira da Motta

Coordenadora da Unidade de

Preservação do Patrimônio Museológico

\section{Davidson Panis Kaseker}

Diretor do Grupo Técnico de Coordenação do Sistema Estadual de Museus

Associação Cultural de Apoio ao Museu Casa de Portinari - ACAM PORTINARI - Organização Social de Cultura Rosameyre Morando

Presidente do Conselho de Administração

Angelica Fabbri

Diretora Executiva

Luiz Antonio Bergamo

Diretor Administrativo Financeiro

Museu Histórico e Pedagógico Índia Vanuíre Tamimi David Rayes Borsato

Gerente Geral

\author{
UNIVERSIDADE DE SÃO PAULO \\ Marco Antonio Zago \\ Reitor \\ Vahan Agopyan \\ Vice-reitor
}

Bernadette Dora Gobossy de Melo Franco

Pró-Reitora de Pós-Graduação

Maria Arminda do Nascimento Arruda

Pró-Reitora de Cultura e Extensão

MUSEU DE ARQUEOLOGIA E ETNOLOGIA

Maria Cristina Oliveira Bruno

Diretora

Paulo DeBlasis

Vice-Diretor

Carla Gibertoni Carneiro

Chefe da Divisão de Apoio à Pesquisa e Extensão

Maria Cristina Nicolau Kormikiari Passos

Chefe da Divisão de Apoio e Ensino

PROGRAMA DE PÓS-GRADUAÇÃO INTERUNIDADES EM MUSEOLOGIA

Marília Xavier Cury

Paulo César Garcez Marins

Coordenação 
IV ENCONTRO PAULISTA QUESTÕES INDÍGENAS E MUSEUS V SEMINÁRIO MUSEUS, IDENTIDADES E PATRIMÔNIOS CULTURAIS

\section{Comissão Científica}

Marília Xavier Cury (presidente)

Angelica Fabbri

Luiz Antonio Bergamo

Tamimi David Rayes Borsatto

\section{Comissão Organizadora}

Angelica Fabbri

Luiz Antonio Bergamo

Marília Xavier Cury

Tamimi David Rayes Borsatto

Andressa Anjos de Oliveira

Ary Soares Landim

Brayam Moreira da Silva

César Fatarelli Ribeiro

Cláudio Aparecido da Rocha

Eduardo Batista Gonçalves

Erivelton Isaac de Souza

Gabriela da Silva Sanches

Gessiara da Silva Góes Andrade

Isaltina Santos Ferreira da Costa

José Luis Alves

Lamara David Ruiz Estevam

Leandro Henrique Andrade

Lílian Budaibes Zorato

Luís Fernando Marques

Luís Otávio Fornazieri

Maria Odete Correa Vieira Roza

Maria Rosalina da Silva

Raquel Maria $F$. Miguel $S$. de Luna

Uiara Potira Ribeiro Daneluti

Valquíria Cristina Martins

Vera Lúcia Pereira de Lima

Viviani Micheli Gonela Bononi

Giramundo Consultoria

Joana Montero Ortiz

\section{Instituições convidadas}

Centro Universitário de Rio Preto

Cesnik Quintino e Salinas

Escola Estadual Indígena Aldeia Ekeruá, T.I.

Araribá

Escola Estadual Indígena Aldeia Nimuendaju, T.I. Araribá

Escola Estadual Indígena Índia Maria Rosa, T.I.

Icatu

Escola Estadual Indígena Índia Vanuíre, T.I.

Vanuíre

Fundação Araporã

Instituto Socioambiental (ISA)

Museus da Civilização, Québec, Canadá

Museu do Índio, Fundação Nacional do Índio

(Funai)

Museu Indígena Kanindé

Museu Indígena Jenipapo-Kanindé

Museu Indígena Kapinawá

Museu Kuahí dos Povos Indígenas do Baixo Oiapoque Museu Nacional, Universidade Federal do Rio de Janeiro (UFRJ)

Museu Paraense Emilio Goeldi, Ministério da Ciência, Tecnologia e Inovação (MCTI)

Núcleo de Estudos e Pesquisas em Etnicidade (Nepe), Universidade Federal de Pernambuco (UFPE) Universidade Federal de São Paulo (Unifesp) Universidade Federal de Minas Gerais (UFMG) Universidade de São Paulo (USP)

Universidade Estadual Paulista "Júlio de Mesquita Filho” (Unesp), campus Marília

Eventos financiados pela Capes (auxílio 0873/2015) e Fapesp (2015/06748-2). 


\section{Direitos indígenas no museu - Novos procedimentos para uma nova política: a gestão de acervos em discussão}

\section{GOVERNO DO ESTADO DE SÃO PAULO}

Geraldo Alckmin

Governador do Estado

Jose Roberto Neffa Sadek

Secretário da Cultura

\section{Renata Vieira da Motta}

Coordenadora da Unidade de

Preservação do Patrimônio Museológico

\section{Davidson Panis Kaseker}

Diretor do Grupo Técnico de Coordenação do

Sistema Estadual de Museus - GTCSISEM-SP

Associação Cultural de Apoio ao Museu Casa de Portinari - ACAM Portinari - Organização Social de Cultura

Presidente do Conselho Administrativo Sérgio Roberto Urbano

Diretora Executiva

Angelica Fabbri

Diretor Administrativo/Financeiro

Luiz Antonio Bergamo

Museu Histórico e Pedagógico Índia Vanuíre Tamimi David Rayes Borsato Gerente Geral

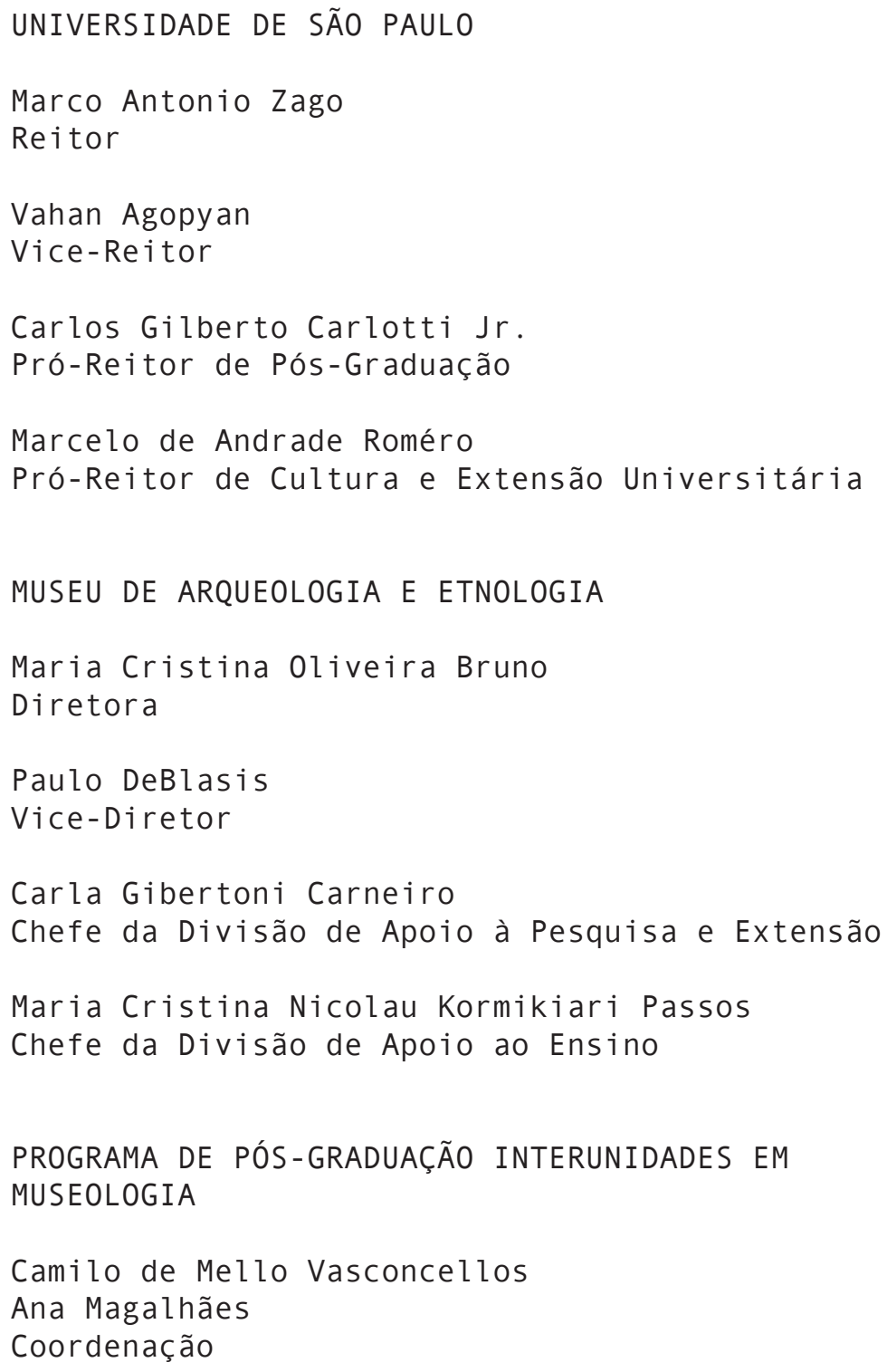


COLEÇÃO MUSEU ABERTO

Direitos indígenas no museu - Novos procedimentos para uma nova política: a gestão de acervos em discussão

\section{Coordenação Editorial}

Marília Xavier Cury

\section{Apresentação e Introdução}

Angelica Fabbri

Maria Cristina Oliveira Bruno

Marília Xavier Cury

\section{Autores}

Alexandre Oliveira Gomes

Aramis Luís Silva

Claudia Leonor Lopez Garcés

Davidson Panis Kaseker

Edmundo Pereira

Fabíola Andréa Silva

Grasiela Lima

Helouise Costa

Ione Helena Pereira Couto

Jean Tanguay

Josué Carvalho

José Francisco Miguel Henriques Bairrão

Juliana Dal Ponte Tiveron

Laércio Fidelis Dias

Leandro da Cruz Silva

Leilane Patrícia Lima

Maurício André da Silva

Niminon Suzel Pinheiro

Robson Antonio Rodrigues

Suzana Primo dos Santos

Viviane Wermelinger Guimarães

Projeto Gráfico

Luciano Pessoa, LP Estúdio

\section{Revisão}

Armando Olivetti

São Paulo, 2016 


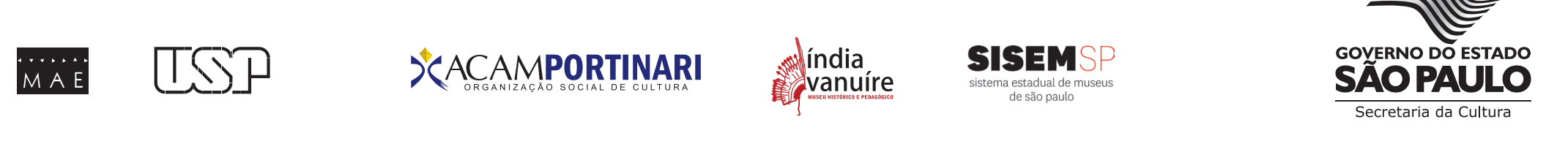

